\title{
Przedsiębiorczość
}

\section{w warunkach globalizacji}

Entrepreneurship in the Conditions of Globalization 
Uniwersytet Pedagogiczny im. Komisji Edukacji Narodowej w Krakowie Instytut Geografii Zakład Przedsiębiorczości i Gospodarki Przestrzennej

\title{
Przedsiębiorczość - Edukacja
} $\mathrm{Nr} 7$

\author{
Pedagogical University of Cracow \\ Institute of Geography \\ Department of Entrepreneurship and Spatial Management
}

Entrepreneurship - Education No. 7 


\section{Przedsiębiorczość}

\section{w warunkach \\ globalizacji}

pod redakcją

Zbigniewa Zioło i Tomasza Rachwała 
Recenzent: prof. UR, dr hab. Jerzy Kitowski

Redaktor naczelny: prof. dr hab. Zbigniew Zioło

Zastępca redaktora naczelnego: dr Tomasz Rachwał

Rada Redakcyjna: Monika Borowiec, Paweł Czapliński, Sławomir Dorocki, Bronisław Górz, Roman Fedan, Wiesława Gierańczyk, Anatol Jakobson, Wioletta Kilar (sekretarz), Sławomir Kurek, Zbigniew Makieła, Paweł Pocheć, Tomasz Rachwał (zastępca przewodniczącego), Natalia M. Syssoeva, Anna Tobolska, Krzysztof Wiedermann, Zbigniew Zioło (przewodniczący)

Redakcja naukowa tomu: prof. dr hab. Zbigniew Zioło, dr Tomasz Rachwał

Publikacja dofinansowana przez Ministra Nauki i Szkolnictwa Wyższego

Projekt okładki: Maciej Galiński

Projekt graficzny i opracowanie graficzne: Jarosław Naus, Iwona Gałuszka Opracowanie redakcyjne i redakcja językowa: Aleksandra Pryczkowska

Wspólpraca redakcyjna: Tomasz Rachwał, Wioletta Kilar

ISBN 978-83-267-0333-1

(C) Copyright by wydawnictwo Nowa Era w Warszawie \& Zakład Przedsiębiorczości i Gospodarki Przestrzennej IG UP w Krakowie

Warszawa - Kraków 2011

Skład i łamanie: Nowa Era Sp. z o.o.

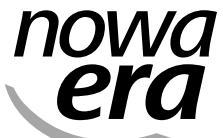

Nowa Era Sp. z o.o.

Aleje Jerozolimskie 146 D, 02-305 Warszawa

tel. 225702580 , faks 225702581

www.nowaera.pl, e-mail: nowaera@nowaera.pl

Druk i oprawa: Łódzkie Zakłady Graficzne 


\section{Wprowadzenie}

Postępujące procesy globalizacji zmieniają uwarunkowania społeczno-gospodarcze i wpływają nie tylko na kształtowanie ludzkich postaw, ale też na zachowania poszukujących możliwości rozwoju podmiotów gospodarczych oraz instytucji. Podstawowym motorem przemian we współczesnej gospodarce jest nasilający się proces koncentracji kapitału, który przejawia się powstawaniem coraz potężniejszych korporacji. Lokalizacja ich zarządów, zakładów produkcyjnych, usługowych i poszczególnych typów oddziałów wpływa na różnicowanie układów przestrzennych, począwszy od przestrzeni światowej, poprzez przestrzenie kontynentalne, regionalne i krajowe, a skończywszy na przestrzeniach układów lokalnych. W stymulowaniu procesów globalizacji podstawową rolę odgrywają odpowiednio przygotowani ludzie, którzy, wykorzystując złożone reguły ekonomicznego i społecznego rozwoju, dzięki coraz doskonalszym formom zarządzania osiągają bardzo dobre rezultaty gospodarcze. Stąd szczególnego znaczenia nabiera obecnie edukacja - umiejętnie prowadzona, pozwoli ona przyszłym pracownikom wykształcić postawę przedsiębiorczą oraz nabyć niezbędne umiejętności produkcji i zarządzania.

Właśnie do tych zagadnień nawiązują prace zawarte w niniejszym, siódmym już tomie serii „Przedsiębiorczość - Edukacja”. Na podkreślenie zasługuje fakt, że Autorzy zamieszczonych w nim prac reprezentują różne krajowe ośrodki akademickie, co umożliwia wymianę myśli i doświadczeń w zakresie efektów badań dotyczących tej szczególnie ważnej problematyki badawczej. Zgromadzone prace mieszczą się w czterech głównych nurtach: kształtowania się podmiotów gospodarczych w warunkach nasilających się procesów globalizacji, roli przedsiębiorczości w aktywizacji gospodarczej układów przestrzennych, źródeł zasilania finansowego działalności gospodarczej oraz roli edukacji w kształtowaniu postaw przedsiębiorczości w warunkach globalizacji.

Tom otwierają rozważania podejmujące problematykę znaczenia kształtowania przedsiębiorczości w warunkach nasilających się procesów globalizacji. Główną uwagę zwrócono w nich na określenie wpływu reguł rozwoju ekonomicznego i typów polityki gospodarczej na podmioty gospodarcze $w$ różnej skali układów przestrzennych, w tym na rozwój działalności gospodarczej małych firm (Z. Zioło). Opierając się na doświadczeniach francuskich, wskazano też na duże znaczenie bezpośrednich inwestycji zagranicznych w rozwoju układów regionalnych (S. Dorocki). Ukazano, że przedsiębiorstwo nie jest odizolowanym elementem gospodarczym, ale kształtuje się pod wpływem różnorodnych czynników otoczenia, wymuszających adekwatne zachowania załogi pracowniczej (A. Oniszczuk-Jastrząbek), na co wskazują także badania ankietowe (T. Gutowski). Jak wynika z rozważań dotyczących zarządzania wiekiem załóg przedsiębiorstw, w podnoszeniu efektywności ekonomicznej i konkurencyjności przedsiębiorstwa duże znaczenie ma wykorzystanie doświadczeń zawodowych pracowników (P. Czapliński).

W części pierwszej niniejszego tomu pojawiły się też rozważania na temat: tworzenia efektywnej instytucjonalnej obsługi biznesowej (A. Tokarski), doskonalenia zarządzania innowacjami w przedsiębiorstwach, zwłaszcza małych i średnich (M. Kochmańska) i kształtowania łańcucha wartości innowacyjnej (D. Janiszewska). Procesy globalizacji w zasadniczym stopniu stymulowane są przez korporacje międzynarodowe, na co wskazują informacje o rozwoju takich korporacji, jak Samsung (W. Kilar) i Google (M. Boguś). Umiędzynarodowienie gospodarki prowadzi jednak do zmian w dotychczasowych procedurach lokalizacyjnych (W. Nogaj), 
czego wyrazem są np. przemiany europejskiego rynku samochodowego wpływające na lokalizację i zmiany funkcji warsztatów samochodowych (M. Włodarczyk, J. Janczewski). Procesy globalizacji prowadzą też do powstania negatywnych zjawisk, np. wykluczenia społecznego. Ich ograniczenie jest możliwe na gruncie etyki (T. Brzozowski).

Prace zawarte w drugiej części tomu podejmują problematykę wpływu przedsiębiorczości na aktywizację gospodarczą. Dotyczą one: znaczenia marketingu jako formy działań przedsiębiorczych samorządów terytorialnych (M. Zdon-Korzeniowska), znaczenia postaw przedsiębiorczych władz i mieszkańców w aktywizacji gospodarczej gminy Horyniec-Zdrój (A. Kłos), roli lokalnych programów rewitalizacji jako czynników rozwoju przedsiębiorczości lokalnej miast (N. Grad) i kształtowania się potencjalnej metropolii Kielc (P. Majcher).

Ważną funkcję w rozwoju przedsiębiorczości, szczególnie w kształtowaniu sektora małych i średnich przedsiębiorstw, spełniają możliwości finansowania ich działalności. Problematyka ta została częściowo podjęta w trzeciej części niniejszego tomu. Przedstawiono w niej: rolę międzynarodowych standardów sprawozdawczości finansowej w procesie harmonizacji i standaryzacji rachunkowości w Polsce (M. Tokarski), zagadnienie rachunkowości kreatywnej (H. Pawlak), sektor małych i średnich przedsiębiorstw województwa podkarpackiego jako potencjalnego odbiorcę środków Funduszu Rozwoju Lokalnego (P. Czapliński) oraz rolę funduszy pożyczkowych w finansowaniu firm (A. Buś-Bidas).

Jak zostało już zauważone, istotne znaczenie dla kształtowania społecznych postaw przedsiębiorczości ma edukacja. Podkreślają to artykuły zawarte w czwartej części tomu, dotyczące analizy szans i zagrożeń w zakresie edukacji wobec nasilających się procesów globalizacji (M. Borowiec) oraz znaczenia otwartego i elastycznego systemu kształcenia, wspierającego aktywność poznawczą szeroko rozumianej przedsiębiorczości w warunkach globalizacji (M. Borowiec, T. Rachwał). Na tym tle pojawiają się założenia i cele realizowanego w Zakładzie Przedsiębiorczości i Gospodarki Przestrzennej Uniwersytetu Pedagogicznego w Krakowie projektu badawczego „Krok w przedsiębiorczość” (S. Dorocki, W. Kilar, T. Rachwał) oraz znaczenie umiejętności komunikowania się w zmieniających się uwarunkowaniach społeczno-gospodarczych (W. Osuch). Tom kończą prace na temat kształcenia w zakresie turystyki na poziomie szkolnictwa wyższego (Z. Długosz, S. Biały; R. Malarz), funkcjonowania bielskiego ośrodka akademickiego (A. Haczek), oceny procesów globalizacji przez młodzież (K. Sowislok) i szkolenia kierowców w warunkach globalizacji (Z. Ożdżyński). Przedstawione prace otwierają nową, szczególnie aktualną problematykę badawczą związaną z rolą edukacji przedsiębiorczości w przygotowaniu ludzi do zarządzania rozwojem społeczno-gospodarczym, zwłaszcza układów lokalnych.

Zaprezentowane w niniejszym tomie prace dają przegląd podejmowanej w krajowych ośrodkach akademickich problematyki badawczej, dotyczącej przedsiębiorczości w dobie nasilających się procesów globalizacji. Należy przy tym zaznaczyć, że bez stopniowego pogłębiania tychże badań, ciągłej modernizacji treści nauczania, a także kształtowania postaw przedsiębiorczych w polskim społeczeństwie trudno będzie włączać się w światowe procesy rozwoju cywilizacyjnego. 


\section{Introduction}

The progressing globalization processes change the social-economic background and not only do they influence human attitudes but also behaviour of business entities and institutions that seek the possibilities of development. In the contemporary economy the intensifying process of concentration of capital that results in creation of even more powerful corporations is the main driving force behind changes. Location of their management boards, manufacturing and service facilities and individual types of branches have their influence on the diversification of spatial arrangements beginning with world space through continental, regional and country spaces and ending with the composition of local spaces. Properly prepared people who use the complex rules of economic and social development and make use of more and more perfect forms of management achieve excellent economic results play the main role in stimulation of the globalisation processes. Taking that into consideration proper education gets particular relevance because it will allow the future employees to shape their entrepreneurial attitude and gain necessary manufacturing and managing skills.

Works enclosed in this seventh volume of the serie „Przedsiębiorczość - Edukacja” [Entrepreneurship - Education] refer to such notions. It has to be emphasized that the authors of the articles represent different national universities which enables to exchange ideas and experiences on results of the researches concerning these especially important research issues.

The collected works belong to four main streams: development of the business entities in the conditions of intensifying globalization, the role of entrepreneurship in the economic revival as spatial arrangements, financial resources for business and the role of education in shaping the attitudes of entrepreneurship in the global environment.

The volume is opened with contemplation of the importance of the development of entrepreneurship in conditions of intensifying globalization. The main attention in it was paid to determine the impact of rules of the economic development and types of economic policy on business entities in different scales of spatial arrangements, including the development of economic activities of small firms (Z. Zioło). Based on French experiences major importance of direct foreign investments in the development of regional arrangements was indicated (S. Dorocki). It was showed that the company is not an isolated element of the economy, but is influenced in its development by various factors of the environment, forcing the staff to maintain adequate behaviour (A. Oniszczuk-Jastrząbek), as indicated by the survey (T. Gutowski). From considerations on the age management of the staff it transpires that making use of the professional experience of the employees plays a major role in increasing economic effectiveness and competitiveness of the company (P. Czapliński).

The first part of this volume also contains a reflection on: creating an effective institutional business services (A. Tokarski), improvement of innovation management in enterprises, especially small and medium (M. Kochmańska) and shaping of innovative value chain (D. Janiszewska). The processes of globalization are essentially driven by multinational corporations, as indicated by information on the development of such corporations e.g. Samsung (W. Kilar) and Google (M. Boguś). The internationalization of the economy leads, however, to changes in the existing procedures for localization (W. Nogaj), like for example changes in the European car market affecting the location and changes in function of car workshops (M. Włodarczyk, J. Janczewski). The processes of globalization lead to the emergence of negative phenomena, such as social exclusion. Their reduction is possible on the basis of ethics (T. Brzozowski). 
The works included in the second part of the volume undertake the issue of the impact of entrepreneurship on economic activation. They concern: the importance of marketing as a form of entrepreneurial activities of local self-governments (M. Zdon-Korzeniowska), the importance of entrepreneurial attitudes of the authorities and inhabitants in economic activation of commune Horyniec-Zdrój (A. Kłos), the role of the Local Revitalisation Programmes as factors in the development of local entrepreneurship of cities (N. Grad) and the development of the potential metropolis in Kielce city (P. Majcher).

An important role in the development of entrepreneurship, especially in the development of small and medium-sized businesses plays their financing option. That problem has been partially adopted in the third part of this volume. It shows: the role of International Financial Reporting Standards in the process of harmonization and standardization of accounting in Poland (M. Tokarski), the issue of creative accounting (H. Pawlak), the sector of small and medium-sized enterprises of the Podkarpackie voivodeship as a potential recipient of the Local Development Fund monies (P. Czaplinski) and the role of loan funds in financing businesses (A. Buś-Bidas).

As it has been already noted, education plays important role in developing of social entrepreneurship attitudes. This is emphasized by the articles in the fourth part of the volume, concerning the analysis of the opportunities and threats in the field of education in view of the increasing globalization processes (M. Borowiec) and the importance of the open and flexible educational system that supports cognitive activity of broadly defined entrepreneurship in globalization conditions (M. Borowiec, T. Rachwał). Against this background, assumptions and objectives pursued in Zakład Przedsiębiorczości i Gospodarki Przestrzennej [the Department of Entrepreneurship and Spatial Management] in the Pedagogical University of Cracow research Project „Step in Entrepreneurship” appear (S. Dorocki, W. Kilar, T. Rachwał) and the importance of communication skills in the changing socio-economic conditions (W. Osuch). The volume ends with works on education in the field of tourism at the higher education level (R. Długosz, S. Biały, R. Malarz), the operation of the Bielsko academic center (A. Haczek), the evaluation of globalization processes by young people (K. Sowislok) and the issue of training drivers in globalization conditions (Z. Ożdżyński). The presented works open new, presentday research issues related to the role of entrepreneurship education in preparing people to manage the socio-economic development with stress put on local arrangements.

Works presented in this volume give an overview of the research problems undertaken in the national academic centers that concerns entrepreneurship in the era of increasing globalization processes. It should be noted that without the gradual deepening of these studies, without the ongoing modernization of curricula and the development of entrepreneurial attitudes in the Polish society it will be difficult to join in the global processes of civilisational development.

Zbigniew Zioło, Tomasz Rachwał 


\section{Kształtowanie się podmiotów gospodarczych w warunkach globalizacji}




\section{Zbigniew Zioło}

Uniwersytet Pedagogiczny

im. Komisji Edukacji Narodowej

w Krakowie

\section{Rola przedsiębiorczości w warunkach nasilających się procesów globalizacji}

Nasilające się procesy globalizacji należy traktować jako obiektywne, gdyż kształtujące się pod wpływem rozwoju cywilizacyjnego i związanego z nim postępującego procesu koncentracji kapitału. Wyrazem tego jest powstawanie coraz potężniejszych korporacji, które dzięki coraz nowocześniejszym i bardziej konkurencyjnym produktom, usługom i organizacjom obejmują zasięgiem oddziaływania coraz rozleglejsze rynki, ograniczając równocześnie działalność mniej konkurencyjnych podmiotów lub wchłaniając je do swojej struktury organizacyjnej w drodze przejęć, fuzji, zakupu i in. W konsekwencji postępujący proces koncentracji kapitału w zasadniczym stopniu wpływa na kształtowanie się ponadnarodowych korporacji, które poprzez inwestycje w zakresie działalności produkcyjnej, usługowej i finansowej systematycznie wzmacniają swoją pozycję w przestrzeni światowej ${ }^{1}$. Dokonuje się to także w wyniku lokowania oddziałów na terenie coraz to innych krajów, co przekłada się na zwiększenie zasięgu wpływów o nowe obszary rynkowe ${ }^{2}$. Ponadnarodowe firmy mogą też stwarzać możliwości dla rozwoju małych i średnich przedsiębiorstw dzięki kształtowaniu określonych powiązań kooperacyjnych czy rozwijaniu działalności usługowej. Przyczynia się to do zwiększania strumieni finansowych płynących do gospodarstw domowych i zwiększania zapotrzebowania rynku na oferowane produkty oraz usługi. Procesy globalizacji prowadzą również do pogłębiania już istniejących rynków i obserwowania rynków potencjalnych, które mogą być atrakcyjne wraz ze zwiększaniem się zasobów finansowych mieszkającej na ich terenach ludności.

Wydaje się, że precyzyjniejsze poznanie złożonych mechanizmów procesów globalizacji pozwoli na określenie możliwości wykorzystania ich wpływu dla aktywizacji działań i postaw przedsiębiorczych społeczności układów lokalnych i regionalnych, co powinno prowadzić do ich rozwoju ekonomicznego, społecznego i kulturowego. Stąd w niniejszej pracy podjęto problematykę kształtowania przedsiębiorczości w warunkach nasilających się procesów globalizacji. Problematyka ta jest kontynuacją wcześniejszych rozważań prezentowanych w kolejnych tomach serii „Przedsiębiorczość - Edukacja”, poświęconych roli przedsiębiorczości w: kształtowaniu społeczeństwa informacyjnego, gospodarce opartej na wiedzy, aktywizacji gospodarczej, podnoszeniu konkurencyjności oraz warunkach integracji europejskiej (Zioło, Rachwał 2005, 2006, 2007, 2008, 2009, 2010).

\footnotetext{
${ }^{1}$ O skali tego zjawiska świadczy potencjał ekonomiczny dominujących światowych korporacji. W $2009 \mathrm{r}$. wartość sprzedaży największej z nich, Wal-Mart Stores, wyniosła 408,21 mld USD („Forbes Globar 2000” z 2010 r.), podczas gdy wartość PKB Polski wynosiła 430,6 mld USD.

${ }^{2}$ Na przykład koncern Toyota ma 61 zakładów zlokalizowanych na terenie 26 krajów, w tym w: Japonii (15 zakładów), Chin (13), Malezji i Tajlandii (po trzy), Kanadzie, Stanach Zjednoczonych, Filipinach, Wielkiej Brytanii oraz Polsce (po dwa).
} 


\section{Przesłanki rozwoju przedsiębiorczości}

Zarysowane procesy tworzą zagęszczające się sieci powiązań politycznych, ekonomicznych, społecznych i kulturowych, które wywierają znaczący wpływ na wzrost działalności gospodarczej oraz przyczyniają się do rozwoju przedsiębiorczości.

Ważną rolę w rozwoju przedsiębiorczości odgrywają relacje polityczne, przejawiające się w celowo tworzonych uwarunkowaniach w zakresie kreowania korzystnych instrumentów dla stopniowego nasilania powiązań między poszczególnymi krajami. Przekładają się one na utrwalanie już istniejących lub kreowanie nowych, ale najczęściej korzystniejszych możliwości powiązań gospodarczych podmiotów gospodarczych oraz instytucji. Mogą także tworzyć nowe bariery ograniczające rozwój wzajemnej współpracy ${ }^{3}$.

Relacje ekonomiczne wynikają najczęściej z: odpowiednich zasobów surowcowych, uwarunkowań rynkowych, jakości przestrzeni społeczno-gospodarczej, kulturowej i przyrodniczej. Pozwalają one na rozwój istniejącej działalności produkcyjno-usługowej oraz na wykorzystywanie nowych lokalizacji. Tworzy się w ten sposób podstawa do rozwijania powiązań w zakresie przepływu kapitału w formie bezpośrednich inwestycji zagranicznych, rynków zbytu dla oferowanych produktów, możliwości rozwijania powiązań kooperacyjnych lokalnych podmiotów gospodarczych, rozwijania źródeł zaopatrzenia surowcowego, modernizacji rynku pracy, powiązań finansowych i in. (Bojar 2008, Domański 2001)

Relacje społeczne wpływają na: pobudzanie, hamowanie przepływu lub wykorzystywanie odpowiednio przygotowanych miejscowych zasobów pracy przez nowo lokowane oddziały produkcyjno-usługowe, rozwijanie działalności edukacyjnej i podnoszenie poziomu kwalifikacji zawodowych pracowników, co w konsekwencji prowadzi do wzrostu dochodów finansowych gospodarstw domowych i układów samorządowych (Zioło 1978).

Z kolei relacje kulturowe wpływają na kształtowanie jakości zasobów pracy, formy zarządzania i tworzenie korzystnych uwarunkowań dla otoczenia biznesu. Umożliwiają stworzenie nowej kultury organizacji pracy, często zwiększającej efektywność działalności gospodarczej, transmisję produktów kultury (literackiej, muzycznej, malarskiej, produktów kultury masowej), a także wzorców zachowań i tolerancji w stosunku do osób kształtowanych na odmiennych zasadach kultury duchowej (religijnych, światopoglądowych, prądów filozoficznych i in.). Wpływają również na aspiracje i plany życiowe młodzieży, które nawiązują do zmieniających się uwarunkowań rozwoju (Turczyn-Zioło 1979). Rozwijając działalność gospodarczą, musimy zatem poznać i odpowiednio wykorzystać relacje kulturowe dla podniesienia konkurencyjności wytwarzanych produktów lub oferowanych usług.

Lokalizacja nowego podmiotu gospodarczego w różnym stopniu i często w odmiennym zakresie oddziałuje na poszczególne elementy przestrzeni geograficznej. Kształtujące się procesy przemian dokonujące się w wyniku postępującego rozwoju cywilizacyjnego nakładają się bowiem na zróżnicowane pod względem rozwoju różnej skali układy przestrzenne. Przyrodnicze, gospodarcze, społeczne i kulturowe zróżnicowanie przestrzeni światowej często w odmiennym stopniu umożliwia wykorzystanie reguł rozwoju i stwarzania korzystnych uwarunkowań dla przyjmowania oraz wchłaniania pojawiających się innowacji.

Procesy generowane w skali globalnej w różnym stopniu oddziałują na układy światowe, poszczególnych kontynentów, krajów, regionów czy układy lokalne, które odznaczają się zróżnicowanym poziomem rozwoju i w określonym stopniu umożliwiają bądź hamują rozwój

\footnotetext{
${ }^{3}$ Przykładem mogą być ostatnio podjęte decyzje rządu chińskiego o ograniczeniu dostaw do Stanów Zjednoczonych, Europy Zachodniej i Japonii metali rzadkich, niezbędnych do produkcji wyrobów ht czy trudności w negocjacjach zaopatrzenia Polski w ropę i gaz.
} 
przedsiębiorczości. W skali światowej podejmowane są działania prowadzące do zaspokojenia uniwersalnych potrzeb społecznych, takich jak wdrażanie do produkcji i usług nowych narzędzi pracy (komputery, telefony komórkowe, Internet, środki transportu), potrzeba bezpieczeństwa, rozwijanie społecznego uznawania i samorealizacji przedsiębiorstw czy podnoszenia jakości instytucji. Podstawowe znaczenia w tym zakresie mają obszary pełniące funkcję światowych biegunów wzrostu (Stany Zjednoczone, Japonia, Unia Europejska) i ostatnio intensywnie rozwijające się (Chiny, Indie, Rosja, Brazylia), które dzięki innowacjom stopniowo obejmują swoim zasięgiem coraz rozleglejszą przestrzeń światową.

Rozwój poszczególnych kontynentów związany jest z odmiennymi warunkami przyrodniczymi i występującymi zasobami surowcowymi, dominującymi wzorcami kulturowymi, które wywodzą się z określonych zasad i tradycji, wyznawanych religii oraz dziedzictwa kulturowego, a także przyjmowanymi systemami zarządzania gospodarką.

Państwa suwerenne kształtują się nie tylko według własnych reguł, ale wraz z nasilającymi się powiązaniami ekonomicznymi, społecznymi i kulturowymi stopniowo przyjmują też zasady globalnego rozwoju, dostosowując stopniowo swoje uwarunkowania instytucjonalne do nowych reguł rozwoju (np. kształtowanie Unii Europejskiej). Procesy integracji w pewnym stopniu są utrudnione początkowo przez specyficzne wewnętrzne bariery ustrojowo-polityczne, jakość oraz rozmiary zasobów intelektualnych, z których wynikają zasoby kapitału ludzkiego i kapitału społecznego (Kamińska, Heffner 2010).

Do zarządzenia tymi złożonymi procesami techniczno-ekonomicznymi i społecznymi, zarówno w poszczególnych przedsiębiorstwach lub instytucjach, jak i krajowych, regionalnych czy lokalnych układach przestrzennych, potrzebni są odpowiednio przygotowani ludzie. Osoby realizujące swoje plany życiowe wynikające z wykształconych uprzednio aspiracji, które powinny być wcześniej podbudowywane w wyniku działalności edukacyjnej, a następnie rozwijane w drodze samokształcenia i zdobywania doświadczenia zawodowego w zakresie lokowania i kierowania coraz bardziej złożonymi strukturami przedsiębiorstw produkcyjnych, usługowych, produkcyjno-usługowych czy instytucji. Duże znaczenie dla rozwoju przedsiębiorczości mają także indywidualne cechy jednostek, kształtowane początkowo przez rodzinę i sytuację układu lokalnego, a w miarę zwiększenia powiązań społeczno-ekonomicznych również przez otoczenie krajowe i międzynarodowe. Brak odpowiednio przygotowanych ludzi osłabia możliwości wykorzystania reguł współczesnego rozwoju dla pobudzania wzrostu gospodarczego.

Wzrost gospodarczy, nasilające się procesy globalizacji i związane z nimi procesy integracji europejskiej są szczególnym wyzwaniem dla kształtowania cech osobowych poszczególnych jednostek ludzkich, przedsiębiorstw oraz społeczności lokalnych, regionalnych i krajowych. Bardzo ważne jest także określenie, w jakim stopniu będą one przydatne do wykorzystania reguł ekonomicznych dla rozwoju gospodarczego, społecznego i kulturowego oraz podnoszenia pozycji konkurencyjnej związanych z nimi układów przestrzennych. Podstawową rolę w tym zakresie odgrywa wybór określonego typu działalności gospodarczej, który wynika z poznania uwarunkowań rozwoju przedsiębiorczości, funkcji produkcyjno-usługowych istniejących podmiotów gospodarczych, w tym podmiotów osób fizycznych oraz warunków otoczenia niezbędnych dla prowadzenia planowanej działalności gospodarczej.

\section{Typy dzialalności gospodarczej}

Procesy dotyczące działalności gospodarczej bardzo silnie nawiązują do procesu koncentracji kapitału prowadzącego do powstawania coraz większych korporacji i obejmują swoim zasięgiem rynek światowy. Firmy międzynarodowe o dużym potencjale techniczno-ekonomicznym są 
w stanie przeznaczyć znaczne środki na prace badawczo-rozwojowe ${ }^{4}$, lepszą organizację i modernizację procesów produkcyjnych, dokształcanie i doskonalenie zawodowe pracowników, co umożliwia im wprowadzanie na rynek coraz bardziej konkurencyjnych produktów oraz zwiększanie przychodów i zysków z działalności gospodarczej (ryc. 1).

Ryc. 1. Typy działalności gospodarczej

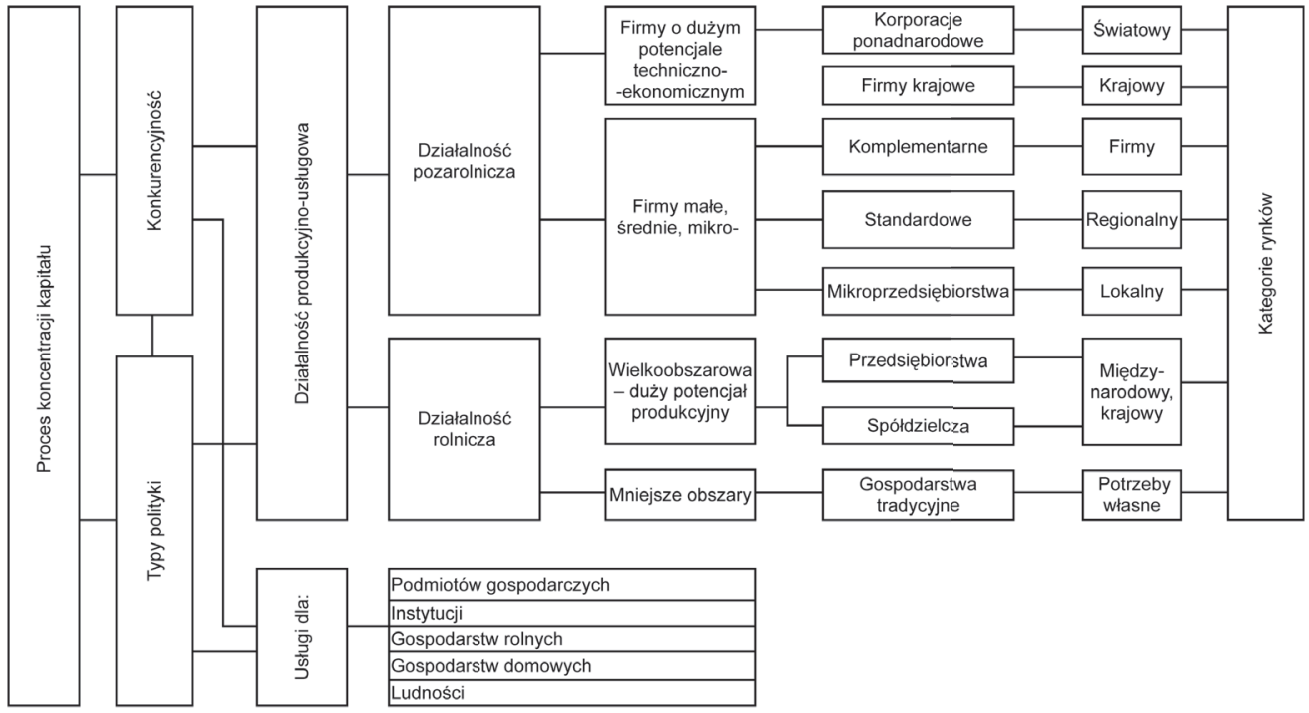

Źródło: opracowanie własne.

W przestrzeni światowej, krajowej czy regionalnej działania te uruchamiają procesy konkurencyjności rynkowej. W wyniku ich nasilania poszczególne przedsiębiorstwa mogą zachowywać się jako elementy:

- zanikłe (które nie sprostały potrzebom rynku i upadły),

- zanikające (których działalność systematycznie się osłabia i prowadzi do upadłości),

- stagnujące (utrzymujące dotychczasową pozycje na rynku),

- rozwijające się (które w wyniku rosnącej pozycji konkurencyjnej rozwijają swoją produkcję i pogłębiają lub zdobywają nowe rynki),

- nowo pojawiające się (które utworzono w wyniku pojawiających się nisz rynkowych i podejmują produkcję nowoczesnych wyrobów).

Proces ten może być wpierany przez odpowiednią politykę ekonomiczną państwa, która może stwarzać bardziej lub mniej korzystne instrumenty pośredniego i bezpośredniego oddziaływania dla rozwoju podmiotów gospodarczych.

Podmioty gospodarcze podejmują określoną działalność gospodarczą w zależności od nisz rynkowych, zasobów kapitałowych i kwalifikacji pracowniczych. Działalność produkcyjna, usługowa czy produkcyjno-usługowa może być wykonywania dla potrzeb przedsiębiorstw prowadzących działalność pozarolniczą lub rolniczą, natomiast działalność usługowa odnosi się zwykle do usług na rzecz podmiotów gospodarczych i instytucji (np. oświatowych, administracyjnych, finansowych, zdrowotnych), gospodarstw rolnych (najczęściej towarowych), ${ }^{4}$ W 2009 r. nakłady na badania i rozwój firmy Toyota (Japonia) wynosiły 6,8 mld USD, Roche (Szwaj-
caria) - 6,4 mld, Microsoft (USA) - 6,1 mld, Volkswagen (Niemcy) - 5,8 mld, Pfizer (USA) - 5,4 mld. 
gospodarstw domowych (naprawy różnego typu sprzętu, prace remontowe i in.) oraz na potrzeby ludności (działalność handlowa, hotelowa, turystyczna, oświatowa, kulturalna i in.).

Działalność pozarolniczą mogą prowadzić firmy o dużym potencjale techniczno-ekonomicznym, które reprezentują korporacje ponadnarodowe pracujące na potrzeby rynku światowego lub firmy krajowe, pracujące na potrzeby rynku krajowego ${ }^{5}$.

Firmy małe, średnie i mikrofirmy wykazują różnego typu powiązania i spełniają różne funkcje. Reprezentują je podmioty gospodarcze o funkcjach komplementarnych, które pracują na potrzeby najczęściej dużych korporacji. W wyniku powiązań kooperacyjnych dostarczają im różne podzespoły, części zamienne, wykonują prace remontowe itp.

Firmy standardowe pracują głównie na potrzeby regionalne. Wpływają na podnoszenie jakości poszczególnych sektorów, przyczyniając się w ten sposób do unowocześnianie struktur społeczno-gospodarczych i podnoszenia ich konkurencyjności.

Głównym celem mikroprzedsiębiorstw jest zaspakajanie potrzeb rynku lokalnego i ponadlokalnego. Rozwój ich działalności zależy w znacznym stopniu od zasobów finansowych ludności. Wzrost zasobów finansowych wpływa na większe zapotrzebowanie na ich usługi, natomiast spadek zasobów finansowych w znacznym stopniu ogranicza możliwości rozwoju i często prowadzi do zaniku działalności.

Odmienne potrzeby rynkowe stwarza działalność rolnicza. Generalnie nawiązuje ona do prowadzenia upraw zbożowych, hodowli i zaspakajania potrzeb remontowo-budowlanych (maszyn, urządzeń i gospodarstw). Odmienne możliwości rozwoju przedsiębiorczości dają wielkoobszarowe gospodarstwa towarowe, inne - gospodarstwa średnie produkujące częściowo na potrzeby rynku i potrzeby własne, a jeszcze inne - gospodarstwa małe, pracujące przeważnie na własne potrzeby konsumpcyjne.

Oznacza to, że w dążeniach do rozwoju przedsiębiorczości należy dokonać bardzo precyzyjnej oceny możliwości chłonności rynku na oferowane produkty lub usługi. Bardziej stabilny rozwój działalności produkcyjnej mają podmioty o wykształconych powiązaniach funkcjonalnych z korporacjami światowymi i krajowymi. Korporacje te stworzyły własne systemy rynkowe i w mniejszym stopniu podatne są na sezonowe wahania. Mniej stabilny jest los przedsiębiorstw pracujących na potrzeby lokalne, zwłaszcza na potrzeby ludności, które w zasadniczym stopniu związane są z rozmiarami zasilenia finansowego gospodarstw domowych. Wahania w zakresie wielkości dochodów gospodarstw domowych wpływają na zachowanie się podmiotów gospodarczych, zwłaszcza usługowych. W miarę zwiększania się zasobów finansowych gospodarstw domowych ich popyt na oferowane produkty i usługi wzrasta, a w miarę ich kurczenia się - maleje.

\section{Uwarunkowania rozwoju przedsiębiorczości}

Rozwój przedsiębiorczości dokonuje się w określonych uwarunkowaniach. Znaczący wpływ wywierają tu: przyjmowane reguły rozwoju, typy polityki społeczno-gospodarczej, skala przestrzeni oraz typy firm (tab. 1).

Regułami makroekonomicznego rozwoju rządzi się państwo, nawiązując także do przyjętych dokumentów lub umów międzynarodowych (np. Unii Europejskiej). Reguły mezoekonomiczne

\footnotetext{
${ }^{5}$ Nawiązujemy tu do struktury modelu ośrodka przemysłowego, w której wyróżniono przedsiębiorstwa o funkcjach egzogenicznych: podstawowe (wiodące) i komplementarne (standardowe) oraz endogenicznych (o funkcjach lokalnych), a także ich powiązania sieciowe w zakresie relacji produkcyjnych (Zioło 1988).
} 
wynikają z uwarunkowań regionalnych. Wykorzystuje się je dla pobudzania i rozwijania gospodarki układów przestrzennych lub określonych sektorów. Regułami mikroekonomicznymi kierują się poszczególne podmioty gospodarcze, których podstawowym celem jest maksymalizacja zysku często poprzez obniżanie kosztów produkcji.

Ważną rolę w zakresie kreowania rozwoju gospodarczego odgrywają typy polityki gospodarczej, w których przyjmuje się określone proporcje udziału mechanizmów rynkowych, oraz wpływ państwa na realizację zakładanych kierunków rozwoju gospodarczego, społecznego i kulturowego. Generalnie nawiązują one do podstawowego prawa ekonomicznego traktującego o tym, że potrzeby społeczne są nieograniczone, natomiast możliwości ich zaspokajania są ograniczone. Bardzo ważnym działaniem w tym zakresie pozostaje przeznaczanie określonych środków na cele konsumpcji i akumulacji oraz kreowanie odpowiednich instrumentów pośredniego lub bezpośredniego oddziaływania na kierunki rozwoju ${ }^{6}$. Krańcowe typy polityki mogą wahać się od polityki rynkowej, w której przemiany społeczno-gospodarcze regulują mechanizmy rynkowe z minimalnym udziałem państwa, do polityki centralnego sterowania, w której decydujący wpływ na kierunki rozwoju ma państwo. Między tymi krańcowymi typami występuje typ polityki mieszanej oraz interwencjonizm państwowy, gdzie reguły rynkowe i rola państwa występują w pewnych proporcjach oraz w różnym stopniu odnoszą się do określonych zakresów działalności gospodarczej czy sektorów gospodarki.

Zarówno efekty reguł rozwoju, jak i typy polityki są bardzo zróżnicowane w zależności od położenia w przestrzeni geograficznej: w przestrzeni światowej, Unii Europejskiej, Europie Wschodniej, poszczególnych krajach, regionach, a nawet układach lokalnych. Wynika to z tezy, że reguły rozwoju ekonomicznego, społecznego i kulturowego oraz typy polityki mają charakter aprzestrzenny, a zróżnicowane uwarunkowania przestrzenne stwarzają często odmienne możliwości ich działania i - w konsekwencji - dają często odmienne rezultaty ${ }^{7}$. Stąd np. zróżnicowane warunki i poziom rozwoju krajowych struktur regionalnych wymagają stosowania różnych instrumentów dla pobudzania ich rozwoju gospodarczego.

Rozwój przedsiębiorczości odnosi się do podmiotów gospodarczych odznaczających się różną wielkością potencjału ekonomicznego oraz funkcjami spełniającymi w przestrzeni gospodarczej. Wśród nich można wyróżnić przedsiębiorstwa o funkcjach krajowych, komplementarnych, standardowych, mikroprzedsiębiorstwa o funkcjach lokalnych (Zioło 1988 ).

Funkcje globalne i międzynarodowe spełniają duże korporacje obejmujące swoim zasięgiem oddziaływania na przestrzeń światową. Działania te przejawiają się głównie w zakresie powiązań rynkowych, inwestycyjnych, kapitałowych, organizacyjnych i in., które dokonują się najczęściej między podmiotami występującymi na obszarze światowych metropolii. Korporacje te są więc głównymi czynnikami integrującymi gospodarkę światową, intensyfikując w ten sposób działania procesów globalizacji (Zioło, Makieła 2003; Zioło 2006; Gierańczyk, Stańczyk 2003; Wajda 2003).

\footnotetext{
${ }^{6}$ Regulują to odpowiednie ustawy umożliwiające rozwój określonych typów działalności gospodarczej na danym obszarze, np. w okresie międzywojennym budowa Gdyni, Centralnego Okręgu Przemysłowego, a współcześnie - tworzenie specjalnych stref ekonomicznych (Kitowski 2009, Kudełko 2006, Zioło 1984).

${ }^{7}$ Obszary będące na różnym poziomie rozwoju gospodarczego czy odznaczające się odmiennymi uwarunkowaniami przyrodniczymi w różnym stopniu przygotowane są na wdrażanie reguł rozwoju społeczeństwa fazy informacyjnej. Inne typy polityki, np. w Korei Południowej i Północnej, dają różne efekty rozwoju społeczno-gospodarczego.
} 
Funkcje krajowe spełniają przedsiębiorstwa pracujące na wewnętrzne potrzeby gospodarki danego państwa. W przestrzeni krajowej nasilają one powiązania międzyregionalne, zwłaszcza między obszarami metropolitalnymi. Obejmują one także powiązania w zakresie organizacji zachodzące między siedzibami zarządów a oddziałami (Śleszyński 2007).

Funkcje komplementarne spełnią firmy pracujące na potrzeby korporacji międzynarodowych i krajowych. Dostarczają one określone produkty wytwarzane w ramach powiązań kooperacyjnych, zaopatrują w maszyny i urządzenia, programy informatyczne, surowce lub wykonują specjalistyczne usługi remontowe i budowlano-montażowe.

Podmioty gospodarcze o funkcjach komplementarnych pracują głównie na potrzeby danego układu regionalnego. Potrzeby w tym zakresie związane są ściśle z ich poziomem rozwoju i strukturą społeczno-gospodarczą. Stąd w określonych układach regionalnych podmioty gospodarcze odznaczają się różnym potencjałem oraz strukturą branżową.

Mikroprzedsiębiorstwa pracują przede wszystkim na potrzeby rynku lokalnego, a główny czynnik ich rozwoju to najczęściej zasoby finansowe ludności określające chłonność rynku.

W procesie rozwoju poszczególne typy przedsiębiorstw mogą zmieniać swoje funkcje, przechodząc od funkcji lokalnych, poprzez funkcje standardowe i krajowe, po funkcje światowe. Licznych przykładów dostarczają w tym zakresie rozwijające się firmy informatyczne, które rozpoczynały swoją działalność od niewielkich przedsiębiorstw i w wyniku dalszego rozwoju w ostatnich latach osiągnęły poważne sukcesy i stały się korporacjami o funkcjach światowych (Kilar 2009).

Poszczególne kategorie uwarunkowań rozwoju przedsiębiorczości kształtują się według własnych reguł rozwoju, co przedstawiają relacje występujące na przekątnej tablicy 1 . Na przykład relacje zachodzące między regułami makroekonomicznymi opisuje - $\mathrm{g}^{\mathrm{g}}$, między regułami polityki rynkowej $-\mathrm{x}^{\mathrm{x}}$, obszarami w przestrzeni światowej $-\mathrm{m}^{\mathrm{m}}$, między korporacjami $-\mathrm{h}^{\mathrm{h}}$, między mikroprzedsiębiorstwami $-\mathrm{k}^{\mathrm{k}}$ itp.

Wymienione kategorie uwarunkowań nie występują w odosobnieniu, ale zachodzą między nimi różnego typu relacje aktywne i pasywne. Relacje aktywne określają wpływ danej kategorii uwarunkowań na pozostałe kategorie, które przedstawiają wiersze tablicy, np. wpływ reguł makroekonomicznych $(\mathrm{G})$ na pozostałe elementy uwarunkowań przedstawia wiersz relacji od $\mathrm{g}^{\mathrm{s}}$ po $\mathrm{g}^{\mathrm{k}}$; wpływ korporacji światowych $(\mathrm{H})$ na pozostałe elementy przedstawia wiersz relacji od $\mathrm{h}^{\mathrm{g}}$ po $\mathrm{h}^{\mathrm{k}}$. W podobny sposób można określić wpływ poszczególnych elementów uwarunkowań na pozostałe elementy. Relacje pasywne ilustrują kolumny, które przedstawiają wpływ poszczególnych elementów uwarunkowań na daną kategorię, np. wpływ poszczególnych elementów uwarunkowań na przestrzeń Europy Wschodniej przedstawia kolumna relacji od gw po $\mathrm{k}^{\mathrm{w}}$; a wpływ poszczególnych elementów uwarunkowań na przedsiębiorstwa ilustruje wiersz od $g^{\mathrm{k}}$ po $\mathrm{b}^{\mathrm{k}}$ itp.

Przedstawione kategorie uwarunkowań oraz relacje zachodzące między nimi wskazują na dużą złożoność problematyki funkcjonowania i rozwoju podmiotów gospodarczych oraz instytucji. Dlatego przedsiębiorca, który chce podejmować racjonalne decyzje, powinien się z nimi zapoznać i określić w nich miejsca firmy, którą zarządza lub którą chce założyć.

\section{Ksztaltowanie mikroprzedsiębiorstw}

Przedstawione rozważania wskazują, że także poszczególne mikroprzedsiębiorstwa funkcjonują i kształtują się w bardzo złożonych uwarunkowaniach - na tablicy 1 wewnętrzny proces ich funkcjonowania przedstawia $\mathrm{k}^{\mathrm{k}}$. Jednak i one w swoisty sposób wpływają na poszczególne firmy i oddziałują na różnego typu uwarunkowania. Wpływ poszczególnych podmiotów na poszczególne segmenty uwarunkowań przedstawia wiersz tablicy od $\mathrm{k}^{\mathrm{g}}$ po $\mathrm{k}^{\mathrm{b}}$, 


\begin{tabular}{|c|c|c|c|c|c|c|c|c|c|c|c|c|c|c|c|}
\hline \multirow{5}{*}{ 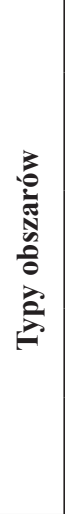 } & 尚当 & $\because \ddot{b}_{0}$ & $\because$ & $\stackrel{2}{2}$ & $\ddot{x}$ & $\stackrel{y}{\lambda}$ & 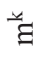 & $\stackrel{y}{=}$ & $\frac{4}{3}$ & $\ddot{0}$ & $\stackrel{I}{I}$ & $\ddot{0}$ & 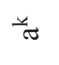 & $\ddot{0}$ & $\underline{\sim}$ \\
\hline & 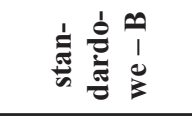 & $f_{0}$ & is & $\stackrel{2}{2}$ & $\stackrel{\circ}{x}$ & $\stackrel{1}{>}$ & $\stackrel{\cap}{\Xi \Xi}$ & $\stackrel{2}{=}$ & $B$ & O & ב & $\dot{0}$ & శ & م & 党 \\
\hline & 当光竞导《 & "5 & in & $\stackrel{\pi}{2}$ & $\ddot{x}$ & $\stackrel{\pi}{>}$ & $\stackrel{\Xi}{\Xi}$ & $\stackrel{\pi}{\exists}$ & 3 & ే & 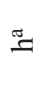 & ూర & $\pi$ & مَ & $\stackrel{\pi}{2}$ \\
\hline & 承 & ion & in & $\stackrel{0}{2}$ & ${ }^{\circ} x$ & $i$ & $\stackrel{\circ}{\Xi}$ & $\stackrel{\circ}{=}$ & $\vdots$ & i & $\stackrel{1}{I}$ & : & $\stackrel{\circ}{\pi}$ & م & ix \\
\hline & 总 & ${ }^{5}=0$ & 需 & $\stackrel{2}{2}$ & $\tilde{x}$ & $\vec{\lambda}$ & ઘే & 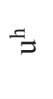 & 3 & $=$ & $\exists$ & $=0$ & $\Rightarrow$ & $\Xi$ & 五 \\
\hline \multirow{4}{*}{ 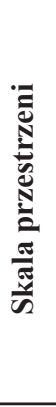 } & 预 & iod & is & ${ }^{\circ} \mathrm{a}$ & $\ddot{x}$ & $i$ & $\stackrel{\Xi}{\sharp}$ & $\stackrel{0}{=}$ & $i$ & ن & If & :0 & ${ }_{\pi}$ & م: & 许 \\
\hline & 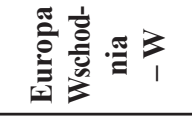 & 菏o & is & 3 & 3 & 吾 & $\stackrel{3}{\Xi}$ & 3 & 3 & 30 & 3 & 30 & $\sqrt[3]{\pi}$ & م3 & 童 \\
\hline & 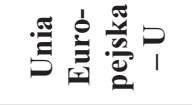 & ${ }^{2} 00$ & $\tilde{F}_{n}$ & $\stackrel{z}{a}$ & $\vec{x}$ & $\vec{\lambda}$ & בี & $\Rightarrow$ & $\overline{3}$ & $\vec{J}$ & $\exists$ & $\exists$ & च & ב & $\underline{z}$ \\
\hline & 离 & $z_{0}$ & $\Xi_{\infty}$ & $\Xi$ & 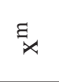 & 忩 & $\Xi$ & $\Xi$ & $\frac{E}{3}$ & ‡ & छ & $\Xi$ & ઘ & छ & 㱏 \\
\hline \multirow{2}{*}{ 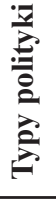 } & 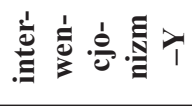 & ते & के & है & $\vec{x}$ & i & ఏ్ & 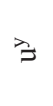 & 高 & $\hat{0}$ & 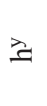 & $\widehat{\partial}$ & స & 3 & 齐 \\
\hline & 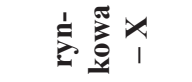 & $x_{0}$ & $x_{\infty}$ & ¿ & $\stackrel{\sim}{\star}$ & $\stackrel{x}{\lambda}$ & $\stackrel{{ }^{\circ}}{\mathrm{g}}$ & $\stackrel{x_{j}}{ }$ & $\stackrel{x}{3}$ & $x_{0}$ & $\stackrel{\ldots}{ \pm}$ & $\approx_{0}$ & ${ }_{\pi}^{*}$ & مِّ & $\underline{\underline{x}}$ \\
\hline \multirow{3}{*}{ 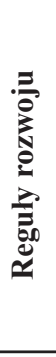 } & 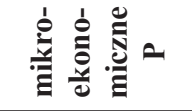 & के & के & בै & $\ddot{x}$ & $\bar{\lambda}$ & $\tilde{\Xi}$ & 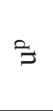 & $\hat{z}$ & $\overrightarrow{0}$ & $\approx$ & 8 & సे & قै & 咅 \\
\hline & 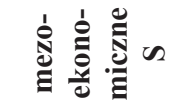 & $b_{0}$ & $\tilde{c}_{n}$ & $\stackrel{n}{n}$ & $\tilde{x}$ & 3 & $\stackrel{\infty}{\Xi}$ & $\stackrel{n}{=}$ & $\hat{\beta}$ & "s & $\stackrel{n}{=}$ & s & ? & מ & 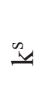 \\
\hline & ט & 매 & 㤎 & $\stackrel{D D}{\Omega}$ & $\stackrel{D D}{\rtimes}$ & $\stackrel{\text { on }}{2}$ & $\stackrel{\infty 0}{\Xi}$ & $\stackrel{D D}{=}$ & $\stackrel{\infty}{3}$ & 哭 & $\stackrel{\infty}{=}$ & of & $\stackrel{D}{\sigma}$ & مد & 叫 \\
\hline & \multirow[t]{2}{*}{ 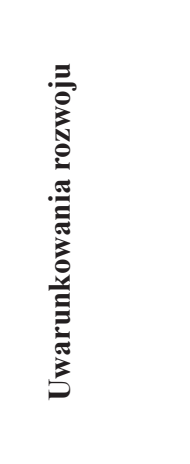 } & 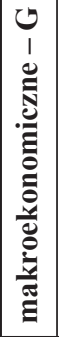 & 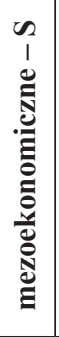 & 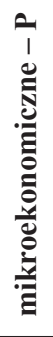 & $\begin{array}{l}x \\
1 \\
0 \\
0 \\
0 \\
0 \\
0 \\
0 \\
0\end{array}$ & 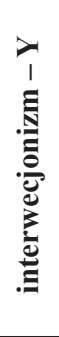 & 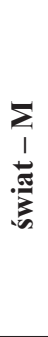 & 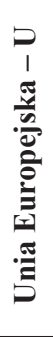 & 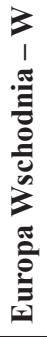 & $\frac{0}{1}$ & 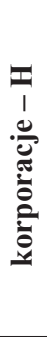 & 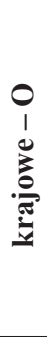 & 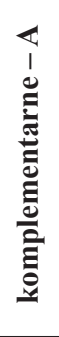 & 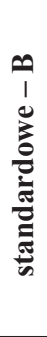 & 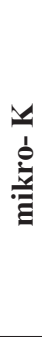 \\
\hline & & \multicolumn{3}{|c|}{ 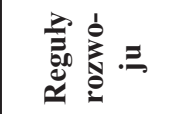 } & \multicolumn{2}{|c|}{ 党: } & \multicolumn{4}{|c|}{ 焉离泀 } & \multicolumn{5}{|c|}{ 至 } \\
\hline
\end{tabular}


natomiast wpływ poszczególnych segmentów uwarunkowań na podmiot gospodarczy ilustruje kolumna od $\mathrm{g}^{\mathrm{k}}$ po $\mathrm{b}^{\mathrm{k}}$. Dlatego należy przyjąć, że sukces ekonomiczny tej kategorii podmiotów gospodarczych gwarantuje uprzednio poznanie zmieniających się uwarunkowań oraz wyznaczanie dla nich miejsca wśród różnorodnych kategorii podmiotów gospodarczych.

Mikroprzedsiębiorstwa nie stanowią jednorodnych podmiotów gospodarczych, ale odznaczają się różnymi funkcjami, które spełniają w przestrzeni gospodarczej układów lokalnych i ponadlokalnych. Wynikają one głównie z określonego rodzaju działalności gospodarczej, który umożliwia im kształtowanie odpowiednich powiązań rynkowych. Powiązania te mogą odnosić się do: kooperacji z firmami międzynarodowymi, krajowymi, działalności usługowo-produkcyjnej z innymi mikropodmiotami gospodarczymi, produkcji i usług dla ludności i in. (ryc. 2). Poszczególne typy powiązań wymagają odmiennego zarządzania zgodnie z regułami mikroekonomicznymi oraz dają różne możliwości rozwoju wynikające z zmieniających się uwarunkowań otoczenia.

Ryc. 2. Funkcje produkcyjno-usługowe mikroprzedsiębiorstw (podmiotów gospodarczych osób fizycznych)

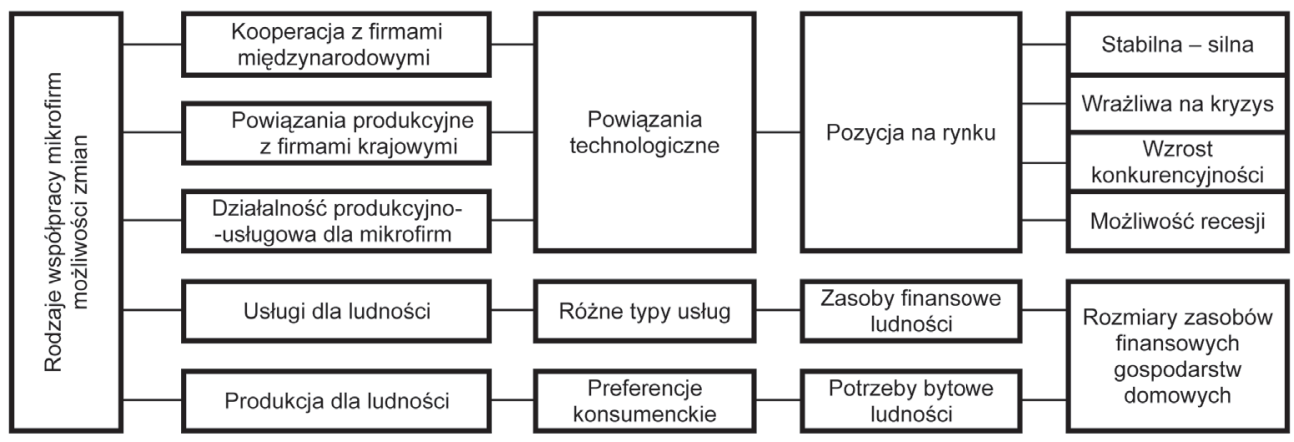

Źródło: opracowanie własne.

Rozwijanie powiązań kooperacyjnych mikroprzedsiębiorstw z korporacjami międzynarodowymi wymaga dbałości o ciągłe doskonalenia procesów wytwarzania oraz zdobywania odpowiednich umiejętności, celem realizacji zamówień i dostarczania właściwych produktów, które następnie wykorzystane są do montowania bardziej złożonych podzespołów. W stosunku do innych podmiotów gospodarczych kształtujące się powiązania technologiczne muszą opierać się na regułach konkurencyjnych zarówno w zakresie jakości dostarczanych produktów czy wykonywanych usług, jak i pod względem oferowanych cen. Współpraca z korporacją umożliwia wdrażanie nowych technologii, zdobywanie kwalifikacji, zapewnia także stabilność działalności oraz ciągły odbiór określonej liczby zamówionych produktów czy usług po ustalonej cenie. Umożliwia to planowanie rozwoju działalności w dłuższym okresie czasu, mniej podatnej na wahającą się koniunkturę rynkową. Podobne relacje, ale mniej trwałe, zachodzą w wyniku powiązań produkcyjno-usługowych z firmami krajowymi, które są podatniejsze na wahania koniunkturalne. Najmniej stabilne możliwości współpracy występują między działalnością produkcyjno-usługową mikroprzedsiębiorstw. Współpraca ta wymaga bowiem dużej elastyczności zmieniającego się rynku oraz ciągłych poszukiwań pojawiających się na nim luk.

Odrębną kategorię mikroprzedsiębiorstw stanowią podmioty wykonujące działalność produkcyjną oraz usługową na potrzeby ludności. Działalność ich nawiązuje do preferencji 
konsumenckich i zapotrzebowania na różnego rodzaju usługi w lokalnych uwarunkowaniach ekonomicznych, społecznych i kulturowych. W zasadniczym stopniu na możliwości rozwoju tego typu podmiotów wpływają zasoby finansowe gospodarstw domowych, które kształtują określone rozmiary rynku lokalnego.

Reasumując, należy przyjąć, że dla rozwoju działalności poszczególnych kategorii mikroprzedsiębiorstw podstawowe znaczenie ma pozycja odbiorców na rynku współpracujących z nimi korporacji międzynarodowych, firm krajowych czy innych mikroprzedsiębiorstw. Najbardziej stabilną sytuacją rynkową odznaczają się zwykle korporacje międzynarodowe. W porównaniu z pozostałymi firmami są one mniej wrażliwe na kryzys i ograniczają możliwość recesji współpracujących z nimi mikrofirm. Wymagają natomiast dbania o wzrost konkurencyjności oferowanych produktów i usług. Firmy krajowe są bardziej wrażliwe na zmieniającą się sytuację rynkową. Wynika to z większych możliwości obniżania ich pozycji konkurencyjnej, co z kolei może prowadzić do recesji. Najmniej stabilne pod tym względem są relacje z mikroprzedsiębiorstwami. Natomiast rozwój działalności mikroprzedsiębiorstw pracujących na potrzeby rynku lokalnego w zasadniczym stopniu związany jest z tendencjami, które kształtują rozmiary źródeł zasilania finansowania gospodarstw domowych. Wraz z ich zmniejszaniem się maleje popyt na oferowane przez te firmy produkty i usługi, często podejmowane są prace we własnym zakresie (np. gastronomiczne, kulturowe). Zmniejsza się także rynek na potrzeby konsumenckie lub potrzeby są zaspakajane przez tańsze suplementy. Natomiast wzrost zasilania finansowego gospodarstw domowych wpływa na zwiększanie rozmiarów rynku dla podmiotów gospodarczych o funkcjach lokalnych.

\section{Kreowanie zachowań przedsiębiorczych}

Poznanie typów działalności, uwarunkowań rozwoju przedsiębiorczości oraz możliwości rozwoju mikroprzedsiębiorstw, pozwala na kształtowanie cech osobowych przedsiębiorcy oraz otoczenia lokalnego, regionalnego i krajowego. Na wstępie należy przyjąć tezę, że procesy rozwoju podmiotu gospodarczego kreuje przedsiębiorca, opierając się na regułach ekonomicznych, funkcjonujących w zmieniającym się otoczeniu, kształtowanym przez nasilające się procesy rozwoju cywilizacyjnego, a także na zasadach etyki. Wyznaczają one kierunki rozwijania cech osobowych oraz określają umiejętności posługiwania się wiedzą odnoszącą się do zachowań przedsiębiorstw w zmieniającym się otoczeniu (tab. 2).

Kształtowanie cech osobowych przedsiębiorcy zasadza się na wrodzonych zdolnościach i związanych z nimi predyspozycjach. Umożliwiają one wykształcanie aspiracji, które są podstawowym motorem rozwijania działalności przez człowieka. Wpływają one na wybór odpowiedniego kierunku kształcenia oraz dbanie o zdobywanie umiejętności dokształcania i doskonalenia w określonej dziedzinie. Rozwijają one inteligencję człowieka oraz zainteresowania związane z podejmowanymi działaniami.

Cechy te dają podstawę do rozwijania umiejętności stawiania racjonalnych celów oraz wytrwałości w ich realizacji na tle zmieniającego się otoczenia. Dzięki temu kształtuje się silna osobowość, odporna na stres i napotykane niepowodzenia, a także potrafiąca posługiwać się zdobytą wiedzą i współpracować ze środowiskiem wewnętrznym (zespołem współpracowników) i zewnętrznym (ludźmi z otoczenia biznesowego).

Ważną rolę w tym zakresie odgrywa umiejętne wykorzystanie reguł kształtowania procesów technologicznych i ekonomicznych dla lokalizacji czy aktywizacji czynników pobudzania rozwoju firmy na podstawie reguł cyklu życia produktu. 
Tab. 2. Wybrane cechy osobowe przedsiębiorczego człowieka i jego otoczenia

\begin{tabular}{|c|c|}
\hline \multicolumn{2}{|r|}{$\begin{array}{c}\text { Procesy globalizacji kreuje przedsiębiorca, opierając się na regułach ekonomicznych } \\
\text { i zasadach etyki, funkcjonujących w zmieniającym się otoczeniu ksztaltowanym } \\
\text { przez zmieniające się tendencje rozwoju cywilizacyjnego }\end{array}$} \\
\hline \multirow{12}{*}{$\begin{array}{l}\text { Cechy } \\
\text { osobowe }\end{array}$} & wrodzone predyspozycje \\
\hline & aspiracje - podstawowy motor działania człowieka \\
\hline & $\begin{array}{l}\text { wykształcenie i jego aktualizowanie formalne, samokształcenie, doskonalenie } \\
\text { zawodowe }\end{array}$ \\
\hline & rozwijana inteligencja \\
\hline & zainteresowanie działaniami i pracowitość \\
\hline & $\begin{array}{l}\text { umiejętność stawiania celów na podstawie analizy zmieniającego się otoczenia } \\
\text { (wypełnianie luk rynku) }\end{array}$ \\
\hline & wytrwałość i elastyczność w zakresie realizowania celów \\
\hline & $\begin{array}{l}\text { silna osobowość (odporność na stres i niepowodzenia, umiejętność gospodarowania } \\
\text { sukcesem) }\end{array}$ \\
\hline & umiejętność posługiwania się interdyscyplinarną wiedzą \\
\hline & $\begin{array}{l}\text { umiejętność i rzetelność współpracy ze środowiskiem wewnętrznym i otoczeniem } \\
\text { (ograniczanie i niwelowanie konfliktów) }\end{array}$ \\
\hline & $\begin{array}{l}\text { umiejętność wykorzystywania reguł procesu techniczno-ekonomicznego dla } \\
\text { pobudzania rozwoju firmy }\end{array}$ \\
\hline & umiejętność określania faz cyklu koniunkturalnego na dany produkt lub usługę \\
\hline \multirow{7}{*}{$\begin{array}{l}\text { Warunki } \\
\text { otoczenia }\end{array}$} & jakość instytucji edukacyjnych \\
\hline & atrakcyjność obszaru i kultura innowacyjna \\
\hline & inwestycje krajowe i zagraniczne \\
\hline & jakość samorządów \\
\hline & jakość instrumentów pośredniego i bezpośrednio oddziaływania \\
\hline & otoczenie finansowe \\
\hline & jakość polityki społeczno-gospodarczej \\
\hline
\end{tabular}

Źródło: opracowanie własne.

Kształtowanie postaw przedsiębiorczych wymaga przyjaznych sytuacji w otoczeniu lokalnym, regionalnym i krajowym. Przejawia się to w:

- dbaniu o podnoszenie poziomu instytucji edukacyjnych na różnym poziomie kształcenia, dokształcania i doskonalenia zawodowego,

- podnoszeniu atrakcyjności danego obszaru i rozwijania kultury innowacyjnej dla przyciągania endogenicznych czynników rozwoju, głównie w formie inwestycji, napływu kapitału, wykształconej kadry, zintensyfikowanie działalności inwestycji krajowych i zagranicznych,

- przyjaznym stosunku i jakości władz samorządowych do podnoszenia konkurencyjności danego obszaru, generowaniu instrumentów pośredniego i bezpośredniego oddziaływania na rzecz rozwoju gospodarczego, społecznego i kulturowego,

- kształtowaniu sprawnie działającego otoczenia finansowego. 
Odpowiednio przygotowani przedsiębiorcy, członkowie władz samorządowych i racjonalnie zachowujące się społeczeństwo będą pobudzać wszelkie możliwe czynniki rozwoju oraz podnosić jakość lokalnej, regionalnej czy krajowej polityki ekonomicznej i społecznej sprzyjającej rozwojowi gospodarczemu.

Wskazuje to na bardzo złożone procesy kształtowania człowieka przedsiębiorczego. Podstawą w tym zakresie jest edukacja przedsiębiorczości, której celem jest poznanie procesów rozwoju na tle zmieniających się tendencji rozwoju cywilizacyjnego, wdrażanie do umiejętnego posługiwania się wiedzą oraz kształtowanie określonych cech osobowych młodzieży.

W warunkach gospodarki rynkowej kształcenie w tym zakresie jest niezbędne nie tylko dla przyszłych przedsiębiorców, którzy kierować będą różnego rodzaju podmiotami gospodarczymi, ale także dla osób, które w przyszłości podejmować będą zajęcia w wolnych zawodach czy zarządzać gospodarstwem domowym. Wiedza z tego zakresu jest więc potrzebna ludziom sztuki (prezentowanie efektów pracy, zdobywanie dla nich rynku), osobom zakładającym własne kancelarie, lekarzom podejmującym samodzielną działalność związaną z ochroną zdrowia. Przyda się ona też w gospodarstwie domowym, dla którego ważną rzeczą jest dbałość o odpowiednie zasilanie finansowe oraz racjonalny podział uzyskanych środków. Dla skutecznej działalności niezbędna jest podstawowa wiedza z zakresu organizacji, marketingu, konkurencyjnego zachowania, składania ofert itp. Często bowiem dla realizacji swoich zamiarów i podnoszenia efektów działalności trzeba podejmować decyzje związane z miejscem lokalizacji działalności gospodarczej, rynkami, korzystaniem z usług instytucji finansowych lub prawnych oraz współdziałać z instytucjami administracyjnymi i pozarządowymi. Edukacja przedsiębiorczości na poziomie kształcenia ponadpodstawowego daje więc podstawy do kształtowania odpowiednich zachowań umożliwiających odnoszenie życiowego sukcesu na wielu polach działalności człowieka. Nasilające się procesy globalizacji i przechodzenia do fazy społeczeństwa informacyjnego wymagają bowiem odpowiednio przygotowanych ludzi, którzy opanują nowe umiejętności i przyjmą nowe wzorce zachowań niezbędne do swobodnego poruszania się w krajowej, europejskiej i światowej przestrzeni gospodarczej, społecznej i kulturowej.

\section{Literatura}

1. Bojar E., (red.), 2008, Bezpośrednie inwestycje zagraniczne $w$ regionach słabo rozwiniętych, Dom Organizatora, Toruń.

2. Borowiec M., 2009, Funkcje wyższych uczelni w procesie kształtowania Rzeszowskiego Obszaru Metropolitalnego [w:] Potencjalne metropolie ze szczególnym uwzględnieniem Polski wschodniej, Z. Makieła (red.), Studia KPZK PAN, t. CXXV, PAN Komitet Przestrzennego Zagospodarowania Kraju, Warszawa, s. 259-279.

3. Borowiec M., 2009, Rola edukacji w ksztaltowaniu społeczeństwa informacyjnego [w:] Rola przedsiębiorczości w kształtowaniu społeczeństwa informacyjnego, Z. Zioło, T. Rachwał (red.), „Przedsiębiorczość - Edukacja”, nr 5, Nowa Era, Zakład Przedsiębiorczości i Gospodarki Przestrzennej Instytutu Geografii Uniwerystetu Pedagogicznego w Krakowie,Warszawa-Kraków, s. 37-47.

4. Domański B., 2001, Kapitał zagraniczny w przemyśle Polski. Prawidłowości rozmieszczenia, uwarunkowania i skutki, Uniwersytet Jagielloński, Instytut Geografii i Gospodarki Przestrzennej, Kraków.

5. Gierańczyk W., Stańczyk A., 2003, Korporacje międzynarodowe w przestrzeni globalnej [w:] Ksztattowanie się struktur przemystowych, Z. Zioło, Z. Makieła (red.), „Prace Komisji Geografii Przemysłu”, nr 5, Warszawa-Kraków, s. 73-84.

6. Kamińska W., 2006, Pozarolnicza indywidualna działalność gospodarcza w Polsce w latach 1988-2003, „Prace Geograficzne”, nr 203, IGiPZ PAN, Warszawa. 
7. Kamińska W., Heffner K. (red.), 2010, Kapitał ludzki i społeczny w procesie rozwoju obszarów wiejskich, Studia KPZK PAN, t. CXXVI, Warszawa.

8. Kilar W., 2009a, Korporacje informatyczne jako element struktury metropolii [w:] Potencjalne metropolie ze szczególnym uwzględnieniem Polski wschodniej, Z. Makieła (red.), Studia KPZK PAN, t. CXXV, PAN Komitet Przestrzennego Zagospodarowania Kraju, Warszawa, s. 136-153.

9. Kilar W., 2009, Rola korporacji Apple w ksztaltowaniu społeczeństwa informacyjnego [w:] Rola przedsiębiorczości $w$ ksztaltowaniu społeczeństwa informacyjnego, Z. Zioło, T. Rachwał (red.), „Przedsiębiorczość - Edukacja”, nr 5, Nowa Era, Zakład Przedsiębiorczości i Gospodarki Przestrzennej Instytutu Geografii Uniwerystetu Pedagogicznego w Krakowie, Warszawa-Kraków, s. 48-56.

10. Kitowski J., 2009, Influence of Global Economic Crisis on Operation of Special Economic Zones in Poland [w:] Countries if Central \& Eastern Europe Versus Global Economic Crisis, Polish Academy of Sciences, Institute of Geography and Spatial Organizations, J. Kitowski (ed.), „Geopolitical Studies”, vol. 15, Warsaw, 235-262.

11. Kudełko J., 2006, Efekty funkcjonowania specjalnych stref ekonomicznych w Polsce jako instrumentu polityki regionalnej. Prace z zakresu polityki ekonomicznej i programowania rozwoju, „Zeszyty Naukowe Akademii Ekonomicznej w Krakowie”, nr 709, Kraków, s. 39-57.

12. Rachwał T., 2009, Rola przedsiębiorstw przemysłowych w ksztaltowaniu obszarów metropolitalnych [w:] Potencjalne metropolie ze szczególnym uwzględnieniem Polski wschodniej, Z. Makieła (red.), Studia KPZK PAN, t. CXXV, PAN Komitet Przestrzennego Zagospodarowania Kraju, Warszawa, s. $121-135$.

13. Śleszyńki P., 2007, Gospodarcze funkcje kontrolne w przestrzeni Polski, „Prace Geograficzne”, nr 213, IGiPZ PAN, Warszawa.

14. Turczyn-Zioło I., 1979, Aspiracje i plany życiowe młodzieży szkót ponadpodstawowych obszaru uprzemysławianego i rolniczego (na przyktadzie województwa tarnobrzeskiego), „Zeszyty Badań Rejonów Uprzemysławianych PAN", z. 72.

15. Wajda E., 1963, Proces kształtowania się Motoroli jako firmy ponadnarodowej [w:] Ksztaltowanie się struktur przemysłowych, Z. Zioło, Z. Makieła (red.), „Prace Komisji Geografii Przemysłu”, nr 5, Warszawa-Kraków, s. 85-114.

16. Zioło Z., 1978, Dochody ludności z pracy pozarolniczej [w:] Przemiany spoleczno-ekonomiczne Tarnobrzeskiego Rejonu Uprzemystawianego, seria „Problemy Rejonów Uprzemysławianych”, PWN, Warszawa, s. 105-120.

17. Zioło Z., 1984, Wpływ polityki państwa na rozwój i przemiany struktury przestrzennej przemystu (na przykładzie Centralnego Okręu Przemysłowego), ,Folia Geographica. Series Geographica-Oeconomica", vol. XVII, s. 89-102.

18. Zioło Z., 1988, Funkcjonowanie i rozwój przedsiębiorstwa przemystowego w przestrzeni geograficznej [w:] Zakład przemysłowy w akademickim kształceniu nauczycieli geografii, ,Materiały i Sprawozdania", nr 16, Z. Zioło (red.), COMSN, Wyd. Nauk. WSP, Kraków, s. 8-24.

19. Zioło Z., Makieła Z. (red.), 2003, Przemyst w procesie globalizacji, „Prace Komisji Geografii Przemysłu PTG”, nr 6, Warszawa-Kraków.

20. Zioło Z., 2006, Zróżnicowanie światowej przestrzeni przemysłowej w świetle siedzib zarzadów wiodacych korporacji [w:] Międzynarodowe uwarunkowania rozwoju polskiego przemystu, „Prace Komisji Geografii Przemysłu PTG”, nr 8, Warszawa-Kraków, s. 9-26.

21. Zioło Z., Rachwał T. (red.), 2005, Przedsiębiorczość a współczesne wyzwania cywilizacyjne, „Przedsiębiorczość - Edukacja”, nr 1, Wydawnictwo MiWa, Zakład Przedsiębiorczości i Gospodarki Przestrzennej Instytutu Geografii Akademii Pedagogicznej w Krakowie, Warszawa-Kraków.

22. Zioło Z., Rachwał T. (red.), 2006, Rola przedsiębiorczości w podnoszeniu konkurencyjności społeczeństwa i gospodarki, „Przedsiębiorczość - Edukacja”, nr 2, Nowa Era, Zakład Przedsiębiorczości i Gospodarki Przestrzennej Instytutu Geografii Akademii Pedagogicznej w Krakowie, Warszawa-Kraków. 
23. Zioło Z., Rachwał T. (red.), 2007, Rola przedsiębiorczości w aktywizacji gospodarczej-zarys mode$l u$, „Przedsiębiorczość - Edukacja”, nr 3, Nowa Era, Zakład Przedsiębiorczości i Gospodarki Przestrzennej Instytutu Geografii Akademii Pedagogicznej w Krakowie, Warszawa-Kraków.

24. Zioło Z., Rachwał T. (red.), 2008, Rola przedsiębiorczości w gospodarce opartej na wiedzy, „Przedsiębiorczość - Edukacja”, nr 4, Nowa Era, Zakład Przedsiębiorczości i Gospodarki Przestrzennej Instytutu Geografii Uniwerystetu Pedagogicznego w Krakowie, Warszawa-Kraków.

25. Zioło Z., Rachwał T. (red.), 2009, Rola przedsiębiorczości w ksztaltowaniu społeczeństwa informacyjnego, „Przedsiębiorczość - Edukacja”, nr 5, Nowa Era, Zakład Przedsiębiorczości i Gospodarki Przestrzennej Instytutu Geografii Uniwerystetu Pedagogicznego w Krakowie, Warszawa-Kraków.

26. Zioło Z., Rachwał T. (red.), 2010, Przedsiębiorczość w warunkach integracji europejskiej, „Przedsiębiorczość - Edukacja”, nr 6, Nowa Era, Zakład Przedsiębiorczości i Gospodarki Przestrzennej Instytutu Geografii Uniwerystetu Pedagogicznego w Krakowie, Warszawa-Kraków.

\section{The Role of Entrepreneurship in the Conditions of Intensifying Globalization Processes}

The paper presents the issues of role of entrepreneurship development in the conditions of intensifying globalization. Particular attention is paid to the impact of the rules of economic development, types of economic policies, the scale of spatial systems and types of businesses. Against this background, the paper discusses the functions and economic development of small businesses. 


\section{Sławomir Dorocki}

Uniwersytet Pedagogiczny

im. Komisji Edukacji Narodowej

w Krakowie

\section{Inwestycje zagraniczne we Francji w dobie globalizacji}

Ostatnie 50 lat, a w szczególności przełom XX i XXI w., to okres znaczącej intensyfikacji międzynarodowych powiązań ekonomicznych, będących częścią ogólnego procesu globalizacji gospodarki światowej. W wyniku tych procesów nastąpiło m.in. zwiększanie się stopnia otwartości gospodarek państw, co z kolei wpłynęło na wzrost roli inwestycji zagranicznych jako czynnika wzrostu gospodarczego kraju (Majewska, Grala 2002).

Współcześnie inwestycje zagraniczne nie tylko warunkują rozwój poszczególnych państw, lecz także stanowią ważny czynnik rozwoju regionalnego. Na wagę bezpośrednich inwestycji zagranicznych w procesie wzrostu gospodarczego zarówno w ujęciu krajowym, jak i zagranicznym zwrócili uwagę w swych publikacjach m.in.: Kudełko (1996), Chojnicki (1999), Domański (2002), Bojar (2001), Namyślak (2002), Gorzelak (2003), Stryjakiewicz (2004), Sala (2006), Sobala-Gwosdz (2006), Zioło (2006) i Brezdeń (2006).

Bezpośrednie inwestycje zagraniczne (BIZ) stanowią obecnie jedną z najbardziej pożądanych form dopływu zagranicznego kapitału do kraju. Wśród przytaczanych atutów inwestycji znajdują się m.in.: brak zadłużenia zagranicznego, generowanie wzrostu gospodarczego kraju oraz przyczynianie się do spadku bezrobocia. Ponadto inwestycje powodują przepływ technologii, wprowadzają innowacyjne metody zarządzania, otwierają dostęp do nowych rynków oraz wspomagają rozwój infrastruktury produkcyjnej. Potwierdzeniem istotności BIZ może być fakt, że w pozyskiwanie inwestycji zagranicznych zaangażowane są głowy największych państw świata, a sam wybór kraju jako miejsca inwestycji odbierany jest jako sukces całej ekipy rządzącej.

W części pierwszej prezentowanego opracowania dokonano krótkiej charakterystyki inwestycji zagranicznych we Francji na tle innych państw. Następnie przedstawiono regionalne zróżnicowanie tych inwestycji w oparciu o liczbę inwestycji oraz miejsc pracy generowanych przez bezpośrednie inwestycje zagraniczne. Na koniec zanalizowano czynniki wpływające na lokalizacje inwestycji zagranicznych. Należy tu zaznaczyć, że w przypadku badania zależności tych procesów rodzi się pytanie o kierunek oraz relacje, jakie zachodzą pomiędzy badanymi zjawiskami (zależność bądź współwystępowanie). Dokonując porównań, wykorzystano dane odnoszące się do czynników mogących stanowić stymulanty inwestycji. Analizowane czynniki występowały wcześniej niż sama inwestycja, nie można jednakże wykluczyć możliwości, że badane inwestycje trafiają do regionów wcześniej już wypromowanych, zgodnie z modelem kumulatywnej przyczynowości Myrdala (1957). Uwzględniając powyższą możliwość, badane stymulanty byłyby zatem wynikiem inwestycji, a nie ich inicjatorem. Mielibyśmy więc do czynienia z współwystępowaniem, a nie - zależnością badanych procesów.

W analizie wykorzystano dane statystyczne publikowane przez Bank Francji (Banque de France), w tym głównie roczne bilanse i raporty: Bilan sur les investissements étrangers en 
Franc Tableau de bord de l'attractivité de la France oraz Bilan des investissements étrangers créateurs d'emploi en France. Ponadto wykorzystano dane dotyczące wielkości inwestycji, zawarte w zestawieniach OECD i UNCTAD (United Nations Conference on Trade and Development) World investment report.

Na wstępie rozważań nad problemem inwestycji zagranicznych we Francji trzeba wspomnieć o funkcjonującym w tym kraju od lat scentralizowanym systemie administracji państwowej, obejmującym również decyzje inwestycyjne. Głównym organem państwowym jest Francuska Agencja Inwestycji Zagranicznych (AFII - Agence Française pour les Investissements Internationaux) działająca na rzecz pozyskania inwestorów zagranicznych. Ponadto każdy region posiada osobną instytucję promującą daną jednostkę wśród zagranicznych inwestorów.

Wśród działań rządu należy wymienić funkcjonujący od 1982 r. system subwencji dla inwestorów (który w 2008 r. wyniósł 20 mld euro), strefy bezcłowe, wprowadzone w $1992 \mathrm{r}$. zwolnienia od kosztów społecznych oraz powstałe w 1996 r. (a zmodyfikowane w 2008 r.) obszary i strefy działań dla inwestycji szczególnie istotnych dla rozwoju gospodarczego. Inwestorzy w powstałych strefach i sektorach gospodarki mogą uzyskać całkowite zwolnienie od podatku dochodowego oraz od kosztów socjalnych, okresowe zwolnienia z podatku zawodowego, zwolnienia od podatku gruntowego, a nawet zwolnienia od podatku dochodowego od osób fizycznych dla rzemieślników i handlowców. Odrębną kwestią jest wspieranie przez państwo badań i rozwoju oraz pomoc publiczna w zakresie szkoleń zawodowych pracowników, również w odniesieniu do inwestycji zagranicznych. Wszystkie podjęte działania są skierowane z jednej strony na przyciągnięcie inwestorów, a z drugiej - na zrównanie uprawnień inwestorów zagranicznych i krajowych oraz zrównanie ich uprawnień odnośnie prowadzonej działalności gospodarczej.

Powyższe działania rządu oraz uwarunkowania międzynarodowe przyniosły w ostatnich latach pożądane efekty. Francja w 2009 r. zajęła trzecie miejsce na świecie (a pierwsze w Europie) pod względem wielkości napływu BIZ oraz drugie miejsce pod względem ich odpływu (UNCTAD 2010). Również w 2009 r. zajęła drugie miejsce w Europie, jeśli chodzi o liczbę projektów realizowanych dzięki BIZ (Ernst\&Young 2010). Od 2007 r. Francja jest drugim krajem w Europie co do liczby miejsc pracy stworzonych przez BIZ (Ernst\&Young 2010). W 2009 r. miała największy udział w wartości BIZ w sektorze B+R i przemysłu w Europie (pierwsze miejsce w technologiach ekologicznych) (AFII 2010). Francja zajmuje także pierwsze miejsce wśród krajów Europy pod względem liczby miejsc pracy stworzonych przez BIZ w sektorze B+R (AFII 2010). Dodatkowo Paryż jest drugim największym na świecie miastem pod względem lokalizacji siedzib międzynarodowych firm (UNCTAD 2010). Wszystkie te wskaźniki wpłynęły pośrednio na wybór Francji jako obiektu badań. Dodatkowo odnotować należy, że kraj ten osiągnął dobre wyniki przy wysokiej stawce podatku oraz wysokich kosztach pracy.

W badaniach wykorzystano francuską terminologię statystyczną, według której bezpośrednie inwestycje zagraniczne (Investissements directs étrangers - IDE) to inwestycje mające na celu uzyskanie trwałego udziału w podmiotach gospodarczych posiadających siedzibę w innym państwie. Są to inwestycje, które mają znaczący wpływ na zarządzanie przedsiębiorstwem (inwestor nabywa co najmniej 10\% kapitału inwestycji). Inwestycje bezpośrednie obejmują nie tylko wstępną transakcję, ale również wszystkie późniejsze transakcje kapitałowe pomiędzy podmiotami ${ }^{1}$.

\footnotetext{
${ }^{1}$ Institut national de la statistique et des études économiques - Définitions et méthodes, 2010, http://www. insee.fr/fr/methodes/
} 
Rozpoczynając poniższą analizę, należy podkreślić, że Francja pod względem udziału wartości inwestycji zagranicznych od wielu lat znajduje się w ścisłej czołówce światowej. Jak widać na przedstawionym wykresie (ryc. 1), wśród pozostałych państw gromadzących prawie połowę wartości światowych inwestycji zagranicznych tylko ona odnotowała wzrost udziału z 4,5\% w 1980 r. do ponad 6\% w 2006 r. Potwierdza to zamieszczone powyżej informacje o wzroście zainteresowania tym krajem wśród zagranicznych inwestorów. Szczególne wyraźnie proces ten widoczny jest w ostatnich latach, w których Francja odnotowała najmniejsze spadki udziału w wartości inwestycji zarówno w aspekcie napływu, jak i odpływu inwestycji zagranicznych w odniesieniu do innych rozwiniętych krajów świata.

Ryc. 1. Udział Francji w wartości światowych inwestycji zagranicznych w latach 1980-2007 oraz saldo BIZ w latach 2007-2009 na tle wybranych państw
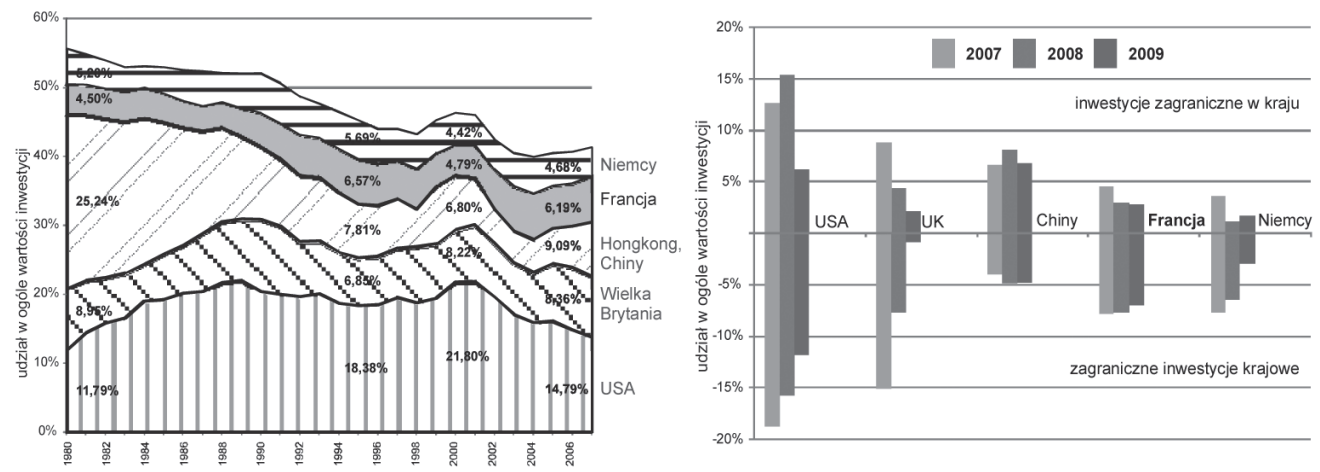

Źródło: opracowanie własne na podstawie danych UNCTAD.

Ryc. 2. Inwestycje zagraniczne w Europie oraz wybranych rozwiniętych krajach świata w stosunku do PKB kraju w 2009 r.

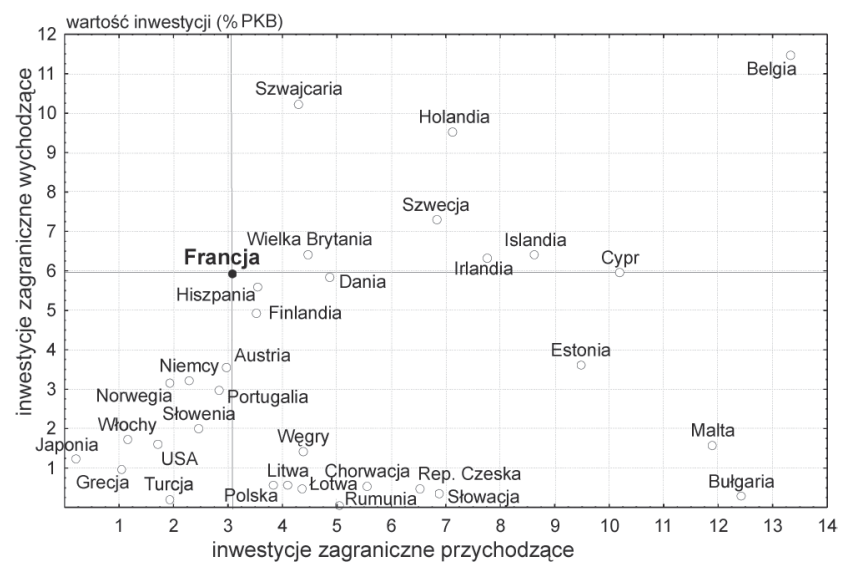

Źródło: opracowanie własne na podstawie danych EUROSTAT.

Przy porównywaniu powyższych zestawień rodzi się wątpliwość, czy zmiany zachodzące w udziale poszczególnych krajów w wielkości inwestycji nie są wynikiem jedynie wzrostu potencjału gospodarczego Francji, przy braku innych stymulantów proinwestycyjnych. Odpowiedź 
na to pytanie można pośrednio odnaleźć w zestawieniu wielkości inwestycji w odniesieniu do wielkości PKB (ryc. 2). Porównując zatem wielkości inwestycji zagranicznych jako udziału wielkości produktu krajowego brutto w 2009 r., widzimy, że wartość inwestycji napływających do Francji (ok. 3\% wielkości PKB) jest prawie dwukrotnie wyższa niż w innych państwach rozwiniętych, np. w Niemczech, we Włoszech czy w Stanach Zjednoczonych. Francja zajmuje również wysoką pozycję wśród krajów europejskich w odniesieniu do własnych inwestycji zagranicznych, które stanowią ok. 6\% wielkości PKB. Powyższe zestawienie potwierdza wysoką pozycję tego kraju w odniesieniu do rynku inwestycyjnego świata oraz świadczy o wysokim stopniu umiędzynarodowienia gospodarki francuskiej.

Francja od lat 90. XX w. utrzymuje stałą tendencję wzrostową, zarówno w odniesieniu do wartości napływu inwestycji zagranicznych do kraju, jak i ich odpływu. W wyniku postępujących procesów globalizacji, przejawiających się m.in. w zjawiskach delokalizacji inwestycji ze względu na koszty produkcji, od końca XX w. zauważalny jest we Francji wzrost ujemnego salda wymiany inwestycyjnej z zagranicą. O procesach delokalizacji świadczy także wysoki udział inwestycji zagranicznych w krajach wschodniej Europy (ryc. 3). Dodatkowo należy zwrócić uwagę na spadek inwestycji we Francji na początku XX w., co mogło mieć swoje konsekwencje we wdrażaniu działań przedakcesyjnych do UE w Europie Środkowej i Wschodniej, oraz mniej wyraźny spadek wywołany kryzysem światowym. Charakterystyczny dla współczesnych inwestycji we Francji wyraźny wzrost wielkości inwestycji na jednego zatrudnionego potwierdza coraz większą kapitałochłonność inwestycji.

Ryc. 3. Wielkość inwestycji zagranicznych we Francji i inwestycji francuskich za granicą w latach 1990-2008 oraz kapitałochłonność inwestycji zagranicznych w latach 1993-2007
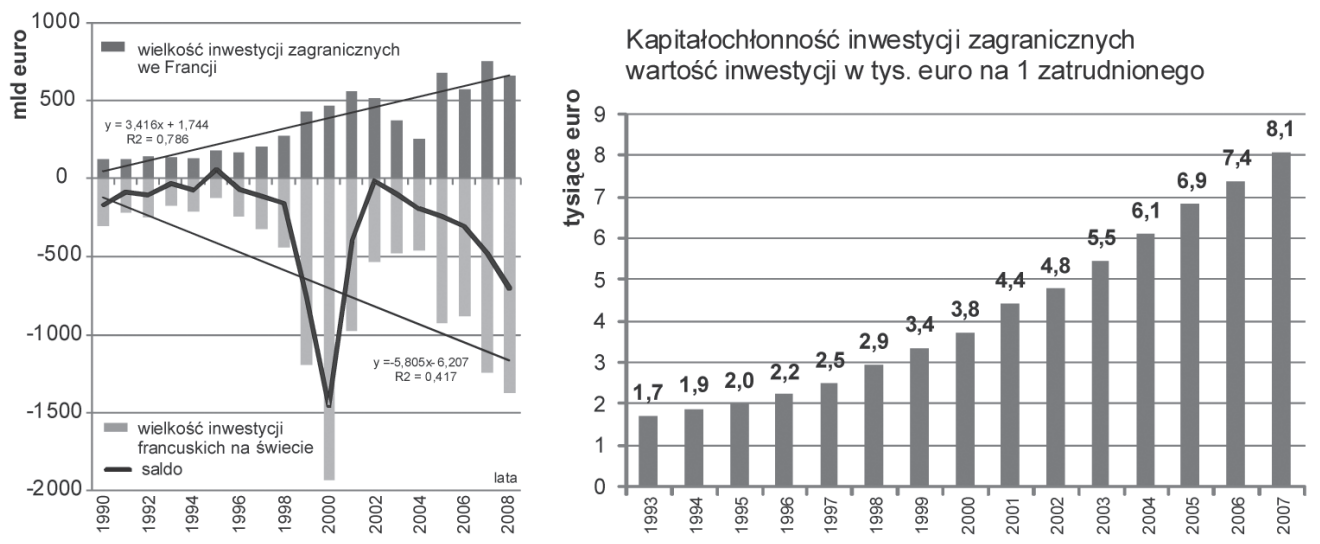

Źródło: opracowanie własne na podstawie danych Banque de France.

Jednym z efektów procesów globalizacji jest stopniowe powiększanie sfery oddziaływań gospodarczych poszczególnych państw. W wypadku Francji spośród jej partnerów inwestycyjnych największy udział zarówno pod względem napływu, jak i odpływu inwestycji w 2009 r. mają państwa sąsiadujące, tj. kraje Beneluksu, Niemcy oraz Wielka Brytania (ryc. 4). Wysoki udział tych krajów w wymianie inwestycyjnej ma źródło nie tylko w ich bliskości geograficznej, ale również w dużym stopniu wynika z powiązań i uwarunkowań politycznych, gospodarczych oraz kulturowych. Powiązania te można dostrzec na obszarze całej Europy Zachodniej, a w szczególności w jej najbardziej rozwiniętym gospodarczo regionie, tzw. europejskiego 
banana. Zaznaczyć należy, że udział państw europejskich, w tym głównie unijnych, w wartości inwestycji napływających do Francji i z niej odpływających w obydwu przypadkach maleje. Proces ten jest zapewne także efektem nasilającej się globalizacji rynku światowego oraz nowych możliwości współpracy zagranicznej. Dodatkowo widoczne jest duże zróżnicowanie udziału poszczególnych krajów w wielkości inwestycji. Zjawisko to dotyczy nie tylko odległych partnerów inwestycyjnych Francji, tj. Japonii czy Stanów Zjednoczonych Ameryki, ale odnosi się także do partnerów europejskich.

Ryc. 4. Najważniejsi inwestycyjni partnerzy Francji w UE i na świecie w latach 2007-2008 według wartości inwestycji

A) francuskie inwestycje zagraniczne

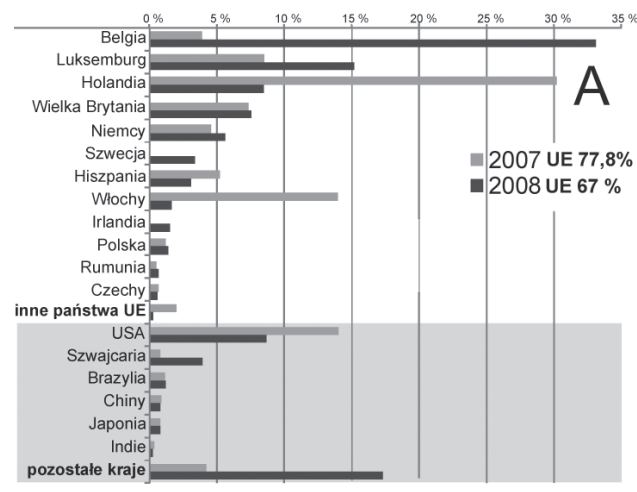

B) inwestycje zagraniczne we Francji

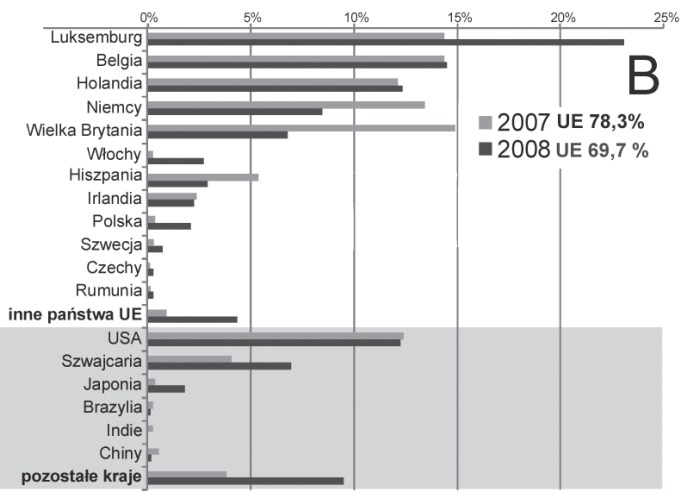

Źródło: opracowanie własne na podstawie danych Banque de France.

Odmienny obraz rozmieszczenia partnerów Francji otrzymujemy przy analizie liczby projektów inwestycyjnych (ryc. 5). Jeśli chodzi o liczbę inwestycji, a nie ich wartość - w czołówce inwestorów znajdują się najbardziej rozwinięci gospodarczo partnerzy Francji: Niemcy i Stany Zjednaczane. Następne w kolejności są państwa europejskie, tj. Włochy, Hiszpania, Wielka Brytania, Szwajcaria, Belgia i Holandia oraz w mniejszym stopniu Szwecja i Dania. To właśnie te państwa odnotowały w 2008 r. w stosunku do roku poprzedniego wyraźny wzrost liczby inwestycji (najwięcej Dania, która zwiększyła przeszło o 70\% liczbę inwestycji we Francji). Spośród partnerów pozaeuropejskich wysoki wzrost odnotowały Indie oraz w mniejszym stopniu Kanada i Chiny.

Zmiany w rozmieszczeniu zagranicznych inwestorów są wynikiem coraz większej ekspansywnej polityki gospodarczej krajów azjatyckich. Natomiast w przypadku innego ważnego partnera Francji - Kanady, wysoki udział inwestycji można tłumaczyć istnieniem powiązań społeczno-gospodarczych wynikających z uwarunkowań historycznych, przeniesionych na współczesne więzi kulturowe. Ten ostatni czynnik wydaje się odgrywać ważną rolę w kwestiach lokowania inwestycji nie tylko w samej Europie, o czym wspomniano wcześniej, ale też inwestycji obejmujących o wiele większy obszar kultury zachodniej ${ }^{2}$. Jednym z podstawowych uwarunkowań w kontaktach handlowych jest możliwość porozumienia (zrozumienia), nie tylko w sferze kulturowej, lecz i lingwistycznej. Tłumaczy to duży udział inwestorów zagranicznych

\footnotetext{
${ }^{2}$ Przykładem może być sukces gospodarczy Irlandii, do którego przyczynili się także Amerykanie irlandzkiego pochodzenia, inwestujący w ojczyźnie przodków w latach 1997-2003 prawie 250 mld euro.
} 
pochodzących z częściowo francuskojęzycznych krajów: Belgii, Luksemburga, Szwajcarii czy Kanady, lecz także wyjaśnia wysoki udział anglojęzycznych Indii i częściowo japońskojęzycznych Chin (prowincja Dalian) w gospodarce światowej. Oczywiście wyżej wspomniane czynniki wpływające na wybór miejsca inwestycji odgrywają największa rolę jedynie w przypadkach, w których konkurencja kosztowa jest najmniejsza, natomiast decydującą rolę zaczynają odgrywać tzw. czynniki miękkie, tj. kapitał ludzki, przyjazna aura dla przedsiębiorców lub dobry klimat inwestycyjny. Przykładem tego typu działań są inwestycje w sektorze szeroko rozumianych usług dla biznesu (Business Process Outsourcing - BPO). Są to usługi zarówno z zakresu księgowości i finansów, jak i usługi typu IT oraz z zakresu prac badawczo-rozwojowych. To właśnie działalność naukowo-badawcza, prowadzona w oparciu o kapitał ludzki, przez wielu badaczy uważana jest obecnie za główny stymulant rozwoju gospodarczego (m.in. Skrzypek 2007; Babiak 2008; Chojnicki, Czyż 2008; Goldberg, Goddard, Kuriakose 2008; Markowski 2008; Borowiec 2008). Gospodarka oparta na wiedzy (GOW) funkcjonuje dzięki wykorzystaniu zasobów wiedzy oraz rozwojowi technologii. Innym ważnym kryterium GOW jest zdolność do generowania i dyfuzji innowacji, które prowadzą do modernizacji i wzrostu konkurencyjności gospodarki.

Ryc. 5. Najważniejsi inwestycyjni partnerzy Francji w UE i na świecie w latach 2007-2008 według wartości inwestycji

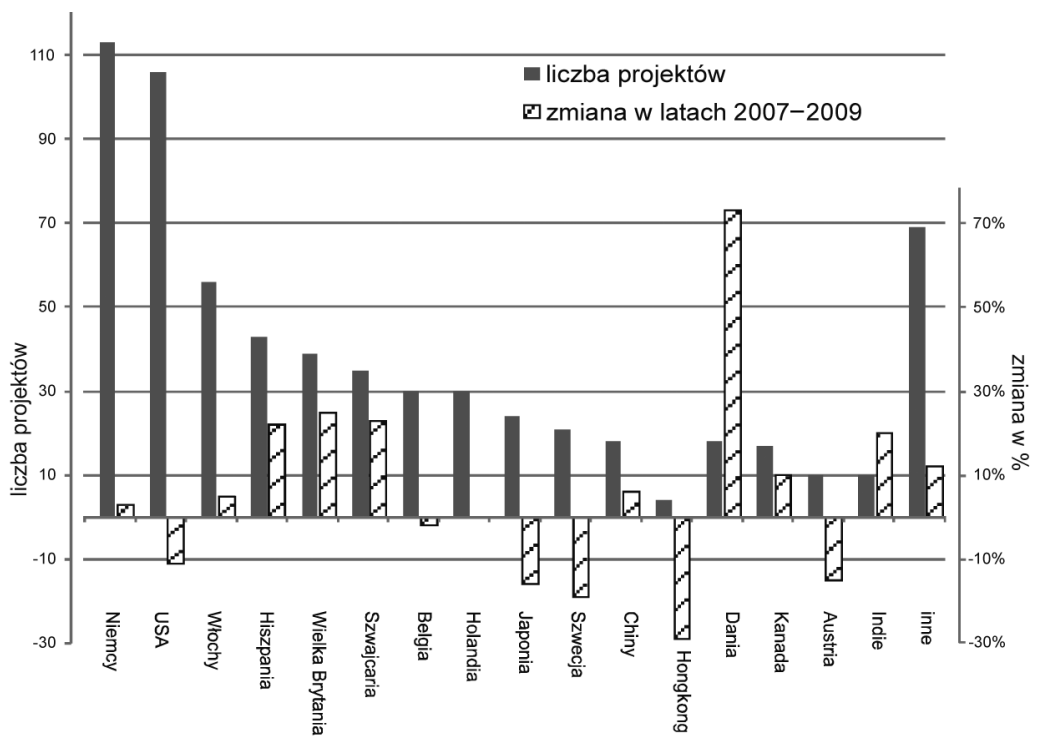

Źródło: opracowanie własne na podstawie danych Banque de France.

Następnym ważnym wskaźnikiem świadczącym o wielkości i znaczeniu inwestycji dla danego kraju czy regionu jest liczba miejsc pracy generowanych przez BIZ. Analizując zatem powyższe wartości, można stwierdzić, że od lat 90. XX w. inwestycje zagraniczne we Francji odnotowały dwie prawidłowości (ryc. 6). Po pierwsze nastąpił ogólny wzrost liczby inwestycji zagranicznych przy jednoczesnym powolnym spadku liczby miejsc pracy generowanych przez inwestycje zagraniczne. Po drugie - niejako wynikiem wcześniejszego procesu był wzrost kosztów poniesionych na powstanie nowych miejsc pracy oraz obniżenie wielkości nakładów na pojedyncze przedsięwzięcia inwestycyjne. Źródła tych procesów należy upatrywać zarówno 
w coraz większej automatyzacji produkcji, jak i w malejącym udziale inwestycji w sektorze przemysłu, który jednakże wciąż stanowi główny sektor inwestycji zagranicznych. Odwołując się zatem do wcześniejszych spostrzeżeń, można domniemywać, że kraje rozwinięte gospodarczo, tj. Niemcy czy USA, inwestują we Francji w sferze usług i IT, co wpływa na obniżenie wielkości inwestycji i ograniczenie zatrudnienia generowanego przez BIZ. Należy tu wspomnieć, że podmioty gospodarcze działające w sektorze B+R charakteryzują się małym zatrudnieniem (Lundin, Sjöholm, Qian 2006). Szczególne widoczne jest to w przypadku przedsiębiorstw z branży biotechnologicznej. We Francji w 2000 r. średnia wielkość firm w tej branży nie przekroczyła średniego zatrudnienia ponad 50 osób (Mangematin, Lemarié, Catherine 2001).

Ryc. 6. Liczba projektów i miejsc pracy generowanych przez BIZ we Francji w latach 1993-2009
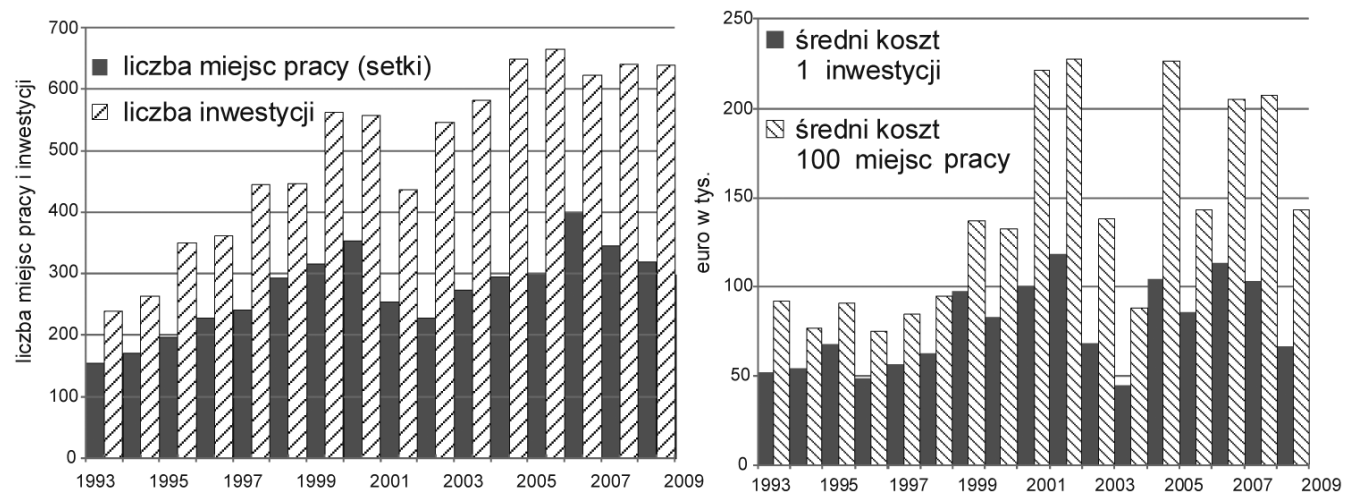

Źródło: opracowanie własne na podstawie danych Banque de France.

Powyższe stwierdzenie, odnoszące się do rodzaju inwestycji zagranicznych podejmowanych we Francji w ostatnich latach, potwierdza zestawienie liczby BIZ ze względu na aktywność gospodarczą (ryc. 7). W badanym okresie największe zatrudnienie na jedną inwestycję generowały projekty inwestycyjne w grupie produkcji, handlu i usług oraz logistyki, podczas gdy inwestycje w sektorze związanym z zarządzaniem i sektorze innowacji generują średnio o 20 etatów mniej. Ponadto tylko w wymienionych grupach nastąpił w latach 2007-2008 wzrost liczby inwestycji o przeszło 10 punktów procentowych. Jednakże podkreślić należy, że w dalszym ciągu (ze względu na udział w liczbie projektów) na pierwszym miejscu znajduje się produkcja, a następnie usługi, zarówno dla przedsiębiorstw, jak i dla ludności. Najmniejszy udział liczby inwestycji (poniżej 10\%) w 2009 r. odnotowano w dziale logistyki i w sektorze $\mathrm{B}+\mathrm{R}$.

Powyższe zmiany w strukturze napływu inwestycji zagranicznych w odniesieniu do wzrostu udziału inwestycji w usługach i w sektorze B+R potwierdza malejący udział projektów inwestycyjnych związanych z infrastrukturą trwałą, tzw. inwestycji trwałych, które zazwyczaj są inwestycjami nowymi, tzw. greenfield (ryc. 8). W latach 1993-2009 wzrósł udział (z około 30 do $70 \%$ ) inwestycji doraźnych, które nie mają wymiaru trwałej infrastruktury materialnej. Świadczy to o zainteresowaniu inwestorów zagranicznych głównie kapitałem ludzkim oraz czynnikami pozakosztowymi inwestycji.

Wobec przedstawionych faktów rodzi się pytanie: czy wyżej zaznaczone procesy zachodzą $\mathrm{z}$ takim samym natężeniem na terenie całej Francji, czy też istnieje regionalne zróżnicowanie natężenia inwestycji zagranicznych? 
Analizując regionalne zróżnicowanie liczby realizowanych inwestycji zagranicznych w latach 2007-2009, można zauważyć wyraźną dominację regionu Île-de-France, przyciągającego ok. 30\% wszystkich projektów. O połowę mniej inwestycji przyciąga region Rhône-Alpes, podczas gdy pozostałe regiony posiadają udział poniżej 5\% (ryc. 9).

Ryc. 7. Inwestycje zagraniczne we Francji wg aktywności gospodarczej w 2009 r.

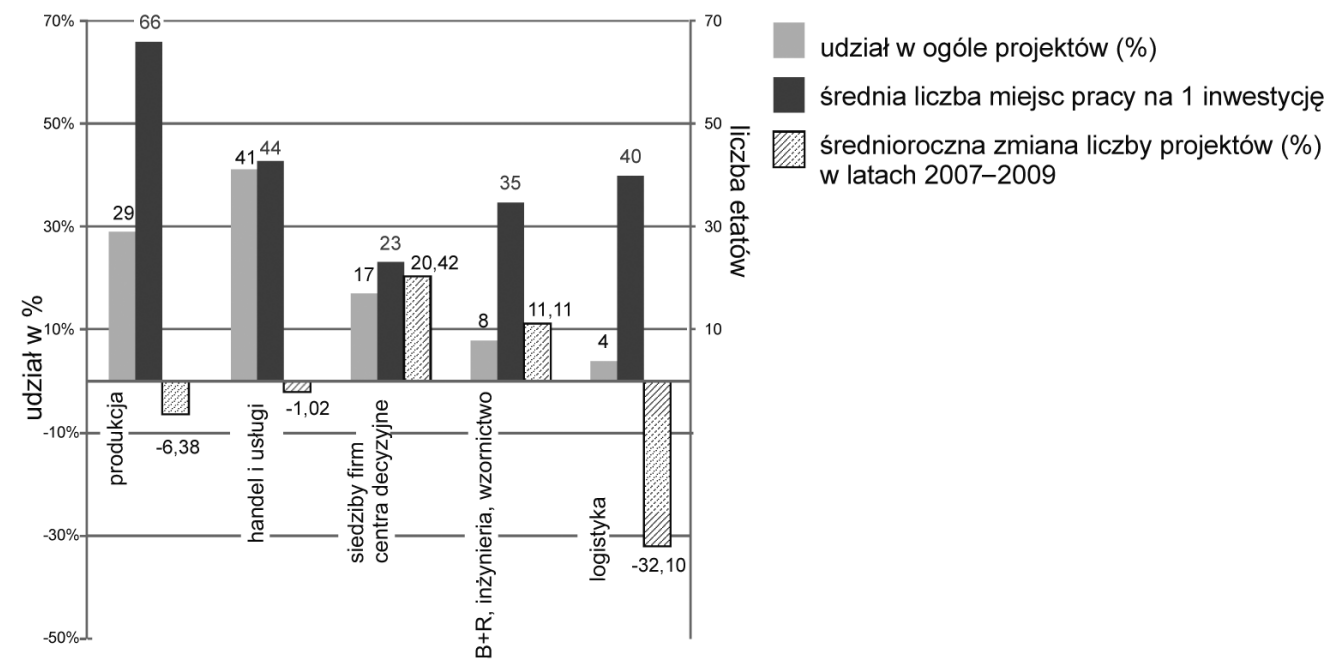

Źródło: opracowanie własne na podstawie danych Banque de France.

Ryc. 8. Rodzaje inwestycji zagranicznych we Francji w latach 1993-2009

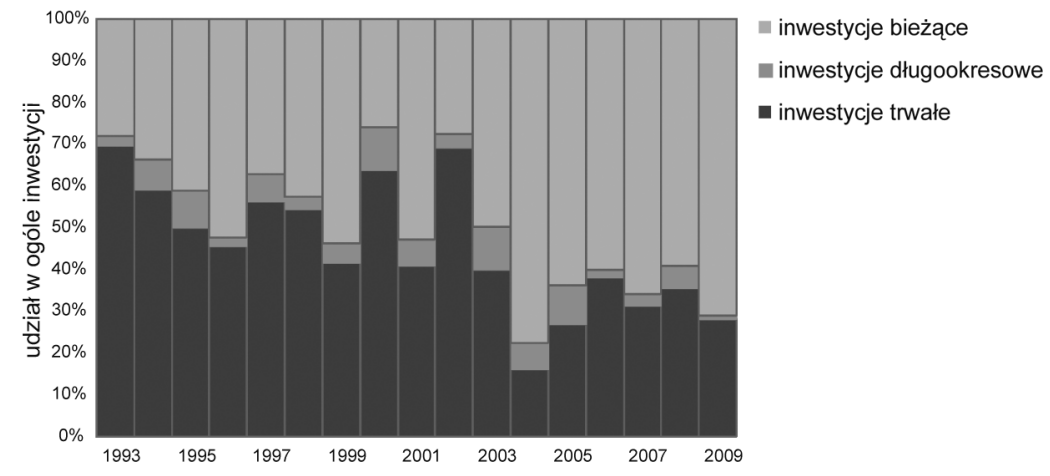

Źródło: opracowanie własne na podstawie danych Banque de France.

Analizując średni udział inwestycji zagranicznych we Francji dla lat 2007-2009 (wybrano wartości średnie, aby wykluczyć jednostkowe, skokowe zmiany analizowanych zjawisk) w układzie regionalnym, można wyróżnić cztery regiony o największym napływie inwestycji zagranicznych: Paryski, Południowo-Wschodni (Rhône-Alpes i Provence-Alpes-Côte d'Azur), Pirenejski i Północny (Nord-Pas-de-Calais). Największy napływ inwestycji do tych regionów związany jest z ogólnym wysokim poziomem rozwoju gospodarczego oraz obecnością największych metropolii Francji, m.in. Paryża, Lyonu, Tuluzy i Lille. Dowodzi to z jednej strony 
strategicznej roli metropolii w przyciąganiu inwestycji zagranicznych ${ }^{3}$, a z drugiej - pośrednio świadczy o wspomnianej dominacji innowacyjności w inwestycjach. To właśnie wielkie aglomeracje jako centra naukowe 4 i badawcze stanowią główny czynnik przyciągający współcześnie inwestycje. Potwierdza to Światowy Raport Inwestycyjny UNCTAD, który stwierdza, że zjawiska stymulujące postęp globalizacji zmieniają sposób, w jaki podmioty gospodarcze, w tym głównie korporacje międzynarodowe, decydują o dokonaniu inwestycji zagranicznych. Inwestorzy w coraz większym stopniu poszukują miejsc, których atrakcyjność wyraża się w czynniku ludzkim, czyli tzw. aktywach wytworzonych, obejmujących cały szereg zjawisk, od zaawansowania technologicznego do wykwalifikowanej siły roboczej. Technologia i innowacyjność zyskały status kluczowych dla konkurencyjności inwestycyjnej regionów (WIR 1998).

Biorąc pod uwagę liczbę inwestycji w przeliczeniu na 1000 zatrudnionych, możemy potwierdzić wcześniejszy układ przestrzenny w rozmieszczeniu inwestycji zagranicznych we Francji. W ujęciu tym traci region Paryża na rzecz uprzemysłowionych regionów zachodnich Francji, głównie Lotaryngii i Alzacji oraz Szampanii. Najniższymi wartościami odznaczają się regiony od Bretanii na zachodzie po Limousin w Masywie Centralnym.

Ryc. 9. Regionalne zróżnicowanie liczby BIZ we Francji w latach 2007-2009

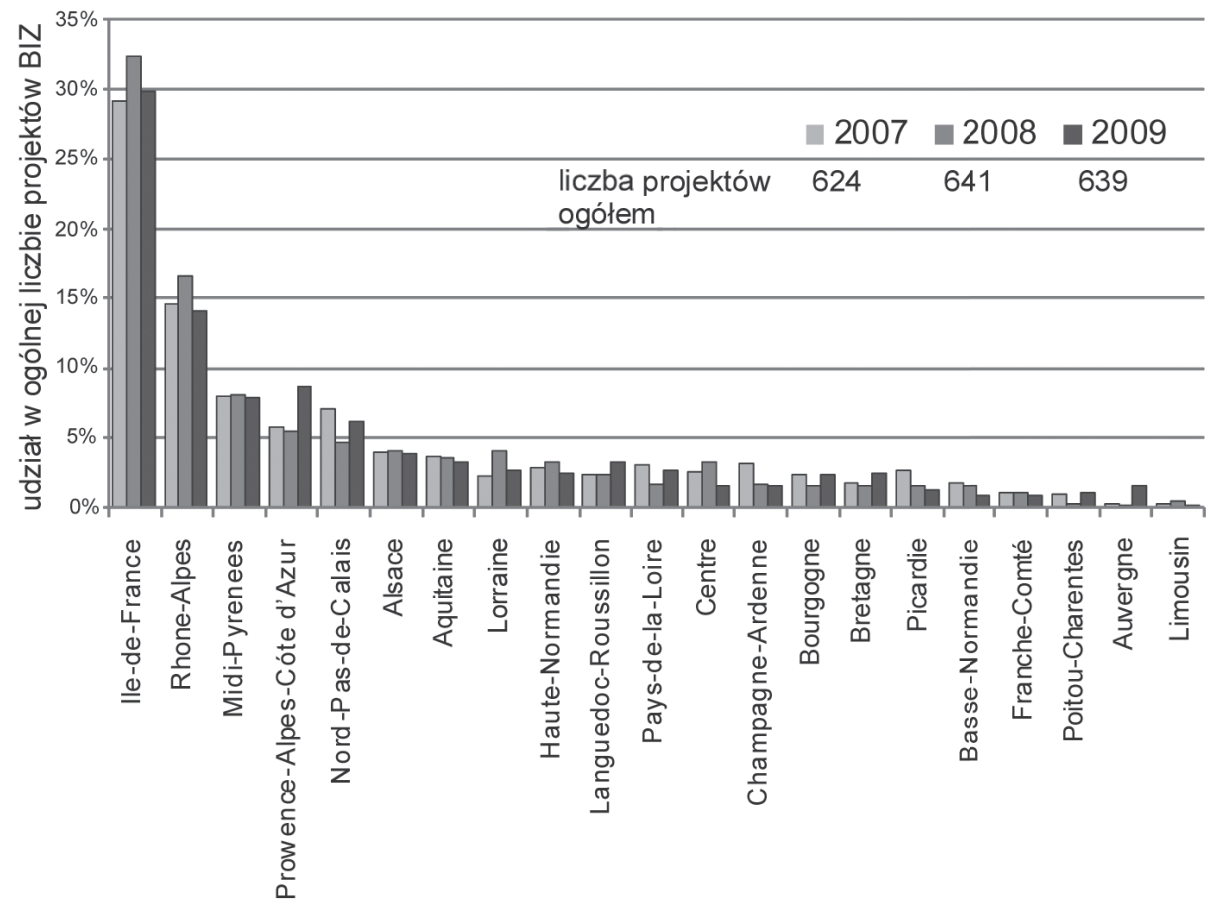

Źródło: opracowanie własne na podstawie danych Banque de France.

\footnotetext{
${ }^{3}$ Szerzej o znaczeniu metropolii w odniesieniu do napływu inwestycji pisali m.in. Domański (2008) oraz Domański, Guzik, Gwosdz (2000).

${ }^{4} \mathrm{O}$ znaczeniu miast w strukturze szkolnictwa wyższego Francji pisali M. Borowiec, S. Dorocki, Procesy transformacji ośrodków akademickich jako czynnik podnoszenia jakości zasobów kapitału ludzkiego w układach regionalnych Francji (w druku).
} 
Ryc. 10. Średnia liczba inwestycji zagranicznych w regionach Francji w latach 2007-2009

A - ogółem, B - na 1000 zatrudnionych

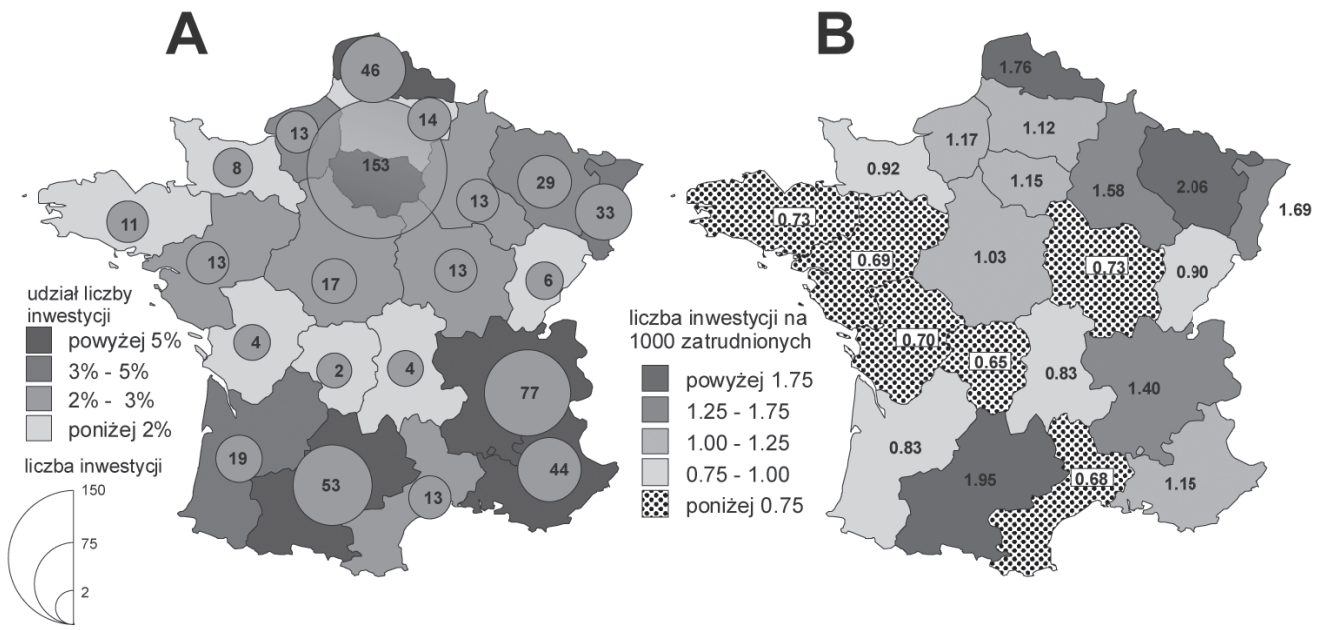

Źródło: opracowanie własne na podstawie danych Banque de France.

Podobny obraz przestrzennego rozkładu inwestycji zagranicznych we Francji otrzymujemy również, analizując udział regionów według liczby stworzonych miejsc pracy (ryc. 11). W tym ujęciu dominacja regionu paryskiego jest jeszcze większa. Region Île-de-France skupia ponad $25 \%$ zatrudnionych w przedsięwzięciach inwestycyjnych, podczas gdy następne według wielkości regiony Rhône-Alpes, Akwitania, Midi-Pyrénées i Nord-Pas-de-Calais skupiają od 5 do $10 \%$ zatrudnionych. W pozostałych regionach udział zatrudnionych w inwestycjach zagranicznych jest podobny, a istniejące różnice ulegają powolnemu zmniejszeniu.

Ryc. 11. Regionalne zróżnicowanie liczby miejsc pracy powstałych dzięki inwestycjom zagranicznym we Francji w latach 2007-2009

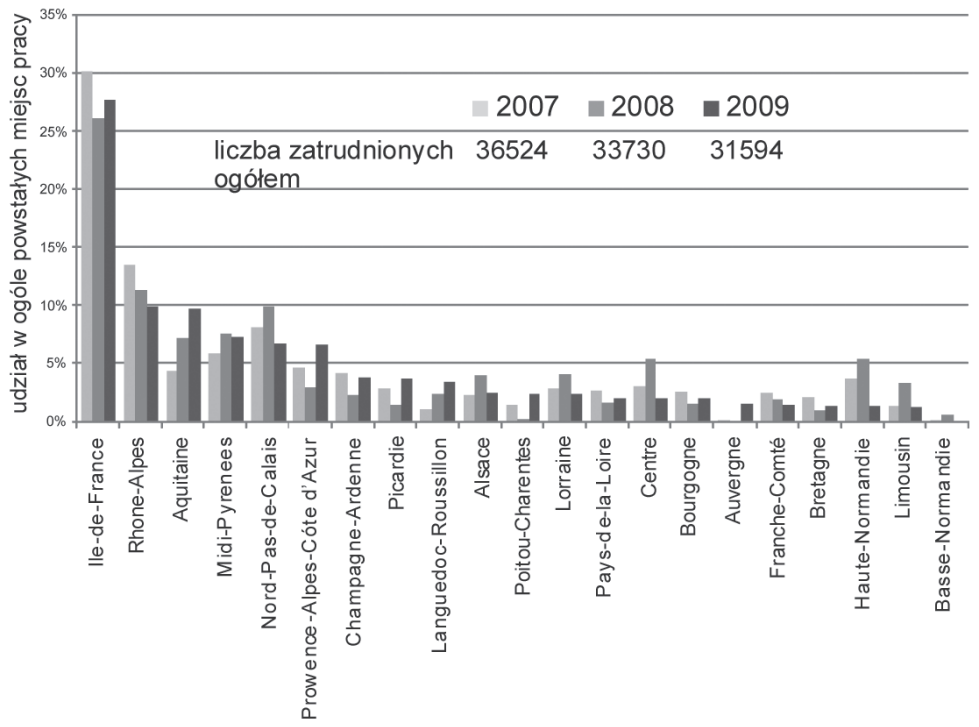

Źródło: opracowanie własne na podstawie danych Banque de France. 
Innym wskaźnikiem poziomu inwestycji zagranicznych jest liczba miejsc pracy generowanych przez inwestycje zagraniczne oraz wartość ta w stosunku do ogółu zatrudnionych. W obydwu przypadkach przedstawione prawidłowości regionalne zostają powielone. Dotyczy to głównie dominacji według powyższych wartości regionów najbardziej rozwiniętych ekonomicznie (ryc. 12). Jedynie według liczby miejsc pracy w BIZ na 1000 miejsc ogółem można zauważyć wzrost znaczenia regionów przemysłowych, szczególnie regionu Midi-Pyrénées, gdzie na 1000 miejsc pracy są 2,12 miejsca wygenerowane przez inwestycje zagraniczne. $\mathrm{W}$ pozostałych regionach o dużym udziale zatrudnionych w projektach inwestycyjnych, tj. Lotaryngia, Champagne-Ardenne, Nord-Pas-de-Calais, wartość ta wynosi około 1,7, podczas gdy w rozwiniętych regionach Île-de-France czy Rhône-Alpes badana wartość oscyluje wokół 1,5. Można stwierdzić, że najwięcej miejsc pracy powstałych dzięki inwestycjom zagranicznym we Francji w latach 2007-2009 znajduje się na północy Francji (głównie w regionach północno-zachodnich), południowym wschodzie i południowym zachodzie, podczas gdy w pozostałych regionach wartość ta nie przekracza jednego etatu i jest najniższa w regionie Limousin $(0,29)$ w Masywie Centralnym.

Ryc. 12. Regionalne zróżnicowanie liczby miejsc pracy powstałych dzięki inwestycjom zagranicznym we Francji w latach 2007-2009

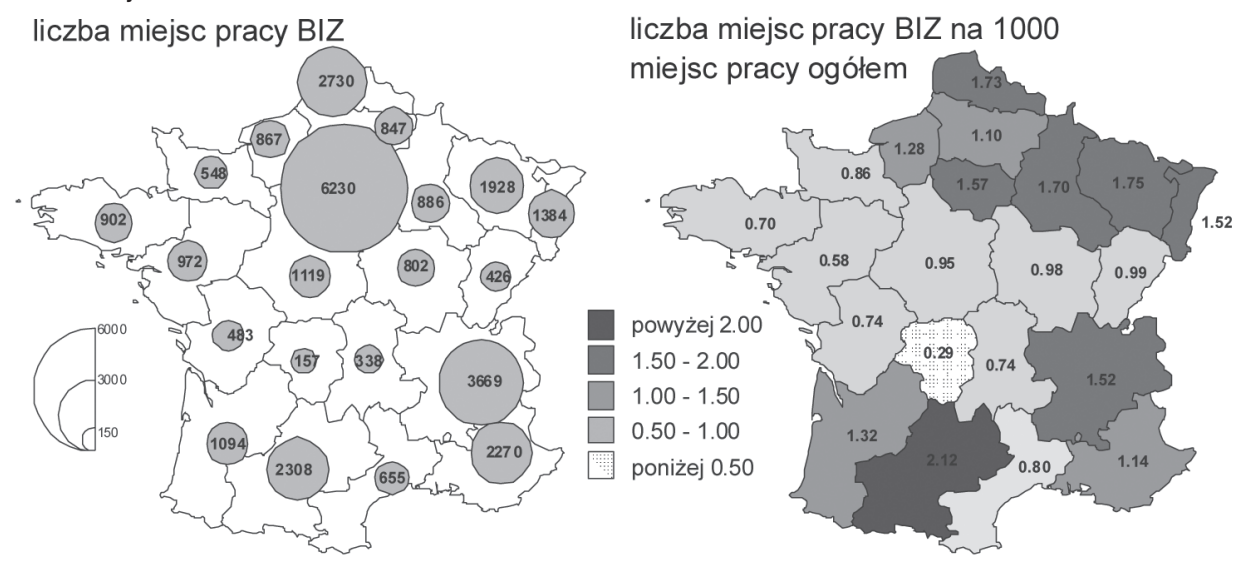

Źródło: opracowanie własne na podstawie danych Banque de France.

Odmienny obraz Francji otrzymujemy w analizie średniorocznej zmiany liczby miejsc pracy stworzonych dzięki BIZ na 1000 miejsc ogółem we Francji w latach 2007-2009 (ryc. 13). Największą dynamiką zmian (ponad 100\%) wykazują się regiony o niskich lub średnich wartościach inwestycji, tj. Owernia, Poitou-Charentes, Dolna Normandia i Szampania. Natomiast spadek miejsc pracy w BIZ na 1000 miejsc ogółem odnotowały regiony zarówno o dużym napływie inwestycji, tj. Rhône-Alpes, Midi-Pyrénées, Lotaryngia, jak i regiony o małym znaczeniu inwestycyjnym, tj. Kraina Loary czy Burgundia. Również w tym przypadku zauważone zmiany mogą mieć swe korzenie w zmianie struktury inwestycyjnej przejawiającej się w odejściu od tradycyjnego przemysłu ku sferze usług i przemysłu high-tech. Potwierdza się także stawiana wcześniej teza o regionalnym wyrównywaniu poziomu zatrudnienia, o czym może świadczyć największy wzrost zatrudnienia odnotowany przez najmniej rozwinięte gospodarczo regiony Francji. Z drugiej strony świadczy to o lokalizacji w tych regionach inwestycji związanych z dużym zatrudnieniem, co zwiększa geograficzne zróżnicowanie kapitału ludzkiego, pogłębiając strukturalny dystans regionów. 
Ryc. 13. Średnioroczna zmiana liczby miejsc pracy stworzonych przez BIZ na 1000 miejsc pracy ogółem we Francji w latach 2007-2009

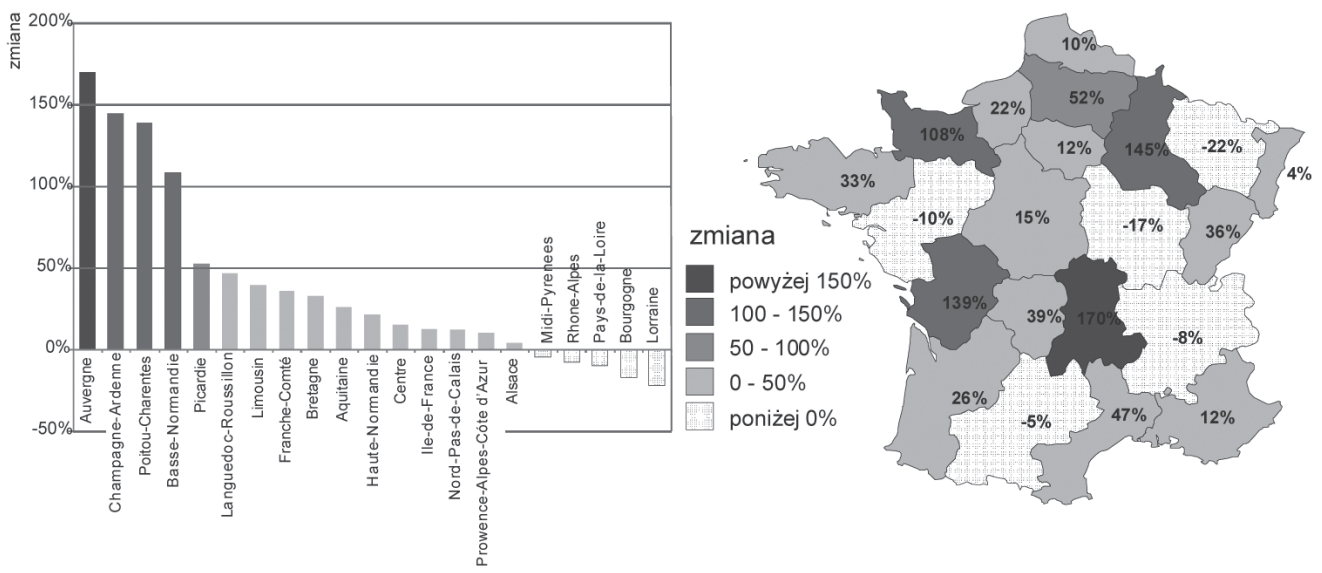

Źródło: opracowanie własne na podstawie danych Banque de France.

Innym wskaźnikiem znaczenia inwestycji zagranicznych jest średnia wielkość stworzonych miejsc pracy przypadających na jeden projekt inwestycyjny (ryc. 14). Wskaźnik ten, jak wspomniano powyżej, można odnieść do rodzaju dokonanej inwestycji. Inwestycje, które tworzą dużo miejsc pracy, to przede wszystkim inwestycje w działalność produkcyjną, w tym głównie przemysłową. Inwestycje takie miały miejsce we Francji w okresie 2007-2009 w regionach peryferyjnych względem centrów gospodarczych, tj. w regionie Akwitanii, Pikardii, Szampanii, Dolnej Normandii oraz Franche-Comté, Północnym i Centre. Średnia liczba miejsc przypadających na jedną inwestycję wahała się tam od ok. 118 etatów w Akwitanii do ok. 70 w Regionie Centralnym. Natomiast inwestycje w MŚP były skupione w rozwiniętych regionach południowych i południowo-wschodnich, Alzacji i Lotaryngii oraz w Bretanii.

Jednakże pomimo tych regionalnych różnic we Francji można zauważyć dużą zależność między udziałem poszczególnych jednostek administracyjnych w liczbie BIZ i stworzonych przez nie miejsc pracy (ryc. 15). Jedynie dwa najbardziej rozwinięte regiony: Île-de-Francei Rhône-Alpes wykazują wyraźną przewagę inwestycji w MŚP, które jak można wywnioskować $\mathrm{z}$ poprzednich danych $\mathrm{w}$ większości są skupione w sektorze innowacyjnym $(\mathrm{B}+\mathrm{R})$.

Na koniec rozważań nad wielkością i regionalnym zróżnicowaniem inwestycji zagranicznych we Francji podjęto próbę odpowiedzi na pytanie, jakie czynniki wpływają na wielkość inwestycji. Jako kanwę rozważań przyjęto wypowiedź prezydenta Francji Nicolasa Sarkozy’ego z 29 lipca 2010 r. Prezydent stwierdził, że „Francja dysponuje licznymi atutami: bardzo dynamiczną demografią, wysokiej jakości siłą roboczą, najlepszą infrastrukturą w Europie; jest krajem doceniającym zmysł przedsiębiorczości, o efektywnie działających firmach"5. Na podstawie powyższej wypowiedzi przyjęto, że głównymi atutami Francji przyciągającymi zagranicznych inwestorów jest wielkość i dynamika rynku, gęstość i wydajności infrastruktury, poziom i kwalifikacje pracowników oraz jakość życia. W celu określenia wpływu powyższych czynników na wielkość inwestycji zestawiono 25 zmiennych opisujących trzy wybrane czynniki, tj. rynek, kwalifikacje (edukacja) i infrastrukturę (tab. 1).

\footnotetext{
5 http://www.ambafrance-pl.org/france_pologne/spip.php?article4006 (stan na dzień 24.10.2010).
} 
Ryc. 14. Wielkość inwestycji wg stworzonych miejsc pracy we Francji w latach 2007-2009

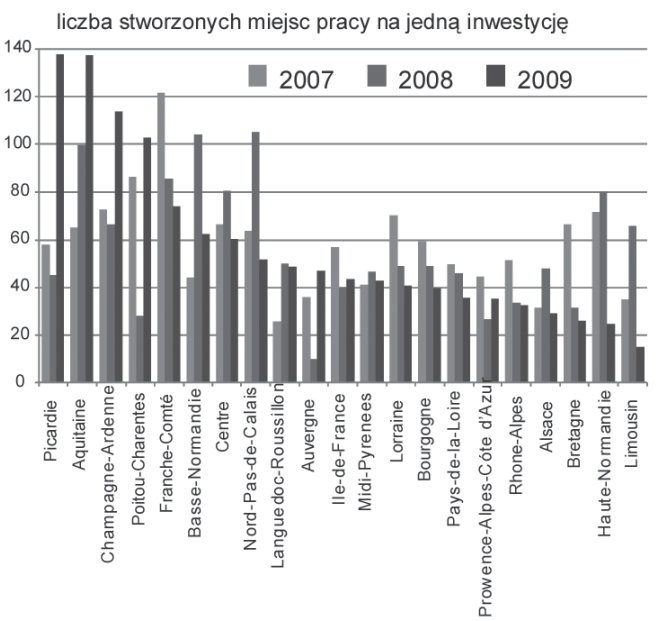

średnia liczba miejsc pracy/BIZ za lata 2007-2009

Źródło: opracowanie własne na podstawie danych Banque de France.

Ryc. 15. Wielkość inwestycji według stworzonych miejsc pracy we Francji w latach 2007-2009

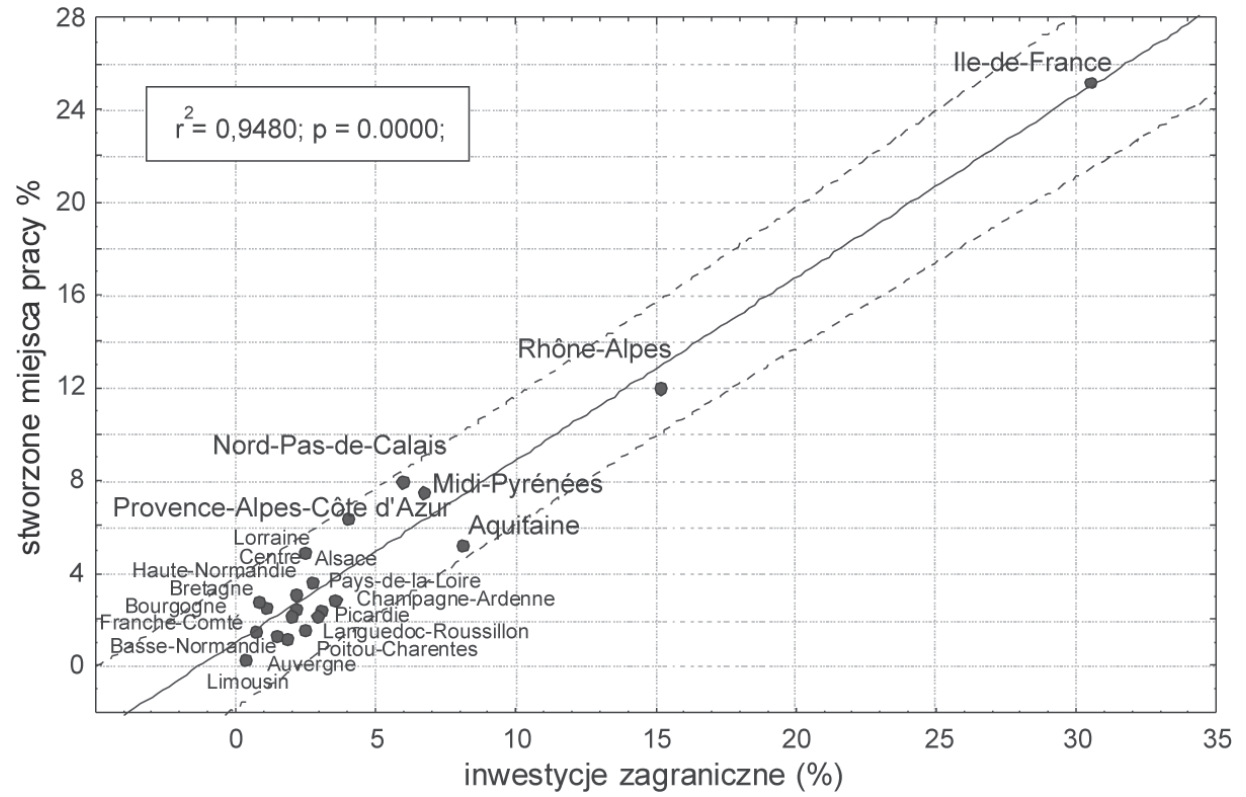

Źródło: opracowanie własne na podstawie danych Banque de France.

Następnie, wykorzystując korelację kanoniczą, dokonano szczegółowego zestawienia wszystkich wyszczególnionych w powyższym tekście cech oraz przyjętych wskaźników obrazujących sytuację społeczno-ekonomiczną regionów Francji. W dalszej analizie ograniczono się do 19 istotnych statystycznie zmiennych. Należy podkreślić, że dokonane zestawienie jest tylko orientacyjną próbą określenia powyższych zależności. Pełne badanie wymaga bowiem powiększenia zakresu zmiennych i ich różnorodności. 
Tab. 1. Zależność pomiędzy wielkością inwestycji zagranicznych we Francji w 2009 r. a wybranymi czynnikami charakteryzującymi warunki regionalne w $2006 \mathrm{r}$.

\begin{tabular}{|c|c|c|}
\hline \multirow[t]{2}{*}{ Zmienne } & $\begin{array}{c}\text { Liczba } \\
\text { inwestycji }\end{array}$ & $\begin{array}{l}\text { Liczba zatrudnio- } \\
\text { nych w inwestycjach } \\
\text { zagranicznych }\end{array}$ \\
\hline & \multicolumn{2}{|c|}{ Rynek R:0,95 p = 0,00622 } \\
\hline korelacja & $\mathbf{0 , 9 4} p=0,00019$ & $\mathbf{0 , 9 5} \mathrm{p}=0,00008$ \\
\hline PKB na osobę & 0,89 & 0,91 \\
\hline wielkość zarobków na 1 osobę & 0,89 & 0,90 \\
\hline \multirow[t]{2}{*}{ wartość dodana na 1 pracującego } & 0,92 & 0,94 \\
\hline & \multicolumn{2}{|c|}{ Kwalifikacje R:0,97 p =0,00001 } \\
\hline korelacja & $\mathbf{0 , 9 6} \mathrm{p}=0,00000$ & $\mathbf{0 , 9 4} \mathrm{p}=0,00000$ \\
\hline wskaźnik HRST & 0,79 & 0,80 \\
\hline studenci na 1000 osób & 0,81 & 0,80 \\
\hline klasa kreatywna (wg R. Florydy): & 0,93 & 0,92 \\
\hline - super kreatywni (core) & 0,92 & 0,90 \\
\hline - profesjonaliści (professionals) & 0,92 & 0,92 \\
\hline \multirow[t]{2}{*}{ - twórcy (bohemians) } & 0,86 & 0,87 \\
\hline & \multicolumn{2}{|c|}{ Infrastruktura R:0,98 $\mathrm{p}=0,00039$} \\
\hline korelacja & $\mathbf{0 , 9 6} p=0,00003$ & $\mathbf{0 , 9 8} \mathrm{p}=0,00001$ \\
\hline wydatki na $\mathrm{B}+\mathrm{R}$ oraz rozwój infrastruktury & 0,93 & 0,94 \\
\hline \multicolumn{3}{|l|}{ liczba zatrudnionych w stosunku do ogółu zatrudnionych w: } \\
\hline - usługach & 0,85 & 0,86 \\
\hline - obsłudze finansowej & 0,76 & 0,79 \\
\hline - obsłudze indywidualnej ludności & 0,82 & 0,83 \\
\hline - obsłudze przedsiębiorstw & 0,94 & 0,94 \\
\hline - usługach w dziale nieruchomości & 0,79 & 0,77 \\
\hline - szkolnictwie, służbie zdrowia, usługach socjalnych & $-0,65$ & $-0,65$ \\
\hline - administracji & 0,08 & 0,07 \\
\hline $\begin{array}{l}\text { udział zakładów usługowych w ogóle podmiotów } \\
\text { gospodarczych }\end{array}$ & 0,94 & 0,95 \\
\hline
\end{tabular}

Źródło: opracowanie własne.

Na podstawie otrzymanych wartości określających siłę zależności (lub współwystępowania) można stwierdzić, że na wielkość inwestycji wpływa w największym stopniu infrastruktura (R:0,98), a spośród analizowanych zmiennych poziom usług $(0,94)$, w tym usług dla przedsiębiorstw. Zaznaczyć należy, że tak wysoka współzależność może wynikać z ogólnego rozwoju 
ekonomicznego regionów, w których odnotowano zarówno duży napływ inwestycji zagranicznych, jak i znaczny udział sektora usług, co jest charakterystyczne dla rozwiniętych gospodarek. W odniesieniu do struktury inwestycji poziom infrastruktury bardziej wpływa na inwestycje kapitałochłonne (inwestycje generujące duże zatrudnienie) niż na inwestycje skierowane do sektora MŚP. Należy zwrócić uwagę na to, że w regionach charakteryzujących się wysokim udziałem zatrudnionych w szkolnictwie oraz służbie zdrowia i usługach socjalnych jest zauważalny najmniejszy napływ inwestycji. Nie mniej ważnym czynnikiem stymulującym napływ inwestycji zagranicznych jest kapitał ludzki (R:0,97). W tym przypadku wykształcenie ludności regionu wpływa w większym stopniu na ilość inwestycji niż na ich rozmiar wyrażony liczbą stworzonych miejsc pracy. Spośród analizowanych zmiennych największy wpływ na wielkość inwestycji ma udział klasy kreatywnej ${ }^{6}$, natomiast mniejszy udział studentów w ogóle ludności lub wskaźnik HRST ${ }^{7}$. Wskazuje to na szczególne znaczenie jakości kapitału ludzkiego w kwestii przyciągania inwestycji i rozwoju gospodarczego. Natomiast wielkość rynku odgrywa najmniejsze znaczenie spośród analizowanych czynników.

W podsumowaniu przeprowadzonych badań można stwierdzić, że w analizowanym okresie znaczenie Francji w globalnym systemie inwestycji zagranicznych stale wzrasta, a jej kontakty w coraz większym stopniu wykraczają poza Europę. Inwestycje zagraniczne lokowane we Francji to głównie projekty związane z produkcją (rozwijający się szybko sektor wysokich technologii) oraz usługami. Świadczą o tym wzrastające koszty inwestycji, malejące zatrudnienie generowane przez inwestycje oraz malejący udział inwestycji trwałych. Inwestycje lokalizowane są w najbardziej rozwiniętych gospodarczo regionach (Region Paryża, Region Północny oraz Region Rodańsko-Alpejski i Środkowo-Pirenejski). Ważnym czynnikiem wydaje się również obecność w tych regionach metropolii. Spośród wszystkich regionów wyraźną przewagą w napływie inwestycji zagranicznych wyróżnia się region Île-de-France, a na drugim miejscu plasuje się Rhône-Alpes. Inwestycje pracochłonne, związane z przemysłem lokalizowane są w regionach słabiej rozwiniętych, o mniejszym potencjale innowacyjnym. Napływ inwestycji zagranicznych jest determinowany w największym stopniu przez poziom infrastruktury i rozwój usług dla biznesu (BPO) oraz poziom wykształcenia społeczeństwa. Dodatkowo należy zaznaczyć, że inwestycje w sektorze MŚP w większym stopniu są związane z kapitałem ludzkim, podczas gdy inwestycje kapitałochłonne są uwarunkowane infrastrukturą i rynkiem zbytu.

Na koniec należy zauważyć, że wszystkie powyższe procesy mają wymiar światowy i wynikają z coraz większej otwartości rynków światowych, co świadczy o pogłębiającym się procesie globalizacji.

\footnotetext{
${ }^{6}$ Według koncepcji R. Floridy klasa kreatywna to grupa ludzi odpowiedzialnych za sferę innowacji i tworzenie nowych koncepcji i teorii, zarówno w sferze nauki, produkcji, jak i sztuki; grupa ta składa się z naukowców i inżynierów, kadry akademickiej oraz artystów i twórców; szerzej na temat zagadnień klasy kreatywnej i jej funkcji w regionie pisał Stryjakiewicz (2008, 2009), Chantelot, Peres, Virol (2010). ${ }^{7}$ Zasoby ludzkie w sektorze naukowym i technicznym (HRST - Human Resources for Science and Technology).
} 


\section{Literatura}

1. Babiak J. (red.), 2008, Fundusze europejskie a innowacyjność polskiej gospodarki, Wydawnictwo Studio Emka, Warszawa.

2. Bojar E., 2001, Bezpośrednie inwestycje zagraniczne w obszarach słabo rozwiniętych, Wydawnictwo Naukowe PWN, Warszawa.

3. Bojar E., 2008, Bezpośrednie inwestycje zagraniczne (BIZ) w regionach słabo rozwiniętych studium porównawcze Polski i Irlandii. Efekty i wdrożenia, TNOiK, Toruń.

4. Borowiec M., 2008, Rola kapitału ludzkiego w procesie podnoszenia konkurencyjności układów przestrzennych [w:] Przeksztatcenia regionalnych struktur funkcjonalno-przestrzennych, D. Ilnicki, K. Janc (red.), Rozprawy Naukowe Instytutu Geografii i Rozwoju Regionalnego Uniwersytetu Wrocławskiego 3, Instytut Geografii i Rozwoju Regionalnego Uniwersytetu Wrocławskiego, Wrocław, s. 91-98.

5. Brezdeń P., 2006, Uwarunkowania bezpośrednich inwestycji zagranicznych i ich wplyw na umiędzynarodowienie działalności gospodarczej w województwie dolnoślaskim [w:] Międzynarodowe uwarunkowania rozwoju przemystu, Z. Zioło, T. Rachwał (red.), „Prace Komisji Geografii Przemysłu PTG”, nr 8, Komisja Geografii Przemysłu PTG oraz Zakład Przedsiębiorczości i Gospodarki Przestrzennej Instytutu Geografii Akademii Pedagogicznej w Krakowie, Warszawa-Kraków, s. 60-73.

6. Chantelot S., Peres S., Virol S., 2010, The geography of French creative class: An exploratory spatial data analysis, Cahiers du GREThA, n 2010-16, Université Montesquieu Bordeaux, France.

7. Chojnicki Z., 1999, Podstawy metodologiczne i teoretyczne geografii, Bogucki Wyd. Nauk., Poznań.

8. Chojnicki Z., Czyż T., 2008, Gospodarka oparta na wiedzy w regionach metropolitalnych i aglomeracjach miejskich $w$ Polsce [w:] Rola polskich aglomeracji wobec wyzwań strategii lizbońskiej, T. Marszał (red.), Studia, t. CXX, tom wydany z okazji jubileuszu 50-lecia KPZK PAN, Komitet Przestrzennego Zagospodarowania Kraju Polska Akademia Nauk, Warszawa.

9. Corolleur F., Mangematin V., Torre A., 2003, French Biotech Start Ups and Biotech Clusters in France: The Importance of Geographic Proximity [w:] Biotechnology in Comparative Perspective Growth and Regional Concentration, G. Fuchs and B. Luib, London: Routeledge, s. 221-275.

10. Domański B., 2001, Kapitał zagraniczny w przemyśle Polski. Prawidłowości rozmieszczenia, uwarunkowania i skutki, IGiGP UJ, Kraków.

11. Domański B., 2002, Problemy metod badań inwestycji zagranicznych w układach przestrzennych [w:] Możliwości i ograniczenia zastosowań metod badawczych w geografi społeczno-ekonomicznej i gospodarce przestrzennej, H. Rogacki (red.), Bogucki Wydawnictwo Naukowe, Poznań, s. 197-206.

12. Domański B., 2008, Rozwój polskich metropolii a regiony peryferyjne. Bezpowrotna separacja czy wspótzależność rozwoju?, Studia KPZK PAN, s. 120, 135-143.

13. Domański B., Guzik R., Gwosdz K., 2000, Konkurencyjność i ranga wielkich miast Polski w świetle inwestycji zagranicznych firm produkcyjnych, Biuletyn Komisji Przestrzennego Zagospodarowania Kraju PAN, s. 99-124, 192.

14. Ernest\&Young et Associés, 2010, Baromètre Associés Attractivité du site France 2010, France Valeur mundiale?

15. Goldberg I., Goddard G., Kuriakose S., 2008, Building Knowledge-Based Economy and Absorptive Capacity to Enhance Growth: The Role of Cross-Border Knowledge Flows in Europe and Central Asia (ECA) [w:] Knowledge-Based Economy as Factor of Competitiveness and Economy Growth, M. Runiewicz-Wardyn, L. Koźmiński (ed.), Academy of Entrepreneurship and Management, Warszawa.

16. Gorzelak G., 2003, Bieda i zamożność regionów [w:] Wymiar i współczesne interpretacje regionu, I. Sagan, M. Czepczyński (red.), Uniwersytet Gdański, Katedra Geografii Ekonomicznej, Gdańsk-Poznań, s. 57-77.

17. Institut national de la statistique et des études économiques - Définitions et méthodes, 2010, http:// www.insee.fr/fr/methodes/ 
18. Kudełko J., 1996, Miejsce inwestycji zagranicznych w gospodarce kraju [w:] Wpływ procesów na transformacji gospodarki narodowej na funkcjonowanie jednostek gospodarczych i uktadów przestrzennych, Z. Zioło (red.), Komisja Geografii PTG, Instytut Geografii Wyższej Szkoły Pedagogicznej w Krakowie, Warszawa, s. 138-145.

19. Lundin N., Sjöholm F., Qian J., 2006, The role of small firms in china's technology development, Working Paper, European Institute of Japanese Studies 227, Stockholm, Szwecja.

20. Majewska M., Grala J., 2002, Wpływ zagranicznych inwestycji bezpośrednich na proces umiędzynarodowienia gospodarki polskiej, „Sprawy Międzynarodowe”, Nr 3, s. 72-91.

21. Mangematin V., Lemarié S., Catherine D., 2001, French ag-biotech smes: development prospects, AgBioForum, Vol. 4, Nr 2, s. 98-104.

22. Markowski T., 2008, Gospodarka bazujaca na wiedzy (GOW) a wyzwania wobec zagospodarowania przestrzennego - konceptualizacja problemu [w:] Rola polskich aglomeracji wobec wyzwań strategii lizbońskiej, T. Marszał (red.), Studia, t. CXX, tom wydany z okazji jubileuszu 50-lecia KPZK PAN, Komitet Przestrzennego Zagospodarowania Kraju Polska Akademia Nauk, Warszawa.

23. Myrdal G., 1957, Economic theory and underdeveloped regions, Duckworth, Londyn.

24. Namyślak B., 2002, Bezpośrednie inwestycje zagraniczne a konkurencyjność regionów [w:] Przedsiębiorczość i innowacyjność jako czynniki rozwoju regionalnego i lokalnego, W. Kosiedowski (red.), Uniwersytet M. Kopernika w Toruniu, Włocławskie Towarzystwo Naukowe, Włocławek, s. 353-357.

25. Rachwał T., 2000, Wpływ inwestycji zagranicznych na zmiany w funkcjonowaniu Huty Szkta Jarosław S.A. w procesie transformacji gospodarczej, „Rocznik Naukowo-Dydaktyczny AP w Krakowie”, z. 209, Prace Geograficzne XVIII, Z. Zioło (red.), s. 63-72.

26. Sala S., 2006, Bezpośrednie inwestycje zagraniczne a procesy globalizacji [w:] Międzynarodowe uwarunkowania rozwoju przemystu, Z. Zioło, T. Rachwał (red.), „Prace Komisji Geografii Przemysłu PTG”, nr 8, Komisja Geografii Przemysłu PTG oraz Zakład Przedsiębiorczości i Gospodarki Przestrzennej Instytutu Geografii Akademii Pedagogicznej w Krakowie, Warszawa-Kraków, s. 80-90.

27. Skrzypek E., 2007, Rola wiedzy we wspótczesnym zarządzaniu [w:] Polskie firmy wobec globalizacji, A. Sitko-Lutek (red.), PWN, Warszawa.

28. Smętkowski M., 2001, Nowe relacje między metropoliq a regionem $w$ gospodarce informacyjnej, „Studia Regionalne i Lokalne”, nr 4.

29. Sobala-Gwosdz A., 2006, Bezpośrednie inwestycje zagraniczne w województwie podkarpackim do końca 2003 r. [w:] Efekty restrukturyzacji polskiej przestrzeni przemysłowej, Z. Zioło i T. Rachwał (red.), „Prace Komisji Geografii Przemysłu PTG”, nr 9, Komisja Geografii Przemysłu PTG oraz Zakład Przedsiębiorczości i Gospodarki Przestrzennej Instytutu Geografii Akademii Pedagogicznej w Krakowie, Warszawa-Kraków, s. 181-191.

30. Stryjakiewicz T., 2004, Wpływ inwestycji zagranicznych na rozwój regionalny i lokalny na przykladzie GlaxoSmithKline Pharmaceuticals S.A. w Poznaniu, Bogucki Wydawnicwto Naukowe, Poznań.

31. Stryjakiewicz T., 2008, Sektor kreatywny jako czynnik ksztaltujacy nowa jakość przestrzeni europejskiej [w:] Przekształcanie regionalnych funkcjonalno-przestrzennych. Europa bez granic - nowe wyzwania, D. Ilnicki, K. Janc (red.), Rozprawy Naukowe Instytutu Geografii i Rozwoju Regionalnego Uniwersytetu Wrocławskiego 3, Instytut Geografii i Rozwoju regionalnego Uniwersytetu Wrocławskiego, Wrocław, s. 11-18.

32. Stryjakiewicz T., 2009, Lokalizacja firm i zachowania przestrzenne pracowników sektora informatycznego (na przykładzie poznańskiego obszaru metropolitalnego) [w:] Funkcje przemystu w ksztattowaniu spoleczeństwa informacyjnego, Z. Zioło i T. Rachwał (red.), „Prace Komisji Geografii Przemysłu PTG”, nr 13, Komisja Geografii Przemysłu PTG oraz Instytut Geografii Uniwersytetu Pedagogicznego w Krakowie, Warszawa-Kraków, s. 21-33.

33. World Investment Report 1998, Trends and Determinants, United Nations, New York and Geneva. 


\section{Foreign Investments in France in the Period of Globalization}

The turn of the 20th and 21st centuries brought an intensive increase of international economic connections that were a part of the process of globalization of the world economy. The result of these processes was opening of the countries' economies which influenced the increase of the role of foreign investments as a factor of economic development of a country.

Foreign direct investments (FDI) are nowadays one of the most sought-after forms of foreign capital flow. Foreign investments do not cause external debt. They influence the flow of technology, generate economic growth, contribute to the decrease in unemployment, introduce new management methods, create access to the new markets and generate production infrastructure. The following study presents a short characteristic of foreign investments in France. It analyses regional differentiation of foreign investments in France on the basis of their quantity and in reference to the number of workplaces generated by FDI. Finally, the article presents the factors that have influence on the localization of foreign investments. 


\section{Aneta Oniszczuk-Jastrząbek}

Uniwersytet Gdański

\section{Otoczenie a przedsiębiorczość w warunkach globalizacji}

Zmiana systemu gospodarczego w Polsce postawiła przedsiębiorstwa w obliczu szeregu nieoczekiwanych szans, które przyczyniły się do rozwoju przedsiębiorczości. Nieustannie zmieniający się rynek stawia przed przedsiębiorstwami nowe wymagania w zakresie kreowania i dostarczania satysfakcji klientom. Dlatego też najistotniejszym czynnikiem rozwoju przedsiębiorczości w gospodarce rynkowej jest popyt, który stwarza nowe miejsca pracy, zachęca do inwestowania, jest głównym źródłem przychodów, umożliwia pełniejsze wykorzystanie i poszerzanie posiadanych zdolności wytwórczych (Śliwa, Wymysłowski 2001).

Wśród czynników sprzyjających wzrostowi przedsiębiorczości w przedsiębiorstwach szczególną rolę powinno odgrywać państwo, wyznaczając kierunki długotrwałej polityki rozwoju. Do podstawowych warunków stwarzających szanse dla rozwoju przedsiębiorczości można zaliczyć usuwanie barier ograniczających popyt na wyroby i usługi, łagodzenie obciążeń fiskalnych, ułatwianie dostępu do źródeł kapitału, budowanie nowych struktur biznesu w handlu, pomoc ze strony nauk o zarządzaniu dla przedsiębiorców poszukujących swego miejsca na rynku, doskonalenie kwalifikacji przedsiębiorców i personelu (Śliwa, Wymysłowski 2001). Należy pamiętać, że przedsiębiorczość to szereg działań ukierunkowanych na stabilny i długotrwały rozwój.

\section{Istota i zakres pojęcia przedsiębiorczości}

We współczesnym świecie, w którym istnieje silna walka o klienta, pojęcie przedsiębiorczości dotyczy każdego przedsiębiorstwa i odnosi się do wszystkich sfer życia i działalności człowieka, gdzie wymagana jest inwencja, inicjatywa, pomysłowość oraz kreatywność. Na przestrzeni wieków przedsiębiorczość rozumiana była w bardzo różny sposób. Jej znaczenie w gospodarce uzależnione było od idei i poglądów reprezentowanych $\mathrm{w}$ danej epoce. Od czasów Arystotelesa aż po X-XII w. utrzymywała się niechęć do handlarzy, kupców i innych przedsiębiorców. Na przełomie XVIII i XIX w. eksponowano wolność gospodarczą zgodną z prawami natury i „niewidzialną ręką rynku”, która zapewnia efektywność i równowagę bez szczególnego działania przedsiębiorcy. Pojęcie przedsiębiorcy po raz pierwszy w swoich pracach wprowadzili klasycy ekonomii, tzn. Adam Smith, David Ricardo oraz Jean B. Say. Do języka polskiego przedsiębiorczość wprowadził Stanisław Staszic na przełomie XVIII i XIX w., tłumacząc łacińskie wyrażenie industria jako 'skrzętność, przemyślność' (czyli przedsiębiorczość). Według tego podejścia, przemysł można definiować jako „działalność produkcyjną o charakterze zarobkowym" (Górka 2004, s. 100). Dopiero po ukazaniu się w 1912 r. książki J. Schumpetera, Teoria rozwoju gospodarczego uznano decydującą rolę twórczego przedsiębiorcy dla wzrostu gospodarczego. 
Przedsiębiorczość jest złożonym i wieloaspektowym zjawiskiem, o czym świadczy fakt, że nie istnieje jedna, ogólnie przyjęta jego definicja. Odpowiednikiem polskiego określenia przedsiębiorca jest angielskie słowo entrepreneur, które stanowi odniesienie do francuskiego określenia entreprendre, czyli 'podejmować'. W wielu językach europejskich pojęcie przedsiębiorcy, przedsiębiorczości oraz przedsiębiorstwa posiadają wspólny rdzeń etymologiczny, bowiem pochodzą od słów 'przedsiębrać', 'podejmować' (Janasz 2004). Zgodnie ze Stownikiem języka polskiego przedsiębiorczość rozumiana jest jako synonim inicjatywy, rzutkości, pomysłowości, zaradności i dynamizmu (Stownik języka polskiego 1998). J. Schumpeter pisze, że przedsiębiorczość to przede wszystkim innowacyjność, wprowadzanie nowych form organizacji produkcji i sprzedaży, odkrywanie nowych źródeł zaopatrzenia, środków produkcji, które w efekcie umożliwiają wprowadzenie nowego produktu lub technologii, otwarcie nowego rynku, pozyskanie źródeł surowców lub wprowadzenie nowej organizacji (Schumpeter 1960). Zatem przedsiębiorczość rozumiana może być jako czynnik rozwoju gospodarczego kraju, opierający się na innowacyjnej kombinacji zasobów (Schumpeter 1960), określonej sile społeczno-ekonomicznej przenoszącej zasoby z obszarów o niższej efektywności do obszarów o efektywności wyższej (Kozioł 2005). Według OECD przedsiębiorczość wiąże się głównie ze zdolnością ludzi do rozpoczynania nowych przedsięwzięć, liczbą i jakością rozpoczynających działalność przedsiębiorstw oraz łatwością, z jaką te przedsiębiorstwa mogą się znaleźć na rynku i go opuścić. Zatem przedsiębiorczość jest czymś więcej niż konkurencją i ponoszeniem ryzyka związanego z rozpoczęciem działalności gospodarczej (OECD 1998). W dokumentach Unii Europejskiej przedsiębiorczość definiowana jest jako „postawa obejmująca indywidualne motywacje i umiejętności identyfikowania możliwości rynkowych niezależnie lub w ramach organizacji ${ }^{1}$ oraz dążenia do ich zrealizowania w celu wytworzenia nowej wartości lub osiągnięcia sukcesu ekonomicznego. Przedsiębiorczość wykorzystuje kreatywność lub innowacje do wchodzenia i konkurowania na istniejącym rynku, zmieniania tego rynku lub kreowanie nowego. [...] Przedsiębiorczość jest postawą i procesem tworzenia i rozwoju działalności gospodarczej przez łączenie ze sobą podejmowania ryzyka, kreatywności i/lub innowacji z dobrym zarządzaniem w ramach nowych lub istniejących organizacji” (Commission 2003, s. 5-6).

W literaturze spotykane są definicje odnoszące się do trzech form przedsiębiorczości w znaczeniu funkcjonalnym, przedsiębiorcy jako jednostki (osoby lub grupy osób) oraz podejścia do zarządzania, których elementem wspólnym jest poszukiwanie i wykorzystywanie pojawiających się szans rynkowych. Można zatem powiedzieć, że przedsiębiorczość to cecha, postawa lub działanie polegające na ciągłym poszukiwaniu okazji (szans) rynkowych i efektywne ich wykorzystywanie. Efektem ich wykorzystania jest aktywność ludzi (przedsiębiorców) działających rynkowo, w tym kształtowanie nowości, które mają kreować nowe wartości dla odbiorców w postaci innowacyjnych wyrobów i usług. Należy w tym miejscu zaznaczyć, że sama wiedza oraz posiadane zasoby nie są warunkiem wystarczającym do tego, aby być przedsiębiorczym. Przez posiadane zasoby rozumie się m.in. poziom wykształcenia i kwalifikacje siły roboczej, rzeczowy i finansowy majątek trwały przedsiębiorstwa, wartości niematerialne i prawne, należności długoterminowe oraz majątek obrotowy, w tym środki pieniężne, należności, zapasy, papiery wartościowe krótkoterminowe, rozliczenia międzyokresowe czynne (Krajewski 2007). Przedsiębiorczość wiąże się jeszcze, oprócz wyżej wymienionych, z umiejętnością przyswajania

\footnotetext{
${ }^{1} \mathrm{~W}$ literaturze spotyka się zamienne stosowanie określeń organizacja i przedsiębiorstwo. W pracy używane jest określenie przedsiębiorstwo, ponieważ jest to jeden z typów organizacji i należy oczekiwać, że w szczególnych przypadkach relacje przedsiębiorstwa $\mathrm{z}$ otoczeniem będą inne niż organizacji niebędących przedsiębiorstwami.
} 
tradycji, rozumianej jako korzystanie z doświadczenia danej społeczności oraz sprzyjających warunków otoczenia kształtowanych przez państwo. Umiejętne wykorzystywanie przez przedsiębiorstwo lub przedsiębiorcę pojawiających się na rynku okazji (szans) przyczynia się do powstawania nowości rozumianych jako innowacje, które stanowią nową wartość dla klienta. Innowacja wymaga jednak systematycznej pracy i polega na, jak pisze P.F. Drucker, ,celowym i zorganizowanym poszukiwaniu zmian oraz na systematycznej analizie możliwości, jakie te zmiany mogą oferować dla innowacji ekonomicznej bądź społecznej” (Drucker 2004, s. 39).

Przez tak zwaną okazję (szansę) rynkową rozumie się zdarzenia mające miejsce w otoczeniu przedsiębiorstwa lub: ,powstały splot różnorodnych okoliczności o charakterze gospodarczym (albo tylko o skutkach gospodarczych), stwarzających możliwość osiągnięcia dodatkowych korzyści, wartości materialnych lub/i niematerialnych" (Krupski 2008, s. 47). Poziom przedsiębiorczości często definiuje się jako stopień innowacyjności, proaktywności i podejmowania ryzyka, ale nie oznacza to, że im więcej każdego elementu w przedsiębiorstwie, tym jego przedsiębiorczość jest większa. Chodzi tu raczej o zrównoważony proces, w którym właściwe natężenie poszczególnych elementów zależne jest od konkretnej sytuacji (Dyduch 2007). Przedsiębiorca powinien zatem poszukiwać zmian, odpowiadać na nie i wykorzystywać je jako szansę (Drucker 2004). S. Shane, S. Venkataraman przedsiębiorcze szanse definiują jako sytuacje, w których mogą być wprowadzane na rynek nowe produkty, usługi, surowce i metody organizacyjne, sprzedawane po cenach wyższych niż wynosi koszt ich produkcji (Shane, Venkataraman 2000). J.T. Eckhardt i S. Shane kładą nacisk na twórczy charakter decyzji przedsiębiorczych, definiując szanse rynkowe jako sytuacje, w których nowe produkty i usługi, surowce i metody organizacyjne mogą być wprowadzane przez tworzenie nowych środków, celów oraz związków między celami a środkami (Eckhardt, Shane 2003). Zdaniem A. Ardichvili i R. Cardozo rozpoznanie szansy jest zdeterminowane przez trzy podstawowe czynniki, tj. przedsiębiorczą wrażliwość, wcześniejszą znajomość rynków i problemów klientów oraz działanie w sieciach społecznych, czyli posiadanie licznych kontaktów, co pozwala na większy dostęp do informacji. Na posiadaną wiedzę o rynku i problemach klienta składa się odpowiednie wykształcenie oraz doświadczenie osobiste i zawodowe (Ardichvili, Cardozo 2000).

Przedsiębiorczość to umiejętność uzupełniania braków na funkcjonujących już rynkach. Jak pisze H. Leibeinstein, ,przedsiębiorczość pojawia się po to, by poprawiać niedoskonałości rynku" (Leibenstein 1995, s. 273-275). Zatem niedoskonałość rynków przyczynia się do wzrostu znaczenia przedsiębiorczości, polegającej na szukaniu nowych dziedzin działalności na bazie innowacji z uwzględnieniem wdrażania w przedsiębiorstwie postępu organizacyjnego i technologicznego. Efektem tych działań będzie powstanie nowego produktu, nowego rynku, nowego klienta. Jak pisze P. Szulich: „Działalność przedsiębiorcza polega na wprowadzeniu innowacji, które są działaniem łamiącym tradycję i wprowadzającym nowość. Wysiłek i ryzyko, które towarzyszą zawsze twórczej nowości, są wpisane w przedsiębiorczość" (Szulich 2004, s. 39). W tym przypadku można mówić o tzw. innowacji radykalnej, przełomowej, która jest czymś nowym i polega na odejściu od znanych wcześniej metod czy technologii, oraz o innowacji przyrostowej, która stanowi nowe wykorzystanie znanych już form czy technologii i polega na udoskonaleniu czegoś, co już istnieje. Innowacje te zapewniają przedsiębiorstwu stały napływ nowych, poprawionych i zróżnicowanych produktów, zapewniających rozwój i utrzymanie konkurencyjności. Innowacje przyrostowe są tańsze i bezpieczniejsze, natomiast innowacje radykalne - aby mogły odniosły sukces - potrzebują cierpliwości i odpowiedniego budżetu, zapewniającego wsparcie w długim horyzoncie czasowym. Innowacja przyrostowa, choć jest mniej ryzykowna i wymaga mniej czasu, nie może zagwarantować przedsiębiorstwu, że w przyszłości pozostanie ono konkurencyjne (Managing 2003). 
Innowacja bierna, zwana też innowacją imitacyjną, związana jest z przenoszeniem rozwiązań powstałych w wyniku innowacji czynnej (twórczej) do innych przedsiębiorstw. W tym przypadku innowacja to kopiowanie pomysłu poprzez bezpośrednie wdrażanie, zaadaptowanie, np. sposobów zarządzania czy działań marketingowych. W tym ujęciu rozwój przedsiębiorczości związany jest ze zdolnością przedsiębiorstwa do dostrzegania luk na rynku, poszukiwania zmian oraz reagowania na nie i wykorzystywanie ich do tworzenia innowacji. Działania przedsiębiorcze odnoszące się do innowacji decydują o konkurencyjności przedsiębiorstwa na rynku. O ile dostosowywanie się przedsiębiorstwa jest reakcją na zachodzące w otoczeniu zmiany, o tyle umiejętność wyprzedzania tych zmian pozwala przedsiębiorstwu wpływać na reakcję otoczenia. Tworzenie nowego rynku nie tylko umożliwia wzrost i powstawanie nowych przedsiębiorstw, ale pozwala na przetrwanie i rozwój już istniejących. Prawdziwie innowacyjny produkt sam kreuje dla siebie rynek, a nie konkuruje o udział w już istniejącym.

Przedsiębiorczość, co należy podkreślić, w swoim zakresie obejmuje właśnie innowacyjność. W tym ujęciu bycie przedsiębiorczym oznacza podejmowanie działań, które mają na celu odkrywanie nowych, dotychczas nieznanych obszarów działania, dających szanse osiągnięcia większych korzyści niż dotychczas. Natomiast umiejętność wykorzystania szans rynkowych wiąże się z postawą twórczą, rozumianą jako kreatywność.

Jak pisze J. Baruk: „Kreatywność polega na kojarzeniu - wykorzystywaniu wiedzy z różnych odrębnych dziedzin do tworzenia nowych, oryginalnych myśli, na odkrywaniu nowych znaczeń w różnych dziedzinach życia i doświadczenia oraz niekonwencjonalnym łączeniu ich ze sobą. Kreatywność zmusza ludzi do ciągłego odkrywania nowych dróg, stawiania wyzwań utartym sposobom myślenia i radzenia sobie z konfliktami, do których te dziedziny nieuchronnie prowadzą" (Baruk 2006, s. 90). Niewątpliwie kreatywność, która jest dostrzegalna w postaci wytworzonych produktów i procesów, czyli przejawia się w procesie tworzenia pomysłów (idei), jest źródłem postępu i przedsiębiorczości.

Informacja to przetworzone dane, które zmieniają naszą świadomość, natomiast wiedza to zbiór informacji wraz z regułami ich interpretowania. Dane w interpretacji subiektywnej stają się wiedzą. Zatem na kreatywność przedsiębiorcy lub menadżera $\mathrm{w}$ przedsiębiorstwie wpływ ma dostępna informacja o okazjach (szansach) rynkowych ${ }^{2}$, posiadana wiedza, nabyta np. w trakcie procesu kształcenia, oraz umiejętności, przez które rozumie się cechy, jakimi powinien odznaczać się człowiek przedsiębiorczy. Do cech tych należą m.in. zdolność do długotrwałego wysiłku oraz podejmowania inicjatyw i ryzyka z nimi związanego, elastyczność, a także umiejętność podejmowania decyzji przy niepełnych informacjach i kierowanie ludźmi oraz wzbudzanie w nich entuzjazmu do realizacji wytyczonych celów, zdolność do przekonywania, łamania zwyczajów i tradycji oraz otwartość na nowe doświadczenia (Schumpeter 1960). A. Gibb określa przedsiębiorcę jako osobę o takich cechach charakteru, jak: „inicjatywa, silna zdolność przekonywania, raczej umiarkowana niż wysoka skłonność do podejmowania ryzyka,

$\overline{{ }^{2} \mathrm{Z} \text { badań prowadzonych } \mathrm{w}}$ polskich przedsiębiorstwach wynika, że w $50 \%$ przedsiębiorstw dominuje podejście przedsiębiorcze nakierowane na aktywne wykorzystywanie okazji. 17\% realizowało swój rozwój zgodnie z klasycznymi kanonami planowania strategicznego, a u 33\% stwierdzono tzw. rozwój dostosowawczy. Do okazji (szans) rynkowych można zaliczyć np. wyjątkowo tani, niezaplanowany zakup środka produkcji, placu, lokalu; niespodziewaną ofertę współpracy ze strony dużego, znanego przedsiębiorstwa; wykorzystywanie różnych środków pomocowych funduszy UE; nowe, sprzyjające rozwiązania systemowe; wykup upadającego, lokalnego konkurenta; wycofanie się z rynku lokalnego konkurenta i przejęcie jego klientów; pozyskanie nowego inwestora, połączenie przedsiębiorstw; usuwanie awarii; niespodziewane wygranie przetargu; niespodziewany wzrost zapotrzebowania, np. z rynków zagranicznych (Krupski 2008). 
elastyczność, kreatywność, autonomia, zdolność rozwiązywania problemów, przywództwo, umiejętność ciężkiej pracy" (Gibb 1990, s. 38). Cechy charakteryzujące przedsiębiorcę wynikają po części z uosobienia człowieka, które warunkuje skłonność do podejmowania ryzyka, ale po części też mogą być wyuczone i wykształcone w czasie edukacji i zdobywania doświadczenia. Zatem kreatywność to zdolność jednostki do myślenia nietypowego (nieschematycznego, swobodnego), podejmowania ryzyka, uczenia, u podstaw którego leżą przeżywane doświadczenia, procesy poznawcze i obserwacje.

Reasumując powyższe rozważania, do głównych rodzajów przedsiębiorczości zaliczyć można: przedsiębiorczość gospodarczą, intelektualną, administracyjną i społeczną. Przedsiębiorczość administracyjna realizowana jest w sektorze publicznym, natomiast przedsiębiorczość społeczna - w organizacjach non profit. Przedsiębiorczość intelektualna polega natomiast na tworzeniu materialnych bogactw z niematerialnej wiedzy (Bieniok, Kraśnicka 2000; Kwiatkowski 2000). Przedsiębiorczość gospodarczą można rozpatrywać na poziomie indywidualnym, oznaczającym cechę osobowości i umiejętności oraz łącznym, inaczej zbiorowym, oznaczającym aktywność gospodarczą wielu przedsiębiorstw. Zatem w przypadku drugim można mówić o „przedsiębiorczym przedsiębiorstwie”, które charakteryzuje się podejmowaniem ryzyka, wprowadzaniem innowacji i praktycznym działaniem jej uczestników (Miller 1983), od opracowania koncepcji do tworzenia wartości. Natężenie przedsiębiorczości zarówno indywidualnej, jak i zbiorowej zmienia się wraz $\mathrm{z}$ wieloma warunkami, takimi jak otoczenie prawne, instytucjonalne czy finansowe.

\section{Otoczenie i jego wplyw na przedsiębiorczość}

Działalności przedsiębiorstwa nie można rozpatrywać bez uwzględnienia jego otoczenia, ponieważ to ono w dużym stopniu decyduje o sukcesie lub niepowodzeniu przedsiębiorstwa. Zmiany w otoczeniu stwarzają przedsiębiorstwu szanse, ale mogą oznaczać dla niego też zagrożenia (Żurek 2008). Zachowanie przedsiębiorstwa na rynku jest zatem konsekwencją wpływu otoczenia, w którym przedsiębiorstwa działają, a które jest złożone i trudno przewidywalne. Zmieniające się szybko otoczenie zmusza przedsiębiorstwa do koncentrowania uwagi na osiąganiu przewagi konkurencyjnej poprzez niekonwencjonalne i innowacyjne zachowania, wyznaczając główny cel ich działania.

Dla przedsiębiorstw decydujących się na działanie na rynku globalnym otoczenie międzynarodowe ma szczególne znaczenie. W jego ramach analizie poddawane są uwarunkowania ekonomiczne, prawne, techniczno-technologiczne, polityczne, socjokulturowe, demograficzne i związane z ochroną środowiska (Żurek 2008). Zmiany w tym otoczeniu są bardzo dynamiczne, zmienne w czasie i trudne do przewidzenia.

Poddawanie się przedsiębiorstwa presji otoczenia zależy od jego pozycji na rynku. Przedsiębiorstwo zajmujące pozycję dominującą ulega w mniejszym stopniu swemu otoczeniu, natomiast przedsiębiorstwo zajmujące pozycję peryferyjną musi reagować szybko i elastycznie na jego żądania. „Złożoność otoczenia związana jest z coraz większą liczbą jego zróżnicowanych elementów, których wpływ jest coraz trudniejszy do przewidzenia, zaś zmienność z coraz szybszym wprowadzaniem innowacji w produktach oraz w innych działaniach przedsiębiorstwa" (Penc 1999, s. 23). Z otoczeniem dalszym wiąże się większe ryzyko występowania niekorzystnych dla przedsiębiorstwa elementów, ponieważ jest ono niemożliwe do przewidzenia.

Współczesna gospodarka globalna stawia przed wszystkimi przedsiębiorstwami coraz większe wymagania, z powodu ciągłego postępu technologicznego, jak i w wyniku dynamicznego rozwoju krajów określanych mianem rynków wschodzących (ang. emerging markets), stosujących z powodzeniem najnowsze technologie i dysponujących dużymi zasobami taniej siły roboczej. 
Prowadzi to do uzyskiwania przez nie znaczących przewag konkurencyjnych, gdyż swoje strategie rozwojowe opierają na zdecydowanej ekspansji eksportowej (Wyżnikiewicz 2009). Globalizację natomiast należy rozumieć jako: ,dokonujący się na świecie długofalowy proces integrowania coraz większej liczby krajowych gospodarek ponad ich granicami, dzięki rozszerzaniu oraz intensyfikowaniu wzajemnych powiązań (inwestycyjnych, produkcyjnych, handlowych, kooperacyjnych), w wyniku czego powstaje ogólnoświatowy system ekonomiczny o dużej współzależności i znaczących reperkusjach działań podejmowanych/toczących się nawet w odległych krajach" (Zorska 1998, s. 14). Według K. Kucińskiego globalizacja oznacza: „ogólnoświatowy proces integracji systemów ekonomicznych i podmiotów gospodarczych. Polega na tym, że działalność gospodarcza jest konfigurowana i koordynowana w skali całego świata w celu zminimalizowania kosztów, maksymalizowania nowo tworzonej wartości produktów i uzyskania dostępu do rynku o również światowym zasięgu. Konsekwencją, a zarazem przyczyną globalizacji gospodarki, jest globalizacja wszelkich przejawów życia społecznego. Jej przejawem jest globalizacja technologii, stylu życia, modeli konsumpcji, kultury, rządzenia, regulacji prawnych, postrzegania i świadomości. Wynika ona z kompresji świata uzyskanej dzięki postępowi technicznemu i ujednolicaniu się form organizacji gospodarki oraz życia politycznego w poszczególnych krajach” (Kuciński 2002, s. 13). Z tego stanowiska wynika fakt swoistego przenikania zjawiska globalizacji przez różne dziedziny. Mówimy więc o globalizacji w odniesieniu do polityki, działalności społecznej i kulturowej. Zatem jak pisze B. Liberska jest to: „zespół procesów prowadzących do intensyfikacji ekonomicznych, politycznych i kulturowych stosunków poprzez granice” (Liberska 2002, s. 17), wskazując na całościowe traktowanie tego procesu i uzyskiwanie różnorodnych jego implikacji. Wpływ na rozwój gospodarczy podkreśla R. Piasecki, definiując globalizację jako: ,rosnącą internacjonalizację produkcji, dystrybucji i marketingu dóbr oraz usług, złożony proces będący wynikiem szybko rosnącego przepływu dóbr, pieniędzy, ludzi i idei” (Piasecki 2003, s. 73). W odniesieniu do procedur zarządzania strategicznego globalizację definiują G. Gierszewska i B. Wawrzyniak jako: ,proces zmiany perspektywy postrzegania reguł i zasad postępowania, zdarzeń, zachowań, działań, uznawanych wartości z perspektywy narodowej na ogólnoświatową" (Gierszewska, Wawrzyniak 2001, s. 13). Dla celów pracy przyjęto definicję Komisji Europejskiej, która globalizację definiuje jako: ,proces, w którym rynki i produkcja w różnych krajach stają się coraz bardziej współzależne w związku z dynamiką wymiany towarów i usług, przepływem kapitału i technologii” (Annual Economic 1997, s. 32). W literaturze przedmiotu najczęściej opisuje się wymiar ekonomiczny globalizacji, ale jest to zjawisko wielowymiarowe i interdyscyplinarne, dotyczące aspektów społecznych czy ekologicznych. W procesie globalizacji konkurencja powinna być powiązana z kooperacją uwzględniającą kwestie etyczne, moralne, a nie powinna skupiać się wyłącznie na aspektach ekonomicznych (Pangsy-Kania 2007).

\section{Warunki rozwoju przedsiębiorczości}

Poziom i intensywność zachowań przedsiębiorczych mogą być różne i zależeć od potencjału przedsiębiorczości oraz od sytuacji (środowiska pracy). Natężenie przedsiębiorczości zmienia się wraz z takimi warunkami, jak otoczenie prawne, finansowe czy instytucjonalne. Należy stwierdzić, że czynnikami warunkującymi przedsiębiorczość są środowisko pracy, czyli zasoby posiadane przez przedsiębiorstwo oraz cechy człowieka przedsiębiorczego i jego motywacja do działań przedsiębiorczych (Kozioł 2005). Zatem czynniki rozwoju przedsiębiorczości można podzielić na wewnętrzne, bazujące na zasobach wewnętrznych przedsiębiorstwa, takich jak np. zasoby ludzkie, rzeczowe składniki majątku, własne zaplecze badawczo-rozwojowe oraz wiedza i informacje technologiczne, oraz czynniki zewnętrzne, tworzone przez zasoby otoczenia pozostające do dyspozycji przedsiębiorstwa. 
Czynniki osobowościowe są istotne dla rozwoju przedsiębiorczości, ale nie mniej ważne są czynniki zewnętrzne, które wypływają z makrootoczenia i które tym samym kształtują ramy rozwoju przedsiębiorczości. Zatem niezbędne są warunki zewnętrzne dostarczające przedsiębiorstwom skutecznych bodźców do działań przedsiębiorczych. Uwarunkowania przedsiębiorczości można podzielić na uwarunkowania osobowościowe, które koncentrują się wokół cech indywidualnych, osobowych oraz wyznaczonych systemów wartości, a także uwarunkowania lokalne i makroekonomiczne. Uwarunkowania lokalne przedsiębiorczości związane są z celami i realizacją polityki lokalnej oraz aktywnością danej społeczności w podejmowaniu działań przedsiębiorczych.

Warunki makrootoczenia, wpływające na charakter i poziom przedsiębiorczości, które są genezą przedsiębiorczości, związane są z warunkami prawnymi, politycznymi, ekonomicznymi, kulturowymi, społecznymi i komunikacyjnymi (Safin 2004). Potencjał wewnętrzny przedsiębiorczości charakteryzowany jest przez motywację do działań przedsiębiorczych, czyli motywację osiągnięć, chęć współpracy i dzielenie się wiedzą, zainteresowanie i zamiłowanie do pracy koncepcyjnej oraz motywację ekonomiczną ukierunkowaną na wartości materialne oraz technikę, technologię, jaką dysponuje przedsiębiorstwo, oraz właściwości intelektualne, czyli cechy potencjału zasobów ludzkich. Środowisko pracy tworzą m.in. struktura oraz kultura organizacyjna ukierunkowane na działania przedsiębiorcze. Zatem tak funkcjonujące przedsiębiorstwo stwarza swoim pracownikom możliwość angażowania znacznej części ich potencjału, zapewniając tym samym dogodne warunki dla rozwoju przedsiębiorczości wewnątrz przedsiębiorstwa. Przedsiębiorczość dużych podmiotów gospodarczych prowadzoną wewnątrz organizacji określa się mianem przedsiębiorczości wewnętrznej lub intraprzedsiębiorczości. Należy ją rozumieć jako „koncepcję wspomagania procesów innowacyjnych w bardzo dużej organizacji, we wszystkich obszarach jej działalności. Jej celem jest stymulowanie i realizacja procesów innowacyjnych, obejmujących identyfikację i wspomaganie przedsiębiorcy, tworzenie struktur innowacyjnych oraz sprzyjającego klimatu w przedsiębiorstwie. [...] Przedsiębiorczość wewnętrzna jest filozofią poszukiwania nowych możliwości rozwiązywania problemów strategicznych, związaną z przedsiębiorczą orientacją organizacji” (Hryń, Kmiotek, Piecuch 2002, s. 55).

Czynniki zewnętrzne rozwoju przedsiębiorczości to szereg uwarunkowań otoczenia oddziałujących na możliwości przedsiębiorstwa. Otoczenie wpływa na przedsiębiorcę, stwarza mu szanse i możliwości, ale jednocześnie stawia wymogi i ogranicza. Przez otoczenie przedsiębiorcy należy rozumieć wszystko to, co znajduje się poza organizacją i ma na nią wpływ, dlatego też przedsiębiorca powinien odznaczać się umiejętnością oceny środowiska, w którym funkcjonuje. W uwarunkowaniach zewnętrznych tkwią zarówno szanse zachęcające do podejmowania działań przedsiębiorczych, jak i zagrożenia zniechęcające do takich działań. Szczególnie ważna zatem wydaje się ocena szans i zagrożeń, które występują w otoczeniu. Każde istotne dla przedsiębiorstwa nowe wydarzenie lub nowy pojawiający się trend na rynku może być dla niego zarówno szansą, jak i zagrożeniem. Zależy to w dużej mierze od tego, jakimi danymi i informacjami dysponują pracownicy tego przedsiębiorstwa i czy podejmą właściwą decyzję. Dla działań przedsiębiorczych istotna jest umiejętność takiego wykorzystania informacji, które staną się szansą i sukcesem przedsiębiorstwa.

Otoczenie prawne jest to prawna regulacja działalności gospodarczej i stosunki między państwem a gospodarką. Można tu zaliczyć prawo gospodarcze, system podatkowy, rozporządzenia wykonawcze do ustaw, orzecznictwo sądów i interpretację przepisów przez urzędników. System prawny określa to, co przedsiębiorca może, a czego nie oraz jaką ma szansę prawnych warunków działania. Otoczenie polityczne kształtuje klimat dla przedsiębiorczości w kręgach 
polityków. Ważne są tu takie czynniki, jak stabilność układów na szczeblu krajowym i lokalnym, koniunktura i zmiany nastawienia, zakres roszczeń i oczekiwań korupcyjnych, postawy etyczne, zmiany w swoim zakresie i w czasie (Korzeniowski 2004).

Zbyt rozbudowane i skomplikowane prawo o niskiej jakości w sposób istotny utrudnia procesy rozwojowe w gospodarce. Istniejące bariery, zwłaszcza biurokracja, ograniczają przedsiębiorczość polskich obywateli, utrudniają prowadzenie działalności biznesowej i zniechęcają zagranicznych inwestorów. Program „Lepsze Prawo” stanowi modyfikację działań określonych w Programie Reformy Regulacji. Intencją jest zwiększenie dynamiki poprawy otoczenia regulacyjnego, stąd realizację procesu podzielono na trzy okresy. Pierwszy okres zmian przewiduje działania związane z naprawą prawa. Zmiany te mają na celu zwiększenie wolności gospodarczej poprzez szybkie, jednostkowe zmiany, m.in. nowelizację ustawy o swobodzie działalności gospodarczej. Dodatkowo przewidziano przygotowanie ustawy derogacyjnej, usuwającej poszczególne przepisy, a nawet całe ustawy szkodzące rozwojowi przedsiębiorczości oraz przygotowanie ustawy dereglamentacyjnej usuwającej zbędne reglamentacje (zezwolenia, pozwolenia, licencje) działalności gospodarczej (Przedsiębiorczość 2008). Drugi okres zmian będzie dotyczył kontynuacji zmiany systemu stanowienia prawa. W tym zakresie przewidziano m.in.:

- ujednolicenie obowiązków związanych z przygotowaniem projektu ustawy, bez względu na podmiot posiadający inicjatywę legislacyjną,

- usprawnienie planowania procesu legislacyjnego,

- zmianę przepisów dotyczących procesu legislacyjnego w ramach działania Sejmu i Senatu (m.in. zmiany zasad składania projektów ustaw i poprawek do projektów),

- usprawnienie konsultacji społecznych na etapie tworzenia założeń projektów ustaw,

- zapewnienie realizacji obowiązku dokonywania przed przygotowaniem założeń projektów ustaw znowelizowanej oceny skutków regulacji - OSR, w tym również dokonywania wyceny kosztów wprowadzania obowiązków administracyjnych dla adresatów prawa (Przedsiębiorczość 2008).

Równolegle będą realizowane programy edukacyjne i promocyjne polegające na edukacji społecznej i promocji zasad pozytywnego działania, np. poprzez:

- promocję przedsięwzięć realizowanych w formie partnerstwa publiczno-prawnego, w tym demonopolizacji administracji publicznej,

- promocję i wsparcie dla sądów polubownych i arbitrażu,

- promocję norm etycznych i moralnych w prowadzeniu biznesu (Przedsiębiorczość 2008).

Działania tego etapu obejmą również odejście od rozszerzania systemu nakazów, zakazów i kar na rzecz dialogu społecznego i konsultacji oraz realizacji projektów edukacyjnych dotyczących podnoszenia świadomości społecznej, np. w zakresie praw obywatelskich, praw przedsiębiorców oraz praw konsumenckich.

Przewagę konkurencyjną terytorium warunkują cechy środowiska rozwoju przedsiębiorczości i innowacji, wytwarzane przez to terytorium. W tradycyjnej teorii lokalizacji jako czynniki lokalizacyjne dla przedsiębiorstwa wskazywano przede wszystkim koszty uzyskania surowców, dostępu do rynku, różniczkowe koszty siły roboczej oraz czynniki dodatkowe, takie jak efekt aglomeracji i korzyści zewnętrzne (Gorzelak, Jałowiecki 2000). Jak pisze M. Gancarczyk: „Obecnie kryteria lokalizacji firm oparte na tzw. prostych zasobach zostały zastąpione przez kryteria jakościowe, o charakterze niematerialnym. Na tę zmianę wpłynął z jednej strony wzrost mobilności czynników produkcji i spadek kosztów transportu, z drugiej zaś, rozwój przemysłów wiedzochłonnych, kosztem tradycyjnych, zasobochłonnych" (Gancarczyk 2001, s. 59). Bliskość geograficzna zapewnia korzystną koncentrację umiejętności oraz wiedzy przedsiębiorstw, instytucji i organizacji, a także klientów na danym terytorium. Do optymalnego wykorzystania 
lokalnych zasobów i dużej elastyczności działania przedsiębiorstw przyczyniają się podobne warunki infrastruktury, uwarunkowania polityczno-prawne, bliskość kulturowa oraz wspólne wartości i obyczaje, co oznacza, że na danym terytorium (regionie, powiecie, gminie) uzyskuje się efekt synergii gospodarczej (Szymoniuk 2008).

Stan rozwoju infrastruktury transportowej w Polsce nie jest zadowalający. Braki w tym zakresie hamują rozwój przedsiębiorczości oraz negatywnie wpływają na wykorzystanie potencjału regionów, zwłaszcza peryferyjnych. Stan infrastruktury drogowej uważany jest za jedną z ważniejszych barier rozwoju przedsiębiorczości. Słabe strony sieci drogowej to brak kompleksowej sieci dróg i autostrad, niedostosowanie dróg do nośności 115 kN/oś, ruch odbywający się przez tereny zabudowane, bezpieczeństwo oraz niedostateczny stan techniczny dróg. Należy zauważyć, że niski przedział nośności dróg jest rezultatem prowadzenia polityki transportowej sprzed okresu transformacji, kiedy to zakładano, że polskie drogi będą służyły do obsługi ruchu osobowego i lekkiego ciężarowego, podczas gdy transport towarowy miał się odbywać drogą kolejową. Efektem takiego podejścia jest zmniejszenie bezpieczeństwa ruchu oraz wzrost kosztów ekonomicznych i społecznych. Transport kolejowy, pomimo znacznego zapóźnienia rozwojowego i w konsekwencji niskiej jego konkurencyjności, może stanowić niedrogi i szybki środek transportu ładunkowego. Jego plusy to możliwość przewozów masowych, niższe stawki, szczególnie przy znacznych odległościach, możliwość łączenia transportu (transport kombinowany). Istotnym argumentem na rzecz jego wykorzystania są kwestie ochrony środowiska. Długość eksploatowanych linii kolejowych wynosi obecnie 19 tys. km, tj. o ok. 3 tys. km mniej niż w 2000 r., przy czym zaledwie 2,3 tys. km linii dostosowanych jest do prędkości 120 km/h (i więcej). Każdy z 72 największych dworców kolejowych obsługuje rocznie około miliona pasażerów. W Ministerstwie Infrastruktury przygotowywany jest, w ścisłej współpracy z Komisją Europejską, Master Plan dla transportu kolejowego w Polsce do 2030 roku. Będzie on strategicznym dokumentem planistycznym, pozwalającym władzom państwa i podmiotom gospodarującym w polskim transporcie kolejowym podejmować zadania inwestycyjne oraz stworzyć harmonogram realizacji innych zadań, szczególnie w zakresie: projektowania i przygotowania inwestycji, budowy i modernizacji infrastruktury, likwidacji zbędnej części istniejącej infrastruktury, świadczenia usług przewozowych, zarządzania infrastrukturą kolejową i jej utrzymania. Działania te mają prowadzić do stworzenia sprawnego i efektywnego systemu transportu kolejowego, będącego konkurencyjną alternatywą wobec innych gałęzi transportu. Dokument będzie również podstawą do planowania i wydatkowania środków pochodzących z Unii Europejskiej, przewidzianych na modernizację infrastruktury kolejowej (Przedsiębiorczość 2008).

Rośnie rola portów regionalnych. Postępująca decentralizacja ruchu, jak również perspektywa wyczerpania się przepustowości największego portu lotniczego Warszawa-Okęcie wpłynęła na rozkwit portów regionalnych, z których w 2007 r. skorzystała ponad połowa pasażerów. W 2007 r. liczba pasażerów portów regionalnych wzrosła o ok. 36\%, z czego najwięcej w portach Kraków-Balice, Katowice-Pyrzowice oraz Gdańsk-Rębiechowo. Wzrost obserwowano również w przypadku przesyłek (ponad 23\%). Z kolei najprężniej rozwijającym się portem w ostatnich latach jest Łódź-Lublinek, który to z małego portu obsługującego ok. 6 tys. pasażerów w 2004 r. zwiększył ich liczbę do ponad 312 tys. w 2007 r. (Przedsiębiorczość 2008).

Jakość, ilość, przepustowość, bezpieczeństwo i dostępność infrastruktury w dużym stopniu wpływają na warunki prowadzenia działalności gospodarczej. Przedsiębiorstwa działające w Polsce, aby sprostać globalnej konkurencji, potrzebują dobrych połączeń transportowych i niezawodnych sieci informacyjno-telekomunikacyjnych. W Ministerstwie Gospodarki powstał projekt Programu działań na rzecz wspierania elektronicznego handlu $i$ ustug. Dokument 
realizuje strategiczne cele działań państwa dla ułatwienia prowadzenia działalności gospodarczej przy wykorzystaniu Internetu i innych środków komunikacji elektronicznej, jak również tworzenia warunków prawnych wykorzystania narzędzi informatycznych i ułatwienia podnoszenia kwalifikacji zawodowych. Program będzie sprzyjać zmianie struktury rynku IT w Polsce w kierunku zwiększenia udziału usług informatycznych i wzrostu rynku produkcji oprogramowania. W drugiej połowie 2008 r. planowane jest przedłożenie projektu pod obrady Rady Ministrów (Przedsiębiorczość 2008).

Konkurencja globalna oraz coraz mniejsze znaczenie fizycznych granic państw sprzyjają tworzeniu się ponadnarodowego rynku. Funkcjonowanie przedsiębiorstwa na terenie obcego kraju zawsze wiąże się z pojęciem różnic kulturowych, które w większym lub mniejszym stopniu, ale zawsze będą miały wpływ na to przedsiębiorstwo. Im bardziej kulturowo kraje są zbliżone do siebie, tym łatwiej jest im prowadzić działalność. Kultura narodowa odgrywa istotną rolę w kształtowaniu wartości, postaw i zachowań w miejscu pracy i poza nim (Schroeder 2000). Przedsiębiorstwa działające na rynku globalnym powinny być szczególnie wrażliwe na kulturę narodów, których potrzeby pragną zaspokoić. Do szeroko rozumianych uwarunkowań kulturowych można zaliczyć religię, zwyczaje konsumpcyjne, poczucie estetyki, nastawienie do produktów zagranicznych, rolę języka, prawo, poziom wykształcenia, znaczenie symboli i kolorów (Oniszczuk-Jastrząbek 2004). Kultura narodowa jest to więc pewien zestaw wierzeń, wiedzy, prawa, motywacji, norm, zdolności i nawyków wyznawanych przez większość mieszkańców danego kraju i nabytych przez człowieka jako członka społeczności, odnoszących się do sposobu życia (Bennett 1999, Bartosik-Purgat 2006, Linton 2000). Kultura narodowa wpływa na kulturę organizacyjną przedsiębiorstwa, która uwzględniać powinna indywidualne zamierzenia, motywacje, normy i wartości, jakie ludzie akceptują jako te, które współtworzą organizacyjną rzeczywistość (Pocztowski 2002). Należy wyraźnie podkreślić, że kultura organizacyjna przedsiębiorstwa uwarunkowana jest cechami kultury narodowej. Ludzie stają się częścią przedsiębiorstwa, jednak posiadają już ugruntowane poglądy na życie zakorzenione w odpowiednim zbiorze norm i wartości (Masłowski 2005). Nośnikami kultury narodowej w przedsiębiorstwie są zatem jego pracownicy, klienci, dostawcy i inne przedsiębiorstwa działające w otoczeniu zewnętrznym, ale także przepisy administracyjne i prawne, zwyczaje czy obyczaje.

Jedną z najistotniejszych determinant przedsiębiorczości o charakterze społeczno-kulturowym jest problem postaw społecznych wobec zjawiska przedsiębiorczości. Czynnik ten określa poziom akceptacji społecznej dla przedsiębiorczości oraz identyfikuje istotne bariery społeczne oraz wyznacza społeczne cele, jakim powinna służyć przedsiębiorczość. Społeczeństwa tworzą gospodarkę, a gospodarki nie istnieją bez społeczeństw. Na postawy społeczne wobec zjawiska przedsiębiorczości składają się postawy wobec przedsiębiorców i bogactwa, które jest efektem działalności przedsiębiorcy. Postawy te wynikają z tradycyjnych, charakterystycznych dla danej kultury norm i wartości, które są konfrontowane z normami i wartościami przejmowanymi z zewnątrz (Kisiel 1999). Polska tradycja opiera się na stosunkowo niskim wartościowaniu przedsiębiorczości jako formy aktywności zawodowej. W kulturze staropolskiej pomnażanie bogactwa, traktowane jako cel życia, było uznawane raczej jako zajęcie niegodne szlachetnego męża, a zajmowanie się handlem zostało zakazane szlachcie już w Kodeksie Łaskiego z 1505 r. Owa niechęć była kultywowana w kulturze polskiej, czego wyrazem jest chociażby literatura z tragiczną postacią Wokulskiego z Lalki czy karykaturalne przedstawienie Nikodema Dyzmy. W kulturze okresu socjalizmu, pomijając czynniki polityczne, brak akceptacji dla przedsiębiorczości spowodowany był kultem pracy fizycznej, której efektem było coś konkretnego, co wymagało fizycznego wysiłku. Wyższość pracy fizycznej nad intelektualną 
powodowała, że przedsiębiorca nie mógł cieszyć się uznaniem społecznym (Kisiel 1999). Przedsiębiorczość w Polsce nie jest postrzegana przez opinię publiczną w sposób, na jaki zasługuje. Przeciętni ludzie patrzą zwykle na przedsiębiorców z punktu widzenia osiąganych przez nich dochodów, a nie przez pryzmat korzyści ogólnospołecznych i gospodarczych, jakie przynosi podejmowanie przez kogoś działalności gospodarczej, stwarzanie nowych miejsc pracy czy rozbudzanie inicjatywy i uniezależnianie się od państwa. Nie bierze się również pod uwagę premii za ryzykowanie własnym kapitałem. Natomiast sukces innowacyjny Stanów Zjednoczonych spowodowany jest m.in. tradycją kulturową opartą na podejmowaniu ryzyka w duchu przedsiębiorczości oraz mocnej społecznej akceptacji innowacji (Pangsy-Kania 2007).

Na aktywność społeczeństw wpływają cztery grupy czynników. W pierwszej wymienia się cechy jednostek, czyli dominujące typy osobowości charakterystyczne dla osób twórczych, kreatywnych, nastawionych na osiągnięcia itp. Do drugiej grupy zalicza się warunki - struktury społeczne - do aktywności zachęca otwartość i akceptacja dla różnorodności i oryginalności, elastyczność i tolerancja. W następnej grupie czynników wymienia się stosunek danego społeczeństwa do własnej historii, z której społeczeństwa są dumne i czerpią siłę do dalszego rozwoju. W czwartej grupie znajdują się optymizm, nadzieja i przekonanie, że od ludzkich działań zależy to, co się stanie (Szcześniak 2009).

Jak pisze K. Pająk, na poziomie indywidualnym może występować sprzężenie zwrotne między innowacyjnością a rodzajem kapitału społecznego, który opiera się na sieci kontaktów z innymi osobami. Natomiast na poziomie organizacji innowacyjność jest obecna pod postacią wartości tworzących daną kulturę organizacyjną, która wpływa na efektywność działania organizacji. Na poziomie społeczeństw i gospodarek krajowych kapitał społeczny oddziałuje na innowacyjność (B+R) pośrednio poprzez kapitał ludzki (Pająk 2006). Bardzo istotny jest zatem stan społeczeństwa jako całości, czyli jego zamożność, mentalność, odpowiedzialność społeczna, czy też międzypokoleniowe podejście do przedsiębiorczości i innowacyjności. Kolejną cechą uwarunkowań społecznych jest liczba i jakość zasobów ludzkich w odniesieniu do pracochłonności i procesów gospodarczych oraz cechy osobowości członków społeczeństwa, ich kreatywność, ciekawość, otwartość i motywacja.

Jak pisze B. Karnat-Jasicka: „,współcześnie w fazie gospodarki opartej na wiedzy, tradycyjne cechy kapitału społecznego, takie jak: pracowitość, przedsiębiorczość, odpowiedzialność, normy moralne i etyczne, kultura, a nawet altruizm społeczny mogą być niewystarczające. Potrzebne są specyficzne atrybuty, czyli: gotowość do ponoszenia ryzyka, otwartość na nowe idee i różnorodność, umiejętność współpracy, zorganizowanie i wykorzystywanie sieci powiązań. [...] Wzrasta znaczenie takich właściwości, jak: inwencja, pomysłowość i wynalazczość, znajomość metodyki poszukiwania twórczych rozwiązań i pobudzania twórczego myślenia we wszystkich dziedzinach. Nie oznacza to oczywiście, że tradycyjne cechy kapitału społecznego nie odgrywają swojej roli, ale raczej to, że ich istnienie staje się podłożem powstawania nowych wyznaczników tego kapitału" (Karnat-Jasicka 2007, s. 55).

Przedsiębiorczość jest nierozerwalnie związana z inwestycją kapitału, dlatego warto krótko omówić dostępność do źródeł jego pozyskiwania. Jednym z najważniejszych wydarzeń w gospodarce światowej, jakie miały miejsce w ciągu ostatnich kilkunastu lat, jest dynamiczny rozwój rynku finansowego. Rynek finansowy, w swojej definicji jest rynkiem, na którym przedmiotem wymiany jest kapitał w formie finansowej. Jego uczestnikami są: reprezentujący podaż kapitału w formie pieniężnej inwestorzy finansowi, reprezentujący popyt na ten kapitał inwestorzy rzeczowi (np. gospodarstwa domowe, przedsiębiorstwa, państwo i instytucje samorządowe) oraz pośrednicy finansowi - banki, fundusze inwestycyjne, towarzystwa ubezpieczeniowe, fundusze emerytalne, biura maklerskie (Przedsiębiorczość 2008). Przedsiębiorca może 
finansować swoją działalność, pozyskując środki z wielu różnorodnych źródeł. Wybór zależy od takich czynników, jak forma działania przedsiębiorstwa, stopień jego rozwoju czy pożądana struktura i koszt kapitału. W początkowym okresie działalność przedsiębiorstwa finansowana jest najczęściej ze środków własnych założycieli oraz z wypracowywanych zysków. W miarę rosnących potrzeb inwestycyjnych źródła te okazują się jednak niewystarczające i właściciele muszą podjąć decyzję o pozyskaniu środków zewnętrznych. Wśród instrumentów rynku kapitałowego najczęściej wykorzystywanych przez przedsiębiorców i służących pozyskaniu kapitału z rynku finansowego pozostają: akcje, prawa do akcji, prawa do poboru, obligacje. Coraz większego znaczenia nabierają także krótkoterminowe papiery dłużne przedsiębiorstw (KPDP). Są to instrumenty finansowe z terminem zapadalności poniżej jednego roku, należące do rynku papierów pozaskarbowych. Najbardziej powszechnym sposobem finansowania działalności przez przedsiębiorstwo jest zaciągniecie kredytu bankowego. Alternatywne instrumenty rynku finansowego to: leasing, forfaiting i factoring, proces sekurytyzacji, fundusze private equity i venture capital, Business Angel Investing (Przedsiębiorczość 2008).

Jednocześnie w działaniach prowadzonych przez Ministerstwo Gospodarki w ramach Reformy Regulacji planowane jest uproszczenie regulacji istniejących na rynku finansowym. Zakłada się, iż obecne uwarunkowania prawne determinujące procesy inwestycyjne są zbyt skomplikowane i niezrozumiałe dla przedsiębiorców (głównie tych z sektora MŚP). W celu poprawy jakości otoczenia regulacyjnego w odniesieniu do MŚP realizowane działania na rynku finansowym będą zmierzały do ułatwienia przedsiębiorcom dostępu do zewnętrznego kapitału inwestycyjnego. Szczególna uwaga zostanie poświęcona podmiotom, które w naturalny sposób wspomagają ten proces ekonomiczny, tj. funduszom wysokiego ryzyka i warunkom ich działalności. Po identyfikacji barier nastąpi przejście do etapu, na którym zostaną wypracowane możliwe rozwiązania dla pojawiających się postulatów rynkowych. Po rozpoznaniu rynku i przeprowadzeniu analizy zostanie stworzony raport, w którym znajdą się konkretne postulaty zmian w prawie (Przedsiębiorczość 2008).

Jedną z zasadniczych zmian z ostatnich lat, która w znacznym stopniu wpłynęła na wzrost inicjatyw przedsiębiorczych, jest rozwój sektora wiedzy i edukacji (Dylak 2006). Działania na rzecz przedsiębiorczości podejmowane są znacznie częściej w społeczeństwach, w których przeciętny poziom wykształcenia jest relatywnie wysoki, ponieważ pozwala on m.in. łatwiej zrozumieć otaczającą rzeczywistość, sprzyja powstawaniu nowych pomysłów oraz zmniejsza poczucie ryzyka, a tym samym redukuje lęk przed niepowodzeniem. Tworzenie i wprowadzanie na rynek innowacji wymaga od ludzi ciągłego podnoszenia poziomu wykształcenia, kompetencji oraz przyswajania nowej wiedzy. Jak piszą M. Klonowska-Matynia i A. Sałek-Imińska: „W gospodarce opartej na wiedzy priorytetami dla państwa są inwestycje wspierające tworzenie wiedzy przez mieszkańców, m.in. wydatki na edukację i naukę, upowszechnianie nowoczesnych technologii i stymulowanie innowacyjności przedsiębiorstw” (Klonowska-Matynia, Sałek-Imińska 2009, s. 108). Tak więc inwestycje w edukację i inne formy wspierające rozwój kapitału ludzkiego mają duży wpływ na wzrost gospodarczy danego państwa. Nie ulega wątpliwości, że duże znaczenie w procesie tworzenia społeczeństwa opartego na wiedzy ma edukacja. Przez prowadzenie badań naukowych szkoły wyższe wnoszą istotny wkład w rozwój zasobów wiedzy społeczeństwa. Instytucje edukacyjne zdobywają, gromadzą i rozpowszechniają wiedzę, a przez związki z praktyką, jak pisze M.B. Wojnarowska: „między innymi przez wdrażanie badań i dbałość o rozwój przedsiębiorczości, biorą udział w procesie wykorzystania wiedzy" (Wojnarowska 2007, s. 149).

Globalizacja, dynamiczne zmiany ekonomiczno-społeczne oraz narodziny gospodarki opartej na wiedzy wymuszają głębokie zmiany w dziedzinie nauki, edukacji i szkolnictwa wyższego. Wzrost znaczenia wiedzy jako czynnika wytwórczego aktywizuje rozwój nowych form 
współpracy nauki i gospodarki. Powszechnym kierunkiem rozwoju instytucji naukowych i edukacyjnych w wielu krajach i regionach staje się szerokie otwarcie na współpracę z biznesem (głównie lokalnymi, małymi firmami) oraz na stymulowanie zdolności przedsiębiorczych wśród studentów, doktorantów i pracowników naukowych. Dotychczasowy model szkoły wyższej oparty na edukacji i badaniach naukowych zostaje poszerzony o przygotowanie do przedsiębiorczości rozumianej jako kształtowanie aktywnych zachowań umożliwiających samodzielne działanie na rynku (Guliński, Zasiadły (red.) 2005). Wewnętrzne i zewnętrzne uwarunkowania przedsiębiorczości należy zatem postrzegać jako wzajemnie uzupełniające się elementy determinujące kreowanie zachowań przedsiębiorczych.

Autorka opracowania, prowadząc badania dotyczące konkurencyjności polskich podmiotów gospodarczych, skupiła swoją uwagę na czynnikach wynikających ze zmian w następujących sferach działalności gospodarczej: inwestycje, personel, wartości niematerialne i prawne, organizacja i zarządzanie, finanse, logistyka, produkcja, badanie i rozwój, jakość oraz marketing. Ankietowani odpowiadali na pytania związane z tymi czynnikami, określając wpływ poszczególnych elementów z tych sfer na konkurencyjność przedsiębiorstwa w skali: bardzo duży, duży, mały, bardzo mały, nie ma wpływu, nie mam zdania. Z uwagi na tytuł opracowania przedstawione zostały jedynie wyniki badania dotyczące warunków otoczenia, które mają lub mogłyby mieć wpływ na dane przedsiębiorstwo. Jak wynika z badania - zdaniem respondentów warunki otoczenia, które w największym stopniu wpływają na prowadzenie działalności to: ulgi w podatkach związane z wprowadzaniem nowych technologii $(57,14 \%)$, wysokość podatków, nieelastyczne prawo pracy, niejasność i zmienność przepisów prawnych, bariery w dostępie do kapitału $(28,57 \%)$ oraz wysokość obciążeń składkowych kosztów pracy $(14,29 \%)$, które ograniczają siłę konkurencyjną przedsiębiorstw. Zmniejszają one bowiem zdolności przedsiębiorstwa, a tym samym skłonność do inwestowania i zwiększania zatrudnienia, co jest działaniem ograniczającym możliwości rozwoju. Istotne znaczenie w opinii badanych przedsiębiorstw mają również rozwój sektora wiedzy i edukacji (28,57\%), działania na rzecz poprawy jakości i stanowienia prawa, wzmacnianie przyjaznego przedsiębiorcom systemu otoczenia, ulgi w podatkach związane z rozpoczęciem własnych badań (14,29\%).

W badaniu, prowadzonym od lipca 2010 r., 14,29\% ankietowanych stanowiły spółki z ograniczoną odpowiedzialnością, 42,86\% to osoby fizyczne prowadzące działalność gospodarczą jednoosobowo, 14,29\% - spółki akcyjne, 28,57\% - spółki jawne, 14,29\% - nie określono (brak odpowiedzi). Z grupy tej największy odsetek stanowili przedsiębiorcy (podmioty gospodarcze) zatrudniający do 10 osób - 57,14\%, od 11 do 49 osób - 28,57\%, brak odpowiedzi - 14,29\%. Na koniec 2009 r. 57,14\% ankietowanych dysponowało aktywami netto na poziomie do 2 mln euro, 28,57\% - od 2 do $10 \mathrm{mln}$ euro, 14,29\% - brak odpowiedzi. Charakterystyka obrotów netto respondentów przedstawiała się następująco: $57,14 \%$ - do $2 \mathrm{mln}$ euro, $28,57 \%$ - od 2 do 10 mln euro, $14,29 \%$ - brak odpowiedzi.

Bogactwo instytucji wspierających rozwój przedsiębiorczości oraz świadczonych przez nie form pomocy niewątpliwie wpływa na zdolność i skłonność przedsiębiorstw do ponoszenia ryzyka związanego z działaniami przedsiębiorczymi. Instytucje wspierające przedsiębiorstwa są cennym partnerem administracji publicznej we wdrażaniu publicznych programów wsparcia. W Polsce działają ośrodki wspierania przedsiębiorczości, których zadaniem jest ułatwienie tworzenia małych przedsiębiorstw i pomoc w rozwoju już istniejących. Instytucje te prowadzą również szkolenia osób bezrobotnych, poradnictwo prawne oraz doradztwo dla MŚP. Kolejną instytucją wspierającą MŚP są fundusze rozwoju przedsiębiorczości, które przejmują od banków ciężar ryzyka związanego z udzielaniem kredytów dla tych przedsiębiorstw. Oferta funduszy 
jest skierowana również do osób bezrobotnych oraz małych przedsiębiorstw, które funkcjonują nie dłużej niż dwa lata (Gierczycka 2007).

Poprzez wspieranie przedsiębiorczości, innowacji i transferu technologii Parki Naukowo-Technologiczne stały się globalnie uznanym narzędziem promocji ekonomicznego rozwoju regionalnego na drodze wspierania przedsiębiorczości i wzrostu przedsiębiorstw. System gospodarczy jest sprawny wówczas, gdy sprzyja przedsiębiorczości poprzez tworzenie stabilnych warunków prawnych i makroekonomicznych dla prowadzenia działalności, redukujących ryzyko, minimalizujących koszty podejmowania i prowadzenia działalności, pobudzających konkurencję oraz przyjaznych harmonizacji działalności gospodarczej (Gierczycka 2008).

\section{Literatura}

1. Annual Economic Report for 1997, European Commission, „European Economy”, nr 63.

2. Ardichvili A., Cardozo R., 2000, A Model of Entrepreneurial Opportunity Process, „Journal of Enterprising Culture", nr 2 (8), London.

3. Bartosik-Purgat M., 2006, Otoczenie kulturowe w biznesie międzynarodowym, PWE, Warszawa.

4. Baruk J., 2006, Zarządzanie wiedzq i innowacjami, Wydawnictwo Adam Marszałek, Toruń.

5. Bennett R., 1999, International Business, Pitman Publishing, London.

6. Bieniok H., Kraśnicka T., 2000, Przedsiębiorczość pracowników jako instrument podnoszenia produktywności firmy [w:] Strategie wzrostu produktywności firmy, A. Stabryła (red.), AE, Kraków.

7. Commission of the European Communities, Green Paper. Entrepreneurship in Europe, Brussels, 21.01.2003. Document based on Com.

8. Drucker P.F., 2004, Natchnienie i fart, czyli innowacja i przedsiębiorczość, Wydawnictwo Studio Emka, Warszawa.

9. Dyduch W., 2007, Innowacyjność organizacji - istota, pomiar i powiąanie z efektywnościa [w:] Działalność innowacyjna przedsiębiorstw $w$ warunkach globalnych, J. Bogdanienko, M. Kuzela, I. Sobczak (red.), Wydawnictwo Adam Marszałek, Toruń.

10. Dylak M., 2006, Główne zmiany uwarunkowań przedsiębiorczości w Polsce [w:] Przedsiębiorczość i innowacyjność. Wyzwania współczesności, A. Kaleta, K. Moszkowicz, L. Woźniak (red.), AE, Wrocław.

11. Eckhardt J.T., Shane S., 2003, Opportunities and Entrepreneurship, „Journal of Management”, nr 29, Portland.

12. Gancarczyk M., 2001, Środowisko dla rozwoju przedsiębiorczości i innowacji jako kapitat intelektualny terytorium [w:] Kapitat intelektualny. Dylematy $i$ wyzwania, A. Pocztowski (red.), WSB, Nowy Sącz.

13. Gibb A.A., 1990, Enterpreneurship and Intrapreneurship - Exploring the Differences [w:] New Findings and Perspectives in Enterpreneurship, R. Donckels, A. Miettinen (ed.), Aldershot.

14. Gierczycka J., 2007, Znaczenie konkurencyjności dla rozwoju sektora małych i średnich przedsiębiorstw $w$ warunkach globalizacji i integracji europejskiej (ze szczególnym uwzględnieniem gospodarki Polski) [w:] Uwarunkowania rozwoju przedsiębiorczości. Determinanty i narzędzia zdobywania przewagi konkurencyjnej, H.G. Adamkiewicz-Drwiłło (red.), PWN, Warszawa.

15. Gierczycka J., 2008, Rola innowacyjności w ksztattowaniu konkurencyjności matych i średnich przedsiębiorstw w Polsce [w:] Europejskie wymiary przedsiębiorczości, H. Kruk, K. Skrzeszewska (red.), AM, Gdynia.

16. Gierszewska G., Wawrzyniak B., 2001, Globalizacja. Wyzwania dla zarządzania strategicznego, Poltext, Warszawa.

17. Globalizacja. Mechanizmy i wyzwania, 2002, B. Liberska (red.), PWE, Warszawa.

18. Gorzelak G., Jałowiecki B., 2000, Konkurencyjność regionów, „Studia Regionalne i Lokalne”, nr 1, vol. 1.

19. Górka K., 2004, Czynniki rozwoju przedsiębiorczości i innowacyjności w przemyśle [w:] Uwarunkowania przedsiębiorczości, K. Jaremczuk (red.), PWSZ, Tarnobrzeg. 
20. Hryń B., Kmiotek K., Piecuch T., 2002, Przedsiębiorczość szansa rozwoju przedsiębiorstw przyszłości [w:] Stan i perspektywy rozwoju teorii i praktyki zarządzania na progu XXI wieku, „Prace Naukowe Akademii Ekonomicznej we Wrocławiu", Nr 940, Wrocław.

21. Innowacyjna przedsiębiorczość akademicka - światowe doświadczenia, 2005, J. Guliński, K. Zasiadły (red.), Wydawnictwo Edit Sp. z o.o., Warszawa.

22. Innowacyjność 2006. Stan innowacyjności, metody wspierania, programy badawcze. Raport, 2006, A. Żołnierski (red.), PARP, Warszawa.

23. Janasz W., 2004, Przedsiębiorczość w świetle uwarunkowań działalności gospodarczej [w:] Innowacje w rozwoju przedsiębiorczości w procesie transformacji, W. Janasz (red.), Difin, Warszawa.

24. Karnat-Jasicka B., 2007, Kapitat społeczny w regionie a rozwój gospodarki opartej na wiedzy [w:] Uwarunkowania rozwoju przedsiębiorczości. Determinanty i narzędzia zdobywania przewagi konkurencyjnej, H.G. Adamkiewicz-Drwiłło (red.), PWN, Warszawa.

25. Kisiel P., 1999, Społeczne uwarunkowania przedsiębiorczości - postawy społeczne wobec przedsiębiorczości [w:] Przedsiębiorczość a lokalny i regionalny rozwój gospodarczy. Materiały konferencji naukowej, J. Targalski (red.), AE, Kraków.

26. Klonowska-Matynia M., Sałek-Imińska A., 2009, Rola morskiego szkolnictwa wyższego w kształtowaniu kapitału ludzkiego $w$ kontekście realizacji zatożeń gospodarki opartej na wiedzy w Polsce [w:] Przedsiębiorstwo w otoczeniu globalnym, O. Dębicka, A. Oniszczuk-Jastrząbek, T. Gutowski, J. Winiarski (red.), UG, Gdańsk.

27. Korzeniowski L., 2004, Przedsiębiorczosśc a prawne i polityczne otoczenie organizacji gospodarczych [w:] Problemy bezpieczeństwa ekonomicznego wobec procesów globalizacji, S. Piocha (red.), PTE, Koszalin.

28. Kozioł L., 2005, Determinanty, obszary i pomiar przedsiębiorczości [w:] Sukces organizacji. Strategie $i$ innowacje, UG, Sopot.

29. Krajewski M., 2007, Podstawowe zasoby decydujące o funkcjonowaniu przedsiębiorstwa [w:] Przedsiębiorstwo - zasady działania, funkcjonowanie, rozwój, J. Żurek (red.), UG, Gdańsk.

30. Krupski R., 2008, Okazje w rozwoju przedsiębiorstw. Aspekt empiryczny [w:] Europejskie wymiary przedsiębiorczości, H. Kruk, K. Skrzeszewska (red.), AM, Gdynia.

31. Kuciński K., 2002, Nasza ziemia - gospodarka globalna, AE, Poznań.

32. Kwiatkowski S., 2000, Przedsiębiorczość intelektualna, PWN, Warszawa.

33. Lebenstein H., 1995, The Supply of Entrepreneurship. Leading Issues in Economic Development, Oxford University Press, New York.

34. Linton R., 2000, Kulturowe postawy osobowości, PWN, Warszawa.

35. Managing creativity and innovation, 2003, Harvard Business School Publishing.

36. Masłowski A., 2005, Kultura organizacyjna wobec zmian otoczenia [w:] Rozwój regionalny w warunkach globalizacji, A. Gomółka (red.), Warszawa.

37. Miller D., 1983, The Correlates of Entrepreneurship In Tree Types of Firms [in:] Management Science, no.7 (29), Hanover.

38. OECD, Fostering Entrepreneurship, Paryż 1998, October.

39. Oniszczuk-Jastrząbek A., 2004, Globalizacja a produkt w marketingu międzynarodowym [w:] Rynki międzynarodowe i gospodarka globalna, K. Misztal (red.), UG, Gdańsk.

40. Oniszczuk-Jastrząbek A., Gutowski T., 2008, Funkcjonowanie polskich małych i średnich, przedsiębiorstw $w$ gospodarce globalnej [w:] Instytucjonalne i rynkowe uwarunkowania rozwoju matych $i$ średnich przedsiębiorstw w Polsce, E. Michalski, S. Piocha (red.), PTE, Koszalin.

41. Pająk K., 2006, Innowacyjność a kapitał społeczny [w:] Innowacyjność w teorii i praktyce, M. Strużycki (red.), SGH, Warszawa.

42. Pangsy-Kania S., 2007, Polityka innowacyjna państwa a narodowa strategia konkurencyjnego rozwoju, UG, Gdańsk.

43. Penc J., 1999, Innowacje i zmiany w firmie. Transformacja i sterowanie rozwojem przedsiębiorstwa, Placet, Warszawa.

44. Piasecki R., 2003, Rozwój gospodarczy a globalizacja, PWE, Warszawa.

45. Pocztowski A., 2002, Międzynarodowe zarządzanie zasobami ludzkimi, Oficyna Ekonomiczna, Kraków. 
46. Przedsiębiorczość w Polsce, 2008, Ministerstwo Gospodarki, Warszawa.

47. Safin K., 2004, Uwarunkowania rozwoju przedsiębiorczości - próba systematyzacji [w:] Uwarunkowania przedsiębiorczości, K. Jaremczuk (red.), PWSZ, Tarnobrzeg.

48. Schroeder J., 2000, Zarządzanie kadra w przedsiębiorstwie międzynarodowym, AE, Poznań.

49. Schumpeter J., 1960, Teoria rozwoju gospodarczego, PWN, Warszawa.

50. Shane S., Venkataraman S., 2000, The Promise of Entrepreneurship as a Field of Research, „Academy of Management Review", nr 1 (25).

51. Stownik języka polskiego, t. II, 1998, PWN, Warszawa.

52. Strużyński M., Przedsiębiorczość w warunkach globalizacji rynków [w:] Przedsiębiorczość a zarządzanie przedsiębiorstwem, J. Rokita, W. Grudzewski (red.), GWSH, Katowice 2003.

53. Szcześniak A., 2009, Praktyczna użyteczność nauki [w:] Przedsiębiorczy uniwersytet. Praktyczna użyteczność badań naukowych i prac badawczo-rozwojowych. Projektowanie i prowadzenie badań naukowych we wspótpracy z gospodarka, M. Bąk, P. Kulawczuk (red.), Instytut Badań nad Demokracją i Przedsiębiorstwem Prywatnym, Warszawa.

54. Szulich P., 2004, Wolność jako prawo przedsiębiorczości [w:] Uwarunkowania przedsiębiorczości, K. Jaremczuk (red.), PWSZ, Tarnobrzeg.

55. Szymoniuk B., 2008, Korzyści lokalizacji w budowaniu globalnej przewagi konkurencyjnej. Doświadczenia polskich klastrów gospodarczych [w:] Regionalizacja globalizacji. Tom 2, J. Rymarczyk, B. Dreich-Skulska, W. Michalczyk (red.), AE im. O. Langego, Wrocław.

56. Śliwa J., Wymysłowski S., 2001, Podstawowe czynniki warunkujące rozwój przedsiębiorczości w Polsce [w:] Przedsiębiorstwo na przełomie wieków, B. Godziszewski, M. Haffer, M.J. Stankiewicz (red.), UMK, Torun.

57. Wojnarowska M. B., 2007, Bariery w procesie zarzadzania wiedza na przykładzie instytutu naukowo-dydaktycznego (wyniki badań) [w:] Uwarunkowania rozwoju przedsiębiorczości. Determinanty i narzędzia zdobywania przewagi konkurencyjnej, H.G. Adamkiewicz-Drwiłło (red.), PWN, Warszawa.

58. Wyżnikiewicz B., 2009, Konkurencyjność MŚP [w:] Raport o stanie sektora matych i średnich przedsiębiorstw w Polsce w latach 2007-2008, Wydawnictwo Naukowe Instytutu Technologii Eksploatacji PIB, Radom.

59. Zorska A., 1998, Ku globalizacji? Przemiany w korporacjach międzynarodowych $i$ w gospodarce światowej, PWN, Warszawa.

60. Żurek J., 2008, Globalizacja wyzwaniem dla polskich przedsiębiorstw [w:] Przedsiębiorstwo w otoczeniu globalnym, O. Dębicka, A. Oniszczuk-Jastrząbek, T. Gutowski, J. Winiarski (red.), UG, Gdańsk.

\section{Environment and Entrepreneurship under Global Conditions}

The functioning of the enterprise in a constantly changing environment means that they should make the necessary transformation, meet challenges, thus anticipate and shape the reality. Each company should be the instigator of continuous change, particularly innovative projects which success depends largely on the mobilization of all employees, on creative thinking, action and learning. Strużyński M. writes: "the contemporary processes of globalization create new conditions for flexible and rapid action on the use of various forms of organized business to gain competitive advantage on specific markets" (Strużyński 2003). Globalization can promote and restrict entrepreneurship, especially the individual one. It is written more often, however, that globalization offers the most professional conditions for the great inspiration in the field of entrepreneurship, and it is the source of modern technology and efficient management methods. 


\section{Tomasz Gutowski}

Uniwersytet Gdański

\section{Zmiany w przedsiębiorstwie wobec procesu globalizacji}

\section{Globalizacja jako czynnik rozwoju}

Funkcjonowanie gospodarki światowej, a w jej ramach - działalność przedsiębiorstw - zarówno w ostatnim dziesięcioleciu XX w., jak i obecnie podlega gwałtownym zmianom. Jedną z przyczyn takiego stanu jest postępujący proces globalizacji gospodarki światowej oraz zawierające się w tym procesie takie zjawiska, jak: postęp nauki, techniki, organizacji i zarządzania, skracanie czasu i przestrzeni, międzynarodowa współzależność, integracja krajów, gospodarek i samych przedsiębiorstw, regionalizacja oraz rozszerzający się zakres międzynarodowej działalności przedsiębiorstw (Żurek 2002).

Powszechne jest przekonanie, iż proces globalizacji to zjawisko nowe, związane z obecnie funkcjonującą gospodarką i przedsiębiorstwami, które w tej gospodarce prowadzą swoją działalność. Pojęcie globalizacji definiowane jest jednak w różny sposób, a charakterystyka tego procesu przedstawiana przez autorów publikacji naukowych także bywa różna. Biorąc pod uwagę określenie procesu globalizacji jedynie w znaczeniu ekonomicznym, za najbardziej syntetyczne można uznać stanowisko przedstawione przez A. Zorską, która twierdzi, iż: ,globalizacja działalności gospodarczej jest to dokonujący się na świecie długofalowy proces integrowania coraz większej liczby krajowych gospodarek ponad ich granicami, dzięki rozszerzaniu oraz intensyfikowaniu wzajemnych powiązań (inwestycyjnych, produkcyjnych, handlowych, kooperacyjnych), w wyniku czego powstaje ogólnoświatowy system ekonomiczny o dużej współzależności i znaczących reperkusjach działań podejmowanych/toczących się nawet w odległych krajach" (Zorska 1998). Według K. Kucińskiego, pod pojęciem globalizacja rozumie się „ogólnoświatowy proces integracji systemów ekonomicznych i podmiotów gospodarczych. Polega on na tym, że działalność gospodarcza jest konfigurowana i koordynowana w skali całego świata w celu zminimalizowania kosztów, maksymalizowania nowo tworzonej wartości produktów i uzyskania dostępu do rynku o również światowym zasięgu. Konsekwencją, a zarazem przyczyną globalizacji gospodarki jest globalizacja wszelkich przejawów życia społecznego. Jej przejawem jest globalizacja technologii, stylu życia, modeli konsumpcji, kultury, rządzenia, regulacji prawnych, postrzegania i świadomości. Wynika ona z kompresji świata uzyskanej dzięki postępowi technicznemu i ujednolicaniu się form organizacji gospodarki oraz życia politycznego w poszczególnych krajach” (Kuciński 2002, s. 136). Z takiego stanowiska wynika ponadto fakt swoistego przenikania zjawiska globalizacji przez różne dziedziny. Można więc mówić o globalizacji np. w odniesieniu do polityki czy też działalności społecznej i kulturowej.

Analizując zagadnienie globalizacji, można potwierdzić, iż proces ten od początku był postrzegany raczej jako pozytywny. Poprzez dekolonizację, wiążącą się z ogłaszaniem przez 
kolejne państwa niepodległości, oraz przez powstające organizacje międzynarodowe, których zadaniem było podejmowanie działań wyrównujących dysproporcje między krajami o różnym stopniu rozwoju gospodarczego, globalizacja „rozwijała się” i oddziaływała na wszystkie sfery życia gospodarczego. W późniejszym okresie powstające organizacje międzynarodowe, tj. Układ Ogólny w Sprawie Taryf Celnych i Handlu (GATT), Europejska Wspólnota Gospodarcza (EWG), Europejskie Stowarzyszenie Wolnego Handlu (EFTA) czy Organizacja Współpracy Gospodarczej i Rozwoju (OECD) miały również sprzyjać rozwojowi tego procesu. Jednym z celów tych instytucji było - tak ważne dla funkcjonowania przedsiębiorstw - wprowadzenie ułatwień w zakresie handlu międzynarodowego poprzez znoszenie lub ograniczanie barier celnych (Bożyk, Mijała, Puławski 1999). Działania te od wielu lat przyczyniają się do zwiększenia wymiany handlowej między przedsiębiorstwami i powodują, że stają się one bardziej konkurencyjne na rynku, mając możliwość dostępu do nowoczesnych technologii oraz stosowania skutecznych metod w zakresie organizacji i zarządzania. Rozpatrując różne aspekty procesu globalizacji, warto wspomnieć o zwiększającej się w poszczególnych krajach wartości bezpośrednich inwestycji zagranicznych. Stały się one motorem procesów globalizacyjnych i w bezpośredni sposób wpłynęły na szybszy wzrost gospodarczy krajów, w sposób pośredni przyczyniły się zaś do poprawy standardów życiowych, wzrostu innowacyjności przedsiębiorstw oraz umożliwiły im ekspansję międzynarodową (Wyrwa 2006).

W gospodarkach poszczególnych krajów tempo zjawiska globalizacji nie jest jednakowe. Wynikać to może m.in. z niskiego poziomu rozwoju gospodarczego kraju lub też braku odpowiedniej infrastruktury technicznej, niezbędnej do inicjacji tego procesu. Barierami opóźniającymi rozwój gospodarki globalnej są ponadto występujące w niektórych państwach bariery prawne, polityczne i ekonomiczne. Wpływ na uczestnictwo w gospodarce globalnej niektórych państw ma również ich położenie geograficzne względem rynków zbytu, kapitału i technologii (Kuciński 2002). Funkcjonowanie współczesnego rynku światowego nie jest zatem możliwe bez zachodzących na coraz większą skalę procesów integracji ekonomiczno-społecznej. Procesy te zachodzą w sferze wymiany handlowej, ścisłej współpracy przedsiębiorstw i rządów, w sferze finansowej, we wzajemnym przenikaniu się kultur i zwyczajów oraz upodabnianiu się instytucji społecznych. Tym samym tworzy się nowe międzynarodowe środowisko, zwane globalnym, w którym funkcjonują przedsiębiorstwa wywierające różny wpływ na gospodarkę.

\section{Istota globalnej gospodarki}

Wydaje się, że rozważania dotyczące samych przedsiębiorstw nie byłyby kompleksowe bez podjęcia próby zdefiniowania gospodarki, w ramach której funkcjonują. W literaturze spotkać można wiele różnorodnych określeń. Wiele z nich nie różnicuje pojęć gospodarki światowej oraz gospodarki globalnej, utożsamiając je ze sobą. Nie są to jednak zagadnienia równoznaczne. P. Bożyk twierdzi, że gospodarka światowa to historycznie ukształtowany i zmieniający się w czasie system powiązań produkcyjnych, technologicznych, handlowych, finansowych i instytucjonalnych między gospodarkami narodowymi różnych krajów, o różnych poziomach rozwoju gospodarczo-społecznego, włączający je w ogólnoświatowy proces produkcji i wymiany (Bożyk 1991). Zwłaszcza określenie „ogólnoświatowy proces produkcji i wymiany” skłania do częstego, zamiennego używania pojęć gospodarka światowa i gospodarka globalna. Nie jest to jednak właściwe zrozumienie obu tych zagadnień. Należy zwrócić uwagę na występujące między nimi różnice. Jedną z nich jest fakt, iż pojęcie gospodarka światowa używane jest z reguły do opisu zachowań „dużego agregatu ekonomicznego w skali ogólnoświatowej, 
w skład którego wchodzą poszczególne gospodarki narodowe” (Bożyk 1991). Określenie gospodarki globalnej jest używane do podkreślenia organicznej całości światowych procesów ekonomicznych, które są nie tylko sumą poszczególnych części, ale wykazują pewne wspólne cechy dla zachowań całościowych. „Pojęcie gospodarka globalna jest więc zbliżone do określenia gospodarka narodowa, które również stosujemy, nie tyle dla przedstawienia cech agregatu, co organizmu ekonomicznego, mającego pewne prawidłowości zachowań całościowych" (Bożyk 1991).

Gospodarkę globalną w odróżnieniu od gospodarki światowej należy więc rozumieć jako system coraz ściślej powiązanych ze sobą na skutek globalizacji gospodarek narodowych. Takie określenie gospodarki globalnej pozwala na ukazanie tego pojęcia zarówno w odniesieniu do gospodarek poszczególnych państw, jak i w szczególności do podmiotów gospodarki, czyli przedsiębiorstw. Ich zadaniem w ramach gospodarki globalnej jest wytwarzanie dóbr i usług, a także ich dystrybucja oraz konsumpcja (Kuciński 2002). Z takiego stanowiska wynika fakt, iż o sile gospodarki globalnej stanowią przedsiębiorstwa zlokalizowane w różnych częściach świata.

Warto również zauważyć, że podstawą gospodarki globalnej nie są tylko przedsiębiorstwa, lecz również przepływ środków pieniężnych, towarów i usług oraz migracja osób, przepływ informacji i pomysłów. Czynniki te stanowią bardzo ważne elementy gospodarki i przyczyniają się do jej rozprzestrzeniania na gospodarki narodowe innych krajów. Szczególną uwagę należy przypisać swobodnemu, niczym nieograniczonemu przepływowi informacji. Przekazywanie informacji pomiędzy państwami, gospodarkami czy też przedsiębiorstwami przyczynia się w największym stopniu do rozwoju gospodarki globalnej. Przekazywanie informacji o nowych technologiach, sposobach wykorzystania ograniczonej ilości zasobów czy też rozwiązaniach w dziedzinie zastosowania określonych wyrobów i usług powoduje rozwój samych przedsiębiorstw. W konsekwencji prowadzi do redukcji kosztów funkcjonowania, a tym samym przyczynia się do stabilizacji działań przedsiębiorstwa.

Kolejnym, nie mniej ważnym elementem gospodarki globalnej jest czas. Wraz z jego upływem wzrasta natężenie, zakres i stopień skomplikowania zarówno przepływów pieniężnych, jak i dóbr materialnych, usług oraz informacji. Taki stan prowadzi do zrastania się narodowych rynków oraz przekształcania ich w rynki globalne. Wzrost wielkości rynków globalnych pociąga za sobą m.in. spadek zależności od państw narodowych. Formułuje się ponadnarodowa organizacja produkcji, wymiany i konsumpcji. Gospodarka globalna jest kształtowana również przez integrację regionalną, w ramach której realizowana jest szeroka współpraca w sferze politycznej i gospodarczej państw zlokalizowanych niedaleko siebie. Celem integracji regionalnej jest aktywizacja tych regionów, między którymi możliwy jest swobodny przepływ siły roboczej, kapitału, towarów, usług i informacji. Pozwala to ponadto na ochronę przestrzeni gospodarczej współpracujących ze sobą krajów. Taka wspólnota - jak dowodzi K. Kuciński posiada znamiona organizmu państwowego. Doskonałym przykładem globalizacji gospodarki w ramach integracji regionalnej jest Unia Europejska, jej wspólny rynek, waluta, polityka gospodarcza oraz parlament.

Z przytoczonych rozważań po raz kolejny wyraźnie wyłania się obraz funkcjonowania współczesnego globalnego rynku. Jak trafnie potwierdza W. Michalak, gospodarki wielu krajów świata są niejako wciągane w ogólnoświatowy system, który jest powiązany poprzez ścisłe związki kapitałowe i produkcyjno-handlowe. Ostatecznie sytuacja taka powoduje zwiększenie siły zależności krajowych gospodarek, które przenikają się wzajemnie i których struktura zmienia się pod wpływem międzynarodowej działalności gospodarczej. 


\section{Uwarunkowania rozwoju przedsiębiorstw w gospodarce globalnej}

Gospodarka globalna, oprócz powiązanego ze sobą ogólnoświatowego systemu, to przede wszystkim przedsiębiorstwa. To od nich w dużym stopniu zależy, czy system ten funkcjonuje efektywnie oraz czy podejmowane działania przekładają się na ich prawidłowy rozwój. Funkcjonowanie i systematyczny wzrost przedsiębiorstwa rozpoczyna się od odpowiedniego wyznaczenia celów jego działalności. Jak pisze J. Żurek, cele muszą być ściśle powiązane z tendencjami w otoczeniu międzynarodowym i krajowym oraz $\mathrm{z}$ wewnętrznymi celami przedsiębiorstwa (Żurek 2007). Osiągane przez przedsiębiorstwo wyniki finansowe, zwiększanie poziomu zatrudnienia, notowane na rynku sukcesy w zakresie wprowadzenia nowych produktów lub usług to tylko niektóre z czynników, które w bezpośredni sposób wpływają z jednej strony na jego rozwój, z drugiej zaś - przekładają się na rozwój gospodarczy kraju lub regionu. Rozwój przedsiębiorstwa uzależniony jest więc zarówno od czynników zewnętrznych, jak i wewnętrznych. Uwarunkowania zewnętrzne sklasyfikować można jako:

- elementy otoczenia krajowego,

- elementy otoczenia międzynarodowego.

W obu grupach mogą występować następujące uwarunkowania: ekonomiczne, ekologiczne, techniczno-technologiczne, prawne, polityczne, demograficzne oraz socjokulturowe. W grupie elementów otoczenia krajowego mają one wymiar krajowy, natomiast w drugiej grupie - charakter międzynarodowy (tab. 1).

Tab. 1. Uwarunkowania zewnętrzne prowadzenia działalności gospodarczej

\begin{tabular}{|c|c|}
\hline \multicolumn{2}{|c|}{ Uwarunkowania zewnętrzne } \\
\hline elementy otoczenia krajowego & elementy otoczenia międzynarodowego \\
\hline $\begin{array}{l}\text { - sytuacja gospodarcza (m.in. poziom i tempo } \\
\text { wzrostu PKB) } \\
\text { - polityka pieniężno-kredytowa } \\
\text { - polityka fiskalna } \\
\text { - rozwój rynku kapitałowego } \\
\text { - sytuacja społeczno-ekonomiczna } \\
\text { - poziom i tempo inflacji } \\
\text { - regulacje prawne } \\
\text { - skala i zakres interwencjonizmu państwowego } \\
\text { - wzrost popytu wewnętrznego ze strony } \\
\text { przedsiębiorstw } \\
\text { - rozwój handlu zagranicznego } \\
\text { - stan oraz kierunki rozwoju techniki } \\
\text { i technologii } \\
\text { - stan podstawowej, ogólnodostępnej } \\
\text { infrastruktury technicznej } \\
\text { - konkurencja ze strony przedsiębiorstw } \\
\text { - pozycja związków zawodowych } \\
\text { - zachowanie się władz samorządowych } \\
\text { - stan i rozwój badań naukowych }\end{array}$ & $\begin{array}{l}\text { - sytuacja polityczno-społeczna } \\
\text { - tempo wzrostu gospodarki światowej } \\
\text { - polityka gospodarcza państw i ugrupowań } \\
\text { integracyjnych } \\
\text { - stan koniunktury na rynku światowym } \\
\text { - skala interwencjonizmu i jego zakres } \\
\text { - rozwój handlu światowego i zmiany w jego } \\
\text { strukturze } \\
\text { - konkurencja na rynku światowym } \\
\text { - zmiany w strukturach organizacyjnych } \\
\text { i systemach zarządzania } \\
\text { - postęp techniczny i technologiczny } \\
\text { - postęp ekologiczny } \\
\text { - międzynarodowe regulacje prawne } \\
\text { - prognozy rynkowe }\end{array}$ \\
\hline
\end{tabular}

Źródło: Żurek J., Przedsiębiorstwo w systemie społeczno-gospodarczym [w:] Przedsiębiorstwo. Zasady działania, funkcjonowanie, rozwój, red. J. Żurek, Fundacja Rozwoju Uniwersytetu Gdańskiego, Gdańsk 2007, s. 62-63. 
Siła oddziaływania poszczególnych czynników na podmiot gospodarczy może być różna. Zależy ona m.in. od wielkości przedsiębiorstwa, formy prawnej prowadzenia działalności gospodarczej, zakresu działalności oraz przyjętej przez przedsiębiorstwo strategii. Wydaje się jednak, że w przypadku przedsiębiorstwa funkcjonującego na rynku lub wielu rynkach zagranicznych czynniki otoczenia zewnętrznego, zarówno w układzie krajowym, jak i międzynarodowym, będą silniej determinowały jego funkcjonowanie i rozwój.

Oprócz czynników o charakterze zewnętrznym na funkcjonowanie przedsiębiorstwa wpływają również czynniki wewnętrzne. K. Bolesta-Kukułka, przedstawiając ujęcie organizacji jako systemu społeczno-technicznego, zalicza do nich następujące elementy (podsystemy): cele i zadania, ludzie (pracownicy przedsiębiorstwa), struktura formalna, wyposażenie oraz technika i technologia (Bolesta-Kukułka 1995). Elementy te wymagają jednak uszczegółowienia. I tak - cele i zadania przedsiębiorstwa to m.in. misja, cele strategiczne, taktyczne i operacyjne oraz zadania realizowane w przedsiębiorstwie przez pracowników, których z kolei motywacje, przyzwyczajenia, postawy kwalifikacje, umiejętności, energia, zdolność uczenia się oraz stosunki międzyludzkie mogą być różne (Wajda 2003). Do struktury formalnej przedsiębiorstwa zaliczyć należy hierarchię, schemat organizacyjny obowiązujący w przedsiębiorstwie, zakresy czynności jego pracowników oraz instrukcje. Wyposażenie i technika to zaś ,zbiór ogólnych i szczegółowych sposobów, technik oraz narzędzi służących realizacji organizacyjnych zadań” (Bolesta-Kukułka 1995).

Do elementów wewnętrznych, odgrywających zasadniczą rolę w rozwoju współczesnego przedsiębiorstwa, zaliczyć należy ponadto zasoby materialne w postaci budynków, maszyn, urządzeń, a także wartości niematerialne i prawne. Prowadząc rozważania nad nowymi, współczesnymi zasobami przedsiębiorstwa, należy zwrócić szczególną uwagę na niespotykane wcześniej w przedsiębiorstwie dowartościowanie zasobów niematerialnych i prawnych, tj. licencje, nieopatentowane wynalazki, wzory użytkowe, patenty czy know-how ${ }^{1}$. Suszyński pisze ponadto, że ,produkty wiedzy, takie jak nowoczesne technologie, a także renoma, marka, tożsamość przedsiębiorstwa, charyzmatyczne przywództwo, oryginalna strategia czy wiele innych podobnych stały się aktywami, a wręcz właściwościami przedsiębiorstwa niezbędnymi w walce o rynek" (Suszyński 2007). Wspólnie z innymi stają się one elementami wpływającymi bardzo dynamicznie na rozwój przedsiębiorstwa. Przekładają się w wyraźny sposób na budowanie konkurencyjności podmiotów gospodarczych na coraz bardziej zglobalizowanym rynku.

Kolejnym, często pomijanym w literaturze czynnikiem o charakterze wewnętrznym, współtworzonym przez nowe zasoby przedsiębiorstwa, jest jego kultura organizacyjna. Definiowana jako pewien zbiór wartości, norm społecznych i tradycji akceptowanych przez członków danego przedsiębiorstwa, może stać się elementem pozytywnie wpływającym na dotychczas

\footnotetext{
${ }^{1}$ Definicja przyjęta przez Międzynarodową Izbę Handlową w Paryżu jako know-how określa całokształt wiadomości, czyli fachowej wiedzy oraz doświadczeń w zakresie technologii i procesu produkcyjnego dla określonego wyrobu. W prawie europejskim definicja know-how zawarta jest w Rozporzadzeniu nr 772/2004 w sprawie stosowania art. 81 ust. 3 „, Traktatu do kategorii porozumień o transferze technologii" (Dz.U. L 123 z 27.4.2004, s. 11-17). Stanowi ona, iż know-how to pakiet nieopatentowanych informacji praktycznych wynikających z doświadczenia i badań, które są: niejawne, czyli nie są powszechnie znane lub łatwo dostępne, istotne, czyli ważne i użyteczne z punktu widzenia wytwarzania produktów objętych umową, oraz zidentyfikowane, czyli opisane w wystarczająco zrozumiały sposób, aby można było sprawdzić, czy spełniają kryteria niejawności i istotności. Źródło: http://pl.wikipedia.org/wiki/Know-how (11.10.2010); Suszyński C. (red.), Przedsiębiorstwo. Wartość. Zarządzanie, PWE, Warszawa 2007.
} 
obowiązującą strukturę organizacyjną podmiotu. W innym przypadku kultura organizacyjna może okazać się istotną przeszkodą w funkcjonowaniu przedsiębiorstwa i przez to w negatywny sposób oddziaływać na jego bieżące funkcjonowanie i rozwój w przyszłości.

\section{Ważność zasobów przedsiębiorstwa dla jego rozwoju}

Interesujące stanowisko przedstawiające oddziaływanie procesu globalizacji przedstawia C. Suszyński. Formułuje on trzy następujące „,wnioski w odniesieniu do samego przedsiębiorstwa:

- przez globalizację tworzy się nowa jakość mechanizmu rynku, który kreuje dla coraz większej grupy jego uczestników wyzwania szersze, wręcz cywilizacyjne, a więc stawia im wymagania na poziomie i o intensywności, jakich wcześniej nie doświadczali,

- sprostanie tym wyzwaniom (alokacja zasobów, dystrybucja efektów) prowadzi do daleko idących zmian podstaw wyodrębnienia (podmiotowości) i funkcjonowania przedsiębiorstw oraz oceny rezultatów prowadzonej przez nie działalności,

- wśród najważniejszych czynników owego wyodrębnienia, funkcjonowania i oceny przedsiębiorstw istotne miejsce zajmują kryteria i wartości szerzej, wręcz globalnie akceptowane (np. wartość dla klienta, wartość dla akcjonariusza” (Suszyński 2007, s. 53).

To właśnie przedsiębiorstwo narażone jest na konieczność dostosowania się do wymogów współczesnej gospodarki. Stopień dostosowania może świadczyć o osiągnięciu przez nie określonego poziomu konkurencyjności, a także wpływać na bieżące funkcjonowanie oraz tempo jego rozwoju w przyszłości.

Zasadniczym kierunkiem rozwoju współcześnie funkcjonującego podmiotu gospodarczego jest dążenie przedsiębiorstwa do osiągania przewagi konkurencyjnej i zwiększenia własnej konkurencyjności. W ramach przewagi konkurencyjnej na pierwszy plan wysuwa się problematyka zasobów przedsiębiorstwa. W dążeniach do sprostania wymogom czasu ulegają one istotnym przewartościowaniom. Jak pisze C. Suszyński: „Jednym z bardziej znaczących zjawisk w okresie ostatnich kilku dekad, o doniosłym w skutkach w wymiarze poznawczym [...], ale przede wszystkim mającym głębokie przełożenia na sferę praktyki gospodarczej, okazało się niespotykane wcześniej dowartościowanie zasobów niematerialnych. [...] «Produkty» wiedzy, takie jak nowoczesne technologie, a także renoma, marka, tożsamość przedsiębiorstwa, charyzmatyczne przywództwo, oryginalna strategia czy wiele innych podobnych stały się aktywami, a wręcz właściwościami przedsiębiorstwa niezbędnymi w walce o rynek" (Suszyński 2007).

W dobie tzw. społeczeństwa informacyjnego nie należy zapominać również o kolejnym elemencie przyczyniającym się do rozwoju przedsiębiorstwa, jakim jest wiedza i informacja. Zdolność do ich zdobywania, analizy oraz umiejętność przekazywania osobom zatrudnionym w przedsiębiorstwie jest niezbędnym czynnikiem rozwoju podmiotu na globalnym rynku. Z jednej strony przyczyniają się one do lepszego zrozumienia otoczenia zewnętrznego, jego specyfiki i stopnia skomplikowania, z drugiej zaś - są niezbędne do podejmowania bieżących decyzji, dotyczących na przykład możliwości efektywnego stosowania w przedsiębiorstwie nowoczesnych technologii. Pojęcie technologii we współczesnej gospodarce ma jednak inny wymiar, niż miało to miejsce przed laty. Jak dowodzi J. Witkowska: „technologia, rozumiana w szerokim sensie, obejmuje wiedzę menedżerską, umiejętności marketingowe oraz inne tzw. nieuchwytne aktywa na poziomie firmy" (Witkowska 2005, s. 33). Rozprzestrzenianie się tak rozumianej technologii wśród wielu przedsiębiorstw powoduje, iż jest ona czynnikiem transnarodowym i poprzez to czynnikiem rozwoju przedsiębiorstw na całym świecie. Proces globalizacji, którego efektem jest upodabnianie się do siebie narodowych gospodarek i całych społeczeństw, zacieranie się granic, ujednolicenie ogólnych wzorców konsumpcji w konsekwencji powodują nasilenie przenikania wiedzy i informacji, które z kolei stanowią o istocie wielu 
innowacji. Faktycznie to właśnie one są końcowym efektem transferu wiedzy i informacji we współczesnej gospodarce. Poziom ważności innowacji w przedsiębiorstwach nie podlega dyskusji. Często stosuje się pojęcie polityki innowacyjnej przedsiębiorstwa, czyli takiego działania, którego celem, w ściśle określonym czasie, ma być wdrożenie określonej innowacji w przedsiębiorstwie i uzyskanie dzięki temu możliwości szybszego rozwoju w porównaniu z konkurencją.

\section{Konkurencyjność podmiotu gospodarczego}

Osiąganie przez przedsiębiorstwo sukcesu rynkowego jest zagadnieniem niezwykle interesującym, lecz nie zawsze jednoznacznym. Z jednej strony sukces przedsiębiorstwa definiuje się głównie według pozycji, jaką udało mu się zająć w dziedzinie prowadzonej działalności. Jeśli na przykład osiąga ono dobre wyniki finansowe i przewyższa swoich konkurentów pod względem jakości, to dzieje się tak dlatego, że dysponuje zasobami i kompetencjami, które umiało sobie wypracować i zastosować w dobrze wybranej dziedzinie działalności (Kotler 1999). Z drugiej zaś strony czasami sukcesem przedsiębiorstwa może być same jego utrzymanie się na coraz bardziej konkurencyjnym rynku. Przy znacznie zmniejszonej skali obrotów i obniżanych corocznie wynikach finansowych, będących jednymi z negatywnych efektów zwiększającej się liczby i jakości konkurentów, myślenie o zdobywaniu lepszej pozycji nie jest możliwe. Z czasem oczywiście sytuacja ta może ulec zmianie, ale w takich warunkach sukces przedsiębiorstwa pojmowany jest zupełnie odmiennie.

Stwierdzić można, że sukces przedsiębiorstwa we współczesnej gospodarce ma swoje źródło zarówno w bieżącym, stabilnym funkcjonowaniu podmiotu gospodarczego, jak również a może przede wszystkim - w jego rozwoju. Wyzwania współczesnego rynku, związane z przebiegiem i rozwojem procesu globalizacji, stwarzają przedsiębiorstwu wiele szans rozwojowych. Stawiają jednak również przed nim wiele zagrożeń, których dynamika jest tak gwałtowna, że znacznie utrudnia lub wręcz uniemożliwia funkcjonowanie podmiotu gospodarczego. Receptą na pewne uniezależnienie się od tych gwałtownych zmian i możliwość odniesienia sukcesu rynkowego jest - wspomniane wcześniej - dążenie do wzrostu konkurencyjności przedsiębiorstw. W teorii ekonomii oraz prowadzonych badaniach empirycznych nie ma zgodności dotyczącej zdefiniowania pojęcia konkurencyjności. W definiowaniu tego zjawiska można spotkać się ze stwierdzeniem, iż jest to pojęcie teoretyczne oraz stan odnoszący się do sfery działalności instytucji rynkowych. Dla istnienia konkurencyjności niezbędny jest rynek, natomiast ona sama jest „cechą i mechanizmem regulującym zachowania podmiotów na rynku” (Roszyk-Kowalska 2007, s. 4). Stwierdzić zatem można, że konkurencyjność nie może być rozpatrywana niezależnie od rynku. Zagadnienie to w bezpośredni sposób dotyczy wszystkich przedsiębiorstw funkcjonujących na tym rynku.

Przedstawiając definicję konkurencyjności, H. Adamkiewicz podaje, że: „Pod pojęciem konkurencyjności przedsiębiorstwa rozumie się właściwość, która określa jego zdolność do ciągłego kreowania tendencji rozwojowej, wzrostu produktywności [...] oraz do skutecznego rozwijania rynków zbytu w warunkach oferowania przez konkurentów towarów lub/i usług nowych, lepszych i tańszych" (Adamkiewicz 2001, s. 1). Jak dowodzą A. Oniszczuk-Jastrząbek i T. Gutowski: „W tej definicji podkreśla się, że omawiane pojęcie konkurencyjności jest ściśle związane z oferowaniem przez przedsiębiorstwo produktu, lepszego pod względem jakości, ceny czy też bardziej funkcjonalnego, niż produkt oferowany klientowi przez innych konkurentów. [...] nie jest to jednak definicja pełna. Oprócz poziomu jakości oferowanego produktu, jego ceny, czy też funkcjonalności [...] zwrócić należy również uwagę na inne czynniki, przyczyniające się do zwiększenia konkurencyjności podmiotów gospodarczych" (Oniszczuk- 
-Jastrząbek, Gutowski 2007, s. 179). Stąd też określenie konkurencyjności, jako umiejętności skutecznego konkurowania przedsiębiorstw na rynku, a więc skutecznego funkcjonowania i rozwoju w konkurencyjnym otoczeniu wydaje się najbardziej trafne (Gorynia 2002; Oniszczuk-Jastrząbek, Gutowski 2007). Pojęcie konkurencyjność można również rozumieć jako agregat złożony z następujących elementów (Rybak 2003, s. 11):

- potencjału konkurencyjności,

- przewagi konkurencyjnej,

- instrumentów konkurowania,

- pozycji konkurencyjnej sprzedającego.

Między tymi elementami zachodzą relacje przyczynowo-skutkowe, co oznacza, że zmiana jednego z tych elementów powoduje zmianę innego.

Ryc. 1. Struktura konkurencyjności przedsiębiorstwa

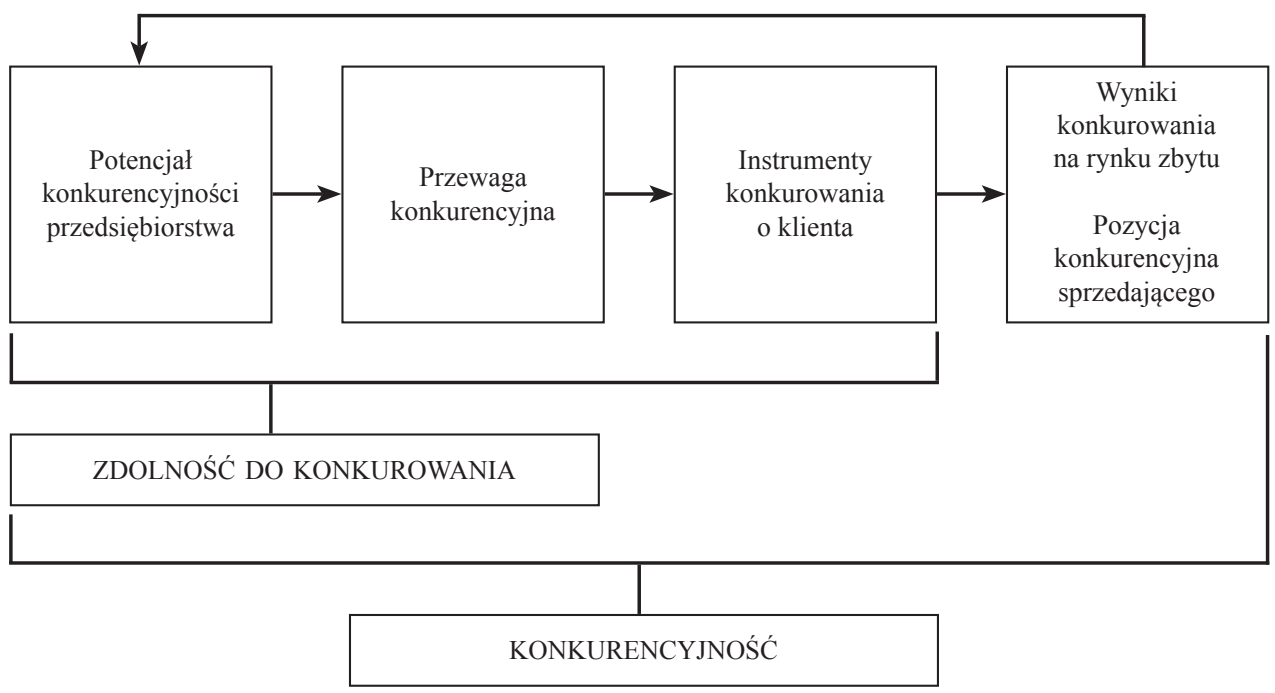

Źródło: opracowanie własne na podstawie Stankiewicz 2000, s. 79.

Jednoczesne zmiany poszczególnych elementów - potencjału konkurencyjności przedsiębiorstwa, przewagi konkurencyjnej oraz instrumentów konkurowania o klienta - wpływają na osiągnięcie przez przedsiębiorstwo określonego poziomu zdolności do konkurowania.

W takim rozumieniu tego pojęcia potencjał konkurencyjności przedsiębiorstwa to możliwość jego skutecznego funkcjonowania na rynku (Otta 1988). Pod tym pojęciem rozumie się również system zasobów materialnych i niematerialnych umożliwiających przedsiębiorstwu budowanie przewagi konkurencyjnej (Godziszewski 1999). Zależy on m.in. od liczebności przedsiębiorstw, łącznej liczby zatrudnionych pracowników, wysokości zaangażowanego kapitału oraz od rodzajów i wielkości luk rynkowych, które przedsiębiorstwa te wypełniają swą produkcją, handlem lub oferowanymi usługami.

Przewaga konkurencyjna możliwa jest zaś do osiągnięcia w wyniku realizowanej strategii. Jej zasadniczym celem jest wytworzenie większego od średniego zysku dla branży i posiadanie znaczącego udziału w rynku. Do instrumentów konkurowania zalicza się natomiast „narzędzia i sposoby pozyskiwania klientów i dostawców w warunkach akceptowanych przez przedsiębiorstwo i służących osiąganiu jego celów” (Roszyk-Kowalska 2007, s. 3). 
W skład łańcucha konkurencyjności wchodzi ponadto pozycja konkurencyjna sprzedającego. Jak podkreśla G. Roszyk-Kowalska: „Jest to wynik oceny przez rynek (w szczególności przez nabywców) tego, co przedsiębiorstwo na nim oferuje. Oznacza ona miejsce na skali korzyści ekonomicznych i pozaekonomicznych, jakie przedsiębiorstwo dostarcza swoim interesariuszom, w porównaniu z tymi miejscami, które pod tymi samymi względami zajmują jego konkurenci. Najbardziej podstawowymi i syntetycznymi miernikami pozycji konkurencyjnej każdego przedsiębiorstwa jest jego udział w rynku oraz osiągnięta sytuacja finansowa" (Roszyk-Kowalska 2007, s. 4). Należy podkreślić, że osiągnięcie pożądanej pozycji konkurencyjnej jest uwarunkowane stanem przewagi konkurencyjnej przedsiębiorstwa.

\section{Sposoby osiągania przewagi konkurencyjnej}

Przewaga konkurencyjna przedsiębiorstwa, stanowiąca jeden z elementów struktury konkurencyjności przedsiębiorstwa, jest zagadnieniem złożonym. Często też jest pojęciem nadużywanym i mylonym z samą konkurencyjnością. Czym więc jest owa przewaga konkurencyjna, będąca często głównym pragnieniem przedsiębiorstw funkcjonujących we współczesnej gospodarce? Stwierdzić można, że przewaga konkurencyjna jest to osiągnięcie przez przedsiębiorstwo nadrzędnej pozycji wobec większej liczby konkurentów. Jest ona relatywną miarą funkcjonowania na rynku, która pozwala na zaoferowanie klientowi usług lub produktów odpowiadających jego oczekiwaniom, a lepszych niż oferty konkurencji. Wyraża się ona w wyższej jakości produktu, niższej cenie i lepszej obsłudze lub bardziej kompleksowym zaspokojeniu potrzeb klienta. W przytoczonej definicji na plan pierwszy wysuwa się zaspokojenie potrzeb klienta, jego satysfakcja, stanowiące główne czynniki osiągania przez przedsiębiorstwo przewagi konkurencyjnej. Postrzeganie usatysfakcjonowanego klienta jako zasobu przedsiębiorstwa ma nie tyle filozoficzny, co silnie ekonomiczny sens (Haffer 2000). M.E. Porter stwierdza natomiast, że zjawisko przewagi konkurencyjnej jest duszą wyników firm działających na konkurencyjnych rynkach (Porter 1985). J.B. Barney definiuje ją jako zdolność do realizowania strategii, której nie są w stanie wdrożyć aktualni i przyszli konkurenci (Barney 1991). W dwóch ostatnich przytoczonych definicjach elementem najważniejszym są przedsiębiorstwa i ich konkurenci działający na tym samym rynku. Wydaje się, że najpełniejszą definicję przewagi konkurencyjnej podaje M.J. Stankiewicz. Twierdzi on, że na tworzenie ogólnej przewagi konkurencyjnej składają się cząstkowe przewagi uzyskiwane w zakresie konkretnych ofert rynkowych. Określa ją ponadto jako zdolność do takiego wykorzystania potencjału konkurencyjności przedsiębiorstwa, jakie umożliwia na tyle efektywne generowanie atrakcyjnej oferty rynkowej i skutecznych instrumentów konkurowania, że zapewnia to powstanie wartości dodanej (Stankiewicz 2002). Widocznymi przejawami uzyskania przewagi konkurencyjnej mogą więc być między innymi następujące elementy: niższe koszty wytworzenia i wynikające stąd niższe ceny, oryginalność produktu, dobra obsługa nabywców oraz obsługa posprzedażna, poprawa organizacji sprzedaży, wyspecjalizowana oferta czy zaoferowanie klientom produktu charakteryzującego się wyższym niż u konkurencji lub wręcz niespotykanie wysokim poziomem jakości (Famielec 1997).

W literaturze spotkać można wiele różnych systematyzacji strategii osiągania przewagi konkurencyjnej oraz dużą liczbę kryteriów ich wyodrębniania. W oparciu o kryterium skali, w jakiej przedsiębiorstwo ją uzyskało lub dąży do jej uzyskania, wyróżnić można globalną oraz lokalną przewagę konkurencyjną (Stankiewicz 2002). Pierwsza z nich realizowana jest na rynkach podlegających globalnej konkurencji i dotyczy przedsiębiorstw, które na tych rynkach prowadzą działalność gospodarczą. Druga - odnosi się do podmiotów gospodarczych, których zasięg działania jest zdecydowanie mniejszy i dotyczy jedynie pewnych ściśle określonych rynków, najczęściej lokalnych czy regionalnych. 
Najbardziej powszechnym kryterium klasyfikacji przewag konkurencyjnych według kryterium ich podstawowej bazy jest propozycja M.E. Portera. Zgodnie z nią wyróżnić można trzy główne źródła i odpowiadające im typy przewag (Porter 1996):

- przewagę wynikającą z przywództwa kosztowego,

- przewagę wynikającą ze zróżnicowania (dywersyfikacji),

- przewagę wynikającą z koncentracji (skupienia).

Ryc. 2. Ogólne strategie konkurencyjne

\section{PRZEWAGA STRATEGICZNA}

\begin{tabular}{|c|c|c|c|}
\cline { 3 - 4 } \multicolumn{2}{c|}{} & $\begin{array}{c}\text { unikalność postrzegania } \\
\text { przez klienta }\end{array}$ & pozycja niskiego kosztu \\
\hline \multirow{4}{*}{$\begin{array}{c}\text { Cele } \\
\text { strategiczne }\end{array}$} & w skali sektora & zróżnicowanie & wiodąca pozycja kosztowa \\
\cline { 2 - 4 } & $\begin{array}{c}\text { w skali } \\
\text { segmentu }\end{array}$ & \multicolumn{2}{c|}{ koncentracja } \\
\hline
\end{tabular}

Źródło: Porter 1996, s. 54.

Każda z wymienionych strategii zakłada odmienny sposób osiągania przewagi konkurencyjnej. W przypadku strategii przywództwa kosztowego celem przedsiębiorstwa jest osiągnięcie, a następnie utrzymanie niższego niż konkurenci poziomu kosztów produkcji przy równocześnie wysokiej jej jakości. „Wiodąca pozycja pod względem kosztów wymaga inwestowania w urządzenia produkcyjne na efektywną skalę, dążenia do obniżenia kosztów poprzez zdobywanie doświadczenia, ścisłą kontrolę kosztów bezpośrednich i ogólnych, unikanie klientów o marginalnym znaczeniu, reklamy, obsługi posprzedażnej itp.” (Kotowicz-Jawor 1998, s. 22). Kolejną strategią konkurencyjną jest strategia zróżnicowania (dywersyfikacji). Jest ona stosowana wówczas, gdy przedsiębiorstwo ma do zaoferowania klientom unikatowy produkt, który będzie najwyżej przez nich ceniony. Elementami różnicowania mogą być na przykład: określona cecha produktu, system jego dostawy lub marketing (Stanieda 2006). Zwykle poprawa tych kryteriów pociąga za sobą z jednej strony konieczność poniesienia przez przedsiębiorstwo wyższych niż konkurencja kosztów, z drugiej zaś umożliwia oferowanie na rynku własnych produktów po wyższej cenie. Trzecią strategią konkurencyjną jest ta, która polega na dążeniu przedsiębiorstwa do osiągnięcia efektów w jednym wybranym segmencie. Powszechnie jest ona nazywana strategią koncentracji (skupienia). Jej istota zakłada, że pewne „ograniczenie” do wybranego segmentu powinno powodować pełne zaspokojenie potrzeb konsumentów. Tę część rynku można bowiem obsłużyć sprawniej i skuteczniej, niż czyni to konkurencja. Tak przedstawiona charakterystyka wszystkich trzech strategii konkurencji pozwala na wyciągnięcie ogólnego wniosku dotyczącego osiągania przewagi konkurencyjnej. Jak trafnie ujmuje J. Stanienda: ,podstawowym warunkiem skutecznego działania [przedsiębiorstwa - T.G.] jest wyróżnienie tego elementu czy tej strefy, w których przedsiębiorstwo będzie miało przewagę nad konkurentami” (Stanieda 2006, s. 21). W związku z tym możliwe jest przyjęcie pewnych zasad warunkujących uzyskanie przewagi, czyli osiągnięcie sukcesu rynkowego. Należy być najlepszym w jednej z trzech wymienionych strategii, stale udoskonalać pozycję lidera w jednej z nich oraz poszukiwać najkorzystniejszej pozycji w pozostałych dwóch (Altkorn 2000). 
Tab. 2. Skutki działań konkurencyjnych przedsiębiorstwa

\begin{tabular}{|c|c|}
\hline $\begin{array}{c}\text { Skutki działań } \\
\text { konkurencyjnych }\end{array}$ & Charakterystyka skutków \\
\hline Ekonomiczne & $\begin{array}{l}\text { - ich istotą jest dążenie do tego, aby osiągnąć jak najwięcej, stworzyć } \\
\text { podstawy rozwoju, sprawnie funkcjonować i osiągać jak najwyższy zysk }\end{array}$ \\
\hline Prestiżowe & $\begin{array}{l}\text { - wyrażają się w jak najlepszej opinii, w utrwalaniu własnego stylu, } \\
\text { uzyskaniu przychylności nabywców przekonanych o dbałości o ich } \\
\text { interesy, stworzeniu korzystnych wyobrażeń o przedsiębiorstwie } \\
\text { i jego działalności }\end{array}$ \\
\hline Bieżące & $\begin{array}{l}\text { - wyrażają się w umiejętności elastycznego operowania celami, } \\
\text { celowego nasilania reklamy handlowej, umiejętności działań } \\
\text { sezonowych }\end{array}$ \\
\hline Odłożone w czasie & $\begin{array}{l}\text { - przedsiębiorstwo chce osiągnąc je nawet za cenę zmniejszonego przez } \\
\text { pewien okres dochodu lub innych zjawisk przyciągających nabywcę, } \\
\text { a pozwalających w przyszłości na osiągnięcie korzystniejszej pozycji } \\
\text { przez przedsiębiorstwo na rynku }\end{array}$ \\
\hline Strategiczne & $\begin{array}{l}\text { - polegają na budowaniu perspektyw ekspansji w danym rejonie, } \\
\text { dokonywaniu przestrzennych zmian w produkcji i obrocie, tworzeniu } \\
\text { nowych związków kapitałowych, wprowadzeniu nowych generacji } \\
\text { produktów do produkcji, obrotu itp. }\end{array}$ \\
\hline Kompleksowe & $\begin{array}{l}\text { - dotyczą całego przedsiębiorstwa i polegają na tworzeniu jego nowego } \\
\text { wizerunku, budowaniu więzi informacyjnych z nowymi odbiorcami, } \\
\text { nasilaniu innowacji w produkcji, obrocie itp. }\end{array}$ \\
\hline Całościowe & $\begin{array}{l}\text { - dotyczą konkretnego produktu i polegają na tworzeniu wyróżniającego } \\
\text { się produktu, który symbolizuje przedsiębiorstwo lub jest absolutnym } \\
\text { przebojem, dzięki czemu przedsiębiorstwo nie tylko się dynamicznie } \\
\text { rozwija, ale również ma dobrą opinię itp. }\end{array}$ \\
\hline
\end{tabular}

Źródło: opracowanie własne na podstawie Stanienda 2006, s. 21.

Nieco inaczej przewagę konkurencyjną opisuje C. Suszyński. Wychodzi on z założenia, iż przedsiębiorstwo musi posiadać i sprawnie zarządzać posiadanymi atutami, do których zalicza wszystko to, co jest lub będzie bardzo trudne do odtworzenia przez konkurencję i co stanowić będzie satysfakcję jego klientów. Głównymi atutami podmiotu gospodarczego w tym przypadku są następujące elementy:

- stosowana w przedsiębiorstwie technologia wytwarzania produktów bądź usług,

- zrozumienie zachowań rynku, gdzie dużą rolę odgrywa informacja i jej przepływ między podmiotami gospodarczymi oraz wewnątrz nich,

- know-how,

- tempo wykonywania zleconych prac,

- atrakcyjny (krótki) czas dostaw od producenta do klienta,

- możliwości wypracowania własnej marki,

- lojalność klienta lub określonej grupy klientów,

- stworzenie odpowiedniego wizerunku przedsiębiorstwa. 
Elementy te prowadzą w konsekwencji do osiągnięcia przewagi konkurencyjnej oraz przede wszystkim do wzrostu wartości dla współwłaścicieli przedsiębiorstwa. „Zdobyta przewaga konkurencyjna generuje wartość dodaną dla przedsiębiorstwa, która z kolei jest źródłem wartości dla akcjonariuszy [...]. Wynika z tego, że tworzenie wartości dla klienta odgrywa główną rolę w tworzeniu wartości dla akcjonariuszy, a cały proces zarządzania wartością rozpoczyna się od klienta i kończy na inwestorze" (Suszyński 2007, s. 64).

Ryc. 3. Współczesny model przewagi konkurencyjnej

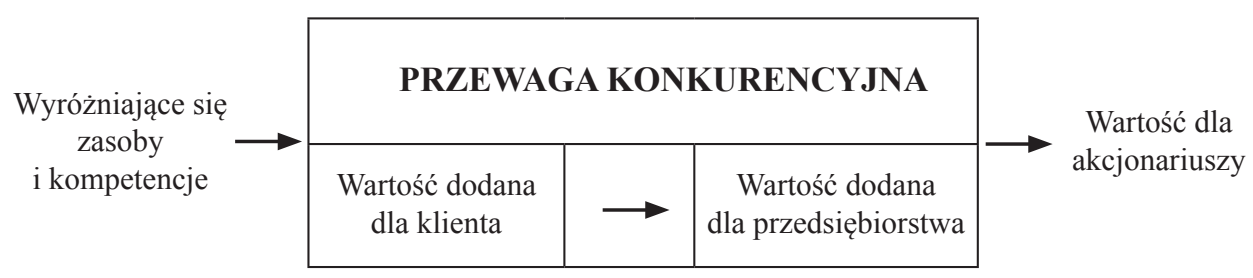

Źródło: opracowanie własne na podstawie Suszyński 2007, s. 128.

Praktycznym narzędziem służącym do określenia pozycji konkurencyjnej przedsiębiorstwa są metody analizy strategicznej firmy. Odpowiedź na pytanie, jakie działania należy podjąć w przedsiębiorstwie przy określonej atrakcyjności przemysłu i znanej pozycji konkurencyjnej, daje na przykład macierz General Electric Corporation, znana bardziej jako macierz GE lub też macierz McKinseya. W zależności od określonej „,siły” dwóch jej elementów, formułowane są na jej podstawie zalecenia strategiczne (Stabryła 2002).

Wyniki przeprowadzonej analizy dają osobom zarządzającym podmiotem gospodarczym możliwość opracowania strategii przedsiębiorstwa, której zasadniczym celem w konsekwencji będzie tworzenie wartości dla jego współwłaścicieli. Jak podkreśla P. Doyle, ocena pozycji strategicznej przedsiębiorstwa dostarcza informacji, na podstawie których może być sporządzona wycena całego przedsiębiorstwa, umożliwia identyfikację czynników determinujących wartość, przez co zachęca kierownictwo podmiotu do wdrażania nowych strategii działania (Doyle 2003).

\section{Obszary zmian w przedsiębiorstwie wobec procesu globalizacji - założenia badań własnych}

Konkurencyjność podmiotów gospodarczych funkcjonujących w Polsce, w warunkach gospodarki coraz bardziej globalnej, jest przedmiotem licznych badań. Ich autorzy, posługując się rozmaitymi metodami badawczymi, starają się zwrócić uwagę na te czynniki, które w najsilniejszy sposób mogą wpłynąć na zwiększenie konkurencyjności. Dla potrzeb badawczych autor artykułu wraz z dr A. Oniszczuk-Jastrząbek w roku 2007 i 2008 przeprowadzili - wśród polskich podmiotów gospodarczych - podobne badania ankietowe. Skupili swoją uwagę na czynnikach wynikających ze zmian w następujących sferach działalności gospodarczej: inwestycje, personel, wartości niematerialne i prawne, organizacja i zarządzanie, finanse, logistyka, produkcja, badanie i rozwój, jakość oraz marketing. Ankietowani odpowiadali na pytania związane z tymi czynnikami, określając wpływ poszczególnych elementów z tych sfer na konkurencyjność przedsiębiorstwa w skali: bardzo duży, duży, mały, bardzo mały, nie ma wpływu, nie mam zdania. W kilku przypadkach ankietowani mieli możliwość dokonania wyboru stopnia ważności kryteriów decydujących o konkurencyjności przedsiębiorstwa w warunkach globalnych. 
Wyniki przeprowadzonych badań pozwoliły na identyfikację najważniejszych sfer działalności tych podmiotów oraz na określenie pożądanych kierunków zmian w celu zwiększenia własnej konkurencyjności wobec wyzwań globalnego rynku. W znacznej części przypadków respondenci, mimo dążenia do rozwoju własnej działalności, w niewielkim stopniu dostrzegali proces globalizacji gospodarki. Zwracali uwagę na kilkadziesiąt czynników, które ich zdaniem mogłyby wpłynąć znacząco na wzrost ich konkurencyjności. Wielu wykazywało jednak bardzo dużą wiarę we własne dotychczas stosowane działania i nie zauważało jakichkolwiek zagrożeń związanych z wyzwaniami współczesnego rynku. Jednym z głównych wniosków było zwrócenie uwagi na fakt, iż brak działań dostosowawczych może w krótszym okresie czasu prowadzić do marginalizacji przedsiębiorstwa, a w dłuższym - przyczynić się do jego upadłości bądź likwidacji. W ubiegłym roku prowadzone były kolejne badania ankietowe, a ich zakończenie nastąpiło z końcem listopada 2010 r. Autorzy - mając doświadczenia z lat poprzednich - postanowili dokonać m.in. uszeregowania kryteriów decydujących o konkurencyjności podmiotu gospodarczego oraz oceny wpływu czynników na konkurencyjność. Osobne pytania dotyczyły innowacyjności przedsiębiorstwa, a odpowiedź na nie umożliwiła poznanie źródeł innowacji oraz określenie jej miejsca w rozwoju przedsiębiorstwa. Autorzy przeprowadzili również wśród kilkuset polskich przedsiębiorstw kampanię informacyjną o prowadzonych badaniach. Ankieta została umieszczona na serwerze Wydziału Ekonomicznego Uniwersytetu Gdańskiego ${ }^{2}$.

Funkcjonowanie gospodarki globalnej, a w jej ramach - oddziaływanie procesu globalizacji na działalność przedsiębiorstw - jest bezsprzeczne. Przedsiębiorstwa, chcąc prowadzić skuteczną walkę konkurencyjną z innymi uczestnikami rynku zmuszone są do przeprowadzenia odpowiednich działań adaptacyjnych. Zadania te mogą być realizowane w wielu obszarach działalności gospodarczej, a ich realizacja może zależeć zarówno od działań samego przedsiębiorstwa, jak i tego, co rozgrywa się w jego otoczeniu.

Warto zatem prowadzić ciągły monitoring działań związanych z rozwojem współczesnego przedsiębiorstwa i cały czas zastanawiać się na tym, co z rozważań teoretycznych na temat konkurencyjności można przełożyć na konkretne działanie.

\section{Literatura}

1. Adamkiewicz H.G., 2001, Adaptacja rynkowa jako istotny czynnik strategiczny osiagnięcia sukcesu przez przedsiębiorstwo w warunkach globalizacji [w:] Prace Naukowe Katedry Zarzadzania, Wydawnictwo Wyższej Szkoły Morskiej, Gdynia.

2. Altkorn J., 2000, Wyróżniki tożsamości przedsiębiorstwa, „Marketing i Rynek”, nr 6.

3. Barney J.B., 1991, Firm Resources and Sustained Competitive Advantage, „Journal of Management”, Vol. 17, No 1, Southern Management Association, s. 99-120.

4. Bolesta-Kukułka K., 1995, Świat organizacji [w:] Zarządzanie. Teoria i praktyka, A. Koźmiński, W. Piotrowski (red.), Wydawnictwo Naukowe PWN, Warszawa.

\footnotetext{
${ }^{2}$ Kwestionariusz ankietowy został umieszczony pod adresem: https://ekonom.ug.edu.pl/gp/ (hasło dostępu: GLOBAL).
} 
5. Bożyk P., 1991, Gospodarka światowa, PWE, Warszawa.

6. Bożyk P., Mijala J., Puławski M., 1999, Międzynarodowe stosunki ekonomiczne, PWE, Warszawa.

7. Doyle P., 2003, Marketing wartości, Wydawnictwo Felberg SJA, Warszawa.

8. Famielec J., 1997, Strategie rozwoju przedsiębiorstwa, Wydawnictwo Akademii Ekonomicznej, Kraków.

9. Godziszewski B., 1999, Potencjał konkurencyjności przedsiębiorstwa jako źródto przewag konkurencyjnych i podstawa stosowania instrumentów konkurowania [w:] Budowanie potencjału konkurencyjności przedsiębiorstwa, M.J. Stankiewicz (red.), Wydawnictwo TNOiK, Toruń.

10. Gorynia M., 2002, Luka konkurencyjna na poziomie przedsiębiorstwa a przystapienie Polski do Unii Europejskiej, Wydawnictwo Akademii Ekonomicznej w Poznaniu, Poznań.

11. Haffer R., 2000, Satysfakcja konsumentów i jej pomiar [w:] Marketingowe testowanie produktów, S. Sudoł, J. Szymczak, M. Haffer (red.), PWE, Warszawa.

12. Kotler P., 1999, Marketing. Analiza, planowanie, wdrażanie i kontrola, Wydawnictwo Felberg SJA, Warszawa.

13. Kotowicz-Jawor J., 1998, Przebudowa mikroekonomicznego mechanizmu rozwoju, PWN, Warszawa.

14. Kuciński K., 2002, Nasza ziemia - gospodarka globalna, Wydawnictwo Kurpisz, Poznań.

15. Oniszczuk-Jastrząbek A., Gutowski T., 2011, Czynniki wptywające na zwiększenie konkurencyjności pomorskich przedsiębiorstw, Toruń (referat w druku).

16. Otta W. J., 1988, Strategia eksportowa producenta, Wydawnictwo TNOiK, Poznań.

17. Porter M.E., 1985, Competitive Advantage. Creating and Sustaining Superior Performance, „The Free Press", New York.

18. Porter M.E., 1996, Strategia konkurencji. Metody analizy sektorów i konkurentów, PWE, Warszawa.

19. Roszyk-Kowalska G., 2007, Przewaga konkurencyjna w aspekcie kluczowych kompetencji przedsiębiorstwa, www.sgh.waw.pl/katedry/ktz/mf2020/referaty/Przewaga_konkurencyjna_w_aspekcie_kluczowych_kompetencji_przedsiebiorstwa.pdf

20. Stabryła A., 2002, Zarzadzanie strategiczne w teorii i praktyce firmy, PWN, Warszawa.

21. Stanienda J., 2006, Determinanty rozwoju i konkurencyjności przedsiębiorstw w regionie, Wydawnictwo Małopolskiej Wyższej Szkoły Ekonomicznej, Tarnów.

22. Stankiewicz M.J., 2000, Istota i sposoby oceny konkurencyjności przedsiębiorstwa, „Gospodarka Narodowa", nr 7/8.

23. Stankiewicz M.J., 2002, Konkurencyjność przedsiębiorstwa, Wydawnictwo Dom Organizatora, Toruń.

24. Suszyński C. (red.), 2007, Przedsiębiorstwo. Wartość. Zarzadzanie, PWE, Warszawa.

25. Wajda A., 2003, Organizacja i zarzadzanie, PWE, Warszawa.

26. Witkowska J., 2005, Zagraniczne źródła innowacji w Polsce [w:] Procesy innowacyjne w polskiej gospodarce, Rada Strategii Społeczno-Gospodarczej przy Radzie Ministrów, Raport nr 26, Warszawa.

27. Wyrwa D., 2006, Małe i średnie przedsiębiorstwa w procesie globalizacji [w:] Integracja a globalizacja. Materiaty konferencyjne, J. Rymarczyk, W. Michalczyk (red.), Akademia Ekonomiczna we Wrocławiu, Wrocław.

28. Zorska A., 1998, Ku globalizacji? Przemiany w korporacjach międzynarodowych $i$ w gospodarce światowej, Wydawnictwo Naukowe PWN, Warszawa.

29. Żurek J., 2002, Globalizacja - współczesny kierunek rozwoju gospodarki światowej [w:] Transport morski w gospodarce globalnej, Fundacja Rozwoju Uniwersytetu Gdańskiego, Gdańsk.

30. Żurek J., 2007, Przedsiębiorstwo w systemie społeczno-gospodarczym [w:] Przedsiębiorstwo. Zasady działania, funkcjonowanie, rozwój, J. Żurek (red.), Fundacja Rozwoju Uniwersytetu Gdańskiego, Gdańsk.

31. Żurek J., 2002, Transport morski w gospodarce globalnej, Fundacja Rozwoju Uniwersytetu Gdańskiego, Gdańsk. 


\section{Competitiveness of Enterprises in the Global Economy}

Process of management in the modern world forces enterprises to take many decisions at the strategic level. The ultimate goal of these decisions is to improve the competitiveness of enterprises and the competitiveness of the countries in which they conduct their business. Management of companies imposes a necessity of having in mind the need for the changes - necessary from the perspective of broader competitiveness - as well as ensuring their implementation in shorter time than the competitors can.

It is true that new management conditions pose new challenges for companies and open up new opportunities. But it would be advisable to carry out accurate identification of the factors where the necessary changes should be made first, then implement these changes, so as to be able in future to exploit these factors for companies' development. 


\section{Pawel Czapliński}

Akademia Pomorska w Słupsku

\section{Zarządzanie wiekiem jako strategia wzrostu konkurencyjności przedsiębiorstw w dobie globalizacji}

Współcześnie zarządzanie wiekiem w przedsiębiorstwie należy traktować jako zespół działań pracodawcy wobec pracobiorcy, którego celem winno być podniesienie standardu miejsca pracy oraz jego otoczenia, a także wzrost możliwości i zdolności wykonywanych zadań i obowiązków z uwzględnieniem wieku pracowników ${ }^{1}$.

Wobec powyższego należy z całą mocą podkreślić, że zarządzanie wiekiem powinno uwzględniać nie tylko odmienne wymagania wszystkich grup wiekowych pracowników, ale również, co ważniejsze, w sposób optymalny czerpać z ich odmiennych możliwości, z potencjału ich wiedzy i doświadczenia.

W tym kontekście warto zwrócić uwagę na fakt, iż pojęcie zarządzanie wiekiem (age management) nie odnosi się li tylko do zagadnień związanych z personelem w starszym wieku. Taka interpretacja terminu bardzo zawęża właściwe znaczenie, ponieważ na zarządzanie wiekiem składa się kilka działań.

Według L. Nowaczyka (2010), jednym z nich jest korygowanie wpływu procesów demograficznych na struktury zatrudnienia. Oczywiste jest przy tym, że przedsiębiorstwo w zasadzie nie ma możliwości, aby wpływać na zachodzące zmiany zarówno w skali makro-, jak i mikro-. Nie oznacza to jednak, że nie może ono prowadzić działań mających na celu choćby nieznaczne zmniejszenie ich negatywnych skutków. Koniecznym do tego warunkiem jest pełna wiedza na temat struktury wiekowej (a także struktur: płci, zamieszkania, wykształcenia, stażu pracy itp.) pracowników. Ponadto istotna jest znajomość prognoz demograficznych odnoszących się do skali krajowej, regionalnej i - przede wszystkim - lokalnej, w której funkcjonuje przedsiębiorstwo.

Spełnienie obu tych warunków umożliwia realizację zarządzania wiekiem w perspektywie strategicznej, a nie tylko operacyjnej. W rzeczywistości pozwala to uniknąć sytuacji, gdzie w określonej perspektywie czasowej (np. 10 lat) konieczna byłaby rekrutacja na dużą skalę, podczas gdy prognozowana podaż na rynku pracy byłaby dramatycznie niska.

\footnotetext{
${ }^{1}$ POKL Poddziałanie 2.1.1: Rozwój kapitału ludzkiego w przedsiębiorstwach - projekty konkursowe, Zespół Instrumentów Szkoleniowych/Zespół Instytucjonalnego Systemu Wsparcia, Polska Agencja Rozwoju Przedsiębiorczości, Warszawa 2010.
} 
Powyższe rozważania podkreślają istotę i rangę prognoz demograficznych publikowanych m.in. przez Główny Urząd Statystyczny. Prognozy te pozwalają na możliwie precyzyjne określenie kształtowania się struktury wiekowej w najbliższych latach, ale, co ważniejsze, wskazują na horyzont czasu dla działań wyprzedzających, łagodzących negatywne skutki zmian strukturalnych, w tym rosnącego w Polsce odsetka osób w wieku 60 i więcej lat, który w roku 2035 ma osiągnąć poziom 30\% ogółu populacji (ryc. 1).

Ryc. 1. Ludność Polski według funkcjonalnych grup wieku (prognoza)

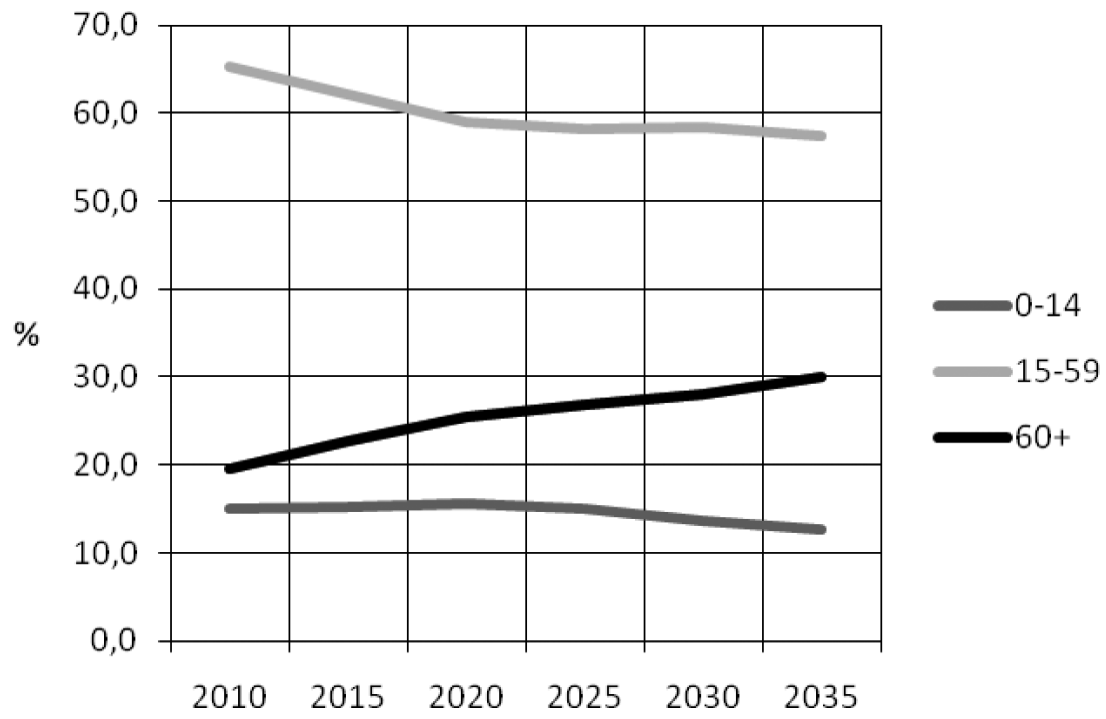

Źródło: opracowanie własne na podstawie publikacji Prognoza ludności na lata 2008-2035, GUS, Warszawa 2008.

Innym działaniem, które należy ściśle wiązać z zarządzaniem wiekiem, jest wykorzystywanie potencjału pracowników w każdej grupie wiekowej. Jak zauważa m.in. C. Sikorski (2001), wiedza staje się obecnie podstawą władzy organizacyjnej, a nawet można zaryzykować stwierdzenie, że wiedza jest tym zasobem, który decyduje o konkurencyjności całej organizacji. Problemem pozostaje jednak optymalne wykorzystanie wiedzy pracowników w każdym wieku. Stąd w zarządzaniu personelem odejście od modelu deficytów, według którego wraz z wiekiem następuje generalny spadek sprawności fizycznej i psychicznej na rzecz modelu kompetencyjnego, w którym każda grupa wiekowa dysponuje atutami (Papińska-Kacperek 2008, Zbiegień-Maciąg 2006) (ryc. 2).

Model kompetencyjny jest wymuszony wieloma stymulantami, takimi jak: turbulentne otoczenie, złożoność informacyjna czy elastyczne, zadaniowe struktury zarządzania. Ponadto ma on charakter dynamiczny, co z kolei wynika z charakteru powyższych przesłanek i - z drugiej strony - procesu nieustannego doskonalenia się. 
Ryc. 2. Efektywność wiekowa

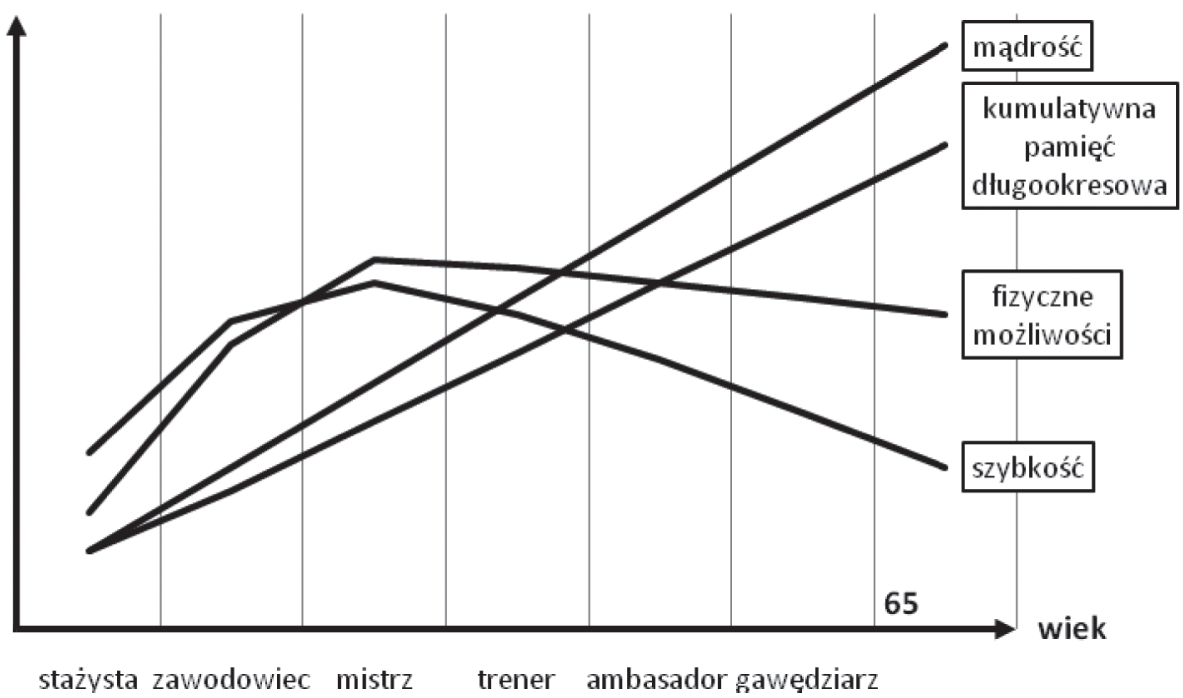

Źródło: Wolińska I., 2009, Projekty innowacyjne służące wydłużaniu aktywności zawodowej, Stowarzyszenie na rzecz Rozwoju Rynku Pracy „S-to-S”, Warszawa, s. 22.

Za jeden z filarów modelu kompetencyjnego należy uznać samoprzywództwo, rozumiane jako umiejętność samodzielnego nadzorowania własnej pracy i ukierunkowywania jej na sprawy ważne dla organizacji. Warto podkreślić, że w strukturach, zwłaszcza sieciowych, istnieje niedobór czasowy, który w znaczący sposób ogranicza możliwość ewentualnych konsultacji. Drugim filarem modelu kompetencyjnego jest adaptacyjność, czyli uznanie zasad i wartości otoczenia, aktywne nawiązywanie relacji z innymi i koewolucja. W tym przypadku kluczową umiejętnością staje się właściwe rozpoznawanie otoczenia. Trzecim ważnym elementem modelu jest innowacyjność, określona jako podejmowanie ryzyka odmienności, szukanie nowych dróg osiągnięcia sukcesu oraz przewidywanie zagrożeń i planowanie. Ostatnią czwartą składową modelu jest przedsiębiorczość, którą należy wiązać z angażowaniem zasobów oraz wyznaczaniem celów, wreszcie z inspirowaniem innych i mobilizowaniem do realizacji zadań (Lenartowicz, Reichhart, Western, Zych 2010).

Powyższe założenia modelu należy odnieść do określonych przedziałów wiekowych pracowników. Jasno z tego wynika, że każda grupa wiekowa, także osób w wieku 60 i więcej lat, ma słabe oraz mocne strony. Stąd postulat, aby tworzyć zespoły, w których wykorzystywane będą mocne strony młodszych pracowników związane choćby z wydolnością organizmu oraz pracowników starszych, którzy posiadają doświadczenie. Takie mieszane wiekowo zespoły wydają się być nie tylko słusznymi moralnie, ale mogą stanowić przewagę konkurencyjną, a w konsekwencji - zysk dla przedsiębiorstwa.

Jeszcze innym działaniem (o zgoła odmiennym charakterze), składającym się na zarządzanie wiekiem jest promowanie zachowań prozdrowotnych oraz ergonomii miejsca pracy. Warto podkreślić, że działania prozdrowotne należy prowadzić na dwóch płaszczyznach, tj. fizycznej i psychicznej, i to w odniesieniu do wszystkich grup wiekowych.

W płaszczyźnie fizycznej, która jest dobrze rozpoznana od wielu lat, a działania mają często bardzo rozbudowaną strukturę, ważna jest sama postawa i mentalność pracowników. Należy 
bowiem pamiętać, że czasem z pozoru drobne nieprawidłowości w wykonywaniu codziennych czynności po latach mogą prowadzić do trwałego kalectwa, a nawet śmierci. Rośnie zatem rola specjalistów BHP, lekarzy, fizjoterapeutów czy dietetyków w profilaktyce i działaniach prozdrowotnych. Działania te powinny przyczynić się do wzrostu liczby i zakresu badań okresowych, które obecnie generalnie są dalece niewystarczające i nieadekwatne do wykonywanego zawodu ${ }^{2}$.

Znacznie bardziej złożona wydaje się być płaszczyzna psychiczna, której ważność w ostatnich latach wyraźnie rośnie. Wszelkie działania nakierowane na sukces organizacji, w tym tempo pracy i związany z tym rygor czasowy, kreatywność, mobilność, odpowiedzialność czy też zakres obowiązków, przyczyniają się do wyczerpania emocjonalnego, depersonalizacji i obniżonego poczucia wartości dokonań osobistych. Taki stan powszechnie nazywany jest syndromem wypalenia zawodowego. Należy go jednak wyraźnie oddzielić od syndromu wynudzenia, ponieważ ten drugi, dotyka osób, które nigdy wcześniej nie miały okresu entuzjazmu (Maslach, Leiter 2001).

Odrębnym, ale równie istotnym pod względem negatywnych skutków zjawiskiem jest mobbing, czyli działania o charakterze przemocy psychicznej, polegające na długotrwałym i usystematyzowanym nękaniu, dręczeniu i/lub terroryzowaniu ofiary w miejscu pracy przez osoby będące wobec niej w stosunku nadrzędności lub przez grupę osób współpracowników (Kędziora, Śmiszek 2010).

Jak podaje Z. Wiśniewski (2009), zarządzanie wiekiem można rozpatrywać z punktu widzenia pracownika, przedsiębiorstwa czy też rynku pracy i każde z tych ujęć ma inną charakterystykę. Zarządzanie wiekiem z pozycji pracownika to możliwość przedłużenia aktywności zawodowej, podniesienia atrakcyjności na rynku pracy oraz zwiększenia możliwości adaptacji do postępujących zmian technicznych i technologicznych poprzez permanentne kształcenie. Zarządzanie wiekiem jako element rynku pracy to inicjowanie i podejmowanie działań zachęcających do rozwiązywania problemów związanych z niekorzystnymi strukturami demograficznymi. Zarządzanie wiekiem dla przedsiębiorstwa to przede wszystkim działania podnoszące świadomość personelu co do swojej wartości przez pryzmat wieku oraz tworzenie strategii zarządzania wiekiem, która winna obejmować rekrutację, szkolenia, rozwój i promocję starszych pracowników oraz lifelong learning (Tokarz 2009).

Oczywistym jest fakt, że w dzisiejszej rzeczywistości gospodarczej zarządzanie wiekiem jest koniecznością, która winna przynieść spodziewane korzyści. Według J. Frycy i B. Majeckiej (2010), korzyściami tymi są m.in.:

- maksymalizacja potencjału rekrutacyjnego,

- zapobieganie niedoborom kwalifikacji,

- wydłużenie aktywności zawodowej pracowników,

- utrzymanie kluczowych kompetencji,

- dłuższy okres zwrotu z poniesionych inwestycji szkoleniowych.

Należy jednak podkreślić, że nie ma jednego algorytmu postępowania dla wszystkich przedsiębiorstw, ponieważ każde przedsiębiorstwo posiada własne, indywidualne podejście do zarządzania wiekiem i do sposobu jego wdrażania. Różne zatem mogą być korzyści z tego płynące.

Z badań sondażowych przeprowadzonych w 2010 r. przez J. Frycę i B. Majecką wynika, że zaledwie 6,3\% polskich przedsiębiorstw stosuje zasady zarządzania wiekiem. Jak się wydaje, przyczyną takiego stanu rzeczy jest nieznajomość tego zagadnienia, ale również, co podkreślają autorki, brak chęci zdobycia takiej wiedzy (ryc. 3).

\footnotetext{
${ }^{2}$ Istnieją także dobre przykłady działań prozdrowotnych w przedsiębiorstwach, np. działania Rady Promocji Zdrowia w Zakładach Koksowniczych „Zdzieszowice” sp. z o.o.
} 
Ryc. 3. Struktura odpowiedzi na pytanie o znajomość pojęcia zarządzanie wiekiem właścicieli badanych przedsiębiorstw

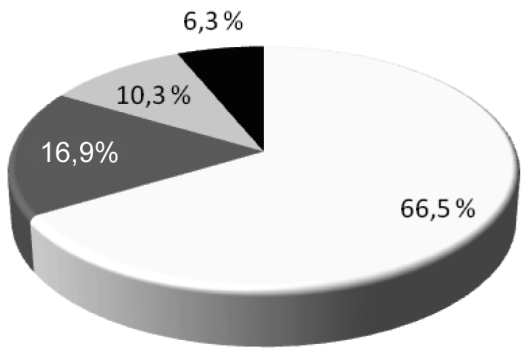

$$
\begin{aligned}
& \text { nie słyszałem o tym } \\
& \text { słyszałem o tym, ale nie } \\
& \text { znam się na tym dobrze } \\
& \text { tak, znam te zasady, ale } \\
& \text { nie są one stosowane } \\
& \text { w mojej firmie } \\
& \text { tak, znam te zasady } \\
& \text { i kieruję się nimi w swojej } \\
& \text { pracy }
\end{aligned}
$$

Źródło: Fryca J., Majecka B., 2010, Istota zarządzania wiekiem w przedsiębiorstwie, „Newsletter”, nr 8, Gdańsk, s. 3 [za:] Wykorzystaj nas! Pracownicy 45+ w twojej firmie, wyniki badań ilościowych - etap I, PBS DGA, Sopot 2010.

W kontekście powyższych wyników pojawiło się pytanie: czy istnieje potrzeba poszerzania wiedzy w zakresie zarządzania wiekiem? Uzyskane odpowiedzi należy uznać za niepokojące, ponieważ prawie $50 \%$ badanych przedsiębiorców nie widzi takiej potrzeby, a $13 \%$ nie potrafiło tego jednoznacznie sprecyzować. Wydaje się jednak, że duży wpływ na uzyskane wielkości ma aktualna sytuacja na krajowym rynku pracy. Otóż relatywnie wysoka liczba osób w wieku produkcyjnym nie zmusza jeszcze przedsiębiorców do efektywniejszego wykorzystywania zasobów pracowników w starszym wieku produkcyjnym i poprodukcyjnym. Jednak według prognoz demograficznych sytuacja ulegnie znacznemu pogorszeniu w przeciągu zaledwie kilku następnych lat, kiedy to roczniki wchodzące na rynek pracy będą zdecydowanie mniej liczne aniżeli obecnie. Można zatem przyjąć, że obecna postawa przedsiębiorców wobec zarządzania wiekiem jest postawą wyczekującą. Istnieje zatem konieczność poszerzenia wiedzy przedsiębiorców o wiedzę z zakresu skutecznych technik zarządzania wiekiem.

Przy dokonywaniu charakterystyki i badaniu uwarunkowań zarządzania wiekiem w polskich przedsiębiorstwach nie bez znaczenia pozostaje czynnik kulturowy odnoszący się do roli osób starszych w społeczeństwie polskim. W tym kontekście można zauważyć nawet pewien paradoks polegający na tym, że z jednej strony wskazuje się na istotną rolę osób starszych w społeczeństwie polskim w wymiarze np. doświadczenia i wsparcia emocjonalnego - jest ona znacznie wyższa aniżeli w społeczeństwach innych wybranych państw europejskich. Z drugiej strony wydaje się, że brak jest pomysłu na wykorzystanie wskazywanych atutów (tab. 1).

Tab. 1. Rola osób starszych w społeczeństwie (\% odpowiedzi „zdecydowanie tak” i „tak”)

\begin{tabular}{|c|c|c|c|c|c|c|}
\hline Wyszczególnienie & Czechy & Estonia & Niemcy & Litwa & Polska & Rumunia \\
\hline Doświadczenie & 81,3 & 65,4 & 89,5 & 75,8 & 92,2 & 84,8 \\
\hline Utrzymanie tradycji & 71,4 & 69,0 & 75,2 & 80,7 & 89,3 & 88,3 \\
\hline Wiedza & 81,6 & 81,1 & 90,1 & 87,8 & 91,3 & 85,3 \\
\hline Wsparcie emocjonalne & 75,5 & 65,6 & 71,1 & 74,8 & 75,9 & 52,1 \\
\hline
\end{tabular}

Źródło: The Demographic Future of Europe - Fact, Figures, Policies, opracowanie opublikowane przez Niemiecki Instytut Federalny ds. Badań Demograficznych i Fundację Roberta Boscha, 2005, s. 25. 
Warto zwrócić przy tym uwagę na fakt, że odsetek osób pracujących w wieku 55-64 lata w każdym z przedstawionych państw może wynikać z różnych przyczyn. Można tu wymienić przyczyny egzystencjalne (przymusowe), ale również dobrowolne, w tym styl, a może sposób na spędzenie jesieni życia oparty np. na samozatrudnieniu (ryc. 4).

Jak pokazują badania przeprowadzone przez firmę Manpower ${ }^{3}$, polscy pracodawcy wydają się mało zainteresowani rekrutacją, ale i utrzymaniem starszych pracowników. Za niepokojącą należy uznać skalę tej niechęci, a raczej brak pomysłu na zatrudnianie osób starszych przy jednoczesnym braku znajomości korzyści płynących z różnorodności wiekowej w przedsiębiorstwie. Polska obok Szwecji znalazła się w takim zestawieniu na jednym z ostatnich miejsc wśród badanych krajów, pozostając w tyle nie tylko za dalekowschodnimi liderami, ale także za większością krajów UE, w tym także nowo przyjętych.

Dlaczego tak jest? Otóż nie decyduje o tym jeden czynnik. Z całą pewnością znaczenie mają tutaj stereotypy czy, mówiąc szerzej, czynnik kulturowy. Ważnym wydaje się ponadto czynnik ekonomiczny sugerujący, że koszty szkoleń są zbyt duże. Ostatecznie więc pracownicy powyżej 55 roku życia to zaledwie 5\% uczestników kursów zawodowych. Przyczyn jednak jest znacznie więcej i leżą one tak po stronie popytu, jak i podaży.

Ryc. 4. Stopa zatrudnienia osób w wieku 55-64 lata w 2008 r. według wybranych krajów

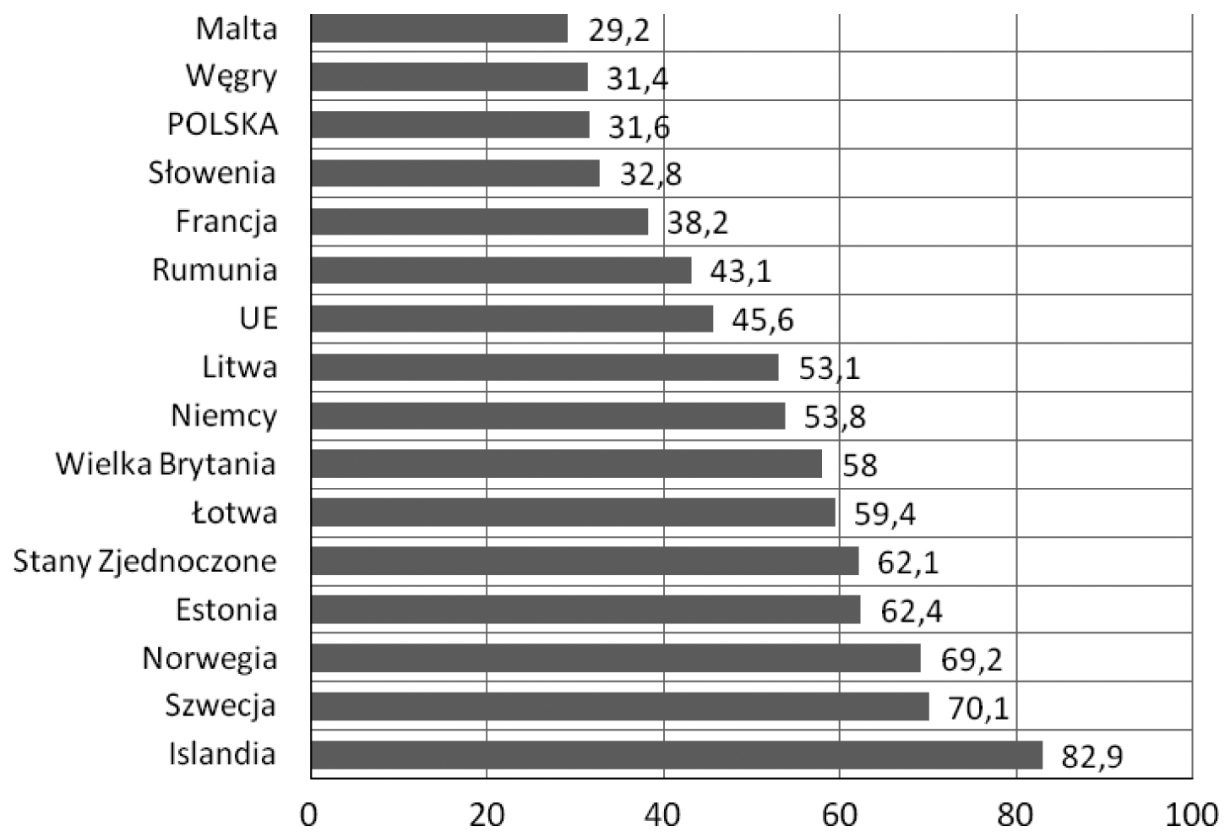

Źródło: opracowanie własne na podstawie danych EUROSTAT.

Zarządzanie wiekiem w pojedynczych przypadkach jest bardzo zróżnicowane i wynika ze wspomnianych wcześniej uwarunkowań, w tym ze specyfiki czy profilu działalności oraz wielu czynników historycznych, społecznych, kulturowych i ekonomicznych, a w tym powiązań organizacyjnych, które determinują obecną strukturę zatrudnienia według wieku.

\footnotetext{
${ }^{3}$ Nowe spojrzenie na pracowników 50+. Raport ekspercki Manpower Polska, Warszawa 2008.
} 
W celu bliższej analizy wykorzystano wiekowe struktury zatrudnienia dotyczące trzech przedsiębiorstw subregionu słupskiego, które reprezentują w skali lokalnej trzy wiodące profile działalności: przemysł środków transportu, przemysł obuwniczy oraz przetwórstwo rybne.

Przedsiębiorstwo „A” to duża pod względem zatrudnienia jednostka produkcyjna wytwarzająca środki transportu. W jej strukturze wiekowej widoczna jest duża liczba pracujących w wieku 26-35 lat, która dodatkowo w latach 2008-2010 powiększyła się. Ponadto, znacząco wysoka jest liczba pracujących w najmłodszej z badanych grup wiekowych (20-25 lat). Można zatem stwierdzić, że załoga tego przedsiębiorstwa jest stosunkowo młoda. Nie oznacza to jednak, że starszy wiekowo personel jest wypierany. Jak wynika z zaprezentowanych danych, udział pracowników powyżej 35 roku życia również się zwiększył, tylko w grupie 56-65 zanotowano nieznaczny spadek.

Przedsiębiorstwo „B” reprezentuje przemysł obuwniczy. Pod względem zatrudnienia jest ono średniej wielkości podmiotem. W wiekowej strukturze zatrudnienia tego przedsiębiorstwa widoczna jest dominacja pracowników w średnim wieku produkcyjnym, przy spadającej liczbie młodych pracowników i względnie stałej, dość wysokiej liczbie pracowników w starszym wieku produkcyjnym. Analizowana struktura zatrudnienia może świadczyć o właściwej realizacji w przedsiębiorstwie strategii zarządzania wiekiem. Niestety, jest to błędna interpretacja, ponieważ kształt tej struktury wymuszony jest przede wszystkim trudnościami w pozyskaniu młodych pracowników, a tym samym - przedłużaniu zatrudnienia osobom w starszym wieku produkcyjnym, co owocuje starzeniem się kadry.

Przedsiębiorstwo „C” to mały zakład przemysłu przetwórstwa rybnego, w którym widoczne są podobne problemy jak w przedsiębiorstwie „B”. Z tą jedną różnicą, że wyraźnie dominującym przedziałem wiekowym załogi jest wiek 36-45 lat oraz spada udział pracujących w najstarszej grupie wiekowej.

$\mathrm{Na}$ podstawie trzech zaprezentowanych przykładów trudno wysnuć daleko idące wnioski uogólniające, ale należy podkreślić, że we wszystkich poddanych badaniu przedsiębiorstwach poszukuje się nowych strategii działania. Niestety, za wyjątkiem przedsiębiorstwa „A” nie dostrzega się korzyści płynących z zarządzania wiekiem, chociaż zaprezentowane struktury mogłyby sugerować coś innego (ryc. 5).

W przedsiębiorstwie „A” przejawami podjętej dopiero strategii zarządzania wiekiem są:

- wprowadzanie stanowisk mentorów na poszczególnych wydziałach,

- podpisanie umowy z prywatną kliniką na świadczenie podstawowych i rozszerzonych usług opieki zdrowotnej,

- uruchomienie kursów nauki języka angielskiego,

- organizowanie raz do roku festynu prozdrowotnego.

W pozostałych dwóch przedsiębiorstwach („B” i „C”) nie wskazano konkretnego, świadomego przykładu działania związanego z zarządzaniem wiekiem, co tylko potwierdza wyniki badań ankietowych przeprowadzonych przez J. Frycę i B. Majecką (2010). 
Ryc. 5. Struktura zatrudnienia wg wieku w wybranych przedsiębiorstwach subregionu słupskiego

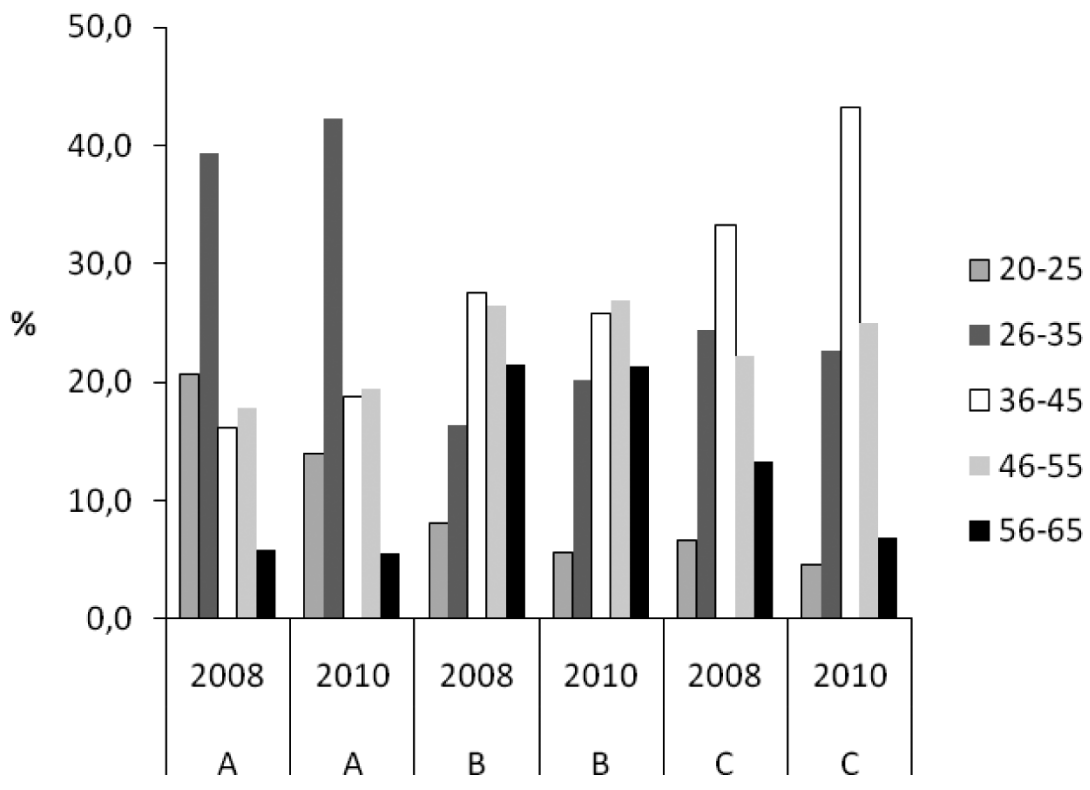

A - przedsiębiorstwo duże, produkcja autobusów

B - przedsiębiorstwo średnie, produkcja obuwia

C - przedsiębiorstwo małe, przetwórstwo rybne

Źródło: opracowanie własne na podstawie danych z przedsiębiorstw.

Reasumując, należy stwierdzić, że zarządzanie wiekiem wydaje się być obecnie jednym ze sposobów uzyskania przez przedsiębiorstwo przewagi konkurencyjnej na podstawie bogactwa różnorodności wiekowej personelu. Większość polskich przedsiębiorstw nie wykorzystuje jednak strategii zarządzania wiekiem, co wynika przede wszystkim z braku świadomości korzyści z tego płynących. Ponadto aktualna, relatywnie dobra pod względem struktury wiekowej sytuacja na rynku pracy nie wymusza na pracodawcach zdecydowanych ruchów w celu aktywizowania osób w starszym wieku. Warto jednak z całą mocą podkreślić, że jest to sytuacja tymczasowa, która ciągu najbliższych kilku lat ulegnie znacznemu pogorszeniu. Dlatego już dzisiaj potrzeba szeroko zakrojonych działań dotyczących zarządzania wiekiem, pamiętając, że wpływa ono obecnie znacznie silniej niż kiedykolwiek wcześniej na ich konkurencyjność na globalnym rynku.

W nieco innej sytuacji znajdują się filie korporacji transnarodowych, które dzięki międzynarodowym powiązaniom już wprowadziły lub wprowadzają elementy strategii zarządzania wiekiem. Nie zmienia to jednak ogólnej oceny zarządzania wiekiem w Polsce, którego zasad nie zna i nie rozumie ponad $80 \%$ przedsiębiorców. 


\section{Literatura}

1. Fryca J., Majecka B., 2010, Istota zarządzania wiekiem w przedsiębiorstwie, „Newsletter”, nr 8, Gdańsk.

2. Kędziora K., Śmiszek K., 2010, Dyskryminacja i mobbing w zatrudnieniu, Wyd. C.H. BECK, Warszawa.

3. Lenartowicz M., Reichhart W., Western S., Zych B., 2010, Rozwój organizacyjny XXI wieku, Wyd. Advisio Press, T. 01, Kraków.

4. Maslach Ch., Leiter M.P., 2001, Die Wahrheit über Burn out. Streß am Arbeitsplatz und was Sie dagegen tun können, Springer, Wien, s. 48-60.

5. Nowaczyk L., 2010, Jak właściwie zarządzać wiekiem w przedsiębiorstwie, www.refa.nf.pl (stan na dzień 12.09.2010).

6. Nowe spojrzenie na pracowników 50+. Raport ekspercki Manpower Polska, 2008, Warszawa.

7. Papińska-Kacperek J., 2008, Spoteczeństwo informacyjne, PWN, Warszawa.

8. Wykorzystaj nas! Pracownicy 45+w twojej firmie, wyniki badań ilościowych - etap I, 2010, PBS DGA, Sopot.

9. Sikorski C., 2001, Zachowania ludzi w organizacji, PWN, Warszawa.

10. Tokarz J., 2009, Efektywne zarządzanie wiekiem, „Biuletyn Euro Info”, nr 109, Warszawa.

11. Wiśniewski Z., 2009, Zarządzanie wiekiem w organizacjach wobec procesów starzenia się ludności, Wyd. TNOiK, Toruń.

12. Wolińska I., 2009, Projekty innowacyjne stużące wydłużaniu aktywności zawodowej, referat wygłoszony na konferencji podsumowującej wdrażanie Programu Operacyjnego Kapitał Ludzki w województwie warmińsko-mazurskim 9 grudnia 2009 r.

13. Zbiegień-Maciąg L., 2006, Nowe tendencje $i$ wyzwania $w$ zarządzaniu personelem, Wyd. Wolters Kluwer Polska, Warszawa.

\section{Age Management as a Strategy of Improving the Competitiveness of Companies in the Era of Globalization}

This article is an attempt to characterise the age management strategies in companies in the context of demographic, economic and cultural conditions. As it is suggested by the conducted research, the majority of Polish companies currently do not use the age management strategies, which is primarily caused by their failure to realise the potential benefits as the fact of possessing rich age diversity in a company is one of the methods to accomplish the competitive advantage. 


\author{
Andrzej Tokarski \\ Wyższa Szkoła Bankowa w Toruniu
}

\title{
Globalizacja a ryzyko bankructwa przedsiębiorstw
}

Jedną z ostro nasilających się w ostatnich latach cech gospodarki i funkcjonowania przedsiębiorstwa jest rosnąca niepewność. Coraz częściej przedsiębiorstwa, kraje i całe regiony gospodarki globalnej zaskakiwane są przez sploty wydarzeń oraz negatywnych, trudnych do przewidzenia i opanowania zjawisk gospodarczych. Spektakularnym tego dowodem jest kryzys finansowy w gospodarce Stanów Zjednoczonych, który rozpoczął się w 2007 r., a którego następstwa dotknęły także inne kraje (Mączyńską 2010g, s. 46). Odzwierciedla to skomplikowaną sieć powiązań w zglobalizowanej i globalizującej się coraz bardziej gospodarce światowej. Występuje tu swego rodzaju efekt domina, dotyczący zwłaszcza bankructw przedsiębiorstw (Mączyńską 2009b, s. 273).

Niepewność i nietrwałość to cecha współczesnej gospodarki wynikająca przede wszystkim z niebywałej gwałtowności, głębokości, intensywności oraz bezprecedensowego dynamizmu innowacji, w tym finansowych, przemian i postępu technologicznego dokonującego się w skali światowej. Towarzyszą temu niezrównoważony, niestety, wzrost gospodarczy i pogłębiające się dysproporcje rozwojowe w skali globalnej. Najbardziej spektakularne przejawy tej sytuacji to bezrobocie i obszary nędzy (przy równoczesnej koncentracji bogactwa), wynaturzenia w relacji między rolą państwa w poszczególnych krajach a siłą ponadnarodowych korporacji, czemu towarzyszą przetaczające się przez świat fale bankructw przedsiębiorstw. Listę tę powiększają narastające zagrożenia dla środowiska naturalnego i jego równowagi oraz rozmaite inne patologie w gospodarce, społeczeństwie i polityce, przy czym szczególnie groźne są konflikty wynikające z cywilizacyjnego podziału i skrajnego zróżnicowania świata.

\section{Aspekt ekonomiczny i prawny upadłości}

Upadłości i bankructwa przedsiębiorstw są nieodłącznym elementem gospodarki rynkowej (Bauer 2009). Stanowią następstwo utraty przez przedsiębiorstwa zdolności do spłaty długów (Tokarski 2009), pełnią tym samym funkcję niezbędnej selekcji w biznesie, w tym racjonalizacji, oczyszczania rynku z jednostek niemogących sprostać wymogom efektywności. Stanowi to zarazem element ochrony wierzycieli i innych jednostek.

Pojęcia bankructwo i upadłość traktowane są jako synonimy (Mączyńska 20091, s. 241). Nie jest to precyzyjne, albowiem bankructwo to pojęcie z zakresu przede wszystkim ekonomii, podczas gdy upadłość to w zasadzie kategoria prawna („Kwartalnik Nauk o Przedsiębiorstwie” 2009, s. 4). Utożsamianie bankructwa z upadłością jest zasadne jedynie w przypadku upadłości zawinionej (podlegającej karze współmiernej do winy, co regulują szczegółowe przepisy).

Upadłość niezawiniona natomiast nie jest traktowana jako bankructwo w sensie ekonomicznym, albowiem nie wynika z nieprawidłowości w zarządzaniu przedsiębiorstwem, lecz z przyczyn leżących poza nim, np. z powodu oszustwa przez kontrahenta. 
Różnice między bankructwem a upadłością przedstawia tabela 1.

Tab. 1. Upadłość a bankructwo

\begin{tabular}{|c|c|c|c|}
\hline Upadłość $\neq$ bankructwo & \multicolumn{3}{|c|}{ Upadłość = bankructwo } \\
\hline niezawiniona & \multicolumn{3}{|c|}{ zawinione } \\
\hline \multirow{3}{*}{ nie podlega karze } & nieumyślne & umyślne & umyślne z chęci zysku \\
\cline { 2 - 4 } & \multicolumn{3}{|c|}{ podlega karze } \\
\cline { 2 - 4 } & $\begin{array}{c}\text { odpowiedzialność karna przedsiębiorców (grzywna, pozbawienie } \\
\text { prawa sprawowania określonych funkcji, kara pozbawienia wolności) }\end{array}$ \\
\cline { 2 - 4 } & kara łagodniejsza & kara ostrzejsza & kara najostrzejsza \\
\hline
\end{tabular}

Źródło: E. Mączyńska, Ocena ryzyka upadłości przedsiębiorstwa [w:] A. Fierla, Ryzyko w działalności przedsiębiorstw. Wybrane aspekty, SGH, Warszawa 2009, s. 58.

Z punktu widzenia ekonomii bankrutem jest przedsiębiorstwo, które nie jest w stanie regulować swoich długów oraz wartość jego majątku nie wystarcza na pokrycie wszystkich zobowiązań (bankrutem jest także firma, która mimo iż zaistniały powyższe przesłanki nadal prowadzi działalność).

W aspekcie prawnym upadłość przedsiębiorstwa następuje dopiero po ogłoszeniu bankructwa przez sąd. Ma to na celu równomierne zaspokojenie wszystkich wierzycieli dłużnika, który nie jest w stanie zaspokoić każdego z osobna. Powinno zapobiec prowadzeniu egzekucji przeciwko dłużnikowi przez niektórych tylko wierzycieli (w wypadku, gdy inni nie mają jeszcze tytułu egzekucyjnego, np. wtedy, gdy ich wierzytelności nie są jeszcze płatne) oraz w przypadku, gdy istnieje system pierwszeństwa w postępowaniu egzekucyjnym. Oznacza to, że fakt bankructwa jest ustalany sądownie na podstawie wniosku skierowanego bądź to przez dłużnika, bądź przez któregoś z wierzycieli lub przez kilku wierzycieli. W pierwszym przypadku można mówić o bankructwie dobrowolnym, w drugim - o bankructwie przymusowym.

Główną przesłanką do złożenia wniosku o ogłoszenie upadłości w wypadku prawodawstwa polskiego jest zaprzestanie płacenia zobowiązań w długim okresie czasu. Tak więc krótkotrwałe wstrzymanie płacenia długów, wskutek przejściowych trudności, nie jest podstawą do ogłoszenia upadłości. Przepisy prawa stanowią, iż upadłość ogłasza się w stosunku do dłużnika, który stał się niewypłacalny (Tokarski A., Tokarski M. 2006). Zgodnie z artykułem 11 Prawa upadłościowego i naprawczego „dłużnik jest niewypłacalny, jeżeli nie wykonuje swoich wymagalnych zobowiązań, przy czym za niewypłacalny uważa się podmiot wtedy, gdy jego zobowiązania przekraczają wartość majątku, nawet wtedy gdy na bieżąco te zobowiązania wykonuje (Prawo upadłościowe i naprawcze 2003).

Drugą przesłanką może być wystąpienie nadwyżki stanu czynnego nad stanem biernym. W języku ekonomicznym oznaczałoby to brak możliwości pokrycia wszystkich zobowiązań $\mathrm{z}$ posiadanego majątku.

Bankructwo w sensie ekonomicznym nie musi oznaczać upadłości w sensie prawnym, ale każda upadłość ogłoszona przez sąd oznacza bankructwo ekonomiczne. 


\section{Globalizacja bankructw jako następstwo nowego paradygmatu cywilizacyjnego - kapitalizmu globalnego (postindustrialnego)}

Postępujące procesy globalizacji, rozwój rynków kapitałowych i przedsiębiorstw ponadnarodowych oraz złożona i zagęszczająca się w wyniku tego sieć powiązań (globalna pajęczyna) w gospodarce sprawiają, że nie tylko gospodarka, przedsiębiorstwa, ale i ryzyko podlegają globalizacji. Dotyczy to także ryzyka bankructwa (Kuciński, Mączyńska 2005). Praktyka wykazuje przy tym, że wirus bankructwa rozprzestrzenia się tym szybciej, im silniejsze są powiązania zaatakowanego chorobą niewypłacalności przedsiębiorstwa z innymi, krajowymi i zagranicznymi partnerami. Globalizacja potęguje siłę rozprzestrzeniania się bankructw (Mączyńska 2004d, s. 105).

Gospodarka we współczesnym świecie nabiera w coraz większym stopniu cech gospodarki nietrwałości. Nietrwałe stają się profesje, stanowiska pracy i pozycje w hierarchii menedżerskiej. Ponadnarodowym fuzjom i przejęciom towarzyszy powstanie nowej grupy zatrudnionych korporacyjnych cyganów (Mączyńska 2008c, s. 17). Nietrwałe stają się byty produkcyjne, jak również teorie, w tym ekonomiczne.

Każda cywilizacja ma swój model funkcjonowania społeczeństwa i gospodarki. Zmiana paradygmatu cywilizacyjnego wypiera dotychczasowe modele nie tylko gospodarki i produkcji w ogóle, ale i zarządzania, inwestowania, handlu, kształcenia, pracy, zatrudnienia. Przekształca się większość metod komunikowania się, produkowania i wymiany handlowej.

Procesy te są przedmiotem wielu analiz i publikacji, m.in. szczegółowej analizie poddał je A. Toffler przede wszystkim w osławionej Trzeciej fali. Jednakże obecnie dynamika przemian jest tak wielka, że Tofflerowska trzecia fala to już prawie przeszłość, historia, a z drugiej strony, pierwsza fala, czyli cywilizacja bazująca na osiadłym rolnictwie, dopiero niedawno ,skończyła ogarniać glob” (Mączyńska 2009a, s. 129).

Natomiast druga fala, która w XVIII w. przyniosła rewolucję przemysłową, prowadząc do rozwoju społeczeństwa industrialnego, choć nadal obejmuje kolejne obszary i społeczeństwa, znajduje się w fazie schyłkowej i jest skazana na wygasanie.

Następująca po niej trzecia fala, bazująca na rozwoju mikroelektroniki, poganiana jest już przez kolejne. Fala czwarta to rewolucja w sferze informacji (Internet), co z kolei sprzyja ponadnarodowym przepływom kapitałowym - piątej fali (światowe fuzje i przejęcia). Natomiast współczesny rozwój naukowo-techniczny oraz rozstrzygająca rola informacji, wiedzy i kwalifikacji tworzą nowy paradygmat rozwojowy, tj. gospodarkę opartą na wiedzy (a raczej na potencjale intelektualnym). Przy tym wiedza, informacja to specyficzne, całkiem odmienne od tradycyjnych, źródło bogactwa: nie zużywa się, kto je sprzedaje, posiada je nadal. Wiedza staje się uniwersalnym substytutem. Można ją jednocześnie wykorzystywać do tworzenia bogactwa i pomnażania samej wiedzy. W przeciwieństwie do dóbr materialnych i surowców, jest niewyczerpywalna. Tworzy to potencjał produktywności tak duży, że najwyżej rozwinięte społeczeństwa będą w stanie pójść w kierunku modelu społeczeństwa czasu wolnego i rozrywki. Ma to charakter swego rodzaju szóstej fali, która obejmuje na razie tylko najbardziej uprzywilejowane społeczeństwa. Zarazem wygospodarowany czas wolny służyć może kreatywności, która staje się podstawowym czynnikiem bogactwa. 
Tab. 2. Przemiany cywilizacyjne

\begin{tabular}{|c|c|c|c|}
\hline Cywilizacje & $\begin{array}{c}\text { Zmiany systemu - } \\
\text { ustroju } \\
\text { gospodarczego }\end{array}$ & $\begin{array}{l}\text { Zmiany typu } \\
\text { przekazu, } \\
\text { komunikacji }\end{array}$ & $\begin{array}{c}\text { Wladza i podwladni } \\
\text { (górne i dolne warstwy } \\
\text { społeczne) }\end{array}$ \\
\hline I. Rolna & feudalizm & epoka słowa pisanego & $\begin{array}{l}\text { feudałowie - } \\
\text { chłopi feudalni }\end{array}$ \\
\hline II. Industrialna & kapitalizm & $\begin{array}{c}\text { epoka słowa drukowa- } \\
\text { nego }\end{array}$ & $\begin{array}{c}\text { fabrykanci, bankierzy - } \\
\text { pracownicy, robotnicy } \\
\text { najemni }\end{array}$ \\
\hline $\begin{array}{l}\text { III. Postindustrialna } \\
\text { - trzecia fala (Toffler) }\end{array}$ & \multirow[t]{5}{*}{$\begin{array}{c}\text { kapitalizm (????) } \\
\text { postindustrialny }\end{array}$} & \multirow[t]{5}{*}{$\begin{array}{l}\text { epoka języka } \\
\text { cyfrowego }\end{array}$} & \multirow{5}{*}{$\begin{array}{l}\text { netokracja (sieciowa } \\
\text { arystokracja) - } \\
\text { konsumtariat }\end{array}$} \\
\hline IV. Internet & & & \\
\hline $\begin{array}{l}\text { V. Ponadnarodowe } \\
\text { fuzje i przejęcia }\end{array}$ & & & \\
\hline $\begin{array}{l}\text { VI. Gospodarka oparta } \\
\text { na wiedzy }\end{array}$ & & & \\
\hline $\begin{array}{l}\text { VII. Wiek } \\
\text { kreatywności }\end{array}$ & & & \\
\hline
\end{tabular}

Źródło: E. Mączyńska, Sytuacje kryzysowe w przedsiębiorstwach [w:] I. Lichniak, Nauka o przedsiębiorstwie. Wybrane zagadnienia, SGH, Warszawa 2009, s. 201.

Wszystkie wymienione fale cywilizacyjne łączyły się z kryzysami w sferze produkcji. Producenci, którzy nie mogli przystosować się do nowych wymogów, w skrajnych wypadkach bankrutowali. Na innych zaś sytuacja kryzysowa wymuszała przemiany prowadzące do sukcesu.

Obecnie zmiany wzorca cywilizacyjnego są szczególnie głębokie. Tradycyjny fabryczny, przemysłowy kapitalizm wypierany jest przez nowy model gospodarki, model, którego kształt jeszcze do końca nie został rozpoznany i który nazywany jest różnie: kapitalizmem globalnym, kapitalizmem trzeciej fali lub postkapitalizmem.

\section{Upadłość a globalna niepewność}

Dokonującym się w skali globalnej przełomowym zmianom towarzyszy narastanie niepewności we wszystkich niemalże obszarach życia ekonomicznego i społecznego. Niepewność zaś w odróżnieniu od ryzyka jest niemierzalna, stąd też w ocenach przemian gospodarczych i społecznych kwestia ta jest często bagatelizowana, co prowadzi do ambiwalentności ocen. Ambiwalencja przejawia się zarówno w sferze makro-, jak i mikroekonomicznej, w sferze teorii oraz praktyki.

Bezprecedensowe szybkie tempo przemian sprawia, że teoria często nie przystaje do praktyki, zaś doświadczenia z przeszłości nie wystarczają, a podstawową umiejętnością staje się zapominanie, wyzbywanie się starych nawyków i wzorców. Zarazem największą barierą rozwojową staje się niewiedza o własnej niewiedzy. Bardzo przystaje tu myśl Konfucjusza: „Wiedzieć, że się wie, co się wie i wiedzieć, że się nie wie, czego się nie wie - oto prawdziwa wiedza" (Sztucki 2000). 
Cykle życia wiedzy stają się coraz krótsze, czemu towarzyszy wydłużanie się życia ludzkiego. Stąd też wiedza staje się coraz bardziej niedemokratyczna, skrajnie różnicując podmioty i ich szansę. Nowa fala cywilizacyjna zatapia nieprzygotowanych, których stale przybywa. Przysparza pracy osobom wysoko wykwalifikowanym, skazując na bezrobocie innych.

Paradoksalnie jednak w epoce gospodarki opartej na wiedzy w gruncie rzeczy ma się do czynienia z ekonomią niedoskonałej wiedzy, wiedzy niepewnej. W takich warunkach ,niedoskonała jest prawda i nieprawdziwa pewność?" (Mączyńska 2009e, s. 58). Ekonomia zaś jest nauką bazującą na badaniu pewnych regularności, prawidłowości. Jeśli natomiast czasy są burzliwe, to powstają trudności ze zidentyfikowaniem tych regularności, prawidłowości. Dlatego też niezbędna jest zmiana podejścia w naukach ekonomicznych. Obecnie modele, w tym matematyczne, zawodzą. Bazują bowiem na pewnych założeniach trwałych i prawidłowościach, zatem w warunkach gwałtownych przemian stają się mniej przydatne. W kształtowaniu strategii konieczne jest podejście holistyczne, z uwzględnieniem nie tylko kwestii ekonomicznych, ale także społecznych i ekologicznych, bo przecież najlepsza nawet teoria ekonomii, ale bez uwzględnienia czynnika społecznego, człowieka, bez analizy zachowań ludzkich, nie może przynieść satysfakcjonujących efektów.

\section{Ucywilizować procesy bankructwa}

Upadłość to nie tylko problem słabo zdiagnozowany, nierzadko to temat tabu. Wyraźna jest bowiem tendencja do uznawania bankructwa za problem wyłącznie przedsiębiorstw słabych.

Podstawowym problemem w funkcjonowaniu współczesnych przedsiębiorstw jest gwałtowność i zawiłość przemian cywilizacyjnych, jakim obecnie podlega gospodarka w skali światowej i lokalnej. Przemiany te sprawiają, że obok beneficjentów, rośnie liczba ofiar. Głębokie przemiany zawsze obarczone są dużym ryzykiem, zważywszy zwłaszcza na rosnącą w warunkach globalizacji łatwość rozprzestrzeniania się sytuacji kryzysowych i wirusa bankructwa (Mączyńska 2009h, s. 8). Odpowiednio szybkie identyfikowanie szans i zagrożeń przedsiębiorstw jest niezbędnym czynnikiem optymalizacji bieżących i strategicznych decyzji, podejmowanych na różnych szczeblach zarządzania.

Niedorozwój w sferze teorii i praktyki upadłości występuje w wielu krajach Unii Europejskiej, w tym także Polski, i świata. Choć świat się globalizuje, globalizuje się biznes, to ciągle jeszcze czyni się zbyt mało, aby w skali globalnej „ucywilizować”, zracjonalizować procesy bankructwa, mimo że z bankructwem przedsiębiorstwa może się wiązać globalny efekt domina (Tokarski 2010).

Działania na rzecz ucywilizowania bankructwa podjęła dopiero w 2004 r. Unia Europejska. Zostały one podjęte w ramach projektu Stigma of failure and early warning tools, którego głównymi celami są:

- opracowanie materiałów informacyjnych dotyczących radzenia sobie z piętnem związanym $\mathrm{z}$ bankructwem,

- opracowanie narzędzi wczesnego ostrzegania służących zapobieganiu upadłości.

W UE podejmowane są też działania praktyczne, ukierunkowane na:

- wspieranie przedsiębiorstw przeżywających trudności,

- usuwanie przeszkód na drodze do drugiej szansy.

Nieprawidłowości w funkcjonowaniu prawa upadłościowego dotyczą także Polski. Mimo zmiany tego prawa, w praktyce nadal wyraźnie widać jego ułomności Przede wszystkim ciągle niedoceniany jest drugi nurt w prawie upadłościowym - nurt naprawczy. Wierzyciele chcą raczej jak najszybciej odzyskać swoje wierzytelności, odzyskać to, co jest jeszcze możliwe. Procesy naprawcze często nie są brane pod uwagę, nawet jeśli istnieją szanse na uzdrowienie. 
Badania wykazują, że bankructwa w naszym kraju są znacznej części wyreżyserowane, a ich przyczyny nie mają cech przyczyn czysto ekonomicznych (Mączyńska 2010i, s. 145). Potwierdzają to opinie praktyków, w tym sędziów sądu gospodarczego. Paradoksalnie, wbrew nazwie ustawy Prawo upadłościowe i naprawcze, marginalizowane są naprawy na rzecz likwidacji i upadłości przedsiębiorstw. Przedsiębiorcy w postępowaniu naprawczym widzą raczej zagrożenie dla swojego wizerunku i pozycji rynkowej, aniżeli szanse na wybrnięcie z doraźnych problemów i poprawie własnej konkurencyjności.

Współcześnie funkcjonowanie przedsiębiorstw charakteryzują rosnące napięcia, rosnący stopień ryzyka i niepewności, co znajduje odzwierciedlenie w rosnącym zagrożeniu bankructwem.

Jedną z zasadniczych przyczyn ograniczeń przemian ukierunkowanych na równoważnie wzrostu gospodarczego i łagodzenie napięć jest niedostosowanie zasad ustroju gospodarczego do wymogów nowego paradygmatu cywilizacyjnego, do dokonującego się przełomu cywilizacyjnego wyrażającego się w wypieraniu cywilizacji industrialnej przez cywilizację opierającą się na wiedzy i informacji, cywilizację gospodarki wirtualnej, skrajnie różnej od swej industrialnej poprzedniczki.

Postępujące procesy globalizacji, rozwój rynków kapitałowych i ponadnarodowych przedsiębiorstw oraz związana z tym złożoność gospodarki, a tym samym rosnące ryzyko biznesu sprawiają, że nie tylko gospodarka i przedsiębiorstwa, ale także ryzyko podlega globalizacji. Wskazuje to na konieczność stałego monitorowania przemian w gospodarce światowej, która w ostatnich latach znajduje się pod silnym wpływem procesów zachodzących w krajach Azji, w tym zwłaszcza przełomowej transformacji w Chinach. Stąd konieczność przede wszystkim analiz z tego zakresu, tym bardziej, że wiążą się z tym złożone zjawiska offsho-ringu, delokalizacji przemysłowej i gospodarczej (Mączyńska 2008m, s. 74).

Globalizacja generalnie, mimo szeregu efektów pozytywnych, wyraźnie wywołuje efekt wypychania, przemieszczania negatywnych zjawisk społeczno-gospodarczych z obszarów (krajów, regionów, aglomeracji, przedsiębiorstw) silniejszych ekonomicznie do słabszych. Dotyczy to przede wszystkim małych i średnich przedsiębiorstw oraz małych gospodarek, które nader często przegrywają w konkurencji z gigantami (Mączyńska 2004j, s. 5).

Wobec nowego paradygmatu rozwojowego oraz wyzwań globalizacyjnych, warunkiem rozwoju przedsiębiorczości i umacniania kondycji przedsiębiorstw staje się odpowiednia synchronizacja polityki mikro- i makroekonomicznej. Wbrew niektórym teoriom, w tym obszarze nie zmniejsza się, a przeciwnie - wzrasta rola państwa w kreowaniu otoczenia przedsiębiorstw, zwłaszcza otoczenia edukacyjnego (Mączyńska 2009k, s. 199). Nowy paradygmat rozwojowy wymusza zmiany w relacjach między biznesem a władzami samorządowymi oraz instytucjami pozabiznesowym. Wymaga to racjonalnej polityki w zakresie pomocy publicznej udzielanej przedsiębiorstwom.

Globalizacja ryzyka sprawia, że warunki funkcjonowania przedsiębiorstw stają się tym trudniejsze, w im większym stopniu na zmiany ustrojowe w gospodarce nakładają się dokonujące się w świecie przemiany paradygmatu rozwojowego, dezindustrializacja i przechodzenie do gospodarki opartej na wiedzy, w tym gospodarki wirtualnej. Wiąże się z tym zagrożenie upadłości przedsiębiorstw. Pod wpływem tych przemian bankructwa mogą się nasilać, co rzutuje na funkcjonowanie i przetrwanie przedsiębiorstw. Stąd też rosnąca waga analiz z zakresu demografii przedsiębiorstw.

W polityce makro- i mikroekonomicznej istotne są ponadto gwarancje, że system nie wymyka się spod kontroli, przeciwnie, jest na tyle przejrzysty, iż umożliwia wczesne identyfiko- 
wanie nieprawidłowości w sektorze przedsiębiorstw, gwarantując tym samym wczesne ostrzeganie inwestorów i kontrahentów (Mączyńska 2009f, s. 57). Łączy się to z koniecznością eliminowania luk informacyjnych, w tym tzw. luki raportowania.

Monitoring i wczesne rozpoznanie zagrożeń jest warunkiem sine qua non podejmowania trafnych decyzji ekonomicznych. Istotne jest przy tym rozpoznanie reakcji przedsiębiorstw na zmiany (w tym zwłaszcza zaostrzanie) polityki gospodarczej i otoczenia instytucjonalno-prawnego.

W związku ze zmianami paradygmatu rozwojowego, dla prawidłowego funkcjonowania i rozwoju przedsiębiorstw niezbędna jest efektywna instytucjonalna infrastruktura biznesu, w tym infrastruktura upadłości, o czym przekonują ujawniające się w ostatnim okresie z całą ostrością słabości nowoczesnej gospodarki i zagrożenia dla światowego systemu gospodarczego (m.in. poprzez spektakularne bankructwa wielkich przedsiębiorstw i agresywną rachunkowość).

\section{Literatura}

1. Bankructwa przedsiębiorstw - zgodnie z prawem czy ekonomią?, „Kwartalnik Nauk o Przedsiębiorstwie", nr 1/2009.

2. Bauer K., 2009, Zarządzanie informacjami w procesie upadłościowo-naprawczym przedsiębiorstw, Uniwersytet Jagielloński, Kraków.

3. Kuciński K., Mączyńska E., 2005, Wprowadzenie [w:] K. Kuciński, E. Mączyńska, Zagrożenie upadłościa, SGH, Warszawa.

4. Mączyńska E., 2009a, Bankructwa - globalny efekt domina [w:] I. Lichniak, Wyzwania ekonomiczne w warunkach kryzysu, SGH, Warszawa.

5. Mączyńska E., 2009b, Bankructwa przedsiębiorstw jako niedostosowanie do przyszłości (analiza $w$ kontekście funkcjonowania sądów gospodarczych [w:] Finanse 2009 - teoria i praktyka. Finanse przedsiębiorstw, Zeszyty Naukowe Uniwersytetu Szczecińskiego, Szczecin.

6. Mączyńska E., 2008c, Bankructwa przedsiębiorstw. Wybrane aspekty instytucjonalne, SGH, Warszawa.

7. Mączyńska E., 2004d, Globalizacja ryzyka a systemy wczesnego ostrzegania przed upadtościa [w:] D. Appenzeller, Upadtość przedsiębiorstw w Polsce w latach 1990-2003. Teoria i praktyka, AE Poznań, Poznań.

8. Mączyńska E., 2009e, Meandry upadłości przedsiębiorstw. Klęska czy druga szansa?, SGH, Warszawa.

9. Mączyńska E., 2009f, Ocena ryzyka upadłości przedsiębiorstwa [w:] A. Fierla, Ryzyko w działalności przedsiębiorstw. Wybrane aspekty, SGH, Warszawa, s. 57.

10. Mączyńska E., 2010g, Rachunkowość a wczesne ostrzeganie przed zagrożeniami działalności gospodarczej [w:] E. Mączyńska, Z. Messner, Zagrożenie działalności gospodarczej a prawo bilansowe, PTE-SK w Polsce, Warszawa.

11. Mączyńska E., 2009h, Siła, tradycja i grzechy rachunkowości, „Rachunkowość”, nr 10.

12. Mączyńska E., 2010i, Syndrom hieny upadłościowej, „Gazeta Bankowa”.

13. Mączyńska E., 2004j, Systemy wczesnego ostrzegania, „Nowe Życie Gospodarcze”, nr 12.

14. Mączyńska E., 2009k, Sytuacje kryzysowe w przedsiębiorstwach [w:] I. Lichniak, Nauka o przedsiębiorstwie. Wybrane zagadnienia, SGH, Warszawa.

15. Mączyńska E., 20091, Upadłość przedsiębiorstwa. Zaprzestanie działalności [w:] I. Lichniak, Nauka o przedsiębiorstwie. Wybrane zagadnienia, SGH, Warszawa.

16. Mączyńska E., 2008m, Zarządzanie w warunkach ekonomii niepewności. Systemy wczesnego ostrzegania [w:] L. Lewandowska, Nowe koncepcje zarzadzania i finansowania rozwoju firm regionu tódzkiego, PTE, Łódź. 
17. Sztucki T., 2000, Myśli o biznesie, Difin, Warszawa.

18. Tokarski A., 2010, Przyczyny i symptomy upadtości przedsiębiorstw w gospodarce rynkowej [w:] P. Maśloch, J.M. Stankiewicz, Zarządzanie w XXI wieku, WSB Torun, Toruń.

19. Tokarski A., 2009, Rola rachunkowości w postępowaniu upadłościowym [w:] T. Kiziukiewicz, Rachunkowość w zarządzaniu jednostkami gospodarczymi, „Zeszyty Naukowe Uniwersytetu Szczecińskiego", Uniwersytet Szczeciński, Szczecin.

20. Tokarski A., Tokarski M., 2006, Rachunkowość źródtem informacji o przewidywaniu upadłości przedsiębiorstw w polskiej gospodarce [w:] T. Kiziukiewicz, Rachunkowość w zarządzaniu jednostkami gospodarczymi, Akademia Rolnicza - Uniwersytet Szczeciński, Szczecin.

21. Ustawa z 28 lutego 2003 roku „Prawo upadtościowe i naprawcze” (Dz.U. nr 60, poz. 535).

\section{The Globalization of Business and the Bankruptcy Risk}

The economy in the world today is becoming increasingly similar to "economic instability".

The progressive processes of globalization, the development of capital markets and transnational companies and the complex and concentrated as a result of this network of connections (global spider web) in the economy mean that not only the economy, business, but also risk are subjected to globalization. This also includes a risk of bankruptcy.

Practice shows that the faster virus spreads to the bankruptcy the stronger is the connection between business attacked with the diseases of insolvency and other, domestic and foreign partners. Globalization intensifies the power of spreading of bankruptcies.

The article presents the impact of the risk of globalization on the bankruptcy risk of firms in the economy. 


\section{Magdalena Kochmańska}

Uniwersytet Pedagogiczny

im. Komisji Edukacji Narodowej

w Krakowie

\section{Zarządzanie innowacjami w małych i średnich przedsiębiorstwach w warunkach globalizacji}

Współcześnie organizacje działają w warunkach globalizacji, stąd ich działalność powinna być rozpatrywana z szerszego niż dotychczas punktu widzenia. Umiędzynarodowienie działalności gospodarczej niesie poważne konsekwencje dla menedżerów. Jednym z ważnych zagadnień jest rozwój innowacyjności przedsiębiorstwa i związany z tym rozwój przedsiębiorczości firmy. Jak pisze P.F. Drucker, „Przedsiębiorcy wprowadzają innowacje. Innowacja jest specyficznym narzędziem przedsiębiorczości - działaniem, które nadaje zasobom nowe możliwości tworzenia bogactwa" (Drucker 1992, s. 39). Innowacja i przedsiębiorczość są potrzebne w takim samym stopniu społeczeństwu jak gospodarce oraz przedsiębiorstwom. Potrzebne jest nam społeczeństwo przedsiębiorcze, w którym innowacja i przedsiębiorczość są czymś normalnym, stałym i ciągłym. Podobnie jak kierownictwo jest specyficznym integrującym organem wszystkich współczesnych przedsiębiorstw i instytucji w naszym społeczeństwie organizacji, tak innowacja i przedsiębiorczość muszą stać się integralną czynnością utrzymującą przy życiu nasze organizacje, gospodarkę i społeczeństwo. To wymaga od kierowników we wszystkich organizacjach podjęcia takich działań, aby innowacja i przedsiębiorczość były normalną, bieżącą, codzienną działalnością, aby były praktykowane przez nich oraz przez ich organizacje.

Problematyka zarządzania innowacjami nabiera znaczenia w sytuacji rosnącej globalizacji rynków. Globalizacja powoduje zanikanie wielu barier, czego efektem jest możliwość korzystania przez małe i średnie przedsiębiorstwa z zasobów i umiejętności wytwarzanych poza granicami własnego kraju, łatwiejszy dostęp do najlepszych produktów i usług dla klientów oraz redukcja kosztów komunikacji.

Jedną z charakterystycznych cech współczesnej gospodarki jest szybko rozwijający się proces jej umiędzynarodowienia. Dokonuje się on w dwóch wzajemnie powiązanych i uzupełniających się formach: handlu międzynarodowego oraz umiędzynarodowienia przedsiębiorstw, które to jest formą nowoczesną i bardziej dynamiczną (Lichtarski 2007). Osiąganie celów globalnych małego i średniego przedsiębiorstwa odbywa się poprzez zarządzanie międzynarodowe dzięki:

- efektywnemu wykonywaniu i koordynowaniu funkcji przedsiębiorstwa w skali międzynarodowej za pomocą dostarczania, alokacji i wykorzystania niezbędnych - ludzkich, a także materialnych i niematerialnych - zasobów oraz

- utrzymywaniu przedsiębiorstwa w stanie dynamicznej równowagi w obrębie środowiska międzynarodowego, w którym ono działa.

Małe i średnie przedsiębiorstwa stanowią ponad 99\% wszystkich przedsiębiorstw w Polsce. To przeważająca grupa podmiotów gospodarki narodowej, wywierająca wpływ na wszystkie dziedziny życia społecznego. Małe i średnie przedsiębiorstwa zasługują w Polsce na miano 
motoru napędowego gospodarki, głównie ze względu na ich wkład w tworzenie PKB. W naszym kraju wkład sektora małych i średnich przedsiębiorstw w PKB wynosi 47,4\% (Lublińska-Kasprzak 2009).

Innowacyjność pojawia się w strukturach, w których nie istnieją hierarchiczne powiązania, a relacje międzyludzkie bliskie są powiązaniom typowym dla społeczności lokalnych. Pod koniec XX w. pojawił się termin gospodarka oparta na wiedzy w odniesieniu do sektora firm wykorzystujących zaawansowane technologie, w szczególności techniki informacyjne. W ślad za tym powstała koncepcja teoretyczna systemu gospodarki opartej na wiedzy, której zasadniczym składnikiem jest kapitał intelektualny, ludzki i społeczny.

Innowacje, nierozłącznie powiązane z tym kapitałem, uznane zostały za główny czynnik przesądzający o wzroście gospodarczym, rozwoju w skali regionów, konkurencyjności gospodarki oraz małych i średnich przedsiębiorstw.

Liberalizacja gospodarki prowadząca do globalizacji jest procesem nieodwracalnym. Przejawem tego jest stopniowe znoszenie barier w przepływie kapitału, towarów i usług oraz pracowników. Pojęcia globalizacji i zarządzania globalnego łączą się z podejściem geocentrycznym, tzn. takim, w którym rynki światowe, a nie rynek krajowy, są podstawowym polem działalności małych i średnich przedsiębiorstw.

\section{Przedsiębiorczość a innowacyjnośćc}

Współczesne organizacje funkcjonujące w konkurencyjnym środowisku powinny w sposób ciągły tworzyć (lub przejmować z otoczenia) i wdrażać różnego rodzaju innowacje zabezpieczające efektywność ich działania i rozwoju.

Analizując zmagania innowacyjne organizacji, rodzi się pytanie o przesłanki tych zmagań. Wydaje się celowe przypomnieć, iż pojęcie postępu i rozwoju ma nad wyraz krótki, bo zapoczątkowany w XVII w., rodowód. Przełom w rozumieniu rozwoju wnoszą jednak dopiero prace Darwina, zaś na gruncie filozofii prace Hegla. W czasach nam współczesnych starły się różnorodne koncepcje rozwoju.

W szczególności w związku z pojawiającym się tu i ówdzie zwątpieniem w sens postępu, w możliwość rozwoju, rozwinęły się koncepcje filozoficzne kwestionujące postęp w ogóle. Pytania te pojawiły się w związku z rozwojem fizyki kwantowej, rozpoznaniem procesów nieodwracalnych w fizyce i - z drugiej strony - z wystąpieniem zagrożeń ekologicznych współczesnego świata.

Postęp nauki, a w jej wyniku - postęp ekonomiczny i techniczny - nie doprowadził do uszczęśliwienia ludzi. Jednym z czołowych wyrazicieli koncepcji zwątpienia w postęp i rozwój był J. Habermas. Jednak we współczesnej nauce obecny jest też nurt nawiązujący do optymistycznych idei Oświecenia. Jego twórcy, wychodząc z tych samych przesłanek rozwoju nauki, zwłaszcza fizyki kwantowej, i dostrzegając zagrożenia współczesnego świata, akcentują przede wszystkim olbrzymie możliwości twórcze współczesnego człowieka w jego zmaganiu się z rzeczywistością i współtwórczy udział każdej jednostki ludzkiej w stawaniu się współczesności (Huczek 1996).

Społeczeństwo, mając do dyspozycji potencjał naukowy i materialny, działając pod wpływem różnych czynników i stosując innowacje, powoduje postęp (społeczny, organizacyjny, techniczny itd.), który decyduje o tempie rozwoju społeczno-gospodarczego oraz o poziomie warunków życia i pracy.

W interpretacji innowacji dominują dwa podejścia, a mianowicie ujęcia innowacji jako rezultatu lub procesu. W ujęciu pierwszym innowacje to zmiany w sferze produkcji, prowadzące 
w konsekwencji do powstania nowych produktów. W ujęciu drugim innowacje to wielkie procesy twórczego myślenia zmierzające do zastosowania i użytkowania ulepszonych rozwiązań w technice, technologii, organizacji, życiu społecznym, politycznym itp.

Literatura naukowa podaje, że „pod pojęciem innowacji należy rozumieć przeprowadzone zmiany w technologii, organizacji, ekonomice oraz w sferze społecznej organizacji” (Huczek 1995, s. 19). Nie ma znaczenia, że np. produkty czy technologie znane są gdzie indziej; dla samego społeczeństwa, które ich przedtem nie znało, są one bez wątpienia innowacjami. Dla analizy procesów rozwojowych właściwsze jest takie rozumienie pojęcia innowacji, w którym jest ona nie tylko nowością dla danego społeczeństwa. Argumentację tę można odnieść do niższego szczebla, to jest do gałęzi przemysłu czy też przedsiębiorstwa. Przy analizowaniu zjawisk innowacyjnych w dowolnej organizacji przyjmuje się, że innowacje powinny być nowością w skali tejże organizacji.

Jak podkreśla M. Dolińska, „Innowacje są nowościami wprowadzonymi w przedsiębiorstwie lub na rynku, jakościowo różnymi od istniejących nowych produktów, rozwiązań technicznych, technologicznych, w sferze zarządzania (personelem, finansami, marketingiem, jakością), w tym w zakresie realizacji procesów produkcyjnych lub organizacyjnych, również powiązanych z otoczeniem rynkowym. Mogą mieć charakter materialny lub niematerialny, a ich efektem są zmiany techniczne, technologiczne, organizacyjne, ekonomiczne, społeczne" (Dolińska 2004, s. 18).

Odnosząc się do pojęcia innowacji, A. Pomykalski pisze, że „obecnie pod pojęciem innowacji rozumie się kompleks zjawisk i procesów obejmujących zarówno powstanie i wdrażanie innowacji, jak i jej efektywność ekonomiczno-społeczną” (Pomykalski 2001, s. 18). Z kolei P.F. Drucker stwierdza: „Innowacja jest raczej pojęciem ekonomicznym lub społecznym niż technicznym” (Drucker 1992, s. 42). Zdaniem W.M. Grudzińskiego i I.K. Hajduka „Wzrostowi innowacyjności gospodarki służyć ma organizowanie infrastruktury instytucjonalnej kreującej innowacyjność, takiej jak parki technologiczne oraz rozwijanie systemu finansowania i gwarancji rynkowych przedsięwzięć innowacyjnych podejmowanych w sferze zaawansowanych technologii (venture capital)" (Grudzewski, Hajduk 2000). A. Francik podkreśla, że terminu innowacja ,używa się do określenia rzeczy nowo wprowadzanej bądź czynności, polegającej na jej wprowadzeniu. Termin innowacja oznacza też koncepcję nowego stanu rzeczy (pomysłu, idei, projektu), czyli inwencję" (Francik 2003, s. 17). Przy czym rozróżnia te dwa pojęcia, tj. innowację i inwencję, twierdząc, że termin innowacja dotyczy zmian wdrażanych do polityki, w odróżnieniu od inwencji, pod którym to pojęciem rozumiemy koncepcję innowacyjną, pomysł, wynalazek. Inwencje są faktami naukowymi naturalnymi pod względem ekonomicznym i dopiero w czasie zastosowania praktycznego stają się innowacjami.

Zdaniem A. Ochojskiego, ,proces innowacyjny - w przeciwieństwie do koncepcji schumpeterowskiej - nie ma charakteru liniowego, lecz jest wynikiem intereakcji i uczenia się na drodze prób i błędów oraz kumulowania wiedzy specyficznej i interdyscyplinarnej” (Ochojski 2006, s. 291). Proces ten ma charakter ciągły i nie oznacza identycznego aplikowania innowacji wszędzie, niezależnie od lokalnych uwarunkowań. Zatem w tym ujęciu, inaczej niż u Schumpetera (wskazującego na innowację jako wynik wysiłków pojedynczego przedsiębiorcy), innowacja jest kreowana przez środowisko lokalne.

Przepływ i wzrost wartości wiedzy w procesie innowacji - uczenia się (ryc. 1) - odbywa się w powtarzającym się cyklu: dostarczanie pomysłów na innowacje, opracowanie rozwiązań innowacyjnych, testowanie i wdrażanie innowacji, promowanie i przygotowanie ich do sprzedaży, tworzenie nowych zastosowań na podstawie wdrożonych wcześniej innowacji. 
Ryc. 1. Przepływ informacji i wiedzy w procesie innowacji

Poziom i uwarunkowania rozwoju gospodarczego, osiągnięcia naukowe, techniczne, polityka innowacyjna państwa, UE, władz regionalnych, lokalnych, rozwiązania innowacyjne instytucji sfery badań i rozwoju, konkurentów, współpracowników na rynku, analiza rynku: potrzeby, oczekiwania, preferencje klientów

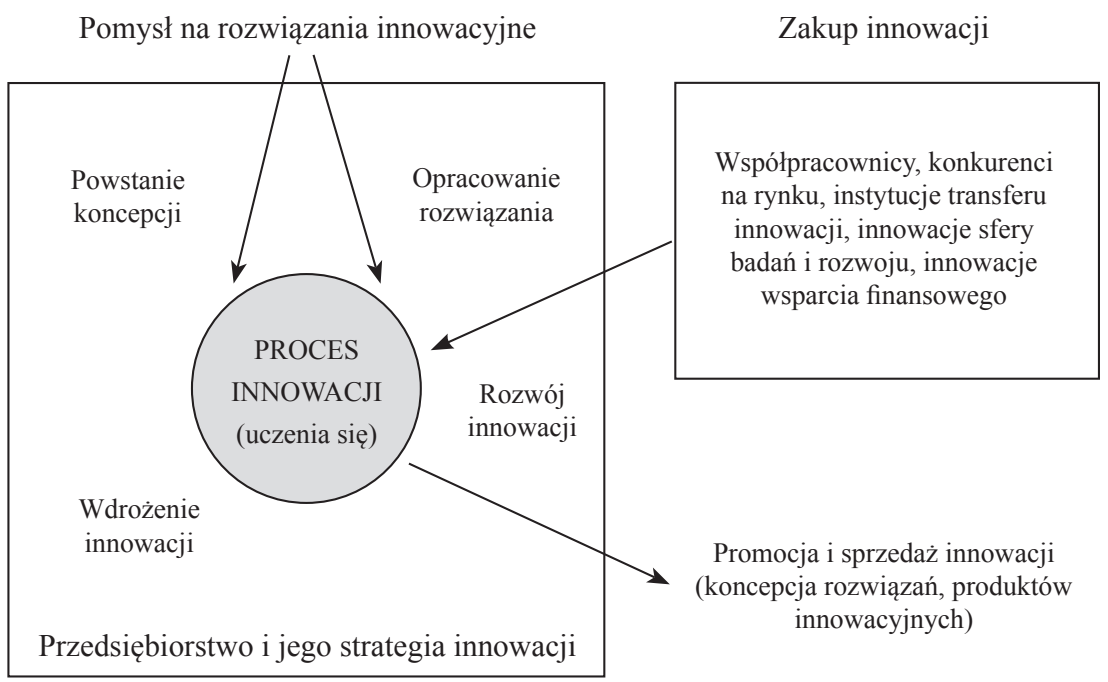

Źródło: M. Dolińska, Innowacje w przedsiębiorstwie, na rynku, w regionie, „Ekonomika i Organizacja Przedsiębiorstw" 2004, nr 9, s. 19.

Efektywność procesu innowacji jest uwarunkowana przepływem i wykorzystaniem w odpowiednim czasie aktualnej informacji i wiedzy oraz zachodzącymi wzdłuż niego relacjami ze współpracownikami na rynku, którzy są zaangażowani w opracowanie, wdrożenie lub transfer i sprzedaż innowacji. Proces ten charakteryzuje się nową organizacją sfery badań i rozwoju, produkcji i marketingu, zgodnie z realizowaną strategią innowacyjną organizacji, ukierunkowaną na osiągnięcie sukcesu rynkowego. Organizacja umacnia wówczas relacje z klientami i współpracownikami, analizuje konkurentów oraz aktualizuje i wykorzystuje bazy danych, które zawierają informacje o rynku i uwarunkowaniach rozwoju gospodarczego, przydatne w tworzeniu wiedzy na temat nowych rozwiązań. P.F. Drucker podkreśla, że „,eechą innowacji opartych na wiedzy - i to wyjątkową - jest to, że niemal nigdy nie są wynikiem wpływu jednej dziedziny naukowej, ale kilku różnych dziedzin, przy czym nie wszystkie z nich mają charakter ścisły lub techniczny" (Drucker 1992, s. 124).

Gromadzona i rozwijana w organizacji oraz pozyskiwana z rynku wiedza ułatwia tworzenie i wdrażanie innowacji. Realizacja procesów innowacji w organizacji jest ukierunkowana na wzrost wartości wiedzy zgromadzonej w produktach tej organizacji, w celu większego zaspokojenia potrzeb klientów proponowaną im ofertą o większej wartości. Zgodnie z zasadami marketingu relacyjnego, w tym stosowanego $\mathrm{z}$ wykorzystaniem systemu CRM, klient uczestniczy aktywnie w tworzeniu i doskonaleniu w czasie oferty organizacji, zgodnej z jego oczekiwaniami i preferencjami. 
Procesy innowacyjne muszą być odpowiednio zarządzane w organizacji, ściśle związane z jej misją i strategią oraz inicjowane zarówno przez rynek, jak i przez wiedzę, a sama organizacja musi być organizacją uczącą się, w której wiedzę i pomysły traktuje się jak zasoby strategiczne.

Organizację można uznać za innowacyjną, jeśli:

- prowadzi w szerokim zakresie prace badawczo-rozwojowe (lub dokonuje zakupów projektów nowych produktów, rozwiązań w zakresie technologii, produkcji, zarządzania),

- systematycznie wdraża innowacje, tj. stosuje nowe rozwiązania w swojej działalności lub w swoich produktach,

- wprowadza innowacje na rynek,

- przeznacza na działalność innowacyjną stosunkowo duże środki finansowe (Dolińska 2004). Istotny jest związek między zmianą a innowacją. Pojęcia te są ze sobą ściśle powiązane. Innowacja zawsze wywołuje zmiany, a nawet jest w jakimś sensie ich istotą. Zmianie nie musi towarzyszyć konkretna innowacja, chyba że w zakresie pojęcia innowacji znajdą się idee, poglądy i zachowania, czyli sploty relacji ewolucyjnych z pominięciem konkretnych bodźców innowacyjnych.

Każda innowacja prowadzi do zmian w jakiejś sferze funkcjonowania organizacji. W organizacjach zachodzą jednak również zmiany, które nie mają swojej przyczyny w innowacji. Występują też zmiany, które wywołują innowacje; najlepszym tego przykładem są przeobrażenia kultury organizacyjnej prowadzące do kreatywności.

Zmiana dotyczy systemu istniejącego, jest reakcją tego systemu na bodziec w jakimś sensie zewnętrzny, niefunkcjonujący w tym systemie, nieswoisty dla tego systemu, natomiast innowacja jest czymś zewnętrznym, ciałem obcym, które wtargnęło w jakiś sposób do tego systemu. Zmiany pozwalają na wchłonięcie innowacji, czyniąc system organizacji elastycznym. Im większa zdolność organizacji do zmian, tym szybsze wchłanianie innowacji. Jeśli zmiany nie nastąpią, innowacja nie ma szans powodzenia. Pozostaje bowiem ciałem obcym, naruszającym równowagę i odrzucanym poza system. W tym sensie zmiany dotyczą przede wszystkim systemu społecznego. P.F Drucker podkreśla, że ,zmiana jest zawsze tym, co stwarza okazję dla nowego i odmiennego. Systematyczna innowacja polega zatem na celowym i zorganizowanym poszukiwaniu zmian oraz na systematycznej analizie okazji do społecznej lub gospodarczej innowacji, którą taka zmiana mogłaby umożliwiać” (Drucker 1992, s. 44).

Przedstawione wyżej poglądy wskazują, że w pojęciu innowacji zawarte są wspólne cechy, takie jak:

- innowacja jest celową i korzystną zmianą w dotychczasowym stanie zaproponowaną przez człowieka,

- zmiana ta musi znaleźć praktyczne zastosowanie i to zastosowanie po raz pierwszy w danej społeczności,

- przedmiotem tej zmiany są wyroby, technologia, procesy społeczne, ekonomiczne, polityczne, ekologiczne itp.,

- innowacja jest środkiem realizacji celów rozwojowych organizacji oraz pozytywnie wpływa na poprawę efektywności jej pracy.

Innowacyjność społeczeństwa zachodzi w procesie historycznym i wpływ na jej rozwój ma szereg czynników. Literatura naukowa wymienia główne czynniki wpływające na rozwój innowacyjności społeczeństwa, takie jak: osobowość, praca w zespole, związki zawodowe, firmy, klienci, edukacja, rząd, uwarunkowania historyczne oraz czynniki społeczno-gospodarcze (Francik 2003). 
Tworzenie i absorpcja innowacji są znacznie utrudnione długotrwałością struktur społeczno-przemysłowych, w których mogą zachodzić zjawiska i procesy opierające się na mechanizmie autodeterminacji. Struktury te wykazują dużą inercję i odporność na zmiany. A. Francik podkreśla, że „dużą rolę w podnoszeniu innowacyjności przypisuje się dążeniom wolnościowym, pozostającym w opozycji do autodeterminacji i resentymentów. Traktuje się je jako główne motywy zachowań ludzkich. Siłą sprawczą zmian w społeczeństwie nie są jakieś nieokreślone całości społeczne, lecz żywi, konkretni ludzie, którzy charakteryzują się dążeniami wolnościowymi. Wolność wewnętrzną daje im m.in. wiedza, której rezultatem może być innowacja poszerzająca pole wolności, bo stawiająca przed nim nowe cele i sposoby ich realizacji" (Francik 2003, s. 72). Dla rozwoju innowacji bardzo ważne jest miejsce, które zajmuje nasze cywilizacja w kolistych nawrotach historii ${ }^{1}$. Społeczeństwa, które się rozwijają i są kierowane przez światowych przywódców (wszystkich szczebli), przejmują języki i wzorce zachowania tych przywódców. Wtedy to innowacje niosą ze sobą pozytywne zmiany we wszystkich sferach życiowych i czynią to życie lepszym.

A. Francik podkreśla, że „obecnie występuje faza załamania cywilizacyjnego; w pewnym stopniu masy naśladują elity, a ekonomiczny składnik kultury rozbija pozostałe, kierujące cywilizacje na tory nie zawsze sprzyjające człowiekowi. Z możliwości, które stwarza wiedza i technologia, wybieramy tylko niewielką część i to one determinują nasze następne wybory. Problem w tym, że nie wybieramy tego, co piękniejsze i bardziej użyteczne, tylko to, co przynosi szybszy wzrost kapitału i co wydaje się bardziej komercyjne" (Francik 2003, s. 73).

Ważnym czynnikiem rozwoju opartego na innowacjach jest ustrój społeczno-gospodarczy i związane z nim formy własności. W warunkach gospodarki rynkowej istnieją realne możliwości dla formowania innowacyjnego typu rozwoju. Pod pojęciami innowacyjnego typu rozwoju należy rozumieć proces przejścia organizacji i całej gospodarki w całości w nowy jakościowo stan w oparciu o innowacje technologiczne, ekologiczne, organizacyjne i inne, zabezpieczające bardziej efekty i dynamiczny rozwój.

Osobliwością innowacyjnego typu rozwoju w porównaniu z intensywnym typem rozwoju jest to, że działa w nim kompleksowo duża grupa różnorodnych czynników dających synergiczny efekt. Warunkami przejścia do innowacyjnego typu rozwoju są:

- ,istnienie wysoko rozwiniętego potencjału naukowo-technicznego,

- wysoka innowacyjna aktywność organizacji,

- działanie efektywnego mechanizmu ekonomicznego w gospodarce,

- rozwój przedsiębiorczości w sferze innowacyjnej,

- istnienie kadr naukowych i menażerskich oraz wysoko kwalifikowanych pracowników zdolnych zabezpieczyć działalność innowacyjną" (Huczek 1996, s. 14).

Sposoby zarządzania zasobami ludzkimi, interakcje z innymi członkami organizacji, kultura organizacyjna itp., w powiązaniu z wartościami i subiektywnie odczuwanymi korzyściami, orientują zachowania ludzi na określone cele i decydują o ich aktywności.

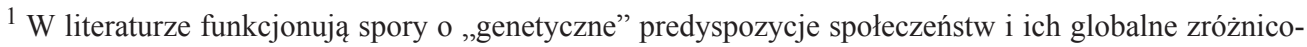
wanie. Teoria kolistej powtarzalności zdarzeń w dziejach ludzkości dzieli cywilizację na wzrastające i dezintegrujące się. Kiedy cywilizacja rozwija się harmonijnie, jej składniki kulturowe (ekonomiczny, polityczny i kulturalny) wzrastają. W cywilizacji dezintegrującej się składniki te konkurują ze sobą, w wyniku czego zaczyna dominować jeden z nich. Wiedza przestaje imponować, pracę twórczą uznaje się za bezwartościową, a etykę i honor za niepotrzebne.
} 
Najistotniejszym z czynników decydujących o stopniu innowacyjności organizacji są ludzie wewnątrz tej organizacji, których istnienie z jednej strony motywuje resztę załogi i wyzwala klimat innowacyjności w sensie ogólnym, z drugiej strony umożliwia przeprowadzenie konkretnych projektów innowacyjnych (Fryzel 2004).

Silny wpływ na rozwój innowacyjności organizacji i regionu ma stan kultury organizacyjnej. Literatura przedmiotu jednoznacznie podkreśla znaczenie kultury organizacyjnej jako istotnego czynnika kształtującego innowacyjność organizacji i społeczeństwa. Sprzężenie zwrotne między innowacją a kulturą charakterystyczną dla danego kraju tworzą w nim niepowtarzalny system zarządzania (Kim, Cameron, Quinn 2003, Stachowicz, Machulski 2001).

P. Drucker pisze, że „uznanie wartości innowacyjności za jeden z najważniejszych celów, do których ludzie powinni dążyć współcześnie, jeśli chcą osiągnąć postęp cywilizacyjny i dobrobyt związane jest z wzorami kultury społeczeństwa" (Drucker 1992). Podstawowym wzorem kultury prorozwojowej jest wytworzenie w danym społeczeństwie nastawienia na sukces i osiąganie sukcesu. Drugim wzorem takiej kultury jest nastawienie na przyczynianie się do osiągnięcia dobra wspólnego - postępu cywilizacyjnego (wzór myślenia i działania innowacyjnego). Trzecim podstawowym wzorem kultury prorozwojowej jest traktowanie zmiany jako szansy na postęp (dobro wspólne), a nie jako zagrożenie dla jednostek i grup społecznych. Te ogólne wzory kultury mogą być podstawą działania całego społeczeństwa lub mogą pojawić się tylko w mniejszych środowiskach lokalnych.

Im bardziej upowszechnione są wzory kultury prorozwojowej, tym większe są szanse na wytworzenie się wzorów innowacyjności i ich upowszechnienie. Im mniej upowszechnione są wzory kultury prorozwojowej, tym wzory kultury innowacyjności realizowane będą w enklawowych, o sprzyjających warunkach brzegowych, środowiskach lokalnych, a społeczeństwo jako całość będzie społeczeństwem zacofanym, pozostającym na peryferiach głównego nurtu przemian cywilizacyjnych współczesności. Postęp cywilizacyjny ograniczony będzie tylko do niewielkich enklaw grup społecznych i instytucji.

W literaturze naukowej funkcjonuje różnorodność klasyfikacji innowacji. Klasyfikacja ta uzależniona jest od szeregu kryteriów, a jedna innowacja może być zakwalifikowana do kilku rodzajów. Jako kryteria podziału innowacji przyjmuje się: złożoność procesu, oryginalność zmian, dziedziny gospodarki (z której się wywodzą), zakres spowodowanych przez nie skutków, stopień nowoczesności, zasięg oddziaływania, warunki psychospołeczne osób je realizujących, korzyści przynoszone społeczeństwu, możliwe skutki zastosowania innowacji, głębokość powodowanych zmian, przedmiot innowacji itd. (Huczek 1996). Dla dalszych rozważań podejmowanych w artykule istotne będą innowacje ze względu na przedmiot innowacji. Wyodrębnia się tutaj innowacje: technologiczne, organizacyjne, ekonomiczne, społeczne i ekologiczne.

Określenie wzajemnych związków między przedsiębiorczością a innowacyjnością nie wydaje się możliwe bez refleksji teoretycznej, a ta wymaga sięgnięcia do teorii Schumpetera. Dla Schumpetera innowacja miała wszechobecny charakter. Przez wprowadzenie nowego produktu (innowacja produktowa) przez otwarcie nowego rynku sprzedaży lub zaopatrzenia (innowacja rynkowa), nowej metody produkcji (innowacja procesowa) lub wprowadzenie nowej struktury działania (innowacja w sferze zarządzania), przedsiębiorca kształtuje nową funkcję produkcji; co pozwala mu osiągnąć zysk, którego podstawę stanowi zdobyta tylko na pewien czas pozycja monopolistyczna. Dla Schumpetera innowacja jest tożsama z przedsiębiorczością (Kwiatkowski 2001). 
S. Kwiatkowski dopuszcza możliwość poważnych modyfikacji już istniejącej funkcji produkcji przez nagromadzenie setek i tysięcy lekceważonych przez Schumpetera subinnowacji. P.F. Drucker przedstawia istotę przedsiębiorczości w ścisłym związku działań przedsiębiorczych i innowacji, za pomocą których zmierza się do sukcesu na rynku. Człowiek przedsiębiorczy zawsze poszukuje zmiany, reaguje na nią i wykorzystuje jako okazję (Drucker 1992). Według P.F. Druckera, „innowacja jest specyficznym narzędziem przedsiębiorczości - działaniem, które nadaje zasobom nowe możliwości tworzenia bogactwa” (Drucker 1992, s. 39).

M. Bratnicki i J. Strużyna piszą, że „możliwe jest dokonanie rozróżnienia pomiędzy innowacyjnością a przedsiębiorczością. Przedsiębiorczość ma cechy procesu, jest sposobem myślenia i robienia rzeczy, w wyniku którego dokonywana jest transformacja innowacji na możliwości rynkowe lub tworzenia przewagi konkurencyjnej” (Bartnicki, Strużyna 2001, s. 40). Organizacje nie są więc w stanie podejmować z zyskiem działań kreatywnych czy też innowacyjnych, jeśli nie mają one charakteru działań przedsiębiorczych. Chociaż trudne jest oddzielenie idei innowacji i przedsiębiorczości, to jednak przyjmuje się, że innowacja jest rezultatem przedsiębiorczego zachowania i przedsiębiorczych strategii istniejących w ramach organizacji.

W tabeli 1 zestawiono przykłady różnych ujęć istoty procesu przedsiębiorczości. Przykłady te przedstawiają związek innowacji z przedsiębiorczością.

Tab. 1. Istota procesu przedsiębiorczości - przykłady różnych ujęć

\begin{tabular}{|l|l|}
\hline Przedsiębiorczość jako proces & \multicolumn{1}{|c|}{ Charakterystyka } \\
\hline tworzenia bogactwa & $\begin{array}{l}\text { przedsiębiorczość wiąże się z podejmowaniem ryzyka i osiąganiem } \\
\text { zysku }\end{array}$ \\
\hline tworzenia przedsiębiorstw & $\begin{array}{l}\text { efektem przedsiębiorczości są nowo powstałe przedsięwzięcia } \\
\text { czy firmy, które wcześniej istniały }\end{array}$ \\
\hline wprowadzania innowacji & $\begin{array}{l}\text { uzewnętrznia się poprzez unikalne kombinacje zasobów, które } \\
\text { czynią istniejące metody i produkty przestarzałymi. }\end{array}$ \\
\hline wprowadzania zmian & $\begin{array}{l}\text { proces przedsiębiorczy pociąga za sobą zmiany poprzez ocenianie, } \\
\text { dostosowanie, modyfikowanie zachowań ludzi, sposobów ich } \\
\text { działania, umiejętności, co umożliwia dostrzeżenie i wykorzystanie } \\
\text { pojawiających się okazji w otoczeniu }\end{array}$ \\
\hline tworzenia nowych miejsc pracy & $\begin{array}{l}\text { przedsiębiorczość łączy się z zatrudnieniem, zarządzaniem } \\
\text { i rozwojem czynników produkcji obejmujących w szczególności } \\
\text { siłę roboczą }\end{array}$ \\
\hline tworzenia wartości & $\begin{array}{l}\text { przedsiębiorczość jest procesem tworzenia wartości dla klientów } \\
\text { poprzez „eksploatowanie” dotąd niewykorzystanych okazji }\end{array}$ \\
\hline wzrostu & $\begin{array}{l}\text { istotą przedsiębiorczości jest silna i pozytywna orientacja na wzrost } \\
\text { sprzedaży, dochodów, aktywów i zatrudnienia }\end{array}$ \\
\hline wykorzystania \\
nadarzających się okazji & $\begin{array}{l}\text { przedsiębiorczość to proces wykorzystania - przez jednostki } \\
\text { działające indywidualnie lub wewnątrz organizacji - szans } \\
\text { dostrzeganych w otoczeniu niezależnie od tego, jakie zasoby } \\
\text { aktualnie znajdują się pod ich kontrolą }\end{array}$ \\
\hline
\end{tabular}

Źródło: T. Kraśnicka, Koncepcja rozwoju przedsiębiorczości ekonomicznej i pozaekonomicznej, Katowice 2002, s. 70. 


\section{Globalizacja a zarządzanie innowacjami}

Istotą globalizacji jest wykorzystywanie praw rynku do zwiększania produktywności gospodarki światowej, a nie tylko wybranych regionów czy krajów. Globalizacja wymusza działania zmierzające do zwiększenia wartości przedsiębiorstw. W warunkach rynku globalnego rosną bowiem szanse rozwojowe tych przedsiębiorstw, które potrafią zwiększać swą wartość dla akcjonariuszy np. poprzez innowacje.

W odniesieniu do przedsiębiorstw globalizacja oznacza m.in.:

- zarządzanie firmą w globalnym otoczeniu,

- zdobywanie globalnej przewagi konkurencyjnej i dążenie do zrównania się z najlepszymi firmami globalnymi,

- wysokie zaangażowanie firmy w operacje na rynkach światowych,

- wykorzystywanie transferów zewnętrznych w zakresie zasobów, technologii, wiedzy oraz innowacji,

- stałe wprowadzanie zmian wynikających z procesów dostosowywania przedsiębiorstwa do uwarunkowań rynków globalnych i potrzeb klientów globalnych (Tubielewicz 2004).

Specyficznymi źródłami korzyści, które mogą zostać uruchomione dzięki globalizacji przedsiębiorstwa, są:

- zwiększenie zysków dzięki wykorzystaniu w skali globalnej wyróżniających kompetencji przedsiębiorstwa,

- możliwości osiągnięcia korzyści z optymalnej lokalizacji działalności firmy w skali światowej przez umiejscowienie jej tam, gdzie może być wykonywana najefektywniej,

- efekty doświadczenia polegające na obniżaniu się kosztu jednostkowego produkcji w miarę kumulowania się ilości wytworzonych produktów dzięki uczeniu się i wzrostowi skali produkcji (Lichtarski 2007).

P. Kotler pisze, że: „Współczesny krajobraz ekonomiczny kształtują dwa kluczowe czynniki: rozwój technologiczny i globalizacja” (Kotler 1999, s. 18). Czynniki te są powiązane, a ich stymulujące działanie na proces rozwoju organizacji powinno być rozważane w ujęciu synergicznym, ponieważ rozwój technologii stymuluje proces globalizacji.

Globalizacja procesu innowacji kształtuje się pod wpływem wielu czynników o różnym pochodzeniu, charakterze, sile i zakresie działania. Można jednak występujące czynniki ująć w następujące grupy:

- rozwój innowacji poprzez rozwój sfery badań i wdrożeń oraz rosnące znaczenie transferu technologii,

- rozwój nowoczesnych gałęzi produkcji i usług,

- konkurencja międzynarodowa, wzrastający popyt na innowacje ze strony globalnie konkurujących przedsiębiorstw,

- polityka gospodarcza, a w tym polityka innowacyjna państwa.

Sukces małego i średniego przedsiębiorstwa na rynku, realizacja ich rozwojowych celów, zależy od procesu tworzenia i dyfuzji innowacji. Innowacja jest oparta przede wszystkim na kompleksowej interakcji pomiędzy pracownikami, przedsiębiorstwem a czynnikami otoczenia. A. Sankowska pisze, że „Innowacyjność przedsiębiorstw to ważny element będący nośnikiem ich pozycji konkurencyjnej oraz źródłem ekspansji na rynki międzynarodowe" (Sankowska 2009, s. 95).

Obecnie coraz częściej mówi się o koncepcji szybkiej innowacji (fast innovation). Szybka innowacja odnosi się do kreowania nowych produktów, usług, modeli biznesowych, procesów oraz rynków wystarczająco zróżnicowanych szybkości, z jakimi przedsiębiorstwo utrzymuje 
przez dekady ponadprzeciętny zwrot dla właścicieli (Georgie, Works, Watson-Hemphill 2005). Uwypukla się w ten sposób konieczność tworzenia innowacji z wyprzedzeniem teraźniejszych i przyszłych konkurentów.

P.F. Drucker podkreśla, że „Innowacja jest pracą zorganizowaną, systematyczną i racjonalną" (Drucker 1992, s. 60). Właśnie dlatego należy wprowadzić zarządzanie innowacjami, w którym przypadkowość w sprawach innowacji zastępuje się systematycznym poszukiwaniem i realizacją szans innowacji i przyjmuje się, że powinno się tak zorganizować przedsiębiorstwo, aby jego struktura nie ograniczała, lecz stymulowała rozwój innowacji. Takie zarządzanie sprawia, że organizacja staje się zdolna nie tylko do innowacji produktowych, procesowych, ale i w sferze samego zarządzania.

A. Pomykalski stwierdza, że „Innowacja jest procesem, a nie, wyrwanym z kontekstu zdarzeniem. Poddaje się więc zarządzaniu. Zarządzanie to jednak sprowadza się do oddziaływania bardziej na proces niż na pojedyncze zachowania. Innowacje podobnie jak jakość są rezultatem procesów pozornie tylko dających się kształtować zachowań” (Pomykalski 2001, s. 78-79).

Istnieje potrzeba efektywnego zarządzania procesem innowacyjnym. Podstawową kwestią jest tu dokładne zrozumienie poszczególnych etapów, przez które przechodzi przedsięwzięcie innowacyjne. Określenie odpowiedniego kierunku rozwoju innowacji i właściwe dostosowanie zasobów to tylko część procesu zarządzania. Przedsiębiorstwo powinno także ustalić specyficzne wymagania dla każdej z faz procesu innowacyjnego oraz efektywnie zarządzać i monitorować przejście z jednej fazy do następnej. Literatura przedmiotu dzieli zarządzanie procesem innowacyjnym na pięć faz (Pomykalski 2001).

Należy podkreślić, że zarządzanie globalne charakteryzuje się:

- globalną strategią,

- globalnym wymiarem podstawowych funkcji gospodarczych, w tym finansowych, marketingowych, badawczo-rozwojowych,

- alokacją podstawowych zasobów przez uwzględnianie warunków ich pozyskiwania na rynku światowym,

- infrastrukturą informatyczną dostosowaną do działalności w skali światowej,

- istnieniu globalnych menedżerów.

Jeśli chcemy, aby proces innowacyjny przebiegał sprawnie, musimy właściwie go zorganizować, tzn. odpowiednio skoordynować wszystkie jego fazy. Rozmiar działalności naukowo-badawczej, jej charakter, a także koszty wymagają określonego ukierunkowania na zadania szczególnie ważne i potrzebne. Wynika stąd konieczność określenia potrzeb rynku w zakresie innowacji.

$\mathrm{Z}$ analizy poszczególnych elementów procesu innowacyjnego oraz z analizy powiązań między nimi wynikają warunki, które decydują o efektywności zarządzania procesem innowacyjnym. Są to:

- proinnowacyjny model gospodarki, uwzględniający innowacje jako ważny element rozwoju,

- wspomaganie regulacjami przez państwo, region, małe i średnie przedsiębiorstwa popytu na innowacje,

- poprawa kluczowych powiązań, ścisłe powiązanie (skoordynowanie) różnych faz procesu rozwojowego w systemie innowacji,

- zapewnienie zasobów marketingowych, produkcyjnych, ludzkich, finansowych niezbędnych do realizacji i wdrażania innowacji,

- selekcja i hierarchizacja celów w sferze badań i rozwoju, monitorowanie, ocena efektywności, porównania narodowych i regionalnych programów rozwoju innowacyjności oraz koncentracji zasobów na ich realizacje. 
W zarządzaniu innowacjami szczególnie istotne są relacje otoczenia makro- i mikro- z zasobami małych i średnich przedsiębiorstw oraz z zasobami firmy, które przyczyniają się do rozwoju innowacji. Siły napędzające rozwój gospodarczy są nierozłącznie związane z metodami i stylami zarządzania dynamicznymi organizacjami działającymi w otoczeniu kształtowanym przez procesy globalizacji, internacjonalizacji i koncentracji. Uwarunkowane jest ono na tworzenie wartości, wzrost przedsiębiorczości, w tym intelektualnej, oraz systematyczną innowację. Przejawia szczególną troskę o wzrost wyróżniających zdolności firmy i kluczowych kompetencji oraz przekształcanie ich w przewagę konkurencyjną na rynku krajowym, międzynarodowym i globalnym.

Literatura naukowa podkreśla znaczenie wiedzy organizacji w kreowaniu innowacyjności. A. Sankowska pisze, że „Innowacja związana jest z użyciem nowej wiedzy, nowym użyciem czy kombinacją istniejącej wiedzy. Innowacja może być związana ze zdolnością do kreowania nowej wiedzy dla łączenia wykorzystania wpływu i rozwoju środowiska, otoczenia i sytuacji w samej organizacji” (Sankowska 2009).

Globalne przedsiębiorstwo buduje swoją przewagę konkurencyjną na fundamencie powiązania i wykorzystania zintegrowanej wiedzy centrali oraz filii zagranicznych. Uzyskuje się dzięki temu możliwość akumulacji wiedzy środowiska lokalnego i międzynarodowego raz uruchomienia dźwigni efektywnościowej i osiągania takich korzyści, jak:

- budowa trwałej i efektywnościowej drogi transferu wiedzy lokalnej pomiędzy filiami a centralą przedsiębiorstwa. Prowadzi to do internalizacji tej wiedzy i ożywienia jej tworzenia i przekazywania,

- przyspieszenie opracowywania i wdrażania innowacji produktowych i procesowych dzięki wykorzystaniu wiedzy filii przedsiębiorstwa,

- zmniejszenie kosztów innowacji dzięki transferowi ponadgranicznemu sprawdzonych rozwiązań pomiędzy filiami przedsiębiorstwa,

- zdobywanie wiedzy o kliencie lokalnym oraz możliwości jej wykorzystania do modyfikacji standardowego produktu globalnego.

Zdaniem A. Trzebielewicza, ważnym wyzwaniem dla zarządzania jest wykorzystanie przedsiębiorczości i innowacyjności w procesie ciągłego dostosowywania do zmieniającego się otoczenia lokalnego, regionalnego czy globalnego. Dla małych i średnich przedsiębiorstw działających w tym otoczeniu oznacza to:

- opanowanie technologii informacyjnych i ich wykorzystanie,

- ciągłe tworzenie zdrowego niezadowolenia i dyskomfortu związanego ze status quo przedsiębiorstwa,

- zdolność odkrywania pojawiających się trendów szybciej niż konkurencja,

- umiejętność szybkiego podejmowania decyzji,

- poszukiwania nowych sposobów działania na rynku (Tubielewicz 2004).

Małe i średnie przedsiębiorstwa, które chcą utrzymać przewagę konkurencyjną na rynku, zdobywać nowe produkty i usługi, muszą być bardziej kreatywne i innowacyjne oraz zapewnić swobodny przepływ informacji, umiejętności uczenia się pracowników i myślenia kategoriami celów i wyników ich działalności. Oznacza to przyswajanie umiejętności szybkiego, elastycznego reagowania na sygnały z rynku oraz związane z tym stałe przyczynianie się do podnoszenia przez innowacje jakości pracy, produktów i procesów oraz dążenie do racjonalizacji gospodarczej.

Należy podkreślić, że zarządzanie innowacjami jest poszukiwaniem, opartym na posiadanych zasobach, takich rodzajów innowacji, które powodują, że proces innowacji staje się efektywniejszy w konfrontacji z wyzwaniami, które stawiają przed organizacją rynek, konkurencja, klient. 
Innowacje są tym elementem w działalności przedsiębiorstwa, który decyduje o jego charakterze i sukcesach. U podstaw nowoczesnego zarządzania innowacjami powinno znajdować się zrozumienie przez kadrę faktu, że tylko te przedsiębiorstwa mogą przetrwać i nie stracić szansy rozwoju, które będą odpowiednio przystosowywały się do otoczenia. Można określić pewne przesłanki o szczególnej ważności dla rozwoju innowacyjności przedsiębiorstwa:

- innowacja udaje się w pełni tylko wtedy, gdy jej wprowadzenie wspierane jest przez całe przedsiębiorstwo,

- efektywna innowacja oparta jest na strategii, stąd konieczność zintegrowania innowacji z ogólną strategią przedsiębiorstwa,

- powodzenie innowacji zależy od efektywnych powiązań mocnych i słabych stron przedsiębiorstwa z otoczeniem mikro-, makro- i globalnym,

- powodzenie innowacji wymaga ze strony przedsiębiorstwa uruchomiania mechanizmów wprowadzania zmian, a w tym budowania modelu sieciowego - opartego na technologii informacyjnej.

Na rozwój innowacji składa się wysiłek pracowników oraz kapitał potrzebny do opracowania i wprowadzania na rynek nowych produktów, procesów i organizacji. Innowacja staje się więc sprawą przedsiębiorstw i organów władzy publicznej, które obecnie grupują zasoby ludzkie i odpowiednie kapitały. Innowacja jest oparta przede wszystkim na kompleksowej interakcji pomiędzy indywidualnymi jednostkami, przedsiębiorstwami a czynnikami otoczenia. Jednym z ważniejszych czynników wpływających na innowacyjność przedsiębiorstwa, wynikającym ze współpracy z partnerami biznesowymi, jest element zaufania - wiarygodność własna osiągnięta dzięki kompetencjom oraz koncentracja na kluczowych kompetencjach. Jest to ciekawa strategia budowania własnego wizerunku, a tym samym podwyższania własnej innowacyjności poprzez ciekawy mechanizm działania wizerunku na partnerów biznesowych. Ten z kolei wzmacniany jest koncentracją na kluczowych stanowiskach.

Innowacyjne zdolności przedsiębiorstwa wyznaczają m.in.: poziom chłonności na innowacje, skłonność do wysiłków innowacyjnych, stworzenie systemu uczenia się, zdefiniowanie innowacji i rozpropagowanie ich wśród pracowników, właściwy system motywacji innowacyjnej, a także posiadanie elastycznej organizacji otwartej na innowacje oraz poziom zasobów, które można zaangażować w działalność innowacyjną. Istotnym uwarunkowaniem przygotowania i wdrożenia nowych przedsięwzięć jest zdolność wdrożenia innowacji. Jest ona rozumiana jako ogół przesłanek, warunków oraz wymagań niezbędnych do praktycznego urzeczywistnienia konkretnych innowacji.

\section{Literatura}

1. Bratnicki M., Strużyna J., 2001, Przedsiębiorczość i kapitat intelektualny, Wydawnictwo Akademii Ekonomicznej w Katowicach, Katowice.

2. Dolińska M., 2004, Innowacja $w$ przedsiębiorstwie, na rynku, w regionie, „Ekonomia i Organizacja Przedsiębiorstwa", nr 9.

3. Drucker P.F., 1992, Innowacja i przedsiębiorczość. Praktyka i zasady, PWE, Warszawa.

4. Francik A., 2003, Sterowanie procesami innowacyjnymi $w$ organizacji, Akademia Ekonomiczna w Krakowie, Kraków.

5. Fryzeł B., 2004, Kultura a konkurencyjność przedsiębiorstwa, TNOiK, Toruń. 
6. Grudzewski M., Hajduk I.K., 2000, Wspieranie innowacyjności przedsiębiorstw, „Organizacja i Kierowanie", nr 3, Warszawa.

7. Georgie M.L., Works J., Watson-Hemphill K., 2005, Fast innovation - achieving superior, differentiation speed to market, and increased profitability, „Journal of Economic Perspectives”, nr. 15, New York, Mc Graw-Hill.

8. Huczek M., 1996, Czynniki wzrostu innowacyjności przedsiębiorstwa, BIT, Bielsko-Biała.

9. Kotler P., 1999, Kotler o marketingu. Jak kreować i opanowywać rynki, Profesjonalna Szkoła Biznesu, Kraków.

10. Kraśnicka T., 2002, Koncepcja rozwoju przedsiębiorczości ekonomicznej i pozaekonomicznej, Wydawnictwo Akademii Ekonomicznej w Katowicach, Katowice.

11. Lichtarski J., 2007, Podstawy nauki o przedsiębiorstwie, Wyd. Akademii Ekonomicznej we Wrocławiu, Wrocław.

12. Lublińska-Kasprzak B., 2009, Raport o stanie sektora MSP w Polsce, Polska Agencja Rozwoju Przedsiębiorczości, Warszawa.

13. Ochojski A., 2006, Przedsiębiorczość sektora publicznego a konkurencyjność i rozwój regionu [w:] Przedsiębiorczość i konkurencyjność a rozwój regionalny, A. Klasik (red.), Akademia Ekonomiczna w Katowicach, Katowice.

14. Pomykalski A., 2001, Zarządzanie innowacjami, PWN, Warszawa-Lódź .

15. Snakowska A., 2009, Organizacja wirtualna. Koncepcja i jej wpływ na innowacyjność, Wydawnictwa Akademickie i Profesjonalne, Warszawa.

16. Tubielewicz A., 2004, Zarządzanie strategiczne w biznesie międzynarodowym, WNT, Warszawa.

\section{Management of the Innovation in Small and Medium Companies in Globalization Conditions}

The essence of the process of globalization is using the market mechanism to enhance productivity of the global economy and not only of particular countries or regions. Globalization compels companies to develop and increase their potential. In the worldwide global conditions the more innovation the companies have the more valuable they are for their shareholders. The author of the article presents the strategies of introducing such types of innovation. 


\section{Danuta Janczewska}

Społeczna Wyższa Szkoła Przedsiębiorczości

i Zarządzania w Łodzi

\section{Ksztaltowanie lańcucha wartości innowacji firm MŚP w warunkach globalizacji}

Innowacje są obecnie postrzegane jako odpowiedź na oczekiwania konsumentów oraz ciągłe reagowanie na ich zmieniające się wymagania, zachowania i doświadczenia (Prahalad, Krishnan 2010, s. 12). Ten pogląd na innowacje można nazwać Nową Erą Innowacji, w której występują nowe zależności i nowe uwarunkowania konkurencyjności przedsiębiorstw. Również innowacyjne procesy biznesowe występujące w przedsiębiorstwie podlegają zmianom uzależnionym od umiejętności menedżerów oraz ich postaw wobec oczekiwań konsumentów i zmiennego otoczenia. Obszarem, na którym operują współczesne firmy innowacyjne, jest rynek globalny z różnorodnymi grupami nabywców oraz źródłami zasobów. Charakterystycznym elementem otoczenia rynkowego przedsiębiorstwa są obecnie zmiany typu turbulentnego, zatem umiejętność identyfikacji tych zmian w skali regionalnej i globalnej, a następnie wybór właściwej strategii jest jednym z ważniejszych problemów współczesnego przedsiębiorstwa.

Nowa wiedza umożliwia tworzenie innowacji. Innowacja to wprowadzanie zmian do układów gospodarczych i społecznych, których efektem są:

- wzrost użyteczności produktów/usług/procesów oraz systemów zarządzania,

- poprawa racjonalności gospodarowania,

- ochrona i poprawa środowiska przyrodniczego,

- lepsza komunikacja międzyludzka,

- poprawa jakości życia zawodowego i prywatnego społeczeństwa.

Innowacyjność jest stanem pożądanym we wszystkich typach współczesnych organizacji, ale jednocześnie nie jest jednorodna, ponieważ innowacje odpowiadają na zróżnicowane zapotrzebowanie przedsiębiorstw. Na kreatywność i wprowadzanie innowacji zwraca się także uwagę w kontekście koncepcji zarządzania wiedzą, w szczególności - w kontekście kreacji wiedzy traktowanej dziś jako kluczowy zasób każdej organizacji, która pretenduje do miana bycia konkurencyjną. Zarządzanie procesami rozwijania nowej wiedzy powinno polegać na kształtowaniu odpowiedniego kontekstu innowacji, środowiska, a nie kontroli samego procesu. Należy przy tym podkreślić, że podmiotami wiedzy są ludzie, a dla przedsiębiorstw istotna jest umiejętność zastosowania zasobów informacji dla kreowania nowych pomysłów (innowacji). Wśród warunków, które sprzyjają kreowaniu innowacji można wymienić:

- swobodę w przedstawianiu pomysłów, czyli promowanie postaw sprzyjających eksperymentowaniu, i zachęcanie do wprowadzania zmian,

- zarezerwowanie czasu na czynności nierutynowe w godzinach pracy, możliwość brania przez pracowników urlopu naukowego,

- stworzenie odpowiedniej przestrzeni fizycznej, odizolowanej od codziennego miejsca pracy, 
- godzenie interesów organizacji z osobistymi celami pracowników, np. częściowe finansowanie prac badawczo-rozwojowych bardzo ważnych dla pracownika, z których kierownictwo przedsiębiorstwa decyduje się wycofać,

- tolerowanie błędów w rozsądnym zakresie, ponieważ popełnianie ich jest nieodłączną cechą eksperymentowania - należy je traktować jako cenę płaconą za odkrycie lepszego rozwiązania, które przyniesie korzyść całej organizacji (Głuszek 2004, s. 89-90).

\section{MŚP jako przedsiębiorstwa innowacyjne}

Istnieje zależnośc pomiędzy wielkością firmy a jej innowacyjnością. Badania empiryczne (Wziątek-Kubiak, Balcerowicz 2009) wykazały, że duże przedsiebiorstwa cechuje znacznie większa innowacyjność, niż ma to miejsce w przypadku firm z grupy MŚP. Korelację pomiędzy kategorią wielkości firmy a odsetkiem firm innowacyjnych można prześledzić na przykładzie polskiego przemysłu przetwórczego (tab. 1).

W latach 1998-2000 spośród ogólnej liczby przedsiębiorstw jedynie 17,1\% stanowiły firmy innowacyjne. W tej grupie przeważającą liczbę - 58,3\% - stanowiły firmy duże, zatrudniające powyżej 250 osób. Podobna tendencja wskaźnikowa występowała w kolejnych badanych okresach. Najniższy odsetek firm innowacyjnych wystąpił wśród przedsiębiorstw z grupy MŚP i to zjawisko również było trwałe.

Tab. 1. Przedsiębiorstwa innowacyjne w przemyśle przetwórczym (jako \% ogółu) w latach 1998-2000 i $2002-2006$

\begin{tabular}{|c|c|c|c|}
\hline Kategoria wielkości przedsiębiorstwa & $\mathbf{1 9 9 8 - 2 0 0 0}$ & $\mathbf{2 0 0 2 - 2 0 0 4}$ & $\mathbf{2 0 0 4 - 2 0 0 6}$ \\
\hline Małe & 10,7 & 17,7 & 14,0 \\
\hline Średnie & 31,0 & 18,5 & 20,5 \\
\hline Duże & 58,3 & 67,5 & 65,5 \\
\hline $\begin{array}{c}\text { Ogółem } \\
\text { (odsetek firm innowacyjnych } \\
\text { w ogólnej liczbie firm) }\end{array}$ & 17,1 & 25,6 & 23,1 \\
\hline
\end{tabular}

Źródło: Nauka i technika w Polsce w 2006 roku, GUS, Warszawa 2007; Nauka i technika w Polsce w 2008 roku, GUS, Warszawa 2010.

Zgodnie z metodologią OSLO Manual, gospodarka oparta na wiedzy cechuje się dużą aktywnością innowacyjną, rozumianą jako wdrażanie ze znaczną intensywnością nowych produktów, technologii oraz innowacji organizacyjnych, zwłaszcza z zakresu zarządzania. Przedsiębiorstwem innowacyjnym jest przedsiębiorstwo, które w badanym okresie (najczęściej trzyletnim) wprowadziło na rynek nowy lub istotnie ulepszony produkt, bądź nowy lub istotnie ulepszony proces. W wypadku przedsiębiorstw z grupy MŚP (składających sprawozdania do GUS) najczęściej wskazują one na ulepszenia procesowe lub produktowe, składając sprawozdania statystyczne.

Elastyczność rynkowa, szybkość reagowania na zmiany turbulentne w otoczeniu i wprowadzania innowacji staje się cechą oczekiwaną współczesnego przedsiębiorstwa, zatem firmy z grupy MŚP mogą lepiej przystosować się do nowych warunków funkcjonowania na rynku.

Przedsiębiorstwo innowacyjne cechuje szereg działań i postaw, wśród nich należy wyróżnić:

- potencjał badawczy,

- pomysły kierownictwa i pracowników, 
- postawa pracowników dotycząca innowacji,

- organizacja pracy,

- strategiczne zarządzanie innowacjami,

- atmosfera sprzyjająca zmianom w organizacji,

- nastawienie na pogłębianie wiedzy i umiejętności,

- kalkulacja ryzyka, niepewności, poszukiwań,

- demokratyzm w rozwiązywaniu problemów,

- akceptacja i wspieranie działań grupowych,

- system motywacyjny promujący innowatorów,

- program wspierający twórcze, wielokierunkowe i alternatywne sposoby myślenia oraz rozwiązywania problemów,

- świadomość potrzeby dokonywania zmian,

- system zapewniający łatwą i bezpośrednią wymianę poglądów,

- nieskrępowany dostęp do informacji.

Odnosząc wyżej wymienione kryteria do cech przedsiębiorstw z grupy MŚP, można zauważyć obszary rzadziej występujące w firmach MŚP (Janczewska 2009). Należą do nich: potencjał badawczy, strategiczne zarządzanie innowacjami, nastawienie na pogłębianie wiedzy, system motywacyjny wspierający motywatorów. Badania PARP prowadzone w roku 2007 wykazały, że innowacje produktowe wprowadzone przez MŚP były w 30\% efektem nowych rozwiązań projektowanych i rozwijanych wewnątrz firmy (Pyciński 2008, s. 83). Sytuacja taka najczęściej występuje w firmach średnich, zatrudniających powyżej 50 pracowników oraz w przedsiębiorstwach przeznaczających na inwestycje ponad 10\% przychodów ze sprzedaży, w których $25 \%$ innowacji jest wynikiem nowych technologii, standardów i regulacji obowiązujących w branży. Klienci stanowią inspirację dla ponad 20\% rozwiązań i projektów innowacyjnych.

Jedną z metod analizy możliwości rynkowych i konstruowania innowacyjnych strategii MŚP w warunkach globalizacji może być analiza łańcucha wartości w odniesieniu do zdolności innowacyjnej przedsiębiorstwa oraz do źródeł idei innowacyjnych. Projektując strategię innowacji w MŚP w warunkach globalizacji, należy uwzględnić następujące elementy:

- wdrażanie nowych produktów, procesów i systemów organizacyjnych,

- wzrost racjonalności gospodarowania wyrażający się w poprawie efektywności, zmniejszeniu chłonności czynników produkcji i wzrostu ich produktywności,

- prawa tożsamości, wizerunku i reputacji organizacji,

- poprawę klimatu innowacyjnego organizacji, a także pozyskiwanie potencjału intelektualnego - jego rozwój i doskonalenie,

- utrzymanie firmy na obecnych rynkach oraz poszerzanie rynków zbytu,

- pozyskiwanie funduszy na sfinansowanie programu innowacyjnego.

\section{Uwarunkowania funkcjonowania MŚP na rynku globalnym}

W ujęciu OECD (OECD Science, Technology and Industry: Scoreboard 2007) globalizacja przemysłu oznacza ewoluujący sposób prowadzenia międzynarodowej działalności przemysłowej przedsiębiorstw, obejmujący inwestycje, handel, porozumienia, które są wykorzystywane w celu wdrażania prac $\mathrm{B}+\mathrm{R}$, wytwarzania i poddostaw produktów oraz ich zbytu.

W warunkach globalizacji innowacje są transferowane od twórców do odbiorców, przy czym przepływ innnowacji przyjmuje wymiar wewnątrzgałęziowy, krajowy oraz międzynarodowy (Wziątek-Kubiak, Balcerowicz 2009, s. 17). Analizując transfer innowacji i nadając mu określone cechy dynamiczne, należy uwzględnić kanały transferu innowacji oraz relacje pomiędzy uczestnikami 
procesu przepływu innowacji. Dla przedsiębiorstw z grupy MŚP podejmujących działalność w wymiarze międzynarodowym dochodzi do formułowania nowych procesów, takich jak:

- proces wymiany międzynarodowej - handlu międzynarodowego,

- proces przepływu siły roboczej,

- proces przepływu kapitału w postaci bezpośrednich inwestycji zagranicznych,

- procesy współpracy kooperacyjnej i podwykonawczej.

Przykładem wymiany międzynarodowej może być eksport realizowany przez przedsiębiorstwa MŚP. Wspieranie działalności proeksportowej firm z grupy MŚP w krajach Unii jest przedmiotem zainteresowania Unii Europejskiej oraz konkretnych działań wielu organizacji i rządu prowadzonych w ramach 7. Programu Ramowego ${ }^{1}$. Do działań wspierających eksport MŚP można zaliczyć: szkolenia kadry, misje gospodarcze, targi, wystawy, spotkania handlowe, informacje o możliwościach rynkowych w krajach docelowych, organizowanie spotkań z handlowcami w kraju docelowym, porady i konsultacje, pomoc w krajach docelowych, współpracę biznesową i organizację sieci współpracy, programy sektorowe, wsparcie finansowe, gwarancje kredytowe, zachęty podatkowe, dotacje, granty etc.

W ramach eksportu występuje też przepływ siły roboczej, w których biorą udział polscy pracownicy świadczący różnorodne usługi (np. budowlane czy montażowe).

Kolejnymi elementami wpływającymi na funkcjonowanie przedsiębiorstwa MŚP na rynku globalnym są umiejętność prawidłowej oceny zasobów, potrzeb odbiorców globalnych oraz zachowań pozostałych uczestników rynku globalnego w danej branży. Innowacja produktowa wywołuje efekt domina w wielu obszarach funkcjonowania przedsiębiorstwa produkcyjnego:

- w obszarze projektowania wyrobów - ze względu na konieczność tworzenia nowych receptur, technologii wytwarzania, doboru opakowań jednostkowych i zbiorczych,

- w obszarze marketingu - z powodu konieczności prowadzenia badań i testów rynkowych, dostosowania instrumentów marketingu do nowego wyrobu, segmentacji rynku, pojawienia się nowych rynków, nowych segmentów rynku, kreowania kolejnych nowych produktów,

- w obszarze techniki - ze względu na konieczność doboru maszyn i urządzeń do wytwarzania nowego wyrobu oraz dostosowania nowej maszyny do linii technologicznych zainstalowanych w przedsiębiorstwie,

- w obszarze technologii - z powodu konieczności doboru procesu technologicznego, ustalenia kolejności procesów technologicznych, dostosowania parametrów produkcji oraz metod monitorowania prawidłowości i efektów procesów technologicznych,

- w obszarze zarządzania - ze względu na konieczność zmiany struktury organizacyjnej przedsiębiorstwa, często dostosowanie jej do sposobu wytwarzania i przygotowania produkcji nowego wyrobu,

- w obszarze logistyki - w sferze zakupów: ze względu na wymagania odnośnie surowców, materiałów, konieczności skoordynowania działań logistycznych w sferze zaopatrzenia i magazynowania, w sferze produkcji: ze względu na umiejętne zarządzanie procesami produkcji i zapewnienie prawidłowości przepływów materialnych i informacyjnych, w sferze dystrybucji: zapewnienie realizacji zadań logistycznych w sferze dostaw na rynek (organizacja kanałów dystrybucji nowego produktu).

\footnotetext{
${ }^{1}$ Instrumenty wspierania działalności eksportowej firm MŚP w krajach Unii Europejskiej były badane przez Instytut EEDRI w Łodzi na zlecenie EIM Business Policy Research UE w ramach projektu „Internationalisation of EU SMEs to third countries” (Badania w ramach projektu „Internacjonalizacja unijnych małych i średnich firm na rynkach krajów trzecich”), w których to badaniach uczestniczyła autorka w roku 2010.
} 


\section{Proces innowacyjny w MŚP - analiza lańcucha wartości}

Innowacja powstaje podczas realizacji procesu, który rozpoczyna się sformułowaniem idei innowacyjnej, a kończy - wdrożeniem i komercjalizacją nowego produktu lub usługi. W wypadku przedsiębiorstwa MŚP przebieg procesu innowacyjnego jest bardziej uproszczony, niż wskazuje literatura opisująca procesy innowacyjne w dużych firmach produkcyjnych (Dworczyk, Szlasa 2001, s. 89). Wynika to z braku dostępu do laboratoriów i ośrodków badawczych, niewielkich zasobów oraz uproszczonej struktury organizacyjnej firm MŚP. Natomiast sam proces innowacyjny w firmie MŚP jest sumą sekwencyjnych faz (ogniw) działań - co pokazuje ryc. 1.

Przebieg procesu innowacyjnego trwa od pomysłu (idei innowacyjnej), przez realizację programu projektowania wyrobu, rozpoznawanie potrzeb nabywców i badania rynku, wprowadzanie modyfikacji i zmian do pierwotnego pomysłu, prace wdrożeniowe, aż po zastosowanie praktyczne, czyli komercjalizację ${ }^{2}$. Realizacja każdej fazy procesu innowacyjnego wymaga odpowiedniej wiedzy, przy czym jednocześnie efektem tejże fazy jest uzyskanie nowej wiedzy. Tak więc nowa wiedza oraz nowe doświadczenia i umiejętności powstałe w toku realizacji procesu innowacyjnego tworzą nowe wartości oraz wpływają na kształtowanie umiejętności przedsiębiorstwa MŚP, a w dłuższej perspektywie - na budowanie społeczeństwa opartego na wiedzy.

Ryc. 1. Łańcuch tworzenia wartości w procesie innowacyjnym - dla przedsiębiorstwa MŚP

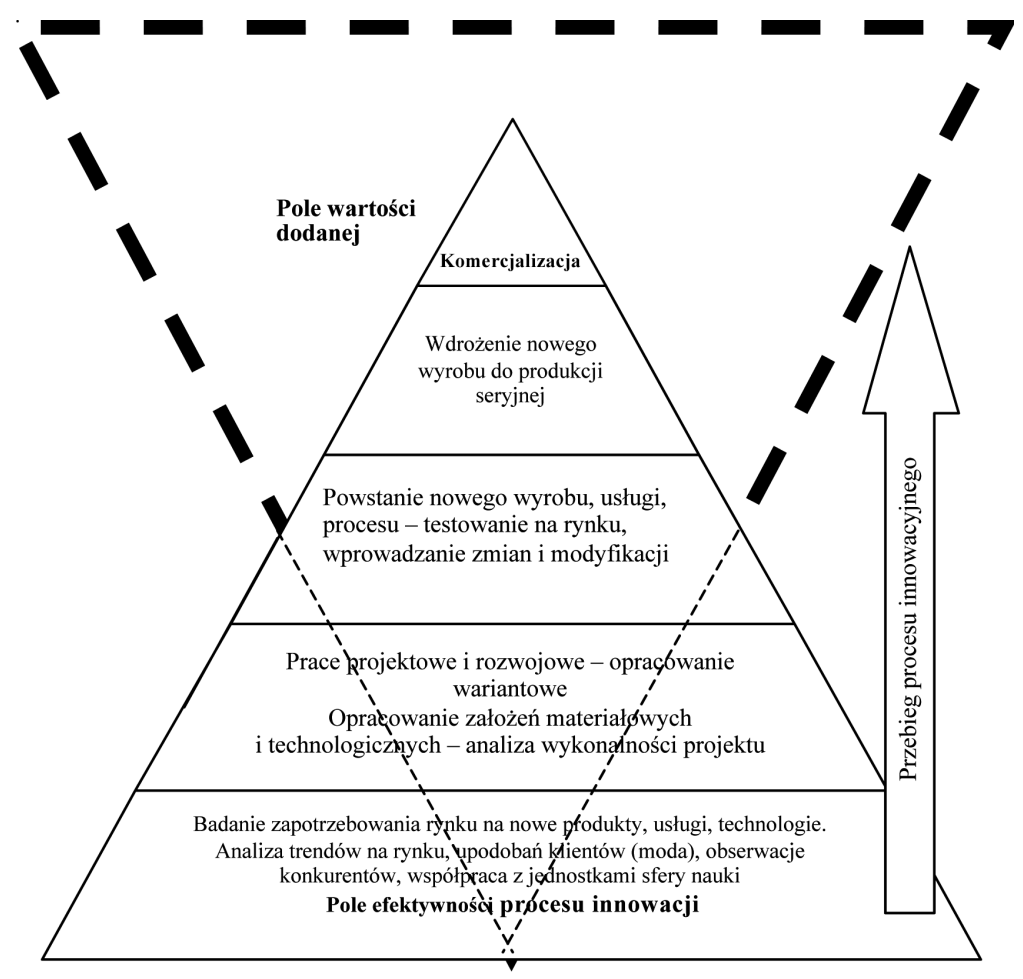

Źródło: opracowanie własne.

2 Koncepcja łańcucha tworzenia wartości innowacji została zaprezentowana przez L. Białoń i D. Janczewską w publikacji pod red. A.H. Jasińskiego Badania nad procesami transformacji wyników prac badawczo-rozwojowych w innowacje (,Studia i Materiały”, 25-7/2007, Uniwersytet Warszawski), w ramach programu badawczego PW-004/ITE/01. 
Łańcuch tworzenia wartości umożliwia analizę i prognozowanie efektów każdego etapu procesu innowacyjnego oraz ocenę efektów doraźnych i długofalowych z tytułu wdrażania innowacji. Zastosowanie metody analizy łańcucha wartości pozwala na tworzenie strategii innowacji oraz zarządzania nimi w przedsiębiorstwie z grupy MŚP. Strategie innowacji są tworzone na podstawie indywidualnych możliwości zasobowych i umiejętności przedsiębiorstwa MŚP. Obrazuje to rycina 2.

Ryc. 2. Elementy wpływające na zarządzanie strategiczne innowacjami w przedsiębiorstwie MŚP

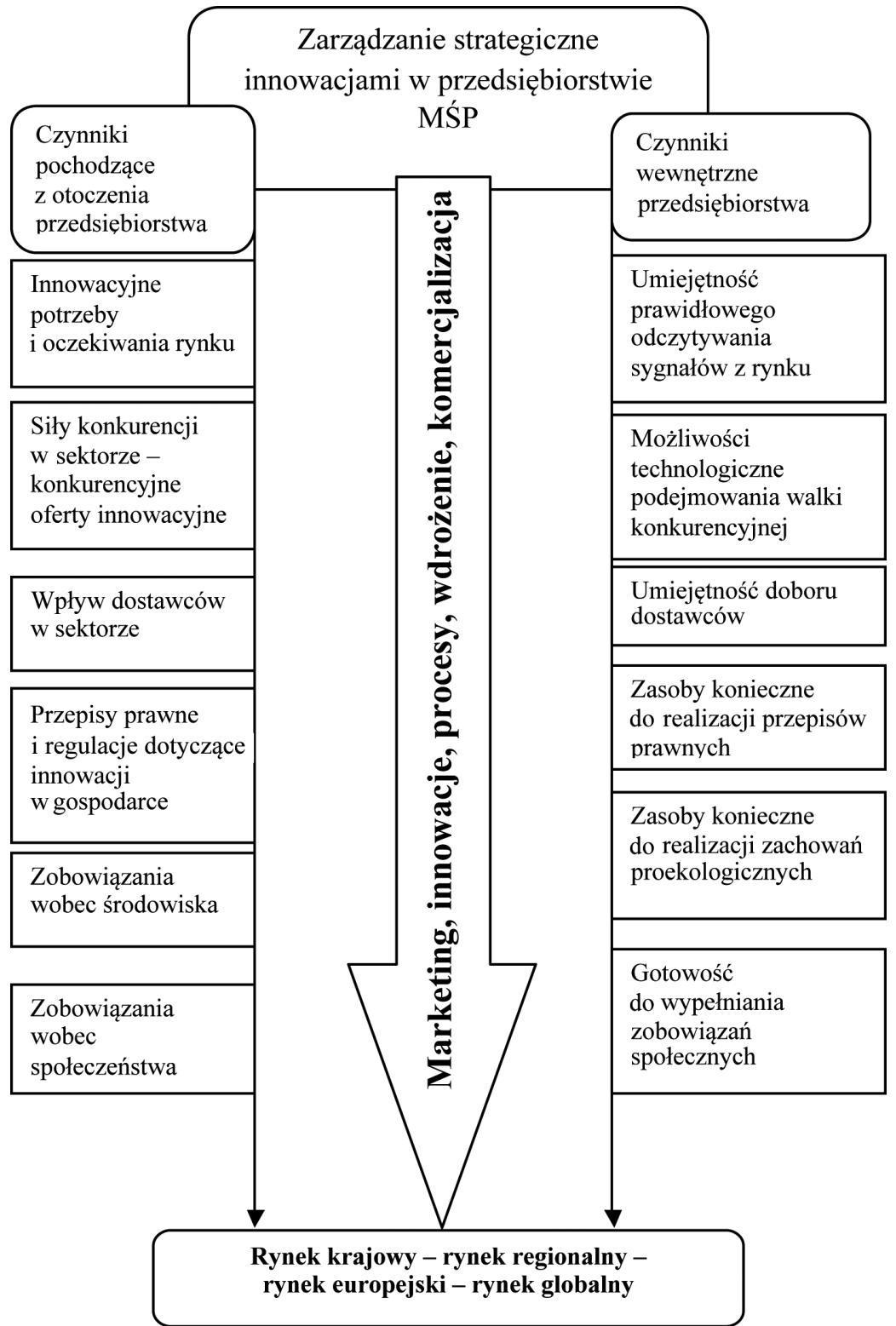

Źródło: opracowanie własne. 
Według A.P. Wiatraka (2004), małe i średnie przedsiębiorstwa mają najlepsze możliwości rozwoju w sektorach, w których nie występuje efekt skali produkcji. Należą do nich dziedziny, gdzie:

- produkcja wyrobów jest uzależniona od popytu sezonowego,

- koszty produkcji mają charakter zmienny i trudny do przewidzenia,

- produkcja odbywa się na mniejszą skalę i w wąskim asortymencie,

- wytwarzane są wyroby ściśle wyspecjalizowane i rzadko poszukiwane,

- produkuje się wyroby zapełniające określone nisze rynkowe, omijane przez dużych producentów,

- rozwija się kooperacja lub integracja pionowa czy pozioma,

- możliwe jest działanie w formie organizacji wirtualnej i zarządzanie poprzez projekty,

- możliwe jest odchudzenie firm - Lean management i outsourcing.

Szczególne efekty marketingowe oraz wartość dodaną dla przedsiębiorstwa MŚP - jako skutek wprowadzenia innowacji produktowej - można wskazać na przykładzie sektora cukierniczego (tab. 2). Firmy zagraniczne działające w sektorze wyrobów cukierniczych w Polsce prezentują innowacje produktowe jako zauważalny dla klientów przejaw rozwoju i dbałości o rynek. Stwarza to sytuację, w której pozostali producenci wyrobów cukierniczych (firmy z grupy MŚP) podejmują starania o wytworzenie podobnie atrakcyjnych wyrobów, interesujących dla nabywców.

Tab. 2. Wpływ innowacji produktowych wprowadzanych przez firmy zagraniczne w sektorze wyrobów cukierniczych na rozwój sektora cukierniczego w Polsce

\begin{tabular}{|c|c|c|}
\hline $\begin{array}{l}\text { Rodzaj } \\
\text { innowacji }\end{array}$ & $\begin{array}{c}\text { Przykład wdrożenia innowacji } \\
\text { produktowej przez firmę zagraniczną } \\
\text { na polskim rynku }\end{array}$ & $\begin{array}{c}\text { Wartość dodana w MŚP jako efekt } \\
\text { wprowadzenia innowacji produktowej }\end{array}$ \\
\hline $\begin{array}{l}\text { Innowacje } \\
\text { produktowe }\end{array}$ & $\begin{array}{l}\text { Nowe wyroby lub technologie całkowi- } \\
\text { cie zastępujące dotychczasowe: } \\
\text { - czekolada napowietrzana (Stollwerck, } \\
\text { Terravita) } \\
\text { - czekolada z „,crispy”, „łaciata” (Kraft } \\
\text { Foods), czekolada z herbatnikiem } \\
\text { (Stollwerck) } \\
\text { - czekolada marcepanowa (Stollwerck) } \\
\text { - seria czekolad nadziewanych galaretką } \\
\text { (Nestlé, Stollwerck) } \\
\text { - zmiana projektu, kolorystyki, formatu } \\
\text { opakowań na czekolady (np. Wedel, } \\
\text { Goplana, Fazer, Wawel, Union } \\
\text { Chocolate i in.) }\end{array}$ & $\begin{array}{l}\text { 1. Rozszerzenie asortymentu czekolad } \\
\text { 2. Wprowadzenie nowych opakowań } \\
\text { 3. Identyfikacja nowych trendów na rynku } \\
\text { 4. Wprowadzenie żywności funkcjonalnej } \\
\text { 5. Wymuszenie na konkurencji swoistego } \\
\text { wyścigu asortymentowego } \\
\text { 6. Efekt naśladownictwa wśród firm } \\
\text { polskich } \\
\text { 7. Możliwość konkurowania na rynkach } \\
\text { zagranicznych } \\
\text { 8. Wzrost kreatywności działów projekto- } \\
\text { wania i rozwoju w polskich firmach } \\
\text { 9. Implementacja nowych technik } \\
\text { i technologii wytwarzania czekolady }\end{array}$ \\
\hline
\end{tabular}

Źródło: opracowanie własne na podstawie Nauka i technika w Polsce w 2006 roku, GUS, Warszawa 2007.

Innowacje stają się czynnikiem stymulującym wzrost konkurencyjności MŚP - w miarę ich możliwości i w danym sektorze. Wzrost zdolności konkurencyjnej tych firm przejawia się w: obniżaniu kosztów działalności, obniżaniu cen produktów czy też świadczonych usług, wprowadzaniu na rynek nowych bądź zmodernizowanych produktów i usług, poprawie ich jakości. 
Aktywność innowacyjna organizacji może być przedmiotem analiz i pomiarów poprzez monitorowanie intensywności wdrażania nowych produktów, technologii, innowacji organizacyjnych, marketingowych i ekologicznych ${ }^{3}$.

Sposób wprowadzania innowacji w przedsiębiorstwie zależy od zasobów i umiejętności MŚP, zwłaszcza od zasobów finansowych, które pozwolą na przygotowanie innowacji w fazie koncepcji, co zostało pokazane na rycina 1.

W literaturze wymieniane są jeszcze inne dziedziny, w których małe i średnie firmy funkcjonujące w warunkach globalizacji mogą szukać swoich szans rozwojowych. Są to w szczególności:

- wstępne przetwórstwo surowców,

- produkcja wyrobów będących specjalnościami regionalnymi,

- produkcja wyrobów oparta na tradycyjnych technologiach,

- produkty ekologiczne,

- produkcja na bezpośrednie zamówienie dużych sieci handlowych.

Efekty dyfuzji wiedzy na przykładzie sektora cukierniczego obrazuje tabela 3.

Tab. 3. Wpływ dyfuzji wiedzy na rozwój MŚP - na przykładzie sektora cukierniczego

\begin{tabular}{|c|c|c|}
\hline $\begin{array}{c}\text { Przykład działania } \\
\text { w przedsiębiorstwie zagranicznym }\end{array}$ & $\begin{array}{l}\text { Przejaw wiedzy } \\
\text { - nowe formy } \\
\text { zarządzania } \\
\text { wiedzą }\end{array}$ & $\begin{array}{l}\text { Efekt dyfuzji wiedzy do polskiej } \\
\text { firmy podwykonawczej (MŚP) }\end{array}$ \\
\hline $\begin{array}{l}\text { Wspólne narady z kierownictwem } \\
\text { holdingu, w których biorą udział } \\
\text { przedstawiciele wszystkich firm-córek, } \\
\text { w tym również zagranicznych } \\
\text { Możliwość wymiany poglądów } \\
\text { między pracownikami wszystkich } \\
\text { przedsiębiorstw w holdingu }\end{array}$ & $\begin{array}{l}\text { Wymiana } \\
\text { poglądów }\end{array}$ & $\begin{array}{l}\text { Podejmowanie wspólnych decyzji, } \\
\text { ustalanie działań jednolitych w skali } \\
\text { grupy - również w ramach całego } \\
\text { holdingu - w firmach zagranicznych } \\
\text { oraz polskich } \\
\text { Wymiana informacji między } \\
\text { pracownikami - prowadzi do przyspie- } \\
\text { szenia procesów innowacyjnych w skali } \\
\text { przedsiębiorstwa }\end{array}$ \\
\hline $\begin{array}{l}\text { Specjaliści z zakresu technologii } \\
\text { dzielą się swoimi umiejętnościami } \\
\text { z zakładami polskimi w zakresie: } \\
\text { - technologii, } \\
\text { - organizacji, } \\
\text { • zarządzania. } \\
\text { Forma: narady, szkolenia, warsztaty, } \\
\text { pokazy }\end{array}$ & $\begin{array}{l}\text { Wymiana } \\
\text { umiejętności }\end{array}$ & $\begin{array}{l}\text { Przyspieszenie wdrożeń technicznych } \\
\text { i technologicznych w wyniku wymiany } \\
\text { umiejętności. } \\
\text { Możliwość szybkiego wdrożenia zasad } \\
\text { nowoczesnego marketingu i planowania } \\
\text { strategicznego jako efekt wymiany } \\
\text { umiejętności z zakresu organizacji } \\
\text { i zarządzania }\end{array}$ \\
\hline $\begin{array}{l}\text { Zapoznanie polskich menedżerów } \\
\text { z doświadczeniami zagranicznymi } \\
\text { dotyczącymi produkcji, kierowania } \\
\text { sprzedażą, marketingu - podczas } \\
\text { wyjazdów do filii za granicą }\end{array}$ & $\begin{array}{l}\text { Wymiana } \\
\text { doświadczeń }\end{array}$ & $\begin{array}{l}\text { Możliwość udziału we wszystkich } \\
\text { działaniach - od unowocześniania } \\
\text { produkcji aż do międzynarodowych } \\
\text { targów słodyczy }\end{array}$ \\
\hline
\end{tabular}

\footnotetext{
${ }^{3}$ Wydaje się, że niskie wskaźniki dotyczące innowacyjności polskich MŚP wynikają z niedokładnego definiowania innowacji, istotnego ulepszenia etc. Nie wszyscy przedsiębiorcy zaliczają do działań innowacyjnych ulepszenia produktów czy procesów.
} 


\begin{tabular}{|c|c|c|}
\hline $\begin{array}{l}\text { Wdrożenie nowych rozwiązań } \\
\text { technicznych w sferze produkcji } \\
\text { czekolad oraz utworzenie między- } \\
\text { narodowego systemu zarządzania } \\
\text { w sferze zaopatrzenia w surowce } \\
\text { i opakowania }\end{array}$ & $\begin{array}{l}\text { Tworzenie } \\
\text { nowych } \\
\text { koncepcji } \\
\text { rozwiązań } \\
\text { technicznych }\end{array}$ & $\begin{array}{l}\text { Możliwość szybkiego dostosowania } \\
\text { procesów produkcji i zarządzania do } \\
\text { wymagań europejskich i światowych }\end{array}$ \\
\hline $\begin{array}{l}\text { Ustanowienie centralnego } \\
\text { i macierzowego systemu zarządzania } \\
\text { - z włączeniem polskich filii } \\
\text { do struktury holdingu }\end{array}$ & $\begin{array}{l}\text { Tworzenie } \\
\text { nowych } \\
\text { rozwiązań } \\
\text { organizacyj- } \\
\text { nych }\end{array}$ & $\begin{array}{l}\text { Możliwość włączenia polskich firm do } \\
\text { systemu zarządzania obowiązującego } \\
\text { w zagranicznych filiach podległych } \\
\text { centrali. Utworzenie jednej sieci } \\
\text { dystrybucji dla grupy polskich filii } \\
\text { poprzez budowę jednolitego systemu } \\
\text { sieci hurtowni regionalnych } \\
\text { Rozpoczęcie wdrażania ISO i HACCP } \\
\text { w branży produkcji czekolady w Polsce } \\
\text { na początku lat } 90 \text {. XX w. wraz } \\
\text { z rozpoczęciem inwestycji zagranicz- } \\
\text { nych w branży. Wdrażanie szczególnych } \\
\text { wymagań w zakresie bezpieczeństwa } \\
\text { produkcji żywności } \\
\text { Dystrybucja słodyczy w Polsce } \\
\text { w firmach zagranicznych realizowana } \\
\text { poprzez Regionalne Centra Dystrybucji } \\
\text { z włączeniem logistyki i dystrybucji } \\
\text { w zakresie sprzedaży krajowej oraz } \\
\text { wprowadzaniem na rynek krajowy } \\
\text { wyrobów przedsiębiorstw z grupy } \\
\text { innych krajów } \\
\text { Dystrybucją wyrobów cukierniczych } \\
\text { grupy na rynki międzynarodowe } \\
\text { zajmują się wyspecjalizowane firmy } \\
\text { handlowe, współpracujące ze wszystki- } \\
\text { mi przedsiębiorstwami z grupy. }\end{array}$ \\
\hline $\begin{array}{l}\text { Organizowanie spotkań i narad } \\
\text { z uczestnikami sieci dystrybucji, } \\
\text { kooperantami, dostawcami surowców, } \\
\text { producentami maszyn - zarówno } \\
\text { w kraju, jak i za granicą }\end{array}$ & $\begin{array}{l}\text { Przekazywanie } \\
\text { wiedzy poza } \\
\text { organizację }\end{array}$ & $\begin{array}{l}\text { Możliwość powstawania sieci } \\
\text { kooperacyjnych, wzajemnie } \\
\text { współpracujących firm podwykonaw- } \\
\text { czych i dostawczych. Możliwość } \\
\text { powstania efektu synergii }\end{array}$ \\
\hline
\end{tabular}

Źródło: opracowanie własne.

Małe i średnie przedsiębiorstwa mają szansę na osiąganie sukcesów rynkowych na rynkach lokalnych, oferując wyroby dostosowane do specyfiki tych rynków oraz produkując tanie wyroby masowe, adresowane do określonego segmentu rynku. Chłonność tych segmentów będzie się jednak zmniejszać. MŚP mają również szanse na występowanie w roli dostawców i kooperantów przedsiębiorstw zagranicznych funkcjonujących na danych rynkach lokalnych poprzez dostosowanie swoich możliwości produkcyjnych do określonych wymagań technicznych, technologicznych, surowcowych i logistycznych. Przykładem wykorzystania tego typu powiązań jest sektor cukierniczy, w którym duże firmy zagraniczne budują relacje kooperacyjne i podwykonawcze z firmami z grupy MŚP: dostawcami usług, opakowań, surowców, części maszyn etc. W tab. 4 przedstawione zostały działania firm zagranicznych w sektorze cukierniczym 
w zakresie transferu wiedzy oraz efekty tego transferu zauważalne w firmach MŚP w tym sektorze. Przed MŚP - oprócz podnoszenia konkurencyjności na rynkach krajowych - jawi się zatem perspektywa poszukiwania rynków zagranicznych poprzez powiązania kooperacyjne np. z międzynarodowymi sieciami handlowymi, poprzez budowanie relacji partnerskich z klientami globalnymi.

Tab. 4. Wartość dodana w procesie budowania marketingu partnerskiego

\begin{tabular}{|c|c|c|}
\hline $\begin{array}{c}\text { Elementy marketingu } \\
\text { partnerskiego }\end{array}$ & $\begin{array}{l}\text { Przykłady realizacji w branży } \\
\text { czekolad }\end{array}$ & Wartość dodana \\
\hline $\begin{array}{l}\text { Tworzenie nowych } \\
\text { wartości } i \text { ich podział } \\
\text { między producenta } \\
\text { a klienta }\end{array}$ & $\begin{array}{l}\text { - budowanie nowych, trwałych marek } \\
\text { czekolad w Polsce, np. Stollwerck, } \\
\text { Cadbury } \\
\text { - współpraca w promocjach czekolad, } \\
\text { przynosząca korzyści obu stronom, } \\
\text { np. promocja czekolady Milka }\end{array}$ & $\begin{array}{l}\text { powstanie nowych marek, } \\
\text { budowanie nowych relacji } \\
\text { pomiędzy producentami } \\
\text { a rynkiem, powstawanie nowych } \\
\text { wyrobów }\end{array}$ \\
\hline $\begin{array}{l}\text { Glówna rola } \\
\text { indywidualnego } \\
\text { klienta, określanie } \\
\text { rodzaju korzyści dla } \\
\text { klienta }\end{array}$ & $\begin{array}{l}\text { - dostosowanie opakowań czekolad do } \\
\text { wymagań klientów (np. dostosowanie } \\
\text { rozmiaru kartonika do wymagań } \\
\text { supermarketów - tak, by mieścił się } \\
\text { na półce) } \\
\text { zwiększanie asortymentu czekolad, } \\
\text { zgodnie z oczekiwaniami klientów } \\
\text { indywidualnych, którzy osiągają } \\
\text { korzyści z bogatszej oferty }\end{array}$ & $\begin{array}{l}\text { - wzrost zadowolenia i satysfakcji } \\
\text { klientów } \\
\text { - wzrost sprzedaży } \\
\text { - wzrost zysków przedsiębiorstw } \\
\text { równiwieść poszerzenia rynków, } \\
\text { we }\end{array}$ \\
\hline $\begin{array}{l}\text { Projektowanie } \\
\text { procesów, narzędzi } \\
\text { komunikacji, } \\
\text { technologii - do } \\
\text { tworzenia wartości } \\
\text { oczekiwanych przez } \\
\text { klientów }\end{array}$ & $\begin{array}{l}\text { - wprowadzanie nowoczesnych } \\
\text { technologii, gwarantujących np. } \\
\text { pakowanie różnych gatunków } \\
\text { czekolad do jednego opakowania } \\
\text { zbiorczego - co ma znaczenie np. } \\
\text { w akcjach promocyjnych } \\
\text { - wprowadzanie nowych kanałów } \\
\text { komunikacyjnych - np. internetowe } \\
\text { witryny producentów czekolad, dające } \\
\text { bezpośredni dostęp do działu } \\
\text { marketingu, sprzedaży i skracające } \\
\text { czas komunikacji }\end{array}$ & $\begin{array}{l}\text { - unowocześnienie produkcji, } \\
\text { przyspieszenie dystrybucji } \\
\text { - wykorzystywanie współcze- } \\
\text { snych kanałów dystrybucji } \\
\text { - rozwój nowych kanałów } \\
\text { dystrybucji globalnej } \\
\text { - przyspieszenie przepływu } \\
\text { towarów } \\
\text { - lepsza komunikacja pomiędzy } \\
\text { producentami a nabywcami }\end{array}$ \\
\hline $\begin{array}{l}\text { Trwala wspólpraca } \\
\text { między nabywcą } \\
\text { a sprzedawcą }\end{array}$ & $\begin{array}{l}\text { - bezpośrednie kontakty z klientami, } \\
\text { ankietowanie celem uzyskania } \\
\text { informacji o oczekiwaniach klientów } \\
\text { - przeprowadzanie degustacji, akcji } \\
\text { promocyjnych celem uzyskania opinii } \\
\text { klientów } \\
\text { - badanie satysfakcji klientów }\end{array}$ & $\begin{array}{l}\text { budowanie trwałych relacji, } \\
\text { przywiązanie klienta do marki, } \\
\text { budowanie lojalności klientów } \\
\text { globalnych }\end{array}$ \\
\hline
\end{tabular}

\footnotetext{
${ }^{4} \mathrm{~W}$ branży czekolad można obserwować rozwój nowoczesnych koncepcji zarządzania - m.in. interfuzji, której istotą są wartości, a celem - budowanie wspólnej świadomości konsumentów. Szerzej na ten temat w: Bogusław Imbs, Niektóre strategiczne problemy rozwoju rolnictwa i obrotu żywnościa, „Przemysł Spożywczy" 1/2003, s. 16.
} 


\begin{tabular}{|c|c|c|}
\hline $\begin{array}{l}\text { Ocena klienta } \\
\text { w całym okresie } \\
\text { aktywności nabywczej }\end{array}$ & $\begin{array}{l}\text { - monitorowanie parametrów dostaw } \\
\text { czekolad, analiza } \\
\text { - indywidualnych klientów } \\
\text { - reagowanie na zmieniające się } \\
\text { potrzeby i oczekiwania } \\
\text { - odbiorców czekolad }\end{array}$ & $\begin{array}{l}\text { - wzmacnianie relacji z klientami, } \\
\text { wzrost roli klienta globalnego } \\
\text { w tworzeniu nowych wyrobów, } \\
\text { wzrost satysfakcji klientów }\end{array}$ \\
\hline $\begin{array}{l}\text { Tworzenie lańcucha } \\
\text { partnerstwa } \\
\text { wewnątrz przedsię- } \\
\text { biorstwa oraz } \\
\text { z partnerami } \\
\text { zewnętrznymi }\end{array}$ & $\begin{array}{l}\text { - budowanie trwałych więzi i zaufania } \\
\text { u klientów } \\
\text { - tworzenie łańcucha partnerstwa } \\
\text { wewnątrz firmy - prawidłowa } \\
\text { komunikacja wszystkich działów } \\
\text { w firmie produkujących czekoladę } \\
\text { - tworzenie łańcucha partnerstwa } \\
\text { z kooperantami - dostawcami } \\
\text { surowców, opakowań, firmami } \\
\text { reklamowymi etc. }\end{array}$ & $\begin{array}{l}\text { wykorzystywanie efektu } \\
\text { synergii poprzez łańcuchy } \\
\text { partnerstwa, obniżanie kosztów, } \\
\text { możliwość realizowania } \\
\text { wspólnych projektów innowa- } \\
\text { cyjnych w dziedzinie wyrobów, } \\
\text { technologii, procesów }\end{array}$ \\
\hline
\end{tabular}

Źródło: opracowanie własne.

Efekty działalności MŚP w poszczególnych ogniwach procesu innowacyjnego, a przede wszystkim fazy wdrażania i dyfuzji innowacji, znajdują wyraz:

- we wzroście udziału MŚP w sektorach nowoczesnych,

- w zmianie proporcji w MŚP pomiędzy wyrobami tradycyjnymi a nowoczesnymi (high-tech, super high-tech, easy-tech),

- w pojawieniu się nowych czynników produkcji w różnych dziedzinach i branżach przemysłu oraz usług,

- w większym zainteresowaniu MŚP zmianą proporcji pomiędzy technologiami tradycyjnymi a nowoczesnymi (ekologicznymi, bezodpadowymi),

- w możliwościach wzrostu w MŚP udziału wyrobów nowoczesnych w dotychczasowych rynkach i segmentach klientów,

- w powstawaniu nowych segmentów klientów - nabywców wyrobów i usług MŚP,

- w monitorowaniu struktury konsumpcji i jej zmian,

- w zmniejszeniu stref zdegradowanych ekologicznie,

- w rozwoju różnych form kształcenia i szkolenia.

Do przejawów wartości dodanej powstałych na skutek wdrożenia innowacji oraz jej upowszechnienia, a występujących na poziomie przedsiębiorstw z grupy MŚP zaliczyć można:

- poprawę struktury asortymentowej wyrobów,

- poprawę jakości wyrobów poprzez wprowadzenie standaryzacji, normalizacji i certyfikacji,

- oszczędności w zużyciu czynników produkcji (surowców, materiałów, energii, przestrzeni, czasu pracy),

- wprowadzenie nowych, czystszych technologii, nowych systemów sterowania produkcją,

- wprowadzanie nowych systemów zarządzania procesowego w MŚP (produkcją, jakością, innowacjami, zasobami ludzkimi, logistyką, wiedzą),

- możliwości poszerzania rynków zbytu, wchodzenia przez MŚP na rynki globalne, dążenie do uzyskania i utrzymania przewagi konkurencyjnej, możliwość szybkiego reagowania na zmienne potrzeby rynku,

- wzrost wiedzy pracowników firm MŚP, stosowanie nowych systemów organizacji pracy, w tym pracę zespołową, 
- wzrost częstotliwości i zakresu szkoleń pracowników, a także konsumentów,

- wzrost powiązań merytorycznych z instytucjami otoczenia biznesowego, bankowego, naukowego, a także z klientami, wzrost powiązań instytucjonalnych z UE.

Szczepaniak (2007) zauważa, że dla polskiego przemysłu spożywczego wraz z poprawą pozycji polskich producentów żywności na rynku Wspólnoty pojawiły się nowe uwarunkowania, które w najbliższym czasie wpłyną na dalsze zmiany struktur podmiotowych tego przemysłu. Zmiany te będą jednak przebiegać w nieco innym kierunku niż w poprzedniej dekadzie, gdyż restrukturyzacja prowadzona przez grupy kapitałowe i liderów poszczególnych sektorów zwiększy zdolności ekspansji rynkowej tych podmiotów. Funkcjonowanie na rynku globalnym poprzez osiąganie standardów wymaganych np. przez UE osiągnęły głównie duże i średnie przedsiębiorstwa, a zatem to te grupy przedsiębiorstw mają największe szanse wejścia na rynek unijny i umocnienia swojej pozycji na tym rynku. Przykładem osiągania celów internacjonalizacji działalności przedsiębiorstwa są duże firmy transnarodowe, grupy kapitałowe lub organizacje typu sieciowego wprowadzające systemy zarządzania i zapewnienia jakości w oparciu o kapitał intelektualny, traktowany na równi z wartością kapitału rzeczowego i finansowego. W branży czekolad podobne postępowanie i procedury wdrażania innowacji i zarządzania wiedzą można odnaleźć w koncernach Kraft Jacobs Suchard, Nestlé, Ferrero. Stały się one przykładem dla wielu firm MŚP, wdrażających innowacje oraz naśladujących sposoby zarządzania wiedzą - w rozwoju konkurencyjności w warunkach globalizacji.

Wyżej wymienione efekty na poziomie przedsiębiorstw z grupy MŚP mogą również uwidocznić się w przyszłości, stanowiąc wartość dodaną w dłuższej perspektywie. Funkcjonowanie MŚP na rynku globalnym może doprowadzić w ostateczności do zmniejszenia luki technologicznej, organizacyjnej etc., przejawiającej się w inicjowaniu i dynamice podczas realizacji procesów innowacyjnych, a nade wszystko do zmniejszenia luki świadomościowej w zakresie roli wiedzy w kształtowaniu poziomu życia społeczeństwa.

Łańcuch wartości może stać się jedną z metod analizy aktywności innowacyjnej MŚP. Niewielki wymiar działalności innowacyjnej firm z tej grupy wynika z ograniczonych zasobów i wówczas właściwym kierunkiem rozwijania innowacyjności MŚP w warunkach globalizacji może stać się działalność eksportowa, wymiana handlowa oraz działania podwykonawcze, polegające na współpracy z zaawansowanymi technologicznie firmami zagranicznymi w kraju bądź na świadczeniu usług podwykonawczych za granicą. Przewidywanie przyszłych efektów działalności innowacyjnej MŚP, tzw. odłożonych w czasie, wywołuje konieczność wspierania działań innowacyjnych MŚP przez instytucje do tego powołane, w tym Unię Europejską.

\section{Literatura}

1. Czaja I., 2006, Procesy globalizacji i ich wplyw na innowacyjność sektora MŚP, „Zeszyty Naukowe Akademii Ekonomicznej w Krakowie", Nr 730.

2. Dworczyk M., Szlasa R., 2001, Zarzadzanie innowacjami, Oficyna Wydawnicza Politechniki Warszawskiej, Warszawa.

3. Głuszek E., 2004, Zarządanie zasobami niematerialnymi przedsiębiorstwa, Wydawnictwo Akademii Ekonomicznej im. O. Langego, Wrocław.

4. Imbs B., Niektóre strategiczne problemy rozwoju rolnictwa i obrotu żywnościa, „Przemysł Spożywczy” $1 / 2003$. 
5. Jasiński A.H. (red.), 2007, Badania nad procesami transformacji wyników prac badawczo-rozwojowych w innowacje, „Studia i Materiały”, nr 25-7, Uniwersytet Warszawski.

6. Janczewska D., 2009, Model zarządzania innowacjami w przedsiębiorstwie jako efekt transferu wiedzy ze sfery nauki do przemystu [w:] Szkoły wyższe kreatorem innowacji w gospodarce, Marcinkowski R. (red.), Wyd. Oficyna Wydawnicza Politechniki Warszawskiej, Warszawa.

7. Małe i średnie przedsiębiorstwa - istota i uwarunkowania ich działalności [w:] Przedsiębiorczość i innowacyjność matych $i$ średnich przedsiębiorstw - wyzwania wspótczesności, A. Kaleta, K. Moszkowicz, L. Woźniak (red.), Prace Naukowe Akademii Ekonomicznej we Wrocławiu, Wrocław 2004.

8. Nauka i technika w Polsce w 2006 roku, GUS, Warszawa, 2007.

9. Nauka $i$ technika $w$ Polsce $w 2008$ roku, GUS, Warszawa, 2010.

10. Piasecki B., Rogut A., Smallbone R., 2000, Wptyw integracji Polski z Unia Europejska na sektor $M S ́ P$, Polska Fundacja Promocji i Rozwoju Małych i Średnich Przedsiębiorstw, Warszawa.

11. Pyciński S., 2008, Ocena innowacyjności sektora MŚP w świetle badań PARP [w:] Przedsiębiorczość i innowacyjność w Polsce w kontekście europejskim - ocena dystansu, Fundacja Rozwoju Przedsiębiorczości, Łódź.

12. Szczepaniak I., 2008, Wpływ procesów globalizacji i integracji z UE na sektor MŚP na przykładzie matych i średnich firm spożywczych, „Zeszyty Naukowe”, Nr 7, Uniwersytet Rzeszowski.

13. Wiatrak A.P., 2004, Małe i średnie przedsiębiorstwa - istota i uwarunkowania ich działalności [w:] Przedsiębiorczość i innowacyjność matych i średnich przedsiębiorstw - wyzwania współczesności, A. Kaleta, K. Moszkowicz, L. Woźniak (red.), Prace Naukowe Akademii Ekonomicznej we Wrocławiu, Wrocław.

\section{Forming the Value Chain of Innovation of SMEs in Conditions of Globalization}

Definition and analysis of value chain of innovation in SMEs working in conditions of globalization can be explained on the ground of the eksport area and trade exchange and works as subcontractors, cooperating with foreign companies in country or realized the services abroad. Supporting and development of innovative activity can bring the effective advantages in future, too - as distance effect. One of the main effect can be growth of competitiveness of SMEs and reduction of technological gap. 


\section{Wioletta Kilar}

Uniwersytet Pedagogiczny

im. Komisji Edukacji Narodowej

w Krakowie

\section{Ksztaltowanie się Grupy Samsung w warunkach globalizacji}

Zachodzące w przestrzeni światowej procesy globalizacji oddziałują na gospodarkę, społeczeństwo, politykę i kulturę. Podstawową rolę w nasilaniu tych procesów odgrywają korporacje ponadnarodowe, które, lokalizując swoje oddziały w światowych układach regionalnych, wpływają na kształtowanie sieciowych układów rynkowych dla oferowanych produktów i usług. W konsekwencji korporacje stanowią wiodącą grupę podmiotów w gospodarce światowej oraz uaktywniają procesy umiędzynarodowienia działalności przedsiębiorstw (Rosińska-Bukowska 2009, Zioło 2006).

Postępujący proces rozwoju społeczno-gospodarczego, związany z przechodzeniem z fazy postindustrialnej do fazy informacyjnej, przejawia się m.in. powstawaniem nowych sektorów gospodarczych oraz instytucji, które spełniają nowe funkcje wynikające z nowych potrzeb postępu cywilizacyjnego. Istotną cechą społeczeństwa informacyjnego jest pojawianie się firm, które reprezentują nowy sektor przedsiębiorstw związanych z IT (Zioło 2004, s. 97).

Jak przyjmuje T. Stryjakiewicz (2009, s. 21-22), ,rozwój sektora informatycznego pociąga za sobą m.in.: zmianę tradycyjnych czynników lokalizacji działalności gospodarczej, zmianę ścieżek rozwoju regionalnego, zmianę polityki regionalnej i lokalizacyjnej”. Co istotne, współcześnie informację i wiedzę uznaje się za podstawowy, strategiczny zasób (bazę) gospodarki i firm, a ludzi za najważniejszy ich kapitał. Szczególną rolę w tej fazie rozwoju odgrywają technologie informatyczne, które są wykorzystywane nie tylko do obsługi i przetwarzania danych (tj. zbierania, przechowywania, analizowania i rozpowszechniania informacji), ale również m.in. do kreowania nowych wartości dla klientów, w postaci innowacyjnych produktów i usług (Borowiec 2009, Dorocki, Jenner 2009, Fields 2006, Kilar 2009, Rachwał 2008, Zioło 2008).

W świetle tych przesłanek zasadniczym celem niniejszej pracy jest przedstawienie analizy procesu kształtowania się Grupy Samsung. Zmierza się do określenia jej potencjału ekonomicznego, zasięgu oddziaływania i przestrzennego zróżnicowania asortymentu produkcji oraz uchwycenia nasilających się procesów globalizacji gospodarki światowej, które wpłynęły na kształtowanie się i rozwój badanej korporacji.

Korporacja Samsung została założona w 1938 r. w Taegu w Korei Południowej. W czasie rozwoju odznaczała się zmianami asortymentu produkcji i zasięgiem rynków. Początkowo firma zajmowała się głównie działalnością eksportową, sprzedając suszone ryby, warzywa i owoce do Mandżurii oraz Pekinu. Po upływie zaledwie jednej dekady firma Samsung posiadała już młyny zbożowe (m.in. ryżu) i urządzenia cukiernicze, zajmowała się produkcją i sprzedażą, a ostatecznie stała się fundamentem współczesnej globalnej korporacji (http://www.samsung.com). 
Rozwój firmy wiązał się z wprowadzaniem na rynek coraz to nowocześniejszych i bardziej funkcjonalnych urządzeń oraz z tworzeniem lub wykupywaniem małych firm z różnych branż.

Wraz z rozszerzaniem asortymentu produkcji i usług zmieniała się też struktura firmy. W latach 50. XX w. w strukturach Grupy Samsung powstały takie spółki-córki, jak: Samsung Moolsan (1951 r., obecnie Samsung Corporation), która zajmowała się głównie handlem, Cheil Industries Inc. (1954 r.), lider w Korei w branży włókienniczej, odzieżowej i chemicznej, oraz zakupiona firma z branży ubezpieczeniowej Ankuk Fire\&Marine Insurance (1958 r., w 1993 r. zmieniono nazwę na Samsung Fire\&Marine Insurance).

W latach 60. XX w. proces rozrastania się korporacji dynamicznie postępował. W $1963 \mathrm{r}$. przejęła ona firmę również z branży ubezpieczeniowej, DongBang Life Insurance (zmieniono nazwę na Samsung Life Insurance w lipcu 1989 r.), w 1966 r. założyła Joong-Ang Development zajmującą się budową m.in. kompleksów restauracji, klubów golfowych (obecnie Samsung Everland). W 1969 r. powstało przedsiębiorstwo Samsung-Sanyo Electronics (1 marca 1975 r. zmieniło ono nazwę na Samsung Electro-Mechanics), w którym po roku działalności rozpoczęto produkcję czarno-białego telewizora (model P-3202).

W latach 70. XX w. Samsung ukształtował strategiczne filary przyszłego rozwoju przedsiębiorstwa, inwestując w przemysł ciężki, chemiczny i petrochemiczny. W tym czasie firma podjęła również inicjatywę zmierzającą do wzmocnienia konkurencyjności na światowym rynku tekstylnym, integrując proces produkcji, począwszy od surowców aż po wyroby końcowe. W wyniku tych przedsięwzięć założono kilka nowych firm, w tym Samsung Heavy Industries Company (w 1974 r.) oraz Samsung Shipbuilding i Samsung Precision Company (obecnie Samsung Techwin w 1977 r.).

Kolejna fala dynamicznego rozwoju firmy nastąpiła wraz z rozwojem działu elektroniki użytkowej. Korporacja nabyła 50\% udziałów w firmie Korea Semiconductor, co spowodowało jej umocnienie jako lidera w dziedzinie produkcji półprzewodników. W 1974 r. rozpoczęła produkcję pralek i lodówek, a w 1979 r. - kuchenek mikrofalowych. W tym czasie Samsung był głównym producentem na krajowym rynku koreańskim i rozpoczął eksport produkowanych urządzeń za granicę.

Pod koniec lat 70. rozpoczął się okres urozmaicenia i globalnego wzrostu w podstawowych obszarach działalności firmy. W 1987 r. została założona firma Samsung Aerospace Industries (obecnie Samsung Techwin), która w bardzo szybkim tempie rozwijała swój potencjał, skupiając się na przemyśle lotniczym i astronautycznym. Korporacja podjęła się wdrażania systemów elektronicznych, otwierając w 1985 r. nową firmę Samsung Data Systems (obecnie Samsung SDS). Stała się ona liderem w zakresie usług technologii informacyjnych, obejmujących integrację systemów, zarządzanie nimi, doradztwo i usługi sieciowe. Rosnący nacisk na technologię w korporacji Samsung doprowadził do utworzenia w tym okresie dwóch instytutów badań i rozwoju (R\&D), które pomogły rozszerzyć zasięg działalności w zakresie elektroniki, półprzewodników, chemikaliów wysokopolimerowych, inżynierii genetycznej, telekomunikacji optycznej, przemysłu lotniczego i astronautycznego. Ponadto podjęto badania w nowych obszarach innowacyjnych technologii, od nanotechnologii po zaawansowaną architekturę sieciową.

Od 1987 r., tj. od śmierci założyciela firmy (Byung-Chull Lee), kiedy jego syn (Kun-Hee Lee) zastąpił go na stanowisku prezesa, Samsung skoncentrował się na restrukturyzacji tradycyjnych obszarów działalności i wprowadzeniu nowych zasad, dzięki którym przedsiębiorstwo miało dążyć do zdobycia pozycji jednej z pięciu głównych światowych firm elektronicznych. W tym okresie rozpoczęto produkcję klimatyzatorów (1980 r.) oraz komputerów osobistych (1983 r.).

Wczesne lata 90. XX w. były okresem ogromnych wyzwań ze względu na szybki rozwój wysoko zaawansowanych technologii. Trwała wówczas ogromna konkurencja i dochodziło do 
konsolidacji korporacji. Firmy zostały zmuszone do dokładnego przeanalizowania swoich technologii i oferty usług. Nastąpił rozwój międzynarodowej działalności handlowej pomiędzy krajami a firmami.

Samsung w pełni wykorzystał swoje możliwości, zmieniając strategię biznesową, tak by móc lepiej odpowiadać na potrzeby rynku. W tym czasie osiągał znakomite wyniki na polu nowych technologii, gdyż zakończono prace nad pierwszą na świecie dynamiczną pamięcią (DRAM 64 MB) oraz nad twardym dyskiem 250 MB, opracowano też własny system telefonów komórkowych. W 1992 r. rozpoczęto produkcję części wyrobów w Chinach.

Od połowy lat 90. w raportach finansowych korporacji wskazuje się na potrzebę dostosowania się do zachodzących procesów globalizacji, skoncentrowania się na wprowadzaniu na rynek innowacji oraz, co się z tym wiąże, zwiększenia nakładów na działalność badawczo-rozwojową z dotychczasowych 5\% wartości sprzedaży do 12\% w kolejnych latach.

W wyniku systematycznego rozwoju Grupa Samsung znacznie zwiększyła swój potencjał ekonomiczny i produkcyjny. W 1995 r. zatrudniała łącznie 256 tys. osób w swoich oddziałach w 66 państwach. Wówczas działalność korporacji koncentrowała się już na przemyśle elektronicznym, w którym zatrudnionych było 104 tys. osób, tj. 40,6\% ogółu zatrudnionych (ryc. 1). Znaczącą rolę odgrywała również działalność finansowa, skupiająca 33,7\% ogółu zatrudnionych. Najwyższe wyniki działalności zanotowano również w przemyśle elektronicznym. Łącznie Grupa Samsung osiągnęła sprzedaż wynoszącą 87 mld USD, w tym przedsiębiorstwa przemysłu elektronicznego uzyskały 27 mld USD, tj. 30,7\% ogółu wartości sprzedaży.

Ryc. 1. Struktura zatrudnienia i sprzedaży Grupy Samsung wg rodzajów działalności w 1995 r.

\section{zatrudnienie}

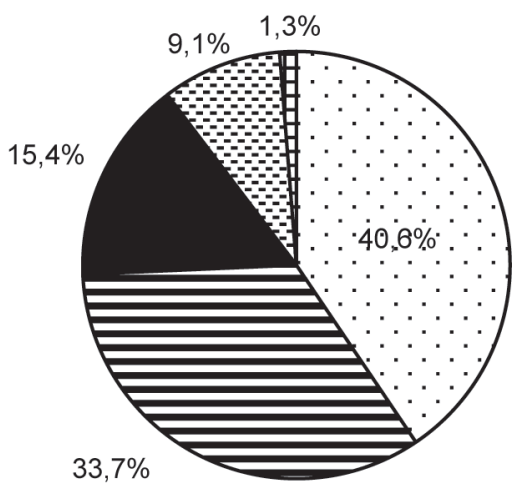

sprzedaż

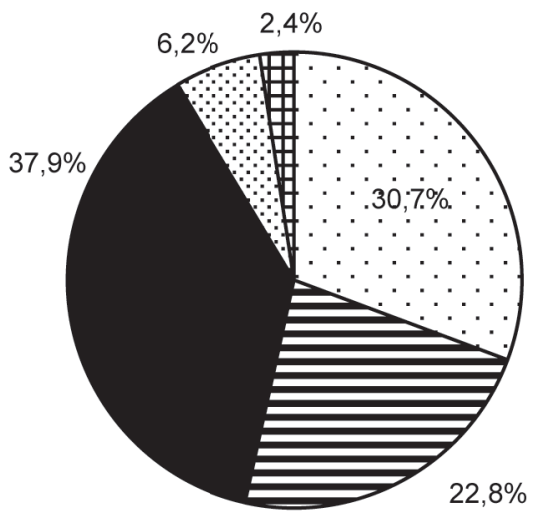

口Elektroniczny aFinanse Inne rodzaje działalności घMaszynowy 田Chemiczny

Źródło: opracowanie własne.

W drugiej połowie lat 90. wiele różnych produktów korporacji Samsung - począwszy od półprzewodników po monitory komputerowe i kolorowe kineskopy - uzyskało rangę czołowych produktów: pięć z nich miało największy udział w globalnym rynku, a kolejnych 12 zdobyło najwyższe pozycje na rynku krajowym (www.samsung.com). 
Uzyskanie czołowej pozycji oznaczało konieczność spełniania korporacyjnych zobowiązań społecznych w zakresie pomocy socjalnej, ochrony środowiska, wydarzeń kulturalnych oraz sportu, co przejawiało się np. poprzez szeroko zakrojony marketing sportowy. Wzmocniono w ten sposób wizerunek firmy jako kluczowego sponsora w sporcie, w tym przede wszystkim w lekkoatletyce. W zakresie nowych osiągnięć technologicznych w tym okresie w Grupie Samsung opracowano pierwszy na świecie aparat fotograficzny z czterokrotnym zoomem (Samsung Aerospace), pierwszy zbudowany w Korei samochód elektryczny (SEV-III; Samsung Heavy Industries), a w dziedzinie elektroniki stworzono najszybszą na świecie jednostkę centralną (CPU).

W końcu lat 90., pomimo kryzysu finansowego w krajach Azji Południowo-Wschodniej, który w 1997 r. dotknął niemal wszystkie firmy koreańskie, Samsung był jedną z niewielu korporacji notujących wzrost za sprawą wiodącej pozycji w dziedzinie technologii cyfrowych i sieciowych oraz koncentracji działań w zakresie elektroniki, finansów i powiązanych z nimi usług. W wyniku kryzysu korporacja Samsung dokonała redukcji liczby firm partnerskich do 45 (zgodnie z ustawą o monopolu i uczciwym handlu), ograniczyła liczbę personelu o prawie 50 tys. osób, sprzedała 10 jednostek handlowych i poprawiła własną kondycję finansową poprzez zmniejszenie zadłużenia. Poza tym rozpoczęła masową produkcję pierwszego na świecie telewizora cyfrowego, opracowała telefon z bezprzewodowym dostępem do Internetu (Smartphone), który cechował się również kompaktowością i wielofunkcyjnością, a także opracowała pierwszy na świecie monitor LCD TFT 3D (www.samsung.com).

Era cyfrowa przyniosła firmom o zasięgu globalnym wiele możliwości. Korporacja Samsung skupiła się na wprowadzaniu kolejnych zaawansowanych technologii, konkurencyjnych produktów i nieustającej innowacyjności. Po 2000 r. dążono nadal do osiągnięcia pozycji światowego lidera poprzez zdobycie największego udziału w rynku w przypadku 13 produktów. Ponadto dokonano historycznych postępów w dziedzinie badań i rozwoju linii półprzewodników, w tym pamięci flash, pamięci komputerowych (DRAM i SRAM), a także w dziedzinie produkcji wiodących w klasie telewizorów LCD, telefonów komórkowych i urządzeń cyfrowych. W tym okresie osiągnięto szereg sukcesów, które współcześnie decydują o pozycji korporacji na rynku międzynarodowym. Wśród nich znalazły się m.in.: opracowanie największego na świecie monitora telewizyjnego 54" TFT-LCD, tj. w technologii umożliwiającej uzyskanie obrazów najwyższej jakości, dotychczas używanej głównie w notebookach, trzeciej generacji nagrywarki optycznej Blu-Ray oraz wypuszczenie na rynek pierwszych na świecie telewizorów LCD 46".

W wyniku tworzenia się kolejnych spółek-córek w ramach korporacji, licznych przejęć i fuzji obecnie w skład grupy Samsung wchodzi 30 firm, reprezentujących różne rodzaje działalności, od elektroniki przez usługi finansowe do przemysłu ciężkiego, handlu i usług.

Działalność związaną z elektroniką reprezentuje siedem firm (tab. 1), z przemysłem ciężkim i maszynowym - jedna firma, z przemysłem chemicznym cztery przedsiębiorstwa, z usługami finansowymi sześć firm oraz 11 przedsiębiorstw reprezentujących inne rodzaje aktywności, m.in. budownictwo (Samsung C\&T Corporation), przemysł tekstylny (Cheil Industries), przemysł energetyczny i ciężki (Samsung Engineering). 
Tab. 1. Profile działalności Grupy Samsung w 2007 r.

\begin{tabular}{|c|c|c|}
\hline Lp. & $\begin{array}{c}\text { Rodzaj } \\
\text { działalności }\end{array}$ & Firmy reprezentujące działalność \\
\hline \multirow{7}{*}{1.} & \multirow{7}{*}{ Elektroniczna } & Samsung Electronics \\
\hline & & Samsung SDI \\
\hline & & Samsung Electro-Mechanics \\
\hline & & Samsung Corning Precision Glass \\
\hline & & Samsung SDS (Internet) \\
\hline & & Samsung Networks (telekomunikacja) \\
\hline & & Samsung Techwin (prod. kamer, rozwiązań optycznych, LED-ów i in.) \\
\hline 2. & Maszynowa & Samsung Heavy Industries (stoczniowy) \\
\hline \multirow{4}{*}{3.} & \multirow{4}{*}{ Chemiczna } & Samsung Total Petrochemicals \\
\hline & & Samsung Total Petrochemical \\
\hline & & Samsung Fine Chemicals \\
\hline & & Samsung BP Chemicals \\
\hline \multirow{6}{*}{4.} & \multirow{6}{*}{ Finanse } & Samsung Life Insurance \\
\hline & & Samsung Fire\&Marine Insurance \\
\hline & & Samsung Venture Investment Corp. \\
\hline & & Samsung Card \\
\hline & & Samsung Securities \\
\hline & & Samsung Investment Trust Managment \\
\hline \multirow{11}{*}{5.} & \multirow{11}{*}{ Inne rodzaje } & Samsung Engineering (elektrownie, rafinerie, huty) \\
\hline & & Samsung C\&T corp. (budowlana) \\
\hline & & Cheil Industries (Teskstylny) \\
\hline & & Samsung Everland (kompleksy restauracji) \\
\hline & & The Shilla Hotels\&Resorts \\
\hline & & Cheil Worldwide (marketing, konsulting) \\
\hline & & S1 (systemy bezpieczeństwa) \\
\hline & & Samsung Lions (dryżyna basebolowa w Korei) \\
\hline & & Samsung Medical Center \\
\hline & & Samsung Economic Research institute \\
\hline & & Samsung Foundation of Culture \\
\hline
\end{tabular}

Źródło: opracowanie własne na podstawie raportów rocznych. 
Współcześnie w strukturze Grupy Samsung dominuje działalność firm elektronicznych. W 2007 r. spośród 275,1 tys. osób zatrudnionych w korporacji przemysł elektroniczny skupiał 209 tys. osób, tj. 76,0\% ogółu (ryc. 2). Również osiągane wyniki wskazują, że firmy elektroniczne dominują w strukturze. Łącznie dla Grupy wartość sprzedaży wynosiła 192,7 mld USD, z czego aż 118,2 mld, tj. 61,4\% skupiona była w przemyśle elektronicznym.

Ryc. 2. Struktura zatrudnienia i sprzedaży Grupy Samsung wg rodzajów działalności w 2007 r.

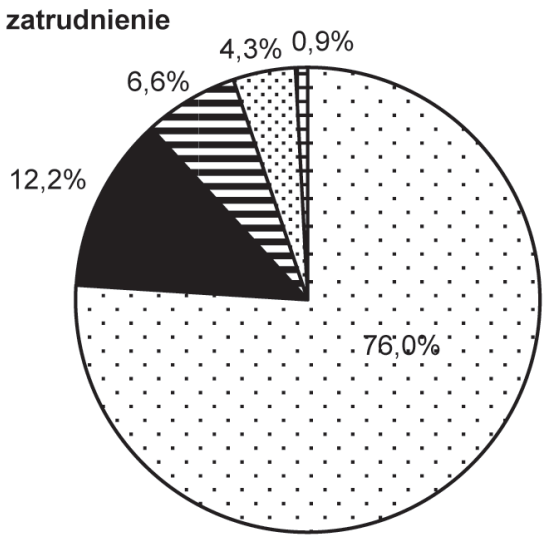

घElektroniczny
Inne rodzaje działalności

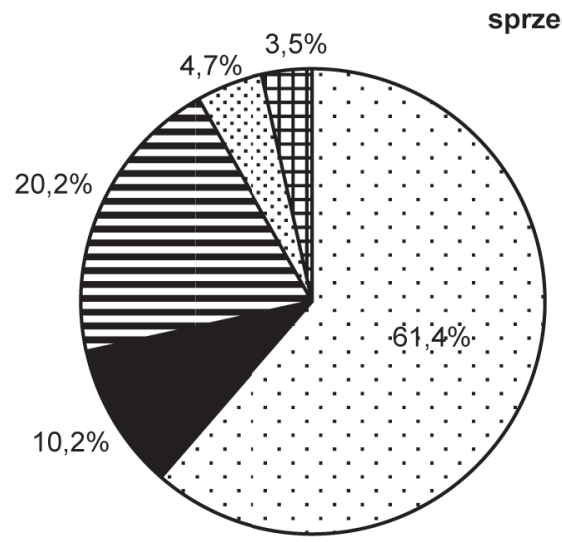

aFinanse DMaszynowy

口Chemiczny

Źródło: opracowanie własne.

Zaznaczyć należy, że spośród firm elektronicznych decydujące znaczenie w strukturze ma Samsung Electronics, który zatrudniał w 2007 r. 150 tys. osób, tj. 54,5\% ogółu zatrudnionych w Grupie Samsung, a jego sprzedaż wynosiła 105 mld USD, tj. 55\% ogółu wartości sprzedaży w Grupie.

Wyrazem rozwoju korporacji Samsung jest wzrost wartości mierników potencjału oraz zasięgu oddziaływania. W latach 1991-2007 wartość dochodów netto wzrosła z 348 mln USD do 13,9 mld USD, tj. niemalże 40-krotnie (tab. 2).

Tab. 2. Zmiany wartości mierników potencjału Grupy Samsung w latach 1991-2007

\begin{tabular}{|c|c|c|c|c|}
\hline Lata & $\begin{array}{c}\text { Przychody netto ze } \\
\text { sprzedaży (net sales) } \\
\text { w mln USD }\end{array}$ & $\begin{array}{c}\text { Aktywa ogólem } \\
\text { (total assets) } \\
\text { w mln USD }\end{array}$ & $\begin{array}{c}\text { Dochód netto } \\
\text { (net income) } \\
\text { w mln USD }\end{array}$ & $\begin{array}{c}\text { Pracujacy } \\
\text { (emplyees) } \\
\text { w tys. osób }\end{array}$ \\
\hline 1991 & 43900 & 43500 & 348 & 183 \\
\hline 1992 & 48900 & 48200 & 357 & 189 \\
\hline 1993 & 51300 & 50600 & 521 & 191 \\
\hline 1994 & 63800 & 64000 & 1681 & 206 \\
\hline 1995 & 83700 & 87100 & 3802 & 233 \\
\hline 1996 & 92721 & 98400 & 164 & 260 \\
\hline 1997 & 96100 & 111800 & 291 & 267 \\
\hline
\end{tabular}




\begin{tabular}{|c|r|r|r|r|}
\hline 1998 & 72000 & 91500 & 201 & 193 \\
\hline 1999 & 93500 & 116700 & 2200 & 161 \\
\hline 2000 & 119500 & 113700 & 7300 & 174 \\
\hline 2001 & 98700 & 124300 & 4500 & 170 \\
\hline 2002 & 116800 & 156100 & 8900 & 175 \\
\hline 2003 & 101700 & 170400 & 5600 & 195 \\
\hline 2004 & 121700 & 209400 & 11800 & 222 \\
\hline 2005 & 140900 & 233800 & 9400 & 229 \\
\hline 2006 & 158900 & 280800 & 12900 & 254 \\
\hline 2007 & 174200 & 302900 & 13900 & 263 \\
\hline $\begin{array}{c}\text { Dynamika } \\
1991-2007\end{array}$ & 396,8 & 696,3 & 3994,3 & 143,7 \\
\hline
\end{tabular}

Źródło: opracowanie własne.

Znacznie mniejsze tempo wzrostu miało miejsce w przypadku aktywów, których wartość wzrosła z 43,5 mld USD do 302,9 mld, tj. blisko siedmiokrotnie. Natomiast wartość przychodów netto ze sprzedaży wzrosła w tym okresie z 44 mld USD do 174 mld, czyli do 396,8\% (ryc. 3). Mimo że korporacja w tym czasie znacznie powiększyła swój potencjał ekonomiczny, ten silny rozwój wynikał przede wszystkim z wprowadzania nowych technologii oraz wzrostu wydajności produkcji. Świadczy o tym stosunkowo niewielki wzrost liczby osób zatrudnionych w korporacji Samsung z 183 tys. do 263 tys. osób, tj. do 143,7\%. Obecnie zasięg oddziaływania Grupy Samsung obejmuje większość państw, przy czym największa koncentracja oddziałów korporacji występuje w Azji Południowo-Wschodniej, Stanach Zjednoczonych i Europie Zachodniej (ryc. 3, tab. 3). Największa liczba oddziałów występuje w rodzimej Korei Południowej, w której skupia się 9,6\% ogółu oddziałów firmy, w Stanach Zjednoczonych i Chinach po 7,5\% ogółu oddziałów oraz w Japonii (5,9\%) i Wielkiej Brytanii (4,6\%).

Ryc. 3. Zasięg oddziaływania Grupy Samsung wg rodzajów działalności w 2007 r.

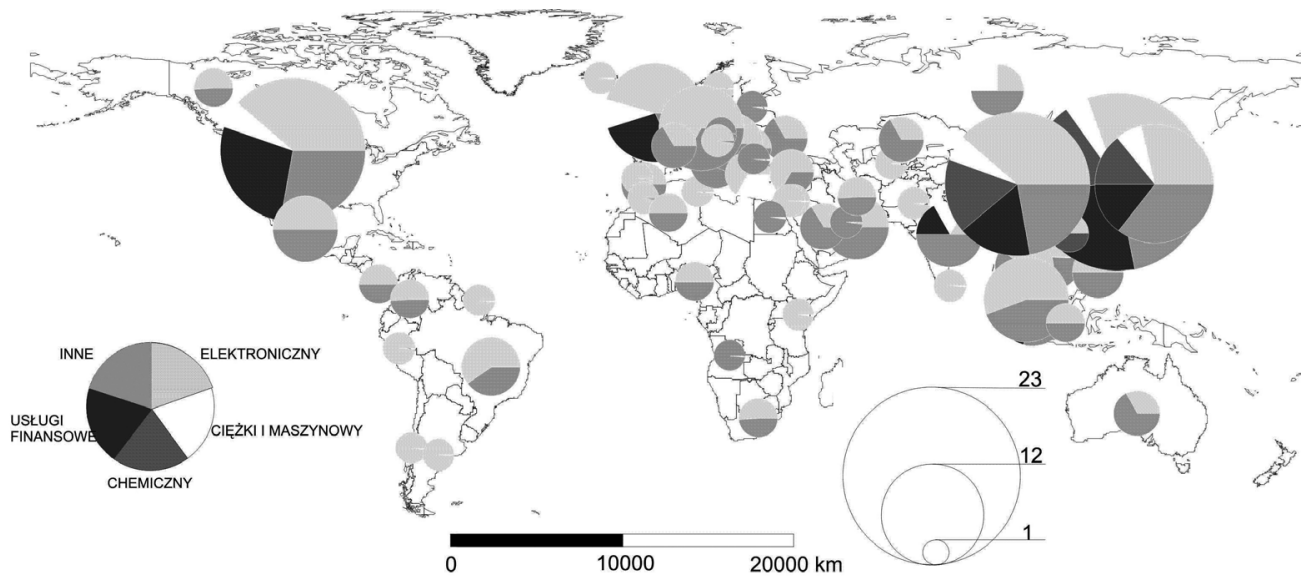

Źródło: opracowanie własne. 
Tab. 3. Zasięg oddziaływania Grupy Samsung wg państw i rodzajów działalności w 2007 r.

\begin{tabular}{|c|c|c|c|c|c|c|}
\hline \multirow[b]{2}{*}{ Państwa } & \multicolumn{5}{|c|}{ Rodzaje dzialalności } & \multirow{2}{*}{$\begin{array}{c}\text { Lączna } \\
\text { liczba } \\
\text { oddzialów }\end{array}$} \\
\hline & elektroniczny & $\begin{array}{c}\text { ciężki } \\
\text { i maszynowy }\end{array}$ & chemiczny & finanse & $\begin{array}{l}\text { inne rodzaje } \\
\text { dzialalności }\end{array}$ & \\
\hline $\begin{array}{c}\text { Korea } \\
\text { Południowa }\end{array}$ & 7 & 1 & 4 & 6 & 5 & 23 \\
\hline $\begin{array}{c}\text { Stany } \\
\text { Zjednoczone }\end{array}$ & 7 & 1 & 0 & 5 & 5 & 18 \\
\hline Chiny & 7 & 1 & 3 & 3 & 4 & 18 \\
\hline Japonia & 4 & 1 & 2 & 2 & 5 & 14 \\
\hline $\begin{array}{c}\text { Wielka } \\
\text { Brytania }\end{array}$ & 5 & 1 & 0 & 3 & 2 & 11 \\
\hline Niemcy & 6 & 0 & 0 & 0 & 3 & 9 \\
\hline Malezja & 5 & 0 & 0 & 0 & 4 & 9 \\
\hline Singapur & 3 & 1 & 0 & 1 & 2 & 7 \\
\hline Wietnam & 2 & 0 & 0 & 2 & 3 & 7 \\
\hline Tajwan & 3 & 0 & 0 & 0 & 3 & 6 \\
\hline Meksyk & 3 & 0 & 0 & 0 & 3 & 6 \\
\hline $\begin{array}{c}\text { Zjednoczone } \\
\text { Emiraty } \\
\text { Arabskie }\end{array}$ & 2 & 1 & 0 & 0 & 3 & 6 \\
\hline Indie & 1 & 1 & 0 & 1 & 3 & 6 \\
\hline Węgry & 3 & 0 & 0 & 0 & 2 & 5 \\
\hline Brazylia & 3 & 0 & 0 & 0 & 2 & 5 \\
\hline Tajlandia & 2 & 0 & 0 & 0 & 3 & 5 \\
\hline Filipiny & 2 & 0 & 0 & 0 & 2 & 4 \\
\hline Rosja & 1 & 1 & 0 & 0 & 2 & 4 \\
\hline Włochy & 1 & 0 & 0 & 0 & 3 & 4 \\
\hline Turcja & 2 & 0 & 0 & 0 & 1 & 3 \\
\hline Grecja & 2 & 1 & 0 & 0 & 0 & 3 \\
\hline Ukraina & 1 & 0 & 0 & 0 & 2 & 3 \\
\hline Hiszpania & 1 & 0 & 0 & 0 & 2 & 3 \\
\hline $\begin{array}{c}\text { Arabia } \\
\text { Saudyjska }\end{array}$ & 1 & 0 & 0 & 0 & 2 & 3 \\
\hline Kazachstan & 1 & 0 & 0 & 0 & 2 & 3 \\
\hline Francja & 1 & 0 & 0 & 0 & 2 & 3 \\
\hline Australia & 1 & 0 & 0 & 0 & 2 & 3 \\
\hline
\end{tabular}




\begin{tabular}{|c|c|c|c|c|c|c|}
\hline $\begin{array}{c}\text { Republika } \\
\text { Południowej } \\
\text { Afryki }\end{array}$ & 1 & 0 & 0 & 0 & 1 & 2 \\
\hline Słowacja & 1 & 0 & 0 & 0 & 1 & 2 \\
\hline Rumunia & 1 & 0 & 0 & 0 & 1 & 2 \\
\hline Polska & 1 & 0 & 0 & 0 & 1 & 2 \\
\hline Panama & 1 & 0 & 0 & 0 & 1 & 2 \\
\hline Nigeria & 1 & 0 & 0 & 0 & 1 & 2 \\
\hline Iran & 1 & 0 & 0 & 0 & 1 & 2 \\
\hline Indonezja & 1 & 0 & 0 & 0 & 1 & 2 \\
\hline Hongkong & 1 & 0 & 1 & 0 & 0 & 2 \\
\hline Kolumbia & 1 & 0 & 0 & 0 & 1 & 2 \\
\hline Kanada & 1 & 0 & 0 & 0 & 1 & 2 \\
\hline Algeria & 1 & 0 & 0 & 0 & 1 & 2 \\
\hline Uzbekistan & 1 & 0 & 0 & 0 & 0 & 1 \\
\hline Tunezja & 1 & 0 & 0 & 0 & 0 & 1 \\
\hline Szwecja & 1 & 0 & 0 & 0 & 0 & 1 \\
\hline Sri Lanka & 1 & 0 & 0 & 0 & 0 & 1 \\
\hline Portugalia & 1 & 0 & 0 & 0 & 0 & 1 \\
\hline Peru & 1 & 0 & 0 & 0 & 0 & 1 \\
\hline Pakistan & 1 & 0 & 0 & 0 & 0 & 1 \\
\hline Niderlandy & 1 & 0 & 0 & 0 & 0 & 1 \\
\hline Maroko & 1 & 0 & 0 & 0 & 0 & 1 \\
\hline Kenia & 1 & 0 & 0 & 0 & 0 & 1 \\
\hline Jordania & 1 & 0 & 0 & 0 & 0 & 1 \\
\hline Izrael & 1 & 0 & 0 & 0 & 0 & 1 \\
\hline Islandia & 1 & 0 & 0 & 0 & 0 & 1 \\
\hline $\begin{array}{l}\text { Gujana } \\
\text { Francuska }\end{array}$ & 1 & 0 & 0 & 0 & 0 & 1 \\
\hline Chile & 1 & 0 & 0 & 0 & 0 & 1 \\
\hline Austria & 1 & 0 & 0 & 0 & 0 & 1 \\
\hline Argentyna & 1 & 0 & 0 & 0 & 0 & 1 \\
\hline Katar & 0 & 0 & 0 & 0 & 1 & 1 \\
\hline Norwegia & 0 & 1 & 0 & 0 & 0 & 1 \\
\hline Litwa & 0 & 0 & 0 & 0 & 1 & 1 \\
\hline
\end{tabular}




\begin{tabular}{|c|c|c|c|c|c|c|}
\hline Egipt & 0 & 0 & 0 & 0 & 1 & 1 \\
\hline Czechy & 0 & 0 & 0 & 0 & 1 & 1 \\
\hline Bułgaria & 0 & 0 & 0 & 0 & 1 & 1 \\
\hline Angola & 0 & 0 & 0 & 0 & 1 & 1 \\
\hline SUMA & $\mathbf{1 0 6}$ & $\mathbf{1 1}$ & $\mathbf{1 0}$ & $\mathbf{2 3}$ & $\mathbf{8 9}$ & $\mathbf{2 3 9}$ \\
\hline
\end{tabular}

Źródło: opracowanie własne.

Osiąganie tak wysokich wyników przez Grupę Samsung było możliwe dlatego, że korporacja od początku swojej działalności przywiązywała szczególnie dużą wagę i poświęcała środki na badania i rozwój, dzięki czemu stale wprowadzała na rynek coraz to nowocześniejsze produkty, które były konkurencyjne do produktów pochodzących m.in. z firm z Doliny Krzemowej.

Pierwsze centra badawczo-rozwojowe, jak już wspomniano, powstały w 1988 r. Obecnie Grupa Samsung posiada sieć jednostek badawczo-rozwojowych, na którą składa się sześć ośrodków w Korei oraz 18 w dziewięciu innych krajach, m.in. USA, Wielkiej Brytanii, Rosji, Izraelu, Indiach, Japonii oraz Chinach, a także 18 ośrodków badawczych w jednostkach uniwersyteckich. W cele badawcze firma inwestuje co roku nie mniej niż $9 \%$ dochodów ze sprzedaży, zatrudniając 42 tys. osób (tj. ponad jedną czwartą wszystkich pracowników). Wszystkie 42 jednostki badawcze znajdujące się na całym świecie współpracują w opracowaniu strategicznych przyszłościowych technologii, które nadadzą kierunek nowym tendencjom na rynku oraz wyznaczą nowe standardy produktów (http://www.sisa.samsung.com/about.htm). W Polsce taki ośrodek znajduje się w Warszawie przy Uniwersytecie Warszawskim. Firma Samsung Electronics w 2000 r. otworzyła w Warszawie Centrum Badań i Rozwoju Oprogramowania. Głównym zadaniem Centrum jest rozwój oprogramowania do odbiorników cyfrowej telewizji satelitarnej, kablowej i naziemnej zgodnych z nowoczesnymi standardami (DVB Digital Video Broadcasting). Dzięki znakomitym efektom pracy, po przeniesieniu się do nowej lokalizacji w 2005 r., zdecydowano o powstaniu nowego działu, zajmującego się tworzeniem oprogramowania do najbardziej zaawansowanych telewizorów LCD. W 2007 r. Centrum Badań i Rozwoju zostało rozszerzone o Centrum Rozwoju Mobilnych Technologii, które zajmuje się rozwojem oprogramowania dla telefonów komórkowych i dostosowaniem go do potrzeb rynkowych.

O znacznym wzroście znaczenia korporacji na świecie świadczy również wzrost rozpoznawalności korporacji na rynku. W rankingu the Best Global Brands, przeprowadzanym w ponad 80 krajach, korporacja ta jest notowana od wielu lat, a jej pozycja stale wzrasta z 49 miejsca w 2001 r. do 19 miejsca w bieżącym roku. W latach 2001-2010 wartość marki Samsung wzrosła z 6,4 mld do 19,5 mld USD, tj. ponad trzykrotnie (http://www.interbrand.com).

Podsumowując, należy podkreślić, że Grupa Samsung stanowi bardzo ważne ogniwo w procesach globalizacji. Poprzez działalność na różnych polach stworzyła własną sieć biznesową, dzięki której poszczególne firmy wchodzące w skład grupy kapitałowej mogą ze sobą kooperować. Stanowi to fundament przewagi konkurencyjnej korporacji na arenie międzynarodowej. Rozwijając swoją działalność, Grupa Samsung jest przykładem podmiotu, który dzięki procesom globalizacji w wyniku ewolucji światowej gospodarki, przez 70 lat swojej działalności stał się konglomeratem o charakterze transnarodowym. 


\section{Literatura}

1. Borowiec M., 2009, Rola edukacji w ksztaltowaniu spoleczeństwa informacyjnego [w:] Rola przedsiębiorczości w kształtowaniu społeczeństwa informacyjnego, Z. Zioło i T. Rachwał (red.), „Przedsiębiorczość - Edukacja”, nr 5, Nowa Era, Zakład Przedsiębiorczości i Gospodarki Przestrzennej Instytutu Geografii Uniwersytetu Pedagogicznego w Krakowie, Warszawa-Kraków, s. 37-47.

2. Dorocki S., Jenner B., 2009, Wpływ wielkości naktadów inwestycyjnych w sektorze $B+R$ na regionalne zróżnicowanie tempa rozwoju Francji [w:] Rola przedsiębiorczości w ksztaltowaniu spoleczeństwa informacyjnego, Z. Zioło i T. Rachwał (red.), „Przedsiębiorczość - Edukacja”, nr 5, Nowa Era, Zakład Przedsiębiorczości i Gospodarki Przestrzennej Instytutu Geografii Uniwersytetu Pedagogicznego w Krakowie, Warszawa-Kraków, s. 188-197.

3. Fields G., 2006, Innovation, Time and Territory: Space and the Business Organization of Dell Computer, „Economic Geography” 82 (2), s. 119-146.

4. Kilar W., 2009, Rola korporacji Apple w ksztaltowaniu społeczeństwa informacyjnego [w:] Rola przedsiębiorczości w kształtowaniu społeczeństwa informacyjnego, Z. Zioło i T. Rachwał (red.), „Przedsiębiorczość - Edukacja”, nr 5, Nowa Era, Zakład Przedsiębiorczości i Gospodarki Przestrzennej Instytutu Geografii Uniwersytetu Pedagogicznego w Krakowie, Warszawa-Kraków, s. 48-56.

5. Koryszewski M., 2010, Kluczowe marki technologiczne 2010 - Samsung wypada najlepiej, http:// technologie.gazeta.pl/technologie/1,81010,7527437,Kluczowe_marki_technologiczne_2010__Samsung_wypada.html

6. Rachwał T., 2008, Problematyka badawcza funkcjonowania przedsiębiorstw przemysłowych [w:] Problematyka badawcza geografii przemystu, Z. Zioło i T. Rachwał (red.), „Prace Komisji Geografii Przemysłu PTG", nr 11, Komisja Geografii Przemysłu PTG i Zakład Przedsiębiorczości i Gospodarki Przestrzennej Instytutu Geografii Akademii Pedagogicznej w Krakowie, Warszawa-Kraków, s. 53-85.

7. Rosińska-Bukowska M., 2009, Rola korporacji transnarodowych w procesach globalizacji. Kreowanie globalnej przestrzeni biznesowej, Dom Wydawniczy Duet, Toruń.

8. Stryjakiewicz T., 2009, Lokalizacja firm i zachowania przestrzenne pracowników sektora informatycznego (na przyktadzie poznańskiego obszaru metropolitalnego) [w:] Funkcje przemystu w ksztattowaniu spoleczeństwa informacyjnego (Functions of Industry in the Development of Information Society), Z. Zioło i T. Rachwał (red.), „Prace Komisji Geografii Przemysłu PTG”, nr 13, Komisja Geografii Przemysłu PTG i Zakład Przedsiębiorczości i Gospodarki Przestrzennej Instytutu Geografii Uniwersytetu Pedagogicznego w Krakowie, Warszawa-Kraków, s. 21-33.

9. Wajda E., 2003, Proces kształtowania się Motoroli jako firmy ponadnarodowej [w:] Ksztattowanie się struktur przemysłowych, Z. Zioło i Z. Makieła (red.), „Prace Komisji Geografii Przemysłu PTG”, nr 5, Komisja Geografii Przemysłu PTG w Warszawie i Instytut Geografii Akademii Pedagogicznej w Krakowie, Warszawa-Kraków, s. 85-114.

10. Wajda E., 2003, Zoričič-Wołek M., Proces ksztaltowania się korporacji IBM [w:] Przemyst w procesie globalizacji, Z. Zioło i Z. Makieła (red.), „Prace Komisji Geografii Przemysłu PTG”, nr 6, Komisja Geografii Przemysłu PTG w Warszawie i Zakład Przedsiębiorczości i Gospodarki Przestrzennej Instytutu Geografii Akademii Pedagogicznej w Krakowie, Warszawa-Kraków, s. 109-118.

11. Wajda E., 2006, Rozwój i struktura przestrzenna działalności Nokii w latach 1997-2003 [w:] Międzynarodowe uwarunkowania rozwoju przemystu, Z. Zioło i T. Rachwał (red.), „Prace Komisji Geografii Przemysłu PTG”, nr 8, Komisja Geografii Przemysłu PTG w Warszawie i Zakład Przedsiębiorczości i Gospodarki Przestrzennej Instytutu Geografii Akademii Pedagogicznej w Krakowie, Warszawa-Kraków, s. 219-240.

12. www.interbrand.com/en/best-global-brands/Best-Global-Brands-2010.aspx

13. www.flickr.com/photos/businesshistory/3264510731/

14. www.samsung.com

15. www.sisa.samsung.com/about.htm 
16. Zioło Z., 2004, Ksztaltowanie się firm informatycznych jako nowych elementów struktury przestrzennej przemystu [w:] Przemiany struktur przemysłowych, Z. Zioło i Z. Makieła (red.), „Prace Komisji Geografii Przemysłu PTG”, nr 7, Komisja Geografii Przemysłu PTG w Warszawie i Zakład Przedsiębiorczości Instytutu Geografii Akademii Pedagogicznej w Krakowie, Warszawa-Kraków, s. 97-106.

17. Zioło Z., 2006, Firmy informatyczne w województwach Polski [w:] Idee i praktyczny uniwersalizm geografii. Geografia społeczno-ekonomiczna, T. Komornicki, Z. Podgórski (red.), „Dokumentacja Geograficzna”, nr 33, PAN, Instytut Geografii i Przestrzennego Zagospodarowania im. Leszczyckiego, Warszawa, s. 282-290.

18. Zioło Z., 2008, Procesy transformacji przemystowych układów przestrzennych na tle zmieniajacego się otoczenia [w:] Procesy transformacji uktadów przestrzennych przemystu na tle zmieniajacego się otoczenia, Z. Zioło i T. Rachwał (red.), „Prace Komisji Geografii Przemysłu PTG”, nr 10, Komisja Geografii Przemysłu PTG i Zakład Przedsiębiorczości i Gospodarki Przestrzennej Instytutu Geografii Akademii Pedagogicznej w Krakowie, Warszawa-Kraków, s. 11-22.

\section{Formation of Samsung Group in the Globalization Era}

The underlying role in the enhancement of globalization processes is held by transnational corporations which exert impact on the formation of market network systems for goods and services by means of locating their affiliates in global regional systems.

The purpose of the paper is to present the analysis of Samsung Group formation processes. The Group's business potential, impact range and production assortment diversification as well as increasing globalization trends in the world economy that have affected the formation and development of the analyzed corporation are analyzed.

The Samsung Group is a significant element in globalization processes. As a result of operations carried out in various fields, the corporation has created its own business network enabling the cooperation of particular entities within the capital group. This is the basis for the corporation competitive advantage in the international market. By developing its operations the Samsung Group is an example of an entity that during its 70 years of business activities has become a conglomerate of a transnational nature owing to globalization processes resulting from the global economy evolution. 


\section{Marta Boguś}

Uniwersytet Pedagogiczny

im. Komisji Edukacji Narodowej

w Krakowie

\section{Proces ksztaltowania się korporacji ponadnarodowej Google}

Charakterystyczny i nieodłączny element współczesnej gospodarki światowej stanowią korporacje ponadnarodowe, będące motorem napędowym i głównymi beneficjentami nasilających się procesów globalizacji (Zorska 1998). „Korporacje ponadnarodowe prowadzą własną politykę rozwoju, zmierzając do podnoszenia swojej konkurencyjności w drodze rozwoju badań naukowych i wprowadzania nowych produktów, opanowywania rynku, przepływu informacji, produktów, technologii itp." (Zioło 2001, s. 29-30). Posiadają one duży potencjał ekonomiczny oraz zdolności integrowania i koordynowania wielkich systemów produkcyjnych, usługowych i finansowych (Zorska 1998), dlatego odgrywają ważną rolę w wytyczaniu reguł funkcjonowania gospodarki światowej. Korporacje poszukują miejsc efektywnej lokalizacji i oplatają świat, warunkując funkcjonowanie innych firm na terenie poszczególnych krajów oraz regionów (Zioło 2009), co powoduje, że są określane jako ,specyficzne podmioty «władzy» w stosunkach międzynarodowych" (Piórko 2008, s. 49).

W XXI w. - erze wiedzy lub erze interakcyjno-intelektualnej - jednym z filarów są technologie informatyczne, które odgrywają ważną rolę w poszczególnych etapach przetwarzania danych oraz tworzeniu innowacyjnych produktów i usług (Olszak 2007). Przemysł wysokiej technologii (high-technology industries), oparty głównie na przemyśle informatycznym, stanowi potężną siłę wytwórczą i traktowany jest jako przełom w rozwoju ludzkości porównywalny z wynalezieniem maszyny parowej (Wieloński 2003).

„Proces kształtowania się korporacji światowych stymulowany jest poprzez mechanizmy konkurencji dokonujące się na rynku globalnym” (Zioło 2009, s. 12). W świetle przedstawionych przesłanek w niniejszych rozważaniach podjęto analizę procesu kształtowania się korporacji ponadnarodowej Google. „Odkąd przed ponad pięcioma stuleciami Goutenberg skonstruował nowoczesną prasę drukarską, dzięki czemu wszelkiego rodzaju publikacje stały się tańsze i powszechniej osiągalne, żaden inny wynalazek nie zrewolucjonizował dostępu do informacji w takim stopniu, jak wyszukiwarka Google" (Vise 2007, s. 3).

\section{Zarys rozwoju firmy}

Historia powstania firmy Google sięga 1995 r., kiedy dwaj matematycy - Amerykanin Larry Page i Rosjanin Sergey Brin - poznali się na Uniwersytecie Stanfordzkim. Larry Page, doktorant Wydziału Informatyki, podjął pracę na temat wyszukiwania informacji w sieci WWW. Fascynacja Internetem i mechanizmami nim rządzącymi, która połączyła matematyków, i owocne badania doprowadziły do powstania systemu BackRub ${ }^{1}$, wzbogaconego później

\footnotetext{
${ }^{1} \mathrm{~W}$ języku polskim 'masaż pleców', od amerykańskiego powiedzonka ,ty pomasujesz moje plecy, ja pomasuję twoje". Nawiązuje do mechanizmu indeksacji, który hierarchię stron tworzy na podstawie liczby odnośników prowadzących do danego adresu.
} 
o przełomowy algorytm PageRank wykorzystany w prototypie wyszukiwarki internetowej. Pierwsza wersja wyszukiwarki ukazała się w serwisie Stanforda w 1996 r. Rozrastający się studencki projekt został przeniesiony z pokoju w akademiku prywatnego Uniwersytetu Stanfordzkiego mieszczącego się w Dolinie Krzemowej (stan Kalifornia, Stany Zjednoczone) do nowego biura w słynnym dziś garażu, w kalifornijskiej miejscowości Menlo Park.

W 1997 r. wyszukiwarce nadano nazwę Google, pochodzącą od terminu matematycznego googol, oznaczającego cyfrę 1 i 100 zer, odzwierciedlającego nieskończoną ilość informacji w Internecie.

W 1998 wynalazcy założyli spółkę akcyjną o kapitale początkowym 1,1 mln USD, zgromadzonym dzięki inwestorom, przy czym 100 tys. USD zainwestował Andy Bechtolsheim - jeden z założycieli Sun Microsystems. Dnia 7 września 1998 r. firma Google Inc. na czele z prezesem Page'em i dyrektorem Brinem rozpoczęła oficjalną działalność. Strona główna wyszukiwarki dzięki nieskomplikowanej formie okazała się jej atutem, a proste logo umieszczone na białym tle pozytywnie wyróżniało się w pełnym przepychu Internecie (ryc. 1). Jednak firma Google musiała stawić czoła silnej konkurencji. Na rynku wyszukiwarek istniały już wtedy m.in. Yahoo (ok. 40\% udziałów w rynku wyszukiwarek) oraz MSN (ponad 20\% udziałów).

Ryc. 1. Historyczne, pierwsze logo Google z 1998 r.

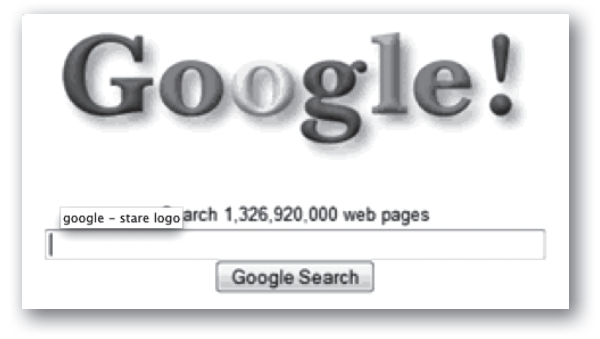

Źródło: http://openzone.pl/news,krotka-historia-google,3000

W 1999 r. firma Google przeniosła się z garażu do obecnej siedziby w Mountain View, w Dolinie Krzemowej, nazywanej Googleplex i uznawanej dziś za jedną ze światowych stolic branży informatycznej. Wizerunek korporacji wzbogacił się o logo i szatę graficzną. Wyszukiwarka obsługiwała wtedy 3 mln zapytań dziennie i została umieszczona przez magazyn „Time” w podsumowaniu kategorii „najlepsza technologia cyfrowa 1999”. Pod koniec roku firma zatrudniała 39 osób, w większości inżynierów różnych specjalizacji.

Firma Google przetrwała załamanie rynku dot-comów ${ }^{2}$ i rozwijała się od tego czasu dzięki prywatnym inwestorom. Zawarcie umowy z Yahoo potwierdzało skuteczność technologii. Nowym źródłem dochodów spółki stała się usługa AdWords. Pod koniec roku wyszukiwarka obsługiwała 60 mln zapytań dziennie, a liczba zatrudnionych w firmie wzrosła do ok. 150 osób.

W 2001 r. na stanowisku dyrektora generalnego zasiadł Eric Schmidt. Korporacja międzynarodowa uruchomiła swoją pierwszą filię w Tokio, zatrudniała ponad 200 pracowników, a jej usługi były dostępne w 26 językach. Wyszukiwarka obsługiwała ponad $100 \mathrm{mln}$ zapytań dziennie.

W 2002 r. firma udostępniła wyszukiwarkę obrazów, która już na początku indeksowała 250 mln plików graficznych, a także usługę Google News, dającą dostęp do wiadomości

\footnotetext{
${ }^{2}$ Okres euforii na giełdach całego świata w latach 1995-2001 związany ze spółkami z branży informatycznej i z pokrewnych sektorów, a dotyczący przeceniania przedsiębiorstw, które prowadziły lub zamierzały rozpocząć prowadzenie działalności w Internecie.
} 
z 4000 różnych źródeł. Wprowadziła także urządzenie indeksujące Google Appliance służące do zarządzania wyszukiwaniem i strukturą sieci lokalnych, weszła na rynek urządzeń mobilnych oraz uruchomiła nową wersję AdWords. Firma oferowała usługi w ponad 40 językach. Jej ogólny dochód w 2002 r. wynosił 440 mln USD, a zysk netto prawie 100 mln USD. Stowarzyszenie American Dialect Society uznało wyraz google najistotniejszym i najczęściej używanym słowem roku 2002 (Word of the Year) (Battelle 2006).

W latach 2003-2004 firma Google odniosła pasmo sukcesów poprzez m.in. uruchomienie platformy blogowej Blogger, usługi AdSense, która umożliwiała zarabianie na reklamach kontekstowych na własnej stronie, programu Picasa. Larry Page i Sergey Brin zostali określeni przez Stowarzyszenie Marconi Society za twórców trwałego wkładu w naukowy postęp ludzkości w dziedzinie komunikacji oraz Internetu.

W 2004 r. swoją premierę miał Gmail. W tym samym roku, 19 sierpnia, firma Google Inc. weszła na amerykańską giełdę przy Wall Street. Cena za akcję, wynosząca 85 USD, pozwoliła na zgromadzenie ok. 2 mld USD. Żadna inna firma z branży nie osiągnęła takiego pułapu. Od tej chwili nastąpiło przyspieszenie ekspansji korporacji.

W 2005 r. firma Google poczyniła milowy krok w dziedzinie wyszukiwania obrazów (Image Search), udostępniając ich w sieci ponad miliard. Ruszyła usługa Google Maps oraz Google Earth. Pobity także został rekord związany z wartością jednej akcji: cena za jedną wynosiła ponad 300 USD, a za wszystkie - ponad 80 mld USD.

Rok 2006 przyniósł ze sobą głównie doskonalenie oferty firmy. Dynamicznie rozwijająca się korporacja zakupiła serwis YouTube, Google Apps i Google Docs. Zapowiedziała także pojawienie się systemu operacyjnego dla urządzeń mobilnych - Android. Wyszukiwarka indeksowała $1000000 \mathrm{mln}$ stron internetowych dziennie.

W 2008 r. firma Google obchodziła dziesięciolecie istnienia. Udostępniono wtedy przeglądarkę Chrom, która w ciągu 10 godzin od premiery przekroczyła 1\% udziału w światowym rynku wyszukiwarek, czyli w ciągu tego czasu pobrano ją 14 mln razy. W 2008 r. do sprzedaży trafił też pierwszy telefon komórkowy oparty na systemie Android - G1 w sieci T-Mobile.

W 2009 r. korporacja wprowadziła usługę Google Latitude oraz nowe narzędzie - Google Wave, a także zapowiedziała pojawienie się systemu operacyjnego ChromeOS przeznaczonego głównie dla urządzeń mobilnych. W połowie 2010 r. działalność rozpoczął serwis Google Books, utworzony w celu sprzedaży książek internetowych.

\section{Współczesna struktura przestrzenna działalności Google}

Korporacje ponadnarodowe szukają nowych miejsc efektywnej lokalizacji. Rozmieszczenie firm informatycznych na świecie jest związane z poziomem rozwoju gospodarczego, zasobami pracy i uwarunkowaniami ekonomicznymi (Kilar 2009). Coraz częściej za granicą kraju macierzystego lokalizuje się ośrodki badań naukowych i prac rozwojowych, w celu przejęcia lub wykorzystania zaawansowanych zdolności technologicznych tamtejszych ośrodków naukowo-badawczych oraz wysoko wykwalifikowanej kadry.

Założyciele Google pracę nad swoim projektem, który rozpowszechnił się wśród poszukujących informacji internautów na całym świecie, rozpoczęli w pokoju akademika Uniwersytetu Stanfordzkiego. Od tamtej pory nastąpił dynamiczny rozwój firmy. Charakterystyczną cechą korporacji ponadnarodowych jest rozprzestrzenianie ich działalności obejmujące coraz to nowe obszary. Poszczególne oddziały korporacji Google zlokalizowane są w 39 państwach na terenie 70 miast świata. Biura firmy umiejscawiane są zazwyczaj w stolicach tych krajów lub innych dużych miastach, co ma związek z głównymi rynkami odbiorców.

Dla korporacji oferującej usługi związane z wyszukiwaniem lokalizacja biur rozwojowych na całym świecie stanowi jeden $z$ elementów strategii sukcesu, ponieważ dzięki temu jest 
w stanie skuteczniej adaptować usługi i produkty do lokalnych potrzeb. Jakość i cechy intelektualne klientów są ważnym źródłem wiedzy w rozwoju i stymulowaniu do działań innowacyjnych (Olszak 2007). Google chce w dalszym ciągu podążać według obranej strategii, a przestrzenne rozmieszczenie biur firmy nawiązuje do poziomu rozwoju ekonomicznego oraz zasobów intelektualnych, które są podstawowym warunkiem rozwoju branży informatycznej.

Jak już zostało powiedziane, główna siedziba korporacji znajduje się w Mountain View, w Stanach Zjednoczonych. Najwięcej oddziałów zlokalizowanych jest na terenie Ameryki Północnej i Europy (po 23 oddziały). Duże skupienie oddziałów występuje także w Azji (16). Dwa oddziały znajdują się w Ameryce Południowej, a najmniej, bo tylko jeden oddział, znajduje się w Australii (tab. 1) .

Tab. 1. Lokalizacja oddziałów firmy Google wg kontynentów

\begin{tabular}{|c|c|c|}
\hline Kontynent & Liczba oddziałów & Udzial w ogóle oddziałów \\
\hline Europa & 23 & 35,4 \\
\hline Ameryka Północna & 23 & 35,4 \\
\hline Azja & 16 & 24,6 \\
\hline Ameryka Południowa & 2 & 3,1 \\
\hline Australia & 1 & 1,5 \\
\hline Ogółem & 65 & 100,0 \\
\hline
\end{tabular}

Źródło: opracowanie własne na podstawie www.google.com.

Poszczególne kraje charakteryzują się zróżnicowanym występowaniem biur korporacji Google. Najwięcej oddziałów korporacji znajduje się w Stanach Zjednoczonych, gdzie zlokalizowane są w 18 miastach (łącznie z siedzibą główną). Stosunkowo duża liczba oddziałów występuje także na obszarze Indii, gdzie Google ma swoją siedzibę w czterech miastach. Podobnie jest w Kanadzie, Polsce i Chinach, gdzie biura korporacji zlokalizowane są w trzech miastach (tab. 2, ryc. 2).

Tab. 2. Lokalizacja oddziałów firmy Google na świecie

\begin{tabular}{|c|c|c|c|}
\hline Państwo & $\begin{array}{c}\text { Liczba } \\
\text { oddziałów } \\
\text { w państwie }\end{array}$ & $\begin{array}{c}\text { Udzial oddzia- } \\
\text { lów w ogóle }\end{array}$ & Siedziby biur \\
\hline $\begin{array}{c}\text { Stany } \\
\text { Zjednoczone }\end{array}$ & 19 & 29,2 & $\begin{array}{c}\text { Mountain View, Ann Arbor, Atlanta, Austin, } \\
\text { Boulder, Cambridge, Chicago, Detroit, Irvine, } \\
\text { Kirkland, Madison, Nowy Jork (2), Pittsburgh, } \\
\text { Reston, San Francisco, Santa Monica, Seattle, } \\
\text { Waszyngton }\end{array}$ \\
\hline Indie & 4 & 6,2 & Bangalor, Gurgaon, Hajdarabad, Bombaj \\
\hline Kanada & 3 & 4,6 & Montreal, Toronto, Waterloo \\
\hline Polska & 3 & 4,6 & Kraków, Wrocław, Warszawa \\
\hline Chiny & 3 & 4,6 & Pekin, Guangzhou, Szanghaj \\
\hline
\end{tabular}




\begin{tabular}{|c|c|c|c|}
\hline Dania & 2 & 3,1 & Arhus, Kopenhaga \\
\hline Niemcy & 2 & 3,1 & Hamburg, Monachium \\
\hline Rosja & 2 & 3,1 & Moskwa, St. Petersburg \\
\hline Szwecja & 2 & 3,1 & Sztokholm, Luleå \\
\hline Izrael & 2 & 3,1 & Hajfa, Tel Awiw \\
\hline Belgia & 1 & 1,5 & Bruksela \\
\hline Finlandia & 1 & 1,5 & Helsinki \\
\hline Francja & 1 & 1,5 & Paryż \\
\hline Węgry & 1 & 1,5 & Budapeszt \\
\hline Irlandia & 1 & 1,5 & Dublin \\
\hline Włochy & 1 & 1,5 & Milan \\
\hline Holandia & 1 & 1,5 & Amsterdam \\
\hline Norwegia & 1 & 1,5 & Oslo \\
\hline Hiszpania & 1 & 1,5 & Madryt \\
\hline Szwajcaria & 1 & 1,5 & Zurych \\
\hline Wielka Brytania & 1 & 1,5 & Londyn \\
\hline Hongkong $^{3}$ & 1 & 1,5 & Hongkong \\
\hline Japonia & 1 & 1,5 & Tokio \\
\hline Korea Południowa & 1 & 1,5 & Seul \\
\hline Singapur & 1 & 1,5 & Singapur \\
\hline Tajwan $^{4}$ & 1 & 1,5 & Tajwan \\
\hline Turcja & 1 & 1,5 & Istambuł \\
\hline $\begin{array}{c}\text { Zjednoczone } \\
\text { Emiraty } \\
\text { Arabskie }\end{array}$ & 1 & 1,5 & Dubaj \\
\hline Argentyna & 1 & 1,5 & Buenos Aires \\
\hline Brazylia & 1 & 1,5 & São Paulo \\
\hline Meksyk & 1 & 1,5 & Lomas de Chapultepec \\
\hline Australia & 1 & 1,5 & Sydney \\
\hline Ogółem & 65 & 100,0 & \\
\hline
\end{tabular}

Źródło: opracowanie własne na podstawie www.google.com.

\footnotetext{
${ }^{3}$ Region administracyjny Chin, potraktowany oddzielnie ze względu na dużą autonomię we wszystkich sprawach, z wyjątkiem polityki zagranicznej i sił zbrojnych.

${ }^{4}$ Uznawany za 23 prowincję Chin, dla potrzeb pracy potraktowany oddzielnie ze względu na suwerenne, demokratyczne władze prowadzące prawie niezależną politykę zagraniczną.
} 


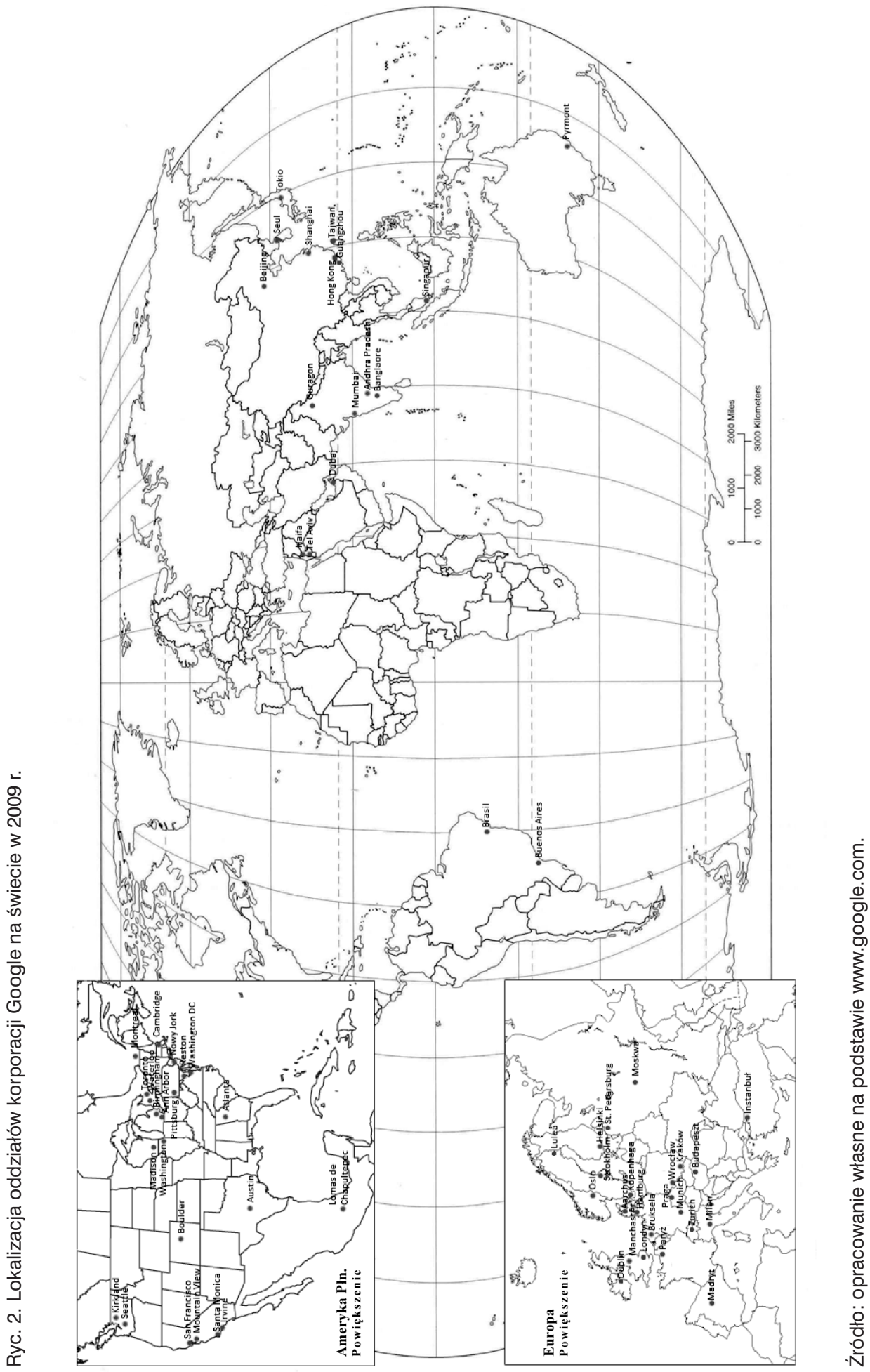


Poszczególne regiony świata odznaczają się zróżnicowanym potencjałem oddziałów korporacji Google, co wyrażono wartością przychodu oraz wartością aktywów. W materiałach źródłowych dotyczących wartości przychodu dokonano podziału na Stany Zjednoczone, Wielką Brytanię i resztę świata w przedziale czasowym od 2006 do 2009 r. Natomiast w wypadku wartości aktywów wyróżniono tylko Stany Zjednoczone na tle reszty świata w przedziale czasowym od 2007 do 2009 r.

Biorąc pod uwagę zróżnicowanie wartości przychodu osiąganego przez poszczególne kraje, na terenach których występują biura firmy Google, zauważono dominację siedzib zlokalizowanych w Stanach Zjednoczonych. Wartość przychodu siedzib firmy Google w Stanach Zjednoczonych zwiększyła się w latach 2006-2009 z 6,0 do 11,2 mld USD (tab. 3), tj. prawie dwukrotnie, co stanowiło od $56,6 \%$ do $47,3 \%$ ogółu wartości przychodu wygenerowanego przez korporację. Wysoką wartość przychodu osiągnęły także biura usytuowane w Wielkiej Brytanii - wzrosła ona z 1,6 mld USD w 2006 do 3,0 mld USD w 2009 r., tj. prawie dwukrotnie, co stanowiło od 15,1\% do 12,6\% ogólnych przychodów firmy. Pozostałe oddziały znajdujące się w innych częściach świata łącznie charakteryzowały się intensywnym wzrostem wartości przychodu z 3,0 mld USD do 9,5 mld USD, tj. ponad trzykrotnym. W związku z dynamicznym wzrostem wartości przychodu tych oddziałów ich udział zwiększył się w ogóle przychodu firmy Google z 28,3\% w 2006 r. do 40,0\% w 2009 r. Mimo wzrostu wartości przychodu biur Google zlokalizowanych w Stanach Zjednoczonych w latach 2006-2009 udział ich wartości w ogóle osiągniętego przychodu zmniejszył się na rzecz oddziałów znajdujących się w pozostałych częściach świata, co oznacza zwiększenie się intensywności opanowywania rynków światowych.

Tab. 3. Zróżnicowanie wartości przychodu firmy Google na świecie w latach 2006-2009

\begin{tabular}{|c|c|r|r|r|r|r|r|r|r|}
\hline Rok & $\mathbf{2 0 0 6}$ & $\mathbf{2 0 0 7}$ & $\mathbf{2 0 0 8}$ & $\mathbf{2 0 0 9}$ & $\mathbf{2 0 0 6}$ & $\mathbf{2 0 0 7}$ & $\mathbf{2 0 0 8}$ & $\mathbf{2 0 0 9}$ \\
\hline & \multicolumn{3}{|c|}{ Wartość przychodu (mld USD) } & \multicolumn{5}{|c|}{ Udział w ogóle przychodu } \\
\hline USA & 6,0 & 8,7 & 10,6 & 11,2 & 56,6 & 52,4 & 48,8 & 47,3 \\
\hline Wielka Brytania & 1,6 & 2,5 & 3,0 & 3,0 & 15,1 & 15,3 & 13,9 & 12,6 \\
\hline Reszta świata & 3,0 & 5,4 & 8,1 & 9,5 & 28,3 & 32,3 & 37,3 & 40,0 \\
\hline Ogółem & 10,6 & 16,6 & 21,8 & 23,7 & 100,0 & 100,0 & 100,0 & 100,0 \\
\hline
\end{tabular}

Źródło: opracowanie własne na podstawie www.google.com.

Podobnie biura zlokalizowane w Stanach Zjednoczonych odgrywały dominującą rolę w firmie Google pod względem wartości aktywów. Wartość majątku (aktywów) zgromadzonego przez Google w Stanach Zjednoczonych w latach 2007-2009 zwiększyła się z 7,3 mld USD do 9,4 mld USD (tab. 4), tj. o 22\%, przy czym jego udział w ogóle aktywów firmy spadł z 91,2\% do $83,3 \%$. Wartość majątku pozostałych oddziałów wzrosła z 0,7 mld USD do 1,9 mld USD, tj. o 66,7\%, w związku z czym jego udział wzrósł z 8,8\% do 16,7\% ogółu aktywów należących do korporacji. Zmniejszanie się udziału wartości aktywów oddziałów znajdujących się w Stanach Zjednoczonych, a zwiększanie się udziału wartości aktywów biur w pozostałych częściach świata potwierdza tendencję korporacji Google do intensywnego opanowywania kolejnych rynków światowych. 
Tab. 4. Zróżnicowanie wartości aktywów firmy Google na świecie w latach 2007-2009

\begin{tabular}{|c|c|c|c|c|c|c|}
\hline Rok & $\mathbf{2 0 0 7}$ & $\mathbf{2 0 0 8}$ & $\mathbf{2 0 0 9}$ & $\mathbf{2 0 0 7}$ & $\mathbf{2 0 0 8}$ & $\mathbf{2 0 0 9}$ \\
\hline & \multicolumn{3}{|c|}{ Wartość aktywów (mld USD) } & \multicolumn{3}{|c|}{ Udział w ogóle aktywów (\%) } \\
\hline USA & 7,3 & 9,8 & 9,4 & 91,2 & 84,4 & 83,3 \\
\hline Reszta świata & 0,7 & 1,8 & 1,9 & 8,8 & 15,6 & 16,7 \\
\hline Ogółem & 8,0 & 11,6 & 11,3 & 100,0 & 100,0 & 100,0 \\
\hline
\end{tabular}

Źródło: opracowanie własne na podstawie www.google.com.

Korporacja zlokalizowała swoje oddziały także na terenie Polski: w Warszawie, Krakowie oraz we Wrocławiu.

Oddział w Warszawie został utworzony w 2005 r. i składa się z zespołów zajmujących się marketingiem i sprzedażą, działalnością operacyjną oraz public relations. Kreatywna kadra specjalistów ma na celu zapewnienie obsługi na najwyższym poziomie partnerom firmy, użytkownikom i reklamodawcom w Europie Środkowej i Wschodniej.

W 2007 r. otwarto centrum badawczo-rozwojowe w Krakowie, które w przeciągu roku stało się trzecim co do wielkości centrum badawczo-rozwojowym regionu. Krakowskie biuro Google nie specjalizuje się w określonym produkcie, natomiast inżynierowie pracują w nim nad rozwiązaniami globalnymi. Dodatkowo, Kraków jest miejscem pracy nad globalnymi projektami dla zespołów z Czech i Słowacji, które dostarczają produkty Google na tamtejszy rynek. W połowie 2008 r. krakowskie centrum zatrudniało 60 inżynierów z 17 różnych krajów, w tym przyjęto osoby bez stażu pracy, jak również osoby z ponad trzydziestoletnim doświadczeniem w pracy nad oprogramowaniem.

Trzecie biuro na terenie Polski otwarto we Wrocławiu. Centrum innowacji we Wrocławiu zajmuje się obsługą użytkowników w różnych językach, z różnych krajów, a dzięki współpracy z centrum badawczo-rozwojowym w Krakowie angażuje się w testowanie nowych innowacyjnych rozwiązań Google. Spełnia ono rolę „,entrum doskonałości” zarówno dla użytkowników, reklamodawców, jak i wydawców.

\section{Technologia i działalność firmy}

Larry Page uważa, że: ,idealna wyszukiwarka to taka, która zrozumiałaby, dokładnie czego potrzebujesz i zwróciłaby dokładnie to, czego chcesz", dlatego też stworzenie takiej wyszukiwarki było celem firmy od początku jej działalności. Wynik, który uzyskano, można scharakteryzować w kilku słowach: prędkość, trafność, obiektywność i łatwość użytkowania.

Poprzez innowacyjność Page i Brin stali się prekursorami w wyszukiwaniu informacji i opracowali własną infrastrukturę usługową dzięki przełomowej technologii PageRank ${ }^{\mathrm{TM}}$. Dokonuje ona obiektywnej oceny ważności stron internetowych na podstawie liczby oraz autorów oddanych na nią głosów. Ważne strony uzyskują wyższe notowanie PageRank i są wyświetlane na początku listy wyników wyszukiwania. Obecnie zaawansowany proces wyszukiwania umożliwia uzyskanie odpowiedzi na konkretne pytanie użytkownika, nie wymagając przekierowania bieżącego widoku do witryny zawierającej zdefiniowane zagadnienie.

W celu szybkiego znajdywania odpowiedzi na pytania zamiast kilku wielkich serwerów, firma Google zastosowała połączone komputery. Zapewniło to krótszy czas reakcji, większą skalowalność i mniejsze koszty. Sposób, w jaki dochodzi do uzyskania informacji, przedstawia rycina 2. 
Ryc. 2. Cykl życia zapytania Google

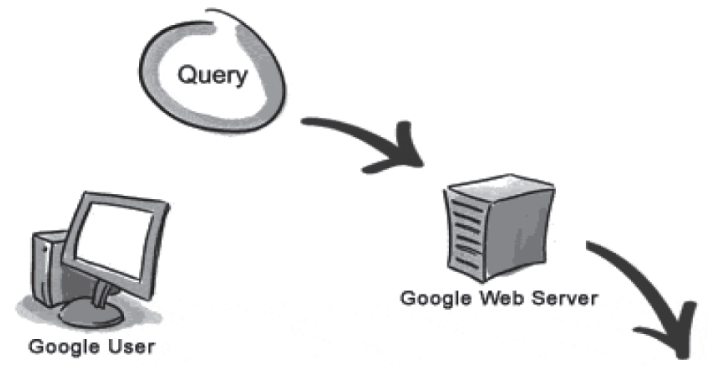

3. Wyniki wyszukiwania są zwracane użytkownikowi w ciągu ułamka sekundy.

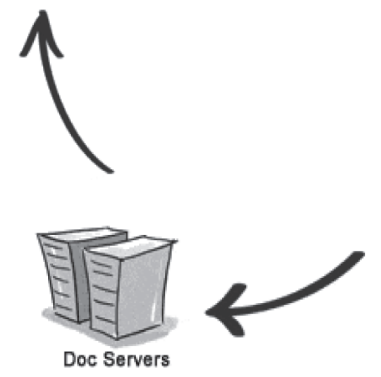

2. Zapytanie jest wysyłane do serwerów dokumentów, które pobierają przechowywane dokumenty. Generowane są fragmenty opisujące każdy wynik wyszukiwania.

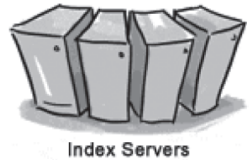

Index Servers

Źródło: www.google.pl.

Firma Google postawiła na prostotę serwisu. Projekt witryny jest przejrzysty i wygodny w użytkowaniu, ponieważ nie zawiera zbędnych elementów dekoncentrujących internautów, a wyniki wyszukiwania są wyraźnie oddzielone od reklam, które zaznaczono jako „linki sponsorowane" (ryc. 3). Minimalistyczny układ witryny obsługującej wyszukiwarkę internetową Google został opatentowany.

Ryc. 3. Projekt witryny Google

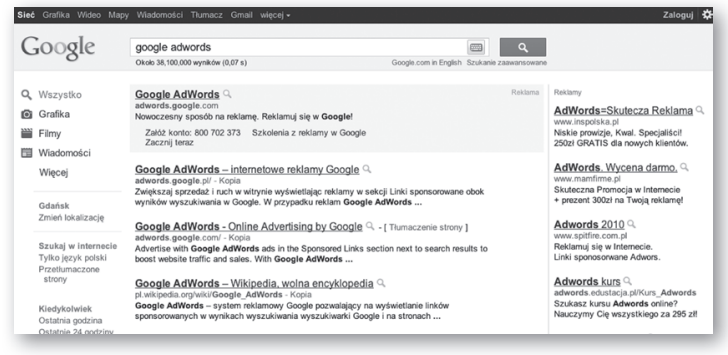

Źródło: www.google.pl.

W 2010 r. wyszukiwarka zyskała nowy układ graficzny, który ma lepiej prezentować użytkownikowi możliwości oraz ujednolicić pod względem graficznym poszczególnych funkcje wyszukiwania (ryc. 4). 
Ryc. 4. Współczesna wersja witryny Google

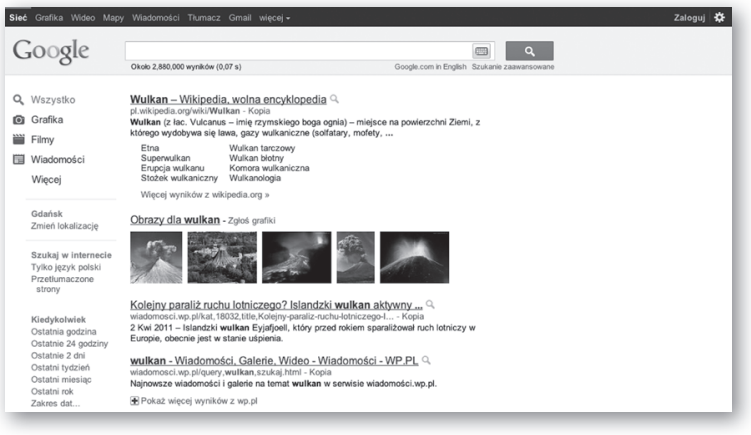

Źródło: http://nt.interia.pl/internet/wiadomosci/news/duze-zmiany-w-google,1474626.

Dysponując technologią wyszukiwania najwyższej klasy oraz obserwując ogromny ruch w witrynie Google.com, firma jako dwie początkowe możliwości pozyskiwania przychodów uznała usługi wyszukiwania i reklamy, które z czasem przekształciły się w dopełniające się sieci. Współcześnie najbardziej dochodowymi usługami Google jest wyszukiwarka internetowa oraz serwisy reklamowe AdWords i AdSense, jednak doświadczenie zespołu, zachodzące zmiany technologiczne, rosnące zainteresowanie użytkowników, a co za tym idzie - coraz większe zyski, umożliwiły poszerzenie oferty korporacji. Szeroki wachlarz usług proponowanych przez firmę Google przedstawia się następująco:

- wyszukiwanie internetowe (Internet Search),

- reklamy internetowe (Online Advertising),

- aplikacje internetowe (Web Applications),

- usługi biznesowe (Enterprise Services),

- rynek urządzeń mobilnych (the Market of Mobile Devices).

Usługi wyszukiwania internetowego umożliwiają internautom szybki dostęp do licznych stron zawierających informacje na interesujący ich temat. Są podzielone na kategorie takie jak: finanse (Finance), obrazki (Images), mapy (Maps), informacje (News), katalogi stron internetowych stworzone przez użytkowników (Directory). Warto wspomnieć także o przeglądarce internetowej Google Chrome oraz Froogle, czyli wyszukiwarce dla e-handlu.

Google posiada dwa systemy reklamowe: AdSense i AdWords. AdSense to usługa, która umożliwia wyświetlanie reklam adekwatnych do treści stron, a wydawca ma swój udział w przychodach generowanych przez czytelników klikających w reklamy. AdWords umożliwia reklamodawcom promocję produktów i usług w sieci przy użyciu profilowanych reklam „linków sponsorowanych” - przyciągających użytkowników z grup docelowych. Wybierają oni kluczowe słowa i płacą, gdy zainteresowani internauci klikną w ich reklamy. Firma oferuje także serwis „Analytics”, służący pomocą reklamodawcom, wydawcom i właścicielom stron przy identyfikacji haseł, reklam, skierowań i kampanii.

Aplikacje internetowe obejmują następujące usługi:

- Gmail - poczta elektroniczna i bezpłatny serwis webmail, pojemność skrzynki pocztowej w serwisie przekracza 7 gigabajtów i jest ciągle zwiększana,

- Google Groups - grupy dyskusyjne, umożliwiające zarządzanie listami mailingowymi oraz ich archiwizowanie, 
- Calendar - stosunkowo zaawansowana aplikacja do zarządzania własnym terminarzem,

- Google Talk - komunikator internetowy wyposażony w funkcjonalność VoIP (Voice over Internet Protocol),

- Google Wave - umożliwiające komunikację i współtworzenie dokumentów multimedialnych w czasie rzeczywistym,

- Analytics - system analizy ruchu sieciowego dostępny dla każdego użytkownika Google,

- YouTube - serwis internetowy, w którym użytkownicy mogą umieszczać i oglądać filmy wideo,

- Blogger - darmowy serwis blogowy,

- Picasa - menadżer i przeglądarka plików graficznych, umożliwia organizowanie kolekcji zdjęć cyfrowych i ich prostą edycję,

- Picasa Web Albums - serwis internetowy umożliwiający publikację w Internecie albumów zdjęć cyfrowych bezpośrednio z programu Picasa lub z poziomu przeglądarki.

Usługi biznesowe gwarantują korporacjom większą wydajność pracowników poprzez połączenie innowacyjności i łatwości obsługi produktów firmy Google oraz bezpieczeństwo organizacji. Dzielą się one na:

- Google Apps - redukujące koszty takich usług, jak: Gmail dla biznesu, Google Calendar, Google Groups, Google Docs, Google Sites i Google Video,

- Google Earth and Maps - ułatwiające pracownikom zrozumienie i podejmowania decyzji na podstawie informacji opartych na lokalizacji. Uwzględnienie danych firmy w Google Maps i Google Earth powoduje, że mogą być one szybko i łatwo wymienianie ze współpracownikami i klientami,

- Google Search - umożliwiający szybkie wyszukiwanie stron biznesowych na interesujący użytkownika temat.

Rynek urządzeń mobilnych obejmuje aplikacje działające w telefonach komórkowych, np. wyszukiwarkę internetową, YouTube, Gmail, SMS, Calendar, News, Maps oraz Google Latitude. Powstała także platforma dla telefonów komórkowych - Android - oparta na systemie Linux.

Firma Google dywersyfikuje swoje produkty i wchodzi na nowe rynki w celu kompleksowego zaspokajania potrzeb odbiorców. W czerwcu 2009 r. zapowiedziała poszerzenie swojej oferty o system operacyjny Chrome OS, posiadający otwarte źródła, którego głównym zadaniem ma być uruchamianie aplikacji internetowych. Oficjalna premiera systemu jest przewidziana na drugą połowę $2010 \mathrm{r}$.

Na przełom czerwca i lipca 2010 r. firma planowała wprowadzenie serwisu Google Editions służącego do sprzedaży elektronicznych książek, które będą pochodzić z różnych stron internetowych i będą możliwe do odczytania na różnych urządzeniach. Podstawą działania serwisu ma być wyszukiwarka Google Books.

Za sprawą systematycznych przejęć konkurencyjnych działalności Google proponuje coraz nowsze produkty i usługi. Jeden z ostatnich zakupów to BumpTop, który może okazać się konkurencyjnym produktem dla Apple i jego iPhone'a oraz iPada.

\section{Struktura wewnętrzna Google}

W wyniku procesu rozszerzania oraz doskonalenia produktów i usług, a także opanowywania nowych rynków zbytu, w firmie Google ukształtowała się odpowiednia do uwarunkowań struktura organizacyjna, której zadaniem jest podnoszenie konkurencyjności. W strukturze tej wyróżniono następujące segmenty powstałe w celu kompleksowego zaspokajania potrzeb klientów: 
- Engineering Operations - dział zajmujący się rozwojem i projektowaniem nowych aplikacji,

- Advertising Sales - oddział zajmujący się dostosowywaniem systemu reklamowego do konkretnych potrzeb klienta oraz Customer Supprot - dział, którego zadaniem jest wspieranie techniczne użytkowników i rozwiązywanie problemów związanych z usługami i aplikacjami Google,

- Product Management - segment dbający o rozwój i zarządzanie usługami w celu zapewnienia lepszego dostępu do zasobów informacji,

- Marketing and Communications - dział zajmujący się marketingiem oraz promowaniem firmy na rynku światowym,

- User Experience - segment badający zachowania i wymagania internautów oraz przyjmujący sugestie użytkowników w celu poprawienia jakości oferowanych produktów i usług,

- Legal and Public Politycy - sekcja regulująca kwestie prawne korporacji,

- Bussines Operations - dział specjalizujący się w efektywnym inicjowaniu i wdrażaniu programów partnerskich z innymi korporacjami,

- Administrative - dział zajmujący się koordynacją pracy poszczególnych zespołów Google w celu skutecznego rozwoju usług, aplikacji oraz całej firmy,

- Enterprise - segment wdrażający swoje produkty i usługi w firmach, placówkach oświatowych oraz organizacjach rządowych,

- Finance - dział zarządzający operacjami finansowymi i prowadzący analizę finansową przedsiębiorstwa,

- Human Resources - segment zajmujący się pozyskiwaniem przyszłych pracowników oraz stwarzaniem odpowiednich warunkach do pracy dotychczasowym kadrom.

\section{Strategia Google}

Kierunek rozwoju korporacji określa strategia rozwoju, w której ustala się misję i cele rozwojowe firmy na tle istniejących uwarunkowań w gospodarce światowej. „Strategia koncentruje się na zrozumieniu otoczenia i formułowaniu polityki przedsiębiorstwa, tak by mogło ono osiągnąc korzystną pozycję w stosunku do konkurentów” (Tobolska 2006, s. 125), wykorzystywać pojawiające się szanse i redukować zagrożenia pojawiające się na rynku.

W przeciągu 12 lat w korporacji Google dokonał się hiperrozwój. Na podstawie cech korporacji, jej działalności i podejmowanych przez nią decyzji, a także ogólnie przyjętych kierunków rozwoju, dokonano próby określenia jej strategii.

Misją firmy jest ,uporządkowanie światowych zasobów informacji, aby stały się one powszechnie dostępne i użyteczne". Za główne wyznaczniki strategii firmy Google w okresie 12-lecia jej działalności uznano:

- partnerstwo i zaufanie między firmą a jej klientami i partnerami w interesach,

- maksymalizację zysków niezbędnych do finansowania rozwoju i innych celów strategicznych,

- ciągłe doskonalenie proponowanych produktów i usług, prowadzące do tworzenia oferty najwyższej jakości w swojej dziedzinie, gwarantujące uznanie oraz lojalność klientów i nabywców na całym świecie,

- dywersyfikację produktów i wchodzenie na nowe, pokrewne rynki w celu kompleksowego zaspokajania potrzeb odbiorców,

- lokalizację nowych oddziałów w różnych krajach w celu dopasowania oferty ściśle do wymagań każdej grupy użytkowników,

- innowacyjność w każdej sferze działalności,

- badania i rozwój nowych technologii, 
- strategię zarządzania ludźmi, gwarantującą pełną swobodę tworzenia (zapewniającą pracownikom $20 \%$ czasu pracy na rozwijanie autorskich projektów) oraz przyjazne środowisko pracy, umożliwiające im relaks i rozwijanie zainteresowań, a także docenianie indywidualnych talentów i osiągnięć pracowników.

W strategii przyjętej przez korporację Google występują elementy strategii firm globalnych eksponujących kapitał ludzki, innowacje oraz jakość.

Na kapitał ludzki składają się kompetencje, wiedza, umiejętności, doświadczenie i talent zarówno menadżerów, jak i pracowników. To kadra decyduje o sprawności i efektywności, a co za tym idzie - o sukcesie firmy, pod warunkiem jednak, że jest zintegrowana ze strategią organizacyjną i strategiami na szczeblu funkcjonalnym. Google swoją przeszłość, teraźniejszość i przyszłość widzi w rozwoju potencjału intelektualnego, stawia na młodych i pomysłowych ludzi, którzy mają w pracy możliwość realizacji własnych idei, ponieważ właśnie z idei studentów zrodziła się ta firma.

W korporacji dostrzeżono cechy firm globalnych eksponujących innowacje, które są nastawione na ciągłe poszukiwanie nowych, lepszych rozwiązań w dziedzinie technologii, organizacji, inwestycji i pracy. Google w procesach innowacyjnych stosuje postawę ukrytych mistrzów (hidden champions). Początkowo firma była uznawana za niegroźną, działającą w cieniu innych globalnych gigantów. Traktuje ona technologie i rynek jako siły napędowe, dlatego w krótkim okresie zagarnęła ponad 80\% rynku światowego w dziedzinie wyszukiwania i zdobyła pozycję monopolistyczną.

Strategia zarządzania przez jakość przejawia się w korporacji Google w krytycznym spojrzeniu na oferowane produkty i usługi, prowadzącym do ich ciągłego ulepszania i gwarantowania pełnej satysfakcji odbiorcom. Dla firmy tak samo ważny jest klient wewnętrzny, czyli pracownik, jak i klient zewnętrzny, czyli końcowy użytkownik usługi. Podejście do jakości uznaje się jako kompleksowe, a jakość nadrzędną stanowi myślenie procesowe. Procesy są analizowane i optymalizowane w dążeniu do perfekcji.

Google w stosunku do konkurencji unika frontalnego ataku. Przykładem napoleońskiej taktyki biznesowej jest nawiązanie stosunków z gigantem wyszukiwania - Yahoo, wprowadzenie działalności portalowej oraz wprowadzenie usługi Gmail (Minakowski 2008).

Google, współpracując z Yahoo, oprócz dostarczania wyników wyszukiwania owej wyszukiwarki działało pod własnym szyldem. Firma zastosowała strategię „okrążania” i otworzyła się na cały świat, tłumacząc swój interfejs na wszystkie możliwe języki (także na polski). Przewagą Google był interfejs użytkownika w kodowaniu Unicode, którego jeden parametr tłumaczył wszystkie teksty na dowolny, obsługiwany język. Korporacja budowała swoją pozycję zagraniczną, podbijając kolejne rynki w dziedzinie wyszukiwarek.

Początkowo twórcy zrezygnowali z działalności portalowej, jednak wraz z rozwojem firmy wszystkie elementy portalowe znalazły się na iGoogle, a korporacja stała się niespodziewanie rywalem dla innych portali.

Firma osiągnęła ogromy sukces w przypadku poczty elektronicznej dzięki temu, że zwróciła uwagę na problem dodawania do wiadomości załączników o dużych rozmiarach. W ten oto sposób wypełniła niszę, tworząc usługę Gmail i udostępniając gigabajtowe skrzynki, których pojemność jest wciąż zwiększana.

Obecnie rynek wyszukiwarek jest na pograniczu oligopolu i monopolu. Największe udziały w nim posiadają: Google (81,1\%), Yahoo (10,5\%), MSN/Live (4,6\%), AOL - Global (2,0\%), a pozostałe wyszukiwarki to zaledwie 1,8\% udziału w rynku (ryc. 5). Sytuacja ta jest odzwierciedleniem zmian, które nastąpiły w ostatnich latach w komunikacji elektronicznej. 
Ryc. 5. Udział poszczególnych wyszukiwarek w rynku wyszukiwarek ogółem w 2009 r.
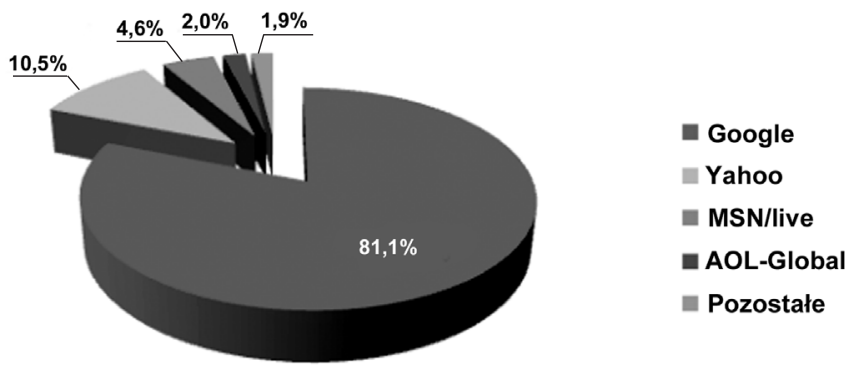

Źródło: opracowanie własne na podstawie http://www.strategie.biz.pl/2009/02/23/potrzeba-matka-wynalazku-i-sukcesu/.

Firma Google pobija rekordy w liczbie przejętych spółek. Od momentu narodzin internetowego giganta maksymalny wynik padł w roku 2007, kiedy przejął 16 spółek, a tylko do czerwca w 2010 r. przejęła 11 spółek i wciąż czeka na zgodę regulatorów transakcji roku poprzedniego (Grynkiewicz 2010). W okresie od 2001 r. do czerwca 2010 r. dokonała 70 przejęć, podczas gdy Microsoft w ciągu 23-letniej historii przejął 128 spółek. Najdroższym nabytkiem Google jest Double Click - firma zajmująca się reklamą internetową - warta 3,1 mld USD. Znaczną większość, bo aż 51 firm przejętych przez korporację, stanowią firmy amerykańskie.

Ogromna przewaga korporacji nad konkurencją wynika z zasady, która stawia skupienie uwagi internautów na użytecznych funkcjach serwisu i rezultatach wyszukiwania. Promocja serwisu jest bardzo subtelna i przemyślana, największą siłą i reklamą jest sam oferowany produkt, a także strategia przyjęta przez korporację w dążeniu do doskonałości. Bardzo ważne znaczenie w podnoszeniu nowoczesności oferowanych produktów ma nauka (Zioło 2009).

Wskazane przykłady postępowania firmy Google świadczą o tym, że potrafi celnie wskazywać potrzeby odbiorców, a także skutecznie je realizować. Głównym celem dalszego rozwoju korporacji jest podnoszenie standardu produktów i usług, doskonalenie metod w zakresie wyszukiwania, systematyczne pogłębianie i rozszerzanie rynku w poszczególnych krajów, jak i światowego, a także ograniczanie kosztów związanych z intensyfikacją rozwoju firmy, a tym samym zmniejszenie kosztów użytkowników, co jest znaczącym czynnikiem podnoszenia konkurencyjności.

\section{Filozofia i kultura Google}

Fenomenem, który udało się osiągnąć założycielom Google, jest fakt, że pomimo hiperrozwoju od momentu narodzin firmy w 1998 r. udało się jej zachować pierwotne wartości i atmosferę małego przedsiębiorstwa.

W celu realizacji misji korporacji i skutecznego tworzenia nowej kultury pracy, wprowadzono pewne zasady postępowania obowiązujące w Google aż do dziś. Credo firmy stanowią słowa wypowiedziane przez jednego z inżynierów, Paula Buchheita: „Nie bądź zły” (Don ’t be evil), wskazujące sposób, w jaki powinna ona prowadzić swoją działalność na arenie międzynarodowej.

W firmie Google priorytetem jest innowacyjność oraz efektywność. Największą wartość stanowi dla niej kapitał ludzki, dlatego poszukuje utalentowanych i kreatywnych pracowników, którzy potrafią sprostać stawianym przed nimi wymaganiom oraz realizować cele korporacji. Prowadzona jest otwarta polityka rekrutacyjna, liczy się wiedza, umiejętność rozwiązywania 
problemów, przedkładane są uzdolnienia nad doświadczenie. Atutem korporacji jest jej niezwykła i ciekawa kultura organizacyjna.

Motto zarządu brzmi: „Inwestycja w pracownika jest inwestycją w firmę”. Efektywność oraz zaangażowanie we wprowadzanie innowacji zależy m.in. od tego, czy Googlersi ${ }^{3}$ czują się swobodnie w miejscu pracy, dlatego zarząd dokłada wszelkich starań, aby zapewnić pracownikom odpowiednie środowisko do tworzenia nowatorskich projektów i technologii, a także umożliwić im rozwijanie ich pasji poprzez tworzenie grup o wszelakich zainteresowaniach. Filozofią Google jest możliwość stworzenia „młodości” warunków do samorealizacji, a tym samym tworzenia podstaw do rozwoju firmy.

Pracownicy działają w małych, trzy- lub czteroosobowych zespołach, przez co mogą szybciej realizować swoje koncepcje, nie czują korporacyjnej presji i poprawiają kontakty interpersonalne. Specyfiką firmy jest przeznaczenie 20\% czasu pracownika na rozwijanie autorskich, nowatorskich projektów, które mają szansę późniejszej realizacji.

Biura Google są zaprojektowane tak, aby wzbudzać wśród pracowników skojarzenia z rozrywką. Posiadają wiele charakterystycznych elementów gwarantujących pracownikom komfort i możliwość relaksu, który wpływa na ich wysoką wydajność i jakość wykonywanych przez nich zadań. Fotele masujące i duże dmuchane piłki, piłkarzyki, stoły bilardowe, boiska do siatkówki, gry wideo, pianina oraz sale gimnastyczne, w których odbywają się zajęcia jogi i tańca, to tylko niektóre propozycje. Googlersi mają do dyspozycji rowery i skutery, które pozwalają im przemieszczać się z jednego spotkania na drugie. Pracownicy mają zagwarantowane zdrowe i pełnowartościowe obiady i kolacje w rozmaitych kantynach i pokoje socjalne wypełnione różnymi przekąskami i napojami, które pomagają im zachować siły i skupienie. Biura Google są bogate w akcenty typowe dla miejsca ich lokalizacji, np. gondole kolejki linowej w Zurychu, odzwierciedlające jego atmosferę i charakter.

W 2009 r. korporacja Google znalazła się na czwartej pozycji (za NetApp, Edward Jones i Boston Consulting Group) w rankingu „,100 najlepszych pracodawców” (,100 Best Companies to Work For”) prestiżowego magazynu „Fortune”, w którym od trzech lat utrzymywała się w pierwszej piątce.

W świetle przedstawionego procesu kształtowania się korporacji ponadnarodowej Google i postępującej globalizacji można stwierdzić, że rozwój korporacji zostanie zachowany. Ciągłe innowacje technologiczne, troska o najwyższą jakość produktów i usług mają na celu sprostać coraz to nowszym oczekiwaniom klientów, a w połączeniu z zarządzaniem zorientowanym na ludzi decydują o sukcesie korporacji.

Dzięki wierności swej filozofii oraz strategii sukcesu firma zdobyła czołową pozycję wśród korporacji branży informatycznej, a także w krótkim czasie stała się częścią życia, niewzbudzającym zaskoczenia elementem rzeczywistości, bez którego niektórzy nie wyobrażają sobie życia. To google stało się synonimem słowa szukać, a Google często utożsamiane jest z Internetem (Maleńczak 2009). O wielkości i roli giganta internetowego, której nie da się przeliczyć na miliardy dolarów świadczą słowa wypowiedziane przez Brewstera Kahle ${ }^{4}$, „Biblioteka aleksandryjska była pierwszą próbą zebrania w jednym miejscu całej wiedzy ludzkości. Ostatnia taka próba to Google".

\footnotetext{
${ }^{3}$ Określenie pracowników firmy Google.

${ }^{4}$ Przedsiębiorca, inżynier komputerowy i założyciel the Internet Archive.
} 


\section{Literatura}

1. Battelle J., 2006, The Search. How Google and its Rivals Rewrote the Rules of Business and Transformed Our Culture, Wydawnictwo Naukowe PWN, Warszawa.

2. Boguś M., 2010, Kształtowanie się korporacji ponadnarodowej Google, praca magisterska napisana w Zakładzie Przedsiębiorczości i Gospodarki Przestrzennej, Instytut Geografii Uniwersytetu Pedagogicznego im. Komisji Edukacji Narodowej w Krakowie pod kierunkiem prof. Z. Zioło.

3. Grynkiewicz T., 2010, Giganci IT mają w gotówce 188 mld dol., „Gazeta Wyborcza. Gospodarka”, nr 27.

4. http://openzone.pl/news,krotka-historia-google,3000.

5. Kilar W., 2009, Zróżnicowanie potencjału ekonomicznego światowych korporacji [w:] Funkcje przemystu w kształtowaniu społeczeństwa informacyjnego, Z. Zioło, T. Rachwał (red.), „Prace Komisji Geografii Przemysłu PTG”, nr 13, Komisja Geografii Przemysłu PTG i Instytut Geografii Uniwersytetu Pedagogicznego w Krakowie, Warszawa-Kraków, s. 110-121.

6. Maleńczak P., Potrzeba matka wynalazku (i sukcesu)!, www.strategie.biz.p1/2009/02/23/potrzeba-matka-wynalazku-i-sukcesu/

7. Olszak C., Ziemba E., 2007, Strategie i modele gospodarki elektronicznej, Wydawnictwo Naukowe PWN, Warszawa.

8. Piórko K., 2008, ,,Władza” korporacji transnarodowych w stosunkach międzynarodowych, Wydawnictwo Naukowe GRADO, Toruń.

9. Tobolska A., 2006, Strategie globalne a nowe formy organizacji przedsiębiorstw transnarodowych [w:] Rola przedsiębiorczości w podnoszeniu konkurencyjności społeczeństwa i gospodarki, Z. Zioło, T. Rachwał (red.), „Przedsiębiorczość - Edukacja”, nr 2, Nowa Era, Zakład Przedsiębiorczości i Gospodarki Przestrzennej Instytutu Geografii Akademii Pedagogicznej w Krakowie, Warszawa-Kraków.

10. Vise D., Malseed M., 2007, The Google Story, Wydawnictwo Dolnośląskie, Wrocław.

11. Wieloński A., 2003, Przemyst nowej gospodarki [w:] Przemyst w procesie globalizacji, Z. Zioło, Z. Makieła (red.), „Prace Komisji Geografii Przemysłu PTG”, nr 6, Komisja Geografii Przemysłu PTG w Warszawie i Zakład Przedsiębiorczości i Gospodarki Przestrzennej Instytutu Geografii Akademii Pedagogicznej w Krakowie, Warszawa-Kraków, s. 21-26.

12. www.google.com

13. Zioło Z., 2001, Struktura branżowa i koncentracja przestrzenna wiodących światowych firm przemystowych [w:] Problemy przemian struktur przemysłowych a w procesie wdrażania regut gospodarki rynkowej, Z. Zioło (red.), „Prace Komisji Geografii Przemysłu PTG”, nr 3, Komisja Geografii Przemysłu Polskiego Towarzystwa Geograficznego w Warszawie, Wydział Ekonomiczny UMCS w Lublinie - Filia w Rzeszowie, Warszawa-Kraków-Rzeszów, s. 29-41.

14. Zioło Z., 2009, Procesy ksztaltowania się światowych korporacji i ich wpływ na otoczenie [w:] Wpływ procesów globalizacji i integracji europejskiej na transformacje struktur przemysłowych, Z. Zioło, T. Rachwał (red.), „Prace Komisji Geografii Przemysłu PTG”, nr 12, Komisja Geografii Przemysłu PTG i Zakład Przedsiębiorczości i Gospodarki Przestrzennej Instytutu Geografii Akademii Pedagogicznej w Krakowie, Warszawa-Kraków.

15. Zorska A., 2002, Korporacje międzynarodowe w Polsce. Wyzwania w dobie globalizacji i regionalizacji, A. Zorska (red.), Difin, Warszawa. 


\section{The Formation of the Multinational Corporation Google}

The formation process of any multinational corporation is driven by mechanisms of competition within global markets. In this modern era of knowledge there is an intensive development of high technology industries, mainly software, which play important roles in the various stages of processing and creation of innovative products and services.

The history of Google goes back to 1995 when its founders - Sergey Brin and Larry Page met at Stanford University in California. On 7th September 1998, Google Inc. was officially incorporated. In 2001 Eric Smidt became Chief Executive Officer. In their twelve years of existence, the company maintained major development and was at the forefront of the development of software industry standards. The most profitable and constantly developing services of the corporation are the search engine, which represents more than $80 \%$ of the total search market and the advertising services such as AdWords and AdSense. However, the company diversifies its products and systematically enters into new markets in order to comprehensively meet the needs of its customers. Its diversification includes web applications, enterprise services and the market of mobile devices.

The various departments of the corporation are located in 70 cities across 39 countries, usually in the capitals of these countries or, if not, in other large cities, which are associated with major public markets. The headquarters of Google is located in Mountain View, California. Most of the departments - twenty three, are located throughout North America and Europe. There are also 16 departments based in Asia. Individual countries have a varying degree of presence of Google offices, the largest being the United States with nineteen, whilst three are located in Poland, in Warsaw, Cracow and Wroclaw.

Google has formed an organizational structure whose main task is to improve its competitiveness. Business development strategy is based on innovation, human potential and high quality standards and its mission is to „organize the world's information and make it universally accessible and useful". With an effective strategy, Google breaks records in the number of acquired companies.

The Corporation has an unusual and interesting organizational culture, which, due to concern for the well-being of employees, ensures high performance. Google's philosophy is that of developing young, talented individuals capable of self-realization, thus creating a basis for development. In 2009 Google found itself in fourth position in the ranking of "100 Best Companies to Work For" in "Fortune Magazine".

By being faithful to its philosophy and strategy for success, Google has become part of a reality, without which some cannot imagine life. As the company is constantly expanding the range of its services and introducing innovative solutions, it is reasonable to assume that the process of the corporation's development will be maintained. 


\section{Wioletta Nogaj}

Uniwersytet Ekonomiczny

w Krakowie

\section{Globalizacja a lokalizacja działalności gospodarczej}

Jednym z głównych zjawisk zachodzących we współczesnym świecie jest zjawisko globalizacji. Dotyka ono wszystkich bez wyjątku państw oraz gospodarek. Z procesem globalizacji wiążą się szybkie przepływy towarów, usług i kapitału, migracje ludzi oraz gwałtowna ekspansja korporacji transnarodowych. To one wprowadzają zasady planowania strategicznego i optymalizację produkcji w globalnej skali, a także przesuwają produkcję przemysłową do krajów i regionów świata o niższych kosztach wytwarzania. Procesy nowej fazy globalizacji kojarzą się nieodłącznie ze zmianą lokalizacji miejsc pracy, produkcji i świadczenia usług. Działania te odzwierciedlają zmiany w funkcjonowaniu przedsiębiorstw i wynikają z adaptacji firm do coraz bardziej konkurencyjnego środowiska, w którym działają oraz z szybkich zmian technologicznych (Hetmańczyk, Noga 2008).

Prawdopodobnie po raz pierwszy termin globalizacja pojawił się w roku $1959 \mathrm{w}$ tygodniku „The Economist” (Sala 2006). W literaturze brak jest powszechnie akceptowanej definicji tego pojęcia. Przykładowo A. Stabryła rozpatruje zjawisko globalizacji zarówno w wąskim, jak i w szerokim zakresie. W wąskim ujęciu globalizacja odnosi się do przedsięwzięć rynkowych, które są charakteryzowane przez produkt globalny (uniwersalny nie zaś lokalny) oraz przez podobne gusty klientów na całym świecie. Natomiast w ujęciu szerokim globalizacja dotyczy stanu myślenia i działania firm opartego na światowej perspektywie, integrującego w jeden system klientów, zasoby, technologię wytwarzania, koszty, układy kooperacyjne i alianse oraz konkurentów (Stabryła 2007). Wielu autorów podejmujących próbę stworzenia definicji globalizacji odwołuje się do pojęcia procesu, definiując globalizację jako:

- proces pogłębiania się światowych powiązań we wszystkich aspektach współczesnego życia politycznego, społecznego, ekonomicznego i kulturowego (Liberska 2002),

- ogólnoświatowe (kontynentalne, regionalne) procesy obejmujące postęp techniczno-organizacyjny, technologie komunikacyjne, nowe formy współpracy politycznej i ekonomicznej między państwami, które determinują procesy gospodarowania i zarządzania organizacjami (Potocki 2009),

- proces stopniowego, realnego scalania gospodarek narodowych, przejawiający się w dynamicznym wzroście obrotów handlowych, międzynarodowych przepływów kapitałowych i usługowych oraz rosnącej tendencji do traktowania całego świata jako rynku zbytu przez coraz większą liczbę przedsiębiorstw (Budnikowski 2000),

- historyczny i spontaniczny proces liberalizacji i postępującej wraz z nią integracji funkcjonujących dotychczas w odosobnieniu lub luźno powiązanych rynków towarów, kapitału i z opóźnieniem i na mniejszą skalę rynku siły roboczej oraz technologii i informacji w jeden współzależny rynek światowy (Kołodko 2008), 
- proces bliższej ekonomicznej integracji rynków globalnych: finansowego, produktu i pracy (Gurría 2006),

- proces, który jest tworzony przez zjawiska lub działania o wymiarze ogólnoświatowym (Zaorska 1998),

- proces rosnącej wielopłaszczyznowej (tj. ekonomicznej, społecznej, kulturowej, politycznej) współzależności pomiędzy poszczególnymi krajami i regionami, wskutek czego dochodzi do powstania silnie zintegrowanego rynku światowego (Matysek-Jędrych 2008).

Powyższe definicje potwierdzają słuszność opinii B. De Wita oraz R. Meyera o tym, że termin globalizacja odnosi się do trzech elementów, którymi są:

- ogólnoświatowy zasięg - znaczenie geograficzne, oznacza przedsiębiorstwo obejmujące swoją działalnością cały świat, w odróżnieniu od przedsiębiorstw o zasięgu lokalnym (krajowym) lub regionalnym (kilka krajów),

- ogólnoświatowa jednorodność - zanikanie międzynarodowej różnorodności oznacza przedsiębiorstwo sprzedające ten sam produkt na wszystkich obsługiwanych rynkach geograficznych, w odróżnieniu od produktu dopasowanego do lokalnej specyfiki,

- ogólnoświatowa integracja - kategoria zależności i zacieśniania powiązań międzynarodowych, oznacza przedsiębiorstwo, które wyraźnie odczuwa skutki zdarzeń zachodzących w innych krajach, w odróżnieniu od rynku lokalnego, gdzie sytuacja zagraniczna ma znikomy wpływ na poziom cen, dynamikę konkurencji, popyt i obowiązujące mody (Wit, Meyer 2007).

W naukach o zarządzaniu czasami utożsamiane są ze sobą dwa różne wymiary globalizacji: globalizacja rynków i globalizacja sektorów. Jest to błędne postępowanie, ponieważ każdy z tych wymiarów niesie odmienne następstwa dla różnych aspektów strategii funkcjonowania organizacji. Globalizacja sektorów jawi się jako druga strona globalizacji rynków. Jeżeli globalna działalność przedsiębiorstwa na rynku koncentruje się na rozpoznawaniu i zaspokajaniu potrzeb konsumentów, to działalność globalna w sektorze skupia się na organizowaniu i koordynowaniu funkcji produkcyjnych poza granicami państwa. Te dwa wymiary globalizacji mają określony wpływ na zarządzanie przedsiębiorstwami w warunkach globalizacji, która w tym kontekście staje się szansą, ale także niesie za sobą zagrożenia (Potocki 2004).

Dociekliwi badacze historii gospodarczej odnajdują korzenie globalizacji w odległych wiekach, w których nastąpił rozwój długodystansowego transportu i rozszerzyły się możliwości komunikowania między ludźmi. W literaturze można spotkać opinie o pionierskiej roli ekspansji buddyzmu i chrześcijaństwa na początku naszej ery, islamu w VII-IX w., pochodu Czyngis-Chana w XIII w. czy rozwoju Imperium Ottomańskiego w XIV w. Jednak szczególne znaczenie przypisuje się wielkim odkryciom geograficznym w XV i XVI w., współcześnie określanym mianem spotkania cywilizacji. Odkrycia geograficzne i wywołany przez nie rozwój handlu ukształtowały kapitalizm merkantylny. Gospodarkę rynkową promowała następnie ideologia liberalizmu, która wyrosła w epoce Oświecenia (Kaliński 2004). Przedstawiciele merkantylizmu udowodnili, że podstawą istnienia bogatych państw jest kapitalistyczne uprzemysłowienie oraz przyspieszony rozwój, realizowany poprzez handel zamorski oraz rodzimą produkcję chronioną przez system monarchii absolutnej. Doprowadziło to m.in. do odkrycia, a następnie eksploatacji kontynentu amerykańskiego oraz dało początek bardzo szybkiemu rozwojowi wymiany międzynarodowej, tworząc na świecie centra gospodarcze mające wpływ na sposób produkowania oraz na procesy dystrybucyjne w wielu różnych gospodarkach narodowych. Na skutek tych zjawisk doszło do międzynarodowego podziału pracy i podporządkowania się większości krajów najwyżej rozwiniętym gospodarkom rynkowym. 
Pojęcie globalizacji nie odnosi się tylko do działalności przemysłowej, ale również do rynków finansowych i pieniężnych (Bednarek 2007). Patrząc przez pryzmat czasu i kosztów transportu, nasza planeta skurczyła się obecnie do rozmiarów globalnej wioski. Wielu ludzi przyjmuje za fakt oczywisty możliwość dostępu do produktów z całego świata oraz możliwość odbywania szybkich i bezpiecznych podróży międzykontynentalnych (Harrison, Hoek 2010). Z punktu widzenia nauki i praktyki zarządzania można przyjąć, że początki zainteresowania terminem globalizacja wynikały z procesów koncentracji kapitału i powstania wielkich ponadnarodowych koncernów, co miało miejsce w drugiej połowie XX w. (Potocki 2004)

Obecna faza globalizacji różni się od poprzednich przede wszystkim tym, że nowoczesne technologie informacyjne i komunikacyjne doprowadziły do gwałtownego wzrostu handlu usługami oraz do zastąpienia fordowskiej produkcji masowej elastycznymi systemami produkcji. Dzisiejsza faza globalizacji charakteryzuje się specyficznym zestawem cech o charakterze zarówno ekonomicznym, jak i pozaekonomicznym. Do tych pierwszych zaliczamy m.in. wzrost obrotów handlowych, inwestycji oraz przepływów finansowych i technologicznych. Po stronie tych drugich można wymienić m.in. rosnącą uniformizację społecznych systemów wartości, będącą rezultatem standaryzacji gustów konsumpcyjnych oraz częściowej utraty suwerenności narodowej. Ekonomiści są zgodni co do tego, że w przyspieszeniu procesu globalizacji ogromną rolę odegrał handel światowy, który w latach 1820-1992 wzrósł 540 razy, podczas gdy liczba ludności na świecie zwiększyła się tylko pięciokrotnie. Do ważnych nowych zjawisk, które zaistniały po drugiej wojnie światowej, należy zaliczyć szybszy wzrost handlu usługami niż handlu wyrobami przemysłowymi, a także dość istotną zmianę struktury eksportu krajów rozwijających się, polegającą na zwiększonym udziale sprzedaży wyrobów przetworzonych kosztem wyrobów surowcowych (Piasecki 2003).

Globalizacja niesie ze sobą bezprecedensowe możliwości uzyskania korzyści ekonomicznych, ale dostęp do tych możliwości nie jest równie łatwy dla wszystkich; wręcz przeciwnie: dla jednych jest bardzo łatwy, dla innych - zamknięty. Im łatwiejszy jest dostęp do Internetu, do globalnych zasobów wiedzy, do globalnej infrastruktury finansowej i innych sieci, tym większe zyski można osiągnąć z działalności gospodarczej, szczególnie w skali globalnej oraz tym łatwiej jest taką działalność rozpocząć lub kontynuować (Flejtarski, Wahl 2003).

Efektem globalizacji jest nie tylko zmniejszenie dystansu między państwami a regionami, zwiększenie się rynków istniejących faktycznie i wirtualnie, ale też pogłębienie różnic między krajami rozwiniętymi a rozwijającymi się, regionami i miastami bogatymi a ubogimi, powodujące rewolucyjne zmiany o charakterze pozytywnym lub negatywnym (Bednarek 2007).

Entuzjaści globalizacji podkreślają jej następujące zalety:

- wzrost efektywności i konkurencyjności,

- spadek kosztów produkcji i komunikacji,

- liberalizacja i demokratyzacja systemu światowego,

- możliwość przyspieszenia wzrostu w obszarach zacofanych,

- zwiększona możliwość uczestnictwa w procesach światowych,

- wyłanianie się nowych (wschodzących) rynków i podmiotów gospodarczych,

- wzrost jakości wyrobów i usług,

- powstawanie nowych zawodów,

- stopniowe zanikanie barier we współpracy międzynarodowej,

- wzrost świadomości międzynarodowej i myślenia globalnego,

- większa współpraca międzynarodowa przy rozwiązywaniu wspólnych problemów,

- wzrost pluralizmu na światowej scenie politycznej,

- łatwiejszy dostęp do zróżnicowanych dóbr i usług, nowych technologii, metod zarządzania, instytucji, osiągnięć kulturowych, rozrywki,

- przyspieszona dyfuzja postępu naukowo-technicznego, 
- upodobnianie się wzorców rozwoju społeczno-ekonomicznego,

- normalizacja i standaryzacja w skali świata,

- możliwość transferu kapitału do słabiej rozwiniętych gospodarek (Flejterski, Wahl 2003). Z kolei W. Misiak wskazuje na następujące ekonomiczno-społeczne procesy i zjawiska towarzyszące globalizacji, które są postrzegane jako jej wady:

- nierówności w rozwoju ekonomicznym,

- rozpiętości w dochodach i poziomie życia - „bogaci się bogacą, biedni biednieją”,

- działalność Banku Światowego, Międzynarodowego Funduszu Walutowego, Światowej Organizacji Handlu, Unii Europejskiej i innych organizacji ponadnarodowych,

- eksploatacja środowiska naturalnego bez troski o przyszłe pokolenia,

- „demokracja selektywna” (typ demokracji, w której ważne jest „co pasuje władzy”), winna być zastąpiona „demokracją partycypacyjną”,

- zagrożenie suwerenności politycznej, państwowej i narodowej,

- polityczna i ekonomiczna zależność mediów,

- degradacja i zagrożenie kultur narodowych, regionalnych i lokalnych,

- unifikacja kultury w skali globalnej,

- wyzysk pracowników w wielkich korporacjach,

- dyskryminacja kobiet,

- zatrudnianie dzieci,

- kontestacje w stosunku do swoiście interpretowanego przez władze pojęcia interesy społeczne, na szczeblu centralnym i lokalnym (W. Misiak 2007).

Globalizacja jest zatem procesem, który niesie za sobą wiele wyzwań i zagrożeń, ale jak zauważył J.P. Jeannet w Managing with a Global Mindset, globalizacja nie jest ani modą, ani tymczasowym trendem, globalizacja jest faktem, do którego większość firm i menedżerów będzie musiała się przystosować (Jeannet 2000).

\section{Lokalizacja dzialalności gospodarczej}

Z punktu widzenia zarządzania przedsiębiorstwem najistotniejszą kwestią związaną z globalizacją jest dostrzeganie tego, co determinuje działania firmy z perspektywy światowej. Oznacza to przede wszystkim dobór metod i filozofii zarządzania, które pozwolą zaistnieć przedsiębiorstwu w świecie konkurencji globalnej (Bednarek 2007). W praktyce globalny wymiar działalności stawia przed przedsiębiorstwami trudne i ambitne zadania, do których możemy zaliczyć:

- oferowanie klientom na całym świecie niepowtarzalnych wartości,

- zmaganie się z coraz silniejszą konkurencją o charakterze globalnym,

- przystosowanie się do wielorakich środowisk narodowych o zróżnicowanej kulturze, odmiennych systemach politycznych i gospodarczych, sposobach prowadzenia działalności oraz infrastrukturze,

- orientacja w globalnej polityce stosunków gospodarczych i handlowych,

- dostępność i poziom rozwoju infrastruktury w transporcie i telekomunikacji,

- złożoność zarządzania rozbudowaną siecią,

- czynniki geograficzne - czas, odległość, umiejscowienie rynków (Schary, Skjott-Larsen 2002). Filozofia działania firmy globalnej jest jasna: rozwijanie biznesu poprzez rozszerzanie rynków i równoczesne dążenie do osiągnięcia zgodności zakresu działań marketingowych oraz asortymentu produktów z redukcją kosztów dzięki efektowi skali w zaopatrywaniu się i produkcji (poprzez specjalizację produkcji i/lub działania montażowe) oraz w logistyce (Christopher, Peck 2005). Jedną z kluczowych decyzji firm globalnych jest wybór lokalizacji. Niezależnie od faktu, czy wybór lokalizacji odbywa się w warunkach ograniczonego wyboru, czyli w sytuacji, kiedy mamy do czynienia z kilkoma możliwymi lokalizacjami, z których jedna musi 
być wybrana, czy też wybór dokonywany jest w warunkach nieograniczonego wyboru, a zatem wówczas, gdy używamy algorytmów geometrycznych do wyznaczania optymalnej lokalizacji, przy nielimitowanych możliwościach wyboru miejsca (Waters 2001), należy pamiętać, że jest to decyzja, która ma wpływ na działanie przedsiębiorstwa przez wiele lat. Błędny wybór lokalizacji może zadecydować o porażce przedsiębiorstwa. Celem wyboru lokalizacji jest takie umiejscowienie geograficzne działalności firmy, które przyniesie najwięcej korzyści. Istnieje kilka powodów, dla których firmy poszukują nowej lokalizacji. Problemy wyboru miejsca lokalizacji są ważne zarówno dla nowo rozpoczynających działalność przedsiębiorstw, jak i dla już funkcjonujących firm. Zagadnieniami związanymi z teorią lokalizacji zajmowali się m.in. tacy ekonomiści, jak J.H. von Thünen (1826), J. Schumpeter (1912), A. Weber (1929), B. Ohlin (1967), A. Predöhl (1971), H. Giersch (1979) czy H. Siebert (2000) (Misala 2004). Lokalizowanie produkcji poza granicami kraju jest obok rozszerzenia i zdobywania nowych rynków, tworzenia joint ventures i zawierania aliansów strategicznych, działaniem będącym podstawą do ewolucji w kierunku globalizacji (Gołębiowska, Szymczak 2004).

Problematyka lokalizacyjna należy do opcji strategicznego zarządzania operacyjnego. W procesie wyborów lokalizacyjnych należy uwzględnić następujące zasady:

- tradycyjne przesłanki motywujące do inwestowania i lokalizacji rzeczowych inwestycji ustępują miejsca nowym przesłankom związanym w większym stopniu z procesem globalizacji (np. atrakcyjne punkty prowadzenia prac badawczo-rozwojowych),

- zagadnienia lokalizacyjne można z powodzeniem rozwiązywać za pomocą odpowiednio zbudowanych modeli matematycznych,

- procedury wyboru miejsc lokalizacji są procedurami wieloetapowymi (Kasiewicz 2002).

Wśród najbardziej znanych koncepcji związanych z procesami globalizacyjnymi, które mają implikacje lokalizacyjne, wymienia się teorię bezpośrednich inwestycji zagranicznych, międzynarodowy model cyklu życia produktu oraz międzynarodowy model Uppsali (tab. 1).

Tab. 1. Wybrane koncepcje związane z procesami globalizacyjnymi, które mają implikacje lokalizacyjne

\begin{tabular}{|c|l|c|}
\hline $\begin{array}{c}\text { Teoria } \\
\text { bezpośrednich } \\
\text { inwestycji } \\
\text { zagranicznych }\end{array}$ & $\begin{array}{l}\text { Inwestycje zagraniczne wynikają z cech funkcji przewag konkurencyjnych, które } \\
\text { zamierzają osiągnąc inwestorzy. Przewagi konkurencyjne mogą być związane } \\
\text { ze strukturą własności (np. technologie, patenty), lokalizacją (np. zasoby naturalne, } \\
\text { niskie koszty pracy), zdolnością równoważenia zdolności konkurencyjnych. }\end{array}$ \\
\hline $\begin{array}{c}\text { Międzynarodowy } \\
\text { model cyklu } \\
\text { życia produktu }\end{array}$ & $\begin{array}{l}\text { Czynnikami lokalizacji działalności produkcyjnych na globalnym rynku } \\
\text { sąnnologiczne know-how, popyt, efekty skali i koszty pracy. } \\
\text { Model wyróżnia cztery fazy: }\end{array}$ \\
$\begin{array}{c}\text { 1. Wejście na rynek - dotyczy lokalizacji zakładów w krajach wysoko } \\
\text { uprzemysłowionych. }\end{array}$ \\
$\begin{array}{c}\text { 2. Faza wzrostu - rozwija się zdolności produkcyjne i eksportuje wyroby } \\
\text { na rynki trzecie. }\end{array}$ \\
$\begin{array}{l}\text { 3. Faza dojrzewania - dokonuje się realokacji potencjału produkcyjnego celem } \\
\text { redukcji kosztów (np. kosztów pracy, transportu), lokując potencjał wytwór- } \\
\text { czy w krajach nowo uprzemysłowionych lub rozwijających się. }\end{array}$ \\
$\begin{array}{l}\text { 4. Faza spadkowa - redukuje się zdolności produkcyjne, zwłaszcza w kraju } \\
\text { siedziby firmy globalnej. }\end{array}$ \\
\hline Model Uppsali & $\begin{array}{l}\text { Koncentruje się na aspektach rynkowych (np. na zakupach, przejęciach, } \\
\text { integracji, wiedzy o rynkach zagranicznych). }\end{array}$ \\
\hline
\end{tabular}

Źródło: opracowanie własne na podstawie S. Kasiewicz, Zarządzanie operacyjne w dobie globalizacji, Centrum Doradztwa i Informacji Difin sp. z o.o., Warszawa 2002, s. 192-193. 
Z analizy tych modeli wynika, że zakłady produkcyjne lokalizowane w krajach uprzemysłowionych wyróżniają się pod względem innowacyjności, natomiast zakłady produkcyjne lokalizowane w krajach rozwijających się i słabo rozwiniętych wyróżniają się czynnikiem kosztowym.

Z kolei G.S. Yip (2004) wyróżnia cztery główne strategie lokalizacji i koordynacji działalności:

- Strategia oparta na eksporcie - polega na lokowaniu możliwie największej liczby wcześniejszych ogniw łańcucha wartości w kraju macierzystym, na zewnątrz zaś tylko działalności późniejszych, takich jak sprzedaż, dystrybucja i serwis. Była to strategia typowa dla spółek japońskich i południowokoreańskich w latach 70. i 80. XX w., zanim zaczęły przenosić swoją produkcję za granicę.

- Strategia multilokalna - polega na geograficznym rozproszeniu działalności i tylko luźnym jej koordynowaniu.

- Strategia kontrolowanych bezpośrednich inwestycji zagranicznych - jest to odmiana strategii globalnej, stanowiąca często jeden z etapów odchodzenia od strategii multilokalnej. Na przykład wiele starych spółek europejskich stwierdzało w latach 80. i 90. XX w., że ich działalność jest nadmiernie rozproszona, co nie odpowiada warunkom nowej gospodarki w globalizującym się świecie. Pierwszą reakcją na ten fakt było nasilenie koordynacji, a potem następowało ograniczenie liczby miejsc prowadzenia działalności.

- Czysta strategia globalna - polega na koncentrowaniu działalności, ale - w odróżnieniu od strategii opartej na eksporcie - niecała działalność spółki jest lokowana w jej kraju macierzystym, lecz w kilku różnych krajach, przy czym w każdym z nich jest umiejscowiony inny jej rodzaj.

Ryc. 1. Decyzje dotyczące lokalizacji i koordynacji działalności

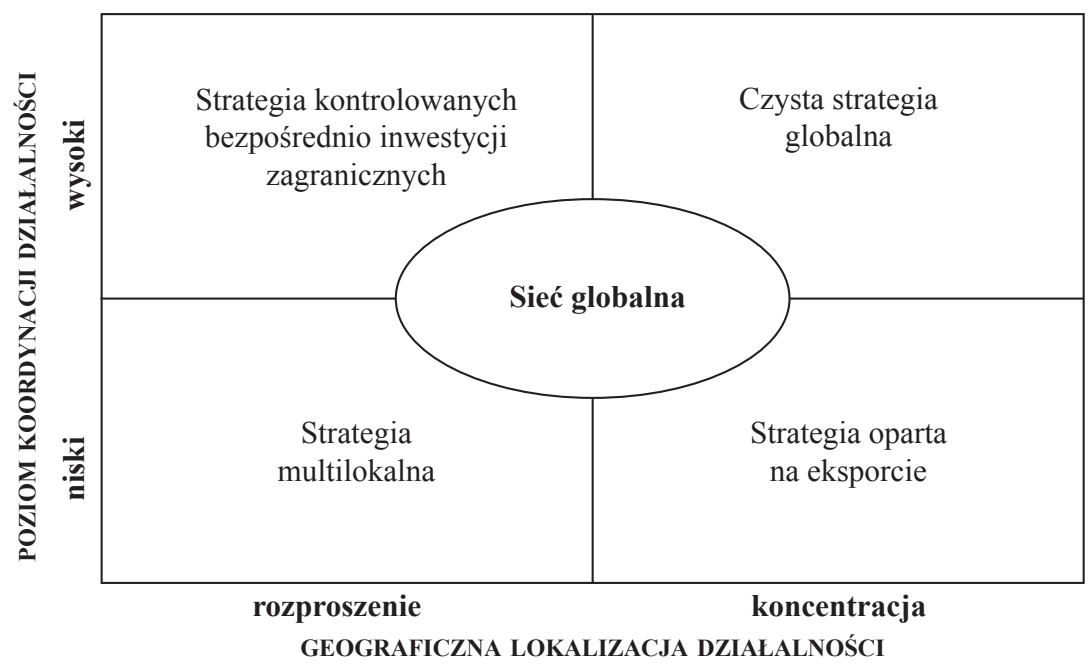

Źródło: G.S. Yip, Strategia globalna, PWN, Warszawa 2004, s. 209.

Od początku lat 20. do końca lat 60. XX w. system masowej produkcji skłaniał korporacje transnarodowe do bezpośredniego zaangażowania się za granicą na podstawie motywów rynkowych i zasobowych, a najbardziej odpowiednim sposobem organizowania działalności 
produkcyjno-handlowej był model wielonarodowy. Czynniki techniczno-organizacyjne implikowały lokalizację produkcji międzynarodowej na dużych i chłonnych rynkach zaopatrzenia i zbytu w tym większym zakresie, im bardziej były chronione barierami handlowymi, posiadały obfite i tanie zasoby, położone były niezbyt daleko i miały podstawową infrastrukturę (porty, drogi, szlaki kolejowe). W latach 50. i 60. silnie ekspansywne amerykańskie korporacje transnarodowe preferowały lokowanie działalności produkcyjno-handlowej na terenie Europy Zachodniej (przetwórstwo przemysłowe) oraz Kanady i Ameryki Łacińskiej (w przetwórstwie i wydobyciu). W miarę dojrzewania wiodących gałęzi przemysłu (np. samochodowego, elektronicznego) i narastania motywów efektywnościowych w masowej produkcji, w latach 70. organizacja działalności korporacji transnarodowych na zagranicznych rynkach ewoluowała w kierunku modelu międzynarodowego. Konsekwencją tych procesów był wzrost znaczenia zagranicznych inwestycji bezpośrednich oraz generowanej przez nie produkcji międzynarodowej w krajach o niskich cenach zasobów wytwórczych (zwłaszcza nisko kwalifikowanej siły roboczej), posiadających odpowiednią bazę przemysłową i infrastrukturę (łączność, lotniska, porty dla przeładunków kontenerowych) oraz prowadzących względnie liberalną politykę importową lub promującą eksport i napływ zagranicznych inwestycji bezpośrednich. Nadal istotne znaczenie lokalizacyjne miały duże rynki zbytu masowej produkcji, gdzie korzyści dużej skali działania można było realizować nie tylko w wytwarzaniu, lecz również w dystrybucji, reklamie i usługach posprzedażnych (Zaorska 1998).

Omawiając niższe koszty międzynarodowej produkcji, należy stwierdzić, że od końca lat 60. wiele korporacji transnarodowych z różnych krajów preferuje walory lokalizacyjne krajów nowo uprzemysłowionych, przede wszystkim azjatyckich. Natomiast względy rynkowe, technologiczne i konkurencyjne skłaniały amerykańskie i japońskie korporacje transnarodowe do lokowania zagranicznych inwestycji bezpośrednich w nowoczesnych branżach, głównie na terenie Europy Zachodniej, a korporacje zachodnioeuropejskie i japońskie do bezpośredniego angażowania się na rynku w USA. W latach 80. zaczęto upowszechniać stosowanie transnarodowego modelu organizacji działalności korporacji transnarodowych. Lokalizacja działalności korporacji transnarodowych stała się pochodną dążenia organizacji do osiągania globalnej efektywności, plasowania się na najbardziej atrakcyjnych rynkach, pozyskiwania zaawansowanych zasobów wytwórczych oraz realizowania taktyki lokalizacyjnej, która umacniała obecność korporacji na strategicznie ważnych odcinkach (Zaorska 1998). Rzadko jednak zdarza się, aby jakieś przedsiębiorstwo mogło stwierdzić, że jego obecny model lokalizacji jest optymalny. Z powodu zmieniających się warunków globalizacji oraz niedostatku myślenia strategicznego w przeszłości, wiele, a być może nawet większość, przedsiębiorstw odkrywa, że charakter sieci ich działalności nie odpowiada potencjałowi globalizacyjnemu sektora, w którym operują (Yip 2004).

Dążenie do niskich kosztów robocizny stwarza pewien dylemat, ponieważ może oznaczać wybór miejsca, z którego czas transportu na rynki jest długi. Długi czas transportu z reguły generuje wyższe koszty składowania zapasów na rynku. Ponadto może on również wywoływać nieodpowiednie reakcje na zmiany popytu. Dlatego też wiele firm decyduje się na wybór lokalizacji o wyższych kosztach, lecz położonej bliżej rynku (Schary, Skjott-Larsen 2002). J. Ishikawy i Y. Komariya dowiedli, że o lokalizacji przedsiębiorstwa przesądza nie różnica w kosztach produkcji pomiędzy różnymi firmami, ale różnica w kosztach pomiędzy krajową a zagraniczną produkcją tego samego przedsiębiorstwa (Ishikawy, Komariya 2008).

G.S. Yip w swej Strategii globalnej oddziela tradycyjne czynniki lokalizacji od przesłanek lokalizacyjnych firm globalnych. 
Tab. 2. Czynniki lokalizacji

\begin{tabular}{|l|l|}
\hline \multicolumn{1}{|c|}{ Tradycyjne czynniki lokalizacji } & \multicolumn{1}{|c|}{ Przesłanki lokalizacyjne firm globalnych } \\
\hline - lokalizowanie firm tam, gdzie koszty wytwarza- & - atrakcyjność z punktu widzenia prowadzenia \\
nia, tzn. surowców, materiałów i innych & prac badawczo-rozwojowych (źródło \\
czynników produkcji są niższe przy danym & innowacji, wysoko wykwalifikowana kadra) \\
wolumenie (przewaga komparatywna) & i oczekiwań wymagających klientów \\
- niższe podatki & - atrakcyjny klimat inwestycyjny (np. stabil- \\
- kwestie wzrostu produktywności i osiągania & ność polityczna, podatki, prawo) oraz \\
wysokiej jakości & czynniki i warunki sprzyjające budowaniu \\
- dogodny transport & konkurencyjnej i strategicznej przewagi \\
- jakość siły roboczej & (np. bliskość głównych rynków, efekt kraju \\
- infrastruktura gospodarcza & pochodzenia, obecność konkurentów) \\
- poziom ryzyka politycznego & polityka kursów wymiany walut (związek \\
\hline
\end{tabular}

Źródło: G.S. Yip, Strategia globalna, PWN, Warszawa 1996, s. 134-140.

W obecnych warunkach technicznych i ekonomicznych wzrastają możliwości wyboru lokalizacji dla globalnie zorientowanej działalności jednostek organizacyjnych korporacji transnarodowych. Następuje zmiana podejścia korporacji transnarodowych do oceny walorów lokalizacyjnych, wśród których relatywnie mniej cenione stają się walory statyczne i ilościowe, a bardziej poszukiwane - walory dynamiczne i jakościowe. Przede wszystkim chodzi o tworzone, zaawansowane zasoby i zdolności, o nowo powstające rynki - integrowane lub wschodzące - oraz o formujące się skupiska branżowo wyspecjalizowanych przedsiębiorstw. Kierunki poszukiwań lokalizacyjnych przez korporacje transnarodowe - ze względu na charakter potrzebnych im walorów - skupiają się głównie na obszarze Triady (tworzą ją trzy obszary: Europa Zachodnia, Ameryka Północna i część Azji Południowo-Wschodniej). Chodzi nie tylko o obecnie istniejący, wysoki poziom rozwoju i zaawansowania zasobów, lecz także o długofalową zdolność polityki państwa do podnoszenia jakości zasobów oraz usprawniania pracy rynku. W praktyce stosunkowo najlepiej spełniają te wymagania kraje rozwinięte i nowo uprzemysłowione (Zaorska 1998). Warto również wspomnieć, iż lokalizacja wielu usług stała się w znacznej mierze niezależna od lokalizacji ich odbiorców. Wcześniej usługi musiały być świadczone w tym samym miejscu i czasie, w którym były konsumowane. Większości z nich nie można było składować i przesyłać na odległość. Obecnie eksportować bądź importować można właściwie każdy rodzaj usług niewymagający osobistego kontaktu z klientem (Gierańczyk 2008).

Na początku obecnego wieku prawie $90 \%$ korporacji transnarodowych miało swoje siedziby macierzyste w krajach Triady. Do największych korporacji należały: General Electric, Exxon Mobil Corporation, Royal Dutch Shell Group, General Motors oraz Ford Motor Company. Filie korporacji transnarodowych zlokalizowane były głównie w krajach wysoko rozwiniętych; połowa z nich działała w Europie, a 10\% w Ameryce Północnej. Na kraje rozwijające się przypadało około 25\% filii i oddziałów. Jednocześnie kraje rozwijające się, takie jak Hongkong, Korea Południowa, Meksyk i Wenezuela, stworzyły własne korporacje transnarodowe, zwłaszcza w przemyśle petrochemicznym i elektronicznym (Radzymińska 2001). Według portalu http://money.cnn.com listę 500 największych firm światowych w roku 2010 według kryterium osiąganego dochodu otwierają Wal-Mart Stores, Royal Dutch Shell oraz Exxon Mobil. Niestety, wśród 500 największych firm tylko jedna pochodzi z Polski. Jest to sklasyfikowana na 398 miejscu Grupa PKN Orlen. 
Proces wyboru lokalizacji składa się z kilku etapów. Harrison oraz van Hoek w Zarządzaniu logistyka proponują następujące etapy procesu decyzyjnego dotyczącego wyboru lokalizacji:

Ryc. 2. Etapy procesu wyboru lokalizacji

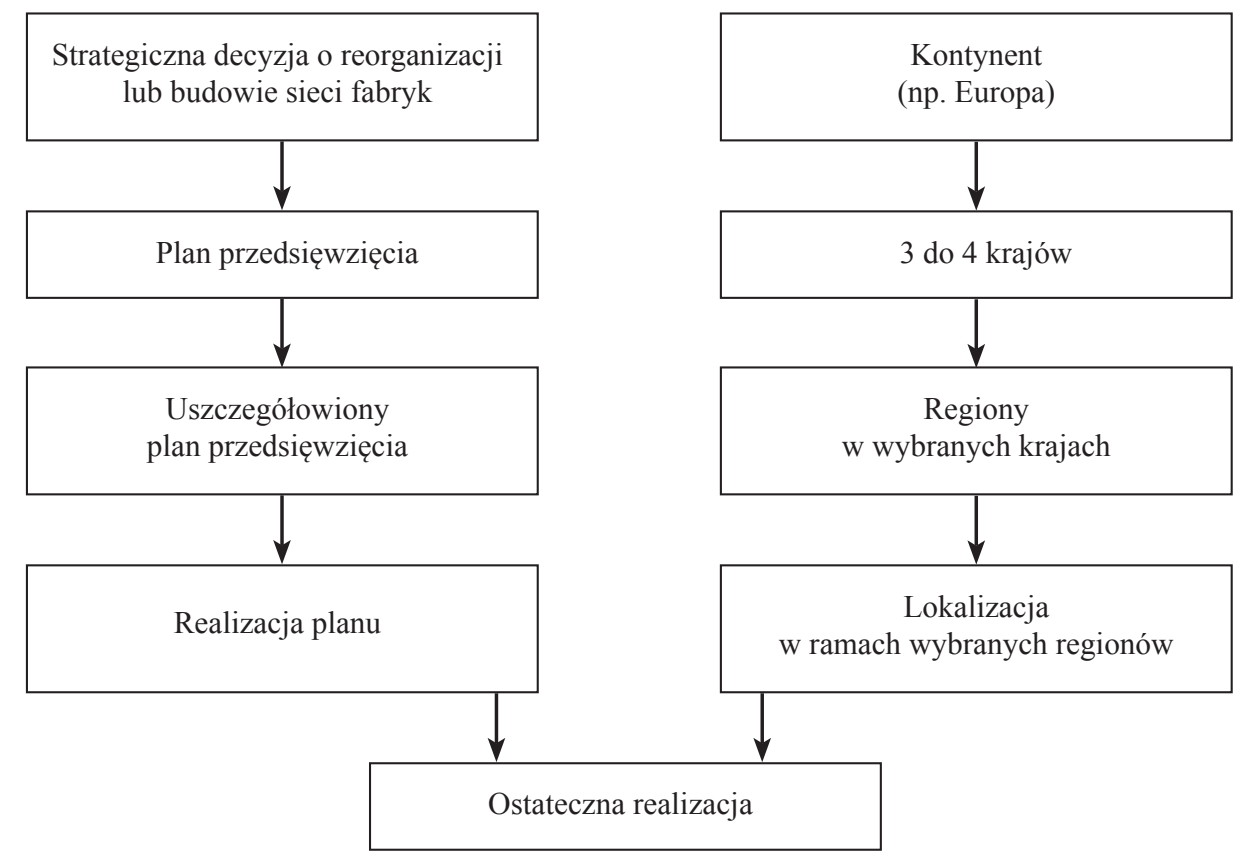

Źródło: A. Harrison, R. van Hoek, Zarządzanie logistyką, Polskie Wydawnictwo Ekonomiczne, Warszawa 2010, s. 172.

Z kolei S. Kasiewicz w książce Zarządzanie operacyjne w dobie globalizacji, opierając się na pracach A.D. MacCormacka, L.J. Newmana III oraz D.B. Rosenfielda, proponuje bardziej szczegółowy, czteroetapowy model wyboru lokalizacji dla firm globalnych.

Tab. 3. Etapy wyboru lokalizacji dla firm globalnych

\section{Ustalenie krytycznych czynników sukcesu, stopnia koniecznej globalnej orientacji i wymaganego wsparcia menedżerów}

- Ustalenie, w jakim elemencie firma globalna konkuruje (koszt, jakość, innowacyjność czy elastyczność) i pokazanie związku rodzaju konkurencji z wyborem miejsca lokalizacji. Firma, która zamierza uzyskać przywództwo kosztowe, będzie poszukiwać lokalizacji redukującej koszty transportu, pracy i zapasów. Natomiast firma globalna dążąca do przywództwa innowacyjnego będzie preferować lokalizacje zapewniające bliskość klientów i wykształcone zasoby ludzkie. 


\begin{tabular}{|c|c|}
\hline & $\begin{array}{l}\text { - Prognozowanie ewolucji branży i wymagań } \\
\text { rynkowych wynikających z globalizacji. Branża } \\
\text { może zmierzać do konsolidacji skali, zakresu lub } \\
\text { fragmentaryzacji nisz rynkowych. Menedżerowie } \\
\text { muszą ustalić, jakie czynniki i w jakim stopniu } \\
\text { będą determinować rozwój branży oraz jakie } \\
\text { wynikają stąd przesłanki dla lokalizacji potencjału } \\
\text { produkcyjnego. } \\
\text { - Ocena wewnętrznych ograniczeń firmy w realizacji } \\
\text { optymalnej strategii lokalizacyjnej. Jeśli firma nie } \\
\text { jest w stanie sfinansować programu inwestycyjne- } \\
\text { go, to powinna dążyć do zawarcia aliansu } \\
\text { strategicznego z inną firmą. } \\
\text { - Synteza wpływu rozważanych czynników na treść } \\
\text { strategii operacyjnej firmy globalnej. }\end{array}$ \\
\hline $\begin{array}{l}\text { 2. Ocena opracowanych opcji konfiguracji } \\
\text { regionalnych zdolności produkcyjnych } \\
\text { uwzględniających dostęp do rynku, } \\
\text { ryzyko zarządzania, charakterystyki } \\
\text { popytu klienta i wpływ technologii } \\
\text { produkcji na wielkość zakładów }\end{array}$ & $\begin{array}{l}\text { - Ocena politycznych i rynkowych barier wejścia. } \\
\text { Najlepiej jest preferować lokalizacje w strefach } \\
\text { bloków handlu (np. NAFTA, UE). } \\
\text { - Ocena regionalnego stopnia ryzyka prowadzenia } \\
\text { działalności (lokalizacja potencjału produkcyjnego } \\
\text { w rejonie wysokiego i stabilnego wzrostu jest } \\
\text { mniej ryzykowna, niż lokowanie w rejonach } \\
\text { niskich dochodów, wysokiego bezrobocia i strefach } \\
\text { występowania potencjalnych napięć społecznych). } \\
\text { Określenie wpływu technologii produkcji na } \\
\text { wielkość zakładu (liczba potencjalnych lokalizacji, } \\
\text { wielkość produkcji, zmiany w czasie zdolności } \\
\text { produkcyjnych). }\end{array}$ \\
\hline $\begin{array}{l}\text { 3. Określenie zbioru potencjalnych miejsc } \\
\text { lokalizacji bazuje zasadniczo na } \\
\text { infrastrukturze, która ma wspierać } \\
\text { prowadzoną działalność i strategię } \\
\text { produkcyjną firmy }\end{array}$ & $\begin{array}{l}\text { - Ocena metodologii produkcji dla każdej lokaliza- } \\
\text { cji. W ocenie określa się wielkość zatrudnienia, } \\
\text { niezbędną bazę dostawców i infrastrukturę } \\
\text { transportowo-komunikacyjną. Ocena infrastruktury } \\
\text { winna objąć elementy twarde i miękkie (poziom } \\
\text { wykształcenia pracowników, certyfikaty dostaw- } \\
\text { ców itp.). } \\
\text { - Badanie poziomu rozwoju infrastruktury rozpatry- } \\
\text { wanych wariantów lokalizacji i ocena, która } \\
\text { lokalizacja zapewnia infrastrukturę zgodną } \\
\text { z przyjętą globalną strategią firmy. }\end{array}$ \\
\hline $\begin{array}{l}\text { 4. Przeprowadzenie rankingu rozważanych } \\
\text { lokalizacji według najbardziej efektyw- } \\
\text { nych rozwiązań pod względem kosztu } \\
\text { w oparciu o wyniki analizy ilościowej, } \\
\text { a następnie ustalenie sposobu dzialania }\end{array}$ & - Wybór lokalizacji. \\
\hline
\end{tabular}

Źródło: opracowanie własne na podstawie S. Kasiewicz, Zarządzanie operacyjne w dobie globalizacji, Centrum Doradztwa i Informacji Difin sp. z o.o., Warszawa 2002, s. 189-191. 
Interesującym wydaje się być również fakt, iż podczas gdy trend do globalizacji gałęzi przemysłu i przedsiębiorstw wydaje się zmniejszać wagę i odrębność subregionów, to tendencja do lokalizacji określonych gałęzi przemysłu i działalności ekonomicznej wydaje się działać w przeciwnym kierunku. Jedna z prób wyjaśnienia tego paradoksu oparta została na teorii grona (Enright, Ffowcs-Williams 2000). Warto w tym miejscu wspomnieć, że w rozwoju i funkcjonowaniu gron istotną rolę odgrywają takie czynniki, jak:

- Dostępność wyspecjalizowanych nakładów i pracowników. Zaopatrywanie się firm na miejscu, czyli wewnątrz grona, minimalizuje konieczność przechowywania zapasów, eliminuje koszty importu, skraca czas oczekiwania, ułatwia komunikację, zmniejsza koszty dostosowania się do szczególnych potrzeb i ułatwia wspólne świadczenie usług pomocniczych, takich jak instalowanie urządzeń, usuwanie wad czy szkolenie pracowników.

- Dostęp do informacji. Firmy i miejscowe instytucje wchodzące w skład grona gromadzą wiele specjalistycznych informacji rynkowych, technicznych oraz z zakresu innych dziedzin. Wewnątrz grona można uzyskać do nich dostęp skuteczniej albo taniej, co umożliwia podwyższanie efektywności.

- Komplementarność. Grono sprzyja zwiększaniu efektywności nie tylko poprzez pozyskiwanie i kojarzenie nakładów, ale także przez wzajemne uzupełnianie się czynności wykonywanych przez uczestników grona, czego wyrazem jest komplementarność produktów. Oznacza to, że poszczególne części grona są zależne od siebie i mogą się wzajemnie wspierać.

- Dostęp do instytucji i dóbr publicznych. Grona przekształcają w dobra publiczne wiele nakładów, które w innym przypadku byłyby kosztowne (np. możliwość zatrudnienia pracowników przeszkolonych na miejscowych kursach eliminuje lub obniża koszty szkolenia wewnętrznego).

- Zachęty i pomiar efektywności. Grona stwarzają okazję do osiągania większej efektywności działania firmy, głównie ze względu na rywalizację z konkurentami wewnątrz grona, którzy działają w podobnych warunkach i z którymi łatwo jest się porównywać. Ułatwiają one także pomiar efektywności czynności wykonywanych wewnątrz firmy, gdyż często inne miejscowe przedsiębiorstwa spełniają podobne funkcje. Menedżerowie uzyskują zatem większe możliwości porównywania ponoszonych kosztów transakcji zawieranych na zewnątrz i obniżania kosztów monitoringu pracowników przez porównywanie na miejscu ich wydajności z innymi jednostkami (Berliński, Penc-Pietrzak 2004). Opierając się na teorii grona, niektóre przedsiębiorstwa chętnie lokują swoją działalność w miejscach, gdzie mają łatwy dostęp do specjalistów w danej dziedzinie. Za przykład mogą posłużyć ośrodki innowacji informatycznych, takie jak Krzemowa Dolina w Kalifornii czy Krzemowe Moczary wokół Cambridge w Wielkiej Brytanii. Do ich powstania przyczyniły się firmy, które umieszczały tam swoje siedziby, gdyż chciały korzystać z wyników badań prowadzonych na pobliskich uniwersytetach. Z drugiej strony, im więcej firm w takim ośrodku, tym większy wpływ mają one na kierunki badań i tym większe korzyści mogą w ich rezultacie osiągnąć. Efekt ten ulega spotęgowaniu, gdy firmy koncentrują w jednym miejscu całą swoją działalność badawczo-rozwojową. Z jednej strony może to oznaczać odcięcie się od innych źródeł utalentowanych pracowników, z drugiej strony pomaga w przyciągnięciu młodych, zdolnych ludzi, którzy w przyszłości będą nadawać ton w danej branży i sprzyja wytwarzaniu synergii między zespołami badawczymi (Harrison, Hoek 2010).

Jedną z polskich firm, która stosuje strategię globalnego rozwoju, tworząc filie za granicą lub przejmując miejscowe firmy w celu ulokowania współzależnych przedsiębiorstw w różnych krajach i regionach, jest Grupa Selena z województwa dolnośląskiego. Grupa Selena to holding 
spółek zajmujących się produkcją i dystrybucją chemii budowlanej, prowadzący działalność na całym świecie i oparty na polskim kapitale. Powstał on w roku 1992 jako jedna z pierwszych firm w Polsce oferujących nowoczesne produkty chemii budowlanej: poliuretanowe piany montażowe i uszczelniacze silikonowe. W ciągu zaledwie kilku lat firma zdobyła znaczącą pozycję na krajowym rynku pian i silikonów. W celu dalszego rozwijania firmy w oparciu o innowacje i wysoką jakość produktów, zdecydowano się na uruchomienie własnej produkcji. Kolejno powstały zakłady produkcyjne pian, uszczelniaczy oraz klejów. Pod koniec lat 90. Grupa Selena poszukiwała dalszych możliwości rozwoju w branży, a te oferował eksport i ekspansja międzynarodowa. Stworzono zagraniczne spółki handlowe, a kolejnym krokiem w rozwoju firmy było rozpoczęcie działalności produkcyjnej za granicą: w Korei Południowej, Brazylii, USA, Chinach i we Włoszech. W skład Grupy Selena wchodzi obecnie 30 spółek krajowych i zagranicznych, w tym 12 zakładów produkcyjnych (sześć zakładów w Polsce, po jednym w Hiszpanii, Brazylii, Korei Południowej, Chinach, USA oraz Turcji). Działalność Grupy Selena obejmuje wszystkie etapy tworzenia produktów: począwszy od zaawansowanych badań, poprzez produkcję, dystrybucję, marketing, aż po sprzedaż na całym świecie. Obecnie holding jest czwartym pod względem wielkości producentem piany poliuretanowej na świecie, skutecznie konkurującym na światowych rynkach chemii budowlanej z globalnymi koncernami o wieloletniej tradycji. Grupa Selena systematycznie rozbudowuje własne zaplecze produkcyjne, zarówno poprzez zwiększanie zdolności produkcyjnych zakładów w Polsce, jak i stopniową intensyfikację działalności produkcyjnej za granicą. O lokalizacji nowej zagranicznej inwestycji decydują w wypadku przejęć podmiotów zagranicznych korzyści wynikające z rozszerzenia skali działalności oraz poszerzenia portfela o zagraniczne marki. Natomiast w wypadku wspólnych przedsięwzięć Grupy Selena z zagranicznymi firmami, wybór lokalizacji determinują korzyści wynikające z włączenia produktów Seleny do sieci dystrybucyjnych partnera oraz możliwość dokapitalizowania i wykorzystania terenu produkcyjnego podmiotu zagranicznego do wytwarzania podstawowych produktów (http://www2.selena.pl/cms/index.php).

W niniejszej pracy podjęłam próbę pokazania, jak od strony teoretycznej rozpatrywany jest bardzo praktyczny problem wyboru lokalizacji produkcji przez podmioty gospodarcze. Podsumowaniem pracy niech będą zaproponowane przez G.S. Yipa wskazówki do lokalizowania globalnej działalności:

- Przy lokalizowaniu działalności menedżerowie powinni odblokować swoje myślenie przez startowanie od podstawy zero i przyjmowanie założenia, że ich przedsiębiorstwo dotychczas nie prowadzi nigdzie na świecie żadnej działalności. Następnie powinni zadać sobie pytanie, jaki powinien być idealny model lokalizacji działalności i dopiero potem powrócić do uwzględniania faktu, gdzie już obecnie jest zlokalizowana działalność firmy i ile kosztowałoby jej przemieszczenie.

- Różnych rodzajów działalności dotyczą odmienne potrzeby w zakresie globalnej koncentracji, lokalnego rozproszenia lub obydwu tych rozwiązań łącznie.

- Idealny model lokalizacji działalności zmienia się wraz ze zmianami zewnętrznymi i wewnętrznymi przedsiębiorstwa.

- Najlepszy model lokalizacji zazwyczaj pozostawia pewne powielanie działalności w celu zachowania elastyczności i zabezpieczenia się przed nieciągłością.

- Koordynowanie geograficzne rozproszonych działalności może w niektórych przypadkach służyć jako substytut globalnej koncentracji.

- Przy lokalizowaniu działalności ze względu na maksymalizację przewagi konkurencyjnej menedżerowie powinni brać pod uwagę przewagę zarówno strategiczną, jak i komparatywną (na bazie krajowej). 
- Niektóre rodzaje działalności, zwłaszcza prace badawczo-rozwojowe, powinny być umiejscowione w krajach o globalnym znaczeniu strategicznym (Yip 2004).

W praktyce niezwykle istotnym jest, aby menedżerowie stający przed wyzwaniem dokonania wyboru lokalizacji dla działalności ich firmy, nie polegali tylko i wyłącznie na swojej intuicji, ale byli świadomi istnienia aparatu teoretycznego opisującego ten skomplikowany proces.

\section{Literatura}

1. Bednarek M., 2007, Doskonalenie systemów zarządzania. Nowa droga do przedsiębiorstwa lean, Centrum Doradztwa i Informacji Difin Sp. z o.o., Warszawa.

2. Berliński L., Penc-Pietrzak I., 2004, Inżynieria projektowania strategii przedsiębiorstwa. Konstrukcja i technologia, Centrum Doradztwa i Informacji Difin Sp. z o.o., Warszawa.

3. Budnikowski A., 2000, Zagrożenia zwiazane z globalizacją i możliwości ich pokonywania, Kolegium Gospodarki Światowej SGH, „Zeszyty Naukowe”, nr 9, Warszawa.

4. Christopher M., Peck H., 2005, Logistyka marketingowa, Polskie Wydawnictwo Ekonomiczne, Warszawa.

5. De Wit B., Meyer R., 2007, Synteza strategii, PWE, Warszawa.

6. Enright M.J., Ffowcs-Williams I., 2000, Local partnership, clusters and some globalization, OECD, Italy.

7. Flejterski S., Wahl P. T., 2003, Ekonomia globalna, Centrum Doradztwa i Informacji Difin Sp. z o.o., Warszawa.

8. Gierańczyk W., 2008, Problematyka definiowania zmian $w$ tendencjach lokalizacyjnych przedsiębiorstw przemysłowych $w$ dobie globalizacji, Problematyka badawcza geografii przemysłu, Z. Zioło, T. Rachwał (red.), „Prace Komisji Geografii Przemysłu PTG, nr 11, Komisja Geografii Przemysłu PTG i Zakład Przedsiębiorczości i Gospodarki Przestrzennej Instytutu Geografii Akademii Pedagogicznej w Krakowie, Warszawa-Kraków.

9. Gołębiowska E., Szymczak M., 2004, Logistyka międzynarodowa, PWE, Warszawa.

10. Gurría A., 2006, Managing globalization and the role of the OECD, http://www.oecd.org/document/ 52/0,3343,en_2649_37447_37478942_1_1_1_1,00.html.

11. Harrison A., Van Hoek R., 2010, Zarządzanie logistyka, PWE, Warszawa.

12. Hetmańczyk A., Noga B., 2008, Nowa faza globalizacji a zmiany inflacji [w:] Globalizacja a konkurencyjność w gospodarce światowej, M. Noga, M.K. Stawicka (red.), CeDeWu Sp. z o.o., Warszawa.

13. http://money.cnn.com/magazines/fortune/global500/2010/full_list/index.html.

14. http://www2.selena.pl/cms/index.php.

15. Ishikawy J., Komariya Y., 2008, Stay or leave? Choice of plant location with cost heterogeneity, http:// www.econ.hit-u.ac.jp/ jota/downloadfiles/IshiKomJERfinal.pdf.

16. Jeannet J.P., 2000, Managing with a Global Mindset, Biddles Ltd., Guildford \& King's Lynn, Great Britain.

17. Kaliński J., 2004, Globalizacja w perspektywie historycznej [w:] Globalizacja od A do Z, A. Czarny (red.), NBP, Warszawa.

18. Kasiewicz S., 2002, Zarzadzanie operacyjne $w$ dobie globalizacji, Centrum Doradztwa i Informacji Difin Sp. z o.o., Warszawa.

19. Kołodko G.W., 2008, Wędrujący świat, Wydawnictwo Prószyński i Spółka, Warszawa.

20. Liberska A. (red.), 2002, Globalizacja, mechanizmy i wyzwania, PWE, Warszawa. 
21. Matysek-Jędrych A., 2008, Wspótczesne przeobrażenia systemu finansowego i ich konsekwencje, „Bank i Kredyt”, nr 1, Warszawa.

22. Misala J., 2004, Lokalizacja działalności gospodarczej w warunkach globalizacji (ujęcie teoretyczne) [w:] Globalizacja od A do Z, A. Czarny (red.), NBP, Warszawa.

23. Misiak W., 2007, Globalizacja więcej niż podręcznik, Centrum Doradztwa i Informacji Difin Sp. z o.o., Warszawa.

24. Piasecki R., 2003, Rozwój gospodarczy a globalizacja, PWE, Warszawa.

25. Potocki A., 2004, Globalizacja a zachowania organizacyjne menedżerów, „Zeszyty Naukowe”, nr 647, Akademia Ekonomiczna, Kraków.

26. Potocki A. (red.), 2009, Instrumenty i obszary przeobrażeń i zmian organizacyjnych $w$ warunkach globalizacji, Difin S.A., Warszawa.

27. Radzymińska T., 2001, Największe korporacje transnarodowe, „Nowe Życie Gospodarcze”, nr 20, Warszawa.

28. Sala S., 2006, Bezpośrednie inwestycje zagraniczne, a procesy globalizacji, „Prace Komisji Geografii Przemysłu PTG”, nr 8, Warszawa, Kraków.

29. Schary P.B., Skjott-Larsen T., 2002, Zarządzanie globalnym łańcuchem podaży, PWN, Warszawa.

30. Stabryła A., 2007, Formuła globalizacji w planowaniu strategicznym [w:] Potencjat restrukturyzacji $w$ warunkach globalizacji i nowej gospodarki, R. Borowiecki, A. Jaki (red.), Wydawnictwo UEK, Kraków.

31. Yip G.S., 1996, Strategia globalna. PWN, Warszawa.

32. Yip G.S., 2004, Strategia globalna, PWN, Warszawa.

33. Zaorska A., 1998, Ku globalizacji? Przemiany w korporacjach transnarodowych $i$ w gospodarce światowej, Warszawa.

\section{Location of Companies as a Function of Globalization Processes}

Choosing a proper location is a critical issue for each global company. This work is an attempt to look from the theoretical perspective at a very practical problem, namely, how to determine the best location for making business. The dilemma is presented in the context of the globalization processes. These processes give a framework for companies operating globally and pose both threat and an opportunity for their development. The case study was based on the analysis of the Selena Group, which is undoubtedly one of the pioneers among Polish companies aspiring to gain status of the global enterprise. The first part of this work includes the definition of the term of globalization both in a broad and a narrow scope as well as short information on the origins of the globalization processes. The second part comprises of the presentation of several globalization concepts which refer to the problem of choosing a location. There are also discussed factors influencing location as well as the stages of the process of selecting a location. 
Mirosław Włodarczyk

Społeczna Wyższa Szkoła Przedsiębiorczości

i Zarządzania w Łodzi

Jerzy Janczewski

Akademia Humanistyczno-Ekonomiczna

w Łodzi

\section{Warsztaty samochodowe w warunkach globalizacji}

W Polsce w ostatnim 20-leciu notuje się dynamiczny rozwój branży motoryzacyjnej. Jesteśmy

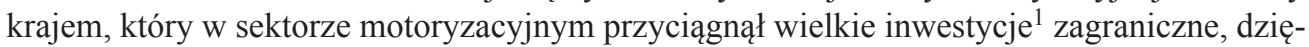
ki czemu sektor ten stał się jedną z kluczowych gałęzi przemysłu pod względem wartości produkcji, zatrudnienia, nakładów inwestycyjnych i udziału w eksporcie.

Dynamikę rozwoju branży motoryzacyjnej ostatnich lat zawdzięczamy m.in. konkurencji w stosowaniu nowych technologii. Ten swoisty wyścig był wielkim wyzwaniem dla producentów. Ponadto ciągle rosnące wymogi związane $\mathrm{z}$ ochroną środowiska naturalnego oraz stałe podnoszenie poziomu bezpieczeństwa czynnego i biernego samochodów sprawiły, iż branża motoryzacyjna została zaliczona do najbardziej innowacyjnych gałęzi przemysłu (Olszowski, Olszewska, Jastrzębska 2009, s. 4).

Lata 90. XX w. i początek XXI w. charakteryzują się również dużymi zmianami na rynku samochodów. W ciągu 20 lat liczba zarejestrowanych pojazdów samochodowych w Polsce wzrosła niemal 2,5-krotnie, a w Unii Europejskiej jesteśmy na szóstym miejscu pod względem liczby zarejestrowanych samochodów. Użytkujemy samochody o coraz większym zaawansowaniu technologicznym, a z naszych dróg prawie całkowicie zniknęły popularne niegdyś Polonezy, Fiaty 126 i 125, Żuki, Nysy i Tarpany.

Oprócz zmian na rynku samochodów rozwój branży motoryzacyjnej implikuje zmiany na rynku usług serwisowych i na rynku części zamiennych. Samochód nie wystarczy tylko wyprodukować; aby spełniał swoje zadanie, musi być prawidłowo serwisowany. Stawia to przed warsztatami ciągle nowe wyzwania. Od warsztatów wymaga się uzupełniania specjalistycznej wiedzy nie tylko mechanicznej, ale również z zakresu elektrotechniki i elektroniki samochodowej. Warsztaty muszą szybko i trafnie diagnozować występujące usterki oraz przeprowadzić naprawę zgodnie z procedurami zalecanymi przez producenta. Rośnie też zapotrzebowanie na specjalistyczną informację techniczną związaną z serwisowaniem poszczególnych modeli i marek samochodów, a wyposażenie samochodów w dużą liczbę wzajemnie powiązanych ze sobą systemów stwarza coraz więcej nowych problemów.

\footnotetext{
${ }^{1}$ Według danych Ministerstwa Gospodarki z 2008 r., inwestycje firm z branży motoryzacyjnej w specjalnych strefach ekonomicznych wyniosły 16 mld zł, czyli 33\% ogólnych nakładów inwestycyjnych w Polsce.
} 


\section{Samochody w Polsce}

W Polsce z roku na rok wzrasta liczba zarejestrowanych pojazdów samochodowych. Według danych GUS (GUS 2010, s. 378), na dzień 31 grudnia 2000 r. w Polsce było zarejestrowanych 14106 tys. pojazdów z tego 9991 tys. stanowiły samochody osobowe ${ }^{2}$. Natomiast w analogicznym okresie roku 2009 liczba zarejestrowanych pojazdów wynosiła 22025 tys., w tym 16495 tys. samochodów osobowych. W strukturze zarejestrowanych samochodów zarówno w roku 2000, jak i w 2008 dominowały samochody osobowe, stanowiące od 70 do $75 \%$ wszystkich pojazdów. Od 2000 r. do końca 2009 r. przybyło w naszym kraju prawie 7919 tys. pojazdów samochodowych (w tym 6509 tys. samochodów osobowych). Oznacza to, że w latach 2000-2009 z każdym rokiem przybywało średnio około 790 tys. zarejestrowanych po raz pierwszy pojazdów samochodowych (650 tys. samochodów osobowych), w tym nowych, zakupionych w salonach, oraz używanych, sprowadzonych z zagranicy.

W roku 2000 średni wskaźnik motoryzacji w Polsce wynosił 270 samochodów na 1000 mieszkańców i był prawie dwukrotnie niższy od wskaźnika motoryzacji w Niemczech. Obecnie różnica ta jest rzędu 25\%, a w przyszłości (2012) powinna być jeszcze mniejsza, gdyż wskaźnik motoryzacji ma tendencję wzrostową (ryc. 1). W Luksemburgu i we Włoszech wskaźnik ten w roku 2007 wynosił około 650 samochodów na 1000 mieszkańców, zaś w Stanach Zjednoczonych około 750 samochodów (GUS 2010, s. 379). W Polsce pomimo dużego przyrostu liczby zarejestrowanych samochodów w ostatnim dziesięcioleciu nadal wskaźnik motoryzacji jest stosunkowo mały, co może świadczyć o dużej potencjalnej chłonności naszego rynku.

Ryc. 1. Wskaźnik motoryzacji - liczba samochodów na 1000 mieszkańców w Polsce i w Niemczech

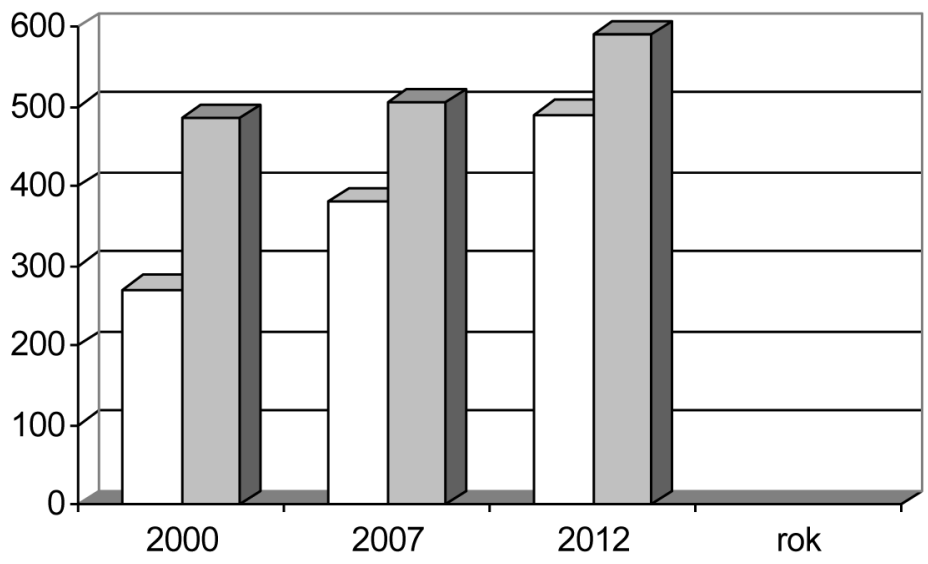

$\square$ Polska

$\square$ Niemcy

Źródło: opracowanie własne.

W Polsce brakuje systematycznych danych na temat stanu taboru użytkowanych indywidualnie samochodów osobowych obrazujących jego strukturę wiekową i strukturę przebiegu. Pomimo tych trudności można na podstawie danych publikowanych przez różne instytucje i firmy analityczne (Samar, Motofocus) oszacować, że najwięcej użytkujemy samochodów starych - mających powyżej 10 lat (ryc. 2), natomiast marginalną grupę stanowią samochody nowe, do 2 lat, i jest ona równoważna grupie samochodów użytkowanych powyżej 31 lat.

\footnotetext{
${ }^{2}$ Pozostałe to samochody ciężarowe, ciągniki siodłowe, balastowe i rolnicze, autobusy i motocykle.
} 
Jedynie Hiszpania (Koch 2004, s. 59) ma podobną do Polski strukturę wiekową samochodów. W pozostałych, bogatszych krajach Unii, np. w Niemczech, samochody 10-letnie i starsze nie są masowo użytkowane (ryc. 3). Warto zauważyć, że od początku bieżącego stulecia aż do roku 2006 zwiększał się średni wiek samochodu osobowego zarówno w Niemczech, jak i w Polsce, przy czym zjawisko to występowało w Polsce znacznie wyraźniej. Wynikało to z rosnącego w tym okresie importu używanych pojazdów do Polski (ryc. 4) i spadku popytu na nowe samochody w Niemczech.

Ryc. 2. Struktura pojazdów według ich wieku - 2008 r.

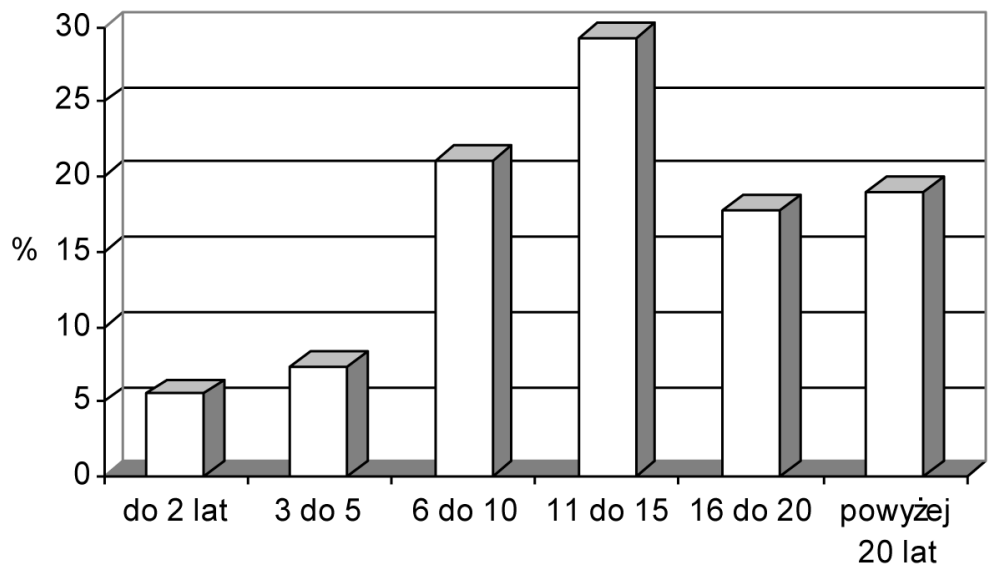

Źródło: opracowanie własne na podstawie danych Instytutu Samar.

Ryc. 3. Średni wiek samochodu osobowego w Polsce i w Niemczech

\section{$\square$ Polska $\square$ Niemcy}

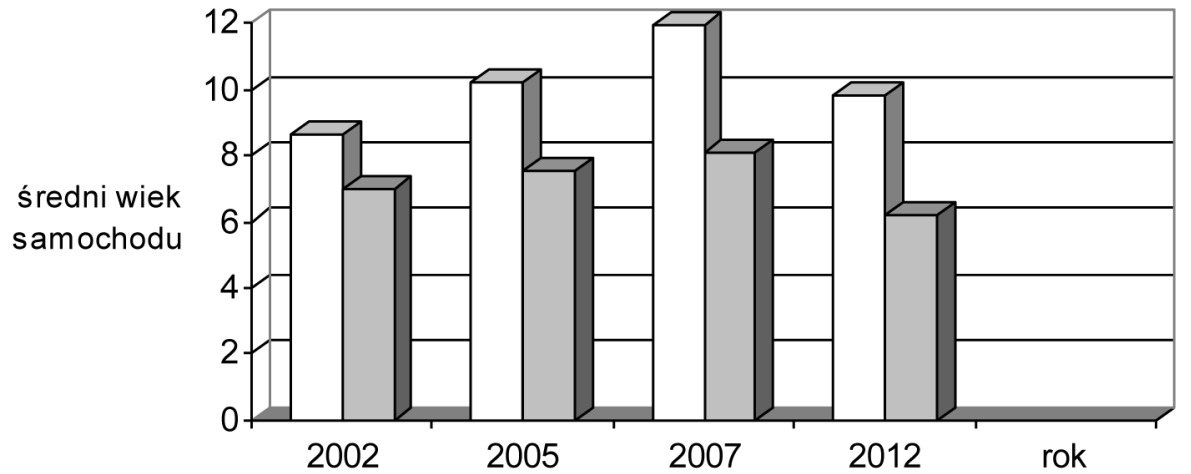

Źródło: opracowanie własne na podstawie Soszyński K., Przyszłość polskich warsztatów, http://www.e-autonaprawa.pl/artykuly/67/przyszlosc-polskich-warsztatow.html (stan na dzień 05.09.2009). 
Ryc. 4. Import samochodów używanych w latach 2005-2009 (sztuki)

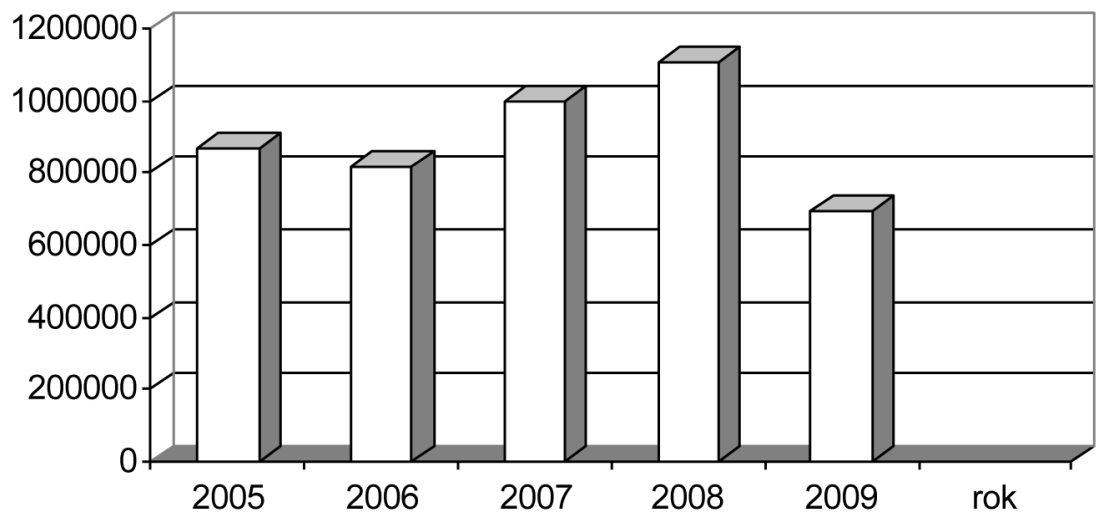

Źródło: opracowanie własne na podstawie danych Instytutu Samar.

W ostatnich latach średni wiek samochodu zmniejszał się zarówno w Polsce, jak i w Niemczech i trend ten powinien występować co najmniej do 2012 r. (Soszyński 2009.09.15; por. ryc. 3). Stosunkowo wysoki wiek samochodów wskazuje, że w najbliższych latach nasz park samochodowy powinien stawać się coraz młodszy prawdopodobnie dzięki importowi samochodów trzy-sześcioletnich i przyrostu sprzedaży nowych. Dla przykładu w marcu 2010 import używanych samochodów w wieku powyżej 10 lat stanowił 42,70\%, od 5 do 10 lat 47,51\%, zaś najmłodszych (do 4 lat) 9,78\%. Natomiast jeszcze w styczniu 2010 r. pojazdy w wieku do 4 lat miały mniejszy udział w imporcie, podczas gdy tych najstarszych było o 3,07\% więcej (Moto Onet.pl, 2010.04.27). Nadal jednak wskaźnik odnowy parku samochodowego - liczony jako stosunek zakupu nowych samochodów do liczby zarejestrowanych - jest w Polsce niewielki, gdyż wynosi zaledwie 2\% i jest 3,5 razy niższy niż średni wskaźnik UE (Kublik 2010).

Najczęściej sprowadzane do Polski marki używanych samochodów to Volkswagen, Opel, Renault i Ford, natomiast liderem polskiego rynku sprzedaży nowych samochodów (dane z roku 2010) pozostaje niezmiennie Škoda, a na drugim miejscu jest Fiat. W dalszej kolejności przemiennie plasują się Toyota, Volkswagen, Opel, Renault, Ford i Peugeot. Najchętniej kupowane nowe samochody należą do klasy niższej średniej (Škoda Octavia, Opel Astra, Ford Focus), najdynamiczniej rośnie sprzedaż samochodów terenowo-rekreacyjnych, nie maleje zainteresowanie samochodami kombi i van (Samar 2010.08.19).

Samochody osobowe w Polsce aż w 92,4\% przypadków nie posiadają żadnej gwarancji ani producenta samochodu, ani żadnego serwisu. Średnia wartość samochodu osobowego również jest niewielka i wynosi tylko 11900 zł. Polacy nie osiągają też dużych przebiegów; jest to tylko 15404 km rocznie (Grześkowiak 2007, s. 9).

\section{Warsztaty samochodowe}

W potocznym języku, dla określenia charakteru przedsiębiorstwa serwisującego pojazdy, bardzo popularne i często zamiennie używane są terminy warsztat, stacja lub serwis samochodowy. Z warsztatem samochodowym najczęściej kojarzy się niewielka firma (mały garaż) z jednym stanowiskiem, wyposażona w podstawowe narzędzia i niewiele prostych urządzeń, a z serwisem - duża, wielostanowiskowa stacja obsługi z rozbudowaną infrastrukturą i z wykwalifikowanym 
personelem. Zatem stacje obsługi to takie warsztaty, które charakteryzuje duży przedział liczby stanowisk, od jednego do kilkudziesięciu, wyposażenie oraz zróżnicowany zakres usług, od usług kosmetycznych i konserwacyjnych po naprawy o różnym zakresie. Ze względu na zakres wykonywanych prac obsługowo-naprawczych M. Uzdowski, K.F. Abramek i K. Garczyński dzielą stacje obsługi samochodów na stacje o pełnym zakresie pracy i stacje o ograniczonym zakresie. Stacje o ograniczonym zakresie stanowią najliczniejszą grupę wśród przedsiębiorstw świadczących usługi motoryzacyjne. Dzielą się one na warsztaty specjalistyczne, stacje kontroli pojazdów i stacje szybkiej obsługi (Uzdowski, Abramek, Garczyński 2003, s. 108).

Warsztaty najczęściej specjalizują się w takich tradycyjnych usługach, jak mechanika pojazdowa (szacunkowo ok. 77\% wszystkich warsztatów), blacharstwo i lakiernictwo (30\%), elektrotechnika i elektronika samochodowa (8\%), diagnostyka, serwis ogumienia, obsługa klimatyzacji, tuning, mycie i konserwacja etc. W zależności od wielkości i wyposażenia mogą one posiadać jedno lub więcej stanowisk. Postęp w dziedzinie konstrukcji pojazdów samochodowych i nowe potrzeby klientów ciągle wymuszają na warsztatach rozwój nowych specjalizacji, na przykład w dziedzinie elektroniki, tuningu, telematyki, klimatyzacji, automatycznych przekładni i urządzeń bezpieczeństwa czynnego.

Jeszcze niedawno (10 lat temu) w Polsce na jeden warsztat przypadało ok. 350 samochodów, podczas gdy w Niemczech w tym samym czasie wskaźnik ten był prawie trzykrotnie wyższy. Obecnie proporcje te znacznie się zmieniły, a na jeden statystyczny warsztat w Polsce przypada około 850 samochodów przy średniej niemieckiej 1200 (ryc. 5).

Ryc. 5. Liczba samochodów przypadających na jeden warsztat w Polsce i w Niemczech

\section{Polska $\square$ Niemcy}

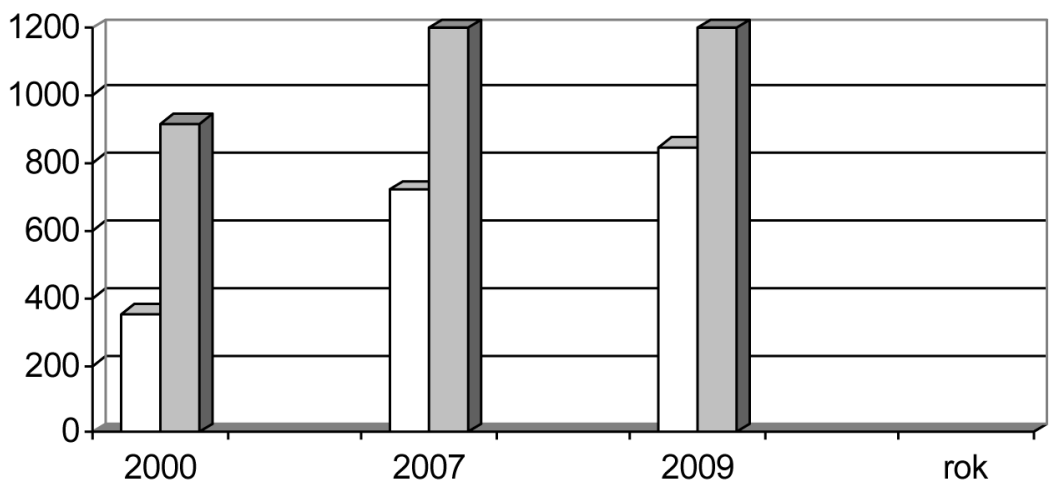

Źródło: opracowanie własne.

Instytut GIPA (GIPA 2003) w badaniach z 2003 r. podzielił grupę warsztatów mechanicznych na małe, średnie i duże. Małe naprawiały po dwa samochody dziennie, średnie -4 , a duże -7 . Również warsztaty te znacznie różniły się między sobą powierzchnią pomieszczeń i wyposażeniem. W badanej wówczas przez GIPA próbie małe warsztaty mechaniczne były najliczniejsze $(53 \%)$. W kolejnych badaniach prowadzonych przez GIPA w następnych latach została wykazana znaczna redukcja małych warsztatów i zmiana proporcji na rynku napraw na korzyść warsztatów średnich i dużych (ryc. 6). W roku 2007 małe warsztaty stanowiły tylko 22\% całego rynku, średnie $43 \%$, a duże - $35 \%$. 
Ryc. 6. Zmiany w strukturze warsztatów samochodowych w Polsce w latach 2003-2007

$\square$ warsztaty małe $\square$ warsztaty średnie $\square$ warsztay duże

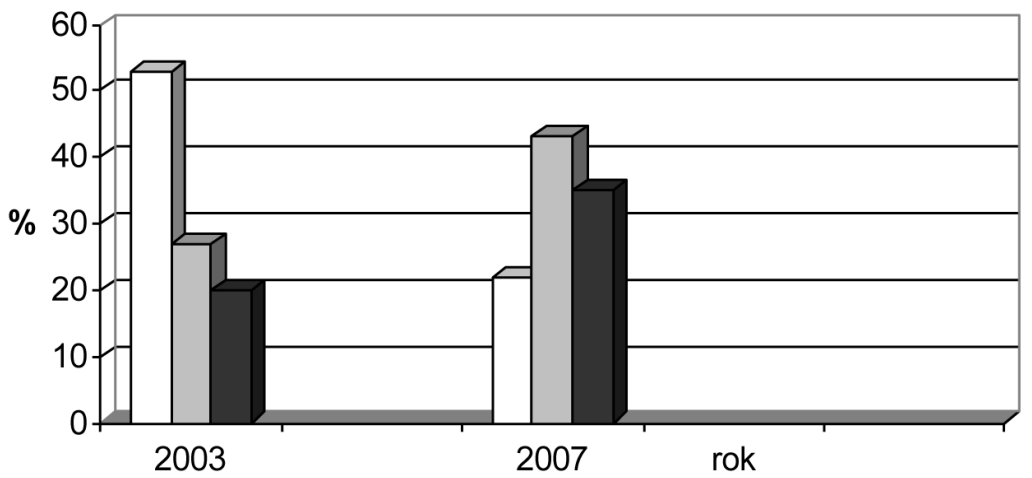

Źródło: opracowanie własne na podstawie GIPA.

W praktyce z powodu dużej różnorodności usług związanych z eksploatacją samochodu podział na małe, średnie i duże dla wszystkich warsztatów z sektora napraw i obsługi samochodów jest niewyraźny i łatwo się zaciera.

Ryc. 7. Liczba warsztatów niezależnych i autoryzowanych przez producentów samochodów w Polsce

\section{$\square$ warsztaty ogółem $\square$ warsztaty niezależne $\square$ warsztaty autoryzowane}

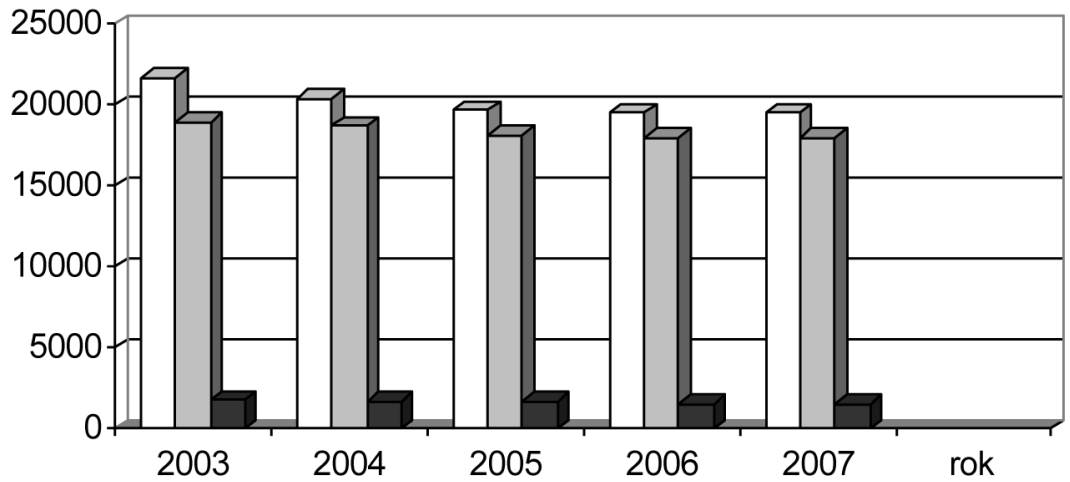

Źródło: opracowanie własne na podstawie GIPA [w:] Soszyński K., Przyszłość polskich warsztatów, http://www.e-autonaprawa.pl/artykuly/67/przyszlosc-polskich-warsztatow.html (stan na dzień 05.09.2009).

Analitycy zajmujący się rynkiem napraw samochodów w Polsce najczęściej dzielą go na warsztaty niezależne, warsztaty autoryzowane przez producentów samochodów (typu dilerskiego) i warsztaty sieciowe. Te ostatnie to warsztaty szybkiej obsługi, firm ubezpieczeniowych lub dużych hurtowni typu kierowniczego, albo warsztaty niezależne, zrzeszone w sieci dystrybutorów i producentów części tzw. właścicielskie. Ponadto na rynku napraw funkcjonują tzw. warsztaty garażowe typu ,zrób to sam”, będące konsekwencją zamiłowania do samodzielnych napraw samochodu i występowania szarej strefy. 
Podział rynku napraw w Polsce jest podobny jak w pozostałych państwach Unii Europejskiej. Istnieją niewielkie i już zanikające różnice wynikające z przeszłości. Na naszym rynku funkcjonują jeszcze sklepy motoryzacyjne sprzedające także części samochodowe, które obsługują samodzielne naprawy garażowe i szarą strefę. W krajach Unii (przed 01.05.2004) znajdowały się również sklepy motoryzacyjne, ale ich oferta obejmowała głównie materiały eksploatacyjne - płyny, oleje, akumulatory - oraz akcesoria - żarówki, dywaniki, foteliki dla dzieci itp. Istotnym wyróżnikiem jest także sposób sprzedaży samochodów używanych; polską specjalnością są giełdy lub autokomisy. W krajach Unii (przed 01.05.2004) najczęstszym miejscem sprzedaży samochodu używanego był diler danej marki lub warsztat, w którym samochód był obsługiwany i naprawiany.

W Polsce tylko do roku 2005 notowany był niewielki spadek liczby warsztatów samochodowych - mimo rosnącego w tym okresie popytu na usługi w zakresie napraw i obsługi samochodów oraz rekordowego importu samochodów używanych w roku 2004 (ryc. 7). Nie było to intensywne zjawisko i dotyczyło przede wszystkim sektora serwisów niezależnych, choć w tym czasie ubywało także i placówek typu dilerskiego, autoryzowanych przez producenta. Inaczej było w Niemczech, gdzie wyraźnie zmniejszała się liczba punktów serwisowych, zarówno autoryzowanych, jak i niezależnych (ryc. 8). Zapewne w obu przypadkach działo się tak dlatego, że nierentowne warsztaty opuszczały rynek, a te pozostające na nim zwiększyły swój potencjał głównie przez wzrost liczby stanowisk warsztatowych. Charakterystyczną cechą dla rynku niemieckiego jest wysoka proporcja (1:1) warsztatów autoryzowanych w stosunku do warsztatów niezależnych (ryc. 8). W Polsce proporcja ta jest dziesięciokrotnie mniejsza (1:12; por. ryc. 7).

Ryc. 8. Liczba warsztatów niezależnych i autoryzowanych przez producentów samochodów w Niemczech

$\square$ warsztaty ogółem $\square$ warsztaty niezależne $\square$ warsztaty autoryzowane

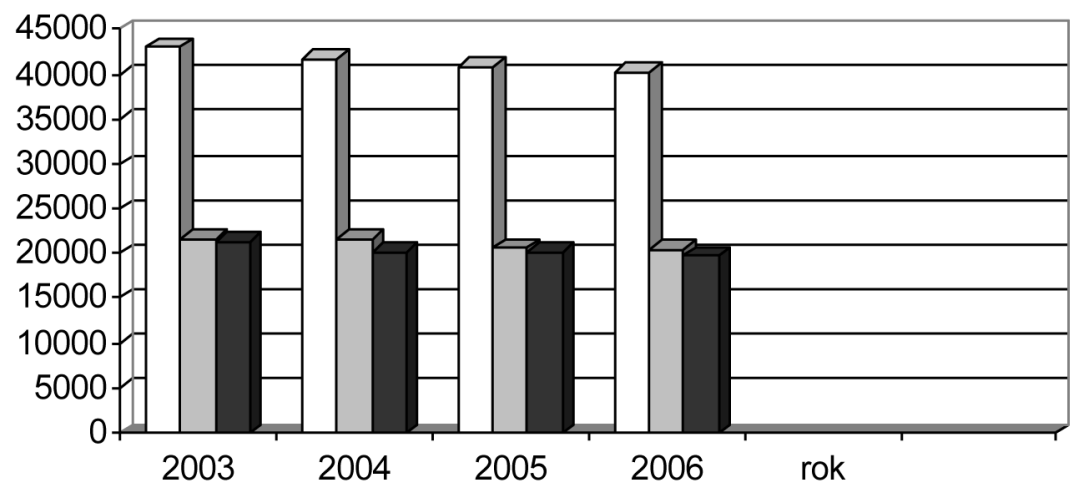

Źródło: opracowanie własne na podstawie Automobilwoche [w:] Soszyński K., Przyszłość polskich warsztatów, http://www.e-autonaprawa.pl/artykuly/67/przyszlosc-polskich-warsztatow.html (stan na dzień 05.09.2009).

Współcześnie szczególnego znaczenia nabierają nowe formy organizacyjne określane mianem przedsiębiorstw sieciowych. Koncepcja sieci warsztatowej jest rezultatem połączenia zalet wynikających z funkcjonowania niezależnych warsztatów z wysokim poziomem świadczonych usług. Składają się na to: wyposażenie specjalistyczne i kompetencje pracowników 
gwarantujące obsługę na wysokim poziomie jakościowym z użyciem oryginalnych części, bliskość warsztatu, szybkość wykonania naprawy i przystępna cena usługi. Niektórzy analitycy (Szczepaniak 2006) rynku motoryzacyjnego uważają, że zjednoczone pod jednym szyldem warsztaty to przyszłość dla niezależnego sektora napraw samochodów zwłaszcza, że doświadczenia europejskie i dotychczasowe doświadczenia polskie pokazują, że warsztaty zorganizowane w sieci mają niekwestionowaną przewagę nad warsztatami niezależnymi w pozyskiwaniu nowych klientów. Wprawdzie w Polsce notuje się zainteresowanie sieciową formą działalności, a w roku 2007 w porównaniu z rokiem 2006 liczba uczestników sieci warsztatowych wzrosła o 10\%, ale udział ten nadal jest niezadowalający. Obecnie w Polsce udział niezależnych warsztatów samochodowych w sieciach jest niewielki (ok. 19\%) i o wiele mniejszy niż w Niemczech (ryc. 9).

Ryc. 9. Odsetek warsztatów niezależnych należących do sieci

$\square$ Polska $\square$ Niemcy

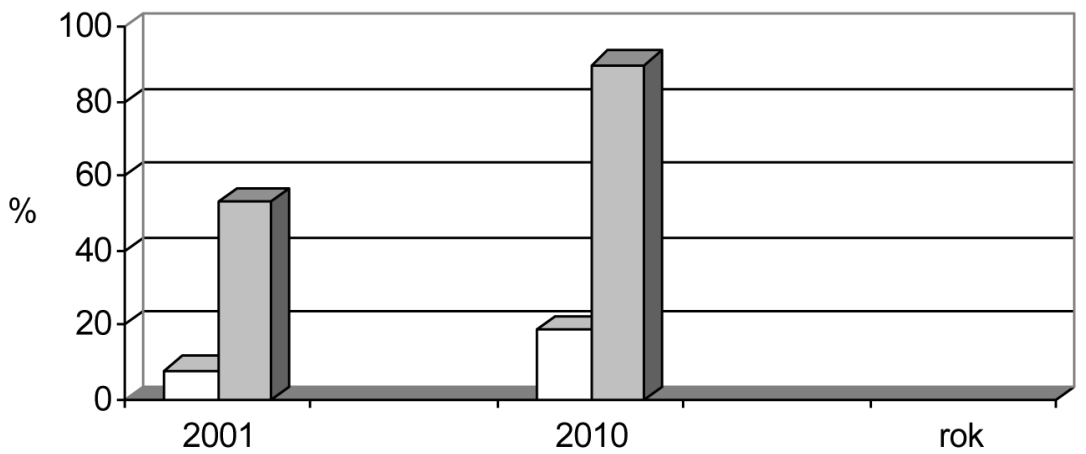

Źródło: opracowanie własne na podstawie Motofocus, GIPA i Bosch.

Sondaż przeprowadzony wśród niezależnych warsztatów (Franke 2009) wskazuje, że w Polsce aż 37\% właścicieli warsztatów samochodowych nie zamierza związać się z siecią warsztatową. Dla blisko 30\% warsztatów zagadnienie to jest w obrębie rozważań, co może oznaczać, że są to potencjalni kandydaci do sieci warsztatowych. Istnieje także duża grupa warsztatów, która decyzję o przystąpieniu do sieci warsztatowej już podjęła i albo już podpisała umowę partnerską, albo zamierza to zrobić w najbliższym czasie. O pozytywnych, ale zbyt powolnych przemianach w postawach warsztatów w sprawie przynależności do sieci świadczy porównanie z wynikami, które uzyskano z badań przeprowadzonych w 2003 r. (GIPA, 12.2003). Wówczas ponad $84 \%$ polskich warsztatów w ogóle nie planowało przyłączać się do jakiejkolwiek sieci. Najczęściej były to duże warsztaty (ponad 92\%), rzadziej małe (ok. 87\%), a najrzadziej średnie (ok. 73\%).

\section{Zachowania wlaścicieli samochodów}

Zachowania właścicieli samochodów w Polsce trafnie obrazują badania z 2005 r. Kto naprawia nasze auta? Wynika z nich, że pięć lat temu niemal jedna trzecia Polaków (32\%) odpowiedzialnych za naprawy samochodu w gospodarstwie domowym samodzielnie wykonywała czynności związane z bieżącą konserwacją i serwisowaniem samochodu. Dla pozostałych najpopularniejszym miejscem dokonywania takich napraw były warsztaty niezależne (nieautoryzowane), 
które odwiedzało 38\% respondentów i warsztaty autoryzowane przez producentów, gdzie tylko $26 \%$ badanych zlecała bieżące naprawy. Inaczej było w przypadku napraw powypadkowych, które są dokonywane zwykle przez specjalistów: 32\% badanych powierzało je warsztatom niezależnym, zaś $20 \%$ warsztatom autoryzowanym. Tylko $6 \%$ badanych decydowało się na samodzielną naprawę samochodu po wypadku. Natomiast blisko jedna trzecia (32\%) osób decydujących o miejscu dokonania naprawy nie potrafiła określić, komu zleciłaby naprawę w razie takiej potrzeby (ryc. 10).

Ryc. 10. Miejsce dokonywania naprawy samochodu

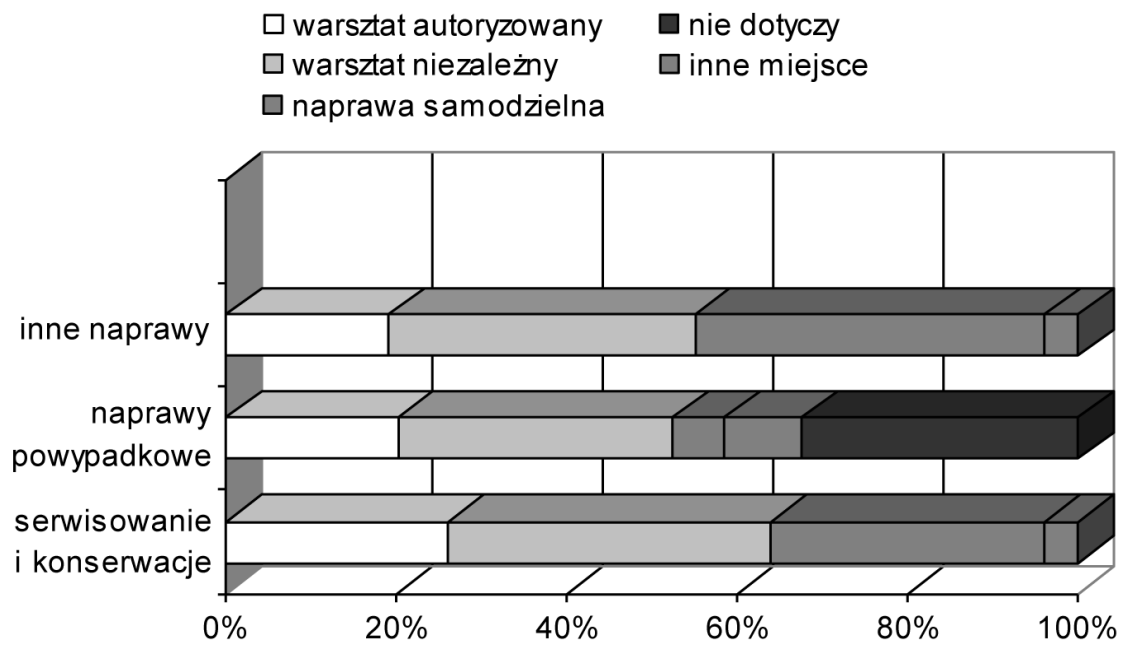

Źródło: opracowanie własne na podstawie badania Kto naprawia nasze auta?, www.tns-global.pl (stan na dzień 01.08.2006).

Inne naprawy, czyli wszelkie prace przy samochodzie poza bieżącą konserwacją i naprawami powypadkowymi, były najczęściej (przez 41\% respondentów) wykonywane samodzielnie (w tym także z pomocą rodziny bądź znajomych). Warsztaty niezależne wybierało wtedy $36 \%$ osób, natomiast na serwisy autoryzowane decydowała się blisko co piąta osoba (19\%) odpowiedzialna w domu za naprawy.

Obecnie ze względu na wzrastający stopień zaawansowania technologicznego we współczesnych samochodach udział napraw dokonywanych samodzielnie w Polsce systematycznie maleje, ale nadal jest wyższy niż w takich krajach europejskich, jak Niemcy czy Francja. Najczęściej sami naprawiają swoje samochody ludzie młodzi, rolnicy i taksówkarze, a zamiłowanie do samodzielnego naprawiania wynika z potrzeby oszczędności i występuje jeszcze dość często w uboższych regionach Polski. Na przykład w Warszawie wymiana klocków hamulcowych odbyłaby się w serwisie (Profi Auto 2010, wnp.pl). Polacy także rzadziej korzystają z usług autoryzowanych warsztatów. Powodem są nie tylko ceny usług w warsztatach, ale także wiek polskich samochodów, gdyż w większości kupujemy używane samochody, co znalazło potwierdzenie w badaniu Intencja zakupu samochodu 2010. Z badania tego wyraźnie widać, że w zdecydowanej większości (89-91\%) Polacy kupują samochody używane, a tylko niewielka grupa (11-19\%) decyduje się na zakup samochodu fabrycznie nowego. Zatem duża liczba samochodów używanych, kupowanych przez Polaków, adekwatny do wieku stan techniczny tych samochodów i ich niewielka wartość pocią- 
gają za sobą popyt na usługi w zakresie napraw samochodowych i tym samym określone wydatki na obsługę i naprawy (ryc. 11). Wydatki te w 2006 r. wynosiły łącznie 665 zł na jeden statystyczny samochód, gdy w tym samym okresie Niemcy przeznaczali na obsługę i naprawę samochodu równowartość 1548 zł. Różna jest też struktura tych kwot: u nas znacznie więcej wydaje się na naprawy niż na systematyczną obsługę, w Niemczech natomiast odwrotnie. W Polsce aż 55\% właścicieli samochodów udaje się do warsztatu dopiero w wypadku awarii, a tylko 45\% działa prewencyjnie (Kierzek 2007, s. 6), systematycznie wykonując przeglądy techniczne. Należy jednak przypuszczać, że te dysproporcje będą się z czasem wyrównywać, gdyż w ostatnich latach rośnie liczba użytkowników samochodów, którzy prewencyjnie przyjeżdżają do warsztatów, a nie tylko wtedy, kiedy pojawia się uszkodzenie. Przyczyną tego jest przede wszystkim wzrost zaleceń obsługowo-naprawczych we współczesnych samochodach, wysokie ceny zespołów koniecznych do późniejszej wymiany i tym samym zwiększona świadomość eksploatacyjna polskich kierowców. Fakt, że na regularną kontrolę stanu technicznego pojazdów i czynności prewencyjne wydawać będziemy coraz więcej, nie pozostanie bez wpływu również na asortyment i jakość oferowanych przez warsztaty usług i jest to prognoza pomyślna dla warsztatów.

Ryc. 11. Wydatki na naprawy i serwis samochodów w Polsce i w Niemczech

\section{$\square$ obsługa $\square$ naprawa $\square$ obsługa i naprawa razem}

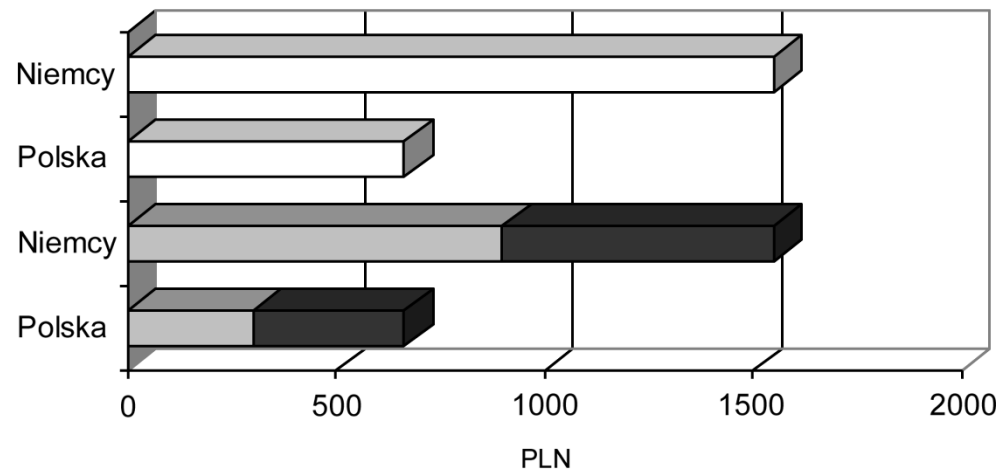

Źródło: opracowanie własne na podstawie ATR, GIPA [w:] Soszyński K., Przyszłość polskich warsztatów, http://www.e-autonaprawa.pl/artykuly/67/przyszlosc-polskich-warsztatow.html (stan na dzień 05.09.2009).

\section{Warsztaty w warunkach postępującej globalizacji gospodarki}

Nie bez znaczenia dla warsztatów samochodowych, jak i dla całej branży motoryzacyjnej pozostają zjawiska gospodarcze, społeczne i polityczne, które obejmują swym zasięgiem wiele państw i są powiązane z szeroko rozumianym procesem globalizacji gospodarki. Proces ten warunkują: rozwój technicznych środków komunikacji, liberalizacja handlu międzynarodowego i redukcja barier przepływu towarów i kapitału (Winiarski 2006, s. 177); sprzyjają temu m.in. korzystne warunki polityczne (odpowiedni klimat) i działalność organizacji światowych, np. MFW, WTO itd. (ryc. 12). Globalizacja jest procesem intensywnym i niemożliwym do zahamowania. Ma ona wiele ujęć oraz definicji, a rozwija się dzięki silnym dążeniom społeczeństw do lepszego życia, przede wszystkim dzięki rozwojowi nowoczesnych technik i technologii. Najpowszechniejsze definicje globalizacji to ujęcia w rozumieniu uniwersalizmu, internacjonalizacji i liberalizacji (Micał 2008, s. 152). 
Ryc. 12. Uwarunkowania i czynniki sprzyjające procesowi globalizacji w branży motoryzacyjnej

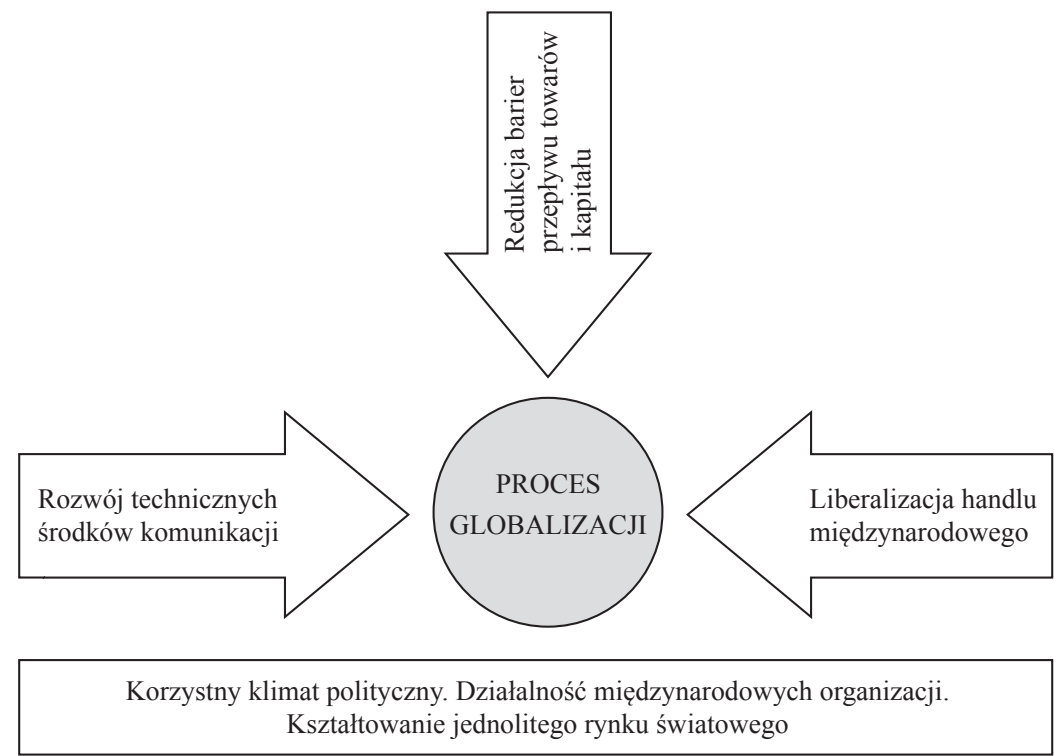

Źródło: opracowanie własne na podstawie definicji globalizacji.

Najwięcej przykładów uniwersalizmu w branży motoryzacyjnej dostarczają rozwiązania konstrukcyjne współczesnych samochodów, ich podatność naprawcza i technologie serwisowe. Internacjonalizacja odnosi się do wzrostu wymiany handlowej pomiędzy państwami i wzrostu zależności podmiotów uczestniczących w handlu. Motoryzacja przyciąga wielkie inwestycje zagraniczne, tak jak ma to miejsce w Polsce. Montaż samochodów odbywa się na różnych kontynentach, a podzespoły stosowane do montażu produkowane są na całym świecie. Na całym świecie dominują też te same marki i modele samochodów wymagające podobnego serwisowania i podobnych napraw. W sektorze warsztatów jest coraz więcej zależności i powiązań nie tylko na szczeblach lokalnych, ale także i w skali międzynarodowej. Widać to szczególnie wyraźnie w sektorze warsztatów autoryzowanych i w sektorze warsztatów zrzeszonych w międzynarodowych sieciach. Celem liberalizacji jest budowanie gospodarki światowej bez granic, gdyż globalizacja wiąże się z procesem międzynarodowej integracji gospodarczej (likwidacji barier w handlu międzynarodowym, ograniczeń transferów kapitałowych). To właśnie m.in. liberalizacja zapoczątkowała masowy import do Polski używanych samochodów i tym samym wzrost zapotrzebowania na usługi warsztatowe. Prawie od podstaw powstało wiele warsztatów przygranicznych nastawionych wyłącznie na obsługę importowanych samochodów. Liberalizacja wymaga także stanowienia odpowiedniego prawa. Konieczne są regulacje w zakresie części zamiennych, napraw oraz serwisu samochodów. 
Tab. 1. Przykładowe zmiany na rynku i w otoczeniu warsztatów w wyniku procesu globalizacji w branży motoryzacyjnej

\begin{tabular}{|c|l|l|}
\hline Lp. & \multicolumn{1}{|c|}{$\begin{array}{c}\text { Zmiany na rynku } \\
\text { i w otoczeniu warsztatów }\end{array}$} & \multicolumn{1}{|c|}{ Przykłady zmian } \\
\hline 1 & $\begin{array}{l}\text { Konsolidacja rynku napraw } \\
\text { i sprzedaży samochodów } \\
\text { oraz części }\end{array}$ & $\begin{array}{l}\text { Rosnący udział warsztatów niezależnych w sieciach, } \\
\text { łączenie się dilerów samochodowych, scalanie na rynku } \\
\text { serwisu opon - Fleet Serwis, Spółka Orzeł }\end{array}$ \\
\hline 2 & $\begin{array}{l}\text { Demonopolizacja prawa } \\
\text { do naprawy - informacji } \\
\text { technicznej i dostępu } \\
\text { do części zamiennych }\end{array}$ & $\begin{array}{l}\text { Zmiany w uregulowaniach prawnych, np. rozporządzenie UE } \\
\text { w sprawie porozumień wertykalnych i praktyk uzgodnionych } \\
\text { w sektorze pojazdów silnikowych, duży udział tanich części } \\
\text { pochodzących z krajów Dalekiego Wschodu }\end{array}$ \\
\hline 3 & $\begin{array}{l}\text { Zmiany w postrzeganiu } \\
\text { bezpieczeństwa - samo- } \\
\text { chód bezpieczny dla } \\
\text { użytkowników i przyjazny } \\
\text { środowisku naturalnemu }\end{array}$ & $\begin{array}{l}\text { Odmładzanie parku samochodowego, nacisk na prewencję, } \\
\text { samochody z napędem alternatywnym (e-samochody), nacisk } \\
\text { na recykling materiałowy i produktowy, wzrost udziału } \\
\text { w naprawach części regenerowanych, wysoki udział technolo- } \\
\text { gii IT, rozwój telematyki, eliminacja patologii w sektorze SKP }\end{array}$ \\
\hline 4 & $\begin{array}{l}\text { Wzrost wskaźnika } \\
\text { motoryzacji }\end{array}$ & $\begin{array}{l}\text { Zwiększenie zapotrzebowania na profesjonalne usługi } \\
\text { serwisowe, malejąca liczba małych warsztatów, większy udział } \\
\text { warsztatów dużych, zwiększenie wydatków na utrzymanie } \\
\text { samochodu }\end{array}$ \\
\hline 5 & $\begin{array}{l}\text { Zmiany w postrzeganiu } \\
\text { zasobów niematerialnych } \\
\text { - warsztat jako organizacja } \\
\text { inteligentna i stale się } \\
\text { ucząca }\end{array}$ & $\begin{array}{l}\text { Wzrost zapotrzebowania na aktualną wiedzę i informację, } \\
\text { przyrost liczby modeli i krótszy cykl życia samochodu, } \\
\text { tendencja do wydłużania resursów obsługowych, postęp } \\
\text { w konstrukcji zespołów, zapotrzebowanie na wykwalifikowaną } \\
\text { kadrę }\end{array}$ \\
\hline obsługi klientów & $\begin{array}{l}\text { Poszerzanie zakresu usług, wzrost mobilności serwisu, } \\
\text { pośrednictwo w zakupie i w odsprzedaży samochodu, jednolite } \\
\text { standardy, ewidencja historii napraw, płatności bezgotówkowe, } \\
\text { samochód zastępczy }\end{array}$ \\
\hline
\end{tabular}

Źródło: opracowanie własne.

Najważniejsze zmiany na rynku i w otoczeniu warsztatów, które niesie ze sobą globalizacja gospodarki, dotyczą konsolidacji rynku napraw i sprzedaży samochodów, demonopolizacji prawa do naprawy ${ }^{3}$, zmian w postrzeganiu bezpieczeństwa, przyrostu liczby samochodów, zmian w postrzeganiu zasobów niematerialnych przez warsztaty oraz zmian w procesach obsługi klientów. Przedstawiono to w tabeli 1, z której wynika, że przed polskimi warsztatami

${ }^{3}$ Rozporzadzenie Komisji (UE) Nr 461/2010 z dnia 27 maja 2010 r. w sprawie stosowania art. 101 ust. 3 „,Traktatu o funkcjonowaniu Unii Europejskiej” do kategorii porozumień wertykalnych i praktyk uzgodnionych w sektorze pojazdów silnikowych 
samochodowymi stoi wiele nowych i trudnych do natychmiastowej realizacji wyzwań. Są to: powiększanie liczby stanowisk obsługowo-naprawczych, a tym samym poszerzanie zakresu usług i zakupy nowego sprzętu, przystępowanie do sieci warsztatowych i współpraca międzynarodowa, uczestnictwo w sektorze napraw mobilnych, stałe lobbowanie na rzecz zmian $\mathrm{w}$ prawie sprzyjających niezależnemu rynkowi, uczestnictwo w procesie recyklingu nie tylko poprzez propagowanie części regenerowanych, ale i aktywne uczestnictwo w odzysku elementów samochodu i innych materiałów powtórnego użytku, stałe doskonalenie umiejętności, pozyskiwanie wiedzy i informacji o nowych rozwiązaniach technologicznych w konstrukcji samochodów, np. przygotowanie się do wzrastającego udziału napędów niekonwencjonalnych (napęd elektryczny, tzw. e-napęd), uczestnictwo w rynku sprzedaży lub zamiany samochodów, ujednolicenie standardów obsługi klienta i warunków gwarancji za naprawy oraz zapewnienie klientowi kompleksowych usług.

Najbliższe dziesięciolecie w wyniku potęgujących się procesów globalizacji powinno przynieść radykalne zmiany na rynku, także w serwisowaniu samochodów w Polsce. Rosnąca świadomość społeczna w zakresie ochrony środowiska naturalnego i konieczność spełnienia coraz surowszych norm ekologicznych doprowadzą do istotnych zmian organizacyjnych i technologicznych w skali globalnej. Można oczekiwać, że branża motoryzacyjna będzie wśród liderów tych zmian. Rynek napraw samochodów w Polsce dysponuje dużymi rezerwami i nie wykorzystuje w pełni swoich możliwości techniczno-organizacyjnych. Porównanie Polski z krajami wysoko rozwiniętymi wskazuje na szanse naszego kraju w utrzymaniu stabilnego rozwoju branży motoryzacyjnej, gdyż w miarę wzrostu stopy życiowej następuje zwiększenie udziału usług określane jako serwicyzacja gospodarki, a siłą napędową tego zjawiska są potrzeby konsumentów.

\section{Literatura}

1. Badanie kanałów dystrybucji, 2003, materiały niepublikowane, GIPA.

2. Franke A., 2009, Warsztat w sieci czy poza siecia, http://www.motofocus.pl/raport/raport_4200.php (stan na dzień 25.07.2009).

3. Grześkowiak R., 2007, Szybkie spojrzenie na polski rynek motoryzacyjny, „Wiadomości Inter Cars SA", nr 23, Warszawa.

4. Import samochodów używanych w marcu, 2010, Moto Onet.pl, http://moto.onet.pl/1609486,1,import-samochodow-uzywanych-w-marcu,artykul.html?node=8 (stan na dzień 19.08.2010).

5. Kierzek R.K., 2007, Rynek wybrat wolność, „Wiadomości Inter Cars SA”, nr 23, Warszawa.

6. Koch K., 2004, Rynek sprzedaży w 2003 r., „Automotoserwis”, nr 7-8, Warszawa.

7. Kto naprawia nasze auta?, badania na temat eksploatacji i napraw samochodów osobowych przeprowadzone przez TNS OBOP i TNS Infratest w 2005 roku, www.tns-global.pl (stan na dzień 01.08.2006).

8. Kublik A., 2010, Polska potrzebuje pót wieku, by wymienić stare auta na nowe, Gazeta.pl http://m. wyborcza.pl/wyborcza/1,105226,8433599,Polska_potrzebuje_pol_wieku_by_wymienic_stare_auta. html (stan na dzień 28.09.2010).

9. Maty rocznik statystyczny Polski 2010, 2010, GUS, Warszawa.

10. Micał M., 2008, Proces globalizacji we współczesnym świecie, „Zeszyty Naukowe Zakładu Europeistyki Wyższej Szkoły Informatyki i Zarządzania w Rzeszowie”, nr 3/(8), Rzeszów.

11. Polacy chętnie sami naprawiają swoje samochody, 2010, ProfiAuto, wnp.pl (stan na dzień 25.08.2010).

12. Transport - wyniki działalności w 2008 roku, 2009, GUS, Warszawa. 
13. Intencja zakupu samochodu 2010, badania OMNIMAS przeprowadzone przez TNS OBOP w okresie 21 stycznia - 7 lutego 2010, www.tns-global.pl (stan na dzień 18.08.2010).

14. Sprzedaż nowych samochodów w lipcu 2010, 2010, http://www.samar.pl/_ /_la/pl/_ac/sec,4/ new/59049/_SAMAR-Sprzeda\%C5\%BC-nowych-samochod\%C3\%B3w-osobowych-w-lipcu-2010. html (stan na dzień 19.08.2010).

15. Najchętniej kupowane auta to niezmiennie klasa niższa średnia, 2010, http://www.samar.pl/index. $\mathrm{html}$ ? la $=\mathrm{pl} \& \quad \mathrm{ac}=\mathrm{sec}, 4 \&$ new=59185 (stan na dzień 19.08.2010).

16. Soszyński K., 2009, Przyszłość polskich warsztatów, 2009, http://www.e-autonaprawa.pl/artykuly/67/ przyszlosc-polskich-warsztatow.html (stan na dzień 05.09.2009).

17. Szczepaniak M., 2006, Sieci serwisowe w Polsce, http://www.autofirmowe.pl/5696,sieci_serwisowe. html (stan na dzień 15.07.2009).

18. Uzdowski M., Abramek K.F., Garczyński K., 2003, Pojazdy samochodowe. Eksploatacja techniczna i naprawa, WKiE, Warszawa.

19. Winiarski B., 2006, Polityka gospodarcza w obliczu procesów globalizacji. Perspektywy na pierwsze dziesięciolecia XXI wieku [w:] Polityka gospodarcza, B. Winiarski (red.), Wyd. 3, Wydawnictwo Naukowe PWN, Warszawa.

\section{Car Workshops in the Conditions of Globalization}

The subject of paper is the issue of car service market in Poland. The development and organizational structure of car service has been presented. The main differences in car service in Poland and Germany have been pointed out. Discussion on global changes in economy linked to the car service market was undertaken. 


\section{Tomasz Tadeusz Brzozowski}

Wałbrzyska Wyższa Szkoła Zarządzania i Przedsiębiorczości

Centrum Kształcenia Ustawicznego przy Zakładzie Karnym nr 1 we Wrocławiu

Autorskie Licea Artystyczne i Akademickie ALA we Wrocławiu

\section{Globalizacja a wykluczenie społeczne Etyczna i kulturowa geneza procesu marginalizacji}

\section{Problematyczność zjawiska globalizacji}

Globalizacja, od samego początku funkcjonowania tego pojęcia w literaturze, uwikłana jest w szereg zależności, w wyniku których pojawiły się pytania o ryzyko związane z jej przebiegiem, intensywnością, a przede wszystkim - skutkami. Jako proces otwarty jest ona narażona na sprzeczności wewnętrzne i głównie to przyczyniło się do trudności w przewidywaniu i kontroli jej przebiegu. Zachodzące procesy globalne, sprowadzone przez badaczy różnych dziedzin do dość wygodnego pojęcia globalizacja, z czasem ujawniły swe ryzyko. Jest to skutek faktu, że dynamika tych procesów spowodowała trwałe, jak się wydaje, zmiany w dziedzinach społecznej, gospodarczej i kulturowej. Postawiło to badaczy tego zjawiska przed potrzebą rozwiązania całkiem nowych, niedających się przewidzieć w niedalekiej przeszłości, problemów. Ich źródła do dziś pozostają niewyjaśnione, bowiem są rezonansem wielu nawarstwiających się procesów i zjawisk, mających określone skutki w różnych sferach rzeczywistości.

Problem i skala ryzyka, na które został narażony współczesny świat pod wpływem przetaczającej się fali procesów globalnych, pozwala na sformułowanie kilku uwag. Po pierwsze, globalizacji zagraża ryzyko zewnętrzne, przez co można rozumieć szereg niepokojących zmian, które zachodzą na skutek oddziaływania świata przyrodniczego. Niektórzy badacze twierdzą, że to ryzyko zostało już w znacznym stopniu opanowane, co dokonało się głównie za przyczyną wzmożonego rozwoju techniki, będącej skutecznym instrumentem przewidywania zjawisk przyrody oraz neutralizującym jej zapędy (Giddens 2008, s. 87). Czy rzeczywiście? Coś, co dla niektórych naukowców jest już pieśnią przeszłości, z całą mocą ukazuje ich błędne przekonania. Jeśli odniesiemy się do obserwowalnych zjawisk ocieplenia klimatu, ruchów tektonicznych, których niepodobna przewidzieć, nagłego wzrostu poziomu rzek czy nieuzasadnionych geologicznie uaktywnień dawno wygasłych wulkanów - kwestia nie jest już tak jednoznacznie oczywista. Dodatkowo problem potęguje fakt zwielokrotnienia występowalności tych zjawisk, który w XXI w. przybrał skalę regularności.

Nieco inaczej akcenty rozkładają zwolennicy tezy o ryzyku stwarzanym przez człowieka. Nie bez znaczenia w tej kwestii pozostaje stwierdzenie, że najbardziej nieprzewidywalnym „czynnikiem” mającym wpływ na rzeczywistość postaje sam człowiek. Otóż stanowisko to uznaje, że globalizacja zagrożona jest skutkami działań człowieka. Najczęściej podnosi się w tej kwestii problem ingerencji w środowisko naturalne, za którym stoi wiedza oraz technika (Giddens 2008, s. 87). Inwazyjność techniki penetrującej bezrefleksyjnie środowisko naturalne stwarza dodatkową obawę o stan zdrowia społeczeństwa. Można to ująć w starej maksymie 
nihil novi sub Solis. Na tego typu zagrożenia wskazywali już dawno inni badacze. Jednym z najprzenikliwszych był Oswald Spengler, już w 1918 r. przewidujący upadek kultury zachodniej, do którego przyczynić się miała w dużej mierze technika. Technika, choć wytwór myśli ludzkiej, a więc tryumf racjonalizmu nad irracjonalizmem świata przyrody, szybko ukazała swe drugie oblicze: z początkowego sprzymierzeńca ludzkości z coraz większą mocą stawała się jego wrogiem (Brzozowski 2003). Zwycięstwo mikrokosmosu nad makrokosmosem i uznanie wyższości tego pierwszego sprawiło, że człowiek bardzo szybko przekształcił się w niewolnika swego tworu (Spengler 2001, s. 441) i takim oto sposobem technika wdarła się w świat, zaś skutki tej ingerencji, miast poprawić jakość życia społeczeństw, coraz bardziej niepokoją.

Pozostać na poziomie obaw wynikających z procesu globalizacji w sferze zagrożenia ze strony techniki, to nie dostrzegać bardziej istotnych, bo odpowiedzialnych za zmiany w obrębie samego człowieka skutków. Problem dotyczy wpływu procesów globalnych na kwestie społeczne i kulturowe, z których najgroźniejszymi, jak sądzę, są osamotnienie, nierówność i spłycenie relacji interpersonalnych. Stopień oddziaływania procesów globalnych na społeczeństwo jest ogromny i choć widzi się go głównie w odniesieniu do czynników makrospołecznych, w nie mniejszym stopniu ujawnia się w obszarach mezostruktury, a przede wszystkim - mikrostruktury, spośród której najwrażliwszą społecznie i kulturowo jest rodzina.

\section{Czy moralność da się zglobalizować?}

W kontekście dotychczasowych rozważań można zadać pytanie: Czy procesy globalne są w stanie tak silnie oddziaływać na naszą rzeczywistość, iż mogą zmienić porządek moralny społeczeństw i tworzących je jednostek? Jednoznaczna odpowiedź na to pytanie byłaby zbyt ryzykowna, ale można pokusić się o próbę częściowej odpowiedzi. Współcześnie niepokój budzi wiele zmian zachodzących szczególnie w mentalności współczesnego człowieka i wcale nie chodzi o to, aby bić na alarm i za wszelką cenę starać się ratować etykę w jej klasycznym kształcie. Zmiany, zarówno w świadomości, jak i zachowaniach ludzi wobec nieustannie zmieniającej się rzeczywistości, to nieuchronny wynik postępujących procesów społecznych, które im towarzyszą. Dlatego mówić o nich jako o czymś z gruntu niewłaściwym jest bezzasadne. Bardziej pożądanym jest więc określenie ich genezy i próba zrozumienia zjawisk, których, podobnie jak procesu globalizacji, zatrzymać się nie da. Można co najwyżej postarać się je zrozumieć lub przewidzieć, w jakich kierunkach zmiany te będą zdążać. Jedną z nich, wynikającą w moim przekonaniu wprost z procesów globalnych, jest indywidualizm. Choć indywidualizm jako postawa wobec otaczającej podmiot rzeczywistości znany jest od starożytności, ujmowany społecznie, budzi zastrzeżenia. Podkreślić od razu należy, że indywidualizm w sensie etycznym może być rozpatrywany adiaforycznie, bowiem podążanie z góry wytyczoną przez siebie drogą nie musi oznaczać, że w takim sposobie egzystencji czai się zło. Naturalny indywidualizm - osiągnięcie współczesnej cywilizacji - pozwala na autozdefiniowanie się jednostki i wolny wybór kształtu, jakości i sposobów realizacji swego człowieczeństwa. Ale współczesne pojęcie wolność charakteryzuje się zdecydowanym wykroczeniem poza dotychczasowe, tj. wypracowane przez powszechną racjonalność moralne horyzonty (Taylor 2002, s. 10). Porzuciwszy je, ludzie przyjęli zupełnie nowe wzorce oparte głównie na kryterium ekonomicznym, odrzucając hierarchicznie uporządkowaną wizję społeczeństwa oraz zmieniając model nowoczesnej rodziny. Innym, ważnym aspektem indywidualizmu jest zawężenie pola wiedzenia. Redukcja dotyczy nie tylko świata przyrody, ale nade wszystko innych ludzi oraz wypracowanych przez nich wartości. 
W przeszłości ludzie odnosili się do świata w kontekście jego dziejów, zatem jawił się im on jako szerokie pasmo dokonań i wartości wypracowanych przez ludzkość. Ważną rolę w tej wizji odgrywał porządek hierarchiczny, którego odbiciem stawał się układ społeczny, gdzie jedni dominowali, inni zaś byli zdominowanymi. Tak zarysowana struktura społeczna odzwierciedlała porządek całego wszechświata. Hierarchiczność, choć w znacznym stopniu determinująca wolność jednostki, wolność rozumianą jako prawo do wyboru sposobu życia, nadawała sens światu oraz stosunkom międzyludzkim. Ci, którzy podlegali hierarchii, nie pełnili jedynie roli podrzędnej, wypełniając tym samym strukturę w sensie pustych i pozbawionych znaczenia elementów, ale byli obdarzeni samodzielnym znaczeniem, które wynikało z miejsca zajmowanego w tej uformowanej w pewnym porządku całości. Jeśli przeniesiemy się na obszar praktyk społecznych w ich obrzędowości, które organizowały i do dziś, choć w innym sensie, organizują relacje społeczne, to ich przeżywanie wiązało się z autentycznym (magicznym) przeżywaniem wyjątkowego i nadzwyczajnego wydarzenia z historii, które obrzęd ten zachowywał i upamiętniał. Dziś tego typu przeżycia stają się dla większości odbiorców kultury obce. Wskazują na to m.in. badania socjologiczne, śledzące np. intensywność przeżyć religijnych podczas obchodzenia świąt (Baniak 2007). Symbolika i oprawa coraz częściej przejmują rolę instrumentu, dzięki któremu możliwym stają się spotkania w gronie rodzinnym, a sposób przeżywania (styl obchodzenia), z Eliadowskim odzyskiwaniem utraconego lub przeszłego czasu niewiele mają wspólnego.

Jak zauważa Ulrich Beck, nowoczesność, choć się radykalizuje, to na obrzeżach pozostawia stare elementy nowoczesnej kultury, które świadczą m.in. o tym, że nie powstał żaden jakościowo nowy ład społeczny. Mimo iż postnowoczesne społeczeństwo stara się je zachować i uchronić przed wymazaniem, nie są one już przydatne dla współczesnej rzeczywistości, ona już tych instytucji nie potrzebuje i równie dobrze potrafi się bez nich obejść. Tak też poprzedni ład nijak ma się do nowych czasów. Nowoczesność, w swym radykalizmie, zapomniała lub zagubiła potrzebę ukonstytuowania nowego, bardziej do obecnych wymagań społecznych adekwatnego ładu. Zdezawuowano wszelkie granice, aby sprostać rodzącym się z coraz większą mocą napięciom związanym z radykalizacją, ale w taki sposób rodzą się nowe i bardziej zagrażające ludziom ryzyka (Beck 2002). W kontekście dyskutowanych dziś problemów można zadać pytanie o jakość i wartość tych przemian. W sytuacji utraty horyzontów społecznych, nadających wartość i wagę naszym jednostkowym wyborom, utraciliśmy „heroiczność” życia. Jakie cele i wartości są dziś w stanie spowodować, że warto za nie oddać życie?

Powyższy problem, zdaniem Charlesa Taylora, związany jest z kwestią zawężenia horyzontów: „Ludzie utracili szerszą wizję rzeczywistości, ponieważ skupili się na swoim własnym, indywidualnym życiu [...]. [...] ciemną stroną indywidualizmu jest skupienie się na sobie, co zarazem spłaszcza i zawęża nasze życie, czyniąc je mniej znaczącym i mniej związanym z innymi ludźmi czy społeczeństwem" (Taylor 2002, s. 12). Zawężenie horyzontów nadających jednostce niepowtarzalne poczucie uczestnictwa w wielowiekowym procesie humanizacji rzeczywistości sprowadza się do tego, że jednostka przeżywa swe życie jako wykorzeniona w sensie społecznym i kulturowym. To najbardziej odczuwalna bolączka naszych czasów, które charakteryzują narcystyczno-egotyczne zachowania. Społeczeństwo permisywne, przyzwalając na wszelkie wybory swych członków, nie interesując się ich życiem prywatnym oraz pozwalając im na swobodny wybór modelu życia rodzinnego i manifestowanie nietypowych zachowań seksualnych, w sposób najbardziej dla siebie naturalny posługuje się racjonalnością instrumentalną. Warto scharakteryzować ten model rozumienia świata, bowiem jest on na tyle powszechny, że stanowi kolejny czynnik ryzyka wynikającego z procesów globalnych i w nie mniejszym stopniu przyczynia się do problemu marginalizacji. 
Pojęciem rozum instrumentalny posługuje się Charles Taylor, definiując go jako rodzaj racjonalności „którym posługujemy się, aby wyliczyć najbardziej ekonomiczny sposób wykorzystania środków prowadzących do danego celu. Maksymalna efektywność, najlepsza relacja nakładów do zysków - oto kryterium sukcesu takiego rozumowania" (Taylor 2002, s. 12). Odstukturalizowane społeczeństwo, bo pozbawione umocowania, które w odczuciu powszechnej świadomości znacznie ograniczało zakres jednostkowej wolności, utraciło cenne narzędzie kulturowe, jakim była busola moralna. Wykorzeniona świadomość „niczyjości” formuje teren dla podejmowania często rozpaczliwych prób mających nadać sens jednostce odrzucającej dorobek poprzednich pokoleń w sensie wypracowanych zachowań kulturowych i obyczajowości. Pojawiający się w tym miejscu rozum instrumentalny bardzo szybko przejął nowy paradygmat osiągania szczęścia. Dokonana wolta kulturowa, spychająca na dalszy plan horyzonty znaczeniowe, zawęziła pole działania jednostki, ograniczając jej zainteresowania do wygody, egoistycznie pojmowanego szczęścia mającego być gwarantem dobrobytu.

Kryteria, którymi operuje racjonalność instrumentalna, polegają głównie na przejęciu całości władzy interpretacyjnej i podporządkowaniu jej wielości pozapodmiotowej, uczyniwszy z niej uprzednio jedynie narzędzia wspomagające człowieka w trudzie zdążania do dobrobytu. Tedy więc zarówno fauna, jak i flora są wykorzystywane jedynie pod kątem zadowolenia i szczęścia człowieka. Tak więc rozum instrumentalny, uwolniwszy się pierwej od ograniczających jego zapędy dokonań ludzkości, samodzielnie, tj. bez liczenia się z podmiotowością innych elementów rzeczywistości (odmówił im prawa do samostanowienia i wolności w pozostawaniu w zgodzie ze stanem natury), przejął całkowitą kontrolę, włączając w obszar swego oddziaływania samego człowieka. Poszerzając zakres wpływów, z czasem zaczął zagrażać ludzkości.

Jednostkowe wybory uwzględniające zupełnie inne (możliwe, że odmienne) kryteria, zostały zmarginalizowane, ponieważ nie zgadzały się z kryterium najważniejszym, mianowicie z ekonomicznością. Racjonalność instrumentalna zaprowadziła zatem swoistą dyktaturę wyboru obliczoną przede wszystkim na uwzględnienie efektywności celu. Stąd obawa, że suwerenne cele, które powinny kierować naszym życiem, zostaną przesłonięte przez postulat maksymalizacji wydajności (Taylor 2002, s. 13). Ujawnienie się odpersonalizowanych, bo operujących głównie statystyką i wykresem, sił w społeczeństwie wyznaczyło nowy biegun dla postępowania człowieka współczesnego, nakazując mu przed dokonaniem wyboru (przede wszystkim o charakterze moralnym) uwzględnienie analizy kosztowo-celowej. Chcąc sprostać temu zadaniu, człowiek sięgnął po narzędzie, mające go wspomóc na drodze rozwoju społecznego po technikę. Ta, z czasem zaczęła zagrażać jego podmiotowości, bowiem stopień uzależnienia postępuje i zmierza w kierunku, na którego krańcach pojawia się implicite postulat częściowej eliminacji człowieka, który z punktu widzenia ekonomii nie zawsze okazuje się opłacalny (Rifkin 2001).

Kwestię zmniejszającego się zapotrzebowania na pracę podejmuje kontrowersyjna książka Koniec pracy. Jej autor - Jeremy Rifkin - zajął stanowisko zgodne z opinią grup socjalistycznych pesymistów twierdzących, że zaawansowana technologia w efekcie doprowadzi do koncentracji bogactwa w rękach wąskich elit, co znacząco wpłynie na globalne bezrobocie mas. W tej perspektywie w niedalekiej przyszłości zabraknie pracy nie tylko dla grupy przejściowo bezrobotnych, ale dla stałej populacji wyłączonych na trwale z uczestnictwa w życiu społecznym. Ich liczba będzie znacząca nie tyle dla poszczególnych społeczeństw, ile w skali globalnej. Innym źródłem wykluczenia staje się ,paradygmat przyrządu”. Określenie to odnosi się do ściśle sprofilowanych dóbr konsumpcyjnych, wyłączających w sensie przeznaczenia inne możliwości ich użytkowania. Problem wiąże się z rezygnacją z wielokierunkowych 
relacji na rzecz konkretnego i w niczym nie powiązanego z innymi czynnościami i ludźmi produktu. Na ten problem zwraca uwagę Albert Borgman, który podaje przykład zmian technologicznych w kontekście ogrzewania domów. Wskazuje, że w przeszłości proces ten wymagał sporego zaangażowania wielu członków rodziny zamieszkującej wspólnie jeden budynek, jedni wyszukiwali drzewa jako źródła energii i opału, inni je rąbali, jeszcze inni przenosili na miejsce składowania. Ktoś z rodziny trudnił się rozpalaniem, ktoś czuwał, aby nieustannie drzewo podkładać. Sytuacja diametralnie się zmieniła, gdy wprowadzono piece centralnego ogrzewania, eliminujące nie tylko potrzebę zatrudnienia ludzi, ale także ich zatroskanie o wspólne dobro. Poza wygodą, jaką niewątpliwie okazało się to rozwiązanie, zaprzepaszczono wspólny wysiłek integrujący na co dzień rodzinę oraz budujący relacje dobrosąsiedzkie (Borgman 1984).

Weberowska żelazna klatka daje o sobie znać szczególnie w sytuacjach, gdy zakusy racjonalności instrumentalnej, poprzez jej ekspansywny charakter, rozciągają się na coraz to rozleglejsze sfery życia. Opresywność rozumu instrumentalnego dotyka przede wszystkim tych, którzy nie potrafią lub nie chcą przeciwstawić się na co dzień dojmującemu ciśnieniu społecznego przymusu. Toteż wiele osób, np. należących do świata biznesu, nie akceptując z subiektywnego punktu widzenia niektórych rozpowszechnionych i okrzepłych w tym środowisku zasad, ulega presji większości, mody lub narzuconych często standardów, resztki swej wolność pozostawiając i demonstrując w osobistych komentarzach krytycznych wygłaszanych w zaciszu swego domu lub w wąskiej grupie przyjaciół. Biznesowi obce jest oddanie się lub poświęcenie czemuś tak dla człowieka oczywistemu, co naturalnemu jak rodzina. Szczególnie kobiety, budując swe pozycje społeczne i zawodowe, przemierzając zaplanowane uprzednio szczeble kariery, choć w poczuciu tego, że je coś ważnego omija (macierzyństwo, rodzina), dokonują mimo to wyborów pod presją i przymusem społecznych oczekiwań rynkowych. Efektywność i analiza kosztowo-celowa pozbawia je tego, z czym w głębi sumienia się często nie zgadzają, ograniczając znacznie margines ich wolności. O ile celne, z punktu widzenia biznesu, wybory skutkują pożądanym efektem ujawniającym się w postaci oczekiwanego zysku lub sukcesu w karierze, o tyle nieudane i nietrafne posunięcia ludzi degradują i wykluczają ich jako przydatnych dla społeczeństwa.

W Taylorowskiej analizie nowoczesnych zjawisk i zachowań społecznych, spośród czynników odpowiedzialnych za erozję dialogicznych relacji interpersonalnych obok indywidualizmu i rozumu instrumentalnego znajdują się struktury społeczeństwa industrialno-technicznego ograniczające w odczuwalny sposób nasze codzienne wybory. Wymuszają one na uczestnikach życia społecznego dezawuowane w sposób dla ludzi naturalny racje, zadając gwałt naszej wolności. Dla tego typu przekonań, w toku poważnych przemyśleń moralnych prawdopodobnie nigdy nie byłoby z naszej strony akceptacji. Jeśli jednak się ona pojawia, to następuje jako skutek przymusu, który ma źródło w racjonalności instrumentalnej, a więc w określonych sposobach przeżywania świata poddanych do wierzenia i zastosowania w praktyce, sporządzonych w ściśle określonym i doraźnym celu. Można zadać, myślę, bardzo zasadne pytanie: Kto stoi za takimi ideami? Bezduszne i nieczułe mechanizmy kierujące światem? Czy może mimo wszystko ludzie? Skoro mówimy o racjonalności jako narzędziu mającym doprowadzić do określonego skutku, to w sposób naturalny wydaje się, że ten właśnie rodzaj racjonalności, o ile zaistniał w przestrzeni społecznej, mógł się zrodzić i wyjść jedynie z innej racjonalności.

W tym miejscu należałoby odpowiedzieć na postawione na początku tego podrozdziału pytanie: Czy moralność, jako określony sposób naszego zachowania wobec innych i otaczającej nas rzeczywistości, za które każdy z nas jest odpowiedzialny, może ulec wpływowi procesów globalnych rodzących wyraźne i odczuwalne zmiany w różnych sferach życia? 
Pytanie jest interesujące, bo wikła nas m.in. w problemy zależności etyki i moralności, które najczęściej w odbiorze społecznym traktowane są jako tożsame. Etyka jako nauka o moralności, w bogatej historii swej dyscypliny, zawiera szereg możliwych odpowiedzi skodyfikowanych w formie zaleceń, twierdzeń i normatywnych regulacji. Toteż w tym sensie stanowi rezerwuar różnych stanowisk wypracowanych w toku historycznych debat społecznych. Mimo to są one w odwrocie, bowiem jako akty normatywne, ściśle regulujące postępowanie człowieka, z uwagi na swą skostniałą formę, zastygłą w niezmiennych formach nakazów i zakazów utraciły dziś swą atrakcyjność. Powodem tego jest, jak sądzę (poza piewcami tzw. etyki sytuacyjnej) m.in. pominięcie w nich elastyczności.

Określenie flexibility odniesione np. do walki z rutyną i skostniałymi formami działań ludzkich ma raczej pozytywne konotacje, ale w perspektywie zmian kulturowych czy społecznych ten dodatni wydźwięk traci na ostrości. Elastyczność oznacza dziś otwarcie na zmiany, innowatykę zachowań, łatwość przystosowywania się do nowych i zmiennych warunków. Elastyczność, jak powiada Sennett, opiera się na trzech zasadniczych elementach. Są nimi: wymyślanie instytucji od nowa, elastyczna specjalizacja produkcji oraz koncentracja władzy bez jej centralizacji (Sennett 2006). Pierwsze prowadzi do przeprojektowania instytucji w sposób gwałtowny i nieodwracalny, podczas którego usuwa się nić wiążącą przeszłość danej organizacji z jej teraźniejszością. Nietrudno się domyślić, że takie praktyki polegają na sporych oszczędnościach w dziedzinie kapitału ludzkiego, co pociąga za sobą masowe zwolnienia z pracy (reeingeering, downsizing). Z kolei zadaniem elastycznej specjalizacji jest jak najszybsze dostarczenie na rynek zróżnicowanych pod względem jakościowym i ilościowym produktów. Zatem funkcjonalizm produkcji elastycznej jest zależny od tego, jak dane społeczeństwo definiuje dobro wspólne. Nie jakość produktu i jego pożądany wpływ np. na zdrowie konsumenta stanowi główne kryterium, ale aktualny gust klienta, pod którego profiluje się produkt. Koncentracja bez centralizacji, mająca pozory wolności i samorządności, w efekcie reorganizuje strukturę organizacji w taki sposób, by stwarzać iluzję małych segmentów przypominających układ sieciowy (usieciowienie relacji interpersonalnych). Kontrole sprawuje się zazwyczaj przez wyznaczenie określonych celów. Kiedy te nie są osiągane, następuje tzw. dociskanie zespołów. Problem w tym, że jednostka nadzorująca podaje podległym zespołom jedynie wskazówki, precyzując wymagania, bowiem ludziom z nadzoru brak niekiedy kompetencji merytorycznych, których zresztą nikt od nich nie wymaga.

Problem rozbija się więc o zakres odpowiedzialności za wyniki pracy zespołowej. W takiej strukturze przypisanie w sposób jednoznaczny komuś odpowiedzialności, w praktyce jest niemożliwe. Najczęściej więc na wynik grupy pracuje kilka osób, zaś brak skutecznych instrumentów pomiaru indywidualnej odpowiedzialności za efekt pozwala na swobodne korzystanie wszystkich z zespołu z dobrodziejstwa skutków wysiłku niewielu. Gmatwanina konstrukcji piramidalnych nadzorujących poszczególne zespoły (teamwork), zaciera rzeczywiste granice nie tyle odpowiedzialności, co zależności między ludźmi, obniżając tym samym wartość naturalnych więzi między pracownikami i prowadząc do poczucia wyobcowania i izolacji (Sennett 2002).

W warunkach globalizującej się rzeczywistości określone wymagania stawia się również etyce. O ile na elastyczność w zakresie etyki normatywnej nie ma co liczyć, o tyle pożądanym stają się wszelkie regulacje o kwalifikacjach moralnych, które, wychodząc na przeciw nowoczesnym zapotrzebowaniom, uwzględniałyby postulat elastyczności w odniesieniu do kwestii moralnych wyborów jednostki, sankcjonując tym samym niezgodne z osobistymi odczuciami posunięcia. Takie teorie wpływają łagodząco na wszelkie przejawy dysonansu moralnego w sytuacjach konfliktowych. 
Rynek pracy, który niewątpliwie jest jednym z najwrażliwszych i podatnych na zmiany wynikające z procesów globalnych, ujawnia zanik tradycyjnych modeli kariery. Wykorzystanie nabytego kiedyś wykształcenia, związanego z wąską specjalizacją lub określonymi umiejętnościami, nie chroni przed zmianami, ale staje się źródłem wielu niepowodzeń i frustracji. Człowiek w wieku szkolnym musi tak planować swą karierę (co stanowi czynnik wysokiego ryzyka), aby w czasie procesu kształcenia był zdolny do jego uzupełnienia o całkiem nowy, niewykluczone, że w żaden sposób niezwiązany z dotychczasowym lub niedawno zdobytym, profil. Współcześnie korporacje zlecają małym podmiotom, często jednoosobowym, które zatrudnia się krótkoterminowo, zadania, uprzednio realizowane przez nie same. Kierunek ten potwierdza szybki rozwój agencji zatrudnienia tymczasowego, co można zaobserwować na naszym rynku. Coraz częściej firmy poszukują kogoś na tzw. umowy na zastępstwo. Ludzie, w których przygotowanie i szkolenie firma zainwestowała spory kapitał, na skutek niepożądanych z punktu widzenia właścicieli firmy posunięć osobistych (zajście w ciążę), wyłączających ich czasowo z czynnego uczestnictwa w rynku pracy, są na tyle cenni, że organizuje się na zwolnione przez nich miejsca pracowników na zastępstwo. Umowy rozciągają się nawet na okres dwóch lat, po czym po ich wygaśnięciu przyjmuje się wcześniej związanego z firmą pracownika. Sytuację na zglobalizowanym rynku pracy trafnie oddaje hasło: No long term (Sennett 2006).

Sennett wskazuje też na inny ważny czynnik cementujący relacje społeczne, mianowicie na problem zaufania społecznego i autentycznych więzi pomiędzy ludźmi. Pośpiech i tymczasowość, a także wspomniana już elastyczność, absolutnie niwelują szanse na zawiązanie się głębszych relacji w miejscach pracy. Brakuje dla nich przede wszystkim niezbędnego czasu, w którym człowiek nabiera do drugiego w toku jego pracy, zaufania: „Nic na długo to zasada, która powoduje erozję zaufania i wzajemnych zobowiązań. Zaufanie może być, rzecz jasna, natury czysto formalnej, jak wówczas, gdy partnerzy zawierają umowę handlową lub liczą na wzajemne przestrzeganie reguł w grze. Zazwyczaj jednak głębsze zaufanie rodzi się w nieformalnych sytuacjach, na przykład gdy ludzie przekonują się, na kim mogą polegać w obliczu trudnego bądź niewykonywalnego zadania. Trzeba czasu, aby takie społeczne więzi mogły się rozwinąć, powoli zapuszczając korzenie w szczelinach sytuacji. Nastawienie na krótkotrwałość w nowoczesnych organizacjach nie pozwala dojrzewać takiemu nieformalnemu zaufaniu" (Sennett 2006, s. 24-25).

Odpowiedź na pytanie o możliwość i podatność naszych zachowań moralnych na oddziaływanie wielotorowych procesów globalizujących nasze życie jest trudna, ale, w moim przekonaniu, procesy te, choć nie zawsze jesteśmy tego świadomi, nasze zachowania moralne globalizują. Tezę swoją opieram na założeniu, że skoro globalizacja, która w sposób widoczny, odczuwalny i mierzalny wkroczyła w każdą dziedzinę życia, zmieniając nasze zachowania w zakresie form spędzania wolnego czasu, wyborów konsumenckich, relacji i form religijnych, sposobów spożywania posiłków, makdonaldyzując nie tylko same sposoby, ale i upodobania kulinarne, siłą rzeczy musi w znaczący sposób wpływać na nasze oceny otaczającego świata i ludzi, a nade wszystko na kryteria i sposoby wartościowania, wywołując eo ipso zmiany w zachowaniach o charakterze moralnym. Agresywna penetracja różnych form i przejawów naszego życia jako wynik procesów globalnych tworzy również zmiany w zakresie codziennych sądów wartościujących, które z kolei są pochodną naszych przekonań moralnych. 


\section{Spadek popytu na religię?}

\section{Religia jako zglobalizowany towar rynkowy}

Zastanawiając się nad skutkami procesów globalnych, nie sposób ominąć problemu zmian, które zaszły we współczesnych czasach płynnej religijności. Sparafrazowane nieco na opak określenie Baumana nich posłuży za pretekst do przyjrzenia się przekształceniom w zakresie nowych form odnoszenia się ludzi do kwestii religii oraz oceny z punktu widzenia siły oddziaływania religii na życie. Idąc tropem intuicji badawczej Vincenta Millera, również nie jestem zwolennikiem prostego przeciwstawiania kultury konsumpcyjnej - chrześcijaństwu. Za kulturą stoją określone wartości, akceptowalne przez jej zwolenników, ale i obecne w praktykach. Chcąc pojąć mechanizm zmian zachodzących w procesie myślenia kategoriami religii i o religii, musimy znaleźć klucz interpretacyjny, który te zmiany pozwoli uchwycić. Konfrontacja obu kultur może nas wyprowadzić jedynie na teoretyczne manowce.

Dzisiejszy problem tkwi, jak sadzę, nie w tym, w jaki sposób postrzegamy religię oraz jak wypełniamy przynależne jej praktyki, ale dlaczego uznanie jej orędzia i aprobata sposobów postępowania zupełnie nie przekładają się na zmiany w sferze życia praktycznego. Innymi słowy: „W jaki sposób praktyka kultury konsumpcyjnej może dokonać reorientacji znaczeń danej tradycji religijnej, powodując, iż nasze najbardziej szczere akty religijne okazują się niezdolne do przekształcenia praktyki naszego codziennego życia" (Miller 2007, s. 49). Problem jest tym bardziej interesujący, że znaczenia w sensie kulturowym można porównawczo odnosić do praktyki życia codziennego, o ile są stosowane przez jakieś grupy lub ich członków. Jeśli chodzi o tradycje religijne, na które składa się szereg wierzeń, rytuałów, świąt i symboli pozostają one obecne w kulturze, ale sytuują się raczej po stronie kultury duchowej. Wyraźny brak ich oddziaływania na wymiar praktyczny może poddawać w wątpliwość ich rangę w sensie znaczenia kulturowego. Należy pamiętać również o sieci instytucji stojących za określonymi religiami, których zadaniem jest m.in. dbałość o jakość nasycenia i przenikania praktycznej sfery życia treściami wypływającymi z religijnego orędzia. Z punktu widzenia naszych zainteresowań chodzi więc o to, w jaki sposób kultura konsumeryzmu, jako wynik uglobalnienia zachowań społeczeństwa klientów, dokonuje zmian w praktykach religijnych, że zmienia ich obraz oraz przekształca zachowania w odniesieniu do symboli, wartości czy form przeżywania doświadczeń religijnych.

Wydaje się, że w sytuacji gdy religia staje się jednym z wielu towarów rynkowych, ulega także mechanizmom, dzięki którym jako produkt się promuje. Nie bez znaczenia jest więc forma reklamy, w której religia, jako jedno z dostępnych dóbr, poddana zostaje wyeksponowaniu. Reklama z największym powodzeniem dociera tam, gdzie istnieje próżnia znaczeń i możliwych odniesień. Będąc jednym z wielu towarów na rynku, religia zaczyna funkcjonować jako bezpańska idea pozbawiona odniesień kontekstowych nakierowanych głównie na wspólnotę, która przydawałaby jej znaczenia. Aby oszacować wartość przedmiotu, należy odnieść go do innego lub innych, które stają się dlań tłem znaczeniowym i kryterium porównawczym. Funkcjonowanie samotnie eksponowanego przez reklamę towaru nie pozwala na dokonanie adekwatnego pomiaru jego przydatności lub wartości. Jeśli wartość ujawnia się w relacyjnej wymianie do innego towaru, to rodzi się pytanie: Na co i z kim da się wymienić religię jako propozycję dla współczesnego konsumenta kultury? 
Religia - przekaz dobrej nowiny i nadziei na pełniejsze i wartościowsze życie - może stać się przejawem miłości człowieka do określonego sacrum, któremu on stara się podporządkować świat swoich wartości i praktykę życia, czując się od owego sacrum zależnym. Problem tkwi w tym, że również miłość coraz łatwiej się merkantylizuje i - wziąwszy pod uwagę obserwacje Taylora - ulega dyktatowi rozumu instrumentalnego, by w efekcie podlegać rachunkowi strat i korzyści. W tym sensie pytanie: Dlaczego kochamy naszego Boga? można zamienić na pytanie: Co w Nim kochamy? Perspektywa ta uświadamia nam możliwe zmiany naszego spojrzenia na religię oraz nakazuje zredefiniować jej wartość dla naszego życia społecznego. Jeśli spojrzy się na analizy Weberowskie, dotyczące religii protestanckiej, widać, że upatruje się w nich katalizatora działań i sposobów samodoskonalenia moralnego oraz rozwoju gospodarczego. Wynika to z faktu, że religia nie izolowała człowieka od świata i że dzięki temu nie doszło do napięć pomiędzy religią a ekonomią (Ciupak 1986, s. 12). Religia, świat i człowiek stanowiły pewną całość. Współcześnie religia bywa odrywana od jej kulturowych kontekstów, od jej rozumienia jako trwale wpisanej i istotnej idei, organizującej w dziejach strukturę społeczną. Jest jedną z wielu, po którą, podobnie jak po towar, można sięgnąć, użyć i szybko się znudzić, dokonując wyboru innej. Bez odniesienia kontekstowego traci swój rzeczywisty wymiar społeczno-kulturowy, stając się pozbawioną odniesień. Jest jednym z towarów szerokiego asortymentu oferowanego przez rynek. Takie ujęcie zrodziło zmiany w jej odbiorze oraz w formach przeżyć religijnych.

Te zmiany, podobnie jak inne, są wynikiem globalizowania się religijności. Nie chodzi o próbę oceny zjawiska nowej religijności, ale o uchwycenie mechanizmów tych zmian i ich związku z procesem marginalizacji pewnych grup społecznych. W sytuacji narastającego kryzysu instytucjonalnych form wyznawania religii, z czym niewątpliwie mamy do czynienia, ludzie w poszukiwaniu sensu własnej egzystencji sięgają po rozmaite w dosłownym tego słowa znaczeniu elementy wierzeń, często doktrynalnie i kulturowo odległych, a nawet ze sobą sprzecznych. Wśród badaczy charakteryzujących współczesność pod kątem cech kulturowych wymienić należy choćby G. Simmla, dostrzegającego w nowoczesnej kulturze poczucie utraty sensu. Tworzenie go w sytuacjach indywidualnego wyboru, nieokreśloności i przygodności jest z gruntu trudniejsze niż w warunkach trwałych fundamentów etycznych. One, gwarantując względną stabilizację, stanowiły oś, wokół której można nadbudowywać wartości dodane w postaci sensów subiektywnych. Zupełny brak podłoża o charakterze aksjologicznym nie pozwala na wytyczenie choćby wskaźników kierunkowych do zawiązania się początkowego szlaku budowania indywidualnej drogi, bowiem redundancja treści i hiperpluralizm sensów sprawiają, że jednostka, nie radząc sobie z racjonalnym wyborem, odstępuje od czynności wyboru. Ratuje się w ten sposób od przytłaczającego chaosu i nadmiaru treści, których nie jest w stanie ogarnąć i zweryfikować pod kątem ich przydatności dla procesu budowania sensu własnej egzystencji: „Jednostka nadaje swojemu życiu sens, kształtując własne „światy sensu”, strzegąc swojej autonomii i niezależności. Żyje coraz częściej w świecie niedoboru ideałów, wartości i norm, w świecie „małych” sensów, sensów bez głębi, pozbawionych wzniosłości, a zwłaszcza w warunkach zanikania wiążącego dla wszystkich sensu życia” (Mariański 2010, s. 42).

Religia, pełniąc do niedawna rolę dostarczyciela takich sensów i organizatora relacji społecznych, poprzez zewnętrzne przejawy kultu i manifestacje wiary, stawała się elementem znacząco wpływającym na procesy integracyjne członków społeczeństwa religijnego. Dziś, gdy należy mówić bardziej o różnych typach duchowości, tj. o indywidualnych dążeniach mających na celu dostarczenie sensu dla pojedynczego życia, ten aspekt religii wskazuje, że wytraciła swą moc integracyjną i normatywną. W zaistniałej sytuacji, ludzie, pozostając wiernymi dawnym praktykom i znaczeniu religii w ich życiu, mogą mieć poczucie jedynych 
wyznawców, których praktyki i oddanie instytucjonalnym formom religijnym gwarantują rzeczywistą obronę ortodoksji. Poczucie to wpływa na wzmocnienie separatystycznych nastrojów, w których ujawnia się forma osamotnienia społecznego i można ją interpretować pod kątem wzrostu procesu atomizacji. W tym sensie religia może stać się czynnikiem swoistego wykluczenia.

Z drugiej strony, zmiany w formach przeżyć religijnych, mające, jak sądzę, źródło w indywidualizmie, kierują poszukiwacza sensu własnej egzystencji w stronę samodzielnych odkryć, co stwarza całkiem inne zagrożenia. Utrata więzi ze wspólnotą religijną zorganizowaną wokół instytucji, której skutkiem jest stan kryzysu instytucjonalnych form przeżywania doświadczeń religijnych zmusza wyznawców do poszukiwania na własną rękę możliwych do zaakceptowania doktryn. Rodzi to pewne problemy, przede wszystkim w sensie zachowania odrębności wiary opartej na zdrowej, tj. zgodnej z ortodoksją takiego lub innego wyznania, nauce. Aktywny również w tej sferze rozum instrumentalny sprzyja eklektyzmowi elementów zaczerpniętych z różnych wyznań. Skutek jest taki, że ludzie nie potrafią konkretnie określić własnej tożsamości religijnej i mają trudność w sformułowaniu odpowiedzi na pytanie, jakiej religii są wyznawcami. Nadmiar treści czerpanych z różnych źródeł przyczynia się w znacznym stopniu do poczucia braku zakorzeniania $\mathrm{w}$ takiej lub innej tradycji. Rozmywają się zatem granice największych religii, dbających usilnie o wysoki poziom autoidentyfikacji swego wyznania, choćby poprzez odwołanie do wielkich ksiąg, których treść bywa uświęcona wielowiekową tradycją. W sytuacji konglomeratu niespójnych treści czerpanych z często odmiennych i obcych kulturowo źródeł rodzi się poczucie osamotnienia jednostki i wzmacnia poczucie oderwania, sprzyjając procesowi dezintegracji społecznej.

Ciekawa pozostaje także kwestia łatwego zaaprobowania takich połączeń przekonań, które z punktu widzenia potocznej logiki muszą budzić co najmniej zdziwienie. Czy można zaakceptować przekonanie o rekoncyliacyjnej i soteriologicznej misji np. Chrystusa z jednoczesnym przyjęciem lub wiarą w treści płynące $\mathrm{z}$ doktryny metempsychozy? Jeśli tak jest, a potwierdzają to badania socjologów religii (Baniak, Mariański, Inglehart, Giddens), to na podstawie tego typu zachowań swoją siłę ponownie ujawnia skrajny i - w tym wypadku - dyletancki indywidualizm. Używam określenia dyletancki dlatego, że nie licząc się z prawidłami podstawowych zasad racjonalności, nie tylko nie dba o spójność indywidualnie konstruowanej doktryny, ale nie liczy się także z horyzontami znaczeń, które budują polistrukturę, przydając religii określonego znaczenia. Sam więc wybór lub arbitralna decyzja co do wartości takiego a nie innego układu elementów różnych doktryn stają się tedy wystarczającym gwarantem uznania i domagają się prawa do ich kwalifikacji jako wyborów równoprawnych i ważnych. Znowu więc zwykła czynność wyboru posiadać ma moc obdarzania jakiejkolwiek treści znaczeniem.

Nie wydaje się, aby religia w czasach nowoczesnych była w odwrocie. Mamy raczej do czynienia z procesem prywatyzacji wiary i należy dziś mówić o duchowości (duchowościach) jako samodzielnej drodze poszukiwania intymnego kontaktu z sacrum niż o religii. To niewątpliwie wynik zmian w postrzeganiu instytucji kościelnych, ale i skutek liberalizacji życia społecznego, jak też procesu pluralizacji różnego typu propozycji duchowych podsuwanych przez bogatą ofertę rynkową. Załatwia się przy tym ważną kwestię społecznych potrzeb: każdy znajdzie coś dla siebie, tj. ci, którzy są spragnieni twardej ortodoksji mogą odnaleźć się np. u lefebrystów, ci, dla których liczy się wzniosła oprawa i patos znajdą je w bogatej formie liturgii kościołów wschodnich, inni, którzy przykładają większą wagę do zdrowia, mogą uprawiać jogę lub oddać się innym praktykom religii Wschodu, inni mogą zwrócić się ku grupom wskazującym na potrzebę zadbania o środowisko itd. Rynek, komercjalizując religię oraz sposoby jej przeżywania, przekształca relację ja - sacrum w stosunek sacrum (towar) - klient. 
W społeczeństwach znajdą się pewnie i tacy, którzy nigdzie odnaleźć się nie mogą. Mogą więc stworzyć własną postać duchowości i z uwagi na fakt, że jest to ich wybór, nikt nie będzie mógł poddać w wątpliwość jego ważności (choćby z punktu widzenia koherencji treści, czyli logiki), bo wybór legitymizuje wszystko: „Coraz popularniejszy staje się przy tym pogląd, że każdy ma prawo do wyboru własnych wartości i norm oraz że nikt nie powinien narzucać ich innym ludziom (co można określić jako swoisty ekumenizm religijny i moralny)" (Mariański 2010, s. 16). O ile prawo do wyboru jest postulatem bezdyskusyjnym, o tyle sama treść tego wyboru, bez narażenia się na zarzut absurdalności, poddaje się wartościowaniu i żaden wybór jako jedna z wielu codziennie dokonywanych czynności, nie może stanowić o znaczeniu wybranych treści: „Rzeczy nabierają znaczenia w relacji do tła sensowności. Nazwijmy je horyzontem. Z tego wynika, że jedną z rzeczy, których nie możemy zrobić - jeśli mamy się znacząco samookreślić - jest stłumienie albo zanegowanie horyzontów, na których tle rzeczy nabierają dla nas znaczenia. Ale taki właśnie samobójczy krok stawia się często w naszej subiektywistycznej cywilizacji. Głosząc prawomocność wyboru jednej z możliwości, bardzo często pozbawiamy zarazem obu możliwości ich znaczenia” (Taylor 2002, s. 41).

\section{Wykluczenie czy rezygnacja? Oto jest pytanie!}

Narcystyczna kultura naszych czasów nasycona jest nade wszystko łatwym relatywizmem (Taylor 2002). Oznacza to, że każdy ma własne wartości, o których nie tylko nie da, ale i nie powinno się dyskutować. W kontekście działań komunikacyjnych człowieka, które miały sprawić, że zaczniemy budowanie społeczeństwa dyskursywnego, obliczonego na consens, swą odśrodkową siłę ujawniają postawy skutecznie eliminujące takiego typu roszczenia. Dyskusja jako narzędzie umożliwiające nie tylko przekazywanie treści, ale nade wszystko wypracowanie wspólnych stanowisk została brutalnie odtrącona przez samych użytkowników języka. Rezygnacja z języka jako podstawowego medium dialogu oznacza proces postępującego „zwijania” własnej egzystencji, pragnącej przeżywać siebie i swe życie w formie wystawnej uczty dla jednej osoby - dla siebie. Skutek jest taki, że ograniczając swą aktywność do własnego świata, rezygnuje tym samym z różnorodności i bogactwa form oferowanych przez innych i świat interpretowany jako suma dorobku wielu pokoleń. Szukając celnego porównania opisującego tę sytuację, na myśl przychodzi jedynie samounicestwienie.

Tendencja do traktowania tego, co poza mną jako Nie-Ja, znana choćby z koncepcji idealizmu subiektywnego Fichtego, staje się powszechnym zachowaniem naszych czasów. Różnica polega na tym, że dla Fichtego owo Nie-Ja było sferą, w której Ja chciało utwierdzać swe wartości, humanizując przez to irracjonalną rzeczywistość świata pozapodmiotowego. Nie-Ja stawało się więc niezbędnym korelatem umożliwiającym podmiotowi urzeczywistnienie celów moralnych, zaś w nowoczesności Nie-Ja osiągnęło status upiora, przeszkody, słowem - czegoś, czyhającego na Ja. W tym sensie jest z gruntu czymś obcym dla refleksji Fichteańskiej. Problem ten dostrzega Taylor, który, charakteryzując indywidualizm, pisze, że „oznacza [on - przyp. T.T.B.] skupienie się na sobie, a w konsekwencji oderwanie od (a nawet nieświadomość) szerszych kwestii czy problemów - religijnych, politycznych bądź historycznych - wykraczających poza jednostkę. To wszystko prowadzi do zawężenia i spłaszczenia życia” (Taylor 2002, s. 21). Czyż nie przypomina to drogi do samozagłady podmiotu?

Jeśli zgodzimy się z tezą, że żyjemy w czasach powszechnej konsumpcji, to musimy także wiedzieć, że ten styl życia wpływa zarówno na nasze codzienne wybory, zachowania moralne, jak i kształtuje współczesną wrażliwość. W świecie konsumpcji nie ma zbytnio miejsca na relacje dialogiczne, bowiem takowe nie są nikomu potrzebne. Społeczeństwo wymiany handlowej jest zbiorem zatomizowanych jednostek, mającym amorficzną strukturę, w której 
każdy jest potencjalnym właścicielem określonego towaru - dobra konsumpcyjnego. Problem w tym, żeby na jego towar był popyt. Jeśli podaż przewyższa popyt, taki człowiek sytuuje się poza grupą osób przydatnych dla innych, nie jest bowiem w stanie zaspokoić ich potrzeb. Ludzie świadczący wzajemne usługi mają prawo oczekiwać od innych, że ci także mają coś interesującego do zaoferowania. Grupa handlująca tym, co wyszło z mody, co nie jest już aktualne, jest eliminowana z rynku, ponieważ wprowadza do obiegu towar przeterminowany. Analogicznie można powiedzieć, że jej przydatność dla innych również się przeterminowała. Trzeba nieustannie nadążać za potrzebami i umieć przewidywać trendy oraz kursy. Kto lepiej opanuje tę sztukę, wciąż będzie potrzebny.

Powyższa charakterystyka społeczeństwa świadczącego wzajemne usługi sprowadza się do postrzegania innych jako narzędzi do zaspakajania efemerycznych potrzeb. Instrumentalizm i reifikacja podmiotowości ludzkiej wpływa znacząco na zmiany w zakresie relacji szacunku i rodzi obawę o kryzys uznania. Bolączki te maja istotny wpływ na nasze codzienne relacje z innymi, czego najlepszym przykładem jest stały spadek zaufania społecznego, powszechna agresja, nieliczenie się z prawami innych, powszechnie akceptowane kłamstwo oraz cwaniactwo. W społeczeństwach gospodarki wolnorynkowej potrzeba uznania realizowana jest na ogół przez zasobność portfela, a nie z tytułu przysługującej każdemu godności i ontologicznej kwalifikacji jako podmiotu: ,kapitalizm wytwarza ogromne bogactwo, lecz mimo to nie zaspokaja ludzkiego pragnienia równego uznania, czyli izotymii. Wraz z podziałem pracy rodzą się różnice godności poszczególnych zawodów: śmieciarze i podkuchenni zawsze będą mniej szanowani niż neurochirurdzy i gwiazdy futbolu, a jeszcze mniej godności mieć będą bezrobotni. Ludziom biednym czy bezdomnym dzieje się krzywda nie tyle fizyczna, ile moralna. Ponieważ nie posiadają własności, pozostała część społeczeństwa ich lekceważy: nie umizgują się do nich politycy, a policja i sądownictwo z mniejszym zapałem walczą o ich uprawnienia; mogą znaleźć tylko taką pracę, która ich poniża; wreszcie mają mniejsze szanse na poprawę swej sytuacji przez edukację lub inny sposób samorealizacji. Dokąd będzie istniało rozróżnienie na ludzi bogatych i biednych, dotąd pewne zawody będą uchodziły za godne szacunku, a inne za godne pogardy, dotąd żaden wzrost bezwzględnego poziomu dobrobytu społeczeństwa nie usunie szkód jakich codziennie doznaje godność ludzi gorzej sytuowanych" (Fukuyama 1997, s. 134).

Pojawiające się przypadki świadomej rezygnacji z aktywnej formy uczestnictwa w życiu społecznym, które kwalifikowane są przez większość jako niewytłumaczalne wybryki, dziwią i sprawiają kłopot interpretacyjny. Wykluczenia społecznego nie można więc mylić z indyferentyzmem lub świadomym działaniem polegającym na samoograniczeniu uczestnictwa i aktywności. Co prawda, to również jest wykluczenie, ale z wyboru. Z wykluczeniem społecznym jako zjawiskiem społecznie niepożądanym mamy do czynienia wtedy, kiedy dochodzi do sytuacji, w której ludzie, grupy lub nawet narody chcą uczestniczyć w życiu szerszej zbiorowości, ale nie wiedzą, w jaki sposób to czynić albo też na drodze prowadzącej do ich uczestnictwa stoją przeszkody polityczne, ekonomiczne lub kulturalne, których własnymi siłami nie są w stanie pokonać. Ludzie o indyferentnych nastrojach nie chcą uczestniczyć w życiu politycznym lub ekonomicznym dlatego, że nie uznają tych dziedzin za istotne dla własnej pomyślności lub inaczej niż reszta społeczeństwa definiują to, co zwykło się uznawać za udane życie.

Analizując skutki wykluczenia społecznego, najbardziej widocznymi są etyczne i społeczne implikacje tego zjawiska. Zaniechanie uczestnictwa w życiu społecznym poprzez pracę, wpływa na poczucie odrzucenia. Choć wykluczony, człowiek i tak zdany jest na społeczeństwo; musi w jego obrębie przebywać i ponosić konsekwencje tego faktu. Wykluczonym ciężko zaakceptować nową dla nich sytuację. Będąc skazanymi na odrzucenie przez innych lub przez 
często niezrozumiałe mechanizmy rynkowe, odnoszą wrażenie bycia gorszymi i skrzywdzonymi. Sprzyja to procesom alienacji. Wewnętrzne poczucie izolacji jest na tyle silne, że uniemożliwia powrót do czynnego udziału w społeczeństwie. Świadomość nienadążania za krokiem społeczeństwa i permanentnie zmieniającym się światem, technologiami, informatyzacją, staje się zarzewiem konfliktów wewnętrznych i ma psychologiczne podłoże. Bywa, że stymuluje posunięcia o charakterze eskapistycznym. Stąd pojawiające się rzesze ludzi pragnących świadomie żyć na marginesie społeczeństwa nawet za cenę znacznego obniżenia standardu życia. Problem ten jest ważny w kontekście debaty o zasadność i sposób implementacji zasad tzw. ekonomii społecznej. Stopień trudności w pozyskiwaniu wyłączonych i przywracaniu ich społeczności pracujących jest ogromny.

Przed samorządami oraz organizacjami pozarządowymi wielkie zadanie: Jak zmotywować grupy, które po wielu nieudanych próbach nie chcą już brać udziału w podziale pracy? Ludzi tych do poszukiwań źródeł dochodu nie motywuje chęć bycia aktywnym, dotrzymania kroku, ale często fatalna sytuacja materialna. W desperacji podejmują pracę poniżej kwalifikacji, godząc się na krótkotrwałe i niepewne formy zatrudnienia. Pozostają więc w stałej dyspozycji i gotowości do podjęcia każdej pracy, często po zaniżonych stawkach. To rodzaj aktywności motywowanej nie poczuciem ducha przedsiębiorczości, ale skutek strachu przed wizją nędzy i upodlenia. Inną przeszkodą na drodze aktywizacji zawodowej jest zaawansowany wiek wykluczonych. Wykluczony ma poczucie osamotnienia w zmaganiu o utrzymanie poziomu swego już nie życia, ale człowieczeństwa. Z punktu widzenia ekonomii wykluczenie niekiedy bezpowrotnie niszczy siły i zdolności ludzkie, zaś z perspektywy społecznej, inicjuje proces erozji życia rodzinnego, skutecznie blokując dostęp do dochodu jako podstawy jej egzystencji.

Zarówno geneza, jak też skutki procesów globalizacji nie do końca zostały rozpoznane, ale same procesy niewątpliwie odcisnęły na tyle trwałe piętno społeczne i kulturowe, że nie da się tej oczywistości w żaden sposób zaprzeczyć. Dążenie za wszelką cenę do autentyczności, będącej aspektem nowoczesnego indywidualizmu, charakteryzuje się tym, że kładzie nacisk na wolność jednostki. Jednak problem leży gdzie indziej. Wydaje się, że ta powszechna akceptacja dla autentyczności, niepowtarzalności i nieskrępowania jednostki zdradza, że jako ludzie współcześni mamy coraz większy problem z wolnością. Nie idzie o to, jak ją zdefiniować. Z klasyfikowaniem i tworzeniem teorii na ogół dobrze sobie radzimy. Chodzi raczej o jej rozumienie. Paradoksem naszych czasów może okazać się fakt, że gdy cały świat w szaleństwie i nieograniczeniu pochłonięty jest wzmożonym wysiłkiem mającym na celu uwolnić jak najwięcej wolności, wywalczył coś, co okazało się jego przekleństwem i nieszczęściem zarazem.

Wolność nie jest wartością, którą można zamknąć w definicji. Jest problematyczna, ponieważ jest ważna i jak każdy problem domaga się odpowiedzi, a nade wszystko - zdefiniowania w działaniu. Póki co, wydaje się, że to przedsięwzięcie jest jeszcze dla nas zbyt trudne. Podobnie rzecz ma się z tożsamością. Kształtuje się ona w najbardziej dla człowieka naturalnej sytuacji, w dialogu z innymi. Jeśli jest zgodna $\mathrm{z}$ opinią tych, którzy nas widzą i z nami żyją, to dobrze, ale równie dobrze jest wtedy, gdy pomiędzy naszymi odczuciami a odczuciami innych jest różnica. Ważne, by był punkt odniesienia, a jego najbardziej autentyczną i wartościową rolę pełnić może jedynie drugi człowiek. Tożsamość jest na tyle istotną wartością, że gdy ją posiadamy, łatwiej nam znosić naszą inność i wykluczenie, nie musimy uporczywie zabiegać o uznanie, bowiem jest ono zawarte w jej istocie. Jest tym bardziej widoczna i wyraźna, o ile rozciąga się na drugiego człowieka: „Odkrywanie własnej tożsamości nie oznacza, że odkrywamy ją w osamotnieniu, lecz raczej, iż negocjujemy ją w ramach dialogu - częściowo jawnego, częściowo zinternalizowanego - z innymi” (Taylor 2002, s. 50). 


\section{Literatura}

1. Baniak J., 2007, Desakralizacja kultu religijnego i świąt religijnych w Polsce. Studium socjologiczne, Kraków.

2. Beck U., 2002, Społeczeństwo ryzyka. W drodze do innej nowoczesności, przeł. S. Cieśla, Warszawa.

3. Borgman A., 1984, Technology and the Character of Contemporary Life, Chicago.

4. Brzozowski T.T., 2003, Technika jako taktyka zagrażająca współczesnej egzystencji? Aktualność Spenglerowskiej krytyki kultury maszyn, ,Zbliżenia Polska - Niemcy”, nr 2 (35), 2003, s. 146-157.

5. Ciupak E., 1982, Religia i religijność, Warszawa.

6. Doświadczenie religijne, 2007, oprac. T. Doktór, Warszawa.

7. Fukuyama F., 1997, Ostatni człowiek, przeł. T. Bieroń, Poznań.

8. Giddens A., 2001, Nowoczesność i tożsamość, przeł. A. Szulżycka, Warszawa.

9. Giddens A., 2008, Socjologia, przeł. A. Szulżycka, PWN, Warszawa.

10. Mariański J., 2010, Religia w społeczeństwie ponowoczesnym, Warszawa.

11. Miller J. V., 2007, Religia w świecie konsumpcji, przeł. T. Szafrański, Warszawa.

12. Norris P., Inglehart R., 2006, Sacrum i profanum. Religia i polityka na świecie, Kraków.

13. Rifkin J., 2001, Koniec pracy, przeł. E. Kania, Wrocław.

14. Rifkin J., 2008, Entropia - nowy światopogląd, przeł. B. Baczyńska, Katowice.

15. Spengler O., 2001, Zmierzch Zachodu, przeł. J. Marzęcki, KR, Warszawa.

16. Sennett R., 2006, Korozja charakteru. Osobiste konsekwencje pracy w nowym kapitalizmie, przeł.

J. Dzierzgowski, Ł. Mikołajewski, Warszawa.

17. Taylor Ch., 2002, Etyka autentyczności, przeł. A. Pawelec, Kraków.

18. Taylor Ch., 2006, Oblicza religii dzisiaj, Kraków.

19. Taylor Ch., 2010, Nowoczesne imaginaria społeczne, przeł. A. Puchejda, K. Szymaniak, Kraków.

\section{Globalization and the Exclusion from Society. Ethical and Cultural Origin of the Social Marginalization}

The Author of this paper studies the impact globalization processes on socio-cultural changes, which lead to social exclusion. Being out of a society has different origins especially in modern world and modern society. A reason does not always lie only on the man's side. Being out of a society is sometimes a result of many different processes like, in my opinion, the most essential ones - global trends and the especially ambiguous process - globalization.

The Author pays attention to the origins of the social marginalization and tries to show the most important ones. Simultaneously, he analyzes them by looking at the intensity of their impact on social marginalization. This article ends with an unaided commentary in which the author passes his judgment on the origins and degree of influence of above-mentioned issues. 


\section{Rola przedsiębiorczości}

w aktywizacji gospodarczej 


\section{Malgorzata Zdon-Korzeniowska}

Uniwersytet Pedagogiczny

im. Komisji Edukacji Narodowej

w Krakowie

\section{Marketing terytorialny jako forma działań przedsiębiorczych samorządów terytorialnych w Polsce}

Procesy globalizacyjne - ich zasięg, przebieg i struktura - są trudne do zdefiniowania, a skutki niełatwe do przewidzenia. Jest to obecnie najszerszy, najbardziej złożony, fundamentalny proces zmian zachodzących w sferze gospodarczej i społecznej (Gregor 2006). Trudno jednoznacznie zdefiniować owo coś, co określamy mianem globalizacji. Wielowymiarowość i zasięg tego wieloaspektowego i trwającego wciąż zjawiska są trudne do ogarnięcia i sprecyzowania. Wydaje się, że najbardziej lakoniczne i ogólne jego określenie jako 'tworzenie globalnej wioski, globalnego świata' paradoksalnie najpełniej ujmuje jego istotę i zakres. Sukcesywna likwidacja barier handlowych i inwestycyjnych, rozwój środków transportu i komunikacji, a także szybki przepływ informacji w mediach powodują niespotykane do tej pory zmiany w sferze społecznej, gospodarczej, kulturowej i politycznej. Wszystko to znacząco przeobraża warunki funkcjonowania nie tylko poszczególnych osób i podmiotów gospodarczych, ale i całych społeczeństw, gospodarek narodowych czy też szerszych ich ugrupowań. Zaistniałe warunki wpływają z kolei na zachowania wymienionych podmiotów, które jak woda na młyńskie koło napędzają spiralę globalizacji. Tworzy się tzw. globalny rynek, zacierają różnice kulturowe, unifikuje styl życia charakteryzujący globalnego konsumenta, który nabywa dobra i usługi oferowane przez transnarodowe korporacje.

Tendencja do zwiększania swobody i szybkości przepływu kapitału, osób, a także dóbr i usług otwiera przed podmiotami gospodarczymi i obywatelami szczególne możliwości. Są one związane m.in. ze swobodą wyboru miejsca prowadzenia działalności gospodarczej, miejsca zamieszkania, miejsca podjęcia pracy czy też miejsca wypoczynku. Powyższe stwarza szczególne perspektywy, ale i poważne wyzwania dla miejsc recepcji inwestycji, przedsiębiorstw czy osób, a więc dla jednostek terytorialnych. Chcąc sprostać wymogom globalnego rynku, muszą one wykazać się elastycznością, innowacyjnością i rynkowym podejściem, przystosowując się do potrzeb zainteresowanych grup klientów: przedsiębiorców, turystów, mieszkańców, inwestorów. W warunkach globalizacji bowiem, jak zauważa T. Markowski, presja konkurencyjna wzrasta ,nie tylko na producentów dóbr rynkowych, ale także na jakość otoczeń przestrzenno-gospodarczych, w których działają producenci” (Markowski 2006, s. 89). Tworzy się więc swoisty rynek, na którym określone jednostki administracyjne konkurują ze sobą o kapitał i klientów. Aby wygrać tę grę konkurencyjną, muszą wykazać się przedsiębiorczością i znajomością reguł rynkowych. Muszą dostrzec pojawiające się szanse i możliwości rozwoju oraz mieć odwagę, ale i wystarczającą wiedzę, aby móc z nich skorzystać. Zdaniem B. Gregora (2006), globalny rynek w ogóle powinien być traktowany jako szansa, a nie bariera rozwoju. A konkurencja na globalnym rynku - jak wskazuje autor - opierać się będzie przede wszystkim na wiedzy, innowacjach i nowoczesnym marketingu (Gregor 2006). 
Współczesną tendencją, stanowiącą niejako przeciwwagę dla tego, co niosą procesy globalizacyjne, jest ,eksponowanie tego, co specyficzne i lokalne oraz zintegrowane wokół wspólnego celu" (Bieńkowska 2004, s. 184). Obserwuje się silną tendencję do podkreślania własnej przynależności regionalnej, do identyfikowania się z tzw. małymi ojczyznami. Pojawia się swego rodzaju paradoks tzw. glokalności, wyrażający jednoczesność globalności i lokalności działań samorządów terytorialnych (Barczyk 2010).

W Polsce - zgodnie z przyjętą ideą decentralizacji władzy publicznej - samorząd terytorialny jest podmiotem zarządzającym sprawami lokalnymi i regionalnymi (Majewska 2006), a więc tym, który odpowiada za gospodarowanie specyficznymi, unikatowymi zasobami określonych obszarów. Po reformie administracyjnej z 1999 r. samorządy uzyskały nowe, szersze kompetencje i większą swobodę działania, co umożliwiło im realizację roli menedżerów jednostek terytorialnych, którymi zarządzają, i stało się szansą na przejęcie swoich spraw we własne ręce, a tym samym posiadanie wpływu na kierunki rozwoju małych ojczyzn. Z drugiej jednak strony rozszerzyło to spektrum wyzwań, które stanęły przed samorządami - spektrum kryjące w sobie niespotykane do tej pory szanse i możliwości, ale i zagrożenia. Aby wykorzystać pojawiające się szanse i możliwości, jednocześnie skutecznie unikając zagrożeń, samorządy terytorialne muszą - jak już wyżej wspomniano - wykazać się przedsiębiorczością i innowacyjnym podejściem.

Zdaniem A. Szromnika (2007), zarządzanie jednostkami terytorialnymi powinno opierać się na dorobku nauk o zarządzaniu przedsiębiorstwami, a myślenie przedsiębiorcze powinno być podstawą podejmowania decyzji w instytucjach samorządowych. Według tego autora, jest to podstawowy warunek ich rozwoju. „Dowolne miasto lub region, ale także wieś, dzielnica czy osiedle, są nie tylko organizmami społecznymi i jednostkami samorządności terytorialnej. Ale także pełnoprawnymi uczestnikami rynku, którzy prowadzą różnorodną działalność, posiadają okresowe zasoby i wykorzystują je dla dobra mieszkańców. Dopuszczalne są analogie między jednostkami przestrzenno-administracyjnymi a przedsiębiorstwami, między samorządową kadrą zarządzającą a kadrą menedżerską, między wójtami, starostami, burmistrzami i prezydentami miasta a dyrektorami i prezesami firm" (Szromnik 2007, s. 11).

Wykorzystanie koncepcji marketingowej bez wątpienia uznać można za jedną z form realizacji działań przedsiębiorczych samorządów terytorialnych w warunkach globalizacji. W niniejszym opracowaniu zawarto rozważania na temat zastosowania marketingu terytorialnego przez jednostki administracji publicznej do zarządzania własnym rozwojem. Opracowanie to nie jest jednak prezentacją wyników badań nad wyżej określoną problematyką. Ma ono raczej charakter rozważań wstępnych, jest swego rodzaju preludium do badań, które autorka zamierza podjąć. Przesłanką do sformułowania niniejszej problematyki badawczej były przeprowadzone wcześniej przez autorkę badania i analizy w zakresie kształtowania regionalnych produktów turystycznych w Polsce (zob. M. Zdon-Korzeniowska, Jak kształtować regionalne produkty turystyczne? Teoria i praktyka, Wyd. UJ, Kraków 2009). Badania te dotyczyły m.in. aktywności samorządów szczebla wojewódzkiego w zakresie budowy i kształtowania tych produktów. Obecnie autorka zamierza rozszerzyć zakres i przedmiot badań, a przede wszystkim uwzględnić w nich samorządy lokalne - zwłaszcza samorządy gminne, które mają największe rzeczywiste możliwości działań związanych z m.in. kształtowaniem oferty terytorialnej oraz inne poza turystyczną - rodzaje ofert, a więc tzw. złożony terytorialny megaprodukt stanowiący sumę subproduktów terytorialnych (takich jak subprodukt inwestycyjny, kulturalno-oświatowy, konferencyjny, handlowo-usługowy itp.).

Koncepcja marketingu terytorialnego wywodzi się z nowszych orientacji marketingowych z tzw. koncepcji marketingu społecznego, zgodnie z którą, według Ph. Kotlera, ,zadanie organizacji polega na określeniu potrzeb, wymagań i interesów rynków docelowych oraz dostarczeniu pożądanego zadowolenia w sposób bardziej efektywny i wydajny niż konkurenci, przy 
jednoczesnym zachowaniu lub podniesieniu dobrobytu konsumenta i społeczeństwa" (Kotler 1994, s. 26). Tak definiowana koncepcja marketingowa ma na uwadze nie tylko zysk przedsiębiorstwa, ale - stawiając w centrum zainteresowania potrzeby pojedynczego konsumenta zmierza w kierunku zaspakajania potrzeb znacznie szerszej społeczności (miejskiej, lokalnej, regionalnej), potrzeb w dziedzinie jakości życia, rozwoju społecznie odpowiedzialnego (Gołembski 1999).

Marketingowa koncepcja funkcjonowania jednostek terytorialnych (gmin, miast, powiatów, regionów i innych obszarów) polega na traktowaniu podmiotów znajdujących się na ich terenie (na tzw. rynku wewnętrznym) oraz na terenie innych jednostek terytorialnych (tzw. rynku zewnętrznym) jako specyficznego rodzaju klientów, o których należy zabiegać. W przypadku niezaspokojenia ich potrzeb i pragnień mogą oni np.: zmienić swoje miejsce zamieszkania czy prowadzenia działalności gospodarczej lub nie zdecydować się na podjęcie tej działalności na terenie danej jednostki albo też nie wybrać jej jako miejsca wypoczynku. W podejściu marketingowym bowiem punktem odniesienia wszelkich działań jest klient i jego potrzeby. Kluczowe staje się zatem zdefiniowanie grup klientów (tzw. rynków docelowych) i rozpoznanie ich potrzeb na podstawie badań marketingowych.

Marketing terytorialny - jak twierdzi T. Markowski - powstał w wyniku próby przeniesienia i adaptacji koncepcji sprzedaży i zarządzania wypracowanych dla typowych produktów w sektorze prywatnym do sektora publicznego (Markowski 1999). Według tego autora, jest to wyjście na przeciw potrzebie profesjonalizacji zarządzania jednostkami terytorialnymi i ich rozwojem, potrzebie, która pojawiała się w konsekwencji odpowiedzi na wyzwania globalizacji gospodarki światowej oraz wzrastającej presji konkurencyjnej nie tylko na producentów dóbr rynkowych, ale także presji konkurencyjnej na jakość otoczeń przestrzenno-gospodarczych, w których działają producenci (Markowski 1999).

A. Szromnik definiuje marketing terytorialny jako całokształt skoordynowanych działań podmiotów lokalnych, regionalnych i/lub ogólnokrajowych zmierzających do wykreowania procesów wymiany i oddziaływania poprzez rozpoznanie, kształtowanie i zaspokajanie potrzeb oraz pragnień mieszkańców (Szromnik 1997). Mieszkańcy są podstawową grupą docelową w działaniach marketingowych samorządów terytorialnych. Można rzec, że są to klienci ,niezbywalni”, a dążenie do zaspokojenia ich potrzeb i pragnień generuje niejako pozostałe grupy adresatów oferty terytorialnej (inwestorów, turystów, pracowników instytucji publicznych, banki oraz inne instytucje czy organizacje).

Marketing terytorialny, gdzie podstawą procesów wymiany, punktem odniesienia działań marketingowych jest dane miejsce (Szromnik 2006) (terytorium) określany jest również jako marketing miejsc od angielskiego określenia place marketing (Kotler, Haider, Rein 1993), który zakłada planowanie i projektowanie danego miejsca w tak sposób, żeby w pełni zaspokoić potrzeby rynków docelowych, tj. mieszkańców, podmiotów gospodarczych, a także odwiedzających i inwestorów. Zastosowanie koncepcji marketingowej do promocji i niejako sprzedaży miejsc zmusza władze lokalne oraz regionalne do spojrzenia na jednostki terytorialne, którymi zarządzają, pod nieco innym kątem.

Obecnie w Polsce jednostki terytorialne wszystkich szczebli w mniejszym lub większym stopniu przyjmują orientację marketingową. Są świadome konieczności działań marketingowych, jednak nie wykorzystują wszystkich dostępnych narzędzi. Jak się wydaje, główną barierą jest nieznajomość pojęć, metod i narzędzi marketingowych. Ciągle dla wielu osób marketing jest mało zrozumiały i utożsamiany tylko i wyłącznie z reklamą czy promocją. Wiedzę i narzędzia z zakresu marketingu, w tym również marketingu terytorialnego, często stosuje się selektywnie, ograniczając je do promocji czy kształtowania wizerunku, a zapominając o powiązaniu 
ich z innymi instrumentami marketingowego oddziaływania, takimi jak produkt, dystrybucja, cena, środowisko świadczenia usług, personel itp. O sukcesie bowiem marketingowych działań przesądza odpowiedni dobór instrumentów marketingowego oddziaływania, ich spójność i niepreferowanie jednych kosztem innych. Jak wskazują Ph. Kotler i N. Lee, utożsamianie marketingu z jednym tylko jego narzędziem, a więc ograniczanie go do działań związanych z promocją, „oznacza niedostrzegania potęgi myślenia marketingowego i płynących z niego korzyści” (Kotler, Lee 2008, s. 9).

Każda jednostka administracyjna sama powinna kształtować użyteczny dla niej zestaw narzędzi marketingowych, a więc skomponować tzw. mieszankę marketingową (znaną w nomenklaturze marketingowej pod nazwą marketing-mix). W literaturze przedmiotu istnieje wiele propozycji tego typu zestawów, pojawiły się również i takie, które opracowano właśnie z myślą o marketingu jednostek terytorialnych. W tabeli 1 zostały przedstawione wybrane z nich, użyteczne z punktu widzenia marketingu jednostek terytorialnych.

Tab. 1. Propozycje koncepcji marketingu-mix dla jednostek terytorialnych

\begin{tabular}{|c|c|}
\hline Nazwa koncepcji & Narzędzia marketingowego oddziaływania \\
\hline $\begin{array}{c}\text { Koncepcja „4P” } \\
\text { E.J. McCarthy’ego }\end{array}$ & $\begin{array}{c}\text { product - produkt } \\
\text { price - cena } \\
\text { place - miejsce, dystrybucja } \\
\text { promotion - promocja }\end{array}$ \\
\hline Koncepcja „7P” & $\begin{array}{c}\text { „4P”+: } \\
\text { people - ludzie (pracownicy i personel) } \\
\text { physical evidence - cechy fizyczne lub środowisko materialne } \\
\text { proces - proces lub procedura świadczenia usług }\end{array}$ \\
\hline $\begin{array}{l}\text { Terytorialny marketing-mix } \\
\text { wg M. Florek }\end{array}$ & $\begin{array}{l}\text { megaprodukt } \\
\text { promocja } \\
\text { partnerstwo } \\
\text { tożsamość }\end{array}$ \\
\hline $\begin{array}{c}\text { Terytorialny marketing-mix } \\
\text { wg Ph. Kotlera, D.H. Haidera } \\
\text { i I. Reina }\end{array}$ & $\begin{array}{c}\text { infrastruktura } \\
\text { ludzie } \\
\text { atrakcje } \\
\text { image i jakość życia }\end{array}$ \\
\hline
\end{tabular}

Źródło: A. Szromnik, Marketing terytorialny - koncepcja ogólna a doświadczenia praktyczne [w:] Marketing terytorialny, red. T. Markowski, TOM CXVI, PAN KPZK, Warszawa 2006, s. 65-72; M. Florek, Podstawy marketingu terytorialnego, Wyd. AE w Poznaniu 2006, Poznań, s. 170-174; Ph. Kotler D.H. Haider, I. Rein, Marketing Places. Attracting Investment, Industry and Tourism to Cities, States and Nations, The Free Press, New York 1993, s. 19.

Współcześnie najpopularniejszą formułą marketingu-mix, również jeśli chodzi o marketing jednostek terytorialnych, jest „4P” (Baruk 2001). Zgodnie z tą koncepcją użytecznymi narzędziami stymulowania zachowań odbiorców (Szromnik 2006) są:

- product (produkt) - odpowiednia kompozycja cech oferowanego produktu,

- price (cena) - warunki cenowe transakcji,

- place (miejsce, dystrybucja) - odpowiednie miejsce, forma i czas oferowania produktu,

- promotion (promocja) - formy i środki promocji (komunikacji). 
Powyższa koncepcja wyrosła z doświadczeń marketingu komercyjnego. Z tego też względu działania marketingowe zorganizowane według formuły „4P” posiadają pewne ograniczenia, które utrudniają (lub wręcz uniemożliwiają) ich pełne adaptowanie do potrzeb marketingu terytorialnego (Szromnik 2006).

Z punktu widzenia działań marketingowych związanych z kształtowaniem produktów o charakterze przestrzennym szczególnie ważną wydaje się być koncepcja instrumentów marketingowych w formule „7P”. Koncepcja ta, zaprojektowana z uwzględnieniem specyfiki produktów o charakterze usługowym, poszerza tradycyjną koncepcję „4P” o kolejne trzy obszary marketingowej aktywności:

- people-pracownicy i personel,

- physical evidence - cechy fizyczne lub środowisko materialne;

- proces - proces lub procedura świadczenia usług.

Ze względu na fakt, że złożony megaprodukt terytorialny ma w znacznej mierze charakter usługowy, formuła „7P” marketingu-mix wydaje się być szczególnie przydatna w definiowaniu obszarów aktywności marketingowej związanej z kształtowaniem tego produktu.

W literaturze przedmiotu znaleźć można również zestawy narzędzi opracowane z myślą o marketingu jednostek terytorialnych, choć jak zauważa M. Florek, mieszanka ,instrumentów marketingu terytorialnego jest wciąż przedmiotem poszukiwań” (Florek 2006, s. 170).

Jedną z pierwszych tego typu propozycji jest terytorialny marketing-mix opracowany przez Ph. Kotlera, D.H. Haidera i I. Reina (1993). Według tych autorów, całokształt świadomych i celowych działań marketingowych podejmowanych przez jednostki terytorialne sprowadza się do (Szromnik 2006):

- kształtowania cech infrastruktury - zarówno ilościowych, jak i jakościowych (infrastruktura),

- przygotowania personelu samorządowego oraz mieszkańców do kontaktowania się i obsługi gości przez właściwe procedury rekrutacyjne, szkoleniowe, motywacyjne informacyjne (ludzie),

- organizacji atrakcji w postaci jednorazowych i cyklicznych wydarzeń oraz imprez masowych o charakterze kulturalnym, sportowym, artystycznym, handlowym, turystycznym (atrakcje),

- kształtowania pozytywnego, wyraźnego i trwałego wizerunku (image) jednostki terytorialnej poprzez szeroką oraz zintegrowaną działalność informacyjno-propagandową, angażującą wszystkie podmioty i osoby (image i jakość życia).

Zatem zaproponowane przez wyżej wymienionych autorów instrumentarium marketingowego oddziaływania dla jednostek terytorialnych obejmuje następujące elementy: infrastrukturę, ludzi, atrakcje oraz wizerunek i jakość życia.

Na szczególną uwagę zasługuje propozycja nowatorskiej mieszanki instrumentów marketingu terytorialnego zaproponowana przez M. Florek (2006). Autorka ta wymienia następujące instrumenty: kształtowanie oferty terytorialnej (megaproduktu regionalnego), komunikowanie się regionu z otoczeniem (promocję), działania podmiotów w regionie (partnerstwo) oraz tożsamość, którą uznaje za nadrzędny, w stosunku do pozostałych, instrument marketingowego oddziaływania. Taka konfiguracja obszarów aktywności marketingowej wydaje się być szczególnie użyteczna w aspekcie marketingu prowadzonego przez jednostki terytorialne, integruje bowiem istotne dla tego typu aktywności aspekty. Uwzględnia złożony zdeterminowany przestrzennie produkt terytorialny, kładzie również nacisk na konieczność współdziałania podmiotów jako niezbędnego warunku skuteczności podejmowanych działań marketingowych. Ponadto wskazuje na tożsamość danego miejsca, której właściwe zdefiniowanie i zaprojektowanie wpływa nie tylko na unikatowość i spójność oferty, ale jest również warunkiem kreowania wyraźnego, pożądanego wizerunku danej jednostki terytorialnej. Wyodrębnione przez autorkę 
partnerstwo jako instrument terytorialnego marketingu-mix jest natomiast istotnym czynnikiem wspomagającym efektywność działań podejmowanych w związku z kształtowaniem zintegrowanych, zdeterminowanych przestrzennie produktów.

Zaprezentowane wyżej zestawy marketingu-mix wskazują na potencjalne obszary marketingowej aktywności jednostek terytorialnych. Najpopularniejszym jednak zestawem narzędzi marketingowych stosowanym $\mathrm{w}$ zakresie marketingu terytorialnego, mimo wielu głosów krytycznych i aplikacyjnej ograniczoności, jest klasyczna koncepcja „4P”. Aby możliwe było jednak efektywne zastosowanie proponowanego w niej zestawu narzędzi, wymaga ona przede wszystkim redefinicji produktu w kierunku złożonego megaproduktu terytorialnego, a także interpretacji dystrybucji jako dostępności danego miejsca (jednostki terytorialnej) i oferowanych przezeń produktów terytorialnych. Ponadto ważnym jest, aby instrumentarium promocyjne zawierało szczególnie użyteczne narzędzia dla prowadzenie polityki promocji jednostek terytorialnych, a więc działania z zakresu public relations.

Z całego zestawu „4P” najmniej celowe i możliwe do zastosowania przez jednostki terytorialne jest prowadzenie zintegrowanej strategii cenowej (Florek 2006), większe możliwości integrowania działań daje aktywność w sferze dystrybucji (dostępności), a zwłaszcza promocji. Kształtowanie samego megaperoduktu terytorialnego, choć ma duże znaczenie z punktu widzenia marketingu terytorialnego, cechuje ograniczona możliwość integracji i koordynacji działań. Najpowszechniej stosowanym narzędziem działań marketingowych jednostek terytorialnych jest promocja. Strategia promocji ma również największe znaczenie dla marketingu terytorialnego, jest też obszarem aktywności w największym stopniu umożliwiającym integrację i koordynację działań.

Podsumowując ogół rozważań dotyczących doboru instrumentów marketingowego oddziaływania w związku z kształtowaniem rpt, należy stwierdzić, że przeniesienie instrumentów marketingowych na poziom jednostek terytorialnych czy też opracowanie odrębnego zestawu tych instrumentów dla zarządzania jednostkami terytorialnymi jest sprawą niezwykle trudną. Wynika to głównie z ogromnej złożoności „organizmu” czy „organizacji”, jaką jest jednostka terytorialna, różnorodności i złożoności oferowanych przezeń w ramach megaproduktu subproduktów terytorialnych, a także wielości podmiotów współtworzących te zintegrowane, przestrzenne koncepcje produktów. Trudność ta związana jest też $\mathrm{z}$ wielowymiarowością procesów zachodzących $\mathrm{w}$ ramach zarządzania daną jednostka terytorialną.

M. Florek (2006) wśród czynników wpływających na wybór optymalnego zestawu instrumentów marketingowych dla jednostek terytorialnych wymienia m.in.:

- cechy i strukturę oferowanego megaproduktu terytorialnego,

- cele marketingowe jednostki terytorialnej,

- pozycję konkurencyjną jednostki terytorialnej,

- charakter segmentu docelowego,

- koszt i wysokość nakładów na poszczególne narzędzia.

Każda jednostka terytorialna kształtuje zatem własną kompozycję narzędzi marketingowych. O sukcesie ich zastosowania decyduje spójność i niepreferowanie jednych instrumentów kosztem innych (np.: nienadużywanie działań promocyjnych względem działań związanych z kształtowaniem struktury produktu, jego jakości czy dostępności). Warto także zwrócić uwagę na fakt, że wypracowana kompozycja narzędzi marketingowych nie jest stała w czasie, a jej struktura może ulegać modyfikacjom na skutek zmian warunków wewnętrznych i zewnętrznych oraz stopnia realizacji założonych celów (Florek 2006).

$\mathrm{Z}$ przeprowadzonych $\mathrm{w}$ zakresie kształtowania regionalnych produktów turystycznych, a wspominanych na wstępie badań wynika, że w strukturze działań marketingowych samorządów działania z zakresu promocji oraz kształtowania wizerunku przeważają nad działaniami 
związanymi z tworzeniem pełnej, zintegrowanej oferty (Zdon-Korzeniowska 2009). W niewystarczającym zakresie lub wcale nie uwzględnia się również działań na rzecz zwiększenia dostępności produktu, co m.in. jest warunkiem jego efektywnej komercjalizacji.

Przykład powyższej sytuacji stanowi Szlak Architektury Drewnianej (dalej: Szlak AD), który uznać możemy za subprodukt turystyczny będący częścią megaproduktu województwa małopolskiego. Szlak ten jest przedmiotem analizy w ramach poniższego studium przypadku.

W przypadku działań marketingowych związanych z kształtowaniem produktu turystycznego: Szlak AD, zdecydowanie przeważają działania na rzecz promocji dokonujące się, jak się wydaje, kosztem dostępności tego produktu. Informacje uzyskane podczas wywiadów przeprowadzonych w punkcie informacji turystycznej przy ul. Wiślnej 12 w Krakowie z pracownikami tejże placówki oraz analiza wyników badań ruchu turystycznego przeprowadzonych w 2006 r. w województwie małopolskim pod względem sposobu organizacji i celu przyjazdu do Małopolski (Badanie ruchu turystycznego 2006) wskazują, że znaczna część turystów - zwłaszcza zagranicznych - nie miała możliwości skorzystania z oferty Szlaku AD. Prawdopodobnie stało się tak ze względu jego słabą dostępność: transportową bądź też np. związaną z warunkami udostępniania obiektów. Zdaniem przedstawicieli punktu informacji turystycznej przy ul. Wiślnej 12, Szlak AD cieszy się dużym zainteresowaniem, zwłaszcza wśród turystów zagranicznych. Osoby, które chciałyby przemierzyć ten szlak, docierają na ul. Wiślną 12, gdzie rozpoczyna się i jednocześnie kończy ich wycieczka. Otrzymują tu profesjonalnie przygotowane i opatrzone licznymi fotografiami foldery czy informatory o szlaku i obiektach architektury drewnianej, ale, nie dysponując własnym środkiem transportu, nie mają możliwości skorzystania z oferty. Jak wskazują bowiem wyniki badań ruchu turystycznego, tylko nieco ponad 18\% turystów zagranicznych przyjeżdża do Małopolski samochodami, a ponad połowa (53\%) przylatuje samolotem (Badanie ruchu turystycznego 2006).

Barierą w skorzystaniu z oferty Szlaku AD dla turystów zagranicznych jest zatem prawdopodobnie ograniczona dostępność transportowa - i to zarówno pod względem dysponowania środkiem transportu, jak i pod względem sprawności dojazdu do poszczególnych obiektów. Bowiem jeżeli turysta zagraniczny jest nawet zmotoryzowany, a Szlak AD oznakowany, to zwiedzanie poszczególnych, leżących w różnych zakątkach regionu i oddalonych od siebie o kilkanaście czy kilkadziesiąt kilometrów, zabytków architektury drewnianej może być dla niego, gdy nie zna terenu i języka polskiego, stosunkowo dużym wyzwaniem. Ponadto możliwość zwiedzenia niektórych obiektów jest ograniczona ze względu na warunki udostępniania wnętrz, gdyż nie są one przystosowane do obsługi ruchu turystycznego i nie ma np. wyznaczanych godzin zwiedzania, co w niektórych przypadkach wymaga wykonania wcześniejszego telefonu do proboszcza parafii, w celu uzgodnienia terminu zwiedzania obiektu. Barierą przy zwiedzaniu obiektów ze Szlaku $\mathrm{AD}$ jest dla turystów zagranicznych również nieznajomość języka polskiego.

Należałoby zatem podjąć działania na rzecz zwiększenia dostępności oferty produktu turystycznego Szlak AD poprzez np.:

- wyznaczenie godzin otwarcia i zasad zwiedzania obiektów drewnianych i udostępnienie turystom pełnej informacji w tym zakresie,

- organizację specjalnych, regularnych przejazdów autokarowych wzdłuż szlaku,

- zaktywizowanie biur podróży na rzecz organizacji wycieczek Szlakiem AD lub też nawiązanie regularnej współpracy w tym zakresie,

- uzupełnienie oferty Szlaku AD o usługi przewodnickie skierowane również do turystów zagranicznych,

- nawiązanie współpracy np.: z wypożyczalnią samochodów lub inną firmą transportową w celu oferowania przejazdu, a tym samym możliwości zwiedzenia Szlaku AD zainteresowanym, ale niezmotoryzowanym turystom. 
Powyższe działania, zwłaszcza w wypadku turystów zagranicznych, mogą przyczynić się do wzrostu możliwości skorzystania z oferty produktu turystycznego: Szlak AD. Dostępność produktu bowiem czy też możliwość skorzystania z oferty w momencie rozpoczęcia i prowadzenia działań związanych z promocją produktu, są warunkiem jego efektywnej komercjalizacji. Istotnym jest więc, aby propozycje te zostały włączone do całościowej oferty Szlaku AD, a skorzystanie z nich było możliwe w określonym, dostępnym dla turystów miejscu i czasie.

Powyższy przykład pokazuje, jak niespójność i wybiórcze stosowanie narzędzi marketingowych prowadzi do mniejszej efektywności.

Poza niepełnym i niespójnym wykorzystaniem instrumentów marketingowego oddziaływania, zakres podejmowanych przez samorządy działań nie obejmuje też stosownych badań marketingowych. Co więcej, wydaje się, że w niewielkim lub znikomym stopniu, przy kształtowaniu oferty, wykorzystuje się dostępne wyniki badań i wtórne dane dotyczące zachowań i potrzeb klientów.

Jakie są zatem przyczyny niepełnego wykorzystania i zastosowania narzędzi i metod z zakresu marketingu terytorialnego przez samorządy? Czy jest to nieznajomość tej koncepcji, niejasność i niepełne jej zrozumienie czy też może - co w pewnym zakresie potwierdzają również przeprowadzone przez autorkę badania - samorządy po prostu nie dostrzegają korzyści płynących z zastosowania metod i narzędzi marketingowego oddziaływania do zarządzania własnym rozwojem? Z czego wynika ta niska świadomość? Udzielenie odpowiedzi m.in. na te i pokrewne pytania miejmy nadzieję będzie możliwe w efekcie badań nad problematyką wykorzystania koncepcji marketingu terytorialnego przez samorządy do zarządzania własnym rozwojem, które autorka zamierza podjąć.

Zastosowanie zasad marketingu w zarządzaniu gminą, powiatem, miastem, wsią czy województwem może pozwolić na celowe i właściwie, ukierunkowane wykorzystywanie posiadanego przez daną jednostkę terytorialną potencjału i prowadzić do wyższej efektywności podejmowanych na rzecz jej rozwoju działań, a w konsekwencji - osiągnięcia przez daną jednostkę przewagi konkurencyjnej.

$\mathrm{Na}$ koniec warto również zwrócić uwagę na fakt, że zastosowanie koncepcji marketingu terytorialnego w zarządzaniu jednostkami terytorialnymi jest $\mathrm{z}$ jednej strony formą i przejawem przedsiębiorczych działań samorządów terytorialnych, ale z drugiej strony może być również traktowane jako swego rodzaju narzędzie wspomagania rozwoju przedsiębiorczości i kreowania postaw oraz zachowań przedsiębiorczych na terenie danej jednostki terytorialnej.

\section{Literatura}

1. Badanie ruchu turystycznego w Małopolsce w roku 2006. Raport końcowy, 2006, Małopolska Organizacja Turystyczna, Kraków 2006, http://www.mot.krakow.pl/index,a,b,c,16.html (odczyt z dnia 02.05.2007).

2. Barczyk S., 2010, Przedsiębiorczy samorzad lokalny i jego instytucje, AE w Katowicach, Katowice.

3. Bieńkowska B., 2004, Lokalne uwarunkowania rozwoju przedsiębiorczości [w:] Przedsiębiorczość stymulatorem rozwoju gospodarczego, J. Brdulak i M. Kulikowski (red.), Instytut Wiedzy, Warszawa.

4. Florek M., 2006, Podstawy marketingu terytorialnego, Wyd. AE w Poznaniu, Poznań.

5. Gołembski G. (red.), 1999, Regionalne aspekty rozwoju turystyki, PWN, Warszawa-Poznań.

6. Gregor B., 2006, Ewolucja oraz współczesne koncepcje marketingu [w:] Marketing terytorialny, T. Markowski (red.), tom CXVI, PAN KPZK, Warszawa.

7. Kotler Ph., 1994, Marketing. Analiza, planowanie, wdrażanie i kontrola, Gebethner\&Ska, Warszawa. 
8. Kotler Ph., Haider D.H., Rein I., 1993, Marketing Places. Attracting Investment, Industry and Tourism to Cities, States, and Nations, The Free Press, New York.

9. Kotler Ph., Lee N., 2008, Marketing w sektorze publicznym. Mapa wyższej efektywności, Wyd. Akademickie i Profesjonalne, Warszawa.

10. Majewska J., Wyzwalanie ducha przedsiębiorczości w środowisku społecznym gmin dla rozwoju lokalnego [w:] Rola przedsiębiorczości w podnoszeniu konkurencyjności społeczeństwa i gospodarki, Z. Zioło, T. Rachwał (red.), „Przedsiębiorczość - Edukacja”, nr 2, Nowa Era, Zakład Przedsiębiorczości i Gospodarki Przestrzennej Instytutu Geografii Akademii Pedagogicznej, Warszawa-Kraków.

11. Markowski T., 2006, Marketing miasta [w:] Marketing terytorialny, T. Markowski (red.), tom CXVI, PAN KPZK, Warszawa.

12. Szromnik A., 1997, Marketing terytorialny - geneza, rynki docelowe i podmioty oddziaływania [w:] Marketing terytorialny: strategiczne wyzwania dla miast i regionów, T. Domański (red.), Centrum Badań i Studiów Francuskich Uniwersytetu Łódzkiego, Łódź.

13. Szromnik A., 2006, Marketing terytorialny - koncepcja ogólna a doświadczenia praktyczne [w:] Marketing terytorialny, T. Markowski (red.), tom CXVI, PAN KPZK, Warszawa.

14. Szromnik A., 2007, Marketing terytorialny. Miasto i region na rynku, Wolters Kluwer, Kraków.

15. Zdon-Korzeniowska M., 2009, Jak kształtować regionalne produkty turystyczne? Teoria i praktyka, Wyd. UJ, Kraków.

\section{Territorial Marketing as a Form of Entrepreneurship of Local Governments in Poland}

Nowadays, functioning of local governments is mostly affected by two phenomena: globalization and locality. Globalizations processes, and among them, tendency to increase the freedom and speed of movement of capital, people, goods and services; give businesses and citizens particular opportunities. These opportunities among others are related with the freedom to choose their place of business, residence, place of work or a place of rest. The above create a specific outlook for the places of reception of investments, businesses or individuals, and so for territorial units managed by local governments. In order to meet the global market requirements, local governments must demonstrate flexibility, innovation and market-based approach, adapting to the needs of interested groups of customers: businesses, tourists, residents, investors.

Counterweight to what entails the processes of globalization is observable tendency to expose what is local by communities to emphasize their own identity and affiliation to the region. Local governments in Poland since the late 90's have gained greater powers and greater freedom of action, which enabled them to implement their role as "managers" of territorial units, which manage, and thus have influence on the directions of development of their "small homelands". To take advantage of emerging, therefore, opportunities, local authorities - as mentioned above - have to demonstrate entrepreneurial and innovative approach. The use of the concept of territorial marketing can be regarded without a doubt as an entrepreneurship attitude of local governments in the conditions of globalization. Market-based approach founded on the marketing concept allows one to increase the efficiency of activities related to resource management of individual territorial units, thus being a useful tool to enhance their competitiveness. This paper contains reflections on application of the concepts of territorial marketing by public authorities to manage their own development. 


\section{Agnieszka Kłos}

Uniwersytet Pedagogiczny

im. Komisji Edukacji Narodowej

w Krakowie

\section{Rola przedsiębiorczości władz i mieszkańców gminy Horyniec-Zdrój w aktywizacji gospodarczej regionu}

Współczesne procesy rozwoju społeczno-gospodarczego i kulturowego w różnej skali układów przestrzennych wykazują coraz silniejsze powiązania z procesami rozwoju globalnego. Procesy te $\mathrm{z}$ jednej strony przyczyniają się do pobudzania konkurencyjności podmiotów gospodarczych, z drugiej strony powodują podnoszenie atrakcyjności układów przestrzennych dla generowania endogenicznych i przyciągania egzogenicznych czynników rozwoju (Zioło 2007).

Powszechnie przyjmuje się, że ,przedsiębiorczość stanowi podstawowy warunek rozwoju gospodarczego, społecznego i kulturowego układów przestrzennych różnej skali” (Zioło 2007, s. 10). W związku z tym niezbędne jest więc kształtowanie postaw przedsiębiorczych w całym społeczeństwie.

Pod pojęciem przedsiębiorczość należy rozumieć takie zachowania władz i miejscowej ludności, które zmierzają do poszukiwania nowych zastosowań posiadanych zasobów w celu aktywizacji gospodarczej regionu (Majewska 2006). Przedsiębiorczość jest zatem zespołem określonych cech osobowych człowieka, które pozwalają mu aktywnie uczestniczyć w życiu społeczno-gospodarczym (Fedan 2005). Aktywność społeczna, pobudzając dany obszar lub ośrodek osadniczy, przyspiesza jego rozwój.

W niniejszych rozważaniach podjęto problematykę roli i znaczenia samorządu gminnego w pobudzaniu przedsiębiorczości lokalnej oraz zwrócono uwagę na przedsiębiorczość samych władz, jak również przejawy przedsiębiorczości mieszkańców i znaczenie przedsiębiorczości zbiorowej w pobudzaniu rozwoju społeczno-gospodarczego gminy Horyniec-Zdrój. Istotne staje się bowiem pytanie o możliwość rozwoju gminy w warunkach nasilającej się globalizacji, a więc także rosnącej konkurencji. Prezentowane wyniki badań stanowią fragmenty pracy magisterskiej pt.: Analiza rozwoju funkcji uzdrowiskowej gminy Horyniec-Zdrój w latach 1995-20081.

Należy zwrócić uwagę na fakt, że poszczególne układy przestrzenne stwarzają odmienne warunki dla pobudzania i kształtowania się na ich obszarze procesów rozwoju społeczno-gospodarczego, co ma związek z różnym stopniem konkurencyjności w zakresie generowania wewnętrznych i przyciągania zewnętrznych czynników rozwoju (Kudełko 2005). W wypadku gminy Horyniec-Zdrój owe odmienne warunki są stwarzane dzięki posiadaniu zasobów surowców balneologicznych.

\footnotetext{
${ }^{1}$ Praca została napisana w Zakładzie Przedsiębiorczości i Gospodarki Przestrzennej Instytutu Geografii Uniwersytetu Pedagogicznego w Krakowie w roku akademickim 2009/2010 pod kierunkiem Pani prof. dr hab. inż. arch. Elżbiety Kaczmarskiej oraz przy pomocy Pani dr Moniki Borowiec i Pani mgr Wioletty Kilar.
} 
Badana gmina położona jest w powiecie lubaczowskim, w województwie podkarpackim, na terenie dwóch krain fizyczno-geograficznych: Płaskowyżu Tarnogrodzkiego i Roztocza Wschodniego. Południowo-wschodnia granica gminy jest jednocześnie granicą państwową z Ukrainą (ryc. 1). Horyniec-Zdrój położony jest z dala od wielkich aglomeracji, od najbliższego ośrodka miejskiego liczącego ponad 100 tys. mieszkańców, Rzeszowa, wieś dzieli odległość $110 \mathrm{~km}$. Dzięki temu, że na terenie gminy Horyniec-Zdrój występują zarówno pokłady borowiny, jak i źródła leczniczych wód siarczkowo-siarkowodorowych, możliwe było utworzenie w niej uzdrowiska.

Należy pamiętać, że funkcja uzdrowiskowa jest szczególna z tego względu, że nie każda miejscowość może ją pełnić. W Polsce jedynie 44 miejscowości spełniają kryteria pozwalające na uzyskanie statusu uzdrowiska - ich rozmieszczenie zostało przedstawione na rycinie 1.

Ryc. 1. Położenie Horyńca-Zdroju na tle pozostałych uzdrowisk statutowych w Polsce

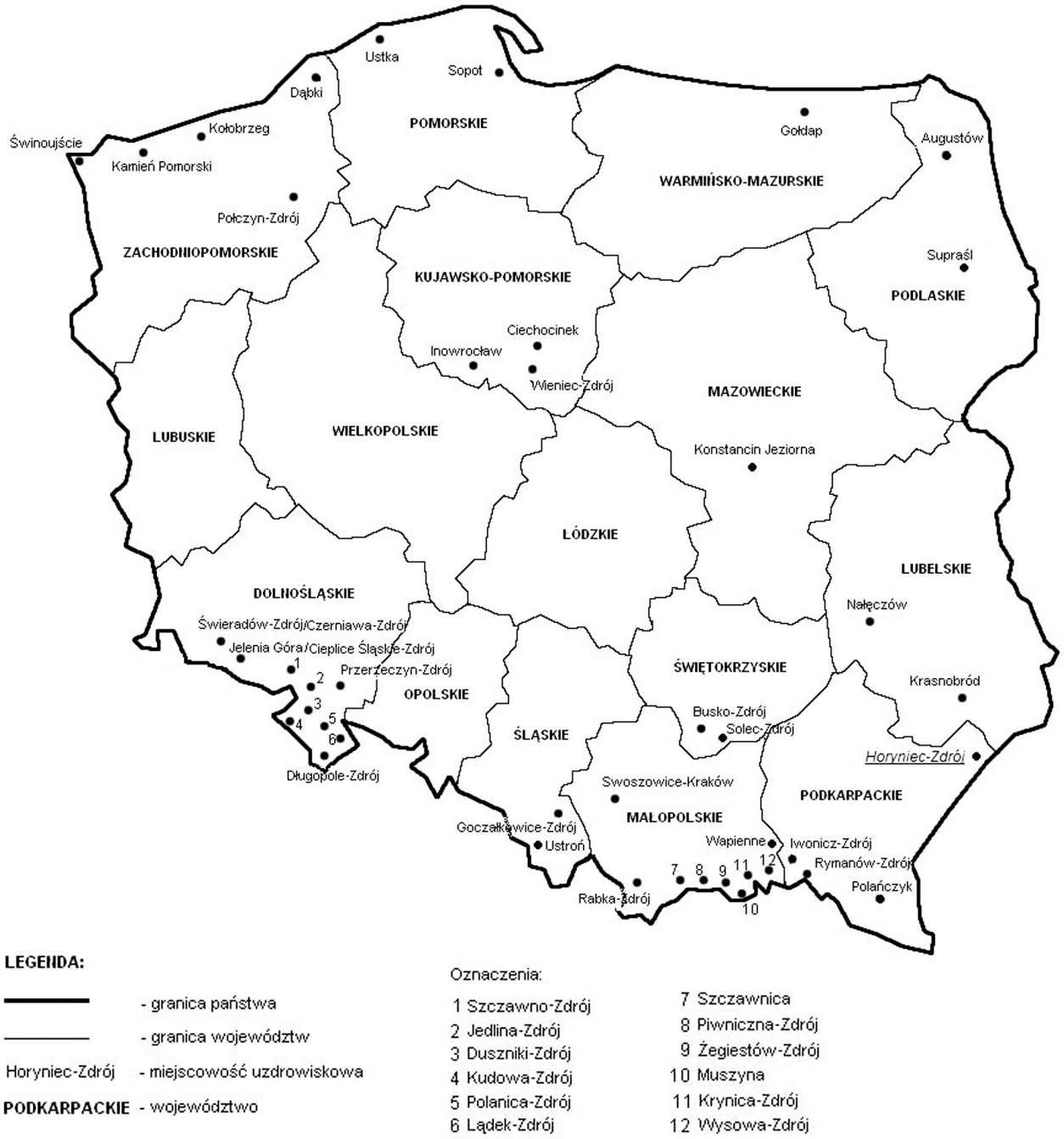

Źródło: opracowanie własne na podstawie danych z www.mz.gov.pl oraz Kajoch 1990. 
Rozwój uzdrowiska wiąże się co prawda z wieloma ograniczeniami, ale pociąga za sobą także wiele korzyści - ma wpływ na rozwój miejscowości poprzez oddziaływanie na wiele aspektów różnych dziedzin życia: wymusza rozwój innych form działalności i, odpowiednio wykorzystany, może stanowić czynnik rozwoju lokalnego. Przyjmuje się, że jedno miejsce pracy w lecznictwie uzdrowiskowym generuje aż siedem miejsc pracy w usługach pokrewnych (Golba 2002).

Posiadanie statusu uzdrowiska może stać się dobrym czynnikiem marketingowym, zapewniającym o tym, że dany obszar może się poszczycić m.in. czystym środowiskiem i zasobami naturalnych surowców leczniczych. Należy jednak pamiętać, że uzdrowiska to miejscowości często monofunkcyjne. Ograniczenia związane z posiadaniem statusu uzdrowiska utrudniają bowiem lub wręcz uniemożliwiają prowadzenie działalności gospodarczej w tych dziedzinach, które kolidują z funkcjami uzdrowiskowymi, a co za tym, idzie aktywność gospodarcza mieszkańców jest ograniczona.

Ponadto na obszarach posiadających status uzdrowiska lub status obszaru ochrony uzdrowiskowej wydziela się trzy rodzaje stref w celu ochrony naturalnych surowców leczniczych, czynników leczniczych oraz klimatu. Są to: strefa ochronna A, B oraz C. We wszystkich tych strefach obowiązują pewne ograniczenia co do lokalizacji w nich obiektów oraz prowadzonej na ich terenie działalności. Najostrzejsze ograniczenia obowiązują w strefie A (strefa ścisłej ochrony uzdrowiskowej), gdzie zabrania się m.in.: lokalizacji zakładów przemysłowych, domków turystycznych i campingowych, stacji benzynowych, stacji nadawczych radiowych i telewizyjnych oraz innych emitujących fale elektromagnetyczne (Ustawa z dnia 28 lipca 2005 r. o lecznictwie uzdrowiskowym, uzdrowiskach i obszarach ochrony uzdrowiskowej oraz o gminach uzdrowiskowych, Dz.U. z dnia 1 września 2005 r.).

Pożądanym kierunkiem działań samorządu powinno być zatem wykorzystanie regionalnej specyfiki i lokalnych zasobów wewnętrznych, szczególnie tych niepowtarzalnych i charakterystycznych, do stymulowania rozwoju gospodarczego, a także tworzenia odpowiednich warunków do wyzwolenia postaw przedsiębiorczych społeczeństwa. Region może bowiem osiągnąć przewagę konkurencyjną jedynie wówczas, gdy wykorzystane zostaną jego indywidualne cechy, a zarazem wewnętrzne siły konkurencyjne regionu dostosują się do warunków i wymagań globalnego otoczenia.

Po roku 1989 funkcja uzdrowiskowa zaczęła być postrzegana jako motor i stymulator rozwoju gminy i całego regionu, w tym także terenów przygranicznych. Zaczęto dostrzegać indywidualne wartości miejscowości uzdrowiskowych jako podstawowe wartości gminy, stanowiące główne źródło jej dochodów (Kaczmarska 2002). Także władze gminy Horyniec-Zdrój dostrzegły możliwości rozwijania swojego terytorium poprzez funkcję uzdrowiskową. W globalizującym się świecie i rosnącej konkurencji oraz w czasach, gdy powstają liczne ośrodki odnowy biologicznej i popularne stają się wczasy spa, ważne jest, aby uzdrowisko było atrakcyjnym miejscem, do którego ludzie będą chcieli przyjeżdżać w celu poprawy stanu zdrowia, regeneracji sił fizycznych i psychicznych. W dokumentach strategicznych gminy podkreśla się potrzebę realizacji działań mających na celu rozwój funkcji uzdrowiskowej jako dominującej, a obsługę lecznictwa uzdrowiskowego jako jednego z głównych źródeł utrzymania mieszkańców.

Władze gminy sukcesywnie podejmują działania zmierzające do osiągnięcia zamierzonych celów. Dokonano już wielu inwestycji, a plany zarówno władz gminy, jak i władz zakładów uzdrowiskowych przewidują kolejne działania. Dotychczas wyremontowano deptak w centrum miejscowości oraz modernizowano i rozbudowano infrastrukturę w Parku Zdrojowym, ukończono również budowę ścieżek rowerowych. W bieżącym roku przewiduje się także zakończenie modernizacji ciągu pieszego prowadzącego z Dzielnicy Lecznictwa Uzdrowiskowego przez przejście podziemne do centrum miejscowości (Plan odnowy miejscowości na lata 2007-2013). 
Przed władzami gminy wciąż jednak jeszcze wiele inwestycji do zrealizowania. Z myślą o mieszkańcach, kuracjuszach, turystach i uczestnikach szkoleń oraz konferencji na lata 2010-2011 przewidziana została adaptacja budynku byłej siedziby PGR w Horyńcu-Zdroju na świetlicę wiejską. W decydującą fazę wkraczają prace przy budowie boiska ORLIK przy gimnazjum w Horyńcu-Zdroju, a w 2011 r. planowane jest ukończenie modernizacji stadionu sportowego. Do 2012 r. mają zostać ukończone budowy parkingów, głównie w centrum miejscowości. W celu podniesienia atrakcyjności turystycznej i zwiększenia powierzchni obszarów rekreacyjno-wypoczynkowych, do 2013 r. ma zostać zagospodarowane nadbrzeże zalewu na Radrużce. Planowane inwestycje zostały uwzględnione w budżecie gminy i będą finansowane zarówno ze środków własnych gminy, jak i z dotacji Programu Rozwoju Obszarów Wiejskich i Regionalnego Programu Operacyjnego Województwa Podkarpackiego (Lokalna strategia rozwoju Grupy Działania ,, Serce Roztocza” na lata 2009-2015; Plan rozwoju lokalnego Gminy Horyniec-Zdrój na lata 2005-2013; Plan odnowy miejscowości na lata 2007-2013).

Ponadto Gminny Ośrodek Pomocy Społecznej w Horyńcu-Zdroju w ramach programu operacyjnego Kapitał Ludzki realizuje projekt pt. „Czas na aktywność w gminie Horyniec-Zdrój”. Program jest przeznaczony dla osób długotrwale bezrobotnych korzystających ze świadczeń pomocy społecznej. Jego celem jest kształcenie aktywnych i przedsiębiorczych postaw zawodowych na otwartym rynku pracy oraz zapewnienie osobom dyskryminowanym na rynku pracy równego dostępu do zatrudnienia oraz podwyższenia ich statusu zawodowego i społecznego poprzez podniesienie samooceny, kwalifikacji, nabycia umiejętności interpersonalnych i pracy w zespole. Na realizację programu Gminny Ośrodek Pomocy Społecznej otrzymał dotację ze środków Europejskiego Funduszu Społecznego.

Ponadto, w ślad za trendami panującymi w uzdrowiskach, w Horyńcu-Zdroju już kilkukrotnie zostały zorganizowane konferencje naukowe. W dniach 5-7 maja 2000 r. odbyła się tu Międzynarodowa Konferencja Naukowa pt. „Agroturystyka szansą aktywizacji przygranicznego powiatu lubaczowskiego w aspekcie przystąpienia do Unii Europejskiej”. Rok później, w dniach 18-19 maja, miała miejsce kolejna Międzynarodowa Konferencja Naukowa pt. „Problemy ochrony środowiska i dziedzictwa kulturowego w przygranicznym pasie Polski i Ukrainy - region Roztocza”. Natomiast w dniach 22-23 kwietnia 2002 r. Horyniec-Zdrój był miejscem obrad Międzynarodowej Konferencji „Forum Gospodarcze Polska - Ukraina”. Wydarzenia te zgromadziły wielu wybitnych naukowców z takich ośrodków naukowych, jak Warszawa, Kraków, Katowice, Lublin, Rzeszów, Częstochowa i Lwów oraz przedstawicieli władz rządowych i samorządowych. Ponadto 28 września 2008 r. w Horyńcu-Zdroju miało miejsce posiedzenie Zarządu Stowarzyszenia Gmin Uzdrowiskowych RP (www.ughoryniec.iap.pl).

Gmina Horyniec-Zdrój jest członkiem Lokalnej Grupy Działania „Serce Roztocza”, w skład której wchodzą również dwie sąsiednie gminy - Cieszanów i Narol. Biorąc pod uwagę uwarunkowania regionu, głównym celem tego stowarzyszenia jest rozwiązywanie wspólnych problemów z zakresu infrastruktury, ochrony środowiska, rynku pracy. Za ważny cel uznano także promocję obszaru oraz upowszechnianie wiedzy o nim (Lokalna strategia rozwoju Grupy Działania ,, Serce Roztocza” na lata 2009-2015).

Ponadto Gmina Horyniec-Zdrój w partnerstwie z miastem Tomaszów Lubelski realizuje projekt „Wspólne działania promocyjne miast Tomaszów Lubelski i Horyniec-Zdrój szansą na dynamiczny rozwój gospodarczy Roztocza Środkowego i Wschodniego". Projekt ten ma na celu zwiększenie popularności turystycznej i gospodarczej regionu i jest realizowany w ramach Programu Operacyjnego Rozwój Polski Wschodniej. W ramach tego projektu ukazała się w bieżącym roku publikacja pt. Horyniec-Zdrój i okolice, wydana w języku polskim i angielskim (www.ughoryniec.iap.pl). 
Warto zauważyć również, że w roku 2006 gmina Horyniec-Zdrój została laureatem konkursu „Gminy FAIR PLAY”. Oznacza to, że kreuje dobre wzorce współpracy samorządów z przedsiębiorcami - wzorce godne naśladowania przez wszystkie jednostki administracyjne. Wyróżnienie to oznacza również, że gmina jest otwarta na nowe inicjatywy gospodarczo-inwestycyjne i zapewnia przyjazny klimat dla inwestorów oraz profesjonalną obsługę inwestycyjną.

Niekorzystnym zjawiskiem w aspekcie rozwoju postaw przedsiębiorczych i funkcji uzdrowiskowej jest wciąż niewystarczający rozwój infrastruktury. Dalszych przedsięwzięć w tym zakresie wymaga przede wszystkim poprawa stanu dróg, budowa planowanej od dawna obwodnicy Horyńca-Zdroju i gazyfikacja gminy, która jak dotychczas nie została przeprowadzona. Ponadto władzom zależy na stworzeniu ogólnogminnego systemu gospodarki odpadami, pełnego zwodociągowania obszaru gminy, rozbudowy i modernizacji gminnego składowiska odpadów. Władze dostrzegają także możliwość budowy siłowni wiatrowych w rejonie Radruża, co niewątpliwie przyczyni się do dbałości o ochronę środowiska (Strategia rozwoju Gminy Horyniec-Zdrój na lata 2005-2013; Program ochrony środowiska dla Gminy Horyniec-Zdrój 2005).

Tab. 1. Zmiany liczby kuracjuszy lecznictwa zamkniętego uzdrowisk w Horyńcu-Zdroju w latach 1995-2008

\begin{tabular}{|c|c|c|}
\hline Rok & $\begin{array}{c}\text { Liczba kuracjuszy } \\
\text { lecznictwa zamkniętego }\end{array}$ & $\begin{array}{c}\text { Dynamika } \\
(\mathbf{1 9 9 5}=\mathbf{1 0 0 \% )}\end{array}$ \\
\hline 1995 & 4859 & 100,00 \\
\hline 1996 & 5647 & 116,22 \\
\hline 1997 & 6432 & 132,37 \\
\hline 1998 & 7121 & 146,55 \\
\hline 1999 & 6640 & 136,65 \\
\hline 2000 & 8047 & 165,61 \\
\hline 2001 & 7848 & 161,51 \\
\hline 2002 & 8749 & 180,06 \\
\hline 2003 & 8856 & 182,26 \\
\hline 2004 & 9209 & 189,52 \\
\hline 2005 & 9327 & 191,95 \\
\hline 2006 & 9076 & 186,79 \\
\hline 2007 & 9661 & 198,83 \\
\hline 2008 & 9671 & 199,03 \\
\hline
\end{tabular}

Źródło: opracowanie własne na podstawie danych GUS (www.stat.gov.pl).

Aktywność oraz postawy przedsiębiorcze przejawia również kadra zarządzająca uzdrowiskami. Należy pamiętać, że dziś, funkcjonując w społeczeństwie konsumpcyjnym, uzdrowiska muszą dostosować się do twardych reguł rynku, rosnącej konkurencji i nierzadko wygórowanych wymagań klientów, aby w dalszym ciągu móc prosperować. Dlatego też Uzdrowisko Horyniec Sp. z o.o. zainwestuje w nowy pawilon o podwyższonym standardzie dla prawie 100 kuracjuszy oraz rozbuduje zakład przyrodoleczniczy. Budowa nowego obiektu wiązać się będzie 
ze zwiększeniem zatrudnienia o 35-40 osób. Natomiast Centrum Rehabilitacji Rolników KRUS, w ślad za trendami obowiązującymi w uzdrowiskach zachodniej Europy, zainwestowało w rozbudowę swojej bazy rekreacyjnej i w 2006 r. otworzyło krytą pływalnię „Wodny Świat”, w której oprócz basenów i atrakcji wodnych mieści się również strefa odnowy biologicznej. Obiekt ten powstał nie tylko z myślą o kuracjuszach i mieszkańcach, ale również z myślą o turystach tu przybywających (Kłos 2010 - niepublikowane).

Podejmowane inwestycje świadczą o wzroście zainteresowania przyjazdami kuracjuszy do Horyńca, co potwierdzają również dane liczbowe zamieszczone w tabeli 2. W latach 1995-2008 nastąpił wzrost liczby kuracjuszy o 4812 osób (z 4859 w 1995 r. do 9671 w 2008 r.), czyli o 99\%. Wzrasta także liczba wykorzystanych łóżek sanatoryjnych i liczba osobodni leczenia. Warto podkreślić, że w 1996 r. liczba kuracjuszy lecznictwa zamkniętego przekroczyła liczbę stałych mieszkańców gminy Horyniec-Zdrój i dziś jest blisko dwukrotnie większa.

Tab. 2. Zmiany liczby turystów korzystających z noclegów w gminie Horyniec-Zdrój w latach 1995-2008

\begin{tabular}{|c|c|c|}
\hline Rok & $\begin{array}{c}\text { Turyści korzystający } \\
\text { z noclegów }\end{array}$ & $\begin{array}{c}\text { Dynamika } \\
\mathbf{1 9 9 5}=\mathbf{1 0 0 \%}\end{array}$ \\
\hline 1995 & 857 & 100,00 \\
\hline 1996 & 1469 & 171,41 \\
\hline 1997 & 1679 & 195,92 \\
\hline 1998 & 1988 & 231,97 \\
\hline 1999 & 2058 & 240,14 \\
\hline 2000 & 2100 & 245,04 \\
\hline 2001 & 2149 & 250,76 \\
\hline 2002 & 3126 & 248,07 \\
\hline 2003 & 5449 & 635,82 \\
\hline 2004 & 6459 & 753,68 \\
\hline 2005 & 6563 & 765,81 \\
\hline 2006 & 6734 & 785,76 \\
\hline 2007 & 6812 & 794,87 \\
\hline 2008 & 6868 & 801,4 \\
\hline
\end{tabular}

Źródło: opracowanie własne na podstawie danych GUS (www.stat.gov.pl).

Można stwierdzić, iż pomimo swojego peryferyjnego położenia Horyniec-Zdrój cieszy się dużym powodzeniem wśród kuracjuszy. Z jednej strony jest to zapewne konsekwencją tego, że nasze społeczeństwo się starzeje i coraz więcej osób potrzebuje fachowej opieki medycznej i rehabilitacji, którą zapewniają sanatoria. Ponadto wzrasta też poziom świadomości społeczeństwa i coraz częściej ludzie decydują się na pobyt w sanatorium w celach profilaktycznych. Rozwój funkcji uzdrowiskowej jest niewątpliwie zjawiskiem korzystnym, gdyż pociąga za sobą rozwój innych dziedzin działalności gospodarczej i wymusza niejako na władzach dbałość o ład przestrzenny gminy oraz o rozwój infrastrukturalny, co w przypadku uzdrowisk jest niezwykle istotne. 
Wraz z rozwojem funkcji uzdrowiskowej rozwija się także funkcja turystyczna gminy. Rozwój funkcji turystycznej, a co za tym idzie - wielkość ruchu turystycznego - ma odzwierciedlenie w liczbie osób korzystających z noclegów. Jak pokazują dane zawarte w tabeli 2, w badanym okresie czasu liczba turystów korzystających z noclegów na terenie gminy Horyniec-Zdrój wzrosła o 5955 osób (z 857 turystów w 1995 r. do 6868 turystów w 2008 r.), czyli o 701,4\%. Dynamicznej rozbudowie ulega także baza noclegowa gminy.

Połączenie przedsiębiorczości mieszkańców z rozwojem funkcji uzdrowiskowej i turystycznej w gminie oraz możliwościami, które to za sobą niesie, wpływa na aktywizację regionu, przejawiającą się głównie we wzroście liczby podmiotów gospodarczych świadczących usługi dla kuracjuszy i turystów, co zwiększa rynek pracy, powoduje wzrost dochodów ludności i samorządu oraz przyczynia się do ograniczenia bezrobocia. Potwierdzają to także dane statystyczne zamieszczone tabeli 3.

Tab. 3. Zmiany w liczbie podmiotów gospodarczych prosperujących w gminie Horyniec-Zdrój w latach 1995-2008

\begin{tabular}{|l|c|c|}
\hline Rok & $\begin{array}{c}\text { Liczba podmiotów } \\
\text { gospodarczych }\end{array}$ & $\begin{array}{c}\text { Dynamika } \\
\mathbf{1 9 9 5}=\mathbf{1 0 0} \%\end{array}$ \\
\hline 1995 & 96 & 100,00 \\
\hline 1996 & 123 & 128,13 \\
\hline 1997 & 133 & 138,54 \\
\hline 1998 & 148 & 154,17 \\
\hline 1999 & 164 & 170,83 \\
\hline 2000 & 166 & 172,92 \\
\hline 2001 & 179 & 186,46 \\
\hline 2002 & 182 & 189,58 \\
\hline 2003 & 187 & 194,79 \\
\hline 2004 & 193 & 201,04 \\
\hline 2005 & 197 & 205,21 \\
\hline 2006 & 202 & 210,42 \\
\hline 2007 & 202 & 210,42 \\
\hline 2008 & 213 & 221,88 \\
\hline
\end{tabular}

Źródło: opracowanie własne na podstawie danych GUS (www.stat.gov.pl).

W gminie Horyniec-Zdrój w badanym okresie czasu liczba podmiotów gospodarczych zwiększyła się o 117 (z 96 w 1995 r. do 213 w 2008 r.), czyli nastąpił wzrost o 121,9\% w porównaniu z rokiem bazowym (1995). Na rycinie 2 wyraźnie widać, że w 2008 r. w strukturze zdecydowanie dominuje sektor usługowy $(77,9 \%)$, mniej stanowi sektor przemysłowy $(17,8 \%)$, najmniej - sektor rolniczy $(4,2 \%)$. 
Ryc. 2. Struktura podmiotów gospodarczych prosperujących w gminie Horyniec-Zdrój w 2008 r.

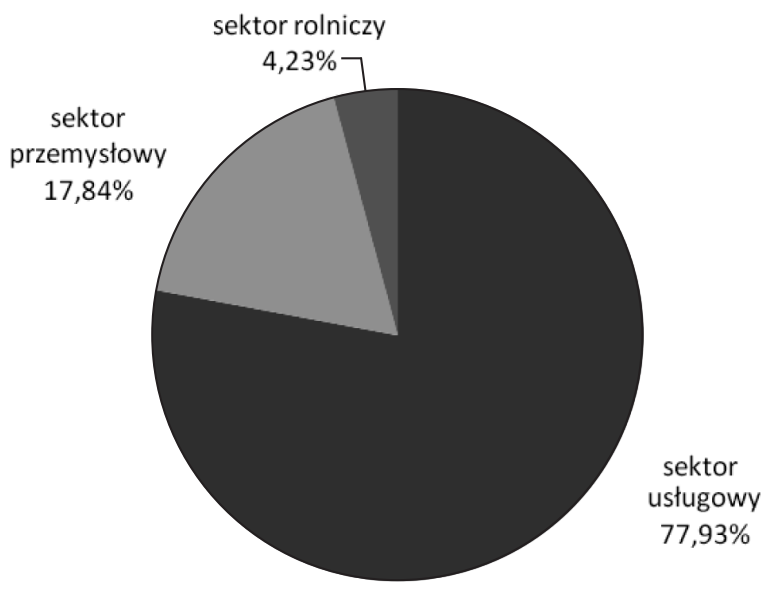

Źródło: opracowanie własne na podstawie danych GUS (www.stat.gov.pl).

Sytuacja ta potwierdza bardzo duże znaczenie usług w gospodarce gminy, co ma związek z rozwijającymi się na jej terenie funkcjami: uzdrowiskową i turystyczną, które pociągają za sobą rozwój regionu w sferze usług i wymuszają na mieszkańcach dostosowywanie profilu działalności do wymagań przybywających tu kuracjuszy i turystów.

Położenie Horyńca-Zdroju w takim rejonie, jakim jest obszar wschodniej Polski, gdzie rolnictwo charakteryzuje się niskim poziomem kultury rolnej, małą produktywnością, niskim poziomem towarowości i dużym rozdrobnieniem gospodarstw (Gorzelak 2000) tym bardziej przemawia za rozwojem takich form, jak działalność uzdrowiskowa czy turystyczna. Powstają nowe gospodarstwa agroturystyczne, pensjonaty, kawiarnie, a wzrost liczy podmiotów gospodarczych przekłada się na zmiany w poziomie bezrobocia, co potwierdzają dane zamieszczone w tabeli 4.

Stopa bezrobocia na badanym obszarze wykazuje tendencję malejącą. W latach 2002-2008 stopa bezrobocia zmalała o $7 \%$ (z 18,8\% w roku 2003 do 11,8\% w roku 2008). Jest to niewątpliwie sytuacja korzystna, świadcząca o rozwoju badanego regionu.

Tab. 4. Zmiany poziomu współczynnika bezrobocia w gminie Horyniec-Zdrój w latach 2002-2008

\begin{tabular}{|c|c|}
\hline Rok & Wspólczynnik bezrobocia (\%) \\
\hline 2002 & 18,8 \\
\hline 2003 & 18,6 \\
\hline 2004 & 18,1 \\
\hline 2005 & 16,0 \\
\hline 2006 & 13,4 \\
\hline 2007 & 12,4 \\
\hline 2008 & 11,8 \\
\hline
\end{tabular}

Źródło: opracowanie własne na podstawie danych GUS (www.stat.gov.pl). 
Przedsiębiorczość i aktywność mieszkańców jest zauważalna również w dbałości o otoczenie oraz kreowaniu pozytywnego wizerunku gminy. Z inicjatywy osób zainteresowanych społeczną działalnością na rzecz gminy Horyniec-Zdrój powstało Stowarzyszenie Przyjaciół Ziemi Horynieckiej. Obecnie liczy ono już 40 członków. Jest ono pomysłodawcą „Gazety Horynieckiej”, w której umieszczane są aktualności na temat gminy. Ponadto Stowarzyszenie realizuje projekt „Kresowe dziedzictwo - kamieniarstwo bruśnieńskie” dofinansowany z Programu Wsparcia Obszarów Wiejskich, z funduszy pozyskanych przez Urząd Gminy w Horyńcu-Zdroju. Projektem objęci są m.in. uczniowie wszystkich szkół Gminy Horyniec-Zdrój, a działania prowadzone w jego ramach to m.in. wycieczki i plenery fotograficzne dla młodzieży, gromadzenie materiałów dokumentujących zabytki kamieniarstwa bruśnieńskiego, tworzenie albumów i wystaw.

„Roztocze - Witalność z natury” to hasło projektu Lokalnej Organizacji Turystycznej Roztocze, projektu, który będzie realizowany na obszarze Roztocza. W jego ramach planowane jest postawienie kilkunastu turystycznych tablic informacyjnych z mapami regionu, a ponadto stworzenie kilku filmów dokumentalnych o Roztoczu (każdy odcinek będzie opowiadał o konkretnej gminie).

Aktywnie udziela się również Grupa Eksploratorów Roztocza Południowego (GERP), która od ponad roku realizuje projekt mający na celu przywrócenie dawnej świetności starym, zniszczonym krzyżom przydrożnym wykonanym z kamienia bruśnieńskiego. W okresie od kwietnia 2009 r. do lipca 2010 r. GERP udało się ocalić od zniszczenia siedem obiektów w najbliższych okolicach Horyńca-Zdroju.

Przytoczone tu przykłady to jedynie część działań i postaw przedsiębiorczych władz oraz mieszkańców gminy Horyniec-Zdrój, które są podejmowane w celu jej aktywizacji oraz podniesienia jej konkurencyjności. Pokazują one, w jaki sposób można wykorzystać specyfikę i potencjał endogeniczny obszaru, pomimo wielu trudności, które władze i mieszkańcy napotykają na swej drodze. W dobie globalnej konkurencji istotne jest bowiem dbanie o konkurencyjność i znalezienie sposobu na skuteczne przyciągnięcie kuracjuszy, turystów i potencjalnych inwestorów. Z globalizacji można jednak czerpać także korzyści, jak chociażby pozyskiwanie funduszy europejskich na realizację nowych inwestycji i projektów - tak jak ma to miejsce w gminie Horyniec-Zdrój.

W świetle przeprowadzonych badań można stwierdzić, że występuje związek pomiędzy postawami przedsiębiorczymi władz i mieszkańców a aktywizacją społeczno-gospodarczą regionu. Rozwój przedsiębiorczości ma bowiem fundamentalne znaczenie dla sukcesu całego obszaru. Realizacja nowych przedsięwzięć prowadzi do wzrostu produktywności i konkurencyjności na rynku, co zmusza również inne firmy do realizacji inicjatyw poprawiających ich efektywność lub reorientacji ich działalności. Rozwój przedsiębiorczości ma zatem bardzo istotne znaczenie w zwiększaniu poziomu zatrudnienia i w przyspieszaniu procesów wzrostu społeczno-gospodarczego.

\section{Literatura}

1. Fedan R., 2005, Rola przedsiębiorczości w aktywizacji ośrodków ponadlokalnych (na przykładzie Jarostawia) [w:] Przedsiębiorczość a wspótczesne wyzwania cywilizacyjne, Z. Zioło, T. Rachwał (red.), „Przedsiębiorczość - Edukacja”, nr 1, Wydawnictwo MiWa, Zakład Przedsiębiorczości i Gospodarki Przestrzennej i Instytutu Geografii Akademii Pedagogicznej w Krakowie, Kraków.

2. Golba J., 2002, Aktywizacja społeczno-gospodarcza gmin uzdrowiskowych jako podstawa ich rozwoju [w:] XI Kongres Uzdrowisk Polskich - Materialy Konferencyjne, Stowarzyszenie Gmin Uzdrowiskowych RP, Krynica-Zdrój.

3. Gorzelak G., 2000, Polska wschodnia - perspektywy rozwoju [w:] Narodowa strategia rozwoju regionalnego, J. Szlachta (red.), Biuletyn KPZK PAN, z. 191, Warszawa. 
4. Kaczmarska E., 2002, Uzdrowisko i jego przestrzeń społeczna. Wybrane zagadnienia przestrzenne polskich uzdrowisk karpackich $w$ aspekcie integracji europejskiej, „Zeszyty Naukowe Politechniki Krakowskiej. Seria Architektura", nr 47, Wydawnictwo Politechniki Krakowskiej, Kraków.

5. Kajoch A. (red.), 1990, Atlas uzdrowisk polskich, Państwowe Przedsiębiorstwo Wydawnictw Kartograficznych im. Eugeniusza Romera, Warszawa-Wrocław.

6. Kłos A., 2010, Analiza rozwoju funkcji uzdrowiskowej gminy Horyniec-Zdrój w latach 1995-2008 (niepublikowane).

7. Kudełko J., 2005, Rozwój regionalny a konkurencyjność regionów [w:] Uwarunkowania rozwoju regionu i konkurencyjność regionów, Instytut Gospodarki WSIiZ, Rzeszów.

8. Lokalna strategia rozwoju Grupy Dziatania ,, Serce Roztocza” na lata 2009-2015.

9. Plan odnowy miejscowości na lata 2007-2013.

10. Plan rozwoju lokalnego Gminy Horyniec-Zdrój na lata 2005-2013.

11. Program ochrony środowiska dla Gminy Horyniec-Zdrój 2005.

12. Majewska J., 2006, Wyzwalanie ducha przedsiębiorczości w środowisku społecznym gminy dla rozwoju lokalnego [w:] Rola przedsiębiorczości w podnoszeniu konkurencyjności społeczeństwa i gospodarki, Z. Zioło, T. Rachwał, „Przedsiębiorczość - Edukacja”, nr 2, Nowa Era, Zakład Przedsiębiorczości i Gospodarki Przestrzennej i Instytutu Geografii Akademii Pedagogicznej w Krakowie, Warszawa-Kraków.

13. Strategia rozwoju Gminy Horyniec-Zdrój na lata 2005-2013.

14. Ustawa z dnia 28 lipca 2005 r. o lecznictwie uzdrowiskowym, uzdrowiskach i obszarach ochrony uzdrowiskowej oraz o gminach uzdrowiskowych (Dz.U. z dnia 1 września 2005 r.)

15. www.mz.gov.pl

16. www.stat.gov.pl

17. www.ughoryniec.iap.pl

18. Zioło Z., 2007, Rola przedsiębiorczości w aktywizacji gospodarczej-zarys modelu [w:] Rola przedsiębiorczości w aktywizacji gospodarczej, Z. Zioło, T. Rachwał (red.), „Przedsiębiorczość - Edukacja”, nr 3, Nowa Era, Zakład Przedsiębiorczości i Gospodarki Przestrzennej i Instytutu Geografii Akademii Pedagogicznej w Krakowie, Warszawa-Kraków.

\section{Role of Entrepreneurship and the Government and Local Residents Horyniec-Zdrój in the Activation of the Region's Economy}

Horyniec-Zdrój is one of 44 statutory spa-resorts in Poland. This means that the development of the community is associated with many limitations, but it also entails many benefits. The spa-resort has an impact on the region's development through its influence on many aspects of different fields of life - it encourages the development of other forms of business activities, which if used appropriately can be a factor in local development.

The article examines the actions and initiatives of the authorities on how to use the resort features for the region's development, how to use EU funds, how to invest in the commune, and how to develop entrepreneurial attitudes.

In order to assess the activity of the population, the author analyzed changes in the employment in three sectors of the economy, the changes in the level of unemployment and the number of business entities in the community in the years 1995-2008.

The studies have contributed to explore the issues of the shaping of entrepreneurship in the Horyniec-Zdrój commune. The author has confirmed the positive effect of the actions of the authorities and residents on the economic activation of the region. 


\author{
Nina Grad \\ Uniwersytet Jagielloński
}

\title{
Przedsiębiorczość miejska - lokalne programy rewitalizacji instrumentami odnowy miast
}

Procesy zachodzące we współczesnym świecie, takie jak globalizacja, otwieranie granic, rozwój gospodarki opartej na wiedzy czy zmiany demograficzne, mają konsekwencje dla układów globalnych, a także regionalnych i lokalnych. Dotyczą one nie tylko państw, ale również niższych szczebli podziału terytorialnego oraz jednostek osadniczych (miast i wsi).

W Polsce w warunkach transformacji ustrojowej wraz z przejściem do gospodarki postindustrialnej, wzrostem poziomu i jakości życia oraz zmieniającymi się preferencjami miejsca zamieszkania, nastąpiło radykalne podniesienie wymagań wobec jakości przestrzeni miejskiej. Następstwem tego stały się przybierające na sile procesy dekoncentracji ludności miejskiej. Oznaczają one depopulację oraz wzrost degradacji śródmieść w wyniku pozostania w nich ludzi ubogich. Należy bowiem pamiętać, że w osiedlach zdegradowanych społecznie stan techniczny zabudowy pogarsza się dużo szybciej niż w osiedlach, gdzie społeczność lokalna dba o utrzymanie odpowiedniego stanu budynków. W następstwie tego centralne obszary miast przestały być miejscem atrakcyjnym do zamieszkania, a do postępującego kryzysu miast przyczynił się brak możliwości ich rozwoju opartego na dotychczasowych potencjałach, którymi były tradycyjne gałęzie przemysłu, duża liczba miejsc pracy czy duże obszary przeznaczone pod budownictwo mieszkaniowe. Taka sytuacja zmusiła miasta do szukania nowych sposobów przyciągnięcia zarówno mieszkańców, jak i inwestorów zewnętrznych. Pozyskanie jednak nowych potencjałów społeczno-gospodarczych wymaga wyjścia poza tradycyjne czynniki lokalizacji przemysłu i stworzenia nowych warunków lokalizacyjnych, możliwych do osiągnięcia tylko poprzez rozwój jakościowy, a nie wzrost ilościowy.

Dzięki szeroko podejmowanej problematyce odnowy tkanki miejskiej miasta mają szansę na odrodzenie i drugą młodość. Jednostki te walczą z degradacją i depopulacją m.in. poprzez: ponowne odkrywanie walorów kulturowych, architektonicznych, historycznych, restrukturyzację obszarów pokolejowych, powojskowych i poprzemysłowych, odnowę starych osiedli mieszkaniowych i innych zniszczonych zasobów budowlanych.

Dodatkowym problemem jest kryzys demograficzny. Liczba ludności w miastach systematycznie się zmniejsza, proces starzenia się społeczeństwa wpływa na coraz więcej dziedzin gospodarki, a malejący przyrost naturalny i masowa emigracja ludzi młodych nie rokują poprawy tej sytuacji. Zadaniem miast stała się zatem odnowa zasobów materialnych i kapitału ludzkiego.

Mówiąc o rewitalizacji jako instrumencie odnowy miast, należy pamiętać, że nie może ona dotyczyć tylko materialnej struktury miasta, ale musi być poszerzona o szeroko pojęte problemy społeczne. Dodatkowo działania rewitalizacyjne muszą być oparte na nowym planowaniu 
poprzez włączanie społeczności lokalnych w procesy planistyczne. Może to przyczynić się do integracji mieszkańców, jak również do większego utożsamiania się ich z miejscem zamieszkania, o które w późniejszych latach będą szczególnie dbać. Tylko takie zintegrowane i kompleksowe podejście może przynieść oczekiwane rezultaty podniesienia poziomu miasta, przy czym pomoc niosą tu lokalne programy rewitalizacji (dokumenty te należy utworzyć przy opracowywaniu programów rewitalizacji).

Przedmiotem pracy jest próba oceny zastosowania lokalnych programów rewitalizacji przy odnawianiu miast. Kompleksowość podejścia do zagadnienia zapewnia tylko rewitalizacja rozumiana jako proces przemian przestrzennych, społecznych i ekonomicznych w zdegradowanych częściach miast, przyczyniający się do poprawy jakości życia mieszkańców, przywrócenia ładu przestrzennego i ożywienia gospodarczego. W pracy omówiono strukturę dokumentu lokalnego programu rewitalizacji oraz porównano programy rewitalizacji wybranych miast pod kątem ich kompleksowości. Podjęto także próbę oceny, czy mogą być one instrumentem odnowy miast przyczyniającym się do ich rozwoju oraz stworzenia nowego oblicza starych miast.

W wyniku licznych przemian funkcjonalno-przestrzennych wiele obszarów miejskich zostało zdegradowanych, a inne zyskały nową rangę. Aby mogła jednak powstać harmonijna przestrzeń miejska, koniecznym stało się podjęcie przedsięwzięć przywracających ład przestrzenny i znaczenie obszarów zmarginalizowanych. W miarę jak hasło to zyskuje na popularności, ogarnia swym zakresem coraz to szersze obszary tematyczne dyscyplin zajmujących się rozwojem miast. W rezultacie funkcjonuje wiele definicji rewitalizacji, a każda z nich proponuje nieco odmienne spojrzenie na ten proces.

Przystąpienie Polski do Unii Europejskiej w maju 2004 r. otwarło drogę do funduszy strukturalnych, które mają wspierać rozwój społeczno-gospodarczy regionów borykających się $\mathrm{z}$ różnego rodzaju problemami. Największa część pomocy z funduszy strukturalnych UE na rozwój regionalny w okresie programowania 2004-2006 udzielana była beneficjentom w ramach Zintegrowanego Programu Operacyjnego Rozwoju Regionalnego (ZPORR). W latach 2007-2013 programami wspierającymi rewitalizację są: JESSICA, JASPERS, JEREMIE, programy operacyjne, a w szczególności regionalne programy operacyjne (RPO). Podstawą ubiegania się o środki z Europejskiego Funduszu Rozwoju Regionalnego w ramach ZPORR był wniosek wraz z dokumentacją techniczną oraz innymi dokumentami świadczącymi o gotowości projektu do realizacji: studium wykonalności, oceną oddziaływania na środowisko, miejscowym planem zagospodarowania przestrzennego, mapami lokalizującymi projekt, pozwoleniem na budowę, kwalifikacjami i wiarygodnością wnioskodawcy ubiegającego się o fundusze, potwierdzone przez statut wnioskodawcy, budżet, bilans - rachunek zysków i strat, deklarację o kwalifikacji podatku VAT, informacje o partnerach projektu (Kawa 2006). Dodatkowym załącznikiem, którego instytucja zarządzająca programem wymagała do dokumentacji w ramach projektów rewitalizacji, był lokalny program rewitalizacji. Miał on świadczyć o tym, iż zgłaszane projekty są działaniami zaplanowanymi, wynikającymi z kompleksowych i zintegrowanych planów rozwoju miasta (Langer 2005).

Przykładowa struktura programu rewitalizacji obszarów miejskich została przedstawiona w Podręczniku procedur wdrażania Zintegrowanego Programu Operacyjnego Rozwoju Regionalnego. Dokument pt. Lokalny program rewitalizacji powinien składać się z następujących części: 1. Charakterystyka obecnej sytuacji w mieście.

Obszary problemowe:

- zagospodarowanie przestrzenne (granice stref ochrony konserwatorskiej, uwarunkowania ochrony środowiska, własność gruntów i budynków, infrastruktura techniczna, identyfikacja problemów), 
- gospodarka (główni pracodawcy, struktura podstawowych branż gospodarki, liczba podmiotów gospodarczych, identyfikacja problemów),

- sfera społeczna (struktura demograficzna i społeczna, określenie grup społecznych wymagających wsparcia w ramach programu rewitalizacji, zróżnicowanie dochodów gospodarstw, identyfikacja problemów),

- tabela z podstawowymi danymi statystycznymi,

- analiza SWOT.

2. Nawiązanie do strategicznych dokumentów dotyczących rozwoju przestrzenno-społeczno-gospodarczego miasta i regionu:

- strategia rozwoju województwa,

- strategia rozwoju gminy,

- studium uwarunkowań i kierunków zagospodarowania przestrzennego gminy,

- dokumenty dotyczące polityk w różnych sektorach społeczno-gospodarczych (mieszkalnictwo, infrastruktura i usługi komunalne, rozwój przedsiębiorczości, gospodarowanie gruntami, ochrona dziedzictwa kulturowego, polityka komunikacji społecznej, polityka transportu, polityka społeczna związana z przeciwdziałaniem patologiom społecznym).

3. Założenia programu rewitalizacji:

- ramy czasowe działań,

- zasięg terytorialny obszaru objętego programem,

- podział wg projektów i działań inwestycyjnych,

- oczekiwane wskaźniki osiągnięć.

4. Planowane działania w wyznaczonych okresach czasu.

5. Cele szczegółowe rewitalizacji. Należą do nich działania dotyczące:

- infrastruktury technicznej,

- rozwoju transportu,

- restrukturyzacji przemysłu,

- remontów i renowacji istniejących zasobów mieszkaniowych,

- budowy nowych mieszkań,

- rozwoju infrastruktury społecznej, kulturalnej i turystycznej,

- projektów miękkich na rzecz społeczności lokalnych.

6. Plan finansowy realizacji rewitalizacji, w tym źródła finansowania programu.

7. System wdrażania.

8. Sposoby monitorowania, oceny i komunikacji społecznej.

Do analizy działań rewitalizacyjnych w niniejszej pracy wybrano 10 lokalnych programów rewitalizacji miast. Kryteriami decydującymi o wyborze były: wielkość, pełnione funkcje, uwarunkowania historyczno-geograficzne oraz zaawansowanie procesów odnowy tkanki miejskiej. Omówiono programy następujących miast: Bielsko-Biała (woj. śląskie), Dzierżoniów (woj. dolnośląskie), Hrubieszów (woj. lubelskie), Krynica-Zdrój (woj. małopolskie), Małogoszcz (woj. świętokrzyskie), Olsztyn (woj. warmińsko-mazurskie), Płock (woj. mazowieckie), Poznań (woj. wielkopolskie), Świnoujście (woj. zachodniopomorskie) i Tomaszów Mazowiecki (woj. łódzkie) (ryc. 1). 
Ryc. 1. Położenie miast wytypowanych do badań

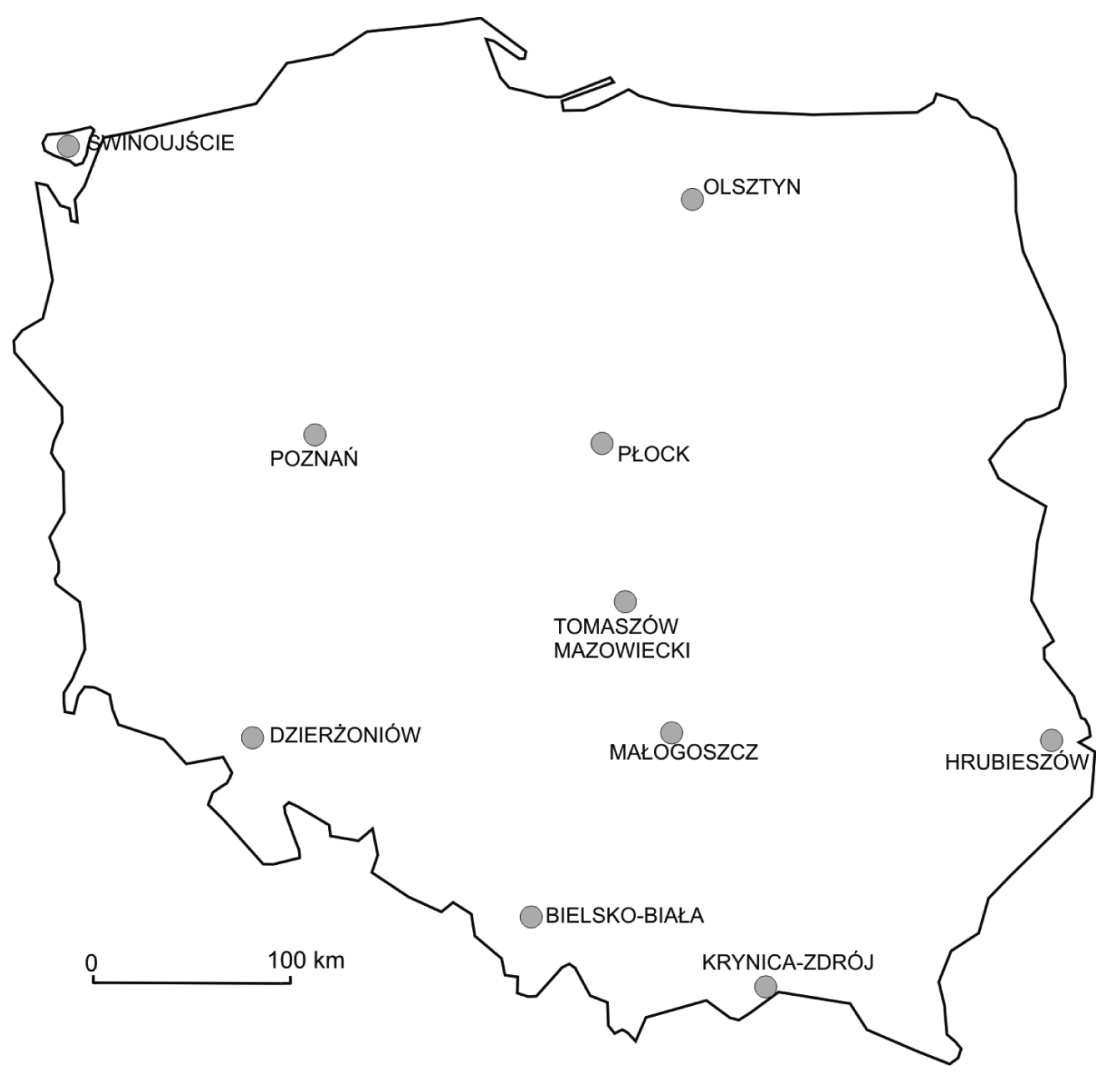

Źródło: opracowanie własne.

Wybrane miasta różnią się liczbą mieszkańców (ryc. 2) i powierzchnią (ryc. 3). Do analizy wybrano trzy miasta małe: Małogoszcz, Krynica-Zdrój, Hrubieszów (do 20 tys. ludności), trzy miasta średnie: Dzierżoniów, Świnoujście, Tomaszów Mazowiecki (do 100 tys. ludności), trzy miasta duże: Płock, Bielsko-Biała, Olsztyn (do 200 tys. ludności) i jedno miasto bardzo duże - Poznań. Poznań zajmuje powierzchnię 26185 ha i liczy 554221 mieszkańców, natomiast najmniejsze miasto - Małogoszcz - zajmuje 968 ha i mieszka w nim 3867 mieszkańców (stan na koniec 2009 r.). 
Ryc. 2. Liczba ludności wybranych miast w 2009 r.

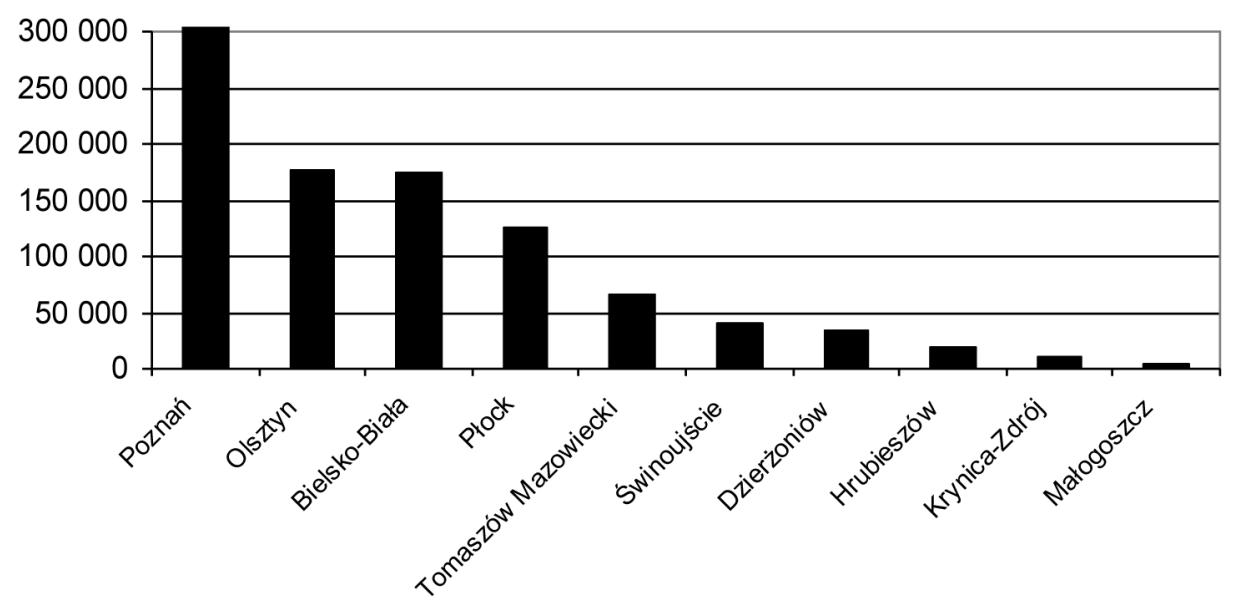

Źródło: opracowanie własne na podstawie danych GUS.

Ryc. 3. Powierzchnia wybranych miast w 2009 r. (w hektarach)

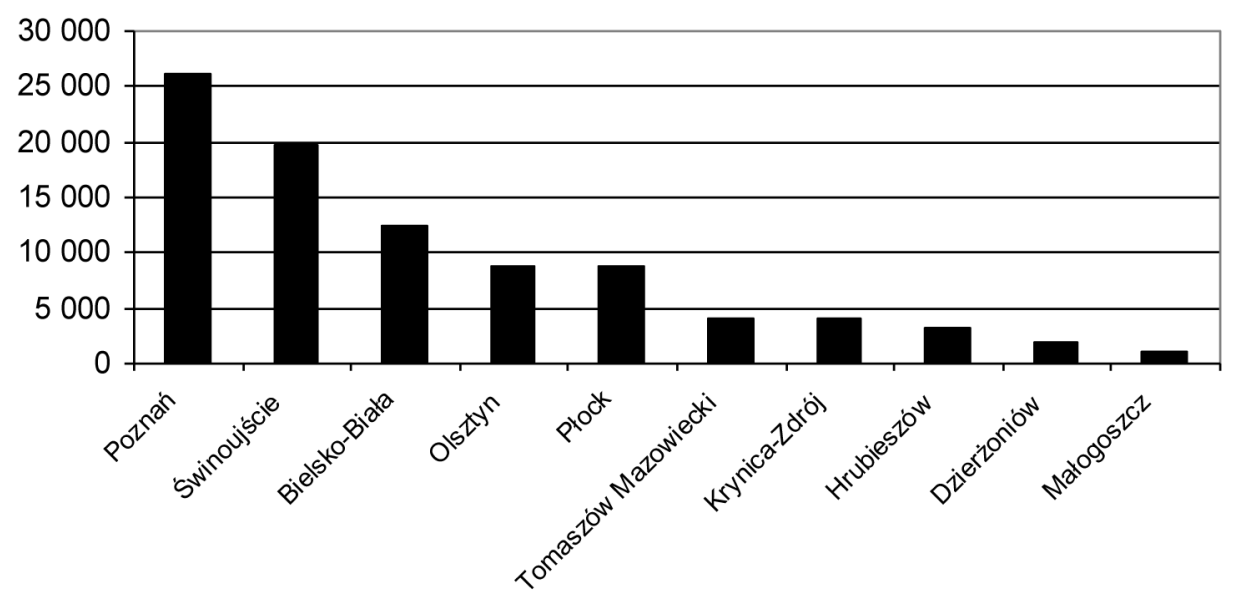

Źródło: opracowanie własne na podstawie danych GUS. 
Nie bez znaczenia dla rozwoju miast pozostaje ich historia. Lata, w których miasta otrzymały prawa miejskie, obrazuje tabela 1 .

Tab. 1. Lata otrzymania praw miejskich przez wybrane miasta

\begin{tabular}{|c|c|}
\hline Miasto & $\begin{array}{c}\text { Rok otrzymania } \\
\text { prawa miejskiego }\end{array}$ \\
\hline Bielsko-Biała & 1424 i 1723 \\
\hline Dzierżoniów & 1258 \\
\hline Hrubieszów & 1400 \\
\hline Krynica-Zdrój & 1889 \\
\hline Małogoszcz & 1996 \\
\hline Olsztyn & 1353 \\
\hline Płock & 1237 \\
\hline Poznań & 1253 \\
\hline Świnoujście & 1765 \\
\hline Tomaszów & 1830 \\
\hline Mazowiecki & \\
\hline
\end{tabular}

Źródło: opracowanie własne na podstawie Leksykonu miast polskich.

Dodatkowymi kryteriami wyboru były dla poszczególnych miast następujące uwarunkowania: Bielsko-Biała - od dziesięcioleci bardzo ważny ośrodek przemysłowy, Dzierżoniów - bogate i wieloletnie doświadczenie w zakresie działań rewitalizacyjnych, Hrubieszów - położenie blisko wschodniej granicy, Krynica-Zdrój - ważny ośrodek uzdrowiskowy, Małogoszcz - bardzo młody i mały ośrodek miejski, Olsztyn - miasto opierające się głównie na statusie stolicy województwa, Płock - ważny ośrodek przemysłowy głównie dzięki rozwojowi przemysłu rafineryjnego, Poznań - piąte pod względem liczby ludności i szóste pod względem wielkości miasto w Polsce, miasto know-how, Świnoujście - położenie na trzech wyspach przy zachodniej granicy kraju, ważny port morski, Tomaszów Mazowiecki - na przełomie XIX i XX w. ważny ośrodek włókienniczy, obecnie szukający nowej drogi rozwoju.

Omawiając lokalne programy rewitalizacji, trzeba zacząć od ich struktury i zgodności z wytycznymi zawartymi m.in. w Podręczniku procedur wdrażania Zintegrowanego Programu Operacyjnego Rozwoju Regionalnego. Wszystkie programy składają się z ośmiu podstawowych elementów, którymi są: charakterystyka obecnej sytuacji w mieście (zagospodarowanie przestrzenne, gospodarka, sfera społeczna, analiza SWOT), nawiązanie do dokumentów strategicznych, założenia i cele programu, planowane działania, plan finansowy, system wdrażania, sposoby monitorowania, oceny i komunikacji społecznej. Wszystkie analizowane programy posiadają ww. części za wyjątkiem programu Świnoujścia, dla którego nie przeprowadzono analizy SWOT i nie nawiązano do dokumentów strategicznych, a w programie Dzierżoniowa tylko wymieniono ich nazwy bez wskazania konkretnych priorytetów i działań.

Charakterystyka obecnej sytuacji w mieście również nie wyglądała w każdym programie jednakowo. Choć składała się ona generalnie z takich samych części, to przeprowadzana była z różną wnikliwością. W większości dokumentów omówiono takie elementy, jak: położenie administracyjne i geograficzne, historia miasta, zabytki, strefa ochrony konserwatorskiej, 
uwarunkowania ochrony środowiska, warunki naturalne, infrastruktura techniczna, podmioty gospodarcze, struktura zatrudnienia, sytuacja demograficzna, bezrobocie, pomoc społeczna, bezpieczeństwo publiczne, dochodowość gospodarstw domowych, edukacja, kultura i sport, turystyka, ochrona zdrowia, mieszkalnictwo oraz identyfikacja problemów każdej ze stref: przestrzennej, gospodarczej i społecznej. Najlepiej opracował tę część zespół poznański, choć niewątpliwy wpływ na taki stan miała wielkość tego miasta i pełnione przez nie funkcje, co wymusiło dokładniejszą analizę. Grupa osób, która pracowała nad tym dokumentem, również nie jest bez znaczenia, gdyż były to aż 53 osoby, gdy np. w Małogoszczy było to 17 osób. Ze względu na bogate uwarunkowania rozwojowe Poznania poza podstawowymi elementami charakterystyki w dokumencie znalazła się szczegółowa analiza struktury i systemu transportu, a w niej: infrastruktura drogowa, system parkowania, bezpieczeństwo w ruchu drogowym, system komunikacji społecznej, system transportu w ocenie społeczności lokalnej, dodatkowo omówiono innowacyjność przedsiębiorstw i relację nauki i produkcji, budownictwo, handel, szkolnictwo i uczelnie wyższe (www.poznan.pl). Wątpliwości odnośnie dokładnego przygotowania tego rozdziału może wzbudzać Zintegrowany lokalny program rewitalizacji miasta Hrubieszów na lata 2007-2015, jednak po wnikliwszej analizie okazuje się, że jest on aktualizacją posiadanego już przez miasto dokumentu planistycznego pt. Lokalny program rewitalizacji na obszar centrum miasta Hrubieszowa na lata 2005-2013. W związku z tym charakterystyka obszaru miejskiego ograniczona została do warunków naturalnych, klimatu, historii miasta i jego zabytków, co zamknięto w pięciu stronach, a sytuacja demograficzna, bezrobocie, stan infrastruktury technicznej, struktura lokalnej gospodarki, zatrudnienie czy mieszkalnictwo przedstawiono w pierwotnym dokumencie. Jedynie identyfikacja problemów każdej ze stref, przedstawiona za pomocą drzewa problemów, wydaje się zbyt ogólna i nieodnosząca się do ściśle określonych problemów miasta (ryc. 4).

Ryc. 4. Drzewo problemów rewitalizacji Hrubieszowa

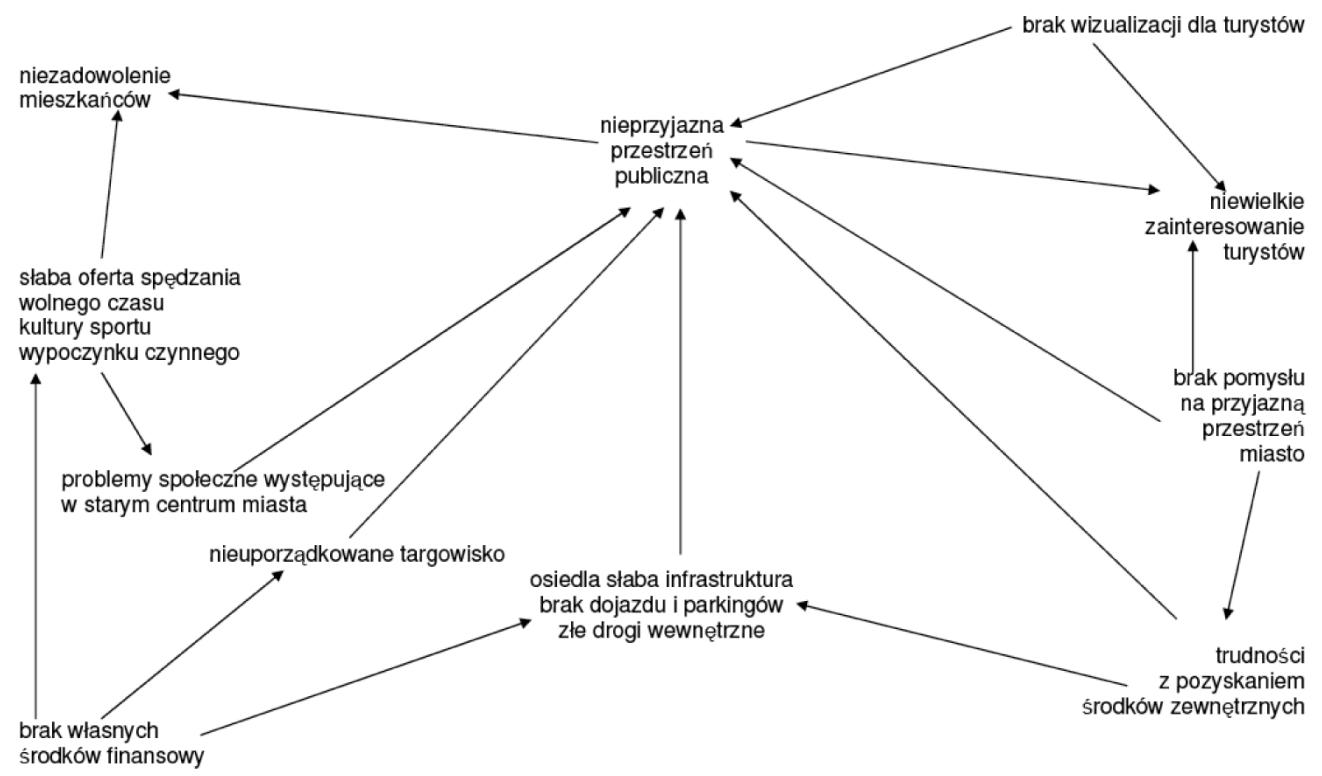

Źródło: Zintegrowany lokalny program rewitalizacji miasta Hrubieszów na lata 2007-2015. 
W wypadku Olsztyna Lokalny program rewitalizacji zawiera tylko informacje o położeniu, historii miasta oraz podstawowe dane o liczbie ludności, podmiotach gospodarczych i infrastrukturze technicznej. Informacje te są zdecydowanie niewystarczające do przedstawienia sytuacji panującej w mieście. Pozostała diagnoza poszczególnych sfer miała być szczegółowo opisana w Strategii rozwoju społeczno-gospodarczego Olsztyna 2006-2020. Diagnoza prospektywna sfery społecznej (www.ebok.olsztyn.eu), jednak dokument ten zawiera tylko bardzo dokładną charakterystykę przestrzeni przyrodniczej. W programie rewitalizacji brakuje więc danych dotyczących m.in.: sytuacji demograficznej, bezrobocia, zatrudnienia, edukacji, kultury, bezpieczeństwa publicznego i ochrony zdrowia.

Charakterystyka obecnej sytuacji w mieście w każdym programie, za wyjątkiem Świnoujścia, kończyła się analizą SWOT. Analiza ta, adaptowana z teorii analizy strategicznej przedsiębiorstw do analizy społeczności lokalnych i regionalnych przez Bank Światowy, służy ocenie sytuacji lokalnej, identyfikacji mocnych i słabych stron społeczności lokalnej oraz szans i zagrożeń w jej otoczeniu. W przypadku programu rewitalizacji ma ona służyć określeniu potencjału społeczno-gospodarczego rewitalizowanego obszaru miejskiego.

Kolejnym elementem poddanym analizie jest nawiązanie do strategicznych dokumentów dotyczących rozwoju przestrzenno-społeczno-gospodarczego miasta i regionu. Jedynym miastem, które pominęło ten rozdział, jest, podobnie jak w wypadku analizy SWOT, Świnoujście, a w programie Dzierżoniowa wymieniono tylko dokumenty, nie odwołując się do konkretnych priorytetów, celów i działań. Pozostałe programy odnosiły się średnio do ośmiu dokumentów, a były wśród nich: regionalne programy operacyjne, strategia rozwoju województwa, strategia rozwoju miasta i gminy, studium uwarunkowań i kierunków zagospodarowania przestrzennego miasta i gminy, miejscowy plan zagospodarowania przestrzennego miasta, wieloletnie plany inwestycyjne, plan rozwoju lokalnego miasta i gminy oraz powiatu, strategia rozwoju kraju, narodowe strategiczne ramy odniesienia, strategiczne wytyczne wspólnoty dla spójności, Program Operacyjny Infrastruktura i Środowisko, Program Operacyjny Kapitał Ludzki.

Poza ww. dokumentami w Olsztynie odniesiono się jeszcze do Miejskiego programu zapobiegania przestępczości oraz ochrony bezpieczeństwa obywateli i porządku publicznego na lata 2004-2010, Gminnego programu opieki nad zabytkami oraz 35 programów realizowanych przez Miejski Ośrodek Pomocy Społecznej. W Bielsku-Białej nawiązano do Gminnego programu prac społecznie użytecznych adresowanego do bezrobotnych klientów Miejskiego Ośrodka Pomocy Społecznej w Bielsku-Białej, Programu wspótpracy Bielska-Białej z organizacjami pozarzadowymi, Gminnego programu profilaktyki i rozwiąywania problemów alkoholowych, Programu pomocy dla przedsiębiorców, Programu ochrony środowiska dla Bielska-Białej. W Płocku uwzględniono Wojewódzki program opieki nad zabytkami, Program ochrony środowiska województwa mazowieckiego na lata 2007-2010 z uwzględnieniem perspektywy do 2014 r., Wojewódzki program wyrównywania szans osób niepetnosprawnych i przeciwdziałania ich wykluczeniu społecznemu oraz pomocy $w$ realizacji zadań na rzecz zatrudniania osób niepetnosprawnych $w$ województwie mazowieckim na lata 2004-2008, Strategie rozwoju turystyki dla województwa mazowieckiego na lata 2007-2013. Poznań wziął pod uwagę: Polityki i programy sektorowe miasta Poznania, Miejska strategię polityki społecznej, vProgram ochrony środowiska dla miasta Poznania na lata 2004-2007, Strategię rozwoju rynku turystycznego w Poznaniu, Miejski program zapobiegania przestęczości oraz ochrony bezpieczeństwa obywateli i porzadku publicznego, Wieloletni program i zasady wspótpracy miasta Poznania z organizacjami pozarzadowymi, Wieloletni program gospodarowania mieszkaniowym zasobem miasta Poznania na lata 2004-2008, Strategię rozwoju produktu turystycznego Trakt Królewsko-Cesarski w Poznaniu. 
W celu kompleksowej odnowy tkanki miejskiej koniecznym warunkiem jest uzyskanie odpowiednich zasobów finansowych. Bez nich trudno bowiem mówić o możliwości podjęcia jakichkolwiek przedsięwzięć zapobiegających dalszej degradacji miast. Wszystkie omawiane miasta realizują inną liczbę projektów o różnej wartości, w zależności od środków pozyskanych z budżetów miast i gmin, funduszy unijnych oraz od prywatnych inwestorów. Poza tym wszystkie województwa mają wpisane w regionalne programy operacyjne działania dotyczące rewitalizacji, ale alokacja środków na ten cel ustalana jest indywidualnie przez każde z województw. Dodatkowo podział tych środków zależny jest od liczby złożonych projektów w ramach tego działania, stąd tak różne kwoty, którymi dysponują poszczególne ośrodki. W wypadku omawianych miast wartość projektów w ramach lokalnych programach rewitalizacji waha się od $40 \mathrm{mln}$ do 309 mln zł (ryc. 5), z tym że dla Olsztyna i Płocka nie wykonano dokładnej analizy finansowej planowanych działań, a jedynie podano przykłady działań, które mogą zostać zrealizowane.

Ryc. 5. Wartość projektów realizowanych w ramach programów rewitalizacji

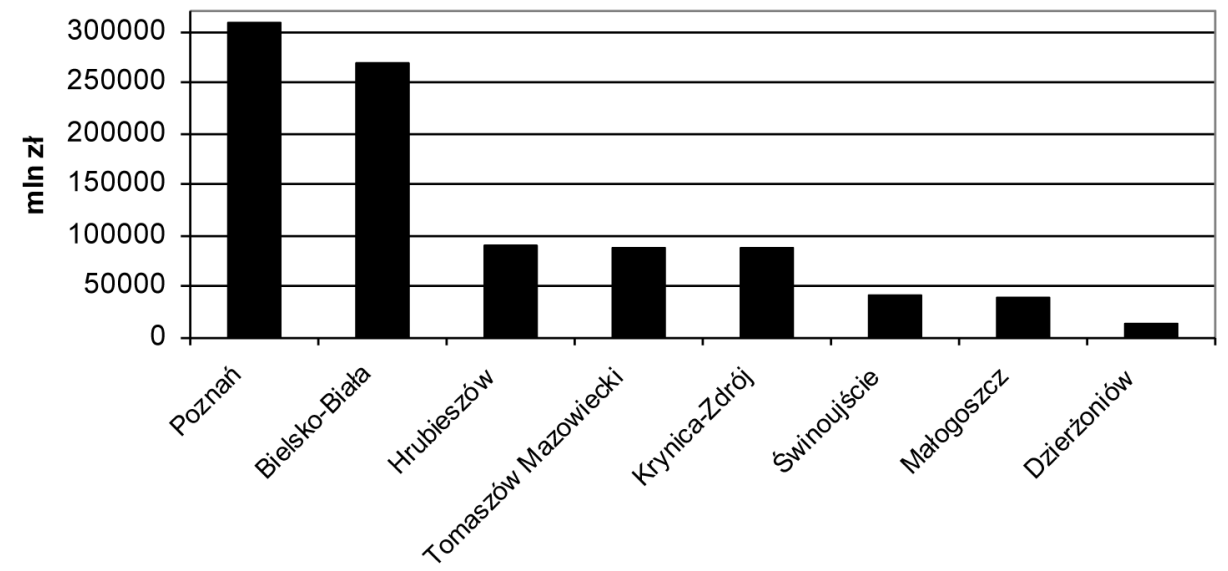

Źródło: opracowanie własne na podstawie lokalnych programów rewitalizacji.

Analizowane miasta otrzymane pieniądze przeznaczały odpowiednio na: modernizację ulic, parkingi, modernizację budynków pomocy społecznej, kulturalnych i oświatowych, rewitalizację rynków miast, modernizację budynków i lokali mieszkalnych, modernizację obiektów sportowo-rekreacyjnych, szpitali i ośrodków zdrowia, ochronę środowiska, gospodarkę wodno-ściekową i ciepłowniczą, place zabaw, kościoły, cmentarze, bezpieczeństwo publiczne, systemy informacji miejskiej, miękkie projekty dotyczące społeczności lokalnych. Choć trudno jest jednoznacznie określić profil realizowanych działań ze względu na ich interdyscyplinarny charakter, to na potrzeby tej pracy przyjęto strukturę podziału kosztów na trzy sfery: przestrzenną (urbanistyka), gospodarczą i społeczną. Jak pokazują ryciny 6 i 7, każde miasto realizuje inną politykę działań w zależności od lokalnych uwarunkowań i potrzeb. Bielsko-Biała większość środków przeznaczyła na projekty infrastrukturalne, Hrubieszów i Krynica-Zdrój na projekty gospodarcze, a Poznań i Tomaszów Mazowiecki - na projekty społeczne. W Bielsku-Białej najdroższym projektem jest rewitalizacja starówki, na którą przeznaczono $62 \mathrm{mln}$ zł, $46 \mathrm{mln}$ poświęcono na modernizację obiektów kulturalnych, a $42 \mathrm{mln}$ na szpitale i ośrodki zdrowia. W Dzierżoniowie najwięcej środków zarezerwowano na modernizację obiektów kulturalnych (10 mln zł), w Hrubieszowie na rewitalizację 
parków (31,5 mln zł), w Krynicy na obiekty sportowe (66,5 mln zł, w tym 65,7 mln na tor saneczkowo-bobslejowo-skeletonowy), w Małogoszczy na lokale mieszkalne (10 mln zł), w Poznaniu na modernizacje budynków oświatowych (60 mln zł), projekty miękkie dotyczące społeczności lokalnych (54 mln zł), rewaloryzację obszaru w rejonie ul. Jana Matejki (dawnej ulicy Nowoogrodowej) oraz zabytkowego zespołu urbanistycznego Maxa Johowa $(50 \mathrm{mln}$ zł). W Świnoujściu po $15 \mathrm{mln}$ zł przeznaczono na rewitalizację parków oraz zagospodarowanie powojskowego obszaru Basenu Północnego, aby spełniał funkcje związane z turystyką morską, w Tomaszowie Mazowieckim $26 \mathrm{ml}$ zł przeznaczono na Centrum Informatyczno-Biblioteczne.

Ryc. 6. Alokacja środków w ramach programów rewitalizacji w podziale na trzy sfery

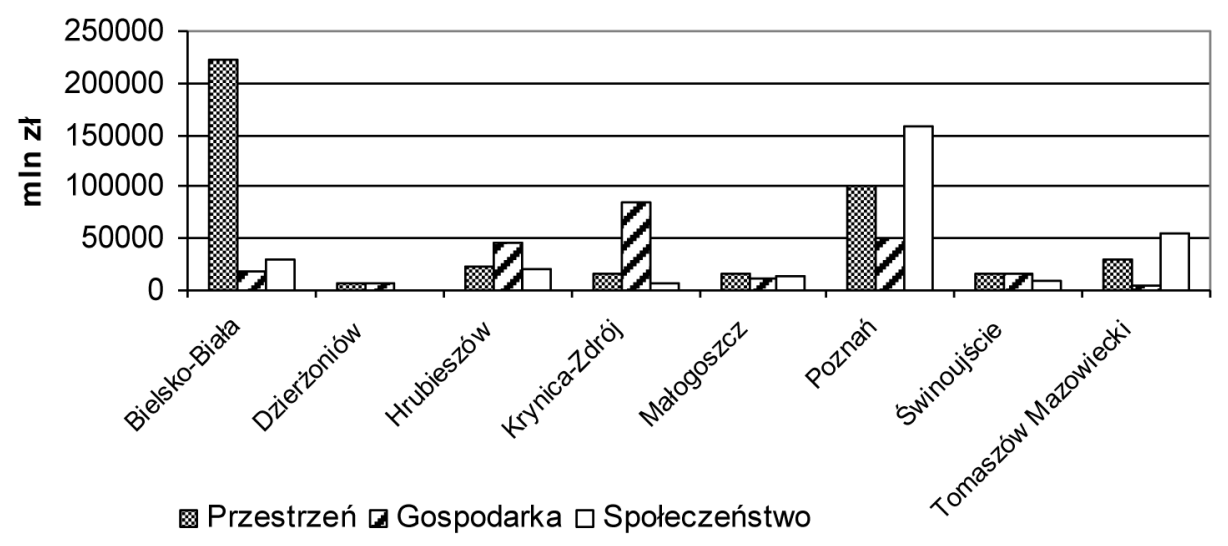

Źródło: opracowanie własne na podstawie lokalnych programów rewitalizacji.

Ryc. 7. Struktura wydatkowanych środków w ramach programów rewitalizacji

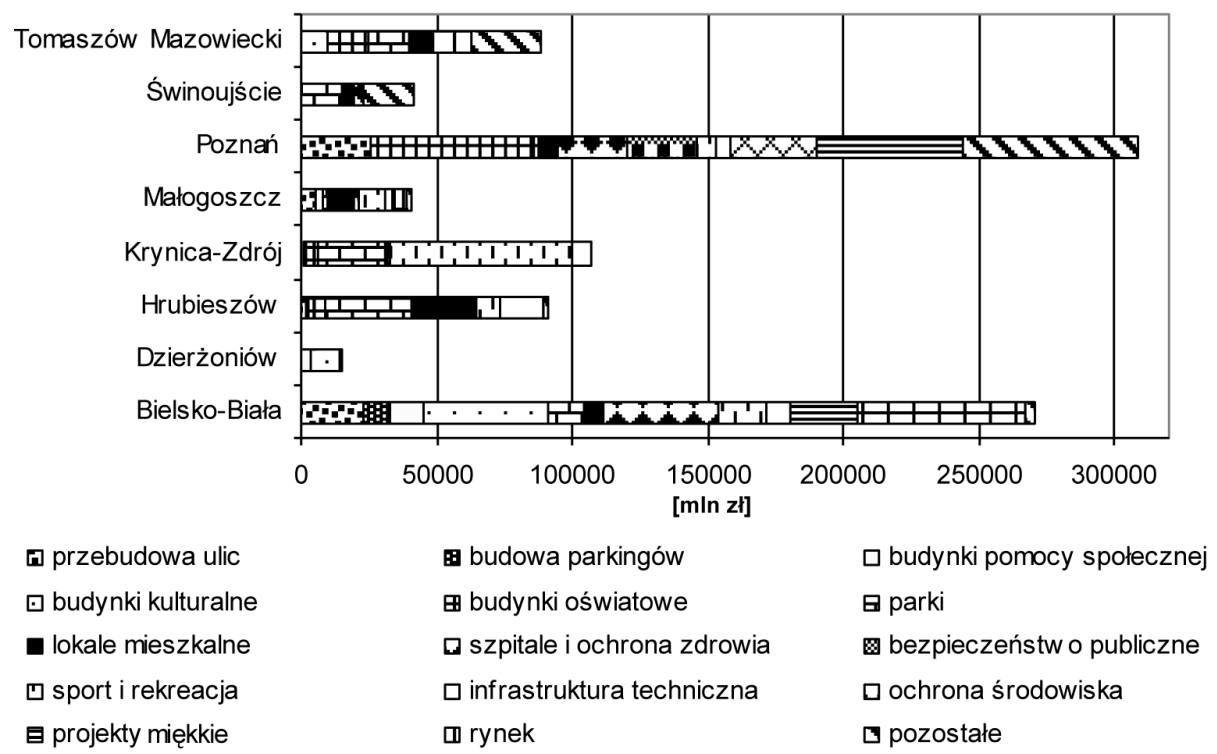

Źródło: opracowanie własne na podstawie lokalnych programów rewitalizacji. 
Obok pozyskania funduszy na rewitalizację, bardzo ważny jest wybór odpowiedniego obszaru objętego projektem. Tylko trafnie wskazany obszar kryzysowy i rzetelnie podjęte działania realnie mogą przyczynić się do przemiany sytuacji panującej na danym terenie i odnowy całej tkanki miejskiej. Zgodnie z kryteriami określonymi w art. 47 rozporządzenia Komisji WE nr 1828/2006 z dnia 8.12.2006 r. (http://www.mg.gov.pl), ustanawiającego szczegółowe zasady wykonywania rozporządzenia Rady (WE) nr 1083/2006, w procesie wyznaczania obszarów kryzysowych miast bierze się pod uwagę kilka kategorii. Jedną z nich są zintegrowane projekty odnowy miejskiej, dla której wyznaczono następujące kryteria (co najmniej dwa z nich muszą zostać spełnione):

- wysoki poziom ubóstwa i wykluczenia,

- wysoka stopa długotrwałego bezrobocia,

- niekorzystne trendy demograficzne,

- niski poziom wykształcenia,

- wysoki poziom przestępczości i wykroczeń,

- szczególnie wysoki stopień degradacji środowiska,

- niski wskaźnik prowadzenia działalności gospodarczej,

- duża liczba imigrantów, grup etnicznych i mniejszości lub uchodźców.

Dla innego obszaru działań - infrastruktura mieszkalnictwa - muszą być spełnione dwa kryteria z ww. oraz jedno z podanych poniżej:

- porównywalnie niski poziom wartości zasobu mieszkaniowego,

- niski poziom wydajności energetycznej budynków.

Osiem z 10 analizowanych miast odniosło się do ww. czynników, jedynie w Krynicy wzięto pod uwagę problem niepełnosprawności, ochrony macierzyństwa, bezpieczeństwa publicznego i zły stan infrastruktury drogowej, a w Małogoszczy, wyznaczając zasięg obszarów rewitalizowanych, starano się objąć tereny historycznej zabudowy miejskiej, tereny o niedostatecznym wyposażeniu w sieć i urządzenia infrastruktury technicznej, tereny mieszkaniowe oraz obiekty związane z kreowaniem życia kulturalnego, edukacyjnego, sportowego i społecznego. W Tomaszowie Mazowieckim odwołano się również do niekorzystnych trendów demograficznych, stanowiących ważny problem rozwojowy tego miasta.

W wypadku dwóch miast: Dzierżoniowa (tab. 2) i Płocka (tab. 3) wyliczono wartości uwzględnionych wskaźników dla obszaru wsparcia oraz podano ich wartości referencyjne. Dla Hrubieszowa, Poznania, Świnoujścia i Tomaszowa Mazowieckiego podano bezwzględne wartości współczynników dla wyznaczonego obszaru wsparcia i miasta (tab. 4), a w wypadku Bielsko-Białej, Krynicy, Małogoszczy i Olsztyna podano tylko czynniki wyboru bez wskazania ich wartości. W Hrubieszowie i Poznaniu, co zostało wielokrotnie podkreślone, przy delimitacji obszaru kryzysowego, dzięki konsultacjom społecznym, uwzględniono również głosy mieszkańców i przedsiębiorców.

Tab. 2. Porównanie wskaźników dla obszarów wsparcia w Dzierżoniowie i ich wartości referencyjnych

\begin{tabular}{|c|c|c|c|}
\hline & $\begin{array}{c}\text { Stopa długotrwałego } \\
\text { bezrobocia }\end{array}$ & $\begin{array}{c}\text { Poziom wykluczenia } \\
\mathbf{i} \text { ubóstwa }\end{array}$ & $\begin{array}{c}\text { Porównywalnie niższa } \\
\text { wartość zasobu } \\
\text { mieszkaniowego (w \%) }\end{array}$ \\
\hline Obszar wsparcia & 14,3 & 76,6 & 98,0 \\
\hline Wartość referencyjna & 5,9 & 65,0 & 83,6 \\
\hline
\end{tabular}

Źródło: Lokalny program rewitalizacji miasta Dzierżoniów, s. 89. 
Tab. 3. Porównanie wskaźników dla obszarów wsparcia w Płocku i ich wartości referencyjnych

\begin{tabular}{|c|c|c|c|c|c|}
\hline & $\begin{array}{c}\text { Stopa } \\
\text { długotrwalego } \\
\text { bezrobocia }\end{array}$ & $\begin{array}{c}\text { Poziom } \\
\text { wykluczenia } \\
\text { i ubóstwa }\end{array}$ & $\begin{array}{c}\text { Wskaźnik } \\
\text { prowadzenia } \\
\text { działalności } \\
\text { gospodarczej }\end{array}$ & $\begin{array}{c}\text { Poziom } \\
\text { przestępczości } \\
\text { i wykroczeń }\end{array}$ & $\begin{array}{c}\text { Porównywalnie } \\
\text { niższa wartość } \\
\text { zasobu mieszka- } \\
\text { niowego (w \%) }\end{array}$ \\
\hline $\begin{array}{c}\text { Obszar } \\
\text { wsparcia }\end{array}$ & 5,4 & 42,4 & 16,5 & 26,8 & 89,7 \\
\hline $\begin{array}{c}\text { Wartość } \\
\text { referencyjna }\end{array}$ & 4,7 & 70,0 & 11,8 & 36,6 & 81,0 \\
\hline
\end{tabular}

Źródło: Lokalny program rewitalizacji miasta Płock, s. 55.

Tab. 4. Porównanie wskaźników dla obszarów wsparcia i miast w trzech ośrodkach

\begin{tabular}{|c|c|c|c|c|c|c|}
\hline & \multicolumn{2}{|c|}{ Hrubieszów } & \multicolumn{2}{c|}{ Świnoujście } & \multicolumn{2}{c|}{ Tomaszów Maz. } \\
\hline & $\begin{array}{c}\text { obszar } \\
\text { wsparcia }\end{array}$ & miasto & $\begin{array}{c}\text { obszar } \\
\text { wsparcia }\end{array}$ & miasto & $\begin{array}{c}\text { obszar } \\
\text { wsparcia }\end{array}$ & miasto \\
\hline Bezrobocie & 1681 & 1849 & 598 & 1206 & 2280 & 4479 \\
\hline Ubóstwo & 2059 & 2106 & 507 & 2106 & & \\
\hline Choroby & 618 & 627 & & & 1251 & 1640 \\
\hline Niepełnosprawność & 716 & 745 & & & 716 & 1200 \\
\hline Przestępczość & & & 296 & 730 & & \\
\hline
\end{tabular}

Źródło: opracowanie własne na podstawie lokalnych programów rewitalizacji.

Powyższe dane pozwalają stwierdzić, że w analizowanych miastach występują obszary kryzysowe, wymagające interwencji, dlatego objęcie ich programem rewitalizacji było jak najbardziej słuszne i poprawne. Dodatkowo poza wskazaniem współczynników dla obszaru wsparcia i ich analizą w wypadku trzech miast dokonano bardzo szczegółowej charakterystyki rewitalizowanych obszarów i działań. W Poznaniu dla terenów objętych programami rewitalizacji syntetycznie zebrano dane dotyczące ich powierzchni, liczby ludności, ubóstwa, bezrobocia, przestępczości, podatników PIT i CIT, rent i emerytur. Opisano także uwarunkowania historyczne tych stref, ich walory i potencjały, deficyty i zagrożenia oraz spodziewane efekty rewitalizacji. W przypadku Tomaszowa Mazowieckiego i Dzierżoniowa wykonano kompleksowy raport dla każdego z planowanych przedsięwzięć, obejmujący następujące elementy: cel projektu, uzasadnienie potrzeby realizacji inwestycji, stan istniejący, zakres planowanych prac, wskaźniki produktu, rezultatu i oddziaływania, wymagane pozwolenia i uzgodnienia, budżet projektu i źródła finansowania, zgodność projektu z celami określonymi w dokumentach regionalnych i krajowych.

Następnym krokiem rzetelnej realizacji programów rewitalizacji jest odpowiedni system wdrażania. Wymaga to podjęcia licznych działań, które powinny znajdować się w obowiązkach kompetentnego zespołu koordynującego cały proces z operatorem programu rewitalizacji na czele. Operator poza kierowaniem zespołem ds. rewitalizacji powinien być odpowiedzialny za sporządzanie i wdrażanie programu, organizację systemu monitorowania, współpracę z administracją rządową i samorządową, przygotowanie projektów aktualizacji programu, upowszechnianie programu i komunikacji społecznej, dokonywanie oceny efektów podejmowanych 
działań. W każdym z miast struktura organizacyjna jednostek odpowiedzialnych za rewitalizację wygląda nieco inaczej. Są miasta, które mają już powołane odpowiednie organy: Bielsko-Biała, Dzierżoniów, Płock, Poznań, Świnoujście, w Krynicy-Zdroju operatorem programu jest samo miasto, a w Małogoszczy - gmina. W wypadku Olsztyna i Tomaszowa Mazowieckiego nie wymienia się odpowiednich zespołów ds. rewitalizacji, a ich programy zostały opracowane przez firmy zewnętrzne (tab. 5).

Tab. 5. Jednostki odpowiedzialne za opracowanie i wdrażanie programów rewitalizacji

\begin{tabular}{|c|c|c|}
\hline & Jednostka wdrażająca & Zespół zadaniowy \\
\hline Bielsko-Biała & $\begin{array}{l}\text { Pełnomocnik Prezydenta Miasta } \\
\text { ds. Rewitalizacji Starówki }\end{array}$ & $\begin{array}{l}\text { Zespół Koordynacyjny ds. } \\
\text { Rewitalizacji Starówki }\end{array}$ \\
\hline Dzierżoniów & $\begin{array}{l}\text { Pełnomocnik ds. Rewitalizacji przy } \\
\text { Urzędzie Miasta }\end{array}$ & \\
\hline Hrubieszów & $\begin{array}{l}\text { Pełnomocnik ds. Rewitalizacji, } \\
\text { konieczność powołania koordyna- } \\
\text { tora programu }\end{array}$ & $\begin{array}{l}\text { Zespół ds. Rewitalizacji Miasta, } \\
\text { konieczność powołania Rady } \\
\text { Konsultacyjnej }\end{array}$ \\
\hline Krynica-Zdrój & $\begin{array}{l}\text { Operatorem jest miasto Krynica- } \\
\text {-Zdrój, konieczność powołania } \\
\text { koordynatora projektu }\end{array}$ & \\
\hline Małogoszcz & Gmina Małogoszcz & Zespół zadaniowy ds. rewitalizacji \\
\hline Olsztyn & b.d. & b.d. \\
\hline Płock & Komitet Monitorujący & $\begin{array}{l}\text { Zespół Rewitalizacji Miasta } \\
\text { Wydziału Gospodarki Mieszkanio- } \\
\text { wej UM Płocka }\end{array}$ \\
\hline Poznań & Pełnomocnik ds. Rewitalizacji & $\begin{array}{l}\text { Doraźna Komisja Rady Miasta } \\
\text { Poznania ds. Rewitalizacji } \\
\text { Zespół Zadaniowy ds. Rewitalizacji } \\
\text { Mieszkańcy Poznania }\end{array}$ \\
\hline Świnoujście & Zespół ds. Rewitalizacji & Zespół Doradczo-Konsultacyjny \\
\hline Tomaszów Mazowiecki & b.d. & b.d. \\
\hline
\end{tabular}

Źródło: opracowanie własne na podstawie lokalnych programów rewitalizacji.

Ostatnim etapem decydującym o sukcesie programów rewitalizacji jest sposób och monitorowania, oceny i komunikacji społecznej. Obowiązek monitorowania wydatków i efektów wdrażania programów w celu efektywnego wykorzystania funduszy europejskich nakłada na państwa członkowskie również Unia Europejska. Monitoring powinien być przeprowadzany na podstawie wskaźników zawartych w diagnozie, a skutkiem oceny powinny być bieżące aktualizacje programów. Proces wdrożenia systemu monitoringu składa się z działań poprzedzonych przygotowaniem odpowiednich nakładów, produktów osiągniętych dzięki odpowiednim nakładom, rezultatów - bezpośrednich wyników uzyskanych produktów i oddziaływania - osiąganego w dłuższym okresie czasu. Przykładowe syntetyczne wskaźniki pomiaru przedstawia tabela 6 . 
Tab. 6. Przykładowe wskaźniki pomiaru

\begin{tabular}{|c|c|c|}
\hline Typ wskaźnika & Nazwa wskaźnika & Nazwa wskaźnika \\
\hline \multirow{11}{*}{ produktu } & szt. & liczba zmodernizowanych obiektów \\
\hline & szt. & liczba wybudowanych obiektów \\
\hline & $\mathrm{m}^{2}$ & powierzchnia zmodernizowanych obiektów \\
\hline & $\mathrm{m}^{2}$ & powierzchnia wybudowanych obiektów \\
\hline & $\mathrm{mb}$ & długość zmodernizowanych instalacji \\
\hline & $\mathrm{mb}$ & długość wybudowanych instalacji \\
\hline & szt. & liczba podmiotów gospodarczych \\
\hline & szt. & liczba miejsc pracy \\
\hline & tys. zł & koszty utrzymania \\
\hline & $\mathrm{m}^{3} /$ dobę & moc przerobowa \\
\hline & t/rok & redukcja emisji \\
\hline \multirow{7}{*}{ rezultatu } & os. & liczba osób korzystających \\
\hline & $\%$ & obniżka kosztów stałych \\
\hline & szt. & liczba podmiotów korzystających \\
\hline & szt. & liczba nowych miejsc pracy \\
\hline & szt. & liczba nowych produktów \\
\hline & szt. & liczba nowo powstałych podmiotów gospodarczych \\
\hline & $\%$ & skala redukcji emisji \\
\hline \multirow{6}{*}{ oddziaływania } & szt. & liczba miejsc \\
\hline & os. & liczba korzystających \\
\hline & szt. & liczba utrzymanych miejsc pracy \\
\hline & szt. & liczba utrzymanych podmiotów gospodarczych \\
\hline & tys. zł & wzrost wartości \\
\hline & t/rok & spadek emisji, stężenia \\
\hline
\end{tabular}

Źródło: opracowanie własne na podstawie lokalnych programów rewitalizacji.

Promocję realizowanych działań zapewnia Dyrektywa Komisji Europejskiej Nr 1159/2000 $z$ dnia 30 maja 2000 r. w sprawie zasad informowania i promocji projektów wspólfinansowanych z funduszy strukturalnych (http://www.efs.2004-2006.gov.pl). Zasadniczym celem komunikacji społecznej jest uzyskanie udziału społeczności lokalnej w procesie rewitalizacji. Dodatkowo może przyczynić się ona do:

- dostępu do informacji na temat celów i problemów rewitalizacji,

- pobudzenia ich do wyrażania własnych opinii,

- nawiązania porozumienia pomiędzy partnerami procesu rewitalizacji a zespołem zadaniowym (partnerstwo publiczno-prywatne). 
W Bielsku-Białej, Dzierżoniowie i Poznaniu w ramach przygotowywanych działań przeprowadzono konsultacje społeczne, w Krynicy-Zdroju celem zaangażowania jak największej liczby podmiotów rozesłano karty zadań, w Płocku planuje się przeprowadzić badanie opinii publicznej nt. programu rewitalizacji, a w Tomaszowie Mazowieckim - spotkania z zainteresowanymi mieszkańcami.

Analizowane miasta poza rozwinięciem aktywności partycypacyjnej społeczeństwa lokalnego w celach promocyjnych deklarują również:

- umieszczenie informacji na stronach internetowych urzędów miast i gmin,

- współpracę z lokalnymi mediami oraz upowszechnienie informacji o programach poprzez organizowanie spotkań informacyjnych, konferencji prasowych, umieszczanie informacji w prasie itp.,

- zamieszczanie tablic informacyjnych w miejscu prowadzenia inwestycji infrastrukturalnej,

- tworzenie publikacji związanych z realizacją programu,

- inicjowanie dodatkowych działań promocyjnych o zasięgu lokalnym, wykorzystanie nowoczesnych technologii, takich jak Internet, poczta elektroniczna, elektroniczna archiwizacja dokumentów, w celu usprawnienia komunikacji pomiędzy podmiotami uczestniczącymi W realizacji programu.

Przemiany ustrojowe, które zaszły w naszym kraju po 1989 r., znalazły swoje odbicie nie tylko w gospodarce i sytuacji społecznej, ale także w przestrzeni. Dotyczy to szczególnie tkanki miejskiej, kiedy to po okresie modernizowania nieruchomości przez państwo nastąpił czas głębokiego niedoinwestowania miast. Z degradacją przestrzeni miejskiej zmagają się nie tylko miasta polskie, ale również europejskie, co dostrzeżone zostało przez Unię Europejską. W opracowywanych przez nią dokumentach wskazuje się bowiem na konieczność przygotowania kompleksowego rozwiązania problemu degradacji miast, marginalizacji i wykluczenia społeczności lokalnych w obszarach kryzysowych.

Reakcją na zachodzące w przestrzeni miejskiej procesy degradacji technicznej, społecznej i gospodarczej oraz wynikające z nich zjawiska kryzysowe jest rewitalizacja. Ma ona na celu przywrócenie terenom zdegradowanym utraconych funkcji, jak również podjęcie przedsięwzięć mających na celu wprowadzenie nowych zadań na obszarach problemowych. Rewitalizacja, traktowana jako czynnik rozwoju miast, prowadzić ma przede wszystkim do wzmacniania ich konkurencyjności i wzrostu gospodarczego. Dążąc do uzyskania założonych celów działań rewitalizacyjnych, niezbędnym jest opracowanie lokalnego programu rewitalizacji. Dokument ten jest warunkiem koniecznym do uzyskania dofinansowania z funduszy europejskich, a dzięki szczegółowym wytycznym jego opracowania, ma on stać się impulsem do wprowadzania zintegrowanego programowania i planowania rozwoju miast polskich.

Z badań Instytutu Rozwoju Miast (Domański, Ziobrowski 2010) wynika, że rewitalizacji wymaga ponad 1/5 obszarów polskich miast, które zamieszkuje blisko 4,5 mln osób. Dlatego tak ważnym jest rzetelne i kompleksowe opracowanie lokalnych programów rewitalizacji oraz trafne wskazanie obszarów kryzysowych, aby dokument ten realnie mógł stać się instrumentem odnowy tkanki miejskiej. Wyznaczenie obszarów rewitalizacji należy przeprowadzić po krytycznej analizie, popartej badaniami oraz konsultacjami społecznymi. Proces ten wymaga współpracy z wieloma jednostkami, m.in. miejskimi ośrodkami pomocy społecznej, urzędami pracy, komendami policji, urzędami statystycznymi, wspólnotami mieszkaniowymi etc., i współudziału społeczności lokalnej oraz partnerów społeczno-gospodarczych. W związku z tym powinny powstać zupełnie nowe struktury współpracy pomiędzy tymi podmiotami a urzędami miast, należy również prowadzić sprawną koordynację działań. 
Analizowane lokalne programy rewitalizacji zostały przygotowane zgodnie z wytycznymi zawartymi m.in. w Podręczniku procedur wdrażania Zintegrowanego Programu Operacyjnego Rozwoju Regionalnego, jednak nie wszystkie planowane działania mają kompleksowy charakter zapewniający zrównoważony rozwój i pozwolą na osiągnięcie strategicznych celów rozwoju miasta.

Do słabych stron analizowanych lokalnych programów rewitalizacji należy przewaga działań o charakterze inwestycyjnym, brak zadań o charakterze społecznym - miękkich programów społecznych - i ekonomicznym. Poprawę w tej kwestii widać jedynie w programach miast z doświadczeniem rewitalizacyjnym, tj. Bielsko-Białej, Dzierżoniowa i Poznania. Nie zaplanowano również odpowiedniego zakresu działań dotyczących renowacji budynków mieszkalnych, a w wypadku czterech miast (Krynica-Zdrój, Olsztyn, Płock, Świnoujście) w ogóle ich nie uwzględniono. Nie uspołeczniono w odpowiednim stopniu procesu tworzenia programu, a najszersze konsultacje społeczne przeprowadzono w Poznaniu, na co niewątpliwy wpływ, poza doświadczeniem, miała wielkość budżetu oraz liczba osób biorących udział w projekcie. W wielu miastach nie wprowadzono innowacyjnych form zarządzania programami rewitalizacji, a Olsztyn i Tomaszów Mazowiecki w ogóle nie miały wskazanych jednostek odpowiedzialnych za wdrażanie działań.

Niewątpliwym atutem programów jest zapisanie rewitalizacji obszarów zdegradowanych w politykach rozwoju miast (za wyjątkiem Krynicy-Zdroju i Świnoujścia) oraz delimitacja obszarów zdegradowanych na podstawie przeprowadzonych badań.

Trudności w przygotowywaniu programów rewitalizacji są jednak następstwem wielu problemów. Jednym z najważniejszych z nich jest brak dobrych, rodzimych przykładów kompleksowej rewitalizacji dzielnic miejskich, gdyż znaczące projekty w tym zakresie są na etapie przygotowania lub realizacji. Doświadczenie krajów zachodnioeuropejskich też nie zawsze udaje się bezpośrednio przełożyć na polskie warunki, a współpraca z nimi nieraz już kończyła się niepowodzeniem ze względu na zbyt duże bariery mentalne i administracyjne. Francuskie Ministerstwo Wyposażenia i Rady Europy po wycofaniu się z prac nad dzielnicą Jurydyka Lubicz w Krakowie w 1990 r. tak podsumowało zaistniałą sytuację: „Niedobrze jest mieć rację zbyt wcześnie..." (Skalski 2000).

Kolejnym zagrożeniem jest pomijanie kwestii społecznych, co uniemożliwia osiągnięcie pełnego sukcesu. Często bierze się pod uwagę projekty przynoszące szybkie i efektowne rezultaty, pomijając te ze sfery problemów społecznych, których efekty nie są wymierne i widoczne w krótkim czasie, chociaż w dłuższej perspektywie są bardzo istotne dla rozwoju oraz podniesienia jakości życia w mieście.

Osobną kwestią jest brak źródeł finansowania procesu - poza funduszami unijnymi i środkami własnymi trudno jest pozyskać inne źródła finansowania, w tym projektów tzw. miękkich, a więc niezwiązanych z prestiżowymi inwestycjami. Niewątpliwie potrzebny jest zespół instrumentów wspomagania, wśród których najważniejsze byłyby kredyty bankowe i subwencje celowe z funduszy publicznych. Brak tych instrumentów stawia wiele programów pod znakiem zapytania.

Czynnikiem sprzyjającym rewitalizacji jest tendencja do odnowy tkanki miejskiej. Coraz większe zainteresowanie rewitalizacją wykazują jednostki samorządu terytorialnego. Niestety, nie zawsze wynika ono z rzeczywistych potrzeb, a z chęci zjednania sobie wyborców i wykazania się aktywnością w kwestii realizacji różnych projektów oraz pozyskiwania funduszy unijnych. 
Choć trudno na tym etapie o jednoznaczne wnioski, to omawiane programy powinny mieć ogromne znaczenie dla wizerunku miast i ich dzielnic, wpływając na atrakcyjność miejsc poprzez poprawę ich wyglądu i warunków życia mieszkańców oraz kreowanie nowych działalności kulturalnych i gospodarczych. Ostateczną jednak ocenę będzie można wystawić kilka lat po zakończeniu planowanych działań, sprawdzając, czy przyniosły one oczekiwane rezultaty i sukcesy, na podstawie badań opinii publicznej na ten temat. Trzeba mieć nadzieję, że przekrój planowanych inwestycji w ramach programów rewitalizacji pozwoli na ożywienie tkanki miejskiej w sferze gospodarczej, społecznej i przestrzennej, a z pozytywnych skutków takich przedsięwzięć będą mogli cieszyć się nie tylko mieszkańcy, ale również lokalni przedsiębiorcy oraz turyści. W konsekwencji będzie to początkiem rozwoju całego zjawiska związanego z odnową miast, a kolejne inicjatywy realizowane w następstwie rewitalizacji mogą przyczynić się do nieustannego podtrzymywania tego procesu. Taka perspektywa i możliwości niewątpliwe pozwalają na stwierdzenia, że lokalne programy rewitalizacji są instrumentami odnowy tkanki miejskiej.

\section{Literatura}

1. Domański B., Ziobrowski Z., 2010, Rewitalizacja miast polskich jako sposób zachowania dziedzictwa materialnego i duchowego oraz czynnik zrównoważonego rozwoju-podsumowanie projektu, Instytut Rozwoju Miast, Kraków.

2. Kawa S., 2006, Możliwości finansowania działań rewitalizacyjnych z wykorzystaniem Funduszy Strukturalnych UE, J.K. Lenartowicz, D. Maciąg (red.), „Czasopismo Techniczne. Seria Architektura”, z. 8-A, Wyd. Politechniki Krakowskiej, Kraków.

3. Kwiatek J., 1998, Leksykon miast polskich, Wyd. Muza, Warszawa.

4. Langer P., 2005, Problem rewitalizacji przestrzeni średnich miast w projektach wspólfinansowanych z funduszy strukturalnych na przyktadzie Bochni [w:] Rola planowania przestrzennego $w$ świetle polityki spójności Unii Europejskiej, E. Węcławowicz-Bilska, M. Marx-Kozakiewicz (red.), „Czasopismo Techniczne. Seria Architektura", z. 15, Wyd. Politechniki Krakowskiej, Kraków.

5. Skalski K., 2000, Rewitalizacja starych dzielnic miejskich [w:] Odnowa miast-rewitalizacja, rehabilitacja, restrukturyzacja, Z. Ziobrowski (red.), Instytut Gospodarki Przestrzennej i Komunalnej, Kraków.

6. Podręcznik procedur wdrażania Zintegrowanego Programu Operacyjnego Rozwoju Regionalnego opracowany przez Ministerstwo Rozwoju Regionalnego, http://www.zporr-bzfe.kielce.uw.gov.pl/dokumenty/pdf/podrecznik_procedur_wdrazan ia_ZPORR.pdf

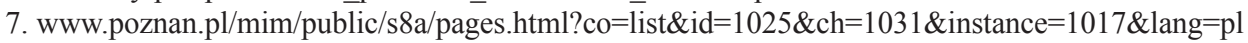

8. www.miasto.hrubieszow.pl/files/bip/plany/rewitalizacja/proj_rew.pdf

9. www.ebok.olsztyn.eu

10. www.efs.2004-2006.gov.pl

11.www.mg.gov.pl/files/upload/10123/Sprostowanie_Rozp_Komisji_1828_8.12.2008_EFRR_EFS_ FS.pdf 


\section{The Urban Enterprise - Local Revitalisation Programmes as the Cities' Revival Tools}

Owing to widely advertized issue of renewal of urban tissue cities gain their chance for re-birth and "second youth". These entities struggle with degradation and depopulation through, among others, re-discovering cultural, architectural and historical values alike, restructuring postrailway, post-military and post-industrial areas as well as renovation of old housing estates and other damaged building resources. Next to the degradation of the housing substance, another problem of the cities is demographic crisis. The amount of cities' inhabitants decreases systematically, the process of ageing of society affects more and more aspects of economy and the decline in population growth as well as mass emigration of young people are not promising. Thus main tasks of cities development became tasks of qualitative revival of material resources and human capital.

Considering revitalization as a cities revival tool one have to have in mind it cannot concern only the material structure of a city but has to be spread over the broadly understood social issues. Moreover, the revitalization actions have to be based on a new planning model through involving local societies into planning processes. In this way it can contribute to the integration of residents as well as to the larger identification with place of residence which may be an object of their special care in coming years. To summarise, only such integrated and complex attitude as above may bring expected results of increasing the quality of the cities and the Local Revitalisation Programmes, which are one of the requirements of revitalization programmes studies, may essentially contribute. 


\author{
Patrycja Majcher \\ Uniwersytet Pedagogiczny \\ im. Komisji Edukacji Narodowej \\ w Krakowie
}

\title{
Strategiczne kierunki ksztaltowania Kielc jako potencjalnej metropolii
}

Postępujący proces globalizacji tworzy nowe uwarunkowania do powstawania różnych układów przestrzennych. Przekształca on przestrzeń społeczno-gospodarczą, sprzyjając rozwijaniu się idei Europy bez granic (Zioło 1999). Rozprzestrzenianie się miast, tworzenie rozbudowanych stref podmiejskich, napływ kapitału zagranicznego czy zmiana struktury zatrudnienia to podstawowe czynniki globalnego rozwoju, w wyniku którego wykształca się kolejny, bardziej złożony proces w przestrzeni geograficznej prowadzący do powstawania metropolii oraz układów metropolitalnych (Majcher 2010). B. Jałowiecki uznał te procesy za kolejną fazę urbanizacji, „którą określić można jako proces przekształcania się przestrzeni miejskich, polegający na zmianie relacji między miastem centralnym i jego bezpośrednim zapleczem oraz na nieciągłym sposobie użytkowania przestrzeni zurbanizowanych” (Jałowiecki 1999, s. 29).

Włączenie Polski do Unii Europejskiej wyraźnie wpłynęło na możliwości rozwojowe poszczególnych miast. Jest to związane z unijnymi dofinansowaniami na różne cele, w tym na rewitalizację ośrodków miejskich oraz na infrastrukturę. Największą szansą stało się jednak otwarcie Polski na kapitał i zasoby ludzkie Europy Zachodniej.

\section{Przedmiot i cel pracy}

Metropolizacja Kielc jest przedmiotem zainteresowania władz samorządowych na różnych szczeblach, a szczególnie miast i gmin powiatu kieleckiego, stolicy województwa - Kielc - oraz samorządu województwa świętokrzyskiego, do którego należy opracowanie planu zagospodarowania przestrzennego obszaru metropolitalnego jako części składowej planu zagospodarowania przestrzennego województwa. Zachodzi zatem potrzeba przeanalizowania uwarunkowań Kielc do stania się potencjalną metropolią w świetle uwarunkowań rozwojowych. Status metropolii krajowej mógłby zapewnić miastu odpowiedni poziom konkurencyjności w stosunku do innych polskich metropolii oraz stać się rzeczywistym impulsem do włączenia ich do europejskiej sieci miast (Eurocities).

Celem niniejszego artykułu jest przedstawienie analizy Kielc jako potencjalnej metropolii, wskazanie możliwości i kierunków rozwoju miasta oraz przedstawienie działań na rzecz rozwoju Kieleckiego Obszaru Metropolitalnego (KOM) jako konkurencyjnego obszaru w strukturze krajowych obszarów metropolitalnych.

Miasto Kielce, pominięte w Koncepcji zagospodarowania przestrzennego kraju jako potencjalna krajowa metropolia, dąży do zwiększenia swej konkurencyjności w sieci osadniczej polskich miast poprzez rozwój funkcji metropolitalnych oraz wzrost potencjału demograficznego i społeczno-gospodarczego potencjalnego obszaru metropolitalnego (ryc. 1). W świetle przedstawionych przesłanek przedmiotem pracy jest wyróżnienie strategicznych kierunków rozwoju i wzrostu potencjalnej metropolii. 
Ryc. 1. Istniejące i potencjalne obszary metropolitalne w Polsce

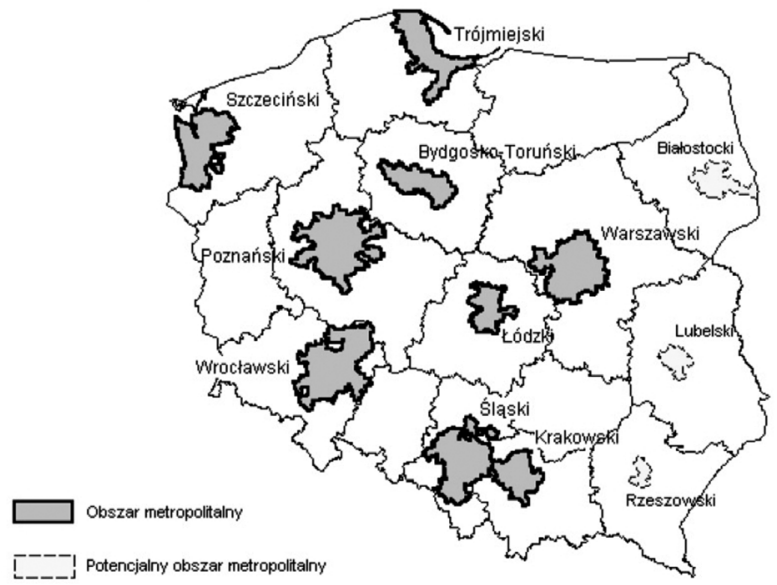

Źródło: Zaktualizowana koncepcja przestrzennego zagospodarowania kraju 2005, s. 95.

\section{Strategiczne kierunki ksztaltowania Kielc jako potencjalnej metropolii}

Potencjalna metropolia kielecka, leżąca pomiędzy dobrze wykształconymi metropoliami - Warszawą i Krakowem - nie jest bardzo konkurencyjna na tle krajowych metropolii (Majcher 2010). Szanse na zaistnienie w polskiej sieci osadniczej miast stwarza skupienie się na wybranych elementach gospodarki. Pozwala to także na wykorzystanie potencjału tego obszaru oraz upraszcza działania w zakresie przedsięwzięć promocyjno-informacyjnych. W postępującej metropolizacji należy dążyć do zwiększania konkurencyjności regionów, tak aby stanowiły obszar atrakcyjny dla inwestorów zarówno krajowych, jak i zagranicznych oraz dla ludności je zamieszkującej.

W świetle Koncepcji zagospodarowania przestrzennego obszaru funkcjonalnego Kielc $w$ aspekcie rozwoju metropolizacji (2007) kształtowanie się funkcji metropolitalnych Kielc, a w szczególności zmiana funkcji miasta z ośrodka przemysłowego na administracyjno-usługowy, datuje się na początek lat 90. XX w. Funkcje te są generowane m.in. przez: dynamicznie rozwijający się ośrodek targowy, rozwój szkolnictwa wyższego i sektora instytucji finansowych, instytucje administracyjne, dobrze rozwiniętą sieć handlu i usług, obecność instytucji oraz jednostek sektora wsparcia biznesu, obecność koncernów międzynarodowych, rozwijającą się kulturę, silny sektor medialny i usług poligraficznych, dobrze rozwiniętą bazę sportową oraz silne relacje między miastem a gminami sąsiednimi.

Kielce na tle innych metropolii wypadają niekorzystnie pod względem: trendów demograficznych, funkcjonowania krajowych i europejskich połączeń komunikacyjnych, innowacyjności technologicznej, liczby przedstawicielstw międzynarodowych i wyspecjalizowanych usług kongresowych (Majcher 2010). Z kolei sektorami szczególnie ważnymi dla zrównoważonego i dynamicznego rozwoju gmin Kieleckiego Obszaru Metropolitalnego oraz sektorami, w których ma on istotną przewagę nad regionalnymi konkurentami w rywalizacji o pozyskiwanie inwestorów zagranicznych, są: sektor budowlany, sektor targowy i usług okołotargowych oraz działalność stadionów i pozostałych obiektów sportowych.

Sektory budowlany i targowy stanowią istotny i silny element gospodarki Kieleckiego Obszaru Metropolitalnego - już w tej chwili mogą one być (i w wielu przypadkach są) ważną przewagą konkurencyjną w rywalizacji o bezpośrednie inwestycje zagraniczne (BIZ). 
Konieczne jest jednak podejmowanie działań mających na celu zwiększenie skuteczności tej rywalizacji (Koncepcja zagospodarowania przestrzennego obszaru funkcjonalnego Kielc w aspekcie rozwoju metropolizacji 2007).

\section{Przemysł i budownictwo}

Przemysł i budownictwo woj. świętokrzyskiego koncentrują się głównie w północnej części województwa, między Końskim a Ostrowcem Świętokrzyskim. Do najważniejszych przemysłowych ośrodków miejskich należą: Kielce, Ostrowiec Świętokrzyski, Starachowice, Skarżysko-Kamienna, Sandomierz, Staszów i Końskie. Większość ośrodków miejskich skupiających znaczną liczbę miejsc pracy w przemyśle koncentruje się na obszarze dawnego Staropolskiego Okręgu Przemysłowego. Ma on bogate tradycje związane z przemysłem, głównie wydobywczym i przetwórczym surowców mineralnych (rud żelaza, miedzi, ołowiu).

Przemysł ukształtowany został w ścisłym powiązaniu z istniejącymi zasobami surowców skalnych, chemicznych i energetycznych oraz tradycjami związanymi z wytwarzaniem i obróbką metali. Duże zasoby różnorodnych kopalin stanowią dobre zaplecze dla rozwoju produkcji materiałów budowlanych, dzięki temu woj. świętokrzyskie zyskało miano „stolicy polskiego budownictwa”. W rejonie Kielc oraz w południowo-zachodniej części województwa występuje koncentracja przemysłu wydobywczego kopalin i przeróbki surowców skalnych dla przemysłu cementowego i wapienniczego. Przemysł cementowy to również północno-wschodnia część województwa, region Ożarowa. Na południowym obszarze występują cegielnie i zakłady branży budowlanej i gipsowej. Województwo świętokrzyskie stanowi ważny w skali kraju ośrodek produkujący materiały budowlane (Majcher 2010).

Według PAIZ, na obszarze województwa świętokrzyskiego działają największe firmy budowlane $\mathrm{w}$ Polsce, natomiast największymi inwestorami zagranicznymi w regionie są firmy z Wielkiej Brytanii, Francji, Niemiec, Japonii, Belgii oraz USA (tab. 1).

Województwo świętokrzyskie posiada dobrze przygotowaną i wykwalifikowaną kadrę pracowniczą, dzięki istnieniu w Kielcach uczelni wyższych kształcących studentów na konkurencyjnych w regionie kierunkach. Obecne na jedynej uczelni technicznej w Kielcach, którą jest Politechnika Świętokrzyska, istnieją dwa wydziały związane z sektorem budownictwa. Są to: Wydział Budownictwa i Inżynierii Środowiska (od 1967) oraz Wydział Elektrotechniki Automatyki i Informatyki (od 1965). Region ten posiada także rozwiniętą sieć szkół technicznych: technika budowlane, Technikum Drogowe oraz Policealne Studium Budowlane.

Na terenie województwa, a tym samym w obrębie Kieleckiego Obszaru Metropolitalnego, istnieje klaster budowlany, który skupia ponad 3000 firm budowlanych, m.in. Dorbud S.A., Skanska S.A., Trakt Sp. z 0.o., Geolbud S.A., Fakt Budownictwo Sp. z o.o., Kolporter Development S.A., Echo Investment S.A, BI Sp. z o.o., Master Kort Sp. z o.o., Eiffage - Mitex S.A., Fart Sp. z o.o., Kartel S.A., Condite S.A., Akwedukt Sp. z o.o., Chemadin Export Sp. z o.o., Hydromel Końskie Sp. z o.o.

Sektor budowlany posiada także dużą sieć podwykonawców i dostawców materiałów wykończeniowych: „Cersanit” S.A. (producent ceramiki łazienkowej), „Barlinek” S.A. (lider produkcji podłóg drewnianych w Polsce), PPH „Jezierski” (producent stolarki budowlanej), „Nordiska Ekofiber” Sp. z o.o. (producent materiałów termoizolacyjnych), „CK Bruk” S.A. (producent kostki brukowej), „Fabet” S.A. (prefabrykaty betonowe dla budownictwa), „Holzexport” Sp. z o.o. (producent parkietów), „Ceramika Końskie” Sp. z o.o. (producent płytek ceramicznych), „Stolbud Włoszczowa” S.A. (producent okien i drzwi), „Alpol” Sp. z o.o. (producent chemii budowlanej).

Istotnym czynnikiem charakteryzującym obszar metropolitalny Kielc jako strefy konkurencyjnej pod względem budownictwa jest obecność międzynarodowych koncernów: Skanska AB (Szwecja), Epstein (USA), Ferrovial (Hiszpania), Acciona (Hiszpania), Apollo-Rida Poland (USA), Bau Holding Strabag AG (Austria), BEG S.A i Eiffage Construction (Francja). 


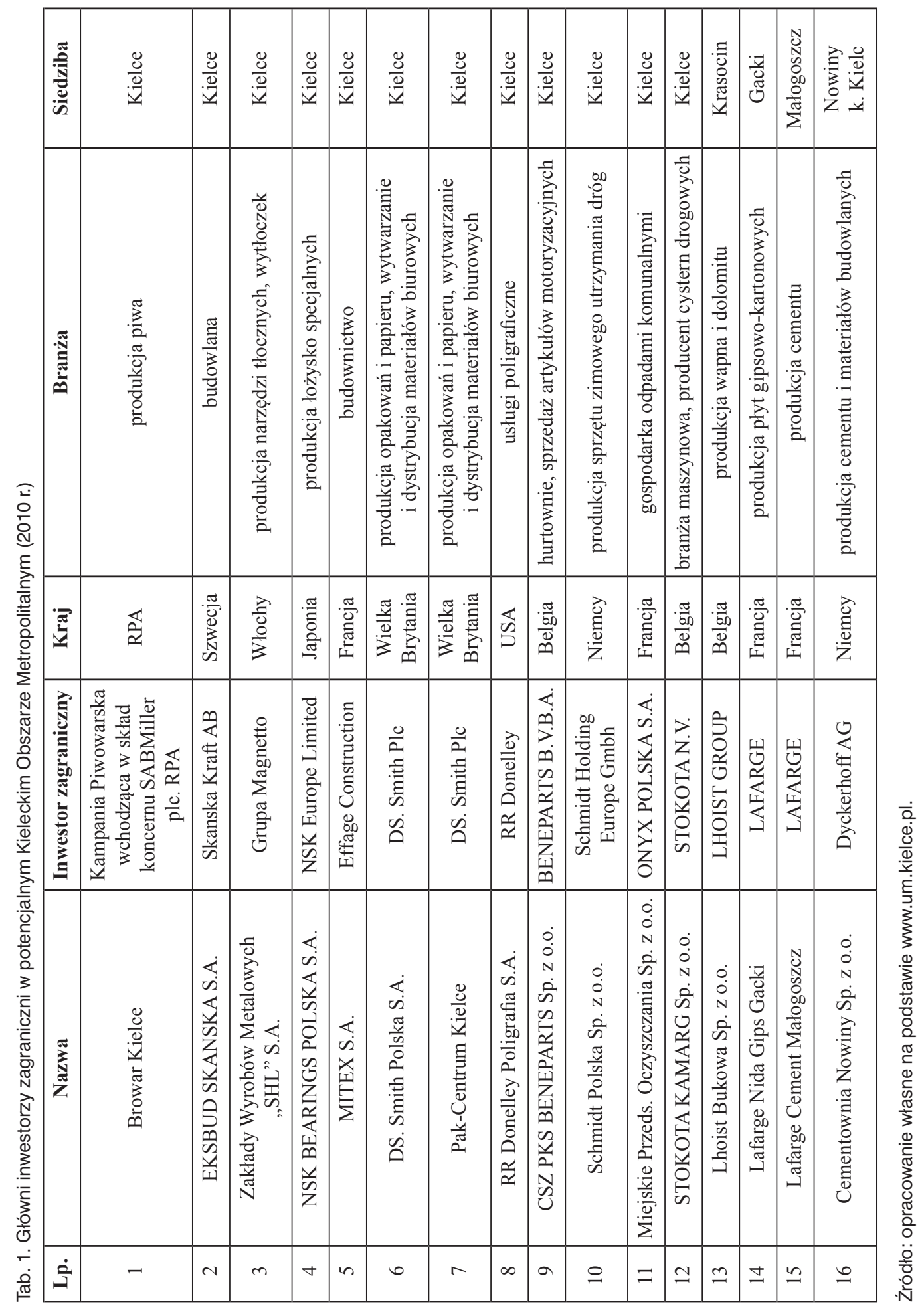




\section{Sektor targowy i usług okołotargowych}

Potencjalny Kielecki Obszar Metropolitalny charakteryzuje się potencjałem rozwojowym w obszarze usług targowo-wystawienniczych, który związany jest głównie z funkcjonującą na terenie Kielc firmą - Targi Kielce Sp. z o.o. Jak wynika z danych Polskiej Izby Przemysłu Targowego za rok 2008, Targi Kielce były drugim największym organizatorem targów w Polsce pod względem liczby wystawców ogółem. W roku tym spółka zagospodarowała ponad 17\% polskiego rynku targowego, zajmując pod tym względem drugie miejsce po Międzynarodowych Targach Poznańskich (Analiza potencjału Kieleckiego Obszaru Metropolitalnego dla wybranych trzech sektorów gospodarki 2009).

Oddziaływanie Targów Kielce jest tak duże, że powstała inicjatywa utworzenia spółki-klastra usługowego wokół centrum targowo-wystawienniczego. Postanie klastra udokumentowane zostało w Koncepcji utworzenia i działalności klastra usługowego „, Grono Targowe Kielce”, w której stwierdzono że „dynamiczny rozwój kieleckiego ośrodka targowego w istotny sposób oddziałuje na życie gospodarcze całego miasta. Targi są wiodącą instytucją promocyjno-handlową województwa świętokrzyskiego i w istotny sposób przyczyniają się do podnoszenia jego konkurencyjności”. Działalność Targów wymaga współpracy z wieloma podmiotami w sektorze usług, transportu i spedycji oraz zapewnia rozwój infrastruktury hotelarskiej i gastronomicznej, której skromna baza już teraz okazuje się niewystarczająca w stosunku do potrzeb. „W chwili obecnej już 100 dni w roku przypada na dni targowe, a jak wynika ze statystyk, liczba gości targowych sukcesywnie wzrasta" (www.targikielce.pl).

Targi Kielce pod względem wielkości dysponują drugą w kraju własną powierzchnią wystawową. Są jedynym w Polsce ośrodkiem targowym, na którego obszarze usługowo-wystawienniczym można prezentować ciężki sprzęt budowlany, transportowy i wojskowy. Do tego celu wykorzystywany jest specjalny teren pokazowy przylegający do terenów targowych. W zależności od branży teren ten może mieć charakter poligonu (podczas targów zbrojeniowych) lub tymczasowego placu budowy (podczas targów budowlanych). Udział Targów Kielce w polskim rynku targowym przedstawia tabela 2 .

Tab. 2. Targi Kielce w latach 2005-2009

\begin{tabular}{|c|c|c|c|c|c|c|}
\hline \multirow{2}{*}{ Rok } & \multirow{2}{*}{ Wystawy } & \multicolumn{2}{|c|}{ Wystawcy } & \multirow{2}{*}{ Odwiedzający } & $\begin{array}{c}\text { Powierzchnia } \\
{\left[\mathbf{m}^{2}\right]}\end{array}$ & $\begin{array}{c}\text { Udzial } \\
\text { w rynku }\end{array}$ \\
\cline { 3 - 4 } & ogółem & $\begin{array}{c}\text { w tym wystawcy } \\
\text { zagraniczni }\end{array}$ & & 85068 & $16,85 \%$ \\
\hline 2005 & 31 & 3819 & 967 & 118934 & 95254 & $19,08 \%$ \\
\hline 2006 & 29 & 4000 & 913 & 182786 & 127798 & $20,48 \%$ \\
\hline 2007 & 38 & 4744 & 1031 & 153757 & 157443 & $21,89 \%$ \\
\hline 2008 & 43 & 5456 & 1242 & 169367 & 155588 & $26,99 \%$ \\
\hline 2009 & $\cdot$ & 5311 & 997 & & & \\
\hline
\end{tabular}

Źródło: opracowanie własne na postawie www.polfair.com.pl.

W 2009 r. Targi Kielce uzyskały 27\% udziału w polskim rynku targowym, co po raz kolejny dało firmie pozycję wicelidera. W 2005 r. udział spółki w rynku wynosił jedynie 16,85\%, w 2006 - 19\%, a w 2008 r. - 22\%. Jak wynika z raportu Polskiej Izby Przemysłu Targowego, Targi Kielce są nadal najdynamiczniej rozwijającym się ośrodkiem wystawienniczym w Polsce. 
Dzięki dynamicznemu rozwojowi w latach 2005-2007 do Kielc przyjechało o 1631 wystawców więcej, w sumie w 2008 r. było ich 5456, co stanowi wzrost o blisko 43\% w stosunku do roku 2005. Wystawcy ci kupili w Kielcach powierzchnię większą o ponad 85\% niż w roku 2005. Stoiska na kilkudziesięciu rocznie imprezach targowych przez ostatnie trzy lata odwiedziło ponad 415 tys. osób (www.targikielce.pl).

Wysoką jakość świadczonych usług przez Targi Kielce poświadcza przynależność do międzynarodowych organizacji targowych UFI i CENTREX. Trzy wystawy: Międzynarodowe Targi Technologii dla Odlewnictwa METAL, Międzynarodowe Targi Przetwórstwa Tworzyw Sztucznych PLASTPOL oraz Międzynarodowy Salon Przemysłu Obronnego MSPO - należą do Międzynarodowego Stowarzyszenia Przemysłu Targowego UFI z siedzibą w Paryżu. Targi Kielce są drugim w historii polskim ośrodkiem targowym, który spełnił wysokie rygory i uwarunkowania uczestnictwa w tej światowej organizacji. Przynależność danej wystawy do UFI gwarantuje jej międzynarodowy poziom, standard organizacyjny i znaczenie (www.targikielce.pl).

Najważniejszymi elementami sfery gospodarczej Kieleckiego Obszaru Metropolitalnego, które mają wpływ na rozwój funkcji targowo-wystawienniczych, są:

- dostępność komunikacyjna (w tym istnienie lotniska obsługującego ruch międzynarodowy),

- różne możliwości spędzania wolnego czasu - oferta kulturalna,

- baza noclegowa i gastronomiczna.

Targi Kielce prowadzą rozbudowaną działalność. Składa się na nią 26 działalności z 25 działów z Polskiej Klasyfikacji Gospodarczej (www.targikielce.pl/bip). Targi posiadają także przedstawicielstwa wielu zagranicznych państw, takich jak Chiny, Tajwan, Hongkong, Czechy, Słowacja, Francja, Indie, Sri Lanka, Niemcy, Pakistan, Rosja, Ukraina, USA, Kanada, Wielka Brytania, RPA oraz Włochy.

Spółka wciąż się rozwija, czego wyrazem jest zaplanowane przeprowadzenie w latach 2009-2014 inwestycji i modernizacji za łączną kwotę ponad $167 \mathrm{mln}$ zł, przy czym część tych środków ma pochodzić z dofinansowania z Unii Europejskiej. W ramach planów modernizacji i rozbudowy ośrodka targowego przewidziane są następujące inwestycje:

- zwiększenie krytej powierzchni wystawienniczej do $47620 \mathrm{~m}^{2}$,

- utworzenie Centrum Administracyjno-Kongresowego na 1000 miejsc z wieżą widokową i salą bankietową,

- modernizacja istniejących pawilonów wystawienniczych (m.in. nowe oznaczenia pawilonów wystawienniczych),

- budowa Pawilonu E o powierzchni 6 tys. $\mathrm{m}^{2}$ i wysokości $15 \mathrm{~m} \mathrm{z}$ antresolami oraz zapleczem konferencyjnym,

- budowa hali wystawienniczej H o powierzchni 12 tys. $\mathrm{m}^{2}$ i wysokości $10 \mathrm{~m}$,

- budowa hali usługowo-garażowej M z parkingiem piętrowym na 400 samochodów,

- stworzenie otwartej powierzchni ekspozycyjnej (90 tys. $\left.\mathrm{m}^{2}\right)$,

- utworzenie dróg, sieci energetycznych, systemu monitoringu, systemu elektronicznej rejestracji wystawców i zwiedzających (www.targikielce.pl).

\section{Ośrodek sportu i rekreacji}

Potencjalna metropolia kielecka posiada wiele atutów. Jednym z nich jest położenie geograficzne w podnóża Gór Świętokrzyskich. W obrębie miasta leżą pasma Kadzielniańskie i Dymińskie, a na jego terenie znajduje się szereg rezerwatów przyrody ożywionej i nieożywionej, m.in. Kadzielnia, Karczówka, Ślichowice, Wietrznia, Biesak-Białogon. Granice administracyjne 
miasta obejmują też sporą część Chęcińsko-Kieleckiego Parku Krajobrazowego. Miasto, jako jedno z nielicznych, charakteryzuje się znacznymi różnicami poziomów - od $260 \mathrm{~m}$ n.p.m. do 408 m n.p.m. (najwyższym wzniesieniem jest Telegraf, na którym usytuowany został stok narciarski). Atutem Kielc są liczne, malownicze tereny rekreacyjne i dobrze rozwinięta baza obiektów sportowych. Umożliwiają one aktywny wypoczynek, sprzyjają także uprawianiu sportu.

Bazę sportową w mieście tworzy: dziewięć hal sportowych (z widowniami), pięć basenów, w tym trzy kryte, osiem dużych sal treningowych, pięć stadionów (jeden lekkoatletyczny, jeden wielofunkcyjny oraz trzy piłkarskie), osiem boisk do piłki nożnej, 14 kortów tenisowych i dwie trasy narciarskie (z wyciągami). Dużą popularnością wśród cyklistów cieszy się ścieżka rowerowa o długości ok. 5 km, prowadząca od zalewu na Szydłówku do stadionu Leśnego. Aktywnemu wypoczynkowi służy także wytyczony wokół Kielc szlak widokowy (dł. 85 km) oraz oznakowany Miejski Szlak Turystyczny. Tuż pod Kielcami, w Miedzianej Górze, znajduje się wyścigowy tor samochodowy, zaś w Masłowie - lotnisko sportowo-dyspozycyjne.

Potencjalna metropolia kielecka ma szansę rozwijać się dzięki postawieniu na sport i rekreację. Kielce posiadają najnowocześniejszy w Polsce stadion piłkarski oraz wielofunkcyjną halę sportową. W planach inwestycyjnych znajduje się budowa, na terenie o powierzchni kilku hektarów, parku rekreacyjno-sportowego.

Stadion Miejski w Kielcach przy ul. Ściegiennego 8 jest głównym obiektem klubu piłkarskiego Korona Kielce, określanym także mianem Areny Kielc. Został oddany do użytku 1 kwietnia 2006 r. To najnowocześniejszy obiekt piłkarski w Polsce, który spełnia wszystkie wymagania FIFA. Pojemność stadionu to 15500 miejsc (wszystkie miejsca siedzące w pełni zadaszone). Stadion posiada podgrzewaną płytę o wymiarach 105 x 68 m, oświetlenie 1400 luksów, nowoczesny system nagłośnienia oraz system monitoringu pozwalający na pełną identyfikację każdej osoby przebywającej na stadionie. Klub, dbając o bezpieczeństwo wszystkich uczestników imprez masowych, wprowadził system wejść i identyfikacji kibiców oparty na karcie kibica (www.korona-kielce.pl).

Kielecki Stadion Miejski, pomimo iż stoi w miejscu, w którym także wcześniej stał stadion, jest obiektem całkowicie nowym, od podstaw budowanym zgodnie z wytycznymi UEFA oraz najnowszymi trendami w budownictwie obiektów sportowych. Wyróżnia się w ten sposób spośród większości obiektów piłkarskich w Polsce, które są na ogół konstrukcjami budowanymi w okresie komunizmu, a obecnie jedynie modernizowanymi tak, aby spełniały minimalne wymagania UEFA (www.korona-kielce.pl).

Potencjalna metropolia kielecka posiada także rozbudowane zaplecze treningowe. W Kielcach istnieje szereg obiektów, które wykorzystywane są nie tylko przez zawodowych sportowców, ale przede wszystkim służą edukacji sportowej. Obiekty te stanowią doskonałą bazę sportowo-rekreacyjną dla młodych ludzi. Istniejący Zespół Obiektów Sportowych wyposażony jest w boiska do koszykówki, piłki ręcznej, siatkowej i plażowej oraz basen letni o olimpijskich wymiarach.

Należy wspomnieć również o działalności promocyjnej władz woj. świętokrzyskiego oraz o cyklicznie organizowanych imprezach kulturalnych, takich jak Off Fashion czy koncerty na odnowionym obiekcie Amfiteatru Kadzielnia. Dobrze rozwinięta baza sportowa miasta wpłynęła także na to, iż Kielce znalazły się w gronie 21 ośrodków (spośród 160 aspirujących) rekomendowanych jako centra pobytowe i treningowe dla reprezentacji narodowych, które wezmą udział w piłkarskich Mistrzostwach Europy Euro 2012. 


\section{Analiza SWOT}

Wyznaczając kierunki rozwoju oraz wzrostu potencjalnej metropolii kieleckiej, należy scharakteryzować oraz określić główne czynniki wpływające na jej rozwój lub go hamujące. Wykazać należy także obszary zewnętrznych uwarunkowań, które mogą być traktowane jako szanse lub zagrożenia rozwojowe. Analizie SWOT zostały poddane sfery problemowe obejmujące potencjał demograficzny, społeczny oraz gospodarczy.

Tab. 3. Analiza SWOT potencjalnej metropolii kieleckiej

\begin{tabular}{|c|c|}
\hline Silne strony & Slabe strony \\
\hline $\begin{array}{l}\text { - duży potencjał młodej i dobrze wykształconej } \\
\text { - } \text { badry } \\
\text { - } \text { dynate zasoby surowców mineralnych } \\
\text { funkcjonowanie uniwersytetu } \\
\text { - dynamicznie rozwijający się ośrodek targowy } \\
\text { - centrum kulturalne regionu } \\
\text { - rozwinięte usługi z zakresu wysokospecjali- } \\
\text { stycznych służb medycznych (Świętokrzyskie } \\
\text { Centrum Onkologii) } \\
\text { - instytucje i jednostki wspierające biznes } \\
\text { - dobrze rozwinięta baza obiektów sportowych } \\
\text { o znaczeniu regionalnym i ponadregionalnym } \\
\text { - Kielce - ośrodek skupiający potencjał } \\
\text { intelektualny regionu } \\
\text { - dobrze rozwinięta baza rekreacyjno-sportowa } \\
\text { (m.in. nowoczesny stadion piłkarski) }\end{array}$ & $\begin{array}{l}\text { - } \text { przewaga w gospodarce tradycyjnych } \\
\text { gałęzi przemysłu i branż produkcji } \\
\text { niskoprzetworzonej } \\
\text { - niskie nakłady na badania i rozwój } \\
\text { - stosunkowo mała liczba inwestorów } \\
\text { zagranicznych } \\
\text { - wysokie bezrobocie } \\
\text { - duży odsetek zatrudnionych w sektorze } \\
\text { publicznym w stosunku do ogółu pracujących } \\
\text { - niski standard obiektów oświatowych } \\
\text { niskie poczucie bezpieczeństwa publicznego } \\
\text { i wizerunek Kielc jako miasta niebezpiecznego }\end{array}$ \\
\hline Szanse & Zagrożenia \\
\hline $\begin{array}{l}\text { - wykorzystanie ugruntowanej i silnej pozycji } \\
\text { - Targów Kielce } \\
\text { - rosnący popyt na usługi targowo-konferencyjno- } \\
\text { - zdynamiowe } \\
\text { na zwiększenie przewagi konkurencyjnej Kielc } \\
\text { - przebudowa sieci drogowej na strategicznych } \\
\text { dla miasta połączeniach } \\
\text { - wykorzystanie potencjału Politechniki } \\
\text { Świętokrzyskiej m.in. do utworzenia parku } \\
\text { naukowo-technologicznego } \\
\text { - budowa Inkubatora Technologicznego } \\
\text { zwiększenie dostępności komunikacyjnej miasta, } \\
\text { m.in. poprzez budowę lotniska w Obicach } \\
\text { - wykorzystanie potencjału turystycznego Gór } \\
\text { Świętokrzyskich } \\
\text { - dynamizacja współpracy naukowej kieleckich } \\
\text { uczelni i jednostek naukowo-badawczych } \\
\text { z odpowiednikami z krajów UE } \\
\text { - zmiana wizerunku miasta Kielce poprzez } \\
\text { wdrożenie programu „Bezpieczne Kielce” } \\
\text { • stworzenie dogodnych warunków do osiedla- } \\
\text { nia się w KOM }\end{array}$ & $\begin{array}{l}\text { - niezwiązanie Kielc i regionu w ciągu kolejnych } \\
\text { kilkunastu lat z krajową siecią autostrad i/lub } \\
\text { dróg ekspresowych, szlakami kolejowymi, czy } \\
\text { też z ruchem lotniczych przewozów pasażer- } \\
\text { skich i towarowych } \\
\text { - pesymistyczne prognozy demograficzne związa- } \\
\text { ne m.in. ze zmniejszająca się liczbą ludności } \\
\text { miasta } \\
\text { - odpływ z Kielc ludzi młodych i wykształconych } \\
\text { - starzejące się społeczeństwo i związane z tym } \\
\text { wzrastające obciążenie demograficzne; }\end{array}$ \\
\hline
\end{tabular}

Źródło: opracowanie własne na podstawie Strategii rozwoju miasta Kielce na lata 2007-2020. 
Metropolizacja będąca następstwem postępującego wzrostu znaczenia innowacji i gospodarki opartej na wiedzy wpływa na strukturę obecnej sieci osadniczej w Polsce. Proces metropolizacji polegający na kształtowaniu się nowego typu struktury przestrzeni staje się motorem do rozwoju innowacyjności i konkurencyjności miast.

Kielce, będące w świetle Zaktualizowanej koncepcji przestrzennego zagospodarowania kraju ośrodkiem miejskim dopiero rozwijającym się, mają szansę oraz podstawy do ukształtowania w przyszłości wraz z sąsiednimi gminami jednego z obszarów metropolitalnych kraju. Dalszemu rozwojowi miasta w kierunku metropolizacji sprzyja także podpisana przez prezydenta miasta Kielce oraz burmistrzów i wójtów gmin sąsiadujących z Kielcami Deklaracja współpracy na rzecz Kieleckiego Obszaru Metropolitalnego w dniu 26 sierpnia 2005 r. Współpraca w ramach Kieleckiego Obszaru Metropolitalnego wykorzystana powinna być przede wszystkim w celu pozyskania nowych inwestorów w regionie jak również środków finansowych na rozwój miasta i sąsiednich gmin z funduszy unijnych.

Sektorami szczególnie ważnymi dla zrównoważonego i dynamicznego rozwoju gmin Kieleckiego Obszaru Metropolitalnego oraz sektorami, w których ma on istotną przewagę nad regionalnymi konkurentami w rywalizacji o pozyskiwanie inwestorów zagranicznych są: sektor budowlany, sektor targowy i usług okołotargowych oraz działalność stadionów i pozostałych obiektów sportowych. Przesłankami dla rozwoju funkcji metropolitalnej Kielc opartego na wybranych sektorach są:

- dynamicznie rozwijający się ośrodek targowy o funkcjach międzynarodowych,

- funkcja miasta jako centrum handlowego i usługowego regionu,

- funkcja centrum kulturalnego regionu,

- rozwijająca się współpraca międzynarodowa,

- dobrze rozwinięta baza obiektów sportowych o znaczeniu regionalnym i ponadregionalnym,

- atrakcyjność położenia geograficznego i walorów krajobrazowych, w tym krajobrazu kulturowego śródmieścia miasta,

Ważne są także inicjatywy wspierające rozwój zaplecza naukowo-badawczego oraz zasobów ludzkich, a także mechanizmy pomocy dla innowacyjnych przedsiębiorstw. Konkurencyjny potencjał metropolii w przypadku Kielc powinien tkwić w zasobach wykształconej kadry, wykorzystaniu szerokiego zaplecza naukowo-badawczego, wspartych działaniami na rzecz budowania niezbędnej infrastruktury technicznej służącej rozwojowi całego obszaru metropolitarnego, a przez to przyczyniających się do wzrostu gospodarczego tego obszaru oraz kraju.

\section{Literatura}

1. Analiza potencjału Kieleckiego Obszaru Metropolitalnego dla wybranych trzech sektorów gospodar$k i, 2009$, Wydział Projektów Strukturalnych i Strategii Miasta, Centrum Obsługi Inwestora, Kielce.

2. Jałowiecki B., 1999, Metropolie, Wyd. Wyższa Szkoła Finansów i Zarządzania, Białystok.

3. Koncepcja zagospodarowania przestrzennego obszaru funkcjonalnego Kielc $w$ aspekcie rozwoju metropolizacji, 2007, ŚBRR, Kielce.

4. Majcher P., 2010, Analiza Kielc jako potencjalnej metropolii, praca magisterska napisana na Uniwersytecie Pedagogicznym w Krakowie.

5. Parysek J.J., 2003, Metropolie: metropolitalne funkcje i struktury przestrzenne [w:] Funkcje metropolitalne i ich rola $w$ organizacji przestrzeni. XVI Konserwatorium wiedzy o mieście, I. Jażdżewska (red.), Łódź.

6. Stownik geograficzno-krajoznawczy Polski, PWN, Warszawa 1998, s. 766. 


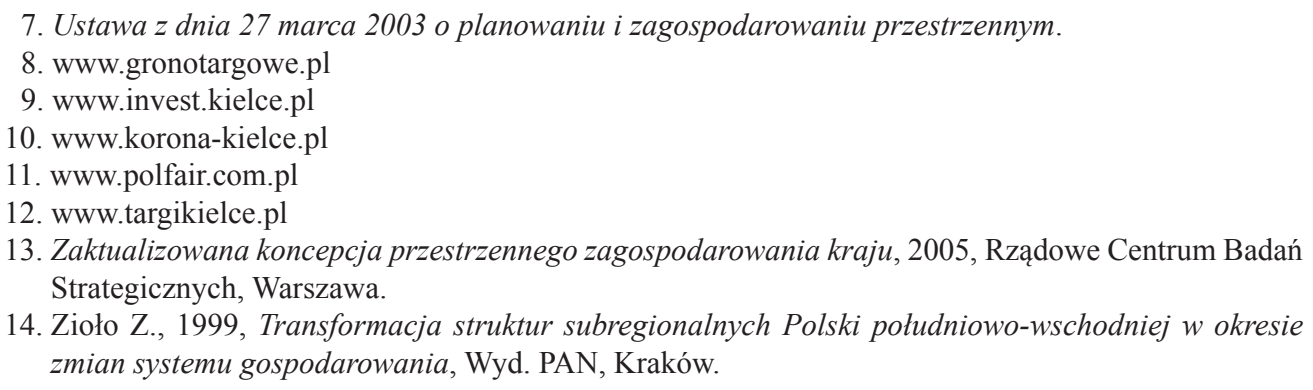

\section{Strategic Directions in Molding Kielce as a Potential Metropolis}

The potential Kielce metropolis, located between well-developed Warsaw and Cracow metropolises, is not highly competitive when compared with domestic ones. Focusing on selected components of the economy, thanks to which a specialization is strived for, determines a bigger chance of arising in the settlement ordination of Poland and allows using a potential as well as simplifies actions in promotion and information ventures. In progressive metropolization it is necessary to increase competitiveness of regions to make them attractive areas not only for local people but especially for foreign and domestic VCs.

According to The Conception of Spatial Development of Kielce Functional Area in Metropolis Progress Aspect the formation of Kielce metropolitan functions, especially the replacement of industrial centre as a city function by administrative and service sector centre, is dated to early 90s. These functions are generated by, among other things, dynamically developing trade fair centre, expansion of the higher education and financial institutions sector, administrative institutions, well-developed trade and service chain, presence of business support institutions and units, the presence of international concerns, developing culture, strong media and publishing services sector, well-developed sport base and finally strong relations between the city and nearby communes.

Kielce area is non-competitive with other metropolises especially because of adverse demographic trends, insufficiently functioning domestic and European communication, low technological innovativeness, only a few international agencies and lack of specialized congressional service.

There are sectors in Kielce Metropolis Area that are especially important for its balanced and dynamic development or are an essential advantage over regional contenders in rivalry for recruitment of foreign VCs. These are: constructional sector, trade fair sector and other services connected with it, stadiums and other sports facilities activity. 


\section{Źródła finansowe}

\section{działalności przedsiębiorstw}




\section{Maciej Tokarski}

Wyższa Szkoła Bankowa

w Toruniu

\section{Międzynarodowe standardy sprawozdawczości finansowej w procesie harmonizacji i standaryzacji rachunkowości w Polsce}

Rachunkowość jako nauka ma bogatą historię i szczególne miejsce we współczesnym systemie nauk ekonomicznych oraz zarządzania. Postępujący proces globalizacji gospodarki przynosi potrzebę harmonizacji rachunkowości. Wyrazem tego jest m.in. ustanowienie międzynarodowych standardów rachunkowości i nowelizacja polskiego prawa o rachunkowości. Regulują one coraz to nowe zagadnienia, wynikające z konieczności zbliżenia rachunkowości do rozwijającego się rynku kapitałowego. Ponieważ stopień szczegółowości zasad prowadzenia rachunkowości w różnych krajach jest różny, przeto narodziło się dążenie do standaryzacji zasad rachunkowości w celu harmonizacji przepisów na świecie.

\section{Harmonizacja i standaryzacja rachunkowości}

Harmonizacja jest ukierunkowana na ograniczenie stosowanych praktyk rachunkowości przez określenie takiego ich zestawu, w ramach którego firmy mogą dokonywać wyboru ewentualnych rozwiązań dotyczących określonych zasad rachunkowości (Roberts, Weetman, Gordon 1998, s. 116). W rezultacie zakres możliwych różnic między firmami jest łatwy do zidentyfikowania. Inaczej mówiąc, jest to proces redukowania różnic w sprawozdawczości pomiędzy poszczególnymi krajami, dzięki któremu zwiększa się porównywalność praktyk rachunkowości przez ustalenie zakresu ich zróżnicowania.

Standaryzacja rachunkowości powoduje stosowanie przez wszystkie organizacje gospodarcze (np. spółki giełdowe) takich samych albo zbliżonych praktyk rachunkowości, czyli jej efektem jest ujednolicenie zasad rachunkowości stosowanych w różnych krajach przez wszystkie organizacje gospodarcze. Jest więc kojarzona z narzucaniem sztywnego i wąskiego zestawu reguł.

Harmonizacja przepisów i standardów rachunkowości nie kończy się na zastosowaniu dyrektyw. Jest to proces ciągły, dostosowujący regulacje prawne do zmieniających się warunków gospodarowania.

\section{Pojęcie standardów rachunkowości}

Pojęcie standard rachunkowości pojawiło się w krajach anglosaskich (Stany Zjednoczone, Wielka Brytania). Oznacza ono wzorzec, normę formułowaną przez krajowe gremia eksperckie rachunkowości i przedstawicieli nauki, której wprowadzenie poprzedzone jest długim okresem badań i konsultacji z udziałem praktyków (Turyna 2006, s. 14-15). Standardy rachunkowości obejmują przedmiotowo zagadnienia dotyczące uznawania zdarzeń i transakcji, ich pomiaru (wyceny) oraz prezentacji w sprawozdaniu finansowym wyróżnionych składników, a także wykazywanie informacji dodatkowych w notach i objaśnieniach. Nie ma w nich miejsca na zasady ewidencji księgowej, konta, dokumenty księgowe czy procedury. Ważny jest ostateczny efekt 
w postaci sprawozdania finansowego, obejmującego zestaw raportów. Są one przedmiotem analiz i decyzji zarządczych, a dane w nich zawarte powinny też być porównywalne z innymi podmiotami gospodarczymi.

\section{Przyczyny i uwarunkowania standaryzacji sprawozdawczości finansowej}

Jedną z głównych przyczyn postępowania procesu zarówno standaryzacji, jak i harmonizacji zasad rachunkowości, jest globalizacja, rozwój rynków kapitałowych, czyli potrzeba ustalenia jednolitych zasad rachunkowości, w celu zwiększenia porównywalności sprawozdań finansowych organizacji gospodarczych, w tym sprawozdań zapisywanych i przetwarzanych w formie elektronicznej. Przykładowo stworzenie i zastosowanie standardu elektronicznej sprawozdawczości finansowej (np. XBRL) było koniecznością w aspekcie stosowania zasad ładu korporacyjnego (zwiększenie przejrzystości i porównywalności informacji sprawozdawczej), a także w aspekcie istnienia globalnej sieci - Internetu (bieżący, równoczesny dostęp dla wszystkich interesariuszy organizacji, do wszystkich ujawnionych informacji itp.). Zwiększający się wraz z rozwojem rynku kapitałowego popyt na informacje finansowe oraz powstawanie ponadpaństwowych (międzynarodowych) korporacji gospodarczych, z którymi związany jest międzynarodowy przepływ kapitału i transfery zysku, wymusza potrzebę zapewnienia:

- porównywalności danych rachunkowych w czasie i w przestrzeni (krajowej i międzynarodowej),

- jednoznacznej interpretacji informacji finansowych, których źródłem jest rachunkowość,

- rzetelności i wiarygodności danych księgowych.

Ponieważ stopień szczegółowości zasad prowadzenia rachunkowości w różnych krajach jest różny, przeto narodziło się dążenie do standaryzacji zasad rachunkowości w celu harmonizacji przepisów na świecie. Przesłanki te legły u podstaw tworzenia standardów rachunkowości rozumianych jako wzorce, normy czy zasady, które przez określone ciało środowiska zawodowego księgowych zostały promulgowane, co przeważnie następuje po długim okresie badań i szeroko zakrojonych konsultacjach.

Do innych czynników standaryzacji oraz harmonizacji zasad rachunkowości zalicza się:

- regionalizację gospodarki światowej,

- rozwój regionalnych ugrupowań gospodarczych (UE, NAFTA itd.),

- globalizację rynków kapitałowych,

- powstanie i rozwój ponadnarodowych korporacji,

- potrzeby Banku Światowego, Międzynarodowego Funduszu Walutowego, giełd i inwestorów odnośnie porównywalnych sprawozdań finansowych,

- procesy prywatyzacji na świecie,

- potrzeby unifikacji i porównywalności informacji finansowych od podmiotów gospodarczych,

- wzrost zapotrzebowania na porównywalne sprawozdania finansowe, szczególnie spółek notowanych na zagranicznych giełdach,

- powstanie i ewolucja dwóch odmiennych filozofii rachunkowości, tj. rachunkowości kontynentalnej oraz rachunkowości anglosaskiej.

\section{Koncepcje rachunkowości na świecie}

Na świecie ukształtowały się dwie odmienne od siebie filozofie rachunkowości:

- rachunkowość typu kontynentalnego (m.in. Niemcy, Francja, Austria, Belgia, Hiszpania, Włochy, Szwajcaria, kraje skandynawskie, Polska, Czechy, Węgry, Japonia),

- rachunkowość typu anglosaskiego (m.in. Wlk. Brytania, USA, Kanada, Australia, Nowa Zelandia, a także po części Holandia) (Jaruga 2002, s. 4). 
Tab. 1. Porównanie systemów rachunkowości

\begin{tabular}{|c|c|}
\hline System kontynentalny & System anglosaski \\
\hline $\begin{array}{c}\text { Podejście prawne, bezpieczeństwo obrotu } \\
\text { gospodarczego }\end{array}$ & Podejście ekonomiczne \\
\hline Duże znaczenie kredytodawców & Orientacja na rynek kapitału \\
\hline Duży wpływ prawa podatkowego & Duże znaczenie informacji dla inwestorów \\
\hline Postawa konserwatywna, unikanie ryzyka & Postawa otwarta na ryzyko \\
\hline Kodeks handlowy & Common Law \\
\hline Plany kont & Standardy rachunkowości koncepcyjne \\
\hline Zasada ostrożności & Duże znaczenie środowiska ekspertów \\
\hline & Przewaga zasady współmierności \\
\hline & Przewaga treści nad formą \\
\hline & $\begin{array}{c}\text { Zasada prawdziwego i rzetelnego obrazu } \\
\text { (True\&Fair View) }\end{array}$ \\
\hline
\end{tabular}

Źródło: Jaruga A.A., Systemy regulacji rachunkowości a międzynarodowa harmonizacja i standaryzacja [w:] Międzynarodowe regulacje rachunkowości. Wpływ na rozwiązania krajowe, A.A. Jaruga (red.), C.H.Beck, Warszawa 2002, s. 4.

Istnieją dwa podstawowe systemy rachunkowości o charakterze ponadnarodowym, tj. międzynarodowe standardy rachunkowości oraz standardy amerykańskie rachunkowości.

Międzynarodowe standardy rachunkowości - MSR (International Accounting Standards IAS) wspierają swoimi założeniami koncepcyjnymi system rachunkowości kontynentalnej. Zorientowane na rynek i instytucje kredytowe, preferują stabilność działalności gospodarczej, opierają się na szczegółowej kodyfikacji prawa bilansowego odnośnie zasad, metod i technik rachunkowości, struktur informacyjnych sprawozdań finansowych, zasadzie nadrzędności prawa nad faktami, konserwatyzmie i ostrożności, ścisłym powiązaniu prawa bilansowego z prawem podatkowym itd.

Założenia koncepcyjne MSR zawężają swoje cele jedynie do sprawozdawczości finansowej. Sprawozdania finansowe spełniają podstawowe potrzeby większości użytkowników, ponieważ prawie wszyscy ich użytkownicy podejmują decyzje gospodarcze dotyczące na przykład:

- tego, czy kupić, utrzymać, czy też zbyć inwestycję,

- oceny sposobu zarządzania i ochrony majątku przez kierownictwo jednostki oraz jego odpowiedzialności,

- oceny zdolności jednostki do wypłacania wynagrodzeń oraz realizacji innych świadczeń na rzecz pracowników,

- oceny zabezpieczenia udzielonych kredytów i pożyczek, określenia polityki podatkowej itd. Sprawozdanie finansowe sporządza się zgodnie z modelem rachunkowości opartym na zasadzie kosztu historycznego i na koncepcji zachowania kapitału nominalnego.

Użytkownicy MSR nie mają możliwości swobodnego doboru koncepcji, zasad i metod rachunkowości innych niż opierających się na koszcie historycznym i koncepcji kapitału nominalnego. Ograniczeń takich nie ma w wypadku amerykańskich standardów rachunkowości. 
Amerykańskie standardy rachunkowości (Generally Accepted Accounting Principles - US GAAP) wspierają swoimi założeniami koncepcyjnymi rachunkowość typu anglosaskiego. Przyjmują prawdziwy i wierny wizerunek finansowy firmy jako nadrzędny cel rachunkowości, są zorientowane na rynek kapitałowy i inwestorów, zakładają dominację treści nad formą i regulacjami prawa bilansowego, preferują ryzyko w działalności gospodarczej.

Celem rachunkowości jest pomiar zasobów będących własnością podmiotu i wyrażanie ich w jednostkach pieniężnych, rejestrowanie zmian wielkości tych zasobów dokonywane okresowo, a także odzwierciedlenie wierzytelności i roszczeń podmiotu w stosunku do otoczenia. Natomiast celem sprawozdawczości finansowej jest dostarczanie informacji dla teraźniejszych i potencjalnych inwestorów, wierzycieli oraz innych użytkowników podejmujących racjonalne decyzje inwestycyjne, kredytowe itp. Założenia koncepcyjne US GAAP dosyć szczegółowo interpretują cele rachunkowości, jak i sprawozdawczości finansowej oraz eksponują je od strony informacyjnej. Zostało w nich przyjęte, że sprawozdawczość finansowa jest elementem rachunkowości z dostrzeżeniem jednak różnic w tych celach (szerszy zakres informacji, jaki powinna dostarczać użytkownikom rachunkowość). Podczas gdy rachunkowość ma dostarczać informacji wszelkim użytkownikom, sprawozdawczość koncentruje się raczej na użytkownikach zewnętrznych.

Harmonizacja przepisów i standardów rachunkowości nie kończy się na zastosowaniu dyrektyw. Jest to proces ciągły, dostosowujący regulacje prawne do zmieniających się warunków gospodarowania. Największy wpływ na harmonizację przepisów o rachunkowości w krajach europejskich wywarły dyrektywy Rady Unii Europejskiej (tab. 2) i MSR.

\section{Problem harmonizacji rachunkowości w skali międzynarodowej. Organizacje zajmują- ce się standaryzacją i harmonizacją rachunkowości}

Harmonizacja rachunkowości w skali międzynarodowej wydaje się konieczna, choć niezwykle złożona i trudna do wprowadzenia (Messner, Pfaff 2001). Potrzeba porównań międzynarodowych, a także możliwość poznania, wykorzystania i rozpowszechnienia najbardziej rozwiniętych koncepcji i wdrożeń praktycznych doprowadziły do powołania organizacji zajmujących się formułowaniem ujednoliconych pojęć i reguł rachunkowości na skalę międzynarodową. Największy wpływ na harmonizację przepisów o rachunkowości w krajach europejskich wywarły:

- dyrektywy Rady Unii Europejskiej,

- Komitet Międzynarodowych Standardów Rachunkowości,

- Rada Międzynarodowych Standardów Rachunkowości.

Problemem harmonizacji rachunkowości w skali międzynarodowej i ujednoliceniem procesu sprawozdawczości zajmują się międzynarodowe organizacje rachunkowości, a wśród nich:

- Unia Europejska za pośrednictwem Dyrekcji Generalnej,

- Rada Międzynarodowych Standardów Rachunkowości,

- Międzynarodowa Federacja Księgowych (International Federation of Accountants - IFAC), a w szczególności Rada Międzynarodowych Standardów Rewizji Finansowej (międzynarodowe wytyczne rewizji finansowej wydawane są przez Międzynarodowy Komitet Zawodowych Norm Rewizji Finansowej (International Auditing Practices Committee - IAPC),

- Konsorcjum XBRL - skupiające organizacje księgowe i instytucje finansowe powstałe w celu utworzenia jednolitego standardu wymiany, interpretacji, analizy i prezentacji szeroko pojętych sprawozdań gospodarczych (zarówno finansowych, jak i niefinansowych),

- pozostałe organizacje, takie jak: organy ONZ m.in. ISAR, czyli grupa robocza ekspertów ds. międzynarodowych standardów rachunkowości i rewizji finansowej działająca przy 
Konferencji Narodów Zjednoczonych ds. Handlu i Rozwoju (UNCTAD), a także Organizacja ds. Współpracy Gospodarczej i Rozwoju (OECD) oraz Europejska Federacja Ekspertów Rachunkowości (Messner, Pfaff 2001, s. 22).

Tab. 2. Dyrektywy Rady Unii Europejskiej dotyczące harmonizacji zasad rachunkowości

\begin{tabular}{|c|c|c|}
\hline Lp. & Nazwa dyrektywy & Treść dyrektywy (wytycznych) \\
\hline 1 & $\begin{array}{l}\text { Dyrektywa czwarta } \\
\text { z } 25 \text { lipca } 1978 \text { roku } \\
\text { w sprawie rocznych } \\
\text { sprawozdań finansowych } \\
\text { niektórych rodzajów spótek }\end{array}$ & $\begin{array}{l}\text { Układ rocznych zamknięć rachunkowych spółek } \\
\text { o różnych formach prawnych. Obejmuje zasady: } \\
\text { - } \text { prowadzenia ksiąg, } \\
\text { - sporządzania sprawozdań, } \\
\text { - zamknięć rocznych, } \\
\text { - dokonywania badania przez biegłych niezależnych, } \\
\text { - ujawniania rocznych zamknięć, } \\
\text { - inwentaryzacji, } \\
\text { - wyceny, tak w trakcie działalności, jak i przy zamknięciach } \\
\text { rocznych. }\end{array}$ \\
\hline 2 & $\begin{array}{l}\text { Dyrektywa siódma } \\
\text { z } 13 \text { czerwca } 1983 \text { roku } \\
\text { w sprawie skonsolidowanych } \\
\text { sprawozdań finansowych }\end{array}$ & $\begin{array}{l}\text { Konsolidacja sprawozdań finansowych jednostek grupy } \\
\text { kapitałowej (bilansów, rachunków zysków i strat, załączników), } \\
\text { ich przygotowanie, publikacja i weryfikacja (rewizja). }\end{array}$ \\
\hline 3 & $\begin{array}{l}\text { Dyrektywa ósma z } 10 \\
\text { kwietnia } 1984 \text { roku }\end{array}$ & $\begin{array}{l}\text { Zatwierdzanie osób odpowiedzialnych za prowadzenie } \\
\text { statutowej rewizji (badań i weryfikacji) ksiąg rachunkowych. }\end{array}$ \\
\hline 4 & $\begin{array}{l}\text { Dyrektywa z } 8 \text { grudnia } 1986 \\
\text { roku w sprawie rocznych } \\
\text { i skonsolidowanych } \\
\text { sprawozdań finansowych } \\
\text { banków } \text { i innych instytucji } \\
\text { finansowych }\end{array}$ & $\begin{array}{l}\text { Roczne zamknięcia rachunkowe i skonsolidowane } \\
\text { sprawozdania rachunkowości banków i innych instytucji } \\
\text { finansowych. }\end{array}$ \\
\hline 5 & $\begin{array}{l}\text { Dyrektywa z } 13 \text { lutego } 1989 \\
\text { roku w sprawie obowiązków } \\
\text { w zakresie publikacji } \\
\text { odnoszacych się do rocznych } \\
\text { sprawozdań finansowych } \\
\text { oddziałów, utworzonych } \\
\text { w państwie członkowskim, } \\
\text { instytucji kredytowych } \\
\text { i instytucji finansowych } \\
\text { majacych swoja siedzibę } \\
\text { poza tym państwem } \\
\text { członkowskim }\end{array}$ & $\begin{array}{l}\text { Obowiązki oddziałów (filii) instytucji kredytowych } \\
\text { i finansowych (utworzonych w krajach członkowskich, } \\
\text { których centrale znajdują się poza danym krajem } \\
\text { członkowskim Unii Europejskiej) odnoszące się } \\
\text { do publikacji sprawozdań. }\end{array}$ \\
\hline 6 & $\begin{array}{l}\text { Dyrektywa z } 19 \text { grudnia } \\
1991 \text { roku w sprawie } \\
\text { rocznych i skonsolidowanych } \\
\text { sprawozdań finansowych } \\
\text { zakładów ubezpieczeń }\end{array}$ & $\begin{array}{l}\text { Skonsolidowane sprawozdania finansowe towarzystw } \\
\text { ubezpieczeniowych. }\end{array}$ \\
\hline
\end{tabular}

Źródło: opracowanie własne. 
W 1973 r. 16 zajmujących się rachunkowością organizacji zawodowych z Austrii, Kanady, Francji, Niemiec, Japonii, Meksyku, Holandii, Wielkiej Brytanii, Irlandii oraz Stanów Zjednoczonych utworzyło Komitet Międzynarodowych Standardów Rachunkowości. W 2001 r. liczył on już 140 członków ze 101 krajów i wydał 41 MSR, które podlegały wielokrotnym zmianom, a część z nich została wycofana.

Uznanie rosnącego znaczenia Komitetu jako światowego twórcy standardów spowodowało, iż od 1 stycznia 2001 r. zmienił on swoją strukturę, przekształcając się w Radę Międzynarodowych Standardów Rachunkowości. Rada zajęła się aktualizacją MSR, a od 2002 r. rozpoczęła opracowywanie międzynarodowych standardów sprawozdawczości finansowej (MSSF), które stopniowo zastępują dotychczasowe MSR (www.iasb.org.uk). Przy Komitecie działał Stały Komitet Interpretacji udzielający wskazówek dotyczących nowo stwierdzonych problemów w zakresie MSR. Od marca 2002 r. jego miejsce zajął Międzynarodowy Komitet Interpretacji Sprawozdawczości Finansowej. Organizacja finansowana jest przez Fundację Komitetu Międzynarodowych Standardów Rachunkowości, której strukturę przedstawia ryc. 1.

Na pełen zestaw międzynarodowych standardów sprawozdawczości finansowej składa się:

- 31 obowiązujących spośród 41 wydanych MSR (tab. 3) oraz ich 11 obowiązujących spośród 33 wydanych interpretacji SIC (tab. 4),

- osiem MSSF oraz wydanych do nich pięć interpretacji IFRIC (tab. 5).

Przedstawione formy regulacji rachunkowości wywarły ogromny wpływ na przeprowadzaną w Polsce reformę systemu prawnego rachunkowości, mającą na celu:

- zrównać prawa i obowiązki różnych rodzajów podmiotów gospodarczych w zakresie prowadzenia rachunkowości,

- nadać właściwą rangę rachunkowości i ludziom, którzy ją prowadzą; chodzi tu o rangę współmierną do roli, jaką rachunkowość odgrywa we współczesnej gospodarce rynkowej, co oznacza wyłączenie systemu rachunkowości spod przepisów podatkowych przy jednoczesnym stworzeniu dogodnych przesłanek do przyszłej synchronizacji przepisów podatkowych z przepisami regulującymi rachunkowość,

- dostosować polskie rozwiązania w zakresie rachunkowości do dyrektyw obowiązujących w krajach Unii Europejskiej,

- dostosować polskie zasady rachunkowości do zasad określonych w MSR, o ile standardy te nie są sprzeczne z dyrektywami Rady Unii Europejskiej, a ich zastosowanie jest możliwe na obecnym etapie rozwoju naszej gospodarki; zbliży to nas do państw stosujących ogólnie akceptowane zasady rachunkowości.

Kolejne nowelizacje Ustawy o rachunkowości wynikały z dostosowania polskiego prawa bilansowego do rozwiązań stosowanych w międzynarodowym prawie bilansowym. Dnia 27 sierpnia 2004 r. Sejm Rzeczpospolitej Polskiej przyjął kilka istotnych nowelizacji następujących artykułów Ustawy o rachunkowości:

1) art. 2 ust. 3 stwierdzającego, iż spółki sporządzające sprawozdania finansowe zgodnie z MSR i MSSF oraz związanymi z nimi interpretacjami ogłoszonymi w formie rozporządzeń Komisji Europejskiej stosują przepisy ustawy oraz przepisy wykonawcze wydane na jej podstawie w zakresie nieuregulowanym przez MSR. Zmiana ta określa kolejność stosowania prawa bilansowego. W pierwszej kolejności spółki będą stosowały zasady wynikające z MSR, a dopiero później (w zakresie nieuregulowanym w MSR) przepisy Ustawy o rachunkowości oraz rozporządzenia wykonawcze;

2) art. 3 ust. 1 pkt. 11 określającego, że przez przyjęte zasady (politykę) rachunkowości należy rozumieć wybrane i stosowane przez spółkę rozwiązania dopuszczone ustawą, w tym także 
Ryc. 1. Struktura IASCF

\section{Fundacja Komitetu Międzynarodowych Standardów \\ Rachunkowości}

(International Accounting Standards Committee Foundation - IASCF)

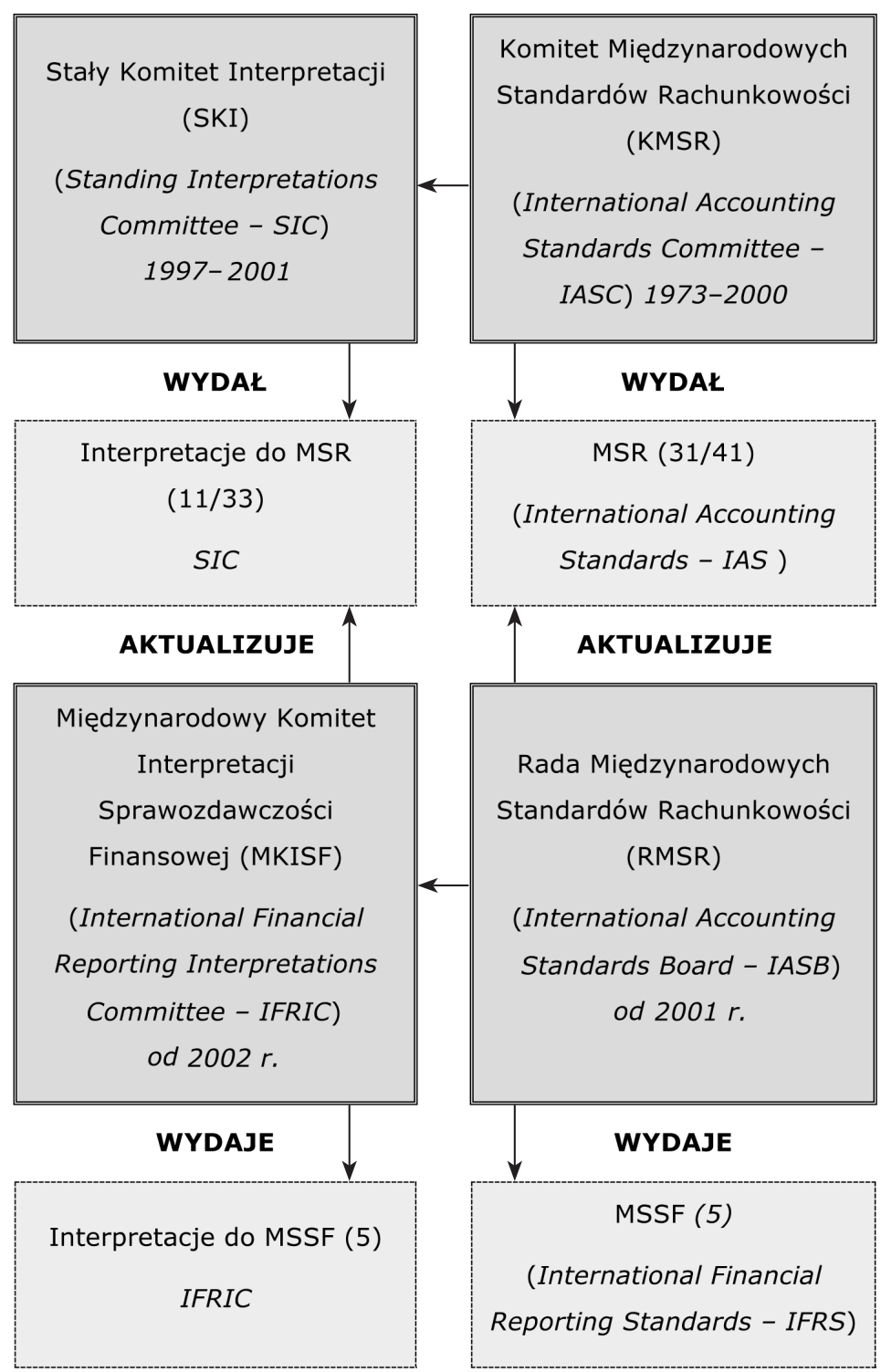

Źródło: opracowanie własne. 
określone w MSR, zapewniające wymaganą jakość sprawozdań finansowych. Oznacza to, że spółka może przyjąć do stosowania zasady (politykę) rachunkowości wynikające z MSR; 3) art. 10 ust. 3 dopuszczającego w sprawach nieuregulowanych przepisami ustawy, że przyjmując zasady rachunkowości, spółki mogą stosować krajowe standardy rachunkowości. W wypadku braku odpowiedniego standardu krajowego, spółki, inne niż wymienione w art. 2 ust. 3, mogą stosować MSR. Zatem spółki, które nie sporządzają sprawozdań finansowych zgodnie z MSR, stosują w pierwszej kolejności Ustawę o rachunkowości oraz rozporządzenia wykonawcze do tej ustawy, a dopiero w sprawach nieuregulowanych postanowieniami tej ustawy mogą stosować krajowe standardy rachunkowości. Zaś w wypadku braku odpowiedniego standardu krajowego takie spółki mogą również stosować MSR.

Tab. 3. Wykaz międzynarodowych standardów rachunkowości

\begin{tabular}{|c|c|}
\hline Numer & Tytuł międzynarodowego standardu rachunkowości \\
\hline 1 & Prezentacja sprawozdań finansowych \\
\hline 2 & Zapasy \\
\hline 3 & Skonsolidowane sprawozdania finansowe (zastąpiony przez MSR nr 27 i MSR nr 28) \\
\hline 4 & Amortyzacja (zastąpiony przez MSR nr 16 i MSR nr 38) \\
\hline 5 & Informacje prezentowane w sprawozdaniach finansowych (zastąpiony przez MSR nr 1) \\
\hline 6 & Uwzględnianie zmian cen (zastąpiony przez MSR nr 15) \\
\hline 7 & Rachunek przepływów pieniężnych \\
\hline 8 & Zasady (polityka) rachunkowości, zmiany wartości szacunkowych i korygowanie błędów \\
\hline 9 & Koszty badań i rozwoju (zastąpiony przez MSR nr 38) \\
\hline 10 & Zdarzenia następujące po dniu bilansowym \\
\hline 11 & Umowy o ustugę budowlana \\
\hline 12 & Podatek dochodowy (zaktualizowany w 2000 r.) \\
\hline 13 & $\begin{array}{l}\text { Prezentacja bieżacych aktywów (majątku obrotowego) i bieżących zobowiązań (zastąpiony } \\
\text { przez MSR nr 1) }\end{array}$ \\
\hline 14 & Sprawozdawczość wedlug segmentów działalności (obowiązujący do końca 2008 r.) \\
\hline 15 & Informacje odzwierciedlające skutki zmian cen (wycofany w 2003 r.) \\
\hline 16 & Rzeczowe aktywa trwate \\
\hline 17 & Leasing \\
\hline 18 & Przychody \\
\hline 19 & Świadczenia pracownicze \\
\hline 20 & Rachunkowość dotacji rzadowych i informacji o pomocy rzadowej \\
\hline 21 & Skutki zmian kursów wymiany walut obcych \\
\hline
\end{tabular}




\begin{tabular}{|c|c|}
\hline 22 & Połaczenie jednostek gospodarczych (zastąpiony przez MSSF nr 3) \\
\hline 23 & Koszty finansowania zewnętrznego \\
\hline 24 & Informacje ujawniane na temat podmiotów powiąanych \\
\hline 25 & Lokaty kapitałowe (inwestycje) (zastąpiony przez MSR nr 39 i MSR nr 40) \\
\hline 26 & Rachunkowość i sprawozdawczość programów świadczeń emerytalnych \\
\hline 27 & Skonsolidowane i jednostkowe sprawozdania finansowe \\
\hline 28 & Inwestycje w jednostkach stowarzyszonych \\
\hline 29 & Sprawozdawczość finansowa w warunkach hiperinflacji \\
\hline 30 & Sprawozdania finansowe banków i podobnych instytucji finansowych \\
\hline 31 & Udziały we wspólnych przedsięwzięciach \\
\hline 32 & Instrumenty finansowe - ujawnienie i prezentacja \\
\hline 33 & Zysk przypadający na jedna akcję \\
\hline 34 & Sprawozdawczość finansowa śródroczna \\
\hline 35 & Zaniechanie (części) działalności gospodarczej (zastąpiony przez MSSF nr 5) \\
\hline 36 & Utrata wartości aktywów \\
\hline 37 & Rezerwy, zobowiazania warunkowe i aktywa warunkowe \\
\hline 38 & Wartości niematerialne \\
\hline 39 & Instrumenty finansowe: ujmowanie $i$ wycena \\
\hline 40 & Nieruchomości inwestycyjne \\
\hline 41 & Rolnictwo \\
\hline
\end{tabular}

Źródło: opracowanie własne.

Tab. 4. Wykaz interpretacji SIC do międzynarodowych standardów rachunkowości

\begin{tabular}{|c|c|c|}
\hline Numer & Nazwa interpretacji Komitetu Stalego & Zastąpiony przez \\
\hline 1 & $\begin{array}{l}\text { Spójność - różne metody ustalania ceny nabycia lub kosztu wytworzenia } \\
\text { zapasów }\end{array}$ & MSR 2 \\
\hline 2 & Spójność - aktywowanie kosztów finansowania zewnętrznego & MSR 8 \\
\hline 3 & $\begin{array}{l}\text { Wyłaczenie niezrealizowanych zysków } i \text { strat wynikających z transakcji } \\
z \text { jednostkami stowarzyszonymi }\end{array}$ & MSR 28 \\
\hline 6 & Koszty modyfikacji dotychczasowego oprogramowania komputerowego & MSR 16 \\
\hline 7 & Wprowadzenie waluty euro & \\
\hline 8 & Zastosowanie po raz pierwszy MSR jako podstawy rachunkowości & MSSF 1 \\
\hline
\end{tabular}




\begin{tabular}{|c|c|c|}
\hline 9 & $\begin{array}{l}\text { Połaczenie jednostek gospodarczych - podziat na przejęcia i łączenia } \\
\text { udziałów }\end{array}$ & MSSF 3 \\
\hline 10 & $\begin{array}{l}\text { Pomoc rzadowa - brak konkretnego powiąania z działalnościa } \\
\text { operacyjna }\end{array}$ & \\
\hline 11 & $\begin{array}{l}\text { Wymiana walut - aktywowanie strat wynikajacych ze znacznej dewalu- } \\
\text { acji waluty }\end{array}$ & MSR 21 \\
\hline 12 & Konsolidacja-jednostki specjalnego przeznaczenia & \\
\hline 13 & $\begin{array}{l}\text { Wspótkontrolowane kontrolowane jednostki-niepieniężny wkład } \\
\text { wspólników }\end{array}$ & \\
\hline 14 & $\begin{array}{l}\text { Rzeczowe aktywa trwałe - odszkodowania dotyczace utraty wartości } \\
\text { poszczególnych składników aktywów lub ich utracenia przez jednostkę }\end{array}$ & MSR 16 \\
\hline 15 & Leasing operacyjny - specjalne oferty promocyjne & \\
\hline 16 & $\begin{array}{l}\text { Kapitat akcyjny - wykupione własne instrumenty kapitałowe } \\
\text { (akcje własne) }\end{array}$ & \multirow[t]{2}{*}{ MSR 32} \\
\hline 17 & Kapitat wtasny - koszty transakcji kapitałowych & \\
\hline 18 & Spójność - metody alternatywne & MSR 8 \\
\hline 19 & $\begin{array}{l}\text { Waluta sprawozdawcza-wycena i prezentacja sprawozdań finansowych } \\
\text { zgodnie z MSR } 21 \text { i MSR } 29\end{array}$ & MSR 21 \\
\hline 20 & Metoda praw własności - ujmowanie strat & MSR 28 \\
\hline 21 & $\begin{array}{l}\text { Podatek dochodowy - realizacja wartości przeszacowywanych aktywów, } \\
\text { które nie podlegaja amortyzacji }\end{array}$ & \\
\hline 22 & $\begin{array}{l}\text { Połączenie jednostek gospodarczych-późniejsze korekty wykazanej } \\
\text { początkowo wartości godziwej i wartości firmy }\end{array}$ & MSSF 3 \\
\hline 23 & Rzeczowe aktywa trwałe - koszty generalnych przegladów i remontów & MSR 16 \\
\hline 24 & $\begin{array}{l}\text { Zysk przypadajacy na jedna akcję - instrumenty finansowe oraz inne } \\
\text { umowy z możliwościa rozliczenia } w \text { akcjach }\end{array}$ & MSR 33 \\
\hline 25 & $\begin{array}{l}\text { Podatek dochodowy-zmiana statusu podatkowego jednostki } \\
\text { gospodarczej lub jej udziałowców }\end{array}$ & \\
\hline 27 & Ocena istoty transakcji wykorzystujących prawna forma leasingu & \\
\hline 28 & $\begin{array}{l}\text { Połaczenie jednostek gospodarczych - ,data wymiany” oraz wartość } \\
\text { godziwa instrumentów kapitałowych }\end{array}$ & MSSF 3 \\
\hline 29 & Ujawnianie informacji-umowy na ustugi koncesjonowane & \\
\hline 30 & Waluta sprawozdawcza - przeliczenie waluty wyceny na walute prezentacji & MSR 21 \\
\hline 31 & Przychody - transakcje barterowe obejmujace ustugi reklamowe & \\
\hline 32 & Wartości niematerialne - koszt witryny internetowej & \\
\hline 33 & $\begin{array}{l}\text { Metoda konsolidacji i metoda praw własności-potencjalne prawa } \\
\text { głosu i przyporzadkowanie udziałów własnościowych }\end{array}$ & $\begin{array}{l}\text { MSR } 27 \\
\text { MSR } 28\end{array}$ \\
\hline
\end{tabular}

Źródło: opracowanie własne. 
Tab. 5. Wykaz międzynarodowych standardów sprawozdawczości finansowej oraz ich interpretacji IFRIC

\begin{tabular}{|c|c|c|}
\hline \multirow{8}{*}{ MSSF } & 1 & $\begin{array}{l}\text { Zastosowanie międzynarodowych standardów sprawozdawczości finansowej } \\
\text { po raz pierwszy }\end{array}$ \\
\hline & 2 & Płatności regulowane akcjami \\
\hline & 3 & Grupy kapitałowe - połaczenia jednostek gospodarczych \\
\hline & 4 & Umowy ubezpieczeniowe \\
\hline & 5 & Aktywa trwałe przeznaczone na sprzedaż i zaprzestanie działalności \\
\hline & 6 & Poszukiwania i ocena złóż mineralnych \\
\hline & 7 & Instrumenty finansowe \\
\hline & 8 & Segmenty operacyjne \\
\hline \multirow{5}{*}{ IFRIC } & 1 & $\begin{array}{l}\text { Zmiany istniejacych zobowiazań z tytulu wycofania z eksploatacji, rekultywacji } \\
\text { i zobowiqzań o podobnym charakterze }\end{array}$ \\
\hline & 2 & Udzialy i podobne instrumenty kapitałowe w podmiotach o charakterze spótdzielni \\
\hline & 3 & Prawa do emisji \\
\hline & 4 & Ustalenie, czy umowa zawiera $w$ sobie elementy leasingu \\
\hline & 5 & Prawo do funduszy zwiazanych z usunięciem skutków zniszczenia środowiska \\
\hline
\end{tabular}

Źródło: opracowanie własne.

\section{Międzynarodowy standard sprawozdawczości finansowej dla malych $i$ średnich przedsiębiorstw}

Kończąc dotychczasowe rozważania, należy wspomnieć o opracowanym przez Radę Międzynarodowych Standardów Rachunkowości standardzie dla małych i średnich przedsiębiorstw - MSSF dla MŚP. Końcowy raport grupy ekspertów: System rachunkowości dla matych przedsiębiorstw - rekomendacje i dobre praktyki opublikowany został w listopadzie $2008 \mathrm{r}$. Standard został natomiast opublikowany 9 lipca 2009 r. Jest on samodzielnym dokumentem (niewchodzącym w skład MSSF) obejmującym zasady rachunkowości analogiczne do pełnego zestawu MSR/MSSF w wersji uproszczonej, dopasowanej do potrzeb mniejszych jednostek.

Międzynarodowy standard sprawozdawczości finansowej dla matych i średnich przedsiębiorstw składa się z 34 rozdziałów, które obejmują łącznie około 230 stron. Jego struktura tematyczna nadaje mu formę instrukcji. Rada dołączyła do tego standardu dwie broszury uzupełniające.

Rada Międzynarodowych Standardów Rachunkowości nie podaje jednoznacznej definicji małych i średnich przedsiębiorstw. Określa jedynie, że standard ten został stworzony dla podmiotów niemających statusu zainteresowania publicznego, a publikujących sprawozdania finansowe ogólnego przeznaczenia dla użytkowników zewnętrznych, którymi mogą być m.in.: agencje ratingowe i kredytodawcy.

Na razie Polska nie zdecydowała się na przyjęcie MSSF dla MŚP, przy czym do niewątpliwych korzyści płynących ze stosowania globalnych standardów dla MSP należałoby zaliczyć:

- zwiększenie porównywalności informacji finansowych dostarczanych użytkownikom,

- zmniejszenie kosztów tworzenia i aktualizowania krajowych przepisów w zakresie sprawozdawczości, 
- ułatwienie gromadzenia kapitału na forum krajowym i zagranicznym,

- ułatwienie wejścia jednostkom na publiczne rynki kapitałowe gdzie obowiązują MSSF (Tokarski A., Tokarski M., Voss 2010, s. 47-49).

Międzynarodowy standard sprawozdawczości finansowej dla matych i średnich przedsiębiorstw jest dużym krokiem w kierunku harmonizacji i standaryzacji przepisów dla tego typu jednostek na całym świecie, a jego wdrożenie z pewnością doprowadziłoby do zwiększenia jakości i porównywalności informacji przekazywanych przez przedsiębiorstwa, jak również uwiarygodniłoby je w oczach instytucji finansowych oraz kontrahentów, przy czym zakres informacji generowanej przez rachunkowość MŚP musi umożliwić odwzorowanie jego głównych cech i być dostosowana przede wszystkim do możliwości prezentowanych przez jej odbiorców.

Jednym z terminów, które w ostatnich latach zrobiły błyskotliwą karierę, jest globalizacja. Choć różnie się ją pojmuje, to bez wątpienia jest ona konsekwencją nowych rozwiązań problemów ekonomicznych, społecznych, technicznych, ekologicznych itd. zachodzących w skali świata na przełomie XX i XXI w. Zainteresowanie terminem globalizacja w teorii i praktyce zarządzania wynika z procesów koncentracji kapitału i tworzenia się wielu ponadnarodowych organizacji. To owocuje konkurencją na skalę dotychczas nieznaną także na rynkach regionalnych i krajowych, co z kolei prowadzi do przeobrażeń w funkcjonowaniu instytucji gospodarczych i administracyjnych.

Przejrzyste informacje o spółkach są obecnie bardziej potrzebne niż kiedykolwiek, gdyż inwestorzy potrzebują jasnych, wiarygodnych i porównywalnych w skali międzynarodowej informacji finansowych oraz niefinansowych, na podstawie których będą mogli podejmować decyzje inwestycyjne. Bez spełnienia tego warunku inwestorzy łatwo mogą stracić zaufanie pokładane w spółce i jej perspektywach rozwoju, stąd niezbędne jest dalsze dążenie do standaryzacji zasad rachunkowości w celu harmonizacji przepisów na świecie.

Idealna sytuacja dla odbiorców informacji finansowych zaistniałaby wówczas, gdyby wszystkie podmioty gospodarcze na całym świecie stosowały jednolite koncepcje i zasady rachunkowości oraz opracowywały swoje sprawozdania finansowe zgodnie ze zunifikowanymi wzorcami i standardami, obowiązującymi we wszystkich krajach świata. Idea ta jednak na razie jest utopią, gdyż istniejące koncepcje oraz zasady rachunkowości obowiązujące w poszczególnych krajach charakteryzują się rozbieżnościami, co wynika m.in. z odmiennych uwarunkowań historycznych, różnic w rozwoju gospodarczym poszczególnych krajów, a także odrębności ich systemów prawnych (Turyna 2006). Z tego względu więc szczególnego znaczenia nabiera dalsza kwestia harmonizacji (standaryzacji) zasad rachunkowości. Harmonizacja jest dokonywana na bieżąco, gdyż w wypadku przepisów i standardów rachunkowości nie kończy się ona na zastosowaniu dyrektyw. Jest to proces ciągły, dostosowujący regulacje prawne do zmieniających się warunków gospodarowania. Jednocześnie prowadzony jest proces ujednolicenia MSSF z regulacjami wynikającymi z amerykańskich zasad rachunkowości. Efektem tego procesu są już liczne zmiany wprowadzone do MSR oraz MSSF, a także zmiany dokonane w US GAAP przez amerykańską instytucję FASB (Federal Accounting Standard Board Federalna Rada Standardów Rachunkowości) odpowiedzialną za kształtowanie standardów amerykańskich. Wszystkie te procesy prowadzą nieuchronnie do powstania jednolitego, ogólnoświatowego języka biznesu, który przyczynić się ma do swobodnego przepływu kapitału, a co za tym idzie - dalszego rozwoju gospodarki światowej. 


\section{Literatura}

1. Jaruga A. (red.), 2002, Międzynarodowe regulacje rachunkowości. Wpływ na rozwiązania krajowe, C.H. Beck, Warszawa.

2. Messner Z., Pfaff J., 2010, Podstawy rachunkowości finansowej, Stowarzyszenie Księgowych w Polsce, Warszawa.

3. Roberts C., Weetman P., Gordon P., 1998, International Financing Accounting. A Comparative Approach, Pitman Publishing, Londyn-San Francisco-Kuala Lumpur-Johannesburg.

4. Tokarski A., Tokarski M., Voss G., 2010, Księgowość w małej i średniej firmie. Uproszczone formy ewidencji, wyd. II zmienione, Cedewu, Warszawa.

5. Turyna J., 2006, Standardy sprawozdawczości finansowej-MSSF, US GAAP, polskie ustawodawstwo, Difin, Warszawa.

6. www.iasb.org.uk

\section{International Financial Reporting Standards in the Process of Harmonization and Standardization of Accountancy in Poland}

Accountancy as a science prides in long history and occupies a special place in the contemporary system of economic and management sciences. Progressing process of globalization of economy brings about the need to harmonize the science of accountancy. The creation of international accountancy standards and amendments to Polish Accountancy Law may be perceived as signs of the process. That rule governs any new issues arising from the necessity of drawing closer the accountancy to the developing capital markets. Due to the fact that the degree of accuracy of the regulations in the book-keeping in various countries is different, the endeavour to standardize the accountancy principles in order to harmonize law regulations came into play and has been shown in the article. 


\section{Grażyna Voss}

Wyższa Szkoła Bankowa

w Toruniu

\section{Rachunkowość kreatywna - ukryty program edukacyjny}

Szkolne i pozaszkolne formy kształcenia są odzwierciedleniem ładu i nieładu społecznego, o czym świadczą przeprowadzane reformy i liczne zmiany w systemach edukacyjnych. Jednak $\mathrm{w}$ całym procesie kształcenia najszybciej na zachodzące zmiany w otoczeniu reaguje edukacja dorosłych, która skupia w sobie problemy społeczne, ekonomiczne i polityczne państwa. Nauki ekonomiczne podatne są także na wpływ czynników o zasięgu międzynarodowym, wynikającym z globalizacji rynku. Ponadto zmiany wynikają z uwarunkowań i wytycznych międzynarodowych w zakresie harmonizacji i standaryzacji procesów gospodarczych oraz z przejmowania przez podmioty gospodarcze przyjętych na świecie dobrych praktyk gospodarczych. Przedstawione elementy stają się wyznacznikami i świadczą o specyficznych cechach edukacji dorosłych, w odniesieniu do przedziału czasowego, w którym te zjawiska miały miejsce.

Specyfika kształcenia dorosłych w systemie szkolnictwa wyższego i systemie pozaszkolnym (fundacje, stowarzyszenia, organizacje społeczne, spółki prawa handlowego) w określonym okresie historycznym nazywana jest kulturą edukacyjną dorosłych i w Polsce można ja odnieść do edukacji sprzed 1989 r., nazywanej starą kulturą edukacyjną dorosłych i edukacji, którą obserwujemy po 1989 r., nazywanej quasi-nową. Kultura ta niewątpliwie wpisuje się w uwarunkowania wolnego rynku, wpływające na usługi edukacyjne poprzez otwarte programy kształcenia, czyli student-klient, odbiorca usług edukacyjnych. Kulturę organizacyjną można rozpatrywać w różnych płaszczyznach związanych z funkcjonowaniem szkolnictwa, jednak w odniesieniu do procesu kształcenia można wyróżnić:

- formę i czas trwania procesu edukacyjnego,

- organizację procesu uczenia (planowanie, program kształcenia),

- przygotowanie (dobór treści i metod),

- realizację (sposób komunikowania się, w tym e-learning).

\section{Rachunkowość kreatywna}

Pojęcie kreatywny od łac. creatio oznacza 'tworzenie'. W potocznym znaczeniu kreatywność oznacza działanie niekonwencjonalne i z pomysłem. W swoim podstawowym znaczeniu jest ono pozytywne, a mimo to nie zawsze jest tak postrzegane w rachunkowości. Tymczasem rachunkowość kreatywna to kreatywność, twórczość oraz wykorzystanie dostępnych metod do tworzenia obiektywnego sprawozdania finansowego. Opisane działania powinny być tak wykorzystane, aby ich zastosowanie nie kolidowało z krajowymi i międzynarodowymi regulacjami prawnymi.

Kreatywną rachunkowość nazywa się również twórczą księgowością i często uważa za przejaw nieuczciwych praktyk księgowych, czyli działań zmierzających do wprowadzenia w błąd użytkowników sprawozdań finansowych. Rachunkowość w wyniku dokonywanych w ciągu 
roku obrotowego pomiarów, wyceny i rejestracji operacji gospodarczych zgodnie z przyjętymi zasadami prawa bilansowego i regulacjami o zasięgu międzynarodowym tworzy zbiór informacji księgowych, którego efektem finalnym jest sprawozdanie. Manipulacja danymi nie ma nic wspólnego ze zjawiskami, które zaszły w rzeczywistości. Przedstawianie nieprawdziwego obrazu jednostki może dać pewną przewagę konkurencyjną nad innymi podmiotami na rynku. Ukrywanie wiarygodnego i rzetelnego obrazu jednostki na dłuższą metę jest jednak niemożliwe i zostaje zweryfikowane przez rzeczywistość gospodarczą (Kolśnik 2006). Przyczyn popełniania oszustw jest wiele i są one uzależnione od sytuacji na rynku, w tym także od interesów właścicieli. Częstą przyczyną kreatywności jest chęć ukrycia niepowodzeń związanych z brakiem realizacji zamierzonych celów finansowych przez jednostkę. Celem tych nadużyć jest przedstawienie nieprawidłowych danych w sprawozdaniu finansowym, a także zniekształcenie rzeczywistego obrazu sytuacji majątkowej i finansowej. Zmiany w gospodarce będące skutkiem globalizacji procesów gospodarczych stawiają ogromne wyzwanie dla osób zarządzających, przetrwanie i utrzymanie się na rynku jest zadaniem niezmiernie trudnym i jednocześnie coraz bardziej ryzykownym. Złożoność współczesnej gospodarki światowej poddała wielkiej próbie zasady wynikające z norm etycznych stosowanych w biznesie. Zjawisko to dotyczy głównie kadry kierowniczej działającej pod presją zaostrzającej się konkurencji i wyborów moralnych dokonywanych w czasach zwiększającej się konkurencji, niepewności i kryzysu. W czasie kryzysu pokusa na stworzenie - wykreowanie sprawozdania finansowego jest coraz większa. Dlatego warto zawsze zadać pytanie, gdzie są granice, których nie należy przekroczyć?

Całkowita eliminacja oszustw nie jest w praktyce możliwa, a fałszowaniu sprawozdań finansowych powinno przeciwdziałać badanie sprawozdań przez biegłego rewidenta. Jednak obecnie w Polsce, zgodnie z Ustawą o rachunkowości, większość przedsiębiorstw nie podlega temu obowiązkowi. Ponadto ryzyko niewykrycia oszustwa przez biegłego rewidenta jest znacznie większe niż ryzyko niewykrycia istotnych nieprawidłowości.

Od rachunkowości kreatywnej w negatywnym znaczeniu tego określenia należy odróżnić rachunkowość agresywną, czyli fryzowanie zysków, pokazywanie nieuczciwych wyników finansowych (Wiatr 2008). Rachunkowość agresywna związana jest z oszustwem mającym znamiona działań zaplanowanych, których celem jest ukrycie prawdy o sytuacji majątkowej i finansowej. Wykorzystuje się w niej wyrafinowane metody, a wykrycie oszustwa stanowi niemałe wyzwanie.

Kreatywna, a nawet agresywna rachunkowość nie jest zjawiskiem nowym, przypadki jej stosowania znane są od dziesięcioleci. W celu określania tego typu zjawisk używano określenia triki finansowe (Gut 2006, s. 2).

\section{Etyka w biznesie}

Etyka jest dziedziną filozofii istniejącą ponad 2 tys. lat. W czasach Arystotelesa, a nawet od czasów Sokratesa różni filozofowie poświęcali jej dużo czasu. Starożytni zastanawiali się nad kryteriami dobra i zła, nad zakresem obowiązków oraz nad istotą i sposobami uzasadnienia norm moralnych. W obecnych czasach etyka jest zbiorem różnych teorii. Jedna z nich, nazywana deontologiczną (gr. deon - 'obowiązek') stawia następujące pytania:

- Jakie są nasze powinności?

- Jak powinniśmy postępować?

- Według jakich norm powinniśmy działać?

- Jakich zakazów i nakazów przestrzegać?

Inne podejście w etyce przedstawia teoria aksjomatyczna (gr. axio - 'wartość') operująca pytaniami:

- Jak osiągnąć wartości przez nas cenione? 
- Do czego dążyć?

- Jak to osiągnąć?

Trzecia grupa teorii nazywanych teoriami aretologicznymi (gr. arete - 'cnota') odpowiada na pytania:

- Kim chcielibyśmy być?

- Jak postępować, by żyć w zgodzie z samym sobą?

- Co robić, aby mieć poczucie własnej wartości?

Etyka zajmuje się opisem i analizą powyższych teorii. Trudno ustalić, jakie są zależności między wiedzą etyczną, znajomością stanowisk i argumentów etycznych a postawami zajmowanymi w życiu. Zdaniem M. Środy, dobroci nie można się nauczyć i nie można jej wymagać, uczciwości trzeba się nauczyć i wymagać jej należy.

Potrzeba istnienia Kodeksu zawodowej etyki w rachunkowości wynika ze świadomości, iż rachunkowość jest nierozerwalnie związana z działalnością gospodarczą i społeczną. Jakość pracy świadczonej przez osoby wykonujące taki zawód określa w dużej mierze nie tylko rozwój zatrudniającej je jednostki. Wpływa ona bowiem także na decyzje różnych grup użytkowników informacji pochodzących z rachunkowości. Kodeks zawodowej etyki w rachunkowości zawiera regulację etycznego postępowania w zakresie najistotniejszych sfer aktywności zawodowej osób zajmujących się rachunkowością, a także zobowiązuje każdą osobę zajmującą się rachunkowością do przestrzegania zasad etyki i postępowania zgodnie $\mathrm{z}$ duchem rozwoju zawodu w dziedzinie rachunkowości i globalnego otoczenia, w którym jest wykonywany. Ponadto ma on również za zadanie informować otoczenie gospodarcze, że w dziedzinie rachunkowości wypracowano określone zasady zapewniające wykonywanie związanej z nim pracy w sposób rzetelny, profesjonalny i odpowiedzialny (Kodeks zawodowej etyki w rachunkowości 2007, s. 13).

\section{Dydaktyka w rachunkowości}

Standardy kształcenia dla kierunku studiów finanse i rachunkowość, studia pierwszego stopnia, w grupie treści kierunkowych przewidują kształcenie w zakresie rachunkowości finansowej obejmujące: koncepcje i zasady rachunkowości finansowej, harmonizację i standaryzację rachunkowości - międzynarodowe normy i wzorce, zasady wyceny bieżącej i wyceny bilansowej aktywów i pasywów - przeszacowania, odpisy aktualizujące, szczegółowe problemy wyceny, ewidencji i sprawozdawczości aktywów trwałych i obrotowych - aktywa operacyjne i aktywa inwestycyjne, zobowiązania finansowe oraz rezerwy bilansowe i pozabilansowe, kapitał własny, przychody i koszty, rodzaje wyników finansowych, prowadzenie ksiąg rachunkowych, skonsolidowana sprawozdawczość finansowa, obowiązki sprawozdawcze przedsiębiorstwa.

Studia drugiego stopnia przewidują w zakresie standardów sprawozdawczości finansowej następujące treści: koncepcyjne założenia sporządzania i prezentacji sprawozdań finansowych, prezentacja instrumentów finansowych w sprawozdawczości, ujęcie rzeczowych aktywów trwałych i wartości niematerialnych, utrata wartości aktywów, prezentacja kapitałów własnych oraz zobowiązań, sprawozdanie zmian w kapitale własnym, aktywa i zobowiązania z tytułu podatku dochodowego, ujęcie przychodów.

Można przyjąć, że kształcenie zawodowe ma na celu:

- opanowanie wiedzy zawodowej,

- przygotowanie do pracy poprzez opanowanie metod, środków i form działania, typowych dla zawodu,

- kształtowanie postaw i przekonań naukowych związanych z przyszłym zawodem,

- rozwinięcie specjalnych uzdolnień, ważnych dla zawodu,

- rozwinięcie potrzeb, motywów i zainteresowań związanych z danym zawodem, 
- wdrożenie do ciągłego doskonalenia kwalifikacji zawodowych poprzez samokształcenie (Okoń 2003).

Współczesne szkolnictwo wyższe odchodzi od tradycyjnego modelu kształcenia. Coraz mniejszy nacisk kładzie się na podawanie wiedzy w formie wykładu. Ważniejsze staje się przygotowanie studenta do aktywnego zdobywania wiedzy oraz rozwoju samodzielnego myślenia i twórczego przetwarzania zdobytej wiedzy. Rozwijanie aktywności i motywacji do zdobywania wiedzy studenta w procesie kształcenia skutkuje w późniejszym czasie umiejętnością rozwiązywania złożonych problemów, które napotyka się w pracy zawodowej. Jednostka zmotywowana twórczo, wyzwolona ze schematycznego sposobu rozwiązywania zadań, jest osobą przedsiębiorczą, posiadającą inicjatywę podejmowania wyzwań, poszukującą niestandardowych rozwiązań. Staje się jednostką twórczą - kreatywną (Kuźbicka 2007).

W procesie kształcenia jako jedną z metod dydaktycznych wykorzystuje się projekt. Jest to metoda planowania, organizowania i oceniania własnej nauki, mająca na celu wykształcenie umiejętności zastosowania zdobytej wiedzy w praktyce. Istotą jej jest to, iż studenci samodzielnie (lub w zespołach, najlepiej trzech- lub pięcioosobowych) realizują jedno duże zadanie. Zwyczajowo przyjmuje się możliwość realizacji zadań przekrojowych lub mających charakter interdyscyplinarny, wymuszających na wykonawcy powiązania wiedzy z różnych obszarów lub obszarów z pogranicza treści podstawowych projektu. Celem tej metody jest kształtowanie umiejętności planowania, organizowania pracy własnej, zbierania i selekcjonowania informacji, rozwiązywania problemów, pracy w grupie, podejmowania decyzji, oceniania i komunikowania się.

Wykorzystanie metody projektu przebiega etapowo, zaczyna się od ustalenia przez wykładowcę treści, które będą realizowane, następnie następuje zapoznanie studentów z wybraną metodą. Omówienie wszystkich zagadnień często jest niemożliwe, dlatego warto odwołać się do literatury przedmiotu, nie ograniczając studenta jedynie do materiałów zaprezentowanych w trakcie wykładów czy konwersatoriów. Etap ten ma na celu wzbudzić zainteresowanie tematyką, pokazać problemy, które mogą się pojawić w danym obszarze oraz możliwości ich rozwiązania. Należy również zaproponować literaturę pomocną (ale nie jedyną) przy realizacji projektu. Następny etap to wybór tematyki (obszarów i poruszanych zagadnień). W jego trakcie można pozwolić na pewną dowolność i samodzielność w wyborze tematu, można także podać listę tematów do wyboru lub opracować jeden temat dla wszystkich.

Przygotowanie do realizacji projektu powinno zawierać:

- opracowanie instrukcji do projektu, w której opisane zostaną cele i standardy, które powinny się znaleźć w projekcie,

- ustalenie konsultacji (jeśli prowadzący przewiduje pytania indywidualne ze strony studentów),

- opracowanie kryterium oceny.

Mocne strony metody projektu to:

- integracja zespołu,

- nauka samodzielności i stosowania zdobytej wiedzy w praktyce,

- nauka poszukiwania i selekcjonowania informacji oraz posługiwania się nowymi źródłami informacji.

Słabe strony metody projektu to:

- długi czas realizacji,

- możliwość powielania przyjętych rozwiązań.

Chcąc osiągnąć sukcesy i być zadowolonym ze swojej pracy zawodowej, absolwent musi nauczyć się planowania i organizacji własnej pracy, podejmowania decyzji i dokonywania właściwych wyborów. Metoda projektu pozwoli na zdobycie opisanych umiejętności, które będą wykorzystane w działalności pozaszkolnej, w tym działalności zawodowej. 
Nauczanie staje się sztuką. Wspieraniem rozwoju profesjonalnego jest dokształcanie zawodowe, które umożliwia transfer wiedzy i umiejętności z sali wykładowej do praktyki zawodowej (Matlakiewicz, Solarczyk-Szwec 2009).

Tab. 1. Czynniki procesu wdrażania efektów szkolenia

\begin{tabular}{|c|l|c|c|c|c|c|}
\hline $\begin{array}{c}\text { Transfer wiedzy } \\
\text { i umiejętności }\end{array}$ & $=$ & $\begin{array}{c}\text { Poziom } \\
\text { szkolenia }\end{array}$ & + & $\begin{array}{c}\text { Motywacja } \\
\text { uczestników }\end{array}$ & + & $\begin{array}{c}\text { Warunki i możliwości } \\
\text { w miejscu pracy }\end{array}$ \\
\hline
\end{tabular}

Źródło: B. Kalinowska, Zarządzane efektami szkoleń [w:] M. Owczarz (red.), Poradnik edukatora, CODN, Warszawa 2005, s. 256.

Niestety, często się tak zdarza, iż w praktyce udział w zajęciach dydaktycznych stosunkowo rzadko wiąże się z wykorzystaniem jego efektów w pracy zawodowej. Zjawisko takie w literaturze zostało nazwane luką transferu efektów szkolenia do praktyki zawodowej. Na poziom zastosowania wiedzy i umiejętności w rzeczywistych warunkach wpływają:

a) metody:

- prezentacja teorii, opis nowych umiejętności i ich zastosowania,

- demonstracja nowych umiejętności,

- praktyczne zastosowanie nowych umiejętności w symulowanych warunkach,

- przekazanie informacji zwrotnej o zastosowaniu nowych umiejętności w symulowanych warunkach,

- opracowanie planu zastosowania nowych umiejętności w rzeczywistych warunkach,

- udzielanie indywidualnej pomocy w zastosowaniu nowych umiejętności w rzeczywistych warunkach;

b) efekty doskonalenia:

- uświadamianie potrzeby nabycia nowych umiejętności,

- zdobycie usystematyzowanej wiedzy o nowych umiejętnościach,

- nabycie nowych umiejętności,

- praktyczne zastosowanie nowych umiejętności (Kalinowska 2005, s. 257).

\section{Ukryty program edukacyjny}

Ukryty program to wszystko to, czego studenci uczą się i poznają oraz czego doświadczają w trakcie studiów, a co jest poza oficjalnym programem nauczania, poza oficjalnymi celami kształcenia, czego świadomie lub nieświadomie chce nauczyć wykładowca, a co jest niezmiernie ważne dla efektów kształcenia. Prowadząc zajęcia z zakresu rachunkowości, przedstawiamy treści kształcenia w świetle przyjętych standardów, jednak nie wszystkie elementy procesu edukacyjnego oparte są wyłączne na treściach kształcenia. Przytaczając liczne przykłady z praktyki, omawiamy zarówno dobre praktyki gospodarcze, jak i negatywne skutki nadużyć. Omawiamy zasady rachunkowości oraz możliwości dokonywania wyboru na etapie tworzenia polityki rachunkowości jak również w przyjętych rozwiązaniach praktycznych. Opierając się na projekcie, pozwalamy na dowolność wyboru metod wyceny, zastosowanych wariantów i regulacji prawnych, w świetle których prezentujemy sprawozdania finansowe.

Mniej lub bardziej świadomie prezentujemy więc rachunkowość kreatywną jako ukryty program. O ukrytych programach warto mówić ze względu na skutki, które powodują w procesie kształcenia. Można tutaj wymienić przynajmniej dwie istotne w skutkach konsekwencje:

- brak wiedzy, umiejętności i świadomości studentów o skutkach stosowania rachunkowości kreatywnej bez odpowiedniej wiedzy merytorycznej może doprowadzić do nieprawidłowości, a w ostateczności do nadużyć, 
- brak zajęć z etyki w biznesie, a tym samym propagowania zagadnień zawartych w Kodeksie zawodowej etyki w rachunkowości.

Ujawnienie programu, wyjście z ukrytego programu, przedstawienie rachunkowości kreatywnej, która w połączeniu z etyką stanie się dobrym przygotowaniem i pozwoli na wykorzystanie wiedzy i umiejętności w praktyce zawodowej, może przynieść korzyści społeczne?

Ukryty program edukacyjny może i dotyczy różnych obszarów edukacyjnych, realizowany jest w ramach zajęć dydaktycznych, nie został nazwany i podany do wiadomości uczestników procesu kształcenia. Rachunkowość kreatywna jest zjawiskiem występującym w praktyce księgowej od wielu lat, chociaż od niedawna nazywana jest kreatywną. Rachunkowość jako nauka i składowa treści kształcenia ma swoje ugruntowane miejsce w edukacji, jednak czy proces edukacyjny może wyeliminować negatywne skutki w praktyce? W literaturze rachunkowość kreatywna łączona jest kryzysem. Zdaniem A. Kameli-Sowińskiej, jedyną drogą wyjścia z kryzysu i szansą, że się nie powtórzy, jest szczególny nacisk na etykę, moralność i społeczną odpowiedzialność biznesu (A. Kamela-Sowińska 2009). Zastanawianie się nad ukrytym programem ma sens, o ile uczynimy go jawnym.

\section{Literatura}

1. Gut P., 2006, Kreatywna księgowość a fatszowanie sprawozdań finansowych, C.H. Beck, Warszawa.

2. Kalinowska B., 2005, Zarządzanie efektami ksztatcenia szkoleń, Poradnik edukatora, CODN, Warszawa.

3. Kamela-Sowińska A., 2009, Rachunkowość w czasach kryzysu, „Zeszyty Teoretyczne Rachunkowości” 51, Stowarzyszenie Księgowych w Polsce, Warszawa.

4. Kodeks zawodowej etyki w rachunkowości, 2007, Stowarzyszenie Księgowych w Polsce, Warszawa.

5. Kolaśnik K., 2006, Kreatywna rachunkowość, fatszowanie sprawozdań finansowych, „Buchalter” 35.

6. Kuźbica B., 2007, Ksztatcenie menedżerów w Polsce doby przemian [w:] Andragogika w ujęciu interdyscyplinarnym, W. Horyń, J. Maciejewski (red.), Wydawnictwo Uniwersytetu Wrocławskiego, Wrocław.

7. Matlakiewicz A., Solarczyk-Szwec H., 2009, Dorośli ucza się inaczej, CKU, Toruń.

8. Okoń W., 2003, Wprowadzenie do dydaktyki ogólnej, Wydawnictwo Akademickie Żak, Warszawa.

9. Wiatr M., Kurek M., Bednarek G., 2008, Sprawozdawczość finansowa a kreatywna rachunkowośćpropozycja bilansu wedlug $W$. Osbahra [w:] Polska praktyka rachunkowości $w$ kontekście procesu harmonizacji międzynarodowej sprawozdawczości finansowej, E. Walińska (red.), Oficyna a Wolters Kluwers Business, Warszawa.

\section{Creative Accounting - Indirect Syllabus}

Changes occurring on the market have made possibilities for development of creative accounting, which is omnipresent in the contemporary accounting. Lectures prepared by an educator do not provide teaching creative accounting. However, following curriculum and using method of projects allow learning creative accounting, which has become indirect curriculum. 
Halina Pawlak

Uniwersytet Jagielloński

\section{Ocena wykorzystania środków finansowych w ramach programu „Różnicowanie w kierunku działalności nierolniczej”}

Tereny wiejskie w Polsce charakteryzują się wzrostem zróżnicowania zarówno pod względem gospodarczym, jak i społecznym. Następuje ciągła przemiana tych obszarów, zmienia się też ich funkcja. Zdominowanie przez rolnictwo ustępuje wzrostowi wielofunkcyjności terenów wiejskich. Zwraca się coraz większą uwagę na potrzebę rozwoju pozarolniczych funkcji gospodarczych (Bański 2004).

Wpływ na rozwój alternatywnych źródeł dochodu na wsi mają czynniki społeczne, ekonomiczne i techniczne. Wśród ekonomicznych szczególną rolę odgrywa pomoc finansowa ze środków Unii Europejskiej (Bański 2004). W ostatnich latach wzrasta w Polsce liczba gospodarstw rolniczych, które prowadzą dodatkowo działalność pozarolniczą. W 2005 r. 57\% rodzin wiejskich utrzymywało się z pracy poza gospodarstwami rolniczymi (Błąd 2006). Przystąpienie do Unii Europejskiej i pozyskanie środków wspierających tereny wiejskie postrzegane jest jako szansa na rozwiązanie głównych problemów polskiego rolnictwa: przeludnienia agrarnego, rozdrobnienia gospodarstw czy braku kapitału (Fałkowski 2005). Pobudzanie działalności gospodarczej na obszarach wiejskich będzie pośrednio wpływać na poprawę konkurencyjności i ukierunkowania rynkowego produkcji, ale przede wszystkim może wpłynąć na poprawę jakości życia na wsi (Babuchowska 2009).

Po przystąpieniu Polski do UE tereny wiejskie zostały objęte dwoma programami, w znacznym stopniu finansowanymi ze środków Unii Europejskiej. W latach 2004-2006 realizowany był Sektorowy Program Operacyjny „Restrukturyzacja i modernizacja sektora żywnościowego oraz rozwój obszarów wiejskich” (SPO 2004-2006). Natomiast w latach 2007-2013 był realizowany (i nadal jest) Program Rozwoju Obszarów Wiejskich (PROW).

\section{Wsparcie finansowe dla działalności pozarolniczych na terenach wiejskich - charakterystyka wybranych programów}

Sektorowy Program Operacyjny „Restrukturyzacja i modernizacja sektora żywnościowego oraz rozwój obszarów wiejskich” był realizowany ze środków Unii Europejskiej pochodzących z Europejskiego Funduszu Orientacji i Gwarancji Rolnej (EFOiGR) oraz z krajowych środków publicznych. Program miał na celu poprawę konkurencyjności oraz trwały i zrównoważony rozwój sektora rolnego, a także wsparcie przemysłu przetwórczego i wielofunkcyjnego rozwoju obszarów wiejskich. Powyższe cele realizowano w ramach trzech priorytetów. Priorytet 
drugi to „Zrównoważony rozwój obszarów wiejskich”, a w nim działanie 2.4 „Różnicowanie działalności rolniczej i zbliżonej do rolnictwa w celu zapewnienia różnorodności działań lub alternatywnych źródeł dochodu" (Rdr SPO). Celem działania Rdr SPO było sprzyjanie tworzeniu alternatywnych źródeł dochodów, promowanie pozytywnego wizerunku wsi i rolnictwa w społeczeństwie, sprzyjanie zachowaniu zasobów przyrodniczych obszarów wiejskich, ułatwianie dostępu rolnikom oraz pozostałym mieszkańcom wsi do usług oraz przyczynianie się do zwiększania opłacalności produkcji i usług w gospodarstwie rolnym (SPO 2005). Podjęcie lub rozwój dodatkowej działalności miało na celu wykorzystanie istniejących zasobów gospodarstwa i regionu w celu stworzenia warunków do rozwoju wielofunkcyjnych i trwałych ekonomicznie gospodarstw rolnych (SPO 2005).

W latach 2007-2013 w ramach II filaru Wspólnej Polityki Rolnej wcielany jest w życie Program Rozwoju Obszarów Wiejskich. W ramach tego programu realizowane są cele zebrane w czterech osiach wiodących. Oś trzecia zajmuje się jakością życia na obszarach wiejskich i zajmuje się realizacją programu „Różnicowanie w kierunku działalności nierolniczej” (Rkdn PROW).

Kryteriami określającymi dostęp do programów jest ściśle określone grono odbiorców oraz miejsce ich zamieszkania. Mają to być rolnicy lub domownicy, w rozumieniu przepisów o ubezpieczeniu społecznym rolników, mieszkający na terenie gminy wiejskiej lub wiejsko-miejskiej, z wyłączeniem miejscowości liczących powyżej 5 tys. mieszkańców (SPO 2005, PROW 2010).

Wsparcie oferowane w ramach tych projektów dotyczy działań mających na celu uruchomienie lub rozwój działalności dodatkowej w zakresie: agroturystyki, usług związanych z turystyką i wypoczynkiem, usług na rzecz rolnictwa i gospodarki leśnej, prowadzenia na małą skalę przetwórstwa produktów rolnych lub jadalnych produktów leśnych, sprzedaży bezpośredniej produktów pochodzących w większości z własnego gospodarstwa rolnego (w PROW 2007-2013 wprowadzono dodatkowo sprzedaż detaliczną i hurtową), wytwarzania materiałów energetycznych z biomasy, rzemiosła i rękodzielnictwa oraz usług dla ludności (SPO 2005, PROW 2010).

Pomoc finansowa udzielana jest w formie refundacji części poniesionych kosztów, uznawanych za koszty kwalifikowalne. Maksymalna wysokość pomocy finansowej udzielonej jednemu beneficjentowi i gospodarstwu rolnemu nie może przekroczyć 100 tys. zł w okresie realizacji programu. Koszty kwalifikowalne mogą obejmować budowę, rozbudowę, remont budynków, zakup instalacji technicznej, maszyn i urządzeń, wyposażenia i sprzętu, zagospodarowanie terenu czy zakup środków transportu (SPO 2005, PROW 2010).

\section{Wysokość środków przyznanych dla poszczególnych lat i województw oraz stopień ich wykorzystania}

Podział środków pomiędzy województwa dla działania Rdr SPO i Rkdn PROW dokonywany był na postawie wskaźnika liczebności grupy docelowej gospodarstw, który został skonstruowany w oparciu o wielkość ekonomiczną gospodarstw wyrażoną ESU - Europejską Jednostką Wielkości (Goraj 2005) oraz liczbę ludności zamieszkującej obszary wiejskie w poszczególnych województwach. Na podstawie tego wskaźnika dokonano podziału środków na tzw. koperty regionalne (Uchwała $n r$ 3/2004). 
W ramach SPO 2004-2006 dla działania „Różnicowanie działalności rolniczej i zbliżonej do rolnictwa w celu zapewnienia różnorodności działań lub alternatywnych źródeł dochodu" przeznaczono kwotę 312686 385,00 zł. Łącznie złożono 7170 wniosków na łączną kwotę 524 782 386,36 zł, a więc na 167,8\% dostępnego limitu finansowego. Po weryfikacji formalnej pozostało 6205 wniosków. Ostatecznie podpisano 4106 umów na kwotę 296797 484,81 zł, przy czym płatności zostały zrealizowane na kwotę 282028 241,46 zł dla 4015 wniosków. Jest to $53,4 \%$ sumy przyznanej dla całego programu.

Zainteresowanie działaniem dla poszczególnych województw, jak i wykorzystanie koperty regionalnej, było zróżnicowane. W ramach Rdr SPO najmniej wniosków wpłynęło w lubuskim, zachodniopomorskim i opolskim, a najwięcej w lubelskim, mazowieckim oraz małopolskim (ryc. 1).

Ryc. 1. Liczba wniosków złożonych w ramach działania Rdr SPO

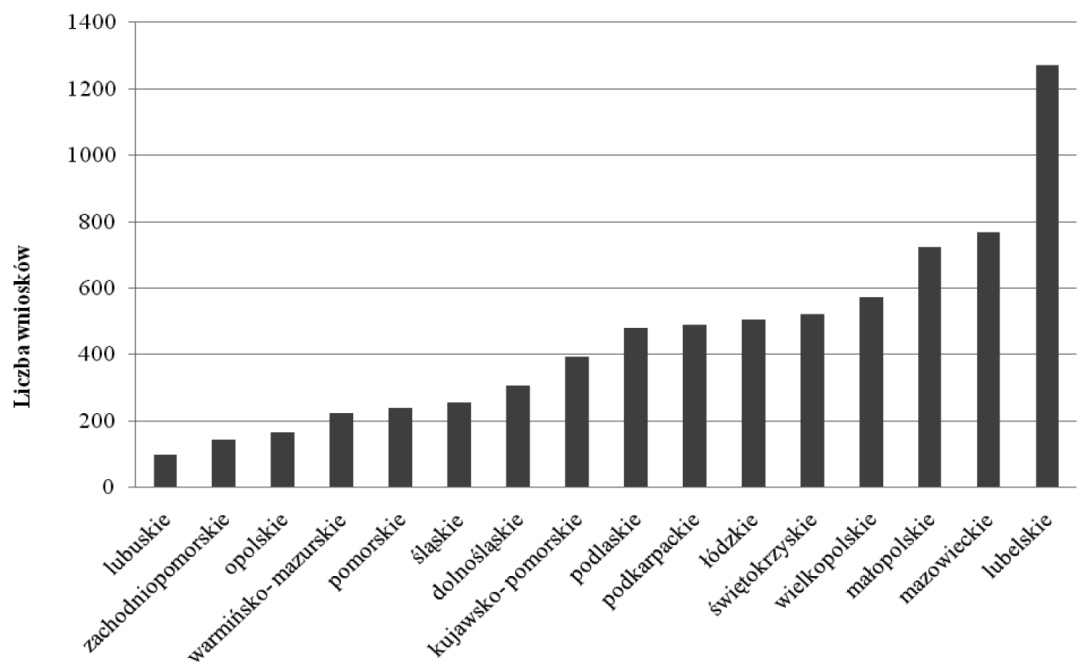

Źródło: opracowanie własne na podstawie danych Systemu Informacji Zarządczej ARiMR.

Innym ważnym elementem obrazującym jakościowe zagospodarowanie środków przeznaczonych do ww. programu jest stopień wykorzystania kwoty, którą beneficjent zadeklarował we wniosku o finansowanie działalności. Porównanie wartości kwoty planowanej do wykorzystania przy finansowaniu inwestycji oraz kwoty przyznanej wykazuje, że najlepiej wykorzystano środki w województwach: świętokrzyskim, lubelskim i małopolskim (powyżej 60\%), najsłabiej - w dolnośląskim, lubuskim oraz zachodniopomorskim (32-39\%). Uwzględniając cały obszar Polski, można zauważyć, że prawie połowa środków zadeklarowanych we wnioskach o przyznanie pomocy nie została wypłacona. 
Ryc. 2. Porównanie wartości kwot wnioskowanych z wartością kwot przyznanych w ramach działania Rdr SPO 2004-2006 z podziałem na województwa

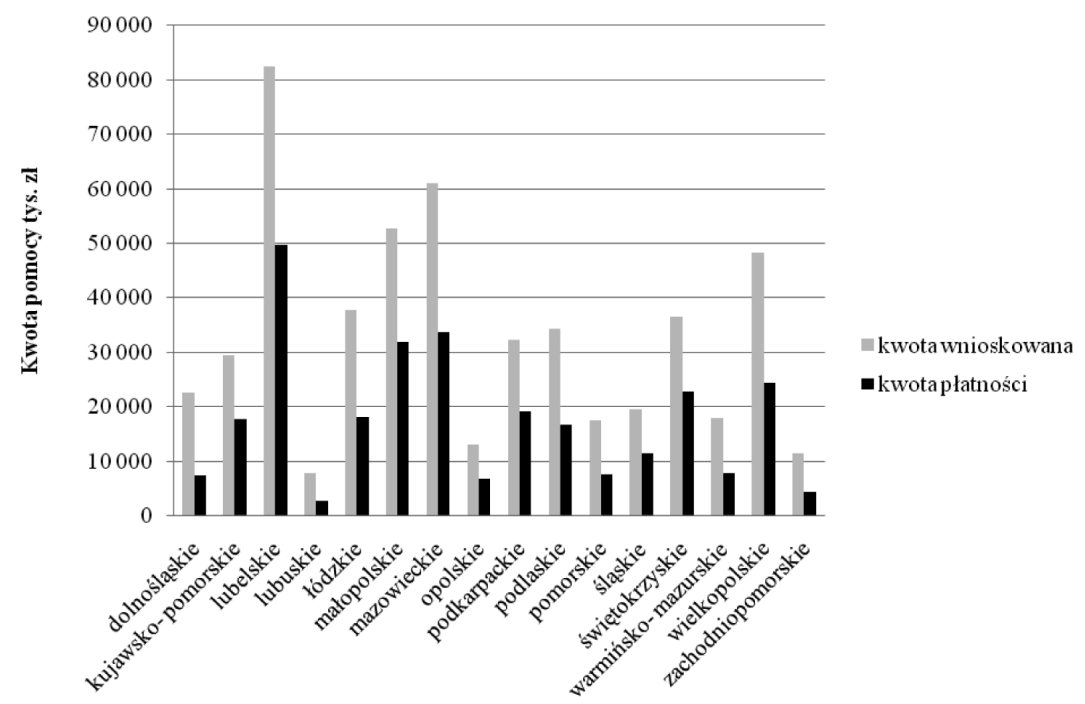

Źródło: opracowanie własne na podstawie danych Systemu Informacji Zarządczej ARiMR.

Jak już wcześniej wspomniano - w ramach programu Rdr SPO beneficjent mógł się starać maksymalnie o 100 tys. zł dofinansowania. Średnia kwota wnioskowanej pomocy w ramach edycji w programie SPO 2004-2006 wynosiła 73191 zł. Najniższe wartości inwestycji były w województwie zachodniopomorskim, opolskim, kujawsko-pomorskim (do 70 tys. zł), najwyższe w małopolskim (pow. 84 tys. zł).

Po zakończeniu wdrażania Sektorowego Programu Operacyjnego rozpoczęto wprowadzanie działania „Różnicowanie w kierunku działalności nierolniczej w ramach PROW 2007-2013”. Rkdn PROW zawiera podobne założenia programowe - ponownie beneficjenci mają możliwość uzyskania do 100 tys. zł pomocy. Ważnym czynnikiem wpływającym na stopień zainteresowania Rkdn PROW jest fakt, iż program ten ma bardzo zbliżone kryteria dostępu, jak znany już beneficjentom Rdr SPO. Dzięki nagłośnieniu w środkach masowego przekazu program trafia do szerokiej rzeszy odbiorców - jest dobrze rozreklamowany.

W ramach PROW 2007-2013 dla działania „Różnicowanie w kierunku działalności nierolniczej” nabór wniosków prowadzony był w 2008, 2009 i 2010 r. (nabór niezakończony). Kryteria podziału puli środków na poszczególne województwa były podobne jak w przypadku działania Rdr SPO.

Porównując nabory wniosków z lat 2008, 2009 i 2010, zauważa się wyraźną zmianę w liczbie złożonych wniosków dla poszczególnych województw. W każdej edycji najwięcej wniosków złożono w województwie mazowieckim i wielkopolskim. Odnośnie najmniejszej liczby złożonych wniosków zróżnicowanie jest większe. W 2008 r. najmniej było ich w lubuskim i opolskim, w 2009 r. - w lubuskim i zachodniopomorskim, a w 2010 - podkarpackim i śląskim. Należy zwrócić uwagę na to, iż w województwach małopolskim i lubelskim liczba złożonych wniosków jest znacznie niższa w stosunku do Rdr SPO. Nabór Rdr SPO wyróżniał się bowiem dużym zainteresowaniem w kierunku tworzenia działalności agroturystycznej. W ciągu kolejnych lat to zainteresowanie zmalało, natomiast inne działalności (w tym głównie usługi dla rolnictwa, które stanowiły ponad połowę wszystkich wniosków w kraju) nie miały tak dużych możliwości rozwoju, jak np. w województwie wielkopolskim. 
Ryc. 3. Liczba wniosków złożonych w trzech edycjach Rkdn PROW z podziałem na województwa

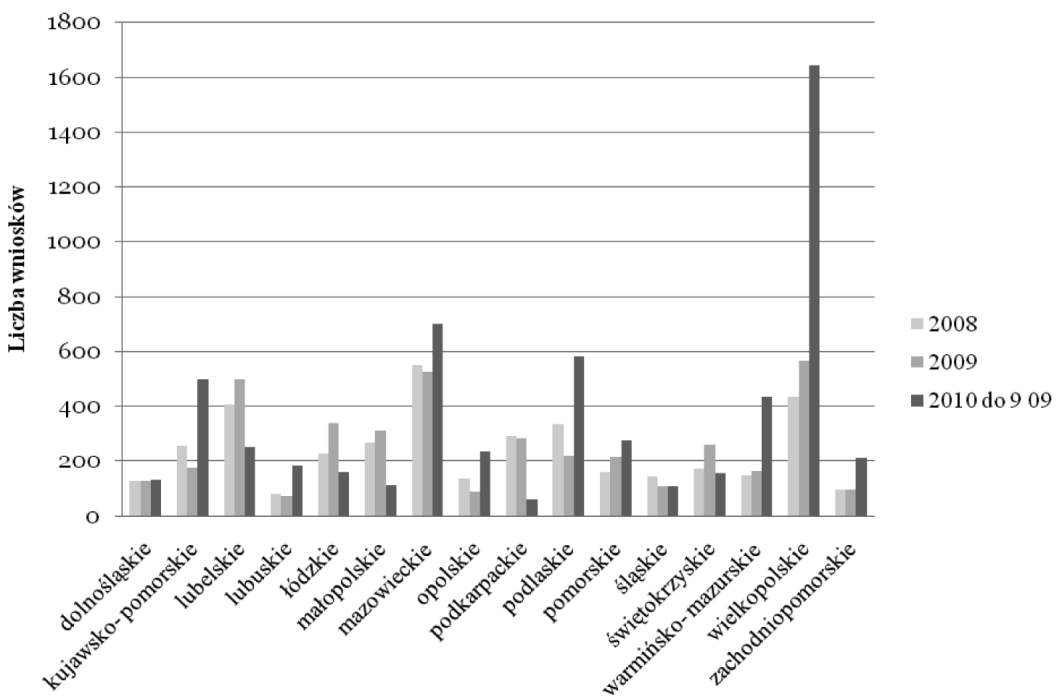

Źródło: opracowanie własne na podstawie danych Systemu Informacji Zarządczej ARiMR.

Stopień wykorzystania środków na terenie całej Polski mierzony liczbą zawartych umów w stosunku do liczby złożonych wniosków wzrósł z 52\% w 2008 r. do 58\% w 2009 r. Wskazuje to na bardziej przemyślane decyzje w kwestii realizowanych inwestycji. Warto podkreślić, że wartość z 2009 r. może być wyższa, gdyż część wniosków może być jeszcze w trakcie realizacji. Porównując lata 2008 i 2009, większość województw odnotowuje wzrost stopnia wykorzystania deklarowanych środków, niektóre regiony osiągnęły wartość 70\% w 2009 r.; są to: śląskie, opolskie, warmińsko-mazurskie i lubelskie. Tylko cztery województwa zanotowały spadek udziału wniosków o płatność w ogólnej liczbie złożonych wniosków w roku 2009.

Ryc. 4. Procentowy udział umów zawartych z ARiMR w ogólnej liczbie wniosków złożonych w Oddziałach Regionalnych ARiMR (edycja w 2008 i 2009 r.)

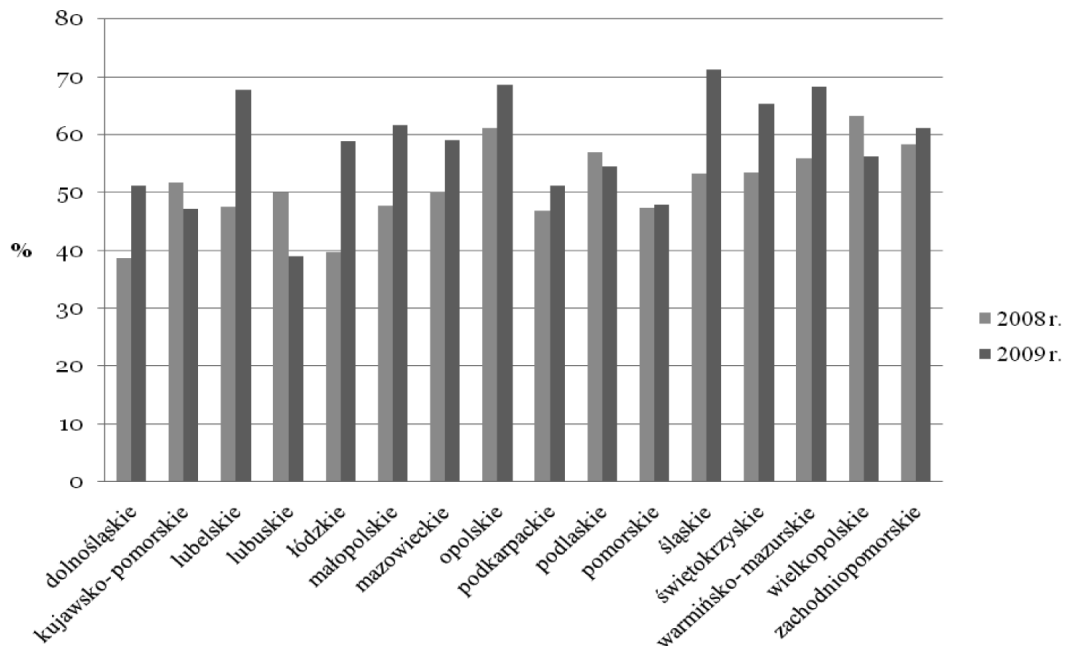

Źródło: opracowanie własne na podstawie danych Systemu Informacji Zarządczej ARiMR. 
Analizując wartość średniej kwoty wnioskowanej pomocy, zauważa się znaczny wzrost wartości dla działania Rkdn PROW 2007-2013 w stosunku do SPO 2004-2006. W 2008 r. wynosiła ona 81810 zł, w 2009 - 80099 zł, natomiast w 2010 r. było to już 92969 zł. W każdej z edycji najmniejsze średnie wartości osiągały inwestycje w podkarpackim, opolskim, małopolskim, a najwyższe w wielkopolskim, zachodniopomorskim, mazowieckim i lubuskim.

Ryc. 5. Średnia wartość kwoty wnioskowanej pomocy dla czterech edycji przyjmowania wniosków w ramach działań Rdr SPO oraz Rkdn PROW

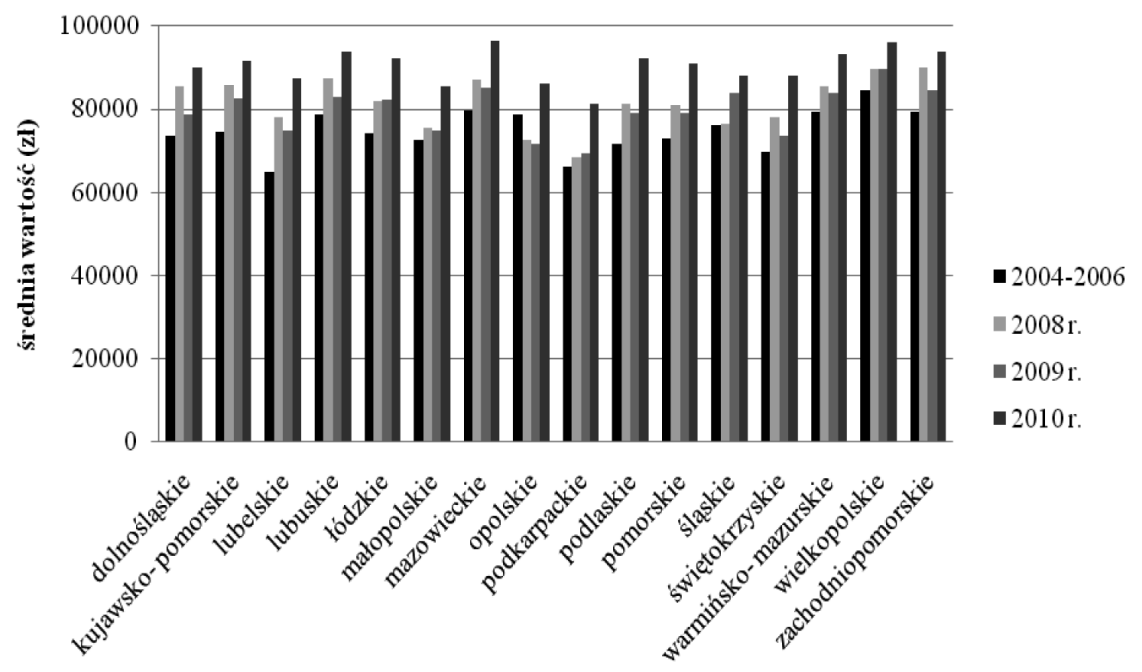

Źródło: opracowanie własne na podstawie danych Systemu Informacji Zarządczej ARiMR.

Kolejnym elementem wskazującym na zainteresowanie mieszkańców wsi programem „Różnicowanie w kierunku działalności nierolniczej” jest zróżnicowanie czasowe wykorzystania puli środków dla poszczególnych województw. W myśl terminarza realizacji programów Agencja Restrukturyzacji i Modernizacji Rolnictwa powiadamiała o planowanym uruchomieniu naboru wniosków dla poszczególnych działań w ramach najpierw SPO, a obecnie PROW. Następnie Oddziały Regionalne ARiMR-u prowadziły monitoring kwoty pomocy zadeklarowanej w składanych wnioskach i w chwili przekroczenia o $20 \%$ puli przeznaczonej dla danego województwa oddział ogłaszał kolejny dzień roboczy ostatnim do przyjmowania wniosków. W tabeli 1 przedstawiono daty, gdzie najwcześniej zakończono przyjmowanie wniosków dla działania Rdr SPO oraz Rknd PROW.

W SPO program uruchomiono 15 września 2004 r., a nabór trwał do 14 kwietnia 2006 r. W części województw większe zainteresowanie spowodowało, że zakończenie przyjmowania wniosków nastąpiło już w 2005 r. Taka sytuacja miała miejsce w pomorskim, lubuskim i warmińsko-mazurskim. Jeszcze szybsze tempo wykorzystania środków zaobserwowano w ramach Rdr PROW 2007-2013. Potencjalni beneficjenci byli znacznie lepiej zorientowani w zasadach pozyskiwania środków. Należy też nadmienić, że w ramach tego programu czas przyjmowania wniosków w każdej z edycji mógł trwać nie dłużej niż do 31 grudnia danego roku. Od dnia 5 czerwca 2008 r. rozpoczęto przyjmowanie wniosków i w tym dniu limit 120\% został wyczerpany w województwach: kujawsko-pomorskim, lubuskim, podlaskim, pomorskim, warmińsko-mazurskim, wielkopolskim i zachodniopomorskim. Dnia 11 czerwca wstrzymano program w dolnośląskim, 16 czerwca w mazowieckim i opolskim, a 25 czerwca - w śląskim. 
Dnia 15 kwietnia 2009 r. został uruchomiony drugi nabór w ramach PROW 2007-2013. Wyczerpanie limitu skutkowało wstrzymaniem naboru najpierw w wielkopolskim, pomorskim i zachodniopomorskim, a potem kolejno w: warmińsko-mazurskim, lubuskim i kujawsko-pomorskim. W pozostałych województwach limit nie został wyczerpany, a zakończenie przyjmowania wniosków nastąpiło 31 grudnia 2009 r. W dniu 24 sierpnia 2010 r. ruszyła kolejna edycja programu. W tym dniu limit złożonych wniosków został przekroczony w województwach: warmińsko-mazurskim, wielkopolskim, zachodniopomorskim, lubuskim i kujawsko-pomorskim. Ponadto do końca sierpnia wstrzymano jeszcze nabór w pomorskim, opolskim i podlaskim. W pozostałych województwach przyjmowanie wniosków nie jest zakończone, a stopień wyczerpania limitu jest bardzo niewielki, np. w małopolskim na dzień 9 września 2010 r. było to $16 \%$.

Tab. 1. Wybrane daty zakończenia przyjmowania wniosków w poszczególnych latach i województwach

\begin{tabular}{|c|c|c|c|c|}
\hline $\begin{array}{c}\text { Data rozpoczęcia } \\
\text { przyjmowania wniosków }\end{array}$ & $\begin{array}{l}15 \text { września } \\
2004\end{array}$ & $\begin{array}{c}5 \text { czerwca } \\
2008\end{array}$ & $\begin{array}{c}15 \text { kwietnia } \\
2009\end{array}$ & $\begin{array}{l}24 \text { sierpnia } \\
2010\end{array}$ \\
\hline Rok edycji & \multirow{2}{*}{2005} & \multirow{2}{*}{2008} & \multirow{2}{*}{2009} & \multirow{2}{*}{2010} \\
\hline Województwo & & & & \\
\hline dolnośląskie & $*$ & 11 czerwca & $*$ & $*$ \\
\hline kujawsko-pomorskie & $*$ & 6 czerwca & 31 sierpnia & 25 sierpnia \\
\hline lubelskie & $*$ & $*$ & $*$ & $*$ \\
\hline lubuskie & 3 czerwca & 6 czerwca & 16 czerwca & 25 sierpnia \\
\hline łódzkie & $*$ & $*$ & $*$ & $*$ \\
\hline małopolskie & 10 listopada & $*$ & $*$ & $*$ \\
\hline mazowieckie & $*$ & 16 czerwca & $*$ & $*$ \\
\hline opolskie & $*$ & 16 czerwca & $*$ & 30 sierpnia \\
\hline podkarpackie & 31 sierpnia & $*$ & $*$ & $*$ \\
\hline podlaskie & $*$ & 6 czerwca & $*$ & 31 sierpnia \\
\hline pomorskie & 9 marca & 6 czerwca & 22 maja & 27 sierpnia \\
\hline śląskie & 18 listopada & 25 czerwca & $*$ & * \\
\hline świętokrzyskie & $*$ & $*$ & $*$ & $*$ \\
\hline warmińsko-mazurskie & 15 czerwca & 6 czerwca & 12 czerwca & 25 sierpnia \\
\hline wielkopolskie & 20 lipca & 6 czerwca & 19 maja & 25 sierpnia \\
\hline zachodniopomorskie & 31 sierpnia & 6 czerwca & 28 maja & 25 sierpnia \\
\hline
\end{tabular}

* zakończenie naboru w 2006 r. dla Rdn SPO, zakończenie naboru w kolejnych miesiącach lub 31 grudnia danego roku - Rkdn PROW.

Źródło: opracowanie własne na podstawie danych Departamentu Komunikacji Społecznej ARiMR. 
Wsparcie rozwoju obszarów wiejskich jest ważnym elementem przyczyniającym się do poprawy jakości życia na tych terenach. Programy wspierające rozwój działalności pozarolniczych mogą być dodatkowym bodźcem dla rodzin z terenów wiejskich do poszukiwania pozarolniczych źródeł dochodu. Przeprowadzona analiza pozyskiwania środków z programu Rdr w SPO, i PROW wskazuje na duże zróżnicowanie przestrzenne zarówno co do liczby składanych wniosków, jak i tempa wykorzystania środków dla poszczególnych województw. Zauważa się słabe wykorzystanie środków w ramach Rdr PROW w województwach o dużym udziale gospodarstw o niskiej dochodowości (małopolskie, podkarpackie, śląskie). Natomiast szybkie zagospodarowanie przyznanej pomocy w województwach warmińsko-mazurskim, wielkopolskim i zachodniopomorskim może być ważnym czynnikiem do zmiany kryteriów podziału środków na regiony. Wzrost zainteresowania programem Rdr w województwach o dużym udziale gospodarstw wysokotowarowych może wskazywać na inwestowanie w maszyny rolnicze, które służą zarówno do produkcji we własnym gospodarstwie, jak i dają możliwość podjęcia dodatkowej działalności w zakresie usług dla rolnictwa. Kolejne edycje wskazują, że beneficjenci planują finansowanie coraz droższych inwestycji, natomiast wciąż zbyt niskie jest wykorzystanie deklarowanych środków. Nadal prawie połowa planowanych we wnioskach inwestycji nie jest realizowana. Może to wynikać ze zbyt długiego okresu rozpatrywania wniosków, a także z braku wkładu własnego na rozpoczęcie inwestycji.

\section{Literatura}

1. Babuchowska K., 2009, Działalność nierolnicza na obszarach wiejskich w województwie warmińsko-mazurskim finansowana w ramach PROW 2007-2013, Roczniki Naukowe Stowarzyszenia Ekonomistów Rolnictwa i Agrobiznesu, tom XI, zeszyt 5, Poznań.

2. Bański J., 2004, Możliwości rozwoju alternatywnych źródet dochodu [w:] Pozarolnicza działalność gospodarcza na obszarach wiejskich, Studia Obszarów Wiejskich, tom 5, red. E. Pałka, Warszawa.

3. Błąd M., 2006, Dywersyfikacja ekonomiczna wsi [w:] Polska wieś. Raport o stanie wsi 2006, J. Wilkin, I. Nurzyńska (red.), FDPA, Warszawa.

4. Fałkowski J., 2005, Sektorowy Program Operacyjny „, Restrukturyzacja i modernizacja sektora żywnościowego oraz rozwój obszarów wiejskich”. Próba oceny dotychczasowych efektów, „Analizy i Opinie”, $\mathrm{Nr} 54$, Kraków.

5. Goraj L., 2005, Wpływ płatności bezpośrednich na dochody polskich gospodarstw rolnych, Urząd Komitetu Integracji Europejskiej, Warszawa.

6. Komitet Sterujący Sektorowym Programem Operacyjnym, Uchwała nr 3/2004.

7. Program Rozwoju Obszarów Wiejskich, 2010, Działanie 311, Poradnik dla beneficjentów, Agencja Restrukturyzacji i Modernizacji Rolnictwa, Warszawa.

8. Sektorowy Program Operacyjny, 2005, Poradnik dla beneficjentów, Działanie 2.4, Agencja Restrukturyzacji i Modernizacji Rolnictwa, Warszawa. 


\section{Assessment of the Use of Funds under the Programme „Różnicowanie w kierunku działalności nierolniczej” [Diversification into non-agricultural activities]}

The paper analyzes the use of EU funds for farmers wishing to start or expand a business. The study was based on the use of funds under the program "Diversification into non-agricultural activities" located within the Sectoral Operational Programme for the years 2004-2006 (SOP) and the Rural Development Plan 2007-2013 (RDP).The assessment indicated a wide variation in the use of the program in different voivodehips. These differences appear when comparing the activities associated with the SOP and those implemented under the RDP. The first edition was popular in the voivodehips characterized by a high percentage of low income households. Implementation of the RDP program has brought a significant change in the number of applications and in the speed of the utilization of resources in regions. The greatest interest in the program in the three editions of the RDP occurred in the voivodehips (with the high agriculture level) where large farms dominate the agricultural and the means are used for service activity. It may be an indicator for changes in the specifications on allocation of resources. The lack of interest in the voivodehips with a large number of not profitable farms and with an excess labour force is puzzling. Subsequent editions indicate that investments planned by the beneficiaries are becoming more thoughtful and the investment value is increasing. 


\section{Sektor MŚP jako potencjalny odbiorca Funduszu Rozwoju Lokalnego Eksportu na przykładzie województwa podkarpackiego}

Powszechnie wiadomo, że wzrost eksportu powoduje z reguły przyspieszenie wzrostu gospodarki oraz spadek bezrobocia. Warto jednak zaznaczyć, że wspieranie eksportu przyczynia się nie tylko do przyspieszenia rozwoju gospodarki, ale również do ochrony krajowych producentów oraz ich produktów przed zagraniczną konkurencją.

Najpowszechniejsze rozwiązania wspierania eksportu to dopłaty bezpośrednie do eksportowanych dóbr oraz zwolnienia działalności eksportowych z niektórych podatków. Najczęściej wspiera się w ten sposób strategiczne sektory gospodarki (np. rolnictwo) lub nowe lokomotywy wzrostu (młode gałęzie gospodarki, które wspiera się w czasie ich dynamicznego rozwoju, aby pomóc im przetrwać i rozwinąć się pomimo silnej konkurencji). W wypadku handlu wewnątrz Unii Europejskiej jakiekolwiek wspomaganie eksportu lub jego ograniczanie jest zabronione. Unia stosuje natomiast politykę ceł wobec krajów zewnętrznych.

W świetle powyższych ustaleń teoretycznych uznano za zasadne przeprowadzenie badań ankietowych w miastach i gminach województwa podkarpackiego, które to badania miały dać odpowiedź na pytanie: Jakie są potrzeby małych i średnich przedsiębiorstw w zakresie promocji eksportu oraz nawiązywania i rozwoju kontaktów gospodarczych z podmiotami z obszaru Unii Europejskiej? Oczekiwano także odpowiedzi na poniższe pytania szczegółowe:

- Czy i jakie są doświadczenia przedsiębiorstw w zakresie wsparcia eksportu?

- Jaki jest poziom świadomości i możliwości korzystania z instrumentów wsparcia eksportu dla MŚP?

- Czy akcje promujące instrumenty wsparcia eksportu spełniają swoją rolę?

- Jakimi działaniami związanymi z rozwojem eksportu są zainteresowani potencjalni wnioskodawcy (potencjalni beneficjenci funduszy grantowych)?

- Jakie są stymulanty i destymulanty utrudniające wykorzystanie przez MŚP instrumentów wsparcia eksportu?

- Jaka jest aktywność przedsiębiorstw w pozyskiwaniu funduszy i czy ma to wpływ na wspieranie działań eksportowych?

Celem przeprowadzonych od stycznia do marca 2010 r. badań ankietowych na terenie województwa podkarpackiego było rozpoznanie podstawowych problemów wynikających z możliwości wspierania eksportu, ze szczególnym uwzględnieniem form finansowania, zarządzania i organizacji działań proeksportowych i oceny popytu na instrumenty wsparcia eksportu w aspekcie ilościowym oraz jakościowym. 
Głównym narzędziem pomiarowym była ankieta internetowa, której użyto w przekrojowym badaniu bezpośrednim. Po dokonaniu oceny uzyskanych odpowiedzi do dalszego etapu badań zakwalifikowano 92 ankiety przedsiębiorstw sektora MŚP, które spełniały kryterium doboru celowego. Warto jednak podkreślić, że z racji wielkości i reprezentatywności próby wszelkie ustalenia dotyczące wyników badań i wniosków mają charakter pilotażowy, niemniej jednak mogą stać się przyczynkiem do dalszych, pogłębionych badań.

Po zrealizowaniu badań terenowych nastąpił etap analizowania uzyskanego materiału. W tym celu stworzono macierz danych wejściowych, które poddano kodowaniu, a następnie przetwono za pomocą arkusza kalkulacyjnego.

\section{Charakterystyka badanych przedsiębiorstw}

W badaniu ankietowym wzięły udział 92 podmioty gospodarcze sektora MŚP na Podkarpaciu. Ze względu na wiek, a co za tym idzie - doświadczenie rynkowe, firmy podzielono na cztery podstawowe grupy, w których za kryterium wydzielenia przyjęto czynnik prawno-administracyjny, związany ze zmianą systemu gospodarowania lub reformą administracyjną. Osobną grupę stanowią przedsiębiorstwa, których staż nie przekracza roku (tab. 1).

Tab. 1. Struktura badanych przedsiębiorstw według stażu rynkowego

\begin{tabular}{|l|c|c|}
\hline Rok powstania przedsiębiorstwa & Liczba przedsiębiorstw & Odsetek przedsiębiorstw \\
\hline przed 1989 & 4 & 4,35 \\
\hline $1989-1998$ & 14 & 15,22 \\
\hline $1999-2008$ & 48 & 52,17 \\
\hline 2009 & 14 & 15,22 \\
\hline Brak odpowiedzi & 12 & 13,04 \\
\hline
\end{tabular}

Źródło: opracowanie własne.

Jak wynika z powyższej tabeli, większość przedsiębiorstw, które wzięły udział w badaniu, to przedsiębiorstwa powstałe w latach 1999-2008. Stanowią one ponad połowę badanych podmiotów. Skłania to do następujących wniosków. Po pierwsze, przedsiębiorstwa z uznanym ponad dziesięcioletnim stażem wykazują większe zainteresowanie inicjatywami związanymi ze wsparciem eksportu, co może się wiązać z ich ustabilizowaną pozycją na rynku lokalnym i chęcią ekspansji terytorialnej. Po drugie, liczba firm, które zgłosiły się do badania, a które powstały przed 1989 r., jest niska, co nie musi oznaczać mniejszego zainteresowania, lecz może być wynikiem znacznie mniejszej ich liczby ogółem. Po trzecie, za relatywnie wysoką należy uznać aktywność firm powstałych w 2009 r., które poszukują nowych sposobów wejścia i funkcjonowania na rynku, w tym także na rynku międzynarodowym (tab. 2). 
Tab. 2. Struktura badanych przedsiębiorstw według zasięgu działania

\begin{tabular}{|l|c|c|}
\hline Zasięg dzialania przedsiębiorstw & Liczba przedsiębiorstw & Odsetek przedsiębiorstw \\
\hline Lokalny & 22 & 23,91 \\
\hline Regionalny & 10 & 10,87 \\
\hline Ogólnopolski & 32 & 34,78 \\
\hline Międzynarodowy & 14 & 15,22 \\
\hline Brak odpowiedzi & 14 & 15,22 \\
\hline
\end{tabular}

Źródło: opracowanie własne.

Zasięg działania badanych firm jest bardzo zróżnicowany. Dominuje jednak poziom ogólnopolski, stanowiący niespełna 35\% ogółu. Na tej podstawie można wysnuć przypuszczenie, iż to właśnie przedsiębiorstwa, których działalność obejmuje terytorium całego kraju, są szczególnie zainteresowane wsparciem eksportu. Są to zwykle firmy stabilne ekonomicznie, doświadczone rynkowo oraz poszukujące nowych rynków zbytu. Natomiast zaskakująco niski procent zainteresowania badaniami - a zatem można przypuszczać - także samą istotą wsparcia eksportu wykazały firmy operujące na poziomie regionu podkarpackiego. Stosunkowo wysoki udział w badaniach przedsiębiorstw operujących dotąd na poziomie lokalnym świadczy o ich dużej aktywności wynikającej bądź z początkowego procesu rozwoju, bądź z poszukiwania stabilności gospodarczej (tab. 3).

Tab. 3. Struktura badanych przedsiębiorstw według wielkości obrotów (w zł)

\begin{tabular}{|l|c|c|}
\hline \multicolumn{1}{|c|}{ Obroty przedsiębiorstw w 2009 r. } & Liczba przedsiębiorstw & Odsetek przedsiębiorstw \\
\hline Mniej niż 100 tys. zł & 37 & 40,22 \\
\hline Powyżej 100 tys. do 500 tys. zł & 11 & 11,96 \\
\hline Powyżej 500 tys. do $1 \mathrm{mln}$ zł & 7 & 7,61 \\
\hline Powyżej 1 mln do 5 mln zł & 15 & 16,30 \\
\hline Powyżej 5 mln do $10 \mathrm{mln}$ zł & 4 & 4,35 \\
\hline Powyżej 10 mln do $50 \mathrm{mln}$ zł & 1 & 1,09 \\
\hline Powyżej 50 mln do $200 \mathrm{mln}$ zł & 1 & 1,09 \\
\hline Powyżej 200 mln zł & 0 & 0,00 \\
\hline Brak odpowiedzi & 16 & 17,39 \\
\hline
\end{tabular}

Źródło: opracowanie własne.

Zdecydowana większość badanych firm (52,17\%) to firmy, w których obroty w 2009 r. nie przekroczyły 500 tys. zł, a zatem o relatywnie niskiej skali gospodarowania. Uznając jednak, że samo zgłoszenie się do badania jest cenną informacją, można zaryzykować stwierdzenie, że największe zainteresowanie wsparciem eksportu deklarują właśnie omawiane przedsiębiorstwa. Wydaje się również, że im obroty wyższe, tym zainteresowanie pomocą dotyczącą działań eksportowych słabnie, co może wynikać z już nawiązanych kontaktów zagranicznych. 
Istnieje bardzo duże zróżnicowanie działowe badanych przedsiębiorstw. Zdecydowana większość z nich to przedsiębiorstwa z szeroko rozumianego sektora usługowego $(81,52 \%)$. Na pozostałe sektory przypadło odpowiednio: rolnictwo $4,35 \%$ oraz przemysł i budownictwo $14,13 \%$ (tab. 4).

Tab. 4. Struktura badanych przedsiębiorstw według rodzaju głównej działalności

\begin{tabular}{|c|c|c|}
\hline Sekcja PKD głównej działalności przedsiębiorstwa & \begin{tabular}{|c|} 
Liczba \\
przedsiębiorstw
\end{tabular} & $\begin{array}{c}\text { Odsetek } \\
\text { przedsiębiorstw }\end{array}$ \\
\hline Rolnictwo, leśnictwo, łowiectwo i rybactwo & 4 & 4,35 \\
\hline Górnictwo i wydobywanie & 3 & 3,26 \\
\hline Przetwórstwo przemysłowe & 4 & 4,35 \\
\hline $\begin{array}{l}\text { Wytwarzanie i zaopatrywanie w energię elektryczną, gaz, parę } \\
\text { wodną, gorącą wodę i powietrze do układów klimatyzacyjnych }\end{array}$ & 0 & 0,00 \\
\hline $\begin{array}{l}\text { Dostawa wody; gospodarowanie ściekami i odpadami } \\
\text { oraz działalność związana z rekultywacją }\end{array}$ & 0 & 0,00 \\
\hline Budownictwo & 6 & 6,52 \\
\hline $\begin{array}{l}\text { Handel hurtowy i detaliczny; naprawa pojazdów } \\
\text { samochodowych, włączając motocykle }\end{array}$ & 10 & 10,87 \\
\hline Transport i gospodarka magazynowa & 3 & 3,36 \\
\hline $\begin{array}{l}\text { Działalność związana z zakwaterowaniem i usługami } \\
\text { gastronomicznymi }\end{array}$ & 6 & 6,52 \\
\hline Informacja i komunikacja & 11 & 11,96 \\
\hline Działalność finansowa i ubezpieczeniowa & 0 & 0,00 \\
\hline Działalność związana z obsługą rynku nieruchomości & 1 & 1,09 \\
\hline Działalność profesjonalna, naukowa i techniczna & 8 & 8,70 \\
\hline $\begin{array}{l}\text { Działalność w zakresie usług administrowania i działalność } \\
\text { wspierająca }\end{array}$ & 0 & 0,00 \\
\hline $\begin{array}{l}\text { Administracja publiczna i obrona narodowa; obowiązkowe } \\
\text { zabezpieczenia społeczne }\end{array}$ & 2 & 2,17 \\
\hline Edukacja & 4 & 4,35 \\
\hline Opieka zdrowotna i pomoc społeczna & 2 & 2,17 \\
\hline Działalność związana z kulturą, rozrywką i rekreacją & 10 & 10,87 \\
\hline Pozostała działalność usługowa & 8 & 8,70 \\
\hline $\begin{array}{l}\text { Gospodarstwa domowe zatrudniające pracowników; } \\
\text { gospodarstwa domowe produkujące wyroby i świadczące } \\
\text { usługi na własne potrzeby }\end{array}$ & 0 & 0,00 \\
\hline Organizacje i zespoły eksterytorialne & 0 & 0,00 \\
\hline Brak odpowiedzi & 10 & 10,87 \\
\hline
\end{tabular}

Źródło: opracowanie własne. 
Najliczniej reprezentowanymi sekcjami usługowymi były handel hurtowy i detaliczny, informacja i komunikacja oraz działalność związana z kulturą, rozrywką i rekreacją. Udział przedsiębiorstw zakwalifikowanych do każdej z wymienionych sekcji przekraczał 10\% ogółu przedsiębiorstw, które wzięły udział w badaniu. Wymienione formy działalności są bardzo różne, niemniej jednak łączy je najprawdopodobniej dobra sytuacja rynkowa, a zatem wyraźna nadwyżka produkcji, którą można potencjalnie eksportować. Przedsiębiorstwa należące do omawianych sekcji to być może lokomotywy wzrostu regionu podkarpackiego. Być może następuje również, zgodnie z megatrendami światowymi, zmiękczanie regionalnej struktury gospodarczej, ponieważ rośnie aktywność przedsiębiorstw usługowych, kosztem przedsiębiorstw przemysłowych i rolniczych (tab. 5).

Tab. 5. Struktura badanych przedsiębiorstw według typu własności

\begin{tabular}{|l|c|c|}
\hline \multicolumn{1}{|c|}{ Typ wlasności przedsiębiorstwa } & $\begin{array}{c}\text { Liczba } \\
\text { przedsiębiorstw }\end{array}$ & $\begin{array}{c}\text { Odsetek } \\
\text { przedsiębiorstw }\end{array}$ \\
\hline Państwowa Skarbu Państwa & 5 & 5,43 \\
\hline Państwowa państwowych osób prawnych & 4 & 4,35 \\
\hline Komunalna & 3 & 3,26 \\
\hline Prywatna - 100\% własność polska & 61 & 66,30 \\
\hline Prywatna - w większości polska & 6 & 6,52 \\
\hline Prywatna - w większości zagraniczna & 4 & 4,35 \\
\hline Prywatna - 100\% zagraniczna & 0 & 0,00 \\
\hline Brak odpowiedzi & 9 & 9,78 \\
\hline
\end{tabular}

Źródło: opracowanie własne.

Aktywność przedsiębiorstw należy łączyć z typem własności. Jest to wyraźnie widoczne w grupie badanych przedsiębiorstw. Sektor prywatny, który w badaniach był reprezentowany przez 77,17\% ogółu przedsiębiorstw, przez sam akces do badania okazał się bardziej zainteresowany wsparciem eksportu aniżeli sektor publiczny.

Powyższe ustalenia są również silnie skorelowane $\mathrm{z}$ formą organizacyjno-prawną firm. Największe zainteresowanie udziałem w badaniach zadeklarowały przedsiębiorstwa osób fizycznych oraz spółki osobowe (w tym głownie spółki cywilne, jawne i partnerskie), które w oczywisty sposób należą do sektora prywatnego. Wysoki udział w badaniach firm własnej, indywidualnej działalności gospodarczej, może świadczyć o wyraźnej luce dotyczącej wspierania eksportu tego typu przedsiębiorstw. Jednakże przyczyn tego stanu można i należy szukać zarówno w samych przedsiębiorstwach (brak doświadczenia, niski kapitał wiedzy, ograniczone możliwości finansowe), jak i w ich otoczeniu (brak wypracowanych skutecznych narzędzi wspierania eksportu lub brak instytucji realizujących takie zadania) (tab. 6). 
Tab. 6. Struktura badanych przedsiębiorstw według formy organizacyjno-prawnej

\begin{tabular}{|l|c|c|}
\hline Forma organizacyjno-prawna przedsiębiorstwa & $\begin{array}{c}\text { Liczba } \\
\text { przedsiębiorstw }\end{array}$ & $\begin{array}{c}\text { Odsetek } \\
\text { przedsiębiorstw }\end{array}$ \\
\hline Przedsiębiorstwo osoby fizycznej & 46 & 50,00 \\
\hline Spółka osobowa & 19 & 20,65 \\
\hline Spółka kapitałowa & 16 & 17,39 \\
\hline Przedsiębiorstwo państwowe lub komunalne & 3 & 3,26 \\
\hline Jednostka budżetowa & 0 & 0,00 \\
\hline Stowarzyszenie lub fundacja & 0 & 0,00 \\
\hline Spółdzielnia & 0 & 0,00 \\
\hline Brak odpowiedzi & 8 & 8,70 \\
\hline
\end{tabular}

Źródło: opracowanie własne.

Spośród pozostałych form organizacyjno-prawnych przedsiębiorstw, które wzięły udział w badaniu, na uwagę zasługuje znaczny odsetek spółek kapitałowych i już znacznie mniejszy odsetek przedsiębiorstw sektora publicznego. Zachowanie sektora publicznego nie jest przy tym jednoznacznie interpretowane. Niskie zainteresowanie może bowiem wynikać np. z już wcześniej nawiązanych kontaktów eksportowych lub z innych form ich nawiązywania. Możliwy jest też scenariusz, w którym przedsiębiorstwa sektora publicznego nie mogą lub nie chcą nawiązywać takich kontaktów. Na uwagę zasługuje również fakt, że do badań nie zgłosiła się ani jedna spółdzielnia, stowarzyszenie czy fundacja. Można to tłumaczyć samą specyfiką tych form organizacyjno-prawnych. Z drugiej jednak strony kontakty zagraniczne, w tym eksportowe, stają się obecnie, w dobie procesów integracyjnych i globalizacyjnych, dla wielu firm celem strategicznym.

Potwierdzeniem dominującego profilu firmy zainteresowanej badaniami wsparcia eksportu jest wreszcie liczba pracujących. W badaniach dominowały mikroprzedsiębiorstwa, których liczba pracujących nie przekroczyła dziewięciu osób, co potwierdza wcześniejsze ustalenia o małych możliwościach kapitałowych, organizacyjnych i handlowych tej wielkości przedsiębiorstw. Jak wynika z analizy struktury wielkościowej przedsiębiorstw, wraz ze wzrostem liczby zatrudnionych w nim osób jego zainteresowanie proponowanym wsparciem eksportu maleje (tab. 7).

Tab. 7. Struktura badanych przedsiębiorstw według liczby pracujących

\begin{tabular}{|l|c|c|}
\hline Liczba pracujących w przedsiębiorstwie & Liczba przedsiębiorstw & Odsetek przedsiębiorstw \\
\hline Do 9 osób & 60 & 65,22 \\
\hline Od 10 do 49 osób & 11 & 11,96 \\
\hline Od 50 do 249 osób & 7 & 7,61 \\
\hline 250 i więcej osób & 4 & 4,35 \\
\hline Brak odpowiedzi & 10 & 10,87 \\
\hline
\end{tabular}

Źródło: opracowanie własne. 
Na podstawie wszystkich powyższych charakterystyk można określić dominujące profile przedsiębiorstw, które wzięły udział w badaniach, a tym samym są zainteresowane działaniami wspierającymi eksport:

\section{- Profil I}

Jest to małej lub średniej wielkości spółka osobowa lub kapitałowa sektora prywatnego, oparta na własności krajowej, która poprzez przynajmniej dziesięcioletni staż na rynku rozwinęła swoją działalność na poziomie ogólnopolskim. Jej roczne obroty wynikające z głównej działalności, którą są szeroko rozumiane usługi, wahają się w przedziale między 100 tys. a 5 mln zł.

\section{- Profil II}

Jest to mikrofirma będąca własnością osoby fizycznej, funkcjonująca na rynku nie dłużej niż dwa lata. Jej usługowa działalność zwykle nie wykracza poza poziom lokalny, a obroty roczne są niższe niż 100 tys. zł.

\section{Analiza problemowa}

Kluczowym dla dalszych rozważań okazało się pytanie o zainteresowanie przedsiębiorców konkretnymi działaniami związanymi z rozwojem eksportu. Jak wynika z odpowiedzi, istnieją trzy zasadnicze kierunki działań, które cieszą się wyraźnie większą popularnością od pozostałych. Są to prace związane z obsługą organizacyjno-administracyjną, bo de facto takimi są tłumaczenia czy też usługi informatyczne. Przy czym wysoka pozycja tego działania świadczy o ciągle istniejącym dystansie przedsiębiorców z podkarpackiego do ogólnie przyjętych zasad funkcjonowania firm na rynku europejskim. Drugim wyróżnionym działaniem jest udział $\mathrm{w}$ targach w charakterze wystawcy. Wydaje się przy tym, że tego typu działanie jest bardzo skuteczną formą nawiązywania nowych kontaktów gospodarczych. Natomiast odrębnym pozostaje pytanie, czy wybór tego działania wynika z dużej aktywności czy pasywności przedsiębiorców, ponieważ udział w imprezach targowych może również wynikać z założenia, iż to potencjalni klienci lub kooperanci będą poszukiwali kontaktów (tab. 8).

Tab. 8. Struktura odpowiedzi na pytanie: Którym z działań związanych z rozwojem eksportu jest Państwa przedsiębiorstwo zainteresowane?*

\begin{tabular}{|l|c|c|}
\hline \multicolumn{1}{|c|}{ Działanie } & $\begin{array}{c}\text { Liczba } \\
\text { wskazań }\end{array}$ & $\begin{array}{c}\text { Odsetek } \\
\text { wskazań }\end{array}$ \\
\hline $\begin{array}{l}\text { Udział w imprezach targowo-wystawienniczych w charakterze } \\
\text { wystawcy }\end{array}$ & 28 & 22,05 \\
\hline Organizacja i udział w misjach zagranicznych & 10 & 7,87 \\
\hline Wyszukiwanie i dobór partnerów na rynkach docelowych & 33 & 25,98 \\
\hline $\begin{array}{l}\text { Uzyskiwanie niezbędnych dokumentów do wprowadzenia } \\
\text { produktów lub usług na rynki docelowe }\end{array}$ & 10 & 7,87 \\
\hline $\begin{array}{l}\text { Doradztwo w zakresie strategii finansowania przedsięwzięć } \\
\text { eksportowych i działalności eksportowej }\end{array}$ & 12 & 9,45 \\
\hline $\begin{array}{l}\text { Doradztwo w zakresie opracowania koncepcji wizerunku } \\
\text { na wybranych rynkach docelowych }\end{array}$ & 23 & 8,66 \\
\hline Inne działania (np. tłumaczenia, usługi informatyczne) & 11 & 18,11 \\
\hline
\end{tabular}

* możliwy był wybór najwyżej trzech odpowiedzi

Źródło: opracowanie własne. 
Natomiast trzecim i najczęściej wskazywanym działaniem okazało się wyszukiwanie i dobór parterów na rynkach docelowych, co potwierdza raczej tezę o pasywności lub wręcz nieumiejętności nawiązywania kontaktów zagranicznych przez przedsiębiorców. Warto przy tym dodać, że niska pozycja organizacji i udziału w misjach zagranicznych wynika właśnie z nikłej wiedzy (a czasami zupełnego jej braku) o istocie tego działania. Przyczyny tego stanu mogą jednak wynikać zarówno z potencjału firmy, jak też z niedoskonałości otoczenia.

Tab. 9. Struktura odpowiedzi na pytanie: Które konkretne czynności w obrębie wybranych działań z zakresu udziału w imprezach targowo-wystawienniczych w charakterze wystawcy leżą w polu Państwa zainteresowań?*

\begin{tabular}{|l|c|c|}
\hline \multicolumn{1}{|c|}{ Działanie } & $\begin{array}{c}\text { Liczba } \\
\text { wskazań }\end{array}$ & $\begin{array}{c}\text { Odsetek } \\
\text { wskazań }\end{array}$ \\
\hline Wynajęcie i zabudowa powierzchni wystawienniczej & 12 & 13,64 \\
\hline Zakup usług w zakresie obsługi technicznej stoiska & 14 & 15,91 \\
\hline $\begin{array}{l}\text { Zakup usług w zakresie transportu eksponatów oraz elementów } \\
\text { zabudowy }\end{array}$ & 5 & 5,68 \\
\hline $\begin{array}{l}\text { Zakup usług w zakresie organizacji spotkań z potencjalnymi } \\
\text { partnerami handlowymi }\end{array}$ & 13 & 14,77 \\
\hline $\begin{array}{l}\text { Wpis do katalogu targowego, opłata rejestracyjna, reklama w me- } \\
\text { diach targowych }\end{array}$ & 10 & 11,36 \\
\hline $\begin{array}{l}\text { Zakup usług doradczych w zakresie promocji podczas zagranicznych } \\
\text { targów i wystaw }\end{array}$ & 20 & 22,73 \\
\hline $\begin{array}{l}\text { Podróże służbowe (trzech osób) opłaty związane z wizami i ubezpie- } \\
\text { czeniem }\end{array}$ & & \\
\hline
\end{tabular}

*możliwy był wybór dowolnej liczby odpowiedzi

Źródło: opracowanie własne.

Poddając wnikliwszej analizie wyżej zaprezentowane działania, daje się zauważyć znaczne zróżnicowanie wewnętrzne. Na przykład w zakresie udziału w imprezach targowych zdecydowanie najwyższym zainteresowaniem cieszyły się wśród przedsiębiorców podróże służbowe, a ściślej rzecz biorąc - ich organizacja. Natomiast o wiele istotniejsze kwestie związane np. z wynajęciem i zabudową powierzchni wystawienniczej, a jeszcze bardziej - z doradztwem w zakresie promocji na targach czy wreszcie transportem eksponatów wystawienniczych zostały zepchnięte na dalszy plan. Może to wynikać z czynnika kosztowego (wiele prac jest realizowanych we własnym zakresie i przy wykorzystaniu własnych środków) lub/i charakteru udziału w imprezach (uczestnictwo bierne, ewentualnie pod egidą organizacji gospodarczych regionu) (tab. 9).

Potwierdza to analiza odpowiedzi na pytanie o odnoszące się do udziału w misjach zagranicznych, ponieważ ponad 25\% wskazań dotyczyło zakupu biletów wstępu na zwiedzanie imprez wystawienniczych. Natomiast sama organizacja misji cieszyła się znacznie mniejszą popularnością przedsiębiorców. Za niepokojący należy uznać fakt, że zakup usług doradczych w zakresie określenia potencjalnych partnerów handlowych, przygotowania ofert współpracy i negocjacji handlowych, a więc clou tego działa, został przez przedsiębiorców niemal niezauważony (tab. 10). 
Tab. 10. Struktura odpowiedzi na pytanie: Które konkretne czynności w obrębie organizacji i udział w misjach zagranicznych leżą w polu Państwa zainteresowań?*

\begin{tabular}{|l|c|c|}
\hline \multicolumn{1}{|c|}{ Dzialanie } & $\begin{array}{c}\text { Liczba } \\
\text { wskazań }\end{array}$ & $\begin{array}{c}\text { Odsetek } \\
\text { wskazań }\end{array}$ \\
\hline Zakup usługi polegającej na zorganizowaniu misji & 6 & 17,65 \\
\hline $\begin{array}{l}\text { Zakup usług w zakresie organizacji spotkań z potencjalnymi } \\
\text { partnerami handlowymi }\end{array}$ & 7 & 20,59 \\
\hline $\begin{array}{l}\text { Zakup usług doradczych w zakresie określenia potencjalnych } \\
\text { partnerów handlowych, przygotowania ofert współpracy oraz } \\
\text { negocjacji handlowych }\end{array}$ & 5 & 14,71 \\
\hline $\begin{array}{l}\text { Zakup biletów wstępu w celu zwiedzenia targów związanych } \\
\text { z misją gospodarczą }\end{array}$ & 9 & 26,47 \\
\hline $\begin{array}{l}\text { Podróże służbowe (trzech osób), opłaty związane z wizami } \\
\text { i ubezpieczeniem }\end{array}$ & 7 & 20,59 \\
\hline
\end{tabular}

*możliwy był wybór dowolnej liczby odpowiedzi

Źródło: opracowanie własne.

Podobnie jak w wypadku wcześniej omówionych działań, również w działaniu polegającym na wyszukiwaniu i doborze partnerów na rynkach docelowych widać duże zróżnicowanie wewnętrzne i wyraźne przeniesienie akcentu istotności ze spraw wydawałoby się najważniejszych na sprawy drugorzędne. Dotyczy to np. organizacji podróży służbowych, które zdecydowanie wyprzedziły pod względem wskazań wszystkie pozostałe działania szczegółowe, łącznie z zakupem usług w zakresie organizacji spotkań handlowych czy wydawałoby się elementarnym poddziałaniem, jakim jest zakup baz danych i baz marketingowych. Najmniej docenionym działaniem szczegółowym okazał się zakup usług prawnych związanych z wyszukiwaniem i doborem partnerów handlowych na rynkach docelowych. Należy jednak podkreślić, że tego typu usługi bywają zwykle dość kosztowne, stąd niechęć lub ograniczenia do ponoszenia tego typu kosztów (tab. 11).

Tab. 11. Struktura odpowiedzi na pytanie: Które konkretne czynności w obrębie wyszukiwania i doboru partnerów na rynkach docelowych leżą w polu Państwa zainteresowań?*

\begin{tabular}{|l|c|c|}
\hline \multicolumn{1}{|c|}{ Działanie } & $\begin{array}{c}\text { Liczba } \\
\text { wskazań }\end{array}$ & $\begin{array}{c}\text { Odsetek } \\
\text { wskazań }\end{array}$ \\
\hline Zakup baz danych oraz baz marketingowych & 13 & 14,61 \\
\hline $\begin{array}{l}\text { Zakup usług prawnych związanych z wyszukiwaniem i doborem } \\
\text { parterów handlowych na rynkach docelowych }\end{array}$ & 10 & 11,24 \\
\hline $\begin{array}{l}\text { Zakup usług doradczych w zakresie wyselekcjonowania, } \\
\text { sprawdzenia wiarygodności grupy docelowej potencjalnych } \\
\text { partnerów handlowych, przygotowania ofert współpracy }\end{array}$ & 22 & 24,72 \\
\hline $\begin{array}{l}\text { Zakup usług w zakresie organizacji spotkań z wyselekcjonowanymi } \\
\text { partnerami handlowymi }\end{array}$ & 17 & 19,10 \\
\hline $\begin{array}{l}\text { Podróże służbowe (trzech osób), opłaty związane z wizami } \\
\text { i ubezpieczeniem }\end{array}$ & 27 & 30,34 \\
\hline
\end{tabular}

*możliwy był wybór dowolnej liczby odpowiedzi

Źródło: opracowanie własne. 
Wśród wszystkich poddziałań dotyczących uzyskiwania niezbędnych dokumentów do wprowadzenia produktów lub usług na rynki docelowe, w zasadzie tylko jedno okazuje się dla przedsiębiorców ważne. Jest to zakup usług, które pozwoliłyby na uzyskanie certyfikatu, atestu itp. Natomiast, mimo że wiele innych poddziałań jest pośrednio związanych z uzyskaniem certyfikatu, nie zostały one przez przedsiębiorców zauważone lub z racji wskazywanego już wcześniej czynnika kosztowego nie były możliwe do realizacji. Dotyczy to przede wszystkim przeprowadzenia badań certyfikacyjnych, które m.in. ze względu na wysoki koszt w zasadzie w ogóle nie znalazły się w polu zainteresowania firm (tab. 12).

Tab. 12. Struktura odpowiedzi na pytanie: Które konkretne czynności w obrębie uzyskiwania niezbędnych dokumentów do wprowadzenia produktów lub usług na rynki docelowe leżą w polu Państwa zainteresowań?*

\begin{tabular}{|l|c|c|}
\hline \multicolumn{1}{|c|}{ Działanie } & $\begin{array}{c}\text { Liczba } \\
\text { wskazań }\end{array}$ & $\begin{array}{c}\text { Odsetek } \\
\text { wskazań }\end{array}$ \\
\hline $\begin{array}{l}\text { Zakup usług doradczych związanych z uzyskaniem certyfikatu, } \\
\text { atestu, świadectwa }\end{array}$ & 9 & 29,03 \\
\hline $\begin{array}{l}\text { Zakup usług prawnych związanych z wprowadzeniem towarów } \\
\text { i usług na wybrane rynki docelowe }\end{array}$ & 6 & 19,35 \\
\hline Przygotowanie dokumentacji technicznej & 4 & 19,35 \\
\hline $\begin{array}{l}\text { Transport i ubezpieczenie próbek wyrobu i dokumentacji } \\
\text { technicznej }\end{array}$ & 1 & 3,90 \\
\hline Przeprowadzenie badań certyfikacyjnych & 5 & 16,13 \\
\hline Wystawienie i wydanie certyfikatu & & \\
\hline
\end{tabular}

*możliwy był wybór dowolnej liczby odpowiedzi

Źródło: opracowanie własne.

Warto przy tym ponownie podkreślić, że całe działanie dotyczące szeroko rozumianej dokumentacji technicznej nie znalazło większego zainteresowania wśród przedsiębiorców. Odpowiedzi na to, dlaczego tak się stało, jest jednak kilka. Po pierwsze, wynika to z ustaleń metodologicznych samego badania, a ściślej rzecz biorąc - ze struktury respondentów, wśród których przeważają firmy usługowe, w znacznie mniejszym stopniu potrzebujące takich dokumentów. Po drugie, wejście na rynki docelowe z produktem wymaga odpowiednio dużego zasobu finansowego, czasowego i organizacyjnego, co skutecznie zniechęca do podejmowania takiego trudu. Po trzecie, brak odpowiedniego przygotowania firm do wdrażania procedur dotyczących dokumentacji technicznej. Po czwarte, wśród przedsiębiorców nadal funkcjonuje silny stereotyp o znacznie niższym poziomie dóbr i usług produkowanych i świadczonych w Polsce, wobec czego polskie produkty nominalnie powinny być tańsze. 
Badając wyniki dotyczące działania związanego ze strategią finansowania przedsięwzięć eksportowych, można wysnuć tezę, że przedsiębiorcy (choć jest ich niewielu) są zainteresowani w zasadzie odpowiedzią na pytanie, skąd pozyskać finanse, zwracając uwagę na wiarygodność źródła. Natomiast nie przywiązują dużej uwagi do budowania samej strategii finansowania, ponieważ brak jest na to czasu albo też - i taka odpowiedź wydaje się najbardziej prawdopodobna - działają głównie na poziomie operacyjnym, zatem nie potrafią takiej strategii budować. W dużej mierze działają intuicyjnie (tab. 13).

Tab. 13. Struktura odpowiedzi na pytanie: Które konkretne czynności w obrębie doradztwa w zakresie strategii finansowania przedsięwzięć eksportowych i działalności eksportowej leżą w polu Państwa zainteresowań?*

\begin{tabular}{|l|c|c|}
\hline \multicolumn{1}{|c|}{ Dzialanie } & $\begin{array}{c}\text { Liczba } \\
\text { wskazań }\end{array}$ & $\begin{array}{c}\text { Odsetek } \\
\text { wskazań }\end{array}$ \\
\hline Opracowanie optymalnej strategii finansowania & 5 & 22,73 \\
\hline $\begin{array}{l}\text { Wskazanie potencjalnych źródeł finansowania i identyfikacja } \\
\text { dostępnych źródeł }\end{array}$ & 9 & 40,91 \\
\hline Rekomendacja źródeł finansowania & 8 & 36,36 \\
\hline
\end{tabular}

*możliwy był wybór dowolnej liczby odpowiedzi

Źródło: opracowanie własne.

Chociaż opracowanie strategii wprowadzenia nowych produktów na rynki docelowe wykazuje wysoki odsetek odpowiedzi, co podważałoby wcześniejszą tezę, to jednak liczba wskazań, zaledwie osiem wobec 92 przedsiębiorstw, świadczy raczej na korzyść powyższych ustaleń. Ponadto jednym z ważniejszych wniosków płynących z badania jest fakt, iż ewentualne uzyskane fundusze na rzecz wsparcia eksportu firmy nie zostałyby wykorzystane do opracowania strategii wprowadzania nowych produktów na rynki docelowe lub też na nowe wzornictwo. Możliwe, że wiele firm zakłada pośrednie wejście na rynki zagraniczne z wykorzystaniem kontaktów produkcyjnych, w tym kooperacyjnych, handlowych i dystrybucyjnych. Przyjmowanie takiej strategii może być jednak groźne dla wizerunku firmy i jej dalszego funkcjonowania (tab. 14).

Tab. 14. Struktura odpowiedzi na pytanie: Które konkretne czynności w obrębie doradztwa w zakresie opracowania koncepcji wizerunku na wybranych rynkach docelowych leżą w polu Państwa zainteresowań?*

\begin{tabular}{|l|c|c|}
\hline \multicolumn{1}{|c|}{ Dzialanie } & $\begin{array}{c}\text { Liczba } \\
\text { wskazań }\end{array}$ & $\begin{array}{c}\text { Odsetek } \\
\text { wskazań }\end{array}$ \\
\hline Opracowanie strategii wprowadzenia nowych produktów na rynki docelowe & 8 & 72,73 \\
\hline Stworzenie wzornictwa w zakresie produktu, opakowania, znaku firmowego & 3 & 27,27 \\
\hline
\end{tabular}

*możliwy był wybór dowolnej liczby odpowiedzi

Źródło: opracowanie własne.

Z drugiej strony wśród działań pozostałych na uwagę zasługują poddziałania promocyjne i informacyjne. Ważne jest jednak to, czy tego typu poddziałania dotyczą firmy, czy produktu. Niestety, badanie tego jednoznacznie nie określa. Ponadto, czy działania promocyjne i informacyjne mają charakter in czy out? Inaczej mówiąc, czy mają być skoncentrowane na dostarczeniu wiedzy firmom o otoczeniu, czy też odwrotnie lub na obu tych działaniach jednocześnie. Warto jednak zwrócić uwagę na liczbę wskazań, która ponownie okazuje się marginalna wobec wielkości próby (tab. 15). 
Tab. 15. Struktura odpowiedzi na pytanie: Które konkretne czynności w obrębie innych działań leżą w polu Państwa zainteresowań?*

\begin{tabular}{|l|c|c|}
\hline \multicolumn{1}{|c|}{ Działanie } & $\begin{array}{c}\text { Liczba } \\
\text { wskazań }\end{array}$ & $\begin{array}{c}\text { Odsetek } \\
\text { wskazań }\end{array}$ \\
\hline Działania promocyjne i informacyjne & 11 & 50,00 \\
\hline Tłumaczenia & 4 & 18,18 \\
\hline Obsługa instrumentów zabezpieczających realizację umowy & 3 & 13,64 \\
\hline $\begin{array}{l}\text { Otwarcie i prowadzenie subkonta na rachunku bankowym } \\
\text { lub odrębnego rachunku }\end{array}$ & 4 & 18,18 \\
\hline
\end{tabular}

*możliwy był wybór dowolnej liczby odpowiedzi

Źródło: opracowanie własne.

Kolejnym ważnym zagadnieniem badawczym jest próba odniesienia powyższych odpowiedzi do kluczowych pytań związanych z ogólną charakterystyką badanych przedsiębiorstw. Dotyczy to np. odpowiedzi na pytanie o wolne moce produkcyjne. Uzyskana odpowiedź na to pytanie może w pewnym sensie tłumaczyć czasem znacząco niską liczbę odpowiedzi we wcześniejszych pytaniach. Ponadto w zadanych pytaniach widoczna jest relatywnie wysoka grupa firm, które nie udzieliły żadnej odpowiedzi, co również może być informacją na temat zasad funkcjonowania podkarpackich przedsiębiorstw, a zwłaszcza przedsiębiorstw z określonego wcześniej profilu II (tab. 16).

Tab. 16. Struktura odpowiedzi w algorytmie decyzyjnym

\begin{tabular}{|l|c|c|c|c|}
\hline \multicolumn{1}{|c|}{ Pytanie } & $\begin{array}{c}\text { Liczba } \\
\text { wskazań } \\
\text { na TAK }\end{array}$ & $\begin{array}{c}\text { Odsetek } \\
\text { wskazań } \\
\text { na TAK }\end{array}$ & $\begin{array}{c}\text { Liczba } \\
\text { wskazań } \\
\text { na NIE }\end{array}$ & $\begin{array}{c}\text { Odsetek } \\
\text { wskazań } \\
\text { na NIE }\end{array}$ \\
\hline $\begin{array}{l}\text { Czy posiadasz wolne moce produkcyjne lub mógłbyś } \\
\text { szybko je powiększyć? }\end{array}$ & 41 & 44,57 & 34 & 36,96 \\
\hline $\begin{array}{l}\text { Czy zwiększenie produkcji zwiększy zyski i obniży } \\
\text { koszty jednostkowe? }\end{array}$ & 42 & 45,65 & 33 & 35,87 \\
\hline $\begin{array}{l}\text { Czy potrzebujesz informacji o zmianach i tendencjach } \\
\text { na rynkach światowych? }\end{array}$ & 34 & 36,96 & 45 & 48,91 \\
\hline $\begin{array}{l}\text { Czy wahania popytu krajowego są dokuczliwe dla } \\
\text { twojej firmy? }\end{array}$ & 36 & 39,13 & 44 & 47,83 \\
\hline $\begin{array}{l}\text { Czy poszukujesz nowych nisz i kontaktów } \\
\text { rynkowych? }\end{array}$ & 45 & 48,91 & 30 & 32,61 \\
\hline $\begin{array}{l}\text { Czy firma chce zwiększyć poziom zyskowności } \\
\text { i obrotów? }\end{array}$ & 48 & 52,17 & 28 & 30,43 \\
\hline $\begin{array}{l}\text { Czy poszukujesz nowych metod finansowania } \\
\text { i instrumentów wsparcia działalności? }\end{array}$ & 49 & 53,26 & 31 & 33,70 \\
\hline $\begin{array}{l}\text { Czy chcesz zwiększyć konkurencyjność na rynku } \\
\text { krajowym? }\end{array}$ & 54 & 58,70 & 20 & 21,74 \\
\hline
\end{tabular}

Źródło: opracowanie własne. 
Wśród uzyskanych odpowiedzi pozytywnie zaskakuje zwłaszcza grupa odpowiedzi negatywnych dotyczących pytania o wahania popytu krajowego. Może to bowiem świadczyć o dobrej kondycji badanych podkarpackich firm, które dzięki popytowi wewnętrznemu nie muszą szukać pomocy w eksporcie. Nie oznacza to jednak, że firmy te nie poszukują nowych kontaktów rynkowych. Poszukują, lecz zwykle krajowych. Pozytywnie również przedstawia się, co prawda tylko deklarowana, odpowiedź na pytanie o zwiększenie zyskowności. W pewnej mierze jest to pytanie retoryczne, jednak w dobie spowolnienia gospodarczego można przyjmować inne strategie przetrwania. Również za pozytywny objaw można przyjąć liczną grupę odpowiedzi na pytanie o poszukiwanie nowych metod finansowania i instrumentów wsparcia działalności. Należy jednak pamiętać o tym, że nie wiemy, co dokładnie kryje się pod stwierdzeniem poszukiwanie nowych metod, czy będzie ono realne, skuteczne i zgodne z prawem. Wreszcie za interesującą należy koniecznie przyjąć odpowiedź na pytanie o konkurencyjność na rynku krajowym. Większość wszystkich badanych przedsiębiorstw deklaruje chęć podnoszenia konkurencyjności na ryku krajowym. Zatem to rynek krajowy dla badanych przedsiębiorstw jest i będzie nadal rynkiem podstawowym, natomiast eksport, o ile występuje, ma jednak znaczenie drugorzędne. Być może świadomość poziomu, jakości itp. własnej produkcji zmusza do postawienia własnej firmy na rynkach międzynarodowych na z góry niekorzystnej pozycji.

Firmy podkarpackie mają doświadczenie w korzystaniu ze wsparcia eksportu. W przeważającej formie są to jednak tylko najbardziej obecnie rozpowszechnione dotacje. Forma ta nie wymaga jednak (poza działaniami biurokratycznymi) dużego wysiłku przedsiębiorców. Ponadto często rodzi ona zachowania roszczeniowe wśród przedsiębiorców. Warto także dodać, że poza dotacjami i kredytami większość rodzajów wsparcia eksportu, takich jak np. factoring, nie cieszy się popularnością. Niska liczba wskazań przy każdym rodzaju wsparcia eksportu wynika z faktu bardzo często deklarowanego braku potrzeby dofinansowywania działań, co jednak można interpretować pozytywnie jak i negatywnie (tab. 17).

Tab. 17. Struktura odpowiedzi na pytanie: Z których rodzajów wsparcia eksportu korzystała Państwa firma w ciągu ostatnich trzech lat?*

\begin{tabular}{|l|c|c|}
\hline \multicolumn{1}{|c|}{ Rodzaj wsparcia eksportu } & Liczba wskazań & Odsetek wskazań \\
\hline Kredyt/kredyt dofinansowywany & 13 & 15,29 \\
\hline Leasing & 15 & 17,65 \\
\hline Gwarancje pożyczkowa & 6 & 7,06 \\
\hline Dotacja & 22 & 25,88 \\
\hline Dotacja UE & 28 & 32,94 \\
\hline Factoring & 1 & 1,18 \\
\hline
\end{tabular}

*możliwy był wybór dowolnej liczby odpowiedzi

Źródło: opracowanie własne.

Odpowiedzi na pytanie o działania związane docelowo z eksportem skłaniają do poniższych stwierdzeń. Istnieje bardzo duża zależność wyboru formy finansowania od wybieranego działania, jak również samej popularności samego działania. Łączna suma wskazań ze wszystkich działań ewidentnie wskazuje na popularność form finansowania. Zdecydowanie najpopularniejszą 
formą wspierania eksportu są dotacje unijne, a następnie kredyty i inne dotacje. Na uwagę zasługuje jednak bardzo duża liczba wskazań na brak potrzeby podejmowania danego działania (tab. 18).

Tab. 18. Struktura odpowiedzi na pytanie: Jakie działania związane docelowo z eksportem wymagają w Państwa firmie finansowania i w jakiej formie?*

\begin{tabular}{|c|c|c|c|c|c|c|c|c|}
\hline Działania & 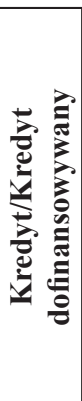 & 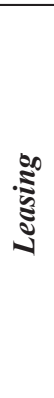 & 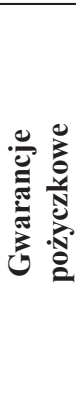 & $\begin{array}{l}\frac{\pi}{\tilde{J}} \\
\stackrel{\tilde{\sigma}}{0}\end{array}$ & 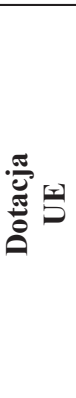 & $\stackrel{\Xi}{\Xi}$ & 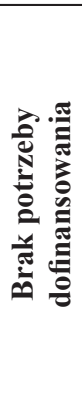 & 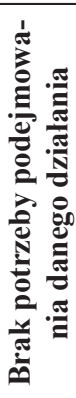 \\
\hline & \multicolumn{8}{|c|}{ Liczba wskazań } \\
\hline Wyjazdy na misje i targi gospodarcze & 24 & 0 & 2 & 14 & 33 & 0 & 1 & 18 \\
\hline Badanie rynku zagranicznego & 10 & 7 & 1 & 1 & 26 & 0 & 4 & 19 \\
\hline $\begin{array}{l}\text { Strategia marketingowa/sprzedaży/reklama na } \\
\text { rynku zagranicznym }\end{array}$ & 6 & 1 & 4 & 14 & 12 & 1 & 2 & 28 \\
\hline Wspólne projekty z partnerami zagranicznymi & 6 & 2 & 2 & 16 & 18 & 0 & 4 & 14 \\
\hline Poszukiwanie partnerów zagranicznych & 12 & 2 & 2 & 0 & 24 & 0 & 4 & 12 \\
\hline Wsparcie na thumaczenia & 8 & 4 & 1 & 0 & 14 & 2 & 8 & 12 \\
\hline Nieruchomości gruntowe & 8 & 1 & 1 & 0 & 19 & 0 & 7 & 22 \\
\hline Nieruchomości budowlane i budowle & 18 & 1 & 1 & 11 & 20 & 0 & 4 & 22 \\
\hline Środki transportu & 12 & 11 & 1 & 0 & 10 & 1 & 8 & 20 \\
\hline Maszyny i urządzenia & 10 & 22 & 1 & 12 & 26 & 1 & 4 & 12 \\
\hline Wdrożenie nowej technologii & 12 & 6 & 1 & 11 & 37 & 0 & 3 & 14 \\
\hline Prowadzenie prac badawczo-rozwojowych & 15 & 1 & 2 & 16 & 24 & 0 & 4 & 19 \\
\hline Know-how & 9 & 4 & 4 & 0 & 30 & 0 & 5 & 21 \\
\hline Oprogramowanie & 11 & 14 & 0 & 11 & 36 & 0 & 6 & 10 \\
\hline $\begin{array}{l}\text { Obsługa doradcza odnośnie działania na rynku } \\
\text { zagranicznym }\end{array}$ & 14 & 3 & 1 & 0 & 15 & 0 & 8 & 10 \\
\hline Projekty techniczne & 10 & 6 & 0 & 12 & 27 & 0 & 7 & 30 \\
\hline Suma wskazań & 185 & 85 & 24 & 118 & 371 & 5 & 79 & 283 \\
\hline
\end{tabular}

*możliwy był wybór dowolnej liczby odpowiedzi

Źródło: opracowanie własne. 
Biorąc pod uwagę poszczególne działania, najwięcej wskazań, niezależnie od formy inwestowania, uzyskały wyjazdy na misje i targi gospodarcze, maszyny i urządzenie oraz projekty techniczne. Wszystkie te działania obliczone są na stosunkowo szybki, czasem doraźny cel. Nie wymagają też zaangażowania obcych zasobów - poza środkami finansowymi.

Spośród wymienionych barier zewnętrznych, utrudniających korzystanie z instrumentów wsparcia eksportu, należy wymienić koszty obsługi oraz czasochłonność na etapie podpisywania umów. Wydaje się jednak, że badani podkarpaccy przedsiębiorcy podkreślają w zasadzie istotność wszystkich wymienionych barier, które mają uwarunkowania głównie finansowe i czasowe, ale także organizacyjne. Daje to również wskazówkę, aby przynajmniej bariery instytucjonalne i prawne zredukować. Godny uwagi jest stosunkowo duży odsetek odpowiedzi „Ani tak, ani nie”, co w rzeczywistości może być utożsamiane z brakiem zdania, wiedzy lub przekonania, tak jak w wypadku bariery określonej jako mała dostępność do instytucji wsparcia MŚP (tab. 19).

Tab. 19. Struktura odpowiedzi na pytanie: Proszę wskazać na bariery zewnętrzne utrudniające wykorzystanie przez Państwa firmę z instrumentów wsparcia eksportu dla MŚP

\begin{tabular}{|c|c|c|c|c|c|}
\hline \multirow[t]{2}{*}{ Bariery } & $\begin{array}{c}\text { Zdecydowanie } \\
\text { tak }\end{array}$ & Tak & $\begin{array}{c}\text { Ani tak, } \\
\text { ani nie }\end{array}$ & Nie & $\begin{array}{c}\text { Zdecydowanie } \\
\text { nie }\end{array}$ \\
\hline & \multicolumn{5}{|c|}{ przybliżony udział odpowiedzi w pytaniu } \\
\hline $\begin{array}{l}\text { Skomplikowane } \\
\text { przepisy }\end{array}$ & 0,5 & 0,3 & 0,05 & 0,05 & 0,0 \\
\hline $\begin{array}{l}\text { Brak standardów } \\
\text { jakości }\end{array}$ & 0,1 & 0,3 & 0,3 & 0,2 & 0,1 \\
\hline $\begin{array}{l}\text { Niski poziom } \\
\text { informatyzacji }\end{array}$ & 0,1 & 0,3 & 0,2 & 0,3 & 0,1 \\
\hline Koszty obsługi & 0,2 & 0,7 & 0,1 & 0,0 & 0,0 \\
\hline $\begin{array}{l}\text { Wymaganie } \\
\text { udziału własnego }\end{array}$ & 0,3 & 0,4 & 0,2 & 0,1 & 0,0 \\
\hline $\begin{array}{l}\text { Mała dostępność } \\
\text { do instytucji } \\
\text { wsparcia MŚP }\end{array}$ & 0,2 & 0,4 & 0,4 & 0,0 & 0,0 \\
\hline $\begin{array}{l}\text { Zbyt wysokie } \\
\text { oprocentowanie }\end{array}$ & 0,3 & 0,3 & 0,3 & 0,1 & 0,0 \\
\hline $\begin{array}{l}\text { Czasochłonność } \\
\text { na etapie } \\
\text { podpisywania } \\
\text { umów }\end{array}$ & 0,4 & 0,5 & 0,1 & 0,0 & 0,0 \\
\hline $\begin{array}{l}\text { Mała dostępność } \\
\text { informacji } \\
\text { o wsparciu MŚP }\end{array}$ & 0,1 & 0,6 & 0,3 & 0,0 & 0,0 \\
\hline
\end{tabular}

Źródło: opracowanie własne. 
Odrębną grupą barier mogących utrudniać korzystanie z instrumentów wsparcia eksportu stanowią bariery wewnętrzne. Wśród nich na szczególną uwagę według przedsiębiorców zasługuje trudność w tworzeniu dokumentacji oraz wymaganie kapitału własnego. Należy koniecznie podkreślić, że $\mathrm{w}$ tej grupie typowanych barier kilka z nich okazało się barierami czysto teoretycznymi i faktycznie nie stanowi trudności dla przedsiębiorców. Są to: jakość obsługi, komputera i oprogramowania, brak dostępu do Internetu, a w dalszej kolejności krótki okres działalności firmy. Również w tej grupie barier istnieją takie, których ocena nie jest jednoznaczna. Należą do nich słabe uzasadnienie projektów oraz brak planowania strategicznego. Wynika to z tych samych przyczyn, które zostały podane przy czynnikach zewnętrznych (tab. 20).

Tab. 20. Struktura odpowiedzi na pytanie: Proszę wskazać na bariery wewnętrzne utrudniające wykorzystanie przez Państwa firmę z instrumentów wsparcia eksportu dla MŚP

\begin{tabular}{|c|c|c|c|c|c|}
\hline \multirow{2}{*}{ Bariery } & $\begin{array}{c}\text { Zdecydowanie } \\
\text { tak }\end{array}$ & Tak & $\begin{array}{l}\text { Ani tak, } \\
\text { ani nie }\end{array}$ & Nie & $\begin{array}{c}\text { Zdecydowanie } \\
\text { nie }\end{array}$ \\
\hline & \multicolumn{5}{|c|}{ przybliżony udzial odpowiedzi w pytaniu } \\
\hline $\begin{array}{l}\text { Trudności } \\
\text { w tworzeniu } \\
\text { dokumentacji }\end{array}$ & 0,3 & 0,4 & 0,2 & 0,1 & 0,0 \\
\hline $\begin{array}{l}\text { Słabe wyniki } \\
\text { ekonomiczne }\end{array}$ & 0,1 & 0,4 & 0,2 & 0,3 & 0,0 \\
\hline $\begin{array}{l}\text { Brak planowania } \\
\text { strategicznego }\end{array}$ & 0,1 & 0,2 & 0,4 & 0,3 & 0,0 \\
\hline $\begin{array}{l}\text { Brak standardów } \\
\text { jakości }\end{array}$ & 0,1 & 0,3 & 0,1 & 0,4 & 0,1 \\
\hline $\begin{array}{l}\text { Słabe uzasadnie- } \\
\text { nie projektów }\end{array}$ & 0,1 & 0,1 & 0,5 & 0,3 & 0,0 \\
\hline $\begin{array}{l}\text { Trudności } \\
\text { z określeniem } \\
\text { celów wsparcia }\end{array}$ & 0,0 & 0,4 & 0,3 & 0,2 & 0,1 \\
\hline $\begin{array}{l}\text { Wymaganie } \\
\text { udziału własnego }\end{array}$ & 0,2 & 0,4 & 0,2 & 0,2 & 0,0 \\
\hline $\begin{array}{l}\text { Krótki okres } \\
\text { działalności firmy }\end{array}$ & 0,2 & 0,1 & 0,2 & 0,5 & 0,0 \\
\hline $\begin{array}{l}\text { Odległa lokaliza- } \\
\text { cja firmy od } \\
\text { instytucji wsparcia }\end{array}$ & 0,0 & 0,3 & 0,3 & 0,3 & 0,1 \\
\hline $\begin{array}{l}\text { Brak dostępu do } \\
\text { sieci Internet }\end{array}$ & 0,0 & 0,0 & 0,0 & 0,3 & 0,7 \\
\hline $\begin{array}{l}\text { Jakość obsługi } \\
\text { komputera } \\
\text { i oprogramowania }\end{array}$ & 0,0 & 0,0 & 0,1 & 0,3 & 0,6 \\
\hline
\end{tabular}

Źródło: opracowanie własne. 
W przeprowadzonych badaniach przedsiębiorcy mieli również ocenić metody promocji instrumentów wsparcia eksportu. Według badanych przedsiębiorców, wysoką skutecznością promocyjną cieszą się kontakty osobiste, co można traktować niekoniecznie pozytywnie. Natomiast na drugim miejscu znalazł się punkt informacyjny jako miejsce realizacji działań promocyjnych np. na imprezach targowo-wystawienniczych. Łącząc zaś te dwa działania promocyjne, można dojść do przekonania, że najwyższą skutecznością promocyjną cieszą się targi i wystawy (tab. 21).

Tab. 21. Struktura odpowiedzi na pytanie: Jak ocenia Pan/i metody promocji mające na celu popularyzację instrumentów wsparcia eksportu dla MŚP?

\begin{tabular}{|l|c|c|c|c|}
\hline \multicolumn{1}{|c|}{ Metody promocji } & $\begin{array}{c}\text { W ogóle } \\
\text { nieprzydatny }\end{array}$ & $\begin{array}{c}\text { Mało } \\
\text { przydatny }\end{array}$ & $\begin{array}{c}\text { Średnio } \\
\text { przydatny }\end{array}$ & $\begin{array}{c}\text { Bardzo } \\
\text { przydatny }\end{array}$ \\
\cline { 2 - 5 } & \multicolumn{3}{|c|}{ przybliżony udział odpowiedzi w pytaniu } \\
\hline $\begin{array}{l}\text { Materiały drukowane (folder, } \\
\text { broszury, prospekty, ulotki itp.) }\end{array}$ & 0,0 & 0,2 & 0,6 & 0,2 \\
\hline $\begin{array}{l}\text { Media lokalne i regionalne } \\
\text { (TV, radio, prasa) }\end{array}$ & 0,0 & 0,4 & 0,4 & 0,2 \\
\hline $\begin{array}{l}\text { Sieci informatyczne, Internet, } \\
\text { portale internetowe }\end{array}$ & 0,1 & 0,1 & 0,1 & 0,7 \\
\hline $\begin{array}{l}\text { Udział w targach, wystawach lub } \\
\text { innych imprezach handlowych }\end{array}$ & 0,0 & 0,0 & 0,6 & 0,4 \\
\hline $\begin{array}{l}\text { Prezentacje komercyjne na } \\
\text { konferencjach, seminariach itp. }\end{array}$ & 0,0 & 0,3 & 0,3 & 0,4 \\
\hline Punkt informacyjny & 0,0 & 0,0 & 0,5 & 0,5 \\
\hline Kontakty osobiste & 0,0 & 0,1 & 0,1 & 0,8 \\
\hline
\end{tabular}

Źródło: opracowanie własne.

W kolejnym pytaniu o poziom świadomości działań wspierających eksport, respondenci ewidentnie wskazali na wzrost zysków, a w dalszej kolejności na zwiększenie sprzedaży. Niestety, poza efektami dochodowymi pozostałe czynniki nie były dla nich zbyt istotne. Przedsiębiorcy (zwłaszcza mali) poprzez takie wskazania sugerują drapieżność swoich działań na rynku, częste naśladownictwo, szukanie przewagi konkurencyjnej tylko w czynniku kosztowym bez podnoszenia jakości produktów i usług (tab. 22).

Tab. 22. Struktura odpowiedzi na pytanie: Proszę wskazać, jakie efekty ekonomiczne może Państwa firma osiągnąć dzięki eksportowi?*

\begin{tabular}{|l|c|c|}
\hline \multicolumn{1}{|c|}{ Efekty ekonomiczne } & Liczba wskazań & Odsetek wskazań \\
\hline Zwiększenie sprzedaży & 39 & 23,93 \\
\hline Zwiększenie zysków & 50 & 30,67 \\
\hline Zmniejszenie kosztów jednostkowych & 25 & 15,34 \\
\hline Poprawa jakości oferowanych produktów lub usług & 21 & 12,88 \\
\hline Wprowadzenie nowych produktów do oferty & 28 & 17,18 \\
\hline
\end{tabular}

*możliwy był wybór dowolnej liczby odpowiedzi

Źródło: opracowanie własne. 
Z drugiej strony przedsiębiorcy wskazują, że to właśnie wysoka jakość produktów i usług może decydować o sukcesie na rynkach zagranicznych. Albo więc istnieje pewna niekonsekwencja wypowiedzi wielu respondentów, albo też następuje odnoszenie wysokiej jakości tylko do rynków zagranicznych. Nieznacznie tylko mniej istotne okazały się konkurencyjna cena i zaawansowanie technologiczne. Za negatywny można uznać niski procent wskazań na ciekawe wzornictwo, ponieważ to może świadczyć o utrwalaniu stereotypu i braku działań mających na celu wypracowanie własnego charakteru i stylu produktów oraz usług. Podobne oceny dotyczą czynnika reklamowego (tab. 23).

Tab. 23. Struktura odpowiedzi na pytanie: Jakie czynniki decydują o sukcesie na rynkach zagranicznych?*

\begin{tabular}{|l|c|c|}
\hline \multicolumn{1}{|c|}{ Czynniki } & Liczba wskazań & Odsetek wskazań \\
\hline Konkurencyjna cena & 35 & 20,23 \\
\hline Wysoka jakość produktów lub usług & 42 & 24,28 \\
\hline Zaawansowane technologie & 36 & 20,81 \\
\hline Ciekawe wzornictwo & 29 & 16,76 \\
\hline Reklama & 31 & 17,92 \\
\hline
\end{tabular}

*możliwy był wybór dowolnej liczby odpowiedzi

Źródło: opracowanie własne.

Bardzo niepokojąca okazała się struktura odpowiedzi na pytanie o to, czy przedsiębiorstwo aplikowało o fundusze krajowe lub unijne. W żadnym ze wskazanych funduszy odsetek wskazań nie przekroczył 30\% ogółu badanych, a w ponad 50\% przypadków funduszy żadne przedsiębiorstwo z badanych nie starało się skorzystać z ich oferty. Można zatem przyjąć, że wiele przedsiębiorstw nie podjęło nawet trudu złożenia wniosków i już sam ten fakt budzi wiele pytań. Ponadto pytanie to ilustruje doświadczenie badanych przedsiębiorstw w pozyskiwaniu środków na wspieranie eksportu. Można więc przyjąć, że doświadczenie to jest nikłe (tab. 24).

Tab. 24. Struktura odpowiedzi na pytanie: Czy przedsiębiorstwo aplikowało o fundusze krajowe lub unijne?

\begin{tabular}{|l|c|c|}
\hline \multirow{2}{*}{\multicolumn{1}{|c|}{ Fundusze }} & \multicolumn{2}{c|}{ Zaokrąglony udział wskazań } \\
\cline { 2 - 3 } & na TAK & na NIE \\
\hline Program Ramowy UE & 0,0 & 0,0 \\
\hline Fundusze PHARE & 0,0 & 0,0 \\
\hline SPO WKP & 0,1 & 0,9 \\
\hline SPO RZL & 0,0 & 1,0 \\
\hline ZPORR & 0,1 & 0,9 \\
\hline PO IG & 0,1 & 0,9 \\
\hline RPO & 0,2 & 0,8 \\
\hline PO RPW & 0,0 & 0,0 \\
\hline PO IŚ & 0,3 & 0,7 \\
\hline PO KL & 0,0 & 1,0 \\
\hline Krajowe granty celowe & 0,0 & 1,0 \\
\hline
\end{tabular}

Źródło: opracowanie własne. 
Potwierdzeniem wniosków płynących z poprzedniego pytania jest pytanie o aktualny stan wykorzystania funduszy unijnych. Na podstawie przeprowadzonych badań ankietowych można stwierdzić, że badane przedsiębiorstwa Podkarpacia nie korzystają powszechnie z funduszy. Co prawda istnieją przedsiębiorstwa, które korzystają głównie z Sektorowego Programu Operacyjnego - Wzrost Konkurencyjności Przedsiębiorstw, Regionalnego Programu Operacyjnego oraz Programu Operacyjnego - Kapitał Ludzki, ale jednak udział tych przedsiębiorstw w badanej grupie nie przekracza 10\% ogółu (tab. 25).

Tab. 25. Struktura odpowiedzi na pytanie: Czy przedsiębiorstwo korzysta lub korzystało z funduszy krajowych lub unijnych?

\begin{tabular}{|l|c|c|}
\hline \multirow{2}{*}{ Fundusze } & \multicolumn{2}{c|}{ Zaokrąglony udzial wskazań } \\
\cline { 2 - 3 } & na TAK & na NIE \\
\hline Program Ramowy UE & 0,0 & 0,0 \\
\hline Fundusze PHARE & 0,0 & 0,0 \\
\hline SPO WKP & 0,1 & 0,9 \\
\hline SPO RZL & 0,0 & 1,0 \\
\hline ZPORR & 0,0 & 1,0 \\
\hline PO IG & 0,0 & 1,0 \\
\hline RPO & 0,1 & 0,9 \\
\hline PO RPW & 0,0 & 0,0 \\
\hline PO IŚ & 0,0 & 1,0 \\
\hline PO KL & 0,1 & 0,9 \\
\hline Krajowe granty celowe & 0,0 & 1,0 \\
\hline
\end{tabular}

Źródło: opracowanie własne.

Badane przedsiębiorstwa wykazują umiarkowane zainteresowanie uzyskaniem grantu na wspieranie działań eksportowych, przy czym widoczne są dwa stanowiska, które ściśle odpowiadają dwóm dominującym profilom przedsiębiorstw. Jedno z nich, związane z mikrofirmami, to granty nieprzekraczające 75 tys. zł. Natomiast przedsiębiorstwa małe i średnie skłonne są przyjąć granty powyżej 100 tys. zł. Ale zaskakująco najwięcej wskazań otrzymały granty o wysokości powyżej 200 tys. Wysokość grantu zgodna jest z celem działań wspierających eksport (tab. 26). 
Tab. 26. Struktura odpowiedzi na pytanie: Jakiej wysokości grantem, udzielanym przez Euroregion Karpaty Polska na wsparcie działań eksportowych, byłby/aby Pan/i zainteresowany/a?

\begin{tabular}{|l|c|}
\hline \multicolumn{1}{|c|}{ Wysokość grantu } & Zaokragglony udział wskazań \\
\hline Do 10 tys. zł & 0,0 \\
\hline Od 11 tys. do 25 tys. zł & 0,1 \\
\hline Od 26 tys. do 50 tys. zł & 0,0 \\
\hline Od 51 tys. do 75 tys. zł & 0,3 \\
\hline Od 76 tys. do 100 tys. zł & 0,1 \\
\hline Od 101 tys. do 150 tys. zł & 0,1 \\
\hline Od 151 tys. do 200 tys. zł & 0,1 \\
\hline Powyżej 200 tys. zł & 0,3 \\
\hline
\end{tabular}

Źródło: opracowanie własne.

Jedną z barier możliwości korzystania z instrumentów wsparcia eksportu okazał się udział kapitału własnego. Stąd tak niski deklarowany maksymalny wkład własny. Warto podkreślić, że większość mikroprzedsiębiorstw deklaruje zerowy wkład własny, natomiast wkład własny powyżej $20 \%$ deklarują tylko przedsiębiorstwa średnie. Taka struktura odpowiedzi wskazuje na niskie zasoby kapitałowe przedsiębiorstw, a przez to na przynajmniej teoretyczną motywację do ich pozyskiwania. Z drugiej strony wymogi administracyjno-prawne mogą znacznie ograniczać te możliwości (tab. 27).

Tab. 27. Struktura odpowiedzi na pytanie: Jaki maksymalny wkład własny, wyrażony procentowo, byliby Państwo w stanie zaangażować w realizację grantu udzielanego przez Euroregion Karpaty Polska, na wsparcie działań eksportowych?

\begin{tabular}{|c|c|}
\hline Wkład (w\%) & Zaokrąglony udział wskazań \\
\hline 0 & 0,5 \\
\hline $1-10$ & 0,2 \\
\hline $11-20$ & 0,1 \\
\hline $21-30$ & 0,1 \\
\hline $31-40$ & 0,1 \\
\hline $41-50$ & 0,0 \\
\hline $51-60$ & 0,0 \\
\hline $61-70$ & 0,0 \\
\hline $71-80$ & 0,0 \\
\hline $81-90$ & 0,0 \\
\hline $91-100$ & 0,0 \\
\hline
\end{tabular}

Źródło: opracowanie własne. 
Przeprowadzone badanie ankietowe miało dać odpowiedź na pytanie o potrzeby małych i średnich przedsiębiorstw w zakresie promocji eksportu oraz nawiązywania i rozwoju kontaktów gospodarczych z podmiotami z obszaru Unii Europejskiej. Oczywistym jest fakt, że takie potrzeby istnieją i dotyczą w zasadzie większości badanych przedsiębiorstw, choć w różnym zakresie. Ponadto istnieje kilka niepokojących zjawisk dotyczących m.in. traktowania ewentualnych pozyskiwanych funduszy bardzo instrumentalnie i tylko w wymiarze ilościowym. Dodatkowo badane przedsiębiorstwa traktują rynek zagraniczny drugoplanowo, koncentrując się jednak na popycie krajowym. Może to wynikać z ich możliwości, ale również przyzwyczajeń i utrwalonych stereotypów. Wreszcie pozyskiwane fundusze w znacznym stopniu rozwiązywałyby doraźne cele eksportowe, a niestety nie przyczyniałyby się do budowania marki, produktu, firmy w dłużej perspektywie czasowej.

Badani przedsiębiorcy z Podkarpacia chcieliby korzystać głównie z funduszy unijnych w celu wspierania eksportu. Przyzwyczajeni do tej formy, nie dostrzegają innych możliwości, które być może wiążą się z większą aktywnością i restrykcyjnością.

Niewątpliwie istnieje więc potrzeba korzystania z instrumentów i działań eksportowych przez mikro-, małe i średnie przedsiębiorstwa. Niestety, wdrażanie tych instrumentów napotyka na wiele ograniczeń tak po stronie samych przedsiębiorstw, jak i po stronie ich otoczenia. Warto podkreślić, że przynajmniej część z barier jest możliwa do pokonania. Wymaga to jednak zmian nie tylko na poziomie administracyjno-prawnym, ale także - a może przede wszystkim mentalnościowym.

\section{SME Sector as a Potential Recipient of the Local Export Development Fund}

This article is an attempt to identify the needs of small and medium enterprises of Podkarpackie voivodeship in the scope of export support as well as establishing and developing economic contacts with subjects from the EU. As it is suggested by the conducted research, there is a considerable need to the use of export instruments and activities. Unfortunately, their implementation is faced with numerous limitations both on the side of enterprises themselves and their environment. It needs to be emphasised, however, that it requires changes not only at the administrative and legal level, but also at mental-related one. 


\section{Agnieszka Buś-Bidas}

Państwowa Wyższa Szkoła Zawodowa

w Tarnobrzegu

\section{Fundusze pożyczkowe w finansowaniu przedsiębiorstw sektora MŚP na przykładzie Funduszu Mikro Sp. z o.o. oddział w Tarnobrzegu}

\section{Rola małych i średnich przedsiębiorstw w gospodarce narodowej}

Uzasadnienie dla dynamicznego wzrostu liczby małych i średnich przedsiębiorstw w gospodarce rynkowej znajdujemy w sformułowanej przez J. Schumpetera tezie o „kreatywnej destrukcji”, zgodnie z którą kapitalizm nie mógłby istnieć bez ciągłego rodzenia się nowych firm i staczania się starych (Schumpeter 1960). Formowanie się sektora MŚP nie przebiega wszędzie jednakowo, jest warunkowane przez szereg czynników o charakterze zewnętrznym i wewnętrznym. Sektor małych i średnich przedsiębiorstw w Polsce wprawdzie boryka się z wieloma barierami rozwoju, jednak nie uniemożliwia mu to pełnienia zarówno funkcji gospodarczych, jak i społecznych. B. Piasecki wymienia szereg działań, które podejmuje sektor MŚP w sferze gospodarczej. Są to:

- aktywny udział w procesie zmian w strukturze przemysłowej kraju (inicjowanie powstawania i rozwoju nowych dziedzin produkcji i nowych rodzajów usług, w tym również tych, które z wielu powodów nie były rozwijane w okresie gospodarki centralnie planowanej),

- odgrywanie ważnej roli w formowaniu się prywatnej własności środków produkcji (przejęcie i produkcyjne zagospodarowanie części maszyn i wyposażenia prywatyzowanych wielkich państwowych przedsiębiorstw i wydzielenie z nich wielu mniejszych jednostek, co sprzyja dekoncentracji i demonopolizacji gospodarki kraju),

- wchłonięcie i zagospodarowanie znacznych zasobów siły roboczej, uwolnionej w wyniku racjonalizacji funkcjonowania sektora publicznego,

- zbudowanie koniecznej dla efektywnego funkcjonowania całego systemu gospodarczego ekonomicznej infrastruktury, zwłaszcza rozwój kooperacji i systemu podwykonawstwa,

- wymuszenie zmian w prawnych uregulowaniach sprzyjających przedsiębiorczości i efektywności funkcjonowania małych podmiotów gospodarczych (Piasecki 2001).

I. Czaja podkreśla, że małe i średnie przedsiębiorstwa w procesie rozwoju gospodarki pełnią ponadto inne role: stanowią źródło informacji, niwelują wielkość wahań ekonomicznych, ułatwiają życie konsumentom, równoważą wpływy dużych firm, zagospodarowują nisze na rynku (Targalski 1999). Regionalna decentralizacja dotycząca sektora MŚP oznacza, że lokalizacja podmiotów gospodarczych następuje w każdym miejscu regionu, również tam, gdzie dużym przedsiębiorstwom to się nie opłaca. Ta funkcja małych i średnich przedsiębiorstw przyczynia się także do ograniczania tendencji monopolistycznych w gospodarce (Safin 2003). 
Z punktu widzenia tzw. efektu produkcyjnego o znaczeniu sektora MŚP w gospodarce przesądzają nie tyle względy efektywnościowe, ile charakterystyki ilościowe. W 2007 r. udział MŚP w tworzeniu produktu krajowego brutto wyniósł 47,4\%, w tym mikroprzedsiębiorstw - 30,1\%, małych przedsiębiorstw - 7,3\%, zaś średnich - 10,0\% (Raport 2009). Cechą charakterystyczną w działalności MŚP, obserwowaną od wielu lat, jest wyraźnie silniejsze zaangażowanie w działalność importową niż eksportową. Udział MŚP w eksporcie ogółem wyniósł w 2004 r. 44,5\% i zwiększył się o około $0,2 \%$ w porównaniu z rokiem poprzednim. Dzięki temu zahamowana została tendencja spadkowa udziału MŚP w eksporcie ogółem, która występowała w latach 2002 i 2003. Z kolei udział MŚP w imporcie ogółem zwiększył się z 59,4\% w 2003 r. do 61,8\% w 2004 r. (Raport 2006). W Polsce, podobnie jak w innych krajach Unii Europejskiej, MŚP przeważają głównie w handlu, budownictwie, działalności gastronomiczno-handlowej. Odgrywają podstawową rolę jako dostawcy półfabrykatów, części maszyn i urządzeń oraz jako wykonawcy specjalistycznych usług dla przedsiębiorstw dużych. Jak twierdzi K. Safin, znaczenie MŚP w dziedzinie produkcji nie maleje, a nadchodzący etap zindywidualizowanych potrzeb stanie się domeną młodych firm (Safin 2003).

Funkcje społeczne pełnione przez MŚP polegają m.in. na uformowaniu klas drobnych właścicieli (jako jednego z ważnych składników pluralizmu politycznego i budowy demokratycznych instytucji), łagodzeniu napięć społecznych i redukcji wysokich społecznych kosztów procesu transformacji poprzez pochłanianie nadwyżek siły roboczej, promowanie samozatrudnienia, wskazywanie możliwości osiągnięcia sukcesu i zmiany statusu społecznego (Piasecki 1998). Korzystny wpływ sektora MŚP na efekty zatrudnienia ma wymiar wielowątkowy (Raport 2006; Safin 2003; Małecka 1999; Kożuch, Plawgo 1999; Bielawska 1992; Raport 2009):

- znaczenie MŚP jako pracodawcy odzwierciedlają dane statystyczne - w 2007 r. liczba pracujących ogółem w przedsiębiorstwach wyniosła 8,969 tys. osób, z czego nieco ponad 69\% pracowało w przedsiębiorstwach sektora MŚP,

- MŚP wnoszą duży wkład w tworzenie nowych miejsc pracy w obszarach trudnych do zagospodarowania i dają większą pewność ich utrzymania niż duże przedsiębiorstwa,

- MŚP mają poważny udział w systemie szkolenia i kształcenia zawodowego,

- małe przedsiębiorstwa generują niższy poziom bezrobocia, co związane jest m.in. z tym, że są one wierne pierwotnej lokalizacji,

- małe i średnie przedsiębiorstwa nie zatrudniają pracowników najemnych (ok. 31\%); oznacza to, że samozatrudnienie jest w poważnej części źródłem nowych miejsc pracy,

- niezbędne nakłady finansowe na utworzenie jednego miejsca pracy w małej firmie są kilkakrotnie niższe niż w dużych przedsiębiorstwach.

Małe i średnie przedsiębiorstwa poprzez pozytywne efekty swojej działalności (np. nowa inwestycja, produkcja, bogacenie się właścicieli) przyczyniają się do tworzenia pozytywnego obrazu przedsiębiorcy, kształtowania postaw przedsiębiorczych i wzrostu odpowiedzialności za własny los (Safin 2003).

\section{Źródła finansowania przedsiębiorstw sektora MŚP}

Istotę gospodarki finansowej przedsiębiorstw stanowi pozyskanie kapitału, sterowanie nim (administrowanie) i stosowanie go w sposób prawidłowy (Łuczka 1997). Korzystanie z kapitału obcego wynika z faktu niedysponowania przez podmioty gospodarcze własnymi środkami w pełni finansującymi bieżące i inwestycyjne przedsięwzięcia. Wybór źródeł finansowania jest uzależniony w dużym stopniu od hierarchii metod finansowania stosowanej przez MŚP oraz kryteriów, mówiących o atrakcyjności poszczególnych źródeł dla przedsiębiorstw. W odniesieniu do MŚP zastosowanie ma teoria hierarchii źródeł finansowania, stworzona przez 
S.C. Myersa. Zakłada ona, że przedsiębiorstwa wybierają źródła finansowania według określonej kolejności, nie starają się przy tym maksymalizować wartości firmy. Teoria ta wskazuje, że przedsiębiorstwa preferują wewnętrzne źródła finansowania. Dopiero w wypadku braku w wystarczającym stopniu źródeł wewnętrznych sięgają po środki zewnętrzne. Wybierając środki zewnętrzne, kierują się kolejnością jak najmniejszego uzależnienia od podmiotu, który je przyznaje (Wolański 2009).

Na pytanie, dlaczego przedsiębiorstwa korzystają z takich, a nie innych źródeł, można odpowiedzieć na podstawie kryteriów atrakcyjności poszczególnych źródeł finansowania. Jednak przy ich ustalaniu bierze się pod uwagę cechy samych źródeł, nie zaś postawę przedsiębiorstw. Można wyróżnić następujące kryteria oceny atrakcyjności poszczególnych źródeł finansowania (Kubiak 2005, Wolański 2009):

- dostępność - zależy od wymagań stawianych MŚP przez źródło finansowania; przedsiębiorstwo musi spełnić warunki określone przez udzielającego wsparcia finansowego (tab. 1),

- koszt - przedsiębiorstwa dążą do jego minimalizowania,

- elastyczność - oznacza szybkość pozyskania źródła, wielkość dostępnych środków, czas spłaty, łatwość zmniejszania i zwiększania wartości zadłużenia, możliwość renegocjacji terminu spłaty.

Tab. 1. Dostępność źródeł finansowania dla małych i średnich przedsiębiorstw

\begin{tabular}{|c|c|c|c|c|}
\hline \multicolumn{5}{|c|}{ Źródla finansowania } \\
\hline $\begin{array}{c}\text { dostępne przede } \\
\text { wszystkim dla } \\
\text { MŚP }\end{array}$ & $\begin{array}{l}\text { bardziej dostępne } \\
\text { dla MŚP niż } \\
\text { dla dużych } \\
\text { przedsiębiorstw }\end{array}$ & $\begin{array}{c}\text { jednakowo } \\
\text { dostępne dla } \\
\text { wszystkich } \\
\text { przedsiębiorstw }\end{array}$ & $\begin{array}{l}\text { bardziej dostępne } \\
\text { dla dużych } \\
\text { przedsiębiorstw } \\
\text { niż dla MŚP }\end{array}$ & $\begin{array}{c}\text { dostępne przede } \\
\text { wszystkim } \\
\text { dla dużych } \\
\text { przedsiębiorstw }\end{array}$ \\
\hline $\begin{array}{l}\text { poręczenia } \\
\text { kredytowe } \\
\text { - środki unijne } \\
\text { - pożyczki od } \\
\text { funduszy } \\
\text { pożyczkowych }\end{array}$ & $\begin{array}{l}\text { - dotacje budżetowe } \\
\text { - pożyczki od } \\
\text { rodziny i znajo- } \\
\text { mych }\end{array}$ & $\begin{array}{l}\text { - środki własne } \\
\text { - kredyty } \\
\text { bankowe } \\
\text { krótko- } \\
\text { terminowe } \\
\text { - leasing } \\
\text { - kredyty od } \\
\text { dostawców } \\
\text { - franchising }\end{array}$ & $\begin{array}{l}\text { - kredyty bankowe } \\
\text { długoterminowe } \\
\text { - kredyty od } \\
\text { odbiorców } \\
\text { - fundusze venture } \\
\text { capital } \\
\text { - factoring } \\
\text { - emisje na rynku } \\
\text { pozagiełdowym }\end{array}$ & 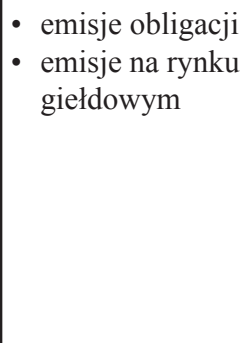 \\
\hline
\end{tabular}

Źródło: Wolański 2009, s. 81.

Na strategię finansowania przedsiębiorstw wpływają różne wymierne i niewymierne czynniki. Składają się na nią zarówno czynniki zależne od przedsiębiorstwa (wewnętrzne), jak i czynniki niezależne od niego (zewnętrzne). Do czynników wewnętrznych zalicza się m.in. cel i charakter prowadzonej działalności, skalę działalności, fazę rozwoju, w której znajduje się przedsiębiorstwo, perspektywy rozwoju przedsiębiorstwa, ryzyko gospodarcze, elastyczność finansową, strukturę posiadanego majątku, kondycję finansową, umiejętności kadr, zdolności produkcyjne. Na czynniki zewnętrzne składają się takie elementy, jak: polityka gospodarcza, komunikacja gospodarcza, obowiązujące przepisy prawne (głównie podatkowe), zakres dostępnych usług finansowych, warunki na rynku kapitałowym, trendy rozwojowe w danym dziale (Michalczuk 2000). Zatem czynniki występujące w otoczeniu oraz wewnątrz przedsiębiorstwa tworzą układ szans i zagrożeń dla wszystkich podmiotów działających w gospodarce. 
Wiedza na temat struktury i powiązań elementów otoczenia oraz kierunków zmian, określenie przewidywanych zmian i szacowanie ich skutków warunkuje trafny wybór decyzji w zakresie finansowania przedsiębiorstw, ich bieżącej działalności i rozwoju (Grzywacz, Okońska 2005).

Głównym źródłem finansowania małych i średnich przedsiębiorstw pozostają niezmiennie od lat własne środki pieniężne właściciela, generowany przez podmiot gospodarczy zysk i pożyczki z sektora pozabankowego. Wynika to m.in. z badań przeprowadzonych w 2008 r. na zlecenie Polskiej Agencji Rozwoju Przedsiębiorczości, poświęconych działalności inwestycyjnej sektora MŚP. Do podstawowych instrumentów finansowania działalności inwestycyjnej w 2007 r. wykorzystywane były: środki własne (tak deklarowało 94\% badanych przedsiębiorstw), kredyty i pożyczki krajowe (29\%), środki publiczne (3\%) (Raport 2008). Zbieżne dane na ten temat prezentują także najnowsze badania dotyczące funkcjonowania małych i średnich przedsiębiorstw wykonane dla Polskiej Konfederacji Pracodawców Prywatnych Lewiatan (tab. 2).

Tab. 2. Sposób finansowania inwestycji przez małe i średnie przedsiębiorstwa

\begin{tabular}{|l|c|c|c|}
\hline \multirow{2}{*}{\multicolumn{1}{c}{ Źródła finansowania inwestycji }} & \multicolumn{3}{|c|}{ Odsetek MŚP korzystających ze źródła } \\
\cline { 2 - 4 } & $\mathbf{2 0 0 5}$ & $\mathbf{2 0 0 6}$ & $\mathbf{2 0 0 7}$ \\
\hline Środki własne (w tym zysk zatrzymany) & $69,1 \%$ & $73,1 \%$ & $72,6 \%$ \\
\hline Kredyt bankowy & $16,6 \%$ & $12,7 \%$ & $17,4 \%$ \\
\hline Leasing & $10,5 \%$ & $9,0 \%$ & $6,9 \%$ \\
\hline Fundusze unijne & $1,4 \%$ & $1,9 \%$ & $1,9 \%$ \\
\hline Inne & $2,4 \%$ & $3,3 \%$ & $1,2 \%$ \\
\hline
\end{tabular}

Źródło: Starczewska-Krzystoszek 2008, s. 16.

Przyjęty sposób finansowania przez MŚP ma charakter konserwatywny i determinowany jest kilkoma czynnikami. Wydaje się, że najważniejszym z nich jest awersja do ryzyka związanego z korzystaniem ze środków obcych. Małe i średnie przedsiębiorstwa to w większości firmy rodzinne i decyzja o rozwoju opartym na obcym kapitale oznacza narażenie firmy na wyższe ryzyko, a tym samym na możliwość utraty firmy (bankructwo, przejęcie), a w konsekwencji - utratę miejsca pracy i dochodu. Drugim czynnikiem są koszty pozyskania kredytów. Nie chodzi tylko o prowizje i odsetki, ale także o koszt zabezpieczeń kredytów. Przedsiębiorstwa małe i średnie nie dysponują bowiem aktywami o wysokiej wartości, które mogłyby stanowić zabezpieczenie dla zaciąganych przez nie kredytów (Starczewska-Krzysztoszek 2008). Stąd przeciwdziałać takiemu stanowi rzeczy mają te instrumenty finansowania zewnętrznego, które adresowane są przede wszystkim do sektora MŚP. Mowa tu o środkach unijnych i budżetowych, pożyczkach i poręczeniach udzielanych przez fundusze pożyczkowe i poręczeniowe. Dla przykładu, stabilne fundusze pożyczkowe (FP), działające sprawnie w gospodarce, stały się idealnym partnerem dla Polskiej Agencji Rozwoju Przedsiębiorczości w niesieniu pomocy przedsiębiorcom, którzy ucierpieli podczas powodzi w roku 2001. W ramach tej współpracy, w ośmiu województwach nawiedzonych przez powódź, 10 funduszy pożyczkowych udzielało pożyczek 
na odtworzenie utraconego przez przedsiębiorców majątku. Rola funduszy pożyczkowych wraz z upływem czasu ewoluuje. Fundusze pożyczkowe dywersyfikują produkty finansowe i oferują dodatkowe usługi komplementarne, jak: szkolenia, doradztwo i konsultacje (Forin i inni 2010).

Głównym celem niniejszego artykułu jest przedstawienie opinii przedsiębiorców - klientów funduszu pożyczkowego: Fundusz Mikro Sp. z o.o. oddział w Tarnobrzegu (FM) na temat otrzymanych usług pożyczkowych i ich wpływu na funkcjonowanie przedsiębiorstw. Fundusz Mikro Sp. z o.o. jest niekomercyjną instytucją, która zaspokaja zapotrzebowanie na środki finansowe wyłącznie mikroprzedsiębiorców. Corocznie udziela ponad 230 pożyczek przedsiębiorcom, którzy nie spełniają warunków stawianych przez banki komercyjne. Wymagania kierowane do potencjalnych klientów FM dotyczą formy organizacyjno-prawnej i opodatkowania, struktury zatrudnienia oraz wskazania celu, na który zostanie udzielona pożyczka (Buś-Bidas 2006).

Charakteryzując portfel pożyczkowy tarnobrzeskiego oddziału Funduszu Mikro od początku działalności do 31.12.2008 r., należy wskazać, iż wyróżniał się on nie tylko liczbą udzielonych pożyczek, ale także ich całkowitą wartością. Udzielił prawie czterokrotnie więcej pożyczek niż łącznie pozostałe instytucje finansujące funkcjonujące w powiecie tarnobrzeskim oraz stalowowolskim, a całkowita wartość udzielonych pożyczek była blisko dwukrotnie wyższa od sumy wartości pożyczek biura obsługi klienta Inicjatywy Mikro i funduszu pożyczkowego przy Regionalnej Izbie Gospodarczej (Buś-Bidas 2009).

\section{Usługi pożyczkowe Funduszu Mikro Sp. z o.o. w opinii przedsiębiorców}

Mikroprzedsiębiorcy działający na terenie powiatu tarnobrzeskiego, sandomierskiego, stalowowolskiego stanowią ważnych odbiorców usług świadczonych przez instytucję pożyczkową. Stąd poproszeni zostali o wyrażenie swoich poglądów na tematy związane z podażową stroną rynku instrumentów finansowych. Prezentacja zbiorowości badawczej, składającej się z 35 przedsiębiorców została dokonana z uwzględnieniem poniższych kryteriów.

- Kryterium 1 - rodzaj prowadzonej działalności gospodarczej (tab. 3).

Tab. 3. Liczba/struktura badanych przedsiębiorstw według rodzaju prowadzonej działalności gospodarczej

\begin{tabular}{|l|c|c|}
\hline \multicolumn{1}{|c|}{ Rodzaj prowadzonej działaIności gospodarczej } & \multicolumn{2}{c|}{ Liczba i odsetek przedsiębiorstw } \\
\hline Przemysł & 3 & $8,6 \%$ \\
\hline Budownictwo & 13 & $8,6 \%$ \\
\hline Handel i naprawy & 4 & $37,0 \%$ \\
\hline Transport, gospodarka magazynowa i łączność & 2 & $11,4 \%$ \\
\hline Pośrednictwo finansowe & 2 & $5,7 \%$ \\
\hline Obsługa nieruchomości i firm & 8 & $5,7 \%$ \\
\hline $\begin{array}{l}\text { Działalność usługowa społeczna, indywidualna } \\
\text { i pozostała }\end{array}$ & 35 & $23,0 \%$ \\
\hline Ogółem & & $100,0 \%$ \\
\hline
\end{tabular}

Źródło: opracowanie własne ma podstawie badań ankietowych. 
Największa liczba przedsiębiorstw działała w sekcji handel i naprawy. Była to grupa licząca 13 podmiotów gospodarczych, tj. 37,0\% ogółu ankietowanych. Przedsiębiorstwa z branży przemysł oraz budownictwo stanowiły łącznie $17,2 \%$. W badanej zbiorowości nie stwierdzono przedsiębiorstw z sekcji rolnictwo, łowiectwo i leśnictwo, hotele i restauracje czy ochrona zdrowia.

- Kryterium 2 - forma organizacyjno-prawna podmiotu gospodarczego (tab. 4).

Tab. 4. Liczba/struktura badanych przedsiębiorstw według formy organizacyjno-prawnej

\begin{tabular}{|l|c|c|}
\hline \multicolumn{1}{|c|}{ Forma organizacyjno-prawna przedsiębiorstwa } & \multicolumn{2}{|c|}{ Liczba i odsetek przedsiębiorstw } \\
\hline Osoba fizyczna prowadząca działalność gospodarczą & 34 & $97,1 \%$ \\
\hline Spółka z ograniczoną odpowiedzialnością & 1 & $2,9 \%$ \\
\hline Ogółem & 35 & $100,0 \%$ \\
\hline
\end{tabular}

Źródło: opracowanie własne ma podstawie badań ankietowych.

Spośród 35 badanych przedsiębiorstw 34 było osobami fizycznymi prowadzącymi działalność gospodarczą. Jeden przedsiębiorca funkcjonował jako spółka z ograniczoną odpowiedzialnością.

- Kryterium 3 - okres prowadzenia działalności gospodarczej (tab. 5).

Tab. 5. Liczba/struktura badanych przedsiębiorstw według długości czasu prowadzenia działalności gospodarczej

\begin{tabular}{|l|c|c|}
\hline \multicolumn{1}{|c|}{ Okres prowadzenia działalności gospodarczej } & \multicolumn{2}{c|}{ Liczba i odsetek przedsiębiorstw } \\
\hline Krócej niż rok & 0 & $0,0 \%$ \\
\hline Od 1 roku do 3 lat & 4 & $11,4 \%$ \\
\hline Od 3 do 5 lat & 10 & $23,0 \%$ \\
\hline Od 5 do 10 lat & 13 & $28,6 \%$ \\
\hline Powyżej 10 lat & 35 & $37,0 \%$ \\
\hline Ogółem & & $100,0 \%$ \\
\hline
\end{tabular}

Źródło: opracowanie własne ma podstawie badań ankietowych.

Najliczniejsza była grupa przedsiębiorstw, które funkcjonowały na rynku dłużej niż 5 lat. Tworzyło ją 23 przedsiębiorców, co stanowiło 65,6\% ogółu ankietowanych. Zatem można stwierdzić, że większość podmiotów gospodarczych posiadała już ugruntowaną pozycję na rynku.

Badani przedsiębiorcy wskazywali różnorodne powody sięgania po pożyczki oferowane przez Fundusz Mikro Sp. z o.o. Większość ankietowanych, tj. 65,7\%, skorzystanie z instrumentów finansowych wiązało z realizacją planów rozwojowych. Prawie co drugi przedsiębiorca twierdził, iż do zgłoszenia zapotrzebowania na usługi pożyczkowe zmusił go bieżący problem lub kryzys. W ocenie pracowników FM sytuacja ekonomiczno-finansowa przedsiębiorstw pozwalała jednak na interwencję bez ryzyka, np. niewypłacalności pożyczkobiorcy. Przedsiębiorcy wymienili jeszcze inne przyczyny sięgania po wsparcie finansowe: brak możliwości uzyskania innego zewnętrznego źródła finansowania, brak informacji o istnieniu innych usług finansowych (tab. 6). 
Tab. 6. Liczba/struktura przedsiębiorstw według głównego powodu skorzystania z finansowania funduszu pożyczkowego

\begin{tabular}{|l|c|c|}
\hline \multicolumn{1}{|c|}{ Glówny powód skorzystania z usług pożyczkowych } & \multicolumn{2}{c|}{ Liczba i odsetek przedsiębiorstw } \\
\hline Przedsiębiorstwo przeżywało kryzys & 7 & $26,0 \%$ \\
\hline Przedsiębiorstwo borykało się z bieżącym problemem & 12 & $34,3 \%$ \\
\hline Przedsiębiorstwo realizowało plany rozwojowe & 23 & $65,7 \%$ \\
\hline $\begin{array}{l}\text { Brak możliwości uzyskania innego zewnętrznego źródła } \\
\text { finansowania }\end{array}$ & 15 & $42,9 \%$ \\
\hline Brak informacji o istnieniu innych usług finansowych & 4 & $11,4 \%$ \\
\hline
\end{tabular}

Źródło: opracowanie własne ma podstawie badań ankietowych.

Badani przedsiębiorcy dokonali oceny usług pożyczkowych, z których skorzystali, uwzględniając siedem następujących kryteriów: dostęp do usług, sposób organizacji usług, polityka cenowa, komunikacja z instytucją pożyczkową, zrozumienie specyfiki przedsiębiorstwa, profesjonalizm pracowników i jakość świadczonych usług. Zdecydowana większość ankietowanych (od 65,7\% do 88,5\% w zależności od rodzaju kryterium) wyraziła swoje zadowolenie z usług finansowych poprzez wystawienie ocen bardzo dobrych i dobrych. Są to czynniki, które wpłynęły na to, że oddział FM był najczęściej wybieraną instytucją finansującą działalność przedsiębiorców w latach 2004-2008. Wyjątek stanowi sytuacja, gdzie tylko 40,0\% respondentów odpowiadały usługi pożyczkowe ze względu na stosowaną politykę cenową, a $26 \%$ badanych oceniło usługi słabo i bardzo słabo (tab. 7). Ten fakt nie dziwi, bowiem wyniki badań przeprowadzonych w 2009 r. dotyczące oferty funduszy pożyczkowych jednoznacznie wskazują, iż prowizje i oprocentowanie od udzielonych pożyczek w analizowanym okresie były najwyższe właśnie w Funduszu Mikro Sp. z o.o. (Buś-Bidas 2009).

Tab. 7. Struktura przedsiębiorstw oceniających usługi pożyczkowe według rożnych kryteriów

\begin{tabular}{|c|c|c|c|c|c|}
\hline \multirow{2}{*}{ Kryterium } & \multicolumn{5}{|c|}{$\begin{array}{c}\text { Odsetek przedsiębiorstw oceniających usługi } \\
\text { pożyczkowe }(\%)\end{array}$} \\
\hline & $\begin{array}{l}\text { bardzo } \\
\text { dobrze }\end{array}$ & dobrze & średnio & słabo & $\begin{array}{c}\text { bardzo } \\
\text { slabo }\end{array}$ \\
\hline Dostęp do usług & 11,4 & 54,3 & 25,7 & 8,6 & 0,0 \\
\hline Sposób organizacji usług & 8,6 & 62,8 & 25,7 & 2,9 & 0,0 \\
\hline Polityka cenowa & 2,9 & 37,0 & 34,3 & 22,9 & 2,9 \\
\hline Komunikacja z instytucją wspierającą & 31,4 & 57,1 & 8,6 & 2,9 & 0,0 \\
\hline Zrozumienie specyfiki przedsiębiorstwa & 28,5 & 65,7 & 0,0 & 2,9 & 2,9 \\
\hline Profesjonalizm pracowników & 37,1 & 51,5 & 11,4 & 0,0 & 0,0 \\
\hline Jakość świadczonych usług & 31,4 & 54,3 & 11,4 & 2,9 & 0,0 \\
\hline
\end{tabular}

Źródło: opracowanie własne ma podstawie badań ankietowych. 
Zdaniem 80,0\% podmiotów gospodarczych, udzielone wsparcie miało korzystny wpływ na funkcjonowanie przedsiębiorstwa. Co piąty ankietowany przedsiębiorca nie miał sprecyzowanego poglądu na ten temat. Nie odnotowano przypadku niekorzystnego wpływu otrzymanych usług pożyczkowych na działalność badanych podmiotów gospodarczych i braku wpływu otrzymanej pomocy ze strony instytucji finansowej.

Najczęściej wymienianymi korzyściami, które przyniosły ankietowanym przedsiębiorstwom świadczone usługi pożyczkowe, były: poszerzenie bazy lokalowej $(51,4 \%)$, realizacja inwestycji rozwojowej (48,6\%). Kolejnymi pozytywnymi efektami otrzymanego wsparcia było rozszerzenie rynku zbytu w kraju/za granicą (34,3\%), komputeryzacja przedsiębiorstwa $(31,4 \%)$. Wskazać można także przykłady, gdzie tego typu pomoc finansowa miała wpływ na: powstanie nowych miejsc pracy, wdrożenie nowej technologii, podniesienie kwalifikacji kadry zarządzającej/pracowników czy poprawę jakości wyrobów/usług (tab. 8).

Tab. 8. Liczba/struktura przedsiębiorstw według wskazania rodzaju korzyści z otrzymanego wsparcia

\begin{tabular}{|l|c|c|}
\hline \multicolumn{1}{|c|}{ Korzyści z otrzymanego wsparcia } & \multicolumn{2}{c|}{ Liczba i odsetek przedsiębiorstw } \\
\hline Powstanie nowych miejsc pracy & 8 & $22,9 \%$ \\
\hline Wdrożenie nowej technologii & 7 & $20,0 \%$ \\
\hline Podniesienie kwalifikacji kadry zarządzającej/pracowników & 5 & $14,2 \%$ \\
\hline Rozszerzenie rynku zbytu w kraju/za granicą & 12 & $34,3 \%$ \\
\hline Realizacja inwestycji rozwojowej & 17 & $48,6 \%$ \\
\hline Wprowadzenie systemu zarządzania & 0 & $0,0 \%$ \\
\hline Poszerzenie bazy lokalowej & 18 & $51,4 \%$ \\
\hline Obniżenie kosztów działalności & 0 & $0,0 \%$ \\
\hline Poprawa jakości wyrobów/usług & 4 & $11,4 \%$ \\
\hline Komputeryzacja przedsiębiorstwa & 11 & $31,4 \%$ \\
\hline
\end{tabular}

Źródło: opracowanie własne ma podstawie badań ankietowych.

Odwołując się do wyników badań ankietowych pt. Fundusze pożyczkowe i poręczeniowe $w$ finansowaniu matych i średnich przedsiębiorstw $w$ Polsce, przeprowadzonych przez B. Bartkowiak, znajdujemy potwierdzenie, iż decydujący lub duży wpływ funduszy pożyczkowych dotyczy następujących aspektów funkcjonowania i rozwoju mikro-, małych i średnich przedsiębiorstw:

- możliwość finansowania inwestycji, w tym przedsięwzięć charakteryzujących się podwyższonym/wysokim ryzykiem,

- wzmacnianie pozycji rynkowej,

- aktywizowanie bezrobotnych i wsparcie przy zakładaniu nowej działalności gospodarczej,

- przełamywanie barier do finansowania (Bartkowiak 2009).

Z kolei umiarkowane oddziaływanie otrzymały następujące czynniki: komplementarność w stosunku do systemu bankowego i innych źródeł zewnętrznego finansowania, kreowanie dobrej historii kredytowej - stworzenie podwalin pod przyszłą współpracę z sektorem bankowym poprzez mniejsze wymogi dotyczące zabezpieczeń zdolności kredytowej. 
Fundusz Mikro Sp. z o.o. można nazwać inkubatorem finansowym, który przygotowuje przedsiębiorców do efektywnego korzystania w przyszłości z pomocy finansowej systemu bankowego. Okazuje się bowiem, że pozytywne doświadczenia związane z otrzymanymi usługami pożyczkowymi miały wpływ nie tylko na częstotliwość korzystania z pomocy instytucji (77,1\% przedsiębiorców korzystało z usług pożyczkowych od dwu do pięciu razy w ciągu ostatnich sześciu lat), ale także na postawę przedsiębiorców wobec innych zewnętrznych źródeł finansowania. Ankietowani deklarują, iż zamierzają korzystać w szczególności z kredytu bankowego (74,2\%), dotacji unijnych $(65,7 \%)$ i leasingu $(45,7 \%)$.

\section{Literatura}

1. Bartkowiak B., 2009, Fundusze pożyczkowe i poręczeniowe w finansowaniu matych i średnich przedsiębiorstw w Polsce, Wyd. CeDeWu, Warszawa.

2. Bielawska A., 1992, Znaczenie małych firm dla rozwoju gospodarczego, „Ekonomista”, nr 3, Warszawa.

3. Buś-Bidas A., 2006, Wpływ ustug wspierających na lokalne przedsiębiorstwa (na przyktadzie powiatu tarnobrzeskiego), praca doktorska (maszynopis).

4. Buś-Bidas A., 2009, Dostęp do zewnętrznych źródel finansowania przedsiębiorstw sektora MŚP w powiecie tarnobrzeskim i stalowowolskim, maszynopis.

5. Forin A. i inni, 2010, Przedsiębiorco! Skorzystaj!, Polska Agencja Rozwoju Przedsiębiorczości, Warszawa.

6. Grzywacz J., Okońska A., 2005, Venture capital a potrzeby kapitałowe małych i średnich przedsiębiorstw, Wyd. Szkoły Głównej Handlowej w Warszawie, Warszawa.

7. Kożuch B., Plawgo B., 1999, Wyzwania rozwojowe matych i średnich przedsiębiorstw [w:] Wyzwania rozwojowe a restrukturyzacja przedsiębiorstw, R. Borowiecki (red.), Wyd. Akademii Ekonomicznej w Krakowie, Kraków.

8. Kubiak J., 2005, Hierarchia źródet krótkoterminowego finansowania przedsiębiorstw, Wyd. Akademii Ekonomicznej w Poznaniu, Poznań.

9. Łuczka T., 1997, Kapitał jako przedmiot gospodarki finansowej małego i średniego przedsiębiorstwa prywatnego: wprowadzenie do finansów przedsiębiorstwa, Wydawnictwo Politechniki Poznańskiej, Poznań.

10. Małecka E., 1999, Znaczenie małych firm w okresie transformacji, „Gospodarka w teorii i praktyce”, nr 1(4), Wyd. Uniwersytetu Łódzkiego, Łódź.

11. Michalczuk G., 2000, Determinanty ksztaltowania strategii finansowej majątku (wyniki badań empirycznych) [w:] Problemy finansów, informatyki i matematyki finansowej, W.L. Jaworski (red.), Wyd. Wyższej Szkoły Finansów i Zarządzania w Białymstoku, Białystok.

12. Piasecki B., 1998, Przedsiębiorczość i mała firma. Teoria i praktyka, Wyd. Uniwersytetu Łódzkiego, Łódź.

13. Piasecki B. (red.), 2001, Ekonomika i zarzadzanie mała firma, Wyd. Naukowe PWN, Warszawa.

14. Raport o stanie sektora matych i średnich przedsiębiorstw w Polsce w latach 2004-2005, 2006, Polska Agencja Rozwoju Przedsiębiorczości, Warszawa.

15. Raport o stanie sektora matych i średnich przedsiębiorstw w Polsce w latach 2006-2007, 2008, Polska Agencja Rozwoju Przedsiębiorczości, Warszawa.

16. Raport o stanie sektora małych i średnich przedsiębiorstw w Polsce w latach 2007-2008, 2009, Polska Agencja Rozwoju Przedsiębiorczości, Warszawa. 
17. Safin K., 2003, Zarządzanie mała firma, Wyd. Akademii Ekonomicznej im. Oskara Langego we Wrocławiu, Wrocław.

18. Schumpeter J., 1960, Teoria rozwoju gospodarczego, PWN, Warszawa.

19. Starczewska-Krzysztoszek M., 2008, Konkurencyjność sektora MŚP 2008 wyniki badania, Polska Konfederacja Pracodawców Prywatnych Lewiatan, Warszawa.

20. Targalski J. (red.), 1999, Przedsiębiorczość i rozwój firmy, Wyd. Akademii Ekonomicznej w Krakowie, Kraków.

21. Wolański R., 2009, Nowe źródła finansowania rozwoju przedsiębiorstw [w:] Raport o stanie sektora matych i średnich przedsiębiorstw w Polsce w latach 2007-2008, Polska Agencja Rozwoju Przedsiębiorczości, Warszawa.

\section{The Loan Funds as the Source of Financing for Enterprises of SMEs Sector on the Example of Mikro Limited Company Fund, Tarnobrzeg Branch}

The article presents the opinions of entrepreneurs - customers of the loan fund concerning the supply of support services. The respondents evaluated loan services and their influence on functioning and development of the enterprises. 


\title{
Kształtowanie postaw
}

przedsiębiorczych w edukacji

\author{
w warunkach globalizacji
}




\section{Monika Borowiec}

Uniwersytet Pedagogiczny

im. Komisji Edukacji Narodowej

w Krakowie

\section{Rola edukacji w procesach globalizacji}

Nasilające się procesy globalizacji zmieniają uwarunkowania rozwoju społeczno-gospodarczego i kulturowego oraz przyspieszają procesy przemian różnej skali układów przestrzennych oraz poszczególnych podmiotów gospodarczych i instytucji reprezentujących określone sektory gospodarki. Procesy te powodują również istotne przemiany w szkolnictwie na wszystkich poziomach kształcenia, stawiając przed edukacją nowe wyzwania.

Można przyjąć, że globalizacja jest złożonym procesem tworzenia współzależności między różnymi dziedzinami życia społecznego, gospodarczego, politycznego i kulturowego w skali światowej, cechującym się:

1. zagęszczaniem i intensyfikacją więzi między różnymi podmiotami (jednostki ludzkie, przedsiębiorstwa, władze lokalne, regionalne, rządy państw, korporacje międzynarodowe, organizacje pozarządowe, instytucje międzynarodowe),

2. zwiększaniem szybkości i zasięgu wzajemnego oddziaływania w ramach systemu światowego wynikającego przede wszystkim z postępu w dziedzinie informatyzacji i telekomunikacji,

3. zwiększającą się otwartością struktur instytucjonalnych,

4. intensyfikacją przenikania każdej sfery naszego życia m.in. warunków gospodarowania, struktury konsumpcji, sposobów spędzania czasu wolnego, programów nauczania, życia kulturalnego i religijnego,

5. wzrostem przepływów różnego rodzaju zasobów (siły roboczej, kapitału, technologii, dóbr i usług, idei, informacji gospodarczej) (Wilkin 2003).

Jak przyjmuje M. Czerny za J.A. Scholte, globalizacja oznacza „rekonfigurację relacji społecznych i gospodarczych w przestrzeni geograficznej" (Czerny 2005, s. 23). Globalizacja poprzez intensyfikację przestrzennych wzajemnych powiązań w skali światowej powoduje konieczność podporządkowania wielu makroekonomicznych reguł funkcjonowania gospodarki narodowej wymogom organizacji czy koncernów ponadnarodowych, w wyniku czego następuje zmniejszenie skuteczności oddziaływania polityki ekonomicznej państwa na układy regionalne i lokalne wprzęgnięte w układ globalnych zależności. W zarządzaniu różnej skali układami przestrzennymi i ich elementami poprzez budowanie strategii rozwoju oraz kreowanie odpowiednich instrumentów sterujących bardzo ważną rolę odgrywa jakość zasobów intelektualnych (Zioło 2010). Potencjał i jakość tych zasobów warunkują możliwości poznania prawidłowości kształtowania się złożonych procesów społeczno-gospodarczych i kulturowych, relacji ilościowo-jakościowych, zmienności uwarunkowań i czynników rozwoju. 
Jakość zasobów intelektualnych zależy od jakości funkcjonowania szkolnictwa, zwłaszcza na poziomie wyższym. Proces edukacji odgrywa istotną rolę w kształtowaniu aspiracji jednostek i społeczeństwa. Przekłada się on na: obierane przez nie strategie rozwoju, metody zarządzania, organizację życia jednostek, postawy przedsiębiorcze społeczeństwa, które realizują się w określonej przestrzeni geograficznej i prowadzą do określonego poziomu społeczno-gospodarczego różnej skali układów przestrzennych. Edukacja powinna przygotowywać ludzi do adaptacji w zmieniających się uwarunkowaniach, tak aby mogli oni w sposób racjonalny wpływać na struktury, które w przyszłości będą podlegać przemianom. „Wiedza i technika zawsze były niezbędnymi katalizatorami przemian cywilizacyjnych. Obecnie, kiedy nasilają się procesy globalizacyjne, fundamentalną rolę odgrywa kreacja i praktyczne wykorzystanie wiedzy, a kapitał ludzki jest czynnikiem, bez którego nie jest możliwe osiągnięcie trwałego i wysokiego tempa rozwoju gospodarczego" (Janc 2003, s. 311). Znaczenie wiedzy, kwalifikacji i postaw przedsiębiorczych zwiększa się zatem nie tylko w wymiarze jednostkowym, umożliwiając uzyskanie wysokiej pozycji na rynku pracy, ale także jako czynnik rozwoju społeczno-gospodarczego (Grzesiuk, Walawender 2002).

Procesy rozwoju zasobów intelektualnych, dokonujące się początkowo głównie w rodzinie, a następnie w wyniku edukacji szkolnej, mają wpływ na jakość kapitału ludzkiego i społecznego. Jak przyjmuje Z. Zioło (2010), procesy zwiększania jakości zasobów intelektualnych dokonują się w zmieniających się uwarunkowaniach społeczno-gospodarczych, kulturowych i politycznych, i w istotnym stopniu zależą one od przemian demograficznych. W wyniku aktywizacji zawodowej część zasobów intelektualnych zostaje przekształcona w kapitał ludzki. Jednakże selekcja na rynku pracy powoduje, że część tych zasobów pozostaje jako potencjalna i może być zaktywizowana m.in. w wyniku zmian na rynku pracy czy procesów migracyjnych. Należy podkreślić, że odpływ zasobów intelektualnych może osłabiać możliwości rozwojowe danego obszaru i wpływać na jego marginalizację.

W świetle literatury przedmiotu można przyjąć, że na kapitał ludzki i społeczny składają się: poziom, kierunki i jakość wykształcenia, wiedza i umiejętność jej wykorzystania, postawy przedsiębiorcze, zdolności, talent, system wartości, postawy etyczne, cechy fizyczne (np. zdrowie), świadomość konieczności ciągłego doskonalenia zawodowego, kształcenia ustawicznego, przygotowywania się do zmieniających się uwarunkowań społeczno-gospodarczych, umiejętności funkcjonowania w strukturach społecznych, współdziałania, budowania relacji społecznych opartych na zaufaniu i zaangażowaniu w realizacje przyjętych celów. W konsekwencji usprawnia to, przyspiesza i czyni efektywniejszymi procesy rozwojowe poszczególnych jednostek, społeczeństwa, instytucji oraz podmiotów gospodarczych. Może to także wpłynąć na procesy integracyjne w danym środowisku: wśród uczniów, wśród pracowników instytucji, przedsiębiorstw, władz samorządowych, organizacji non profit, którym przyświeca wspólny, nadrzędny cel (np. polepszenie jakości życia, usprawnienie funkcjonowania, zwiększanie strumieni finansowych, podnoszenie konkurencyjności itp.).

Badania dotyczące zróżnicowania przestrzeni europejskiej w zakresie jakości kapitału ludzkiego wskazują, że jest ono duże zarówno w układach krajowych, jak i regionalnych. Biorąc pod uwagę miernik syntetyczny kapitału ludzkiego, można stwierdzić, że poszczególne państwa w Europie charakteryzują się bardzo dużym zróżnicowaniem, czego wyrazem jest jego wartość wahająca się od 0,74 do 5,39 (Borowiec 2008). Najwyższą jakością kapitału ludzkiego odznaczają się Dania, Szwecja, Islandia, Norwegia, Finlandia i Wielka Brytania, na co wskazuje wartość miernika syntetycznego wahająca się dla tych państw od 4,15 do 5,39. Natomiast najniższą wartością miernika syntetycznego charakteryzują się Turcja, Chorwacja, Rumunia i Bułgaria, dla których jego wartość 
waha się od 0,74 do 1,96. Dla Polski wartość miernika syntetycznego wynosi tylko 2,89. Najwyższe pozycje pod względem jakości kapitału ludzkiego zajmują państwa o wysokim poziomie rozwoju społeczno-gospodarczego, państwa rdzeniowe Unii Europejskiej, a z nowych członków UE również Słowenia, Estonia i Litwa. Najniższe pozycje zajmują państwa kandydujące do Unii - Turcja i Chorwacja, nowi członkowie - Bułgaria i Rumunia, a także państwa Europy Środkowowschodniej.

Podobnie duże zróżnicowanie jakości kapitału ludzkiego zaznacza się w europejskich układach regionalnych na poziomie NUTS 2, na co wskazuje wartość miernika syntetycznego wahająca się od 0,20 Ost for Storebaelt w Danii do 2,2 Mellersta Norrland w Szwecji (Borowiec, Dorocki, Jenner 2009).

Najwyższymi wartościami miernika syntetycznego (powyżej 0,70) charakteryzuje się 31 regionów Europy, co stanowi 17,1\% ich ogólnej liczby. Znajdują się one na obszarach 13 państw, przy czym najwięcej ich leży w Szwecji, Finlandii, Austrii, Francji, Hiszpanii, Niemczech, Wielkiej Brytanii oraz Norwegii. Natomiast najniższymi wartościami miernika syntetycznego (poniżej 0,40) odznacza się 39 regionów, stanowiących 21,5\% ogólnej ich liczby, znajdujących się na obszarach 11 państw. Najwięcej z nich jest położonych w Szwajcarii, Czechach, Austrii, Polsce, Portugalii, we Włoszech i na Słowacji.

Powszechnie przyjmuje się, że czynnikiem decydującym o kierunkach i poziomie rozwoju społeczno-ekonomicznego jest jakość funkcjonowania systemu nauki i szkolnictwa, który wpływa na jakość zasobów intelektualnych społeczeństwa w układach lokalnych i regionalnych. W nasilających się procesach globalizacji szczególną funkcję ogniska przemian i przyszłego rozwoju spełniają ośrodki szkolnictwa wyższego. Od ich rozmieszczenia, dostępności oraz przestrzennego oddziaływania zależy jakość zasobów intelektualnych. Szkoły wyższe muszą dostosować się do konieczności przygotowania dla gospodarki, nauki, oświaty i kultury określonych grup pracowników o nastawieniu innowacyjnym oraz kadr specjalistów do nowych zawodów lub przeobrażających się specjalności.

W 2006 r. w Unii Europejskiej w szkołach wyższych kształciło się 18,7 mln studentów (od 1998 r. ich liczba wzrosła o 25\%), tj. 17\% uczących się na wszystkich poziomach edukacji (ryc. 1).

Ryc. 1. Zróżnicowanie udziału studentów (ISCED 5 i 6) w ogólnej liczbie uczących się w państwach Europy w 2006 r.

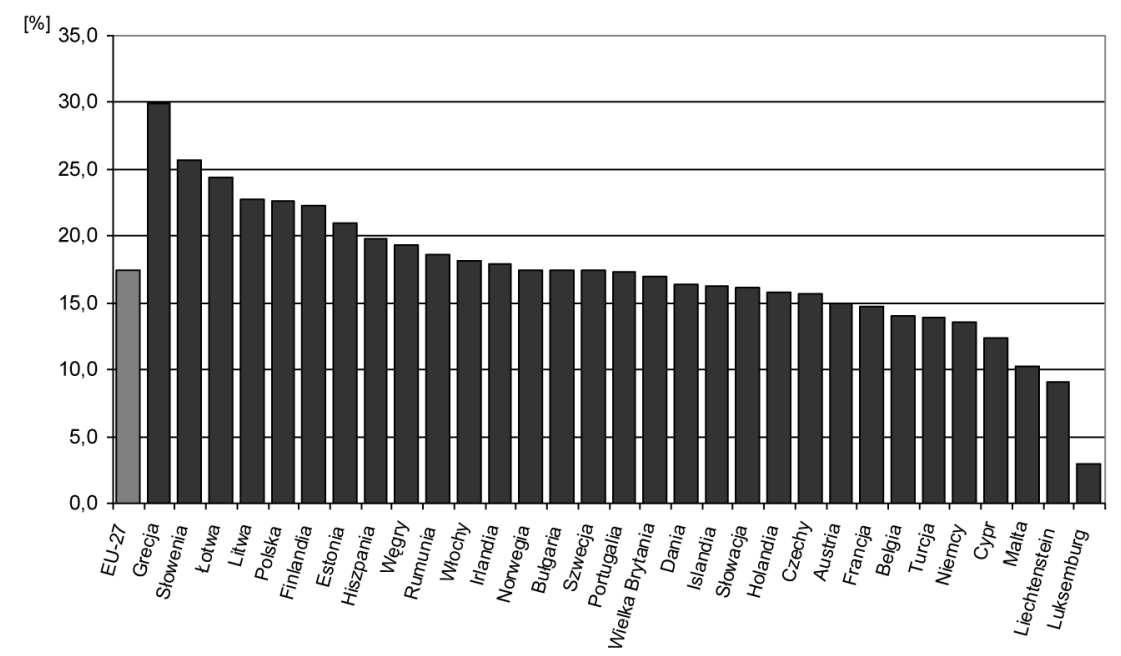

Źródło: Opracowanie własne na podstawie raportu Kluczowe dane o edukacji w Europie 2009, Komisja Europejska. 
Udział studentów w ogólnej liczbie kształcących się osób wahał się od 29,9\% w Grecji do 2,9\% w Luksemburgu. Wysokim udziałem studentów (powyżej 20\%) odznaczały się również Słowenia, Łotwa, Litwa, Polska, Finlandia i Estonia. Natomiast najniższy udział studentów (poniżej 14\%) zaznaczył się w Liechtensteinie, na Malcie, Cyprze, w Niemczech i Turcji.

W warunkach nasilających się procesów globalizacji, upowszechnienia szkolnictwa wyższego i rosnącej konkurencji na rynku pracy coraz większego znaczenia nabiera nie tylko poziom wykształcenia i doświadczenie zawodowe, ale także kierunek ukończonych studiów. W 2006 r. w Unii Europejskiej dominowali absolwenci nauk społecznych, ekonomii oraz prawa. Stanowili oni aż 35,4\% ogólnej liczby absolwentów (ryc. 2). Kolejne pozycje zajmowali absolwenci zdrowia i opieki społecznej (14,4\%), a następnie inżynierii, produkcji i budownictwa (12,5\%) oraz humanistyki i sztuki (12,2\%). Łącznie absolwenci tych kierunków stanowili 74,5\% ogólnej liczby absolwentów. Mniejsze znacznie w strukturze kierunków mieli absolwenci edukacji, nauk ścisłych, matematyki, informatyki, usług oraz rolnictwa i weterynarii, którzy łącznie stanowili 25,5\% ogólnej liczby absolwentów w UE.

Ryc. 2. Struktura absolwentów według kierunków studiów w Unii Europejskiej i Polsce w 2006 r.

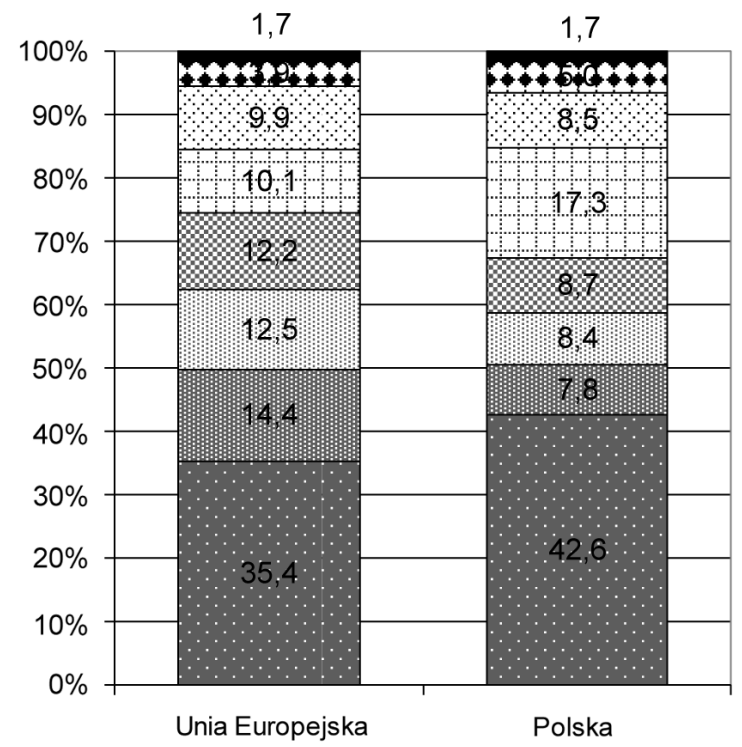

\author{
- Rolnictwo i weterynaria \\ Usługi \\ Nauki ścisłe, \\ matematyka, informatyka \\ Edukacja \\ 중 Humanistyka i sztuka

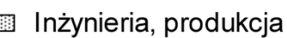 \\ i budownictwo \\ Zdrowie i opieka \\ społeczna \\ - Nauki społeczne, \\ ekonomia, prawo
}

Źródło: Opracowanie własne na podstawie raportu Kluczowe dane o edukacji w Europie 2009, Komisja Europejska.

W strukturze absolwentów w Polsce, podobnie jak w Unii Europejskiej, dominowali absolwenci nauk społecznych, ekonomii oraz prawa, ale ich udział wynoszący aż 42,6\% znacznie przewyższał średni udział europejski. Natomiast drugą pozycję zajmowali absolwenci edukacji, którzy stanowili aż 17,3\% (o 7,2 pp. więcej niż średnio w UE). Kolejne pozycje zajmowali absolwenci trzech grup kierunków o zbliżonym udziale: humanistyki i sztuki (8,7\%), nauk ścisłych, matematyki i informatyki $(8,5 \%)$ oraz inżynierii, produkcji i budownictwa (8,4\%). Łącznie absolwenci tych pięciu grup kierunków studiów stanowili 85,5\% ogólnej liczby absolwentów szkół wyższych w Polsce. Mniejszy udział w ogólnej liczbie absolwentów 
w porównaniu ze średnim europejskim udziałem stanowili absolwenci zdrowia i opieki społecznej (o 6,8 pp.), inżynierii, produkcji i budownictwa (o 4,1 pp.) oraz humanistyki i sztuki (o 3,5 pp.).

Struktura kierunków kształcenia w poszczególnych państwach była znacznie zróżnicowana. Jak wspomniano, najwięcej studentów kończyło kierunek nauki społeczne, ekonomia i prawo (42,6\%), ale udział absolwentów tego kierunku wahał się od 56,1\% na Łotwie do 23,4\% w Finlandii (ryc. 3). Udział absolwentów kierunku zdrowie i opieka społeczna wahał się od 24,6\% w Norwegii oraz Szwecji do 5,2\% na Łotwie; inżynierii, produkcji i budownictwa - od 20,7\% w Finlandii do 1,6\% w Bułgarii; humanistyki i sztuki - od 19,1\% w Irlandii do 5,1\% w Słowenii; edukacji - od 26,5\% na Islandii do 2,1\% we Francji; nauk ścisłych, matematyki, informatyki - od 13,8\% w Irlandii do 3,5\% w Słowenii; usług - od 14,3\% na Cyprze do 0,8\% w Wielkiej Brytanii, rolnictwa i weterynarii - od 4,0\% w Turcji do 0,2\% na Cyprze.

Ryc. 3. Zróżnicowanie struktury absolwentów szkół wyższych w Europie w 2006 r.

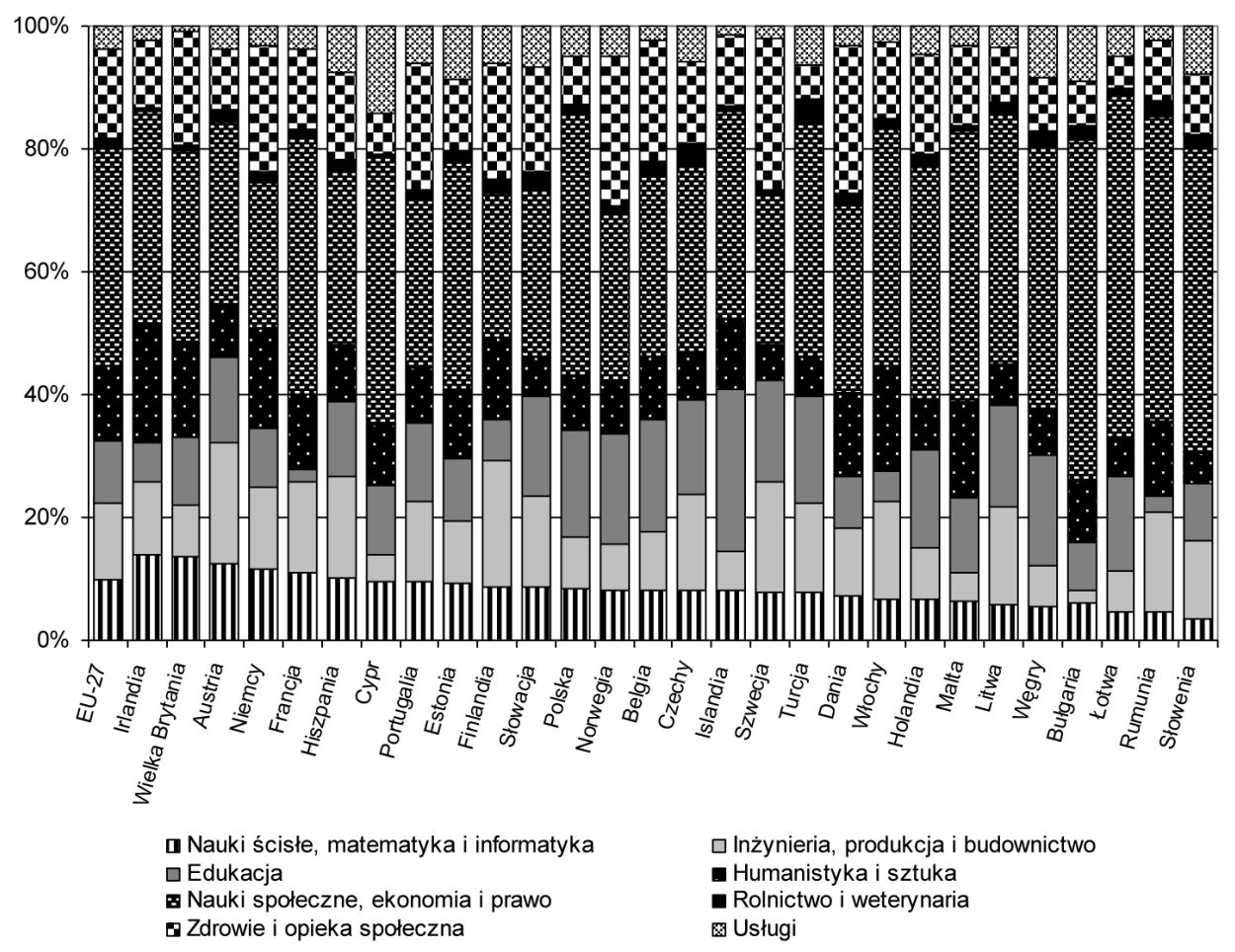

Źródło: Opracowanie własne na podstawie raportu Kluczowe dane o edukacji w Europie 2009, Komisja Europejska.

Szkolnictwo wyższe w Europie podlega przemianom, które wiążą się ściśle z realizacją idei budowania Europejskiego Obszaru Szkolnictwa Wyższego jako najważniejszego założenia procesu bolońskiego rozpoczętego w 1999 r. Szkolnictwo wyższe odgrywa również ważną rolę W realizacji strategii lizbońskiej mającej na celu stworzenie najbardziej konkurencyjnej i dynamicznie rozwijającej się gospodarki opartej na wiedzy w przestrzeni światowej. Proces boloński obejmuje różnorodne obszary działań, w tym m.in.: 
- zwiększenie mobilności studentów i pracowników,

- wprowadzenie studiów trójstopniowych,

- wprowadzenie systemu porównywalnych dyplomów,

- wprowadzenie systemu punktowego ECTS,

- współdziałanie w zakresie zapewnienia jakości kształcenia,

- kształcenie bez granic,

- kształcenie ustawiczne (Lifelong Learning - program edukacyjny, na który składają się: Comenius, Erasmus, Grundtvig, Leonardo da Vinci, Jean Monnet),

- współpracę z krajami nienależącymi do UE (Chmielecka, Kraśniewski, Woźnicki 2003). Z realizacją założeń procesu bolońskiego wiąże się zarówno wiele szans na przyspieszenie rozwoju cywilizacyjnego, jak i zagrożeń. Pozytywnym efektem może stać się m.in.:

- zwiększenie możliwości edukacyjnych i podnoszenia kwalifikacji przez studentów i pracowników naukowych,

- poznanie i wzrost poszanowania innych kultur,

- wzrost konkurencyjności uczelni,

- rozwój nowych, odpowiadającym na potrzeby rynku pracy, kierunków kształcenia,

- upowszechnienie nauczania języków obcych,

- upowszechnienie umiejętności wykorzystywania mediów elektronicznych, zwłaszcza Internetu,

- rozpowszechnienie edukacji na odległość.

Podobnie wiele szans niesie za sobą koncepcja budowania Europejskiego Obszaru Szkolnictwa Wyższego. Są to m.in. szanse na:

- uczestnictwo w pracach i osiągnięciach nauki światowej,

- likwidację barier we współpracy naukowej,

- koncentrację badań,

- zwiększenie mobilności pracowników nauki,

- szybszą realizację prac badawczych i ewentualne wdrożenie wyników badań,

- zwiększenie międzynarodowej roli wspólnotowych badań naukowych,

- uświadamianie roli nauki w życiu współczesnego społeczeństwa i inicjowanie społecznej debaty wokół zagadnień związanych z badaniami naukowymi.

Do zagrożeń związanych z realizacją koncepcji rozwoju szkolnictwa wyższego i nauki w Europie poprzez wdrażanie procesu bolońskiego i kształtowanie Europejskiego Obszaru Szkolnictwa Wyższego należą m.in.:

- trudności w sprostaniu presji konkurencyjnej ze strony zachodnioeuropejskich uczelni,

- bezkrytyczne przyjmowanie zagranicznych rozwiązań,

- obniżenie poziomu badań naukowych,

- zwiększenie biurokratyzacji,

- podejmowanie głównie badań istotnych z punktu widzenia potrzeb ponadnarodowych, a nie krajowych, regionalnych czy lokalnych,

- trudności w ujednoliceniu systemów edukacji i obniżenie jakości kształcenia,

- dezintegracja więzi społecznych.

Według raportów Bologna Process Stocktaking przedstawiających stan zaawansowania poszczególnych krajów we wdrażaniu postulatów procesu bolońskiego, Polska znajduje się powyżej średniej europejskiej i sytuuje się na poziomie takich państw, jak Niemcy, Francja, Anglia, Czechy, Łotwa, Estonia, Rumunia i Węgry (Morawski 2009). Przodujące pozycje we wdrażaniu postulatów zajmują kraje skandynawskie oraz Holandia, Irlandia i Szkocja. W wyniku postępującej globalizacji ekonomicznej obserwuje się nasilenie globalizacji edukacji, 
zwłaszcza na poziomie wyższym. Zalecenia dotyczące internacjonalizacji szkolnictwa wyższego, metodyki wykorzystania dobrych wzorców międzynarodowych, możliwości, jakie stwarzają międzynarodowe, a przede wszystkim europejskie instytucje i organizacje oraz zarysowane tendencje w rozwoju polskiego szkolnictwa na tle przemian światowych zawarte zostały w raporcie pt. Polskie szkolnictwo wyższe. Stan, uwarunkowania, perspektywy (2009).

Problematyka szans i zagrożeń wynikających z procesów globalizacji oraz integracji powinna znaleźć swój wyraz w programach nauczania i procesie wychowawczym na wszystkich szczeblach kształcenia. Szczególne znaczenie dla rozumienia szans i zagrożeń wynikających z nasilających się procesów globalizacji ma nauczanie przedsiębiorczości, podczas którego uwrażliwia się młodych ludzi na sprawy człowieka jako podmiotu w zarządzaniu i gospodarowaniu w określonych strukturach społecznych. Celem edukacji przedsiębiorczości jest zdobycie ,podstawowych umiejętności w zakresie rozumienia procesów społeczno-gospodarczych oraz funkcjonowania we współczesnym świecie różnej skali podmiotów gospodarczych, analizy i rozumienia podstawowych mechanizmów ekonomicznych we współczesnych systemach zarządzania gospodarką i firmą w zróżnicowanej przestrzeni geograficznej oraz zdobycie umiejętności konkurencyjnego zachowania się na rynku pracy” (Borowiec 2005, s. 167-168). Poza treściami merytorycznymi istotnym celem edukacji powinno być kształtowanie postaw przedsiębiorczych na podstawie zasad etyki. Szanse i zagrożenia związane z procesami globalizacji powinny być rozważane w różnorodnych dziedzinach życia, takich jak: polityka, gospodarka, społeczeństwo, relacje międzyludzkie, kultura, demografia itd. Jak przyjmuje wielu autorów (m.in. Dylus 2004, Giddens 2000, Jóźwik 2007, Kotyński 2005, Łęcka 2005, Wilkin 2003), postępujące procesy globalizacji niosą ze sobą wiele zagrożeń, wśród których należy zwrócić uwagę na:

- nasilenie polaryzacji rozwoju społeczno-gospodarczego,

- nasilenie fundamentalizmu, który jest określany mianem dziecka globalizacji,

- brak gwarancji praw obywatelskich i możliwości kontroli gospodarki przez instytucje społeczeństwa obywatelskiego oraz demokratycznie wyłaniane władze państwowe w systemie globalnym,

- konsumpcjonizm i kreację sztucznych potrzeb,

- zagrożenie wystąpienia globalnej katastrofy finansowej,

- marnotrawienie zasobów,

- uprzedmiotowienie człowieka,

- przewagę sfery „mieć” nad „być”,

- uniformizację kultury,

- rozpowszechnienie kultury rywalizacji,

- marginalizację i wykluczenie społeczne,

- wzrost patologii i przestępczości,

- narastanie poczucia zagubienia, bezradności, alienację, zmniejszenie poczucia bezpieczeństwa, egzystencjalne zagubienie utrudniające odpowiedzialne pełnienie różnych ról społecznych,

- pojawianie się nowych zniewoleń,

- dezintegrację więzi społecznych,

- rozprzestrzenianie się chorób zakaźnych.

Wymienione zagrożenia objawiają się w skali lokalnej, ale ich źródła można odszukać w skali globalnej. Nasilające się procesy globalizacyjne z jednej strony powodują uniformizację i wytworzenie tzw. kultury globalnej, a z drugiej strony wzmagają dążenia do zachowania własnej, odrębnej tożsamości. „Globalna standaryzacja cywilizacja światowych prowadzi do 
przebudzenia kultur lokalnych" (Dziemidok 2003, s. 209). Globalizacja powoduje również powstanie tzw. klasy metropolitalnej. Obejmuje ona ludzi funkcjonujących w sieci światowych metropolii, tworzących społeczność niekonstytuowaną przez wspólne terytorium, lecz przez sposób życia, której polem działania są miejsca o tych samych funkcjach oraz neoświaty wspólna przestrzeń kulturowa, w której funkcjonują pracownicy globalni (Luke 1995).

Przebieg konfrontacji pomiędzy tym, co lokalne a tym, co globalne może przejawiać się w: pełnej akceptacji kultury globalnej, totalnym jej odrzuceniu (globalizacja jako zagrożenie), selektywnej adaptacji (przywiązanie do wartości i tradycji, ale przejęcie form kultury konsumpcyjnej), hybrydyzacji (koadaptacja kultur - kompromis pomiędzy lokalnością, narodowością a kulturą konsumpcyjną), dualizmie kulturowym (dwa poziomy kultury - kultura globalna nie niszczy kultur tożsamościowych) (Łuczak 2007 za Krzysztofek 2002).

Za pewien układ odniesienia do oceny postępującego procesu globalizacji oraz roli człowieka w rozwoju cywilizacyjnym możemy przyjąć zasady etyczne. Podczas VII Sesji Plenarnej Papieskiej Akademii Nauk Społecznych w 2001 r. w Watykanie przyjęto, że globalizacja nie jest a priori ani dobra, ani zła i będzie taka, jaką uczynią ją ludzie (Borowiec 2006). Podkreślano, że żaden system nie jest celem samym w sobie i że globalizacja, jak każdy inny system, musi służyć człowiekowi, solidarności i dobru wspólnemu, a dobro wspólne wymaga, aby wewnętrzna logika rynku podlegała pewnym mechanizmom kontrolnym i aby respektowała ona podstawowe wartości ludzkie. Wskazywano, że przy całej różnorodności form kultury istnieją uniwersalne wartości ludzkie, które należy stawiać na pierwszym planie jako wiodącą siłę rozwoju cywilizacyjnego. Podstawowe zasady etyczne w procesie globalizacji polegają zatem:

- „po pierwsze na niezbywalnej wartości człowieka, która jest źródłem wszelkich praw ludzkich i wszelkiego ładu społecznego. Człowiek musi być zawsze celem, a nie środkiem, podmiotem, a nie przedmiotem ani towarem rynkowym;

- po drugie, na wartości ludzkich kultur, których żadna władza nie ma prawa lekceważyć ani tym bardziej niszczyć - globalizacja nie może być nową postacią kolonializmu, musi respektować wielość kultur, które w ramach powszechnej harmonii narodów są jakby różnymi kluczami interpretacyjnymi ludzkiego życia" (ks. Mariański 2003, s. 61).

Globalizacja często postrzegana jest jako odgórny, niezależny od nas proces, na który nie mamy wpływu, jednakże dokonuje się ona na poziomie indywidualnych doświadczeń i lokalnych procesów. Istotna jest zatem świadomość zachodzących procesów i reakcja na nie wpływająca na przemiany w relacjach społecznych i gospodarczych. Jan Paweł II pisał, że całe życie człowieka i wszystkie jego relacje są zbudowane na wierze, iż to, co mówi drugi człowiek, jest prawdą. Współcześnie bardzo często za główne źródło prawdy uznawane są media i w nich weryfikowana jest wiedza przekazywana w rodzinie i w szkole. Elektroniczne środki przekazu niepostrzeżenie zmieniają środowisko życia człowieka i sposób postrzegania rzeczywistości. Metody socjotechniczne wykorzystywane są do przykuwania uwagi poprzez odwoływanie się do reakcji fizjologicznych człowieka i odwoływanie do pierwotnych instynktów przetrwania - seksu i przemocy. Niepokojące są wyniki badań wskazujące, że przeciętnie nastolatek w Europie spędza na kontaktach z rodzicami lub rówieśnikami 32 godz., a przed telewizorem lub komputerem 40 godz. Jeśli do tego często rodzice mają ograniczony kontakt z dziećmi, a szkoła przestaje pełnić funkcje wychowawczą, to nieuchronnie rolę tę przejmą media elektroniczne, które kształtują nieprawdziwy obraz świata (konsumpcjonizm, hedonizm, egoizm, agresja, brak empatii, powierzchowność relacji międzyludzkich, nowe mody, nowe wzorce zachowań, wykreowane autorytety, zmiana języka, szybkość i łatwość w osiąganiu celów). 
Już podczas V Zgromadzenia Ogólnego Papieskiej Akademii Nauk Społecznych 6 marca 1999 r. Jan Paweł II podkreślał, że ,globalizacja ekonomii i pracy wymaga także globalizacji odpowiedzialności” („L’Osservatore Romano” 1999, s. 55). Odnosząc te słowa Jana Pawła II na temat globalizacji do procesów edukacji, wydaje się, że szczególnie istotna jest odpowiedzialność w wymiarze jednostkowym, ponieważ często same relacje międzyludzkie są trwalsze niż ich wymierne efekty. Powszechnie wiadomo, że wiedza merytoryczna przekazywana w procesie edukacji ulega pewnej dezaktualizacji lub jest zapominana, natomiast relacje z innymi często na trwałe pozostają w pamięci i oddziaływają na nasze przyszłe decyzje życiowe czy zawodowe, postawy, cechy osobowościowe, stosunek do ludzi i świata.

Odpowiedzialność w procesie edukacji powinna zatem przejawiać się nie tylko w odpowiedzialności za przekazywaną wiedzę, ale również za kształtowane postawy życiowe i relacje międzyludzkie. Traktując pracę jako współdziałanie, ludzie wzajemnie zbliżają się do siebie i uczą się, aby być dla innych, co powoduje zacieśnianie więzi wspólnotowych ludzi pracy (Brzozowski 2006). Wydaje się, że szczególnie w procesie edukacji powinno się pamiętać o tym, aby myśleć globalnie, a działać lokalnie, zdając sobie sprawę, że procesy globalizacji przez zagęszczanie i intensyfikowanie więzi oraz przyspieszanie oddziaływania w wyniku postępu w dziedzinie informatyzacji i telekomunikacji, zwiększają również możliwości poszerzania zasięgu oddziaływania poszczególnych jednostek i ich wpływu na kształtowanie określonych procesów, integrowania szerokich kręgów ludzi wokół podejmowanych inicjatyw, współpracy nad realizacją przyjętych celów i upowszechniania wyników realizacji podejmowanych działań.

W świetle przedstawionych rozważań należy przyjąć, że nasilającym się procesom globalizacyjnym towarzyszyć powinno zwiększenie odpowiedzialności w wymiarze jednostkowym w tym większym stopniu, im większa możliwość oddziaływania m.in. poprzez pełnione funkcje w życiu społeczno-gospodarczym.

Jak przyjmują Cz. Kupisiewicz $(1985,1995)$ i W. Błażejewski (2005), powszechnie zauważalny kryzys wartości i wzorców osobowościowych, będący m.in. konsekwencją procesów globalizacji, ma wpływ na systemy kształcenia i przejawia się m.in. w traktowaniu nauczania jak towaru a nie środka służącego rozwojowi człowieka, fetyszyzacji dyplomów, dyskryminowaniu młodzieży z uboższych warstw społecznych, tłumieniu inicjatywy uczniów, niezdrowej rywalizacji, konformizmie, encyklopedyzmie w programach nauczania, nieprzygotowaniu do samodzielnego myślenia, braku kompleksowego rozważania problemów (wyposażenie w wiedzę z systematyki specjalistycznej), nieprzystosowaniu do potrzeb współczesności. Już B. Suchodolski (1958) wskazywał na to, że absolwent powinien wiedzieć nie tyle, jaki jest stan wiedzy w poszczególnych dyscyplinach, ile jak za pomocą zdobytej wiedzy zrozumieć rzeczywistość.

Główne wyzwania dla edukacji to kształtowanie umiejętności współpracy, umiejętności budowania warsztatu naukowego, który będzie umożliwiał podejmowanie racjonalnych działań z zakresie dokształcania i systematycznego doskonalenia zawodowego, świadomości konieczności ustawicznego kształcenia (wiedza i umiejętności będą weryfikowane na rynku pracy), rozwiązywania problemów, umiejętności korzystania z rozwijającej się wiedzy, łączenia jej różnych obszarów i praktycznego, szybkiego zastosowania, rozumienia zmieniającej się rzeczywistości, kształtowania postaw przedsiębiorczych, etycznych, odpowiedzialności za siebie i innych, zarówno w miejscu edukacji, jak i pracy zawodowej.

„Człowiek XXI w. powinien być istotą racjonalną, umieć dostrzegać i poprawnie analizować zachodzące wokół niego zjawiska i procesy oraz współpracować z nimi, być wrażliwym na losy bliźnich, dbać o środowisko naturalne, umieć roztropnie gospodarować surowcami 
i energią, dysponować umiejętnością szybkiego przystosowania się do zmieniających się warunków życia, mieć nawyk systematycznego i efektywnego samokształcenia, a oprócz tego wiedzieć, że w procesie kształcenia i samokształcenia należy dbać nie tylko o rozwój umysłu, lecz «całego człowieka», tzn. jego intelektu, woli i uczuć” (Kupisiewicz 1999, s. 180-181).

Podobnie W. Błażejewski (2005, s. 47 za Pachocińskim 1999) zauważa, że „zmieniający się świat i wzrastające znaczenie nauki dla dalszego rozwoju powodują, że wyzwaniom nadchodzącego XXI w. może sprostać tylko człowiek wielostronnie wykształcony, zdolny do myślenia w kategoriach innowacyjnych i alternatywnych, energiczny, sprawny, wrażliwy na wartości, uznający je za dyrektywy postępowania, drogowskazy życia, czyli «człowiek pełny»".

Postęp cywilizacyjny ma się dokonywać przez człowieka i dla człowieka oraz owocować w człowieku (Jan Paweł II, LE IV,18). Od procesu edukacyjnego w istotnym stopniu zależy, czy młody człowiek będzie potrafił wykorzystać szanse i eliminować zagrożenia związane z nasilającymi się procesami globalizacji.

\section{Literatura}

1. Błażejewski W., 2005, Funkcjonowanie systemu oświaty w okresie cywilizacji informacyjnej [w:] Przedsiębiorczość a współczesne wyzwania cywilizacyjne, Z. Zioło, T. Rachwał (red.), „Przedsiębiorczość - Edukacja”, nr 1, Wydawnictwo MiWa, Zakład Przedsiębiorczości i Gospodarki Przestrzennej Instytutu Geografii Akademii Pedagogicznej w Krakowie, Kraków.

2. Borowiec M., 2005, Rola praktyk z przedsiębiorczości w kształceniu studentów na specjalności „,przedsiębiorczość z gospodarka przestrzenna" [w:] Przedsiębiorczość a współczesne wyzwania cywilizacyjne, Z. Zioło, T. Rachwał (red.), „Przedsiębiorczość - Edukacja”, nr 1, Wydawnictwo MiWa, Zakład Przedsiębiorczości i Gospodarki Przestrzennej Instytutu Geografii Akademii Pedagogicznej w Krakowie, Kraków.

3. Borowiec M., 2006, Etyczne aspekty globalizacji w procesie ksztaltowania przedsiębiorczości [w:] Przedsiębiorczość a wspótczesne wyzwania cywilizacyjne, Z. Zioło, T. Rachwał (red.), „Przedsiębiorczość - Edukacja”, nr 2, Nowa Era, Zakład Przedsiębiorczości i Gospodarki Przestrzennej Instytutu Geografii Akademii Pedagogicznej w Krakowie, Warszawa-Kraków.

4. Borowiec M., 2008, Rola kapitału ludzkiego w procesie podnoszenia konkurencyjności układów przestrzennych [w:] Przeksztatcenia regionalnych struktur funkcjonalno przestrzennych, D. Ilnicki, K. Janc (red.), „Rozprawy Naukowe Instytutu Geografii i Rozwoju Regionalnego Uniwersytetu Wrocławskiego 3", Instytut Geografii i Rozwoju Regionalnego Uniwersytetu Wrocławskiego, Wrocław.

5. Borowiec M., Dorocki S., Jenner B., 2009, Wpływ zasobów kapitału ludzkiego na ksztattowanie społeczeństwa informacyjnego i innowacyjności struktur przemystowych [w:] Funkcje przemystu w kształtowaniu spoleczeństwa informacyjnego / Functions of industry in the developing of an information society, Z. Zioło, T. Rachwał (red.), „Prace Komisji Geografii Przemysłu PTG”, nr 13, Komisja Geografii Przemysłu PTG Instytut Geografii Uniwersytetu Pedagogicznego w Krakowie, Warszawa-Kraków.

6. Brzozowski T.T., 2006, Praca i przedsiębiorczość w świetle wybranych encyklik Jana Pawła II [w:] Przedsiębiorczość a współczesne wyzwania cywilizacyjne, Z. Zioło, T. Rachwał (red.), „Przedsiębiorczość - Edukacja”, nr 2, Nowa Era, Zakład Przedsiębiorczości i Gospodarki Przestrzennej Instytutu Geografii Akademii Pedagogicznej w Krakowie, Warszawa-Kraków.

7. Chmielecka E., Kraśniewski A., Woźnicki J., 2003, Korzyści i koszty zwiąane z przystapieniem Polski do Unii Europejskiej w sferze szkolnictwa wyższego, Urząd Komitetu Integracji Europejskiej, Warszawa.

8. Czerny M., 2005, Globalizacja a rozwój, Wydawnictwo Naukowe PWN, Warszawa.

9. Dylus A., 2004, Dylematy procesu globalizacji [w:] Annales. Etyka w życiu gospodarczym, Salezjańska Wyższa Szkoła Ekonomii i Zarządzania, t. 7, nr 1, Łódź. 
10. Dziemidok B., 2003, Globalizacja a kwestia tożsamości narodowej [w:] Globalizacja i my. Tożsamość lokalna wobec trendów globalnych, R. Piekarski, M. Gaban (red.), Universitas, Kraków.

11. Giddens A., 2000, Runway World. How Globalization Is Reshaping our Lives, New York.

12. Grzesiuk A., Walawender P., 2002, Rola wykształcenia w opinii kadry zarządzającej przedsiębiorstwami z województwa podkarpackiego [w:] Wiedza i kwalifikacje w okresie zmian. Rynek pracy intelektualnej $w$ regionach peryferyjnych $w$ dobie globalizacji, R. Fedyna (red.), „Studia o Gospodarce 1", Instytut Gospodarki WSIiZ w Rzeszowie, Rzeszów.

13. Jan Paweł II, 1995, Laborem Exercens, reprint editricevaticana, TUM, Wrocław.

14. Janc K., 2003, Rola nauki i techniki we wspótczesnym świecie [w:] Geograficzne aspekty globalizacji i integracji europejskiej, M. Śmigielska, J. Słodczyk (red.), PTG Uniwersytet Opolski, Opole.

15. Jóźwik B. (red.), 2007, Globalizacja i integracja europejska, Wydawnictwo KUL, Lublin.

16. Kotyński J. (red.), 2005, Globalizacja i integracja europejska. Szanse i zagrożenia dla polskiej gospodarki, Polskie Wydawnictwo Ekonomiczne, Warszawa.

17. Krzysztofek K., 2002, Kulturowa ścieżka globalizacji [w:] Oblicza procesów globalizacji, M. Pietraś (red.), Wydawnictwo UMCS, Lublin.

18. Kupisiewicz Cz., 1985, Paradygmaty $i$ wizje reform oświatowych, PWN, Warszawa.

19. Kupisiewicz Cz., 1995, Kanon wyksztatcenia ogólnego. Próba porównawczego zastosowania kierunków i dylematów przebudowy [w:] Kanon kształcenia ogólnego, A. Bogaj (red.), Warszawa.

20. Kupisiewicz Cz., 1999, Paradygmaty $i$ wizje reform szkolnych, PWN, Warszawa.

21. „L'Osservatore Romano” 1999, nr 5-6, s. 55.

22. Luke T.W., 1995, New World Order or Neo-world Orders: Power, Politics and Ideology in Informationalizing Glocalites [w:] Global Maternities, M. Featherstone, S. Lash, R. Robertson (ed.), sage Publications, London.

23. Łęcka I. (red.), 2005, Społeczne skutki globalizacji. Globalizacja a bezpieczeństwo i zdrowie publiczne, Wydawnictwo Uniwersytetu Warszawskiego, Warszawa.

24. Łuczak R., 2007, Nowoczesne technologie a globalizacja [w:] Globalistyka. Procesy globalne i ich lokalne konsekwencje, M. Czerny, R. Łuczak, J. Makowski (red.), Wydawnictwo Naukowe PWN, Warszawa.

25. Mariański J. (ks.), 2003, Gospodarka rynkowa w ocenie społecznego nauczania Kościoła [w:] Annales. Etyka w życiu gospodarczym, Salezjańska Wyższa Szkoła Ekonomii i Zarządzania, t. 6, Łódź.

26. Pachociński R., 1999, Oświata XXI wieku, „Kierunki Przeobrażeń”, IBE Warszawa.

27. Polskie Szkolnictwo Wyższe. Stan, uwarunkowania, perspektywy, 2009, KRASP Warszawa, FRP Warszawa, Wydawnictwo Uniwersytetu Warszawskiego, Warszawa.

28. Scholte J.A., 2000, Globalization: a critical introduction. Plagrave, Houndmills.

29. Suchodolski B., 1958, Nowoczesna treść i organizacja wykształcenia ogólnego, „Nowa Szkoła”, nr 4.

30. Wilkin J., 2003, Globalizacja - moje nadzieje i obawy, www.ceo.org.pl - Centrum Edukacji Obywatelskiej, głos autora w dyskusji poświęconej globalizmowi zorganizowanej przez redakcję „Res Publiki Nowej” 15 października 2003 r., toczącej się wokół zagadnień poruszonych w numerze 7: http://www.ceo.org.pl/dokument.php?dzial=1726\&id=25097

31. Zioło Z., 2010, Rola zasobów intelektualnych, kapitatu ludzkiego i społecznego w procesach rozwoju obszarów wiejskich [w:] Kapitat ludzki i społeczny w procesie rozwoju obszarów wiejskich, W. Kamińska, K. Heffner (red.), Studia KPZK PAN T. CXXVI, Warszawa. 


\section{The Role of Education in the Globalization Process}

Globalization is changing determinants of socio-economic and cultural development, and causes significant changes in education, and it poses new challenges. Intellectual resources are developed in the educational process. They are the most important factor in socio-economic development of different scale of spatial systems. The importance of education also increases the chances of the individual in getting a high position on the labor market. The article presents the variation in the quality of human capital in the European space and also the opportunities and threats posed by globalization for education especially at the tertiary level. The increasing role of entrepreneurial attitudes and ethics for the proper functioning in a changing world and for the understanding and proper evaluation of the contemporary development of the socio-economic processes was also noted. 


\author{
Sławomir Dorocki, Wioletta Kilar, Tomasz Rachwal \\ Uniwersytet Pedagogiczny \\ im. Komisji Edukacji Narodowej \\ w Krakowie
}

\title{
Założenia i cele Projektu „Krok w przedsiębiorczość” dla nauczycieli szkół ponadgimnazjalnych
}

Przedsiębiorczość, definiowana zarówno w szerokim ujęciu, jako postawa człowieka kreatywnego, zdolnego do aktywnego uczestnictwa w życiu społeczno-gospodarczym, jak i nieco w węższym zakresie, jako zdolność oraz chęć do założenia i prowadzenia własnego przedsiębiorstwa (Brzozowski 2007; Rachwał 2005a, b, 2006), jest jednym z podstawowych czynników rozwoju społeczno-gospodarczego układów przestrzennych różnej skali (Kurek, Rachwał 2010a; Naudé 2008; Zioło 2006, 2007, 2009; Zioło, Rachwał, 2005, 2006, 2007, 2008, 2009). Rozwój ducha przedsiębiorczości w społeczeństwie oraz przedsiębiorczości rozumianej jako wyraz aktywności przedsiębiorców jest uważany za szczególnie ważny czynnik wzrostu gospodarczego w krajach transformujących swoje gospodarki, szczególnie w Polsce oraz innych krajach Europy Środkowo-Wschodniej. Należy przy tym zauważyć, za W. Naudé (2008), że w krajach rozwijających się przedsiębiorczość odgrywa swoją rolę głównie w przyspieszeniu wzrostu gospodarczego i generowaniu impulsów do transformacji strukturalnej gospodarek, natomiast w krajach wysokorozwiniętych gospodarczo jest ona rozpatrywana w dużej mierze w kontekście pozyskania nowych źródeł wzrostu wydajności pracy, która leży u podstaw konkurencyjności.

Jednocześnie współczesne tendencje rozwoju cywilizacyjnego, związane z budową gospodarki opartej na wiedzy (Zioło 2008) i kształtowaniem społeczeństwa informacyjnego (Borowiec, Dorocki, Jenner 2009; Gierańczyk 2009; Zioło 2009) wymagają stałego unowocześnienia procesu dydaktycznego na wszystkich poziomach edukacji, tak aby dostosować cele, treści, metody i zakładane efekty kształcenia szkolnego do wyzwań czekających młode pokolenie we współczesnym świecie, w tym do znalezienia i wykonywania pracy najemnej i/lub samozatrudnienia, poprzez zaprojektowanie, założenie i poprowadzenie własnej firmy (Kurek, Rachwał 2010b; Rachwał 2004, 2010; Wach 2007). Ważną funkcję w tym zakresie pełni edukacja ekonomiczna, której znaczenie uwidacznia się szczególnie w czasie trwającego w Europie od początku 2008 r. kryzysu gospodarczego. W warunkach spadku produkcji i ograniczania zatrudnienia okazało się, że dla wielu osób praca na własnych rachunek staje się jedynym możliwym sposobem zapewnienia sobie godziwych środków do życia. Należy zdawać sobie sprawę z faktu, że umiejętność stworzenia i poprowadzenia własnego przedsiębiorstwa, szczególnie w trudnych warunkach recesji gospodarczej, nie wynika tylko z wrodzonych zdolności, ale jest także wynikiem kształtowania przedsiębiorczej postawy oraz nabywania niezbędnych do tego umiejętności w toku edukacji szkolnej (Rachwał 2006; 2010). 
Przedsiębiorczość odgrywa więc ogromną rolę nie tylko w polskim, ale także europejskim systemie edukacji. Jest jedną z kompetencji kluczowych w europejskim obszarze edukacyjnym (ryc. 1), obok m.in. posługiwania się językiem ojczystym i obcym, a także kompetencji matematycznych i informatycznych (Recommendation 2006, Kompetencje 2005, 2007).

Ryc. 1. Kompetencje kluczowe w europejskim obszarze edukacyjnym

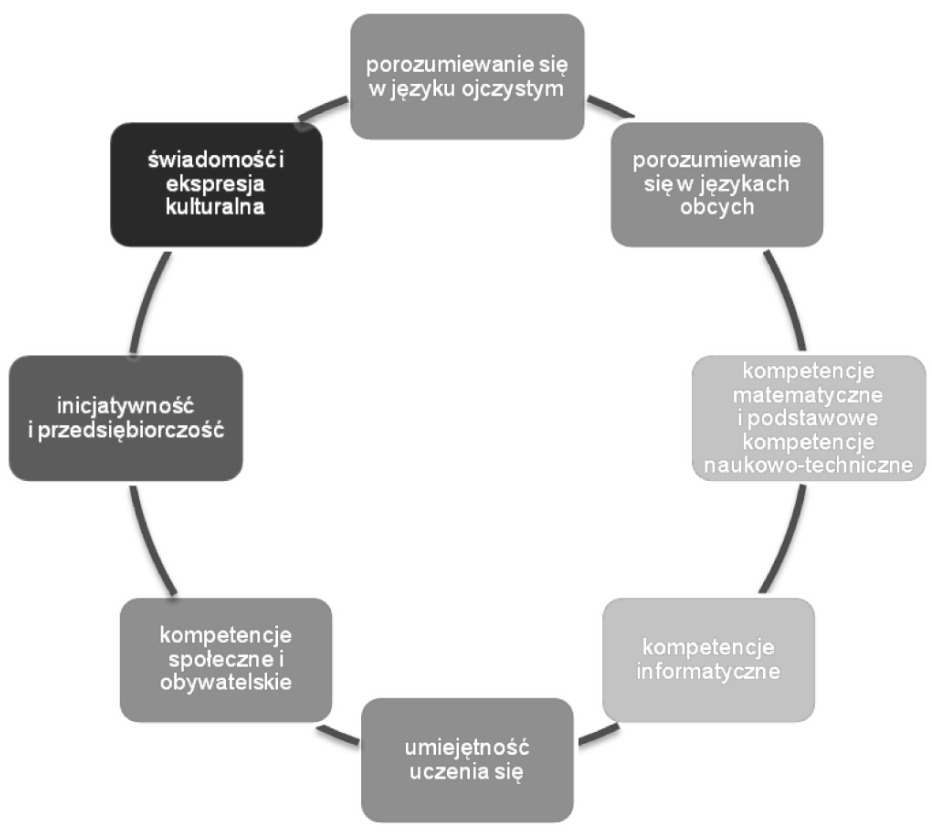

Kompetencje kształtowane w proponowanej strategii kształcenia:

kompetencja główna,

kompetencje podstawowe bezpośrednio powiązane z kompetencją główną,

kompetencje dodatkowe, których kształtowanie jest wspierane w proponowanej strategii,

kompetencja pozostała, w niewielkim stopniu wspierana przez realizację strategii.

Źródło: Innowacyjna strategia kształcenia w zakresie przedsiębiorczości oraz kształtowania kompetencji informatycznych i matematycznych z wykorzystaniem wirtualnej Otwartej Platformy Edukacyjnej opracowana w ramach Projektu „Krok w przedsiębiorczość” (wstępna wersja), Nowa Era, Warszawa 2011.

Bardzo często kształcenie w zakresie przedsiębiorczości jest rozumiane jako przygotowanie do założenia i prowadzenia własnej firmy. Jednak należy zwrócić uwagę, za A. Szabó (2008), iż europejscy politycy zgadzają się obecnie z opinią, że zakres kształcenia w obrębie przedsiębiorczości jest znacznie szerszy niż tylko szkolenie na temat rozpoczęcia działalności gospodarczej czy pisania biznesplanu, gdyż obejmuje on także rozwój wielu cech osobowych, takich jak kreatywność, inicjatywa, pewność siebie i in. W świetle definicji przyjętej przez Komisję Europejską, kompetencje określone jako inicjatywność i przedsiębiorczość oznaczają zdolność osoby do wcielania pomysłów w czyn. Mieszczą się w nich takie cechy, jak kreatywność, innowacyjność i podejmowanie ryzyka, jak również zdolność do planowania przedsięwzięć i prowadzenia ich dla osiągnięcia zamierzonych celów. Kompetencje te stanowią wsparcie dla 
indywidualnych osób nie tylko w ich codziennym życiu prywatnym i społecznym, ale także w miejscu ich pracy, pomagając uzyskać świadomość kontekstu pracy oraz zdolność wykorzystywania szans. Są one podstawą konkretniejszych umiejętności i wiedzy potrzebnych tym, którzy podejmują przedsięwzięcia o charakterze społecznym lub handlowym, lub w nich uczestniczą. Powinny one obejmować świadomość wartości etycznych i promować dobre zarządzanie (Commission 2006, Kompetencje 2007). Na potrzeby edukacji szkolnej przyjęto więc w Projekcie dosyć szerokie rozumienie przedsiębiorczości - podobne stanowisko zajmuje Rachwał (2005b, 2006). Nie można jednak tym samym negować faktu, że jednym z ważnych przejawów, jeśli nie najważniejszym, przedsiębiorczości jest założenie i prowadzenie własnego przedsiębiorstwa. Ten punkt widzenia na przedsiębiorczość stanowi bazę programową do realizacji Projektu „Krok w przedsiębiorczość”, w ramach którego wypracowana zostanie Innowacyjna strategia kształcenia (2011), pozwalająca, obok przedsiębiorczości, kształtować większość z ośmiu europejskich kompetencji kluczowych (ryc. 1).

Potrzeba kształcenia w zakresie przedsiębiorczości nie wynika tylko z samego faktu zaliczenia jej do listy kompetencji kluczowych. W ostatnich latach powszechnie zauważany jest, zarówno przez pracodawców, jak i specjalistów od rynku pracy, brak dostatecznych kompetencji absolwentów szkół do podjęcia pracy i samozatrudnienia, wynikający z niedostatecznego wyposażenia w wiedzę i umiejętności związane z funkcjonowaniem w świecie biznesu oraz umiejętności komputerowe i matematyczne. Jest to efektem m.in. ograniczenia w XX w. edukacji ekonomicznej w Polsce (a także w wielu innych krajach europejskich, por. Szabó 2008) do szkolnictwa wyższego, ewentualnie szkół średnich, głównie jednak o profilu ekonomicznym (Rachwał, Kurek 2010). W efekcie, postawy przedsiębiorcze w kształceniu ogólnym kształtowane są tylko w ramach - bardzo często marginalnie traktowanego w szkołach ponadgimnazjalnych - przedmiotu podstawy przedsiębiorczości oraz częściowo w ramach przedmiotu wiedza o społeczeństwie w gimnazjum. Tę niekorzystną sytuację pogłębia fakt, że przedsiębiorczość nie jest przedmiotem maturalnym, choć stanowi podstawowy filar europejskiej strategii edukacyjnej, a modernizacja podstawy programowej i wprowadzenie w czasie trwającej w Polsce reformy systemu edukacji dodatkowego, fakultatywnego przedmiotu ekonomia w praktyce, niekoniecznie podniesienie rangę edukacji ekonomicznej w polskiej szkole (Rachwał 2009).

Obserwuje się też tradycyjne podejście do nauczania przedsiębiorczości (m.in. Tracz, Rachwał 2007, 2008; E. i W. Osuch 2005) - nauczyciele w małym stopniu wykorzystują na lekcjach gry symulacyjne, np. dotyczące tworzenia wirtualnej firmy, uważając je za zbyt trudne do przeprowadzenia oraz ze względów organizacyjnych. Analiza wyników badań nauczycieli przeprowadzonych na potrzeby Projektu wykazała, że wśród najczęściej stosowanych metod dydaktycznych są: ćwiczenia, pogadanka i wykład (razem 44\% stosowanych metod). Tylko 1/3 ankietowanych stosuje w nauczaniu metody aktywizujące. Wśród wymienionych przyczyn stosowania metod podających wskazywane są głównie: brak możliwości technicznych, brak środków dydaktycznych dostosowanych do potrzeb lekcji, zbyt liczne klasy i ograniczenia czasowe. Wśród innych metod stosowanych przez nauczycieli znalazła się praca projektowa w grupie. Nauczyciele zwracali uwagę na potrzebę stosowania metod, które wymuszają na uczniach samodzielność i rozwijają umiejętność współpracy, jednak ich stosowanie w praktyce napotyka na szereg barier.

Wykorzystanie w szkołach bardziej zaawansowanych środków dydaktycznych jest więc znikome. W większości przypadków powodem tego stanu rzeczy jest brak pomocy dydaktycznych, czasu lub dostępu do sal (np. komputerowych), w których znajdują się te narzędzia. 
Spośród najczęściej wykorzystywanych środków dydaktycznych nauczyciele wymienili podręczniki szkolne, książki i teksty źródłowe. Następne w kolejności były komputery i pomoce dydaktyczne do pokazu oraz pomoce audiowizualne. Najrzadziej wskazywane były zeszyty ćwiczeń oraz inne, m.in. tablice interaktywne. Stan ten - w kontekście potrzeby kształtowania umiejętności i postaw - jest wysoce niezadowalający.

Badania przeprowadzone w ramach Projektu potwierdziły spostrzeżenia niektórych autorów nt. stanu edukacji w zakresie przedsiębiorczości. Zdaniem m.in. P. Szeligi „Do systemu kształcenia wprowadzono edukację przedsiębiorczą, ale dziś zajmujemy się często edukacją ekonomiczną. Zamiast uczyć postaw przedsiębiorczych, zaradności, samodzielności, przekazujemy wiedzę o gospodarce, systemie gospodarczym. Sądzę, że dominacja makroekonomii, ujęć strukturalnych i systemowych oraz wiedzocentryczność programów nauczania przedsiębiorczości nie odpowiadają potrzebom chwili. To tak, jakby edukację zdrowotną zaczynać od zasad funkcjonowania systemu opieki zdrowotnej! Tego typu podejście jest pochodną akademickiego sposobu patrzenia na rzeczywistość, którą twórcy podręczników szkolnych traktują jako obiekt badań, a nie przedmiot przekształceń. Nic dziwnego, że młody człowiek nie widzi w tym miejsca dla siebie. Odrzuca niestrawne i dalekie od jego osobistych doświadczeń wielosłowie" (2007, s. 140-141). Również wcześniejsze badania M. Tracz i T. Rachwała (2007), których celem było: ustalenie rodzaju i częstotliwości stosowania metod aktywizujących w nauczaniu - uczeniu się podstaw przedsiębiorczości, poznanie opinii nauczycieli o stopniu wyposażenia szkół w środki dydaktyczne niezbędne do realizacji zadań związanych z nauczanym przedmiotem, ustalenie rodzajów środków dydaktycznych najczęściej wykorzystywanych na lekcjach podstaw przedsiębiorczości, wykazały, że nauczyciele są przekonani o konieczności stosowania metod aktywizujących, ale nie robią tego zbyt często. Ze względu na ograniczenia czasowe na realizację przedmiotu w ramowym planie nauczania oraz niedostateczne wyposażenie szkół w nowoczesne środki dydaktyczne często są zmuszeni do rezygnacji ze stosowania metod aktywizujących i najczęściej na lekcjach wykorzystują podręcznik. Wśród badanych nauczycieli $30 \%$ wykorzystuje strony internetowe wybranych instytucji, a tylko $8,2 \%$ korzysta z programów komputerowych tematycznie związanych z lekcją. Generalnie zauważono, że uczniowie osiągają słabe wyniki kształcenia, a spośród wymienionych przyczyn takiego stanu rzeczy połowa nauczycieli $(46,7 \%)$ wskazała brak wystarczającej ilości czasu na lekcjach. Poza tym zwracano uwagę na brak motywacji uczniów (związany poniekąd z niemożnością wyboru podstaw przedsiębiorczości do zdawania na maturze) oraz brak innowacyjnych pomocy dydaktycznych. Brak czasu jest tym bardziej zauważalny, że ponad 75\% nauczycieli wykorzystuje czas na zajęciach w sposób efektywny lub bardzo efektywny. Wydaje się zatem zasadne bądź to zwiększenie liczby godzin dydaktycznych, bądź wykorzystanie metod pracy na odległość, które pozwalają na częściową realizację materiału poza szkołą.

Jednocześnie warto zwrócić uwagę, że różnorodność systemów kształcenia w poszczególnych krajach europejskich prowadzi do sytuacji, w których kompetencje w tym zakresie uzyskiwane w toku edukacji szkolnej kształtują się na różnym poziomie, co przekłada się na gorsze warunki dostępu części młodzieży do europejskiego rynku pracy. Chodzi tu głównie o młodzież z krajów transformujących swoje gospodarki, gdzie w okresie centralnego sterowania gospodarką ograniczano możliwość rozwoju własnej działalności gospodarczej i tym samym sukcesji firm oraz przekazywania doświadczeń przez rodziców. Wyraźnie jest to widoczne $\mathrm{w}$ analizach porównawczych, m.in. prowadzonych w ramach europejskiego projektu badawczego „Fit for Business: Developing Business Competencies in School” (FIFOBI) „Zdolni do biznesu: kształtowanie kompetencji biznesowych uczniów” (Kurek, Rachwał 2010a). 
Należy sobie również zdawać sprawę z faktu, że w nowych warunkach rozwoju gospodarczego, związanych z kształtowaniem się cywilizacji informacyjnej, szybki postęp technologiczny skazuje na marginalizację osoby, które mają braki w posługiwaniu się technologią komputerową. Prowadzi to w warunkach dynamicznego rozwoju społeczeństwa informacyjnego do tzw. wykluczenia cyfrowego. Równie ważne, obok rozwijania kompetencji informatycznych, z punktu widzenia aktywnego uczestnictwa w gospodarce opartej na wiedzy, jest kształtowanie kompetencji matematycznych. Zwrócili na to słusznie uwagę autorzy raportu Centralnej Komisji Egzaminacyjnej nt. osiągnięć maturzystów w 2009 r., podkreślając, że ,trzeba uświadomić uczniom, że znajomość matematyki na poziomie podstawowym to fundament logicznego myślenia w każdym aspekcie życia", niezbędny w podejmowaniu życiowych decyzji ekonomicznych i prowadzeniu własnego biznesu. Niestety, wśród polskich uczniów obserwowane są słabe efekty kształcenia w zakresie umiejętności matematycznych (wg raportów CKE Osiagnięcia maturzystów w 2009 r. i 2010 r.; potwierdzają to także Badania OECD PISA 2009) oraz strach przed egzaminem maturalnym z tego przedmiotu (czego dowodem był niski odsetek osób wybierających go na maturze; w 2009 r. było to tylko 19\%). Matematyka, choć jest jednym z najważniejszych przedmiotów szkolnych, przegrała z biologią, wiedzą o społeczeństwie i geografią. Przywrócenie obligatoryjności matury z matematyki samo w sobie w niewielkim stopniu wpłynie na poprawę tej sytuacji. Potwierdzają to wyniki matury z 2009 i 2010 r. - informatyka i matematyka to były dwa przedmioty o najniższym odsetku zdających maturę na poziomie podstawowym (odpowiednio 78\% i 81/87\%, wg raportu CKE za 2009/2010 r.), a średni wynik matury z informatyki, zarówno na poziomie podstawowym, jak i rozszerzonym, był najniższy ze wszystkich przedmiotów (odpowiednio 40 i 35 p. w 2009 r., 47 i 38 p. w 2010 r., wg danych CKE). Badania OECD PISA 2009 wskazują, że na tle innych wysoko rozwiniętych krajów Europy, w tym najlepszej pod względem wyników z matematyki Finlandii, wypadamy stosunkowo słabo (choć należy zauważyć, iż Polska mieści się w grupie krajów o średnim wyniku).

Konieczne wydaje się więc podjęcie działań na rzecz rozwoju nie tylko przedsiębiorczości, ale także tych dwóch kompetencji kluczowych. Nie jest to łatwe, gdyż istnieje potrzeba przełamania strachu uczniów przed matematyką, która jawi się jako bardzo trudna dziedzina wiedzy. Choć uczniowie są bardzo chętni do zabawy z komputerem, nieco gorzej wygląda już sytuacja, kiedy trzeba opanować bardziej zaawansowane techniki komputerowe, szczególnie, jeśli wykorzystywane muszą być wiedza i umiejętności z zakresu matematyki. Nauczyciele stoją więc przed problemem, jak skutecznie kształtować postawy przedsiębiorcze uczniów w sytuacji, gdy przedmiot podstawy przedsiębiorczości nie ma dużej rangi w szkole (Kawecki 2005; Tracz, Rachwał 2007, 2008) i jak rozwijać kompetencje matematyczne i informatyczne w obliczu obaw uczniów przed trudnościami oraz często występującej niechęci do matematyki jako przedmiotu mało atrakcyjnego $\mathrm{i}$ - jak im się często wydaje - mocno teoretycznego, a przez to nieprzydatnego bezpośrednio w życiu.

Należy także zwrócić uwagę na niekorzystne tendencje związane z przemianami demograficznymi, tj. niżem dotykającym szkoły ponadgimnazjalne (głównie zawodowe), co stawia nauczycieli w niekorzystnej sytuacji zagrożenia utratą pracy w obliczu redukcji liczby klas i godzin. Umiejętność wykorzystania innowacyjnych strategii nauczania może dać im przewagę konkurencyjną na edukacyjnym rynku pracy.

Niezbędne wydaje się więc opracowanie nowej strategii edukacyjnej, ukierunkowanej na wzmocnienie kompetencji uczniów szkół ponadgimnazjalnych w zakresie kształtowania postaw przedsiębiorczych oraz rozwijania kompetencji matematycznych i posługiwania się technologiami informacyjnymi, którą mogliby wykorzystać w swojej pracy nauczyciele. Odpowiedzią na te potrzeby może stać się Projekt „Krok w przedsiębiorczość” (Innowacyjna strategia 2011). 


\section{Cele Projektu}

Głównym celem Projektu „Krok w przedsiębiorczość” jest opracowanie i pilotażowe wdrożenie (w woj. małopolskim i podkarpackim) innowacyjnego programu kształtowania postaw przedsiębiorczych, rozwijania kompetencji informatycznych i matematycznych w szkołach ponadgimnazjalnych. Przyjęty w jego ramach program kształcenia oparty jest na koncepcji tworzenia przez uczniów wirtualnej firmy (zlokalizowanej na Otwartej Platformie Edukacyjnej stworzonej na potrzeby Projektu) i konkurowania na wirtualnym rynku. Program ten może być wykorzystany powszechnie w szkołach ponadgimnazjalnych jako wiodąca metoda kształcenia w realizacji zajęć pozalekcyjnych lub w ramach przedmiotu podstawy przedsiębiorczości i nowego fakultatywnego przedmiotu ekonomia w praktyce, który zostanie wprowadzony zgodnie z harmonogramem reformy oświaty od roku szkolnego 2012/2013. W ramach Projektu przewiduje się również wypracowanie szeregu pomocniczych materiałów edukacyjnych dla nauczycieli (scenariusze zajęć, poradnik) oraz uczniów.

Ważniejsze cele szczegółowe Projektu „Krok w przedsiębiorczość” to:

- diagnozowanie i analizowanie stosowanych metod kształcenia oraz potrzeb środowiska szkolnego (głównie poprzez diagnostyczne warsztaty metodyczne i badania opinii nauczycieli), a także oczekiwań uczniów i pracodawców;

- przygotowanie innowacyjnego programu kształcenia opartego na koncepcji tworzenia przez uczniów wirtualnej firmy (zlokalizowanej na platformie internetowej) i konkurowania na wirtualnym rynku (przez okres jednego roku szkolnego); program jest oparty na nowej, holistycznej, interaktywnej metodzie kształcenia, bazującej na metodzie projektów z grupy metod aktywizujących;

- szczegółowe opracowanie, nazwanie, przetestowanie i rozpropagowanie nowej metody kształcenia w zakresie przedsiębiorczości, kompetencji matematycznych i informatycznych, którą można będzie wykorzystywać powszechnie w szkołach ponadgimnazjalnych;

- analizowanie podstawy programowej kształcenia ogólnego w IV etapie edukacyjnym pod kątem możliwości realizacji nowego innowacyjnego programu kształcenia oraz przedstawienie propozycji (jeśli okaże się to konieczne) modyfikacji podstawy programowej, głównie w zakresie podstaw przedsiębiorczości, matematyki, informatyki;

- przeszkolenie nauczycieli-opiekunów grup uczniowskich, reprezentujących szkoły zrekrutowane do uczestniczenia w fazie testowej Projektu, z zakresu jego realizacji (w tym prowadzenia zajęć przygotowawczych z uczniami);

- kształtowanie postaw przedsiębiorczości u uczniów poprzez przygotowanie biznesplanu, zakładanie i prowadzenie firmy w szkolnych zespołach, pod opieką nauczyciela;

- rozwijanie kompetencji informatycznych poprzez:

- przygotowanie planu działalności firmy w edytorze tekstu i zaprezentowanie go w programie do pokazów multimedialnych,

- wykorzystanie arkusza kalkulacyjnego do rozliczeń finansowych,

- zaprojektowanie stron WWW własnych firm i materiałów promocyjnych w programach graficznych,

- stałe wykorzystywanie Internetu i poczty elektronicznej w bieżącej działalności firmy, komunikacji z innymi członkami grupy i nauczycielem-opiekunem;

- praktyczne wykorzystanie wiedzy i umiejętności matematycznych w przygotowaniu planu finansowego działalności, prowadzeniu rozliczeń w trakcie działalności firmy, w tym przygotowywaniu cenników, ofert itp.;

- rozwijanie umiejętności radzenia sobie w sytuacjach niestandardowych poprzez funkcjonowanie na wirtualnym rynku, na którym będzie konieczność reakcji (odpowiedzi) na 
nietypowe zmiany sytuacji rynkowych (pojawienie się nowej oferty, zmiana sytuacji makroekonomicznej itp.);

- rozwijanie kreatywności uczniów poprzez przygotowanie przez nich nowatorskich pomysłów związanych z działalnością firmy (nazwa i logo przedsiębiorstwa, struktura organizacyjna, wygląd materiałów promocyjnych, kształt i zakres oferty);

- wypracowanie szeregu pomocniczych materiałów edukacyjnych w formie drukowanej i/lub elektronicznej dla nauczycieli (poradnik dotyczący wdrażania strategii kształcenia scenariusze zajęć) i uczniów.

Cele Projektu są zgodne z celem szczegółowym nr 3 określonym na poziomie Priorytetu III: Wysoka jakość systemu oświaty PO Kapitał ludzki, jako „Poprawa stopnia powiązania oferty w zakresie kształcenia i szkolenia z potrzebami rynku pracy przez liczbę opracowanych i upowszechnionych innowacyjnych programów nauczania w zakresie przedsiębiorczości”.

Główną ideą Projektu jest więc próba wykorzystania dużego zainteresowania uczniów przedsiębiorczością realizowaną nie w sposób encyklopedyczny, ale twórczy, w formie zespołowej pracy online nad planowaniem i prowadzeniem wspólnej działalności gospodarczej. W działaniach tych będzie konieczne praktyczne wykorzystanie umiejętności komputerowych (m.in. w zakresie posługiwania się edytorem tekstu, arkuszem kalkulacyjnym, programami graficznymi, technologiami komunikacyjnymi) oraz wybranych umiejętności matematycznych (w zakresie wykonywania obliczeń niezbędnych m.in. w planowaniu budżetu). Strategia zakłada wykorzystanie, jako podstawowego środka dydaktycznego, wirtualnego środowiska, jakim jest Otwarta Platforma Edukacyjna. Zaletą platformy jest jej z góry założone podobieństwo do programów do zarządzania projektami, z którymi uczniowie będą mogli się zetknąć w dorosłym życiu w każdej firmie. Ponadto, oprócz funkcji platformy edukacyjnej, jest ona środowiskiem pracy dydaktycznej, w którym uczeń może rozwiązywać różnego typu zadania (aktywności) podstawowe i dodatkowe (testy, quizy, krzyżówki), korzystać z bogatych zasobów materiałów edukacyjnych (w tym multimedialnych), komunikować się na forum i czacie z nauczycielem i innymi uczniami - członkami zespołu. Platforma jest też miejscem swoistej rozgrywki, gdyż zawiera elementy symulacji realnego życia gospodarczego dzięki możliwości przeprowadzania - w końcowym etapie realizacji zadań rzeczywistych, choć wirtualnie - transakcji gospodarczych.

Szczegółowa metodyka kształcenia w ramach wypracowanej Innowacyjnej strategii ksztatcenia została określona w załączonych do niej Kartach opisu Projektu jako składowych tej metodyki. Karty te przygotowano do każdego tematu realizowanego na zajęciach. Ponadto częściami składowymi przyjętej strategii kształcenia są scenariusze 50 zajęć szkolnych (z niezbędnymi załącznikami), poradnik dla nauczycieli oraz dodatkowe materiały edukacyjne dla uczniów w postaci przykładowego biznesplanu działalności firmy ze szczegółowymi wskazówkami jego wykonania.

Innowacyjność przygotowywanych w wyniku realizacji Projektu zmian w systemie kształtowania postaw przedsiębiorczych oraz kompetencji matematycznych i informatycznych polega więc, po pierwsze, na wykorzystaniu innowacyjnego środka dydaktycznego, którym jest wirtualna Otwarta Platforma Edukacyjna, a po drugie, na stworzeniu nowej metody zintegrowanego kształcenia wybranych kompetencji kluczowych, która może zostać wdrożona do edukacji jako rozwiązanie systemowe wraz z ewentualną propozycją modyfikacji zapisów obowiązującej podstawy programowej, które byłyby spójne z wykorzystaniem przygotowanej metody.

Podejście to, oparte na działaniach uczniów na wirtualnym rynku, symulującym realną rzeczywistość gospodarczą, jest rozwiązaniem zasadniczo różnym od dotychczasowego kształcenia $\mathrm{w}$ ramach podstaw przedsiębiorczości, opartego - jak wskazują badania - głównie na 
klasycznych metodach dydaktycznych. Mimo stosunkowo szerokiej oferty programów edukacyjnych i interaktywnych stron internetowych z zakresu przedsiębiorczości nie ma ogólnie dostępnej platformy, pozwalającej na tworzenie przez grupy uczniów firm funkcjonujących na wirtualnym rynku. Tego typu inicjatywy, choć pojawiały się w formie częściowej realizacji w ramach różnych projektów edukacyjnych, nie zostały wdrożone systemowo do edukacji.

Projekt „Krok w przedsiębiorczość” stwarza więc szansę na lepsze kształtowanie tych ważnych, z punktu widzenia funkcjonowania uczniów we współczesnym świecie i większego zainteresowania studiami na kierunkach ścisłych i technicznych, kompetencji kluczowych. Dzięki powiązaniu kształtowania postaw przedsiębiorczych z rozwojem kompetencji matematycznych i umiejętności komputerowych, może się on przyczynić do zwiększenia zainteresowania uczniów szkół ponadgimnazjalnych kontynuacją kształcenia na kierunkach o kluczowym znaczeniu dla gospodarki opartej na wiedzy.

\section{Grupy docelowe - odbiorcy Projektu}

Projekt kierowany jest przede wszystkim do nauczycieli przedsiębiorczości, a także osób uczących matematyki oraz informatyki w szkołach ponadgimnazjalnych. W fazie testowej Projektu przewidziano uczestnictwo nauczycieli i uczniów z 30 szkół w województwie małopolskim i podkarpackim, ale produkty wypracowane w ramach Projektu adresowane będą do nauczycieli wszystkich szkół w Polsce.

Grupy docelowe Projektu to:

1. na etapie testowania:

a) 30 nauczycieli szkół ponadgimnazjalnych w województwach małopolskim i podkarpackim,

b) 300 uczniów tych szkół ponadgimnazjalnych;

2. na etapie upowszechniania:

a) nauczyciele podstaw przedsiębiorczości i innych przedmiotów ekonomicznych oraz matematyki i informatyki z terenu całej Polski,

b) uczniowie szkół ponadgimnazjalnych z terenu całej Polski,

c) dyrektorzy szkół, przedstawiciele wojewódzkich kuratoriów oświaty, przedstawiciele jednostek samorządu terytorialnego (organów prowadzących), przedstawiciele ośrodków doradztwa metodycznego oraz ośrodków doskonalenia nauczycieli w Polsce.

Dodatkowo do grup odbiorców działań projektowych należy zaliczyć:

- uczestników konferencji organizowanych przez partnera Projektu (Uniwersytet Pedagogiczny w Krakowie) przy współpracy lidera Projektu (Nowa Era), tj. blisko 200 osób: nauczycieli uczących podstaw przedsiębiorczości i innych przedmiotów ekonomicznych, przedstawicieli ośrodków doradztwa metodycznego, pracowników szkół wyższych oraz dyrektorów szkół; na konferencjach prezentowane będą cele i założenia, przebieg oraz efekty realizacji fazy testowej Projektu;

- odbiorcy kolejnych tomów publikacji z niniejszej serii „Przedsiębiorczość - Edukacja”, wydawanej przez Zakład Przedsiębiorczości i Gospodarki Przestrzennej IG Uniwersytetu Pedagogicznego w Krakowie oraz wydawnictwo Nowa Era; w publikacjach opisane zostaną cele, założenia oraz efekty realizacji Projektu;

- młodzież w wieku 15-18 lat - odbiorcy kampanii społecznej mającej na celu uświadamianie istoty kształcenia kompetencji kluczowych, zwłaszcza przedsiębiorczości.

Realizacja Projektu powinna więc pomóc nauczycielom - w okresie reformy programowej kształcenia - dokonać takiej zmiany strategii nauczania przedsiębiorczości, aby uczniowie posiadali motywację do aktywnego udziału w kształceniu w tym zakresie oraz byli chętni do wyboru kierunków studiów inżynieryjno-technicznych o kluczowym znaczeniu dla gospodarki. 
Wypracowana strategia kształcenia może być włączona przez Ministerstwo Edukacji Narodowej w system edukacyjny i stanowić element polityki edukacyjnej w zakresie kształtowania tych ważnych, w warunkach rozwoju społeczeństwa informacyjnego, kompetencji kluczowych.

\section{Etapy realizacji Projektu}

Czas realizacji całego Projektu to sierpień 2010 - grudzień 2012. Zgodnie z założonym harmonogramem Projekt realizowany jest w trzech fazach.

Faza I - przygotowawcza: 01.08.2010-31.01.2011. Rozpoczęła się ona badaniem stopnia przygotowania uczniów szkół ponadgimnazjalnych z zakresu przedsiębiorczości, a także potrzeb i oczekiwań nauczycieli oraz przedsiębiorców w Polsce w zakresie edukacji ekonomicznej, umiejętności komputerowych i matematycznych związanych z prowadzeniem działalności gospodarczej. Zakończeniem stało się wypracowanie wstępnej wersji Innowacyjnej strategii kształcenia wraz ze szczegółową koncepcją funkcjonowania Otwartej Platformy Edukacyjnej;

Faza II - złożenia strategii do opinii Krajowej Sieci Tematycznej w obszarze „Edukacja i szkolnictwo wyższe"1 oraz akceptacji instytucji pośredniczącej (MEN) oraz zgłoszenia innowacji przez szkoły uczestniczące w Projekcie do kuratoriów oświaty: 01.02.2011-31.03.2011;

Faza III - wdrożeniowa (testowa): od 01.04.2011-31.11.2012. Została ona poprzedzona rekrutacją uczestników do Projektu; obejmuje następujące działania:

- praca na Otwartej Platformie Edukacyjnej (poprzedzona warsztatami szkoleniowymi dla użytkowników i przeprowadzeniem zajęć w szkole),

- przeprowadzenie konsultacji online przez nauczycieli i uczestnictwo w dyskusjach z uczniami poprzez narzędzia komunikacyjne platformy,

- przeprowadzenie analizy prac szkolnych zespołów projektowych,

- opracowanie raportu końcowego na temat funkcjonalności i efektów dydaktycznych uzyskanych w wyniku wykorzystania produktu finalnego,

- opracowanie końcowej wersji produktu finalnego oraz ostatecznych wersji materiałów edukacyjnych.

\section{Instytucje realizujące Projekt}

Projekt jest realizowany przez podmioty mające duże doświadczenie w zakresie opracowywania strategii edukacyjnych, kształcenia i doskonalenia nauczycieli oraz działalności publikacyjnej dla sektora oświatowego:

- wydawnictwo Nowa Era (lider Projektu) - wiodący wydawca podręczników szkolnych i innych publikacji edukacyjnych w Polsce, posiadający także duże doświadczenie w realizacji projektów edukacyjnych,

- Uniwersytet Pedagogiczny w Krakowie (partner) - najlepsza uczelnia pedagogiczna w Polsce (w świetle rankingu „Perspektyw” i „Rzeczpospolitej”) kształcąca nauczycieli od blisko 65 lat, specjalizująca się m.in. w badaniach naukowych z zakresu dydaktyk szczegółowych, w tym dydaktyki przedsiębiorczości (działalność ta jest skoncentrowana głównie w Zakładzie Przedsiębiorczości i Gospodarki Przestrzennej Instytutu Geografii, wydawcy serii „Przedsiębiorczość - Edukacja" oraz organizatora corocznych metodycznych konferencji naukowych poświęconych przedsiębiorczości i ogólnopolskich zjazdów nauczycieli tego przedmiotu),

\footnotetext{
${ }^{1}$ Na posiedzeniu KST w dnia 11 marca 2011 r. Projekt uzyskał jednoznaczną, bezwarunkową pozytywną opinię w sprawie realizacji fazy testowej.
} 
- Podkarpackie Centrum Edukacji Nauczycieli w Rzeszowie (partner) - wiodący ośrodek doskonalenia nauczycieli w Polsce (największy w województwie podkarpackim), posiadający duże doświadczenie w realizacji projektów edukacyjnych.

Ponadto w Projekt będą zaangażowani pracownicy innych instytucji naukowych i edukacyjnych w Polsce, w szczególności z uczelni ekonomicznych, pedagogicznych i ośrodków doskonalenia nauczycieli, doświadczeni nauczyciele oraz przedsiębiorcy - praktycy życia gospodarczego i trenerzy-psychologowie zarządzania.

\section{Oczekiwane efekty realizacji Projektu}

W wyniku opracowania Innowacyjnej strategii kształcenia w zakresie przedsiębiorczości oraz kształtowania kompetencji informatycznych $i$ matematycznych $z$ wykorzystaniem wirtualnej Otwartej Platformy Edukacyjnej oczekuje się następujących efektów:

- zwiększenie umiejętności poruszania się uczniów i uczennic w świecie biznesu i otwartego rynku pracy,

- zwiększenie wykorzystania elektronicznych narzędzi jako wsparcia edukacyjnego,

- uatrakcyjnienie prowadzonych w szkołach zajęć z podstaw przedsiębiorczości i możliwość zastosowania innowacji jako podstawowej, kompleksowej strategii kształcenia w ramach nowego przedmiotu ekonomia w praktyce (od 2012/2013),

- wsparcie nauczycieli w przekazywaniu trudnej wiedzy z zakresu przedsiębiorczości, powiązanej z wiedzą i umiejętnościami z zakresu matematyki i informatyki, w przystępny i ciekawy sposób,

- zwiększenie dostępu do wartościowych materiałów edukacyjnych zarówno w szkole, jak i w domu,

- zwiększenie zainteresowania studiami o kluczowym znaczeniu dla gospodarki, w tym studiami na kierunkach inżynierskich i matematyczno-przyrodniczych.

Do realizacji strategii kształcenia w szkołach - po zakończeniu Projektu - potrzebne są niewielkie nakłady finansowe i zmiany organizacyjne. Wystarczy tylko zdecydować się na jeden z zaproponowanych wariantów organizacyjnych, zainstalować darmowe oprogramowanie platformy z wszystkimi materiałami dodatkowymi (co ze względu na przyjęte rozwiązania techniczne nie będzie zadaniem trudnym), ustawić parametry gry i rozpocząć pracę. Oczywiście potrzebni są chętni uczniowie i nauczyciele, ale z tym nie powinno być problemu ze względu na atrakcyjność proponowanej strategii w stosunku do tradycyjnych metod kształcenia. Realizacja strategii wymaga zaangażowania nauczyciela w dyskusje z uczniami oraz ocenianie ich prac. Nagrodą powinno być jednak duże zaangażowanie uczniów i satysfakcja z osiąganych efektów kształcenia, a także świadomość uczestnictwa w procesie podnoszenia jakości pracy polskiej szkoły, szczególnie w kontekście wyzwań, które stawia wchodzenie w informacyjną fazę rozwoju cywilizacyjnego i budowa gospodarki opartej na wiedzy. 


\section{Literatura}

1. Borowiec M., Dorocki S., Jenner B., 2009, Wpływ zasobów kapitalu ludzkiego na ksztaltowanie społeczeństwa informacyjnego i innowacyjności struktur przemysłowych [w:] Funkcje przemystu w kształtowaniu społeczeństwa informacyjnego, Z. Zioło, T. Rachwał (red.), „Prace Komisji Geografii Przemysłu PTG”, nr 13, Wydawnictwo Naukowe UP, Warszawa-Kraków, s. 95-109.

2. Commission Communication „Fostering entrepreneurial mindsets through education and learning”, COM (2006), 33 final.

3. Gierańczyk W., 2009, Rozwój społeczeństwa informacyjnego a przedsiębiorczość w krajach transformujących się [w:] Rola przedsiębiorczości w kształtowaniu społeczeństwa informacyjnego, Z. Zioło, T. Rachwał (red.), „Przedsiębiorczość - Edukacja”, nr 5, Nowa Era, Zakład Przedsiębiorczości i Gospodarki Przestrzennej Instytutu Geografii Uniwersytetu Pedagogicznego w Krakowie, Warszawa-Kraków, s. 19-36.

4. Innowacyjna strategia kształcenia w zakresie przedsiębiorczości oraz kształtowania kompetencji informatycznych i matematycznych z wykorzystaniem wirtualnej Otwartej Platformy Edukacyjnej opracowana w ramach Projektu „Krok w przedsiębiorczość” (wstęnna wersja), 2011, Nowa Era, Warszawa.

5. Kawecki Z., 2005, Ranga przedmiotu podstawy przedsiębiorczości w edukacji szkolnej [w:] Przedsiębiorczość a wspótczesne wyzwania edukacyjne, Z. Zioło, T. Rachwał (red.), „Przedsiębiorczość Edukacja”, nr 1, Wydawnictwo MiWa, Zakład Przedsiębiorczości i Gospodarki Przestrzennej Instytutu Geografii Akademii Pedagogicznej w Krakowie, Kraków, s. 203-206.

6. Kompetencje kluczowe w uczeniu się przez całe życie. Europejskie Ramy Odniesienia, 2007, Urząd Oficjalnych Publikacji Wspólnot Europejskich, Luxembourg.

7. Kompetencje kluczowe. Realizacja koncepcji na poziomie szkolnictwa obowiązowego, 2005, Eurydice, Fundacja Rozwoju Systemu Edukacji, Warszawa.

8. Kurek S., Rachwał T., 2010a, Założenia i wstępne wyniki europejskiego projektu badawczego FIFOBI w zakresie ksztattowania kompetencji uczniów gimnazjum do prowadzenia działalności gospodarczej [w:] Rola przedsiębiorczości w warunkach integracji europejskiej, Z. Zioło, T. Rachwał (red.), „Przedsiębiorczość - Edukacja”, nr 6, Nowa Era, Zakład Przedsiębiorczości i Gospodarki Przestrzennej Instytutu Geografii Uniwersytetu Pedagogicznego w Krakowie, Warszawa-Kraków, s. 472-485.

9. Kurek S., Rachwał T., 2010b, The Role of Business Education in the Development of Entrepreneurship in the Member States of the European Union, Europa XXI, Warszawa, s. 127-142.

10. Naudé W., 2008, Entrepreneurship in Economic Development. Research Paper No. 2008/20, World Institute for Development Economics Research, s. 1-47.

11. Rachwał T., 2004, Cele i treści kształcenia przedsiębiorczości w szkołach ponadgimnazjalnych [w:] Przedsiębiorczość stymulatorem rozwoju gospodarczego, J. Brdulak, M. Kulikowski (red.), Instytut Wiedzy SGH, Warszawa, s. 263-270.

12. Rachwał T., 2005a, Ksztaltowanie postaw uczniów na lekcjach przedsiębiorczości [w:] Przedsiębiorczość a współczesne wyzwania cywilizacyjne, Z. Zioło, T. Rachwał (red.), „Przedsiębiorczość - Edukacja”, nr 1, Wydawnictwo MiWa, Zakład Przedsiębiorczości i Gospodarki Przestrzennej Instytutu Geografii Akademii Pedagogicznej w Krakowie, Kraków, s. 137-144.

13. Rachwał T., 2005b, Podstawy przedsiębiorczości. Słownik, wyd. 2, Nowa Era, Warszawa.

14. Rachwał T., 2006, Kształtowanie postaw przedsiębiorczych w edukacji szkolnej [w:] Szkoła w nauce i praktyce edukacyjnej, B. Suchacka (red.), t. II, Oficyna Wydawnicza „Impuls”, Akademii Pedagogiczna w Krakowie, Kraków, s. 427-434.

15. Rachwał T., 2009, Ocena projektu zmian podstawy proramowej podstaw przedsiębiorczości [w:] Rola przedsiębiorczości w kształtowaniu społeczeństwa informacyjnego, Z. Zioło, T. Rachwał (red.), „Przedsiębiorczość - Edukacja”, nr 5, Nowa Era, Zakład Przedsiębiorczości i Gospodarki Przestrzennej Instytutu Geografii Uniwersytetu Pedagogicznego w Krakowie, Warszawa-Kraków, s. 349-372.

16. Rachwał T., 2010, Chapter 9. Entrepreneurship Education as a Growth Stimulus for Family Firms [w:] Exploring the Dynamics of Entrepreneurship, A. Surdej, K. Wach (ed.), A. Marszałek Publishing House, Toruń, s. 139-156. 
17. Recommendation of the European Parliament and of the Council of 18 December 2006 on key competences for lifelong learning (2006/962/EC). Official Journal of the European Union, L 394, 30.12.2006.

18. Szabó A., 2008. Education for entrepreneurship from kindergarden to adult learning. Prepared for the International Conference On Law, Economics And Management ICELM3, 4-7 June 2008 Targu-Muresh - Romania.

19. Szeliga P., 2007, Chwasty na polu przedsiębiorczości, czyli czego w szkole nie uprawiać [w:] Ksztattowanie postaw przedsiębiorczych a edukacja ekonomiczna, P. Wachowiak, M. Dąbrowski, B. Majewski (red.), Fundacja Promocji i Akredytacji Kierunków Ekonomicznych, Warszawa, s. 140-145.

20. Tracz M., Rachwał T., 2007, Przedmiot podstawy przedsiębiorczości - założenia realizacji a przygotowanie nauczycieli [w:] Rola przedsiębiorczości w aktywizacji gospodarczej, Z. Zioło, T. Rachwał (red.), „Przedsiębiorczość - Edukacja”, nr 3, Nowa Era, Zakład Przedsiębiorczości i Gospodarki Przestrzennej Instytutu Geografii Akademii Pedagogicznej w Krakowie, Warszawa-Kraków, s. 286-296.

21. Tracz M., Rachwał T., 2008, Metody i środki dydaktyczne stosowane przez nauczycieli podstaw przedsiębiorczości - wyniki badań [w:] Rola przedsiębiorczości w gospodarce opartej na wiedzy, Z. Zioło, T. Rachwał (red.), „Przedsiębiorczość - Edukacja”, nr 4, Nowa Era, Zakład Przedsiębiorczości i Gospodarki Przestrzennej Instytutu Geografii Uniwersytetu Pedagogicznego w Krakowie, WarszawaKraków, s. 325-330.

22. Wach K., 2007, Ksztaltowanie postaw przedsiębiorczych w programach nauczania. Stan obecny i proponowane kierunki zmian [w:] Kształtowanie postaw przedsiębiorczych a edukacja ekonomiczna, P. Wachowiak, M. Dąbrowski, B. Majewski (red.), Fundacja Promocji i Akredytacji Kierunków Ekonomicznych, Warszawa, s. 120-127.

23. Zioło Z., 2006, Rola przedsiębiorczości w podnoszeniu konkurencyjności społeczeństwa i gospodarki [w:] Rola przedsiębiorczości w podnoszeniu konkurencyjności społeczeństwa i gospodarki, Z. Zioło, T. Rachwał (red.), „Przedsiębiorczość - Edukacja”, nr 2, Nowa Era, Zakład Przedsiębiorczości i Gospodarki Przestrzennej Instytutu Geografii Akademii Pedagogicznej w Krakowie, Warszawa-Kraków, s. $10-17$.

24. Zioło Z., 2007, Rola przedsiębiorczości w aktywizacji gospodarczej-zarys modelu [w:] Rola przedsiębiorczości w aktywizacji gospodarczej, Z. Zioło, T. Rachwał (red.), „Przedsiębiorczość - Edukacja”, nr 3, Nowa Era, Zakład Przedsiębiorczości i Gospodarki Przestrzennej Instytutu Geografii Akademii Pedagogicznej w Krakowie, Warszawa-Kraków, s. 10-17.

25. Zioło Z., 2008, Ekonomiczne i społeczne uwarunkowania rozwoju gospodarki opartej na wiedzy [w:] Rola przedsiębiorczości w gospodarce opartej na wiedzy, Z. Zioło, T. Rachwał (red.), „Przedsiębiorczość - Edukacja”, nr 4, Nowa Era, Zakład Przedsiębiorczości i Gospodarki Przestrzennej Instytutu Geografii Uniwersytetu Pedagogicznego w Krakowie, Warszawa-Kraków, s. 12-23.

26. Zioło Z., 2009, Rola przedsiębiorczości w ksztattowaniu społeczeństwa informacyjnego [w:] Rola przedsiębiorczości w kształtowaniu społeczeństwa informacyjnego, Z. Zioło, T. Rachwał (red.), „Przedsiębiorczość - Edukacja”, nr 5, Nowa Era, Zakład Przedsiębiorczości i Gospodarki Przestrzennej Instytutu Geografii Uniwersytetu Pedagogicznego w Krakowie, Warszawa-Kraków, s. 10-18.

27. Zioło Z., Rachwał T. (red.) 2005, Przedsiębiorczość a współczesne wyzwania cywilizacyjne, „Przedsiębiorczość - Edukacja”, nr 1, Wydawnictwo MiWa, Zakład Przedsiębiorczości i Gospodarki Przestrzennej Instytutu Geografii Akademii Pedagogicznej w Krakowie, Kraków.

28. Zioło Z., Rachwał T. (red.) 2006, Rola przedsiębiorczości w podnoszeniu konkurencyjności społeczeństwa i gospodarki, „Przedsiębiorczość - Edukacja”, nr 2, Nowa Era, Zakład Przedsiębiorczości i Gospodarki Przestrzennej Instytutu Geografii Akademii Pedagogicznej w Krakowie, Warszawa-Kraków.

29. Zioło Z., Rachwał T. (red.) 2007, Rola przedsiębiorczości w aktywizacji gospodarczej, „Przedsiębiorczość - Edukacja”, nr 3, Nowa Era, Zakład Przedsiębiorczości i Gospodarki Przestrzennej Instytutu Geografii Akademii Pedagogicznej w Krakowie, Warszawa-Kraków.

30. Zioło Z., Rachwał T. (red.), 2008, Rola przedsiębiorczości w gospodarce opartej na wiedzy, „Przedsiębiorczość - Edukacja”, nr 4, Nowa Era, Zakład Przedsiębiorczości i Gospodarki Przestrzennej Instytutu Geografii Uniwersytetu Pedagogicznego w Krakowie, Warszawa-Kraków. 
31. Zioło Z., Rachwał T. (red.) 2009, Rola przedsiębiorczości w kształtowaniu społeczeństwa informacyjnego, „Przedsiębiorczość - Edukacja”, nr 5, Nowa Era, Zakład Przedsiębiorczości i Gospodarki Przestrzennej Instytutu Geografii Uniwersytetu Pedagogicznego w Krakowie, Warszawa-Kraków.

32. Zioło Z., Rachwał T. (red.), 2010, Rola przedsiębiorczości w warunkach integracji europejskiej, „Przedsiębiorczość - Edukacja”, nr 6, Nowa Era, Zakład Przedsiębiorczości i Gospodarki Przestrzennej Instytutu Geografii Uniwersytetu Pedagogicznego w Krakowie, Warszawa-Kraków.

\section{The Aims and Objectives Of The Project "Step In Entrepreneurship" for Upper Secondary School Teachers}

This article presents the rationale and purpose of the Project "Step in entrepreneurship" to the secondary school teachers. The main objective of the project is to design and pilot testing of implementation (in Małopolska and Podkarpackie voivodeships) an innovative program of development of entrepreneurial attitudes, IT and mathematics competence in upper secondary schools. The developed training program is based on the concept of creating a virtual company by the students. It is located on the Open Educational Platform created specifically for the Project and the students compete on the virtual market. 


\section{Ksztaltowanie postaw przedsiębiorczych na lekcjach geografii wyzwaniem edukacyjnym w procesach globalizacji}

W procesie kształtowania społeczeństwa informacyjnego oraz procesach globalizacyjnych istotną rolę odgrywa wiedza i nauka, a kapitał ludzki jest czynnikiem, bez którego nie jest możliwe osiągnięcie trwałego i wysokiego tempa rozwoju społeczno-gospodarczego (m.in. Borowiec 2003, 2009, 2010; Chojnicki, Czyż 2008; Harańczyk 2008; Janc 2003; Zioło 2009, 2010). Cywilizacja informacyjna jest cywilizacją szybkich zmian, co oznacza konieczność reagowania na nowe uwarunkowania, a siłą motoryczną jej rozwoju są zasoby kapitału ludzkiego (Kołodziejski 1998). Jak przyjmuje I. Zioło: „współczesne wyzwania cywilizacyjne stawiają nowe, wysokie zadania w zakresie edukacji i przygotowania do pełnienia określonych ról zawodowych. Zadania edukacji są bowiem determinowane rozwojem społecznym, gospodarczym i kulturalnym, stanem świadomości społecznej oraz potrzebami i zainteresowaniami ludzi żyjących w określonych strukturach społeczno-ekonomicznych. One wyznaczają zasadnicze priorytety polityki oświatowej oraz konstrukcję systemu edukacji” (Zioło 1999, s. 127). Zadaniem edukacji jest przygotowanie ludzi do adaptacji w nowych uwarunkowaniach społeczno-gospodarczych, tak aby mogli oni w sposób racjonalny wpływać na struktury, które dziś podlegają przemianom. Umożliwia to jak zakłada L. Kuźnicki (2004) realizację głównego megatrendu współczesnego procesu rozwoju jakim jest budowa gospodarki opartej na wiedzy.

Zdaniem A. Wielońskiego (2003), przyspieszenie w ostatnich latach budowy gospodarki opartej na wiedzy wynika w dużej mierze ze zwiększającego się znaczenia innowacyjności we współczesnej gospodarce. Prowadzi to do wzrostu roli wiedzy jako czynnika, od którego zależy przyszły rozwój społeczeństw, przedsiębiorstw, instytucji i gospodarek krajowych w fazie informacyjnego rozwoju. Występuje tu rodzaj sprzężenia zwrotnego między innowacyjnością technologiczną a wzrostem zapotrzebowania na wiedzę. Postęp technologiczny staje się podstawą rozwoju społeczeństwa i gospodarki. Konkurencja w tym zakresie między korporacjami międzynarodowymi powoduje nasilenie się presji na systematyczne przyspieszanie rozwoju nauki i technologii, gdyż - zdaniem A. Wielońskiego (2003) - to właśnie kapitał intelektualny jest podstawą przewagi konkurencyjnej przedsiębiorstw we współczesnej gospodarce. Nasilenie się presji konkurencyjnej w układzie globalnym wymusza na przedsiębiorstwach ciągłe podnoszenie efektywności produkcji, odbywające się m.in. poprzez podnoszenie kwalifikacji i wykształcenia pracowników przedsiębiorstw, a także instytucji otoczenia.

Podobnie M. Kabaj (1997) podkreśla, że ważne miejsce w postępie technologicznym, gospodarczym i społecznym zajmuje rozwój i doskonalenie kwalifikacji zasobów ludzkich, tworzenie i wykorzystywanie wiedzy. Produktywność, konkurencyjność i efektywność zależą 
od zasobu i nowoczesności wiedzy ludzi, od jakości pracy, wykształcenia, umiejętności ciągłego myślenia innowacyjnego i wdrażania nowych rozwiązań do procesów wytwarzania, dystrybucji oraz usług. W dobie silnego postępu technologicznego zaniechanie tych dostosowań skazuje uczestników procesów globalizacji na marginalizację (Zajączkowska-Jakimiak 2002). W konsekwencji kraje, które szybciej dokonują transformacji w kierunku gospodarki opartej na wiedzy, uzyskują przewagę w globalnej gospodarce światowej. Z kolei N. Juszkiewicz uważa, że w cywilizacji informacyjnej na znaczeniu zyskuje wiele nowych czynników rozwoju społeczno-gospodarczego, a za jeden z najważniejszych uznaje się poziom szkolnictwa i rozwoju nauki. Zdaniem autorki „można zatem przyjąć tezę, że wyniki funkcjonowania systemu nauki i szkolnictwa, w szczególności szkolnictwa wyższego, w postaci ilości i jakości kadr na każdym poziomie przygotowania zawodowego, są czynnikiem decydującym o kierunkach i poziomie rozwoju gospodarczego i społecznego oraz jego konkurencyjności" (Juszkiewicz 1997, s. 211). „Edukacja powoduje poprawę życia, podnosząc jego jakość i prowadzi do zwiększenia korzyści społecznych. Oświata zwiększa poziom produktywności i kreatywności jednostek, daje impuls do nowych inicjatyw, wyzwala przedsiębiorczość i postęp techniczny [...] Zauważono także, że żadnemu państwu współczesnego świata nie udało się podtrzymanie ekonomicznego rozwoju bez znacznej inwestycji w kapitał ludzki" (Grodzicki 2000, s. 6).

Rolę wiedzy jako czynnika podnoszącego konkurencyjność gospodarki podkreślono w przyjętej w 2000 r. strategii lizbońskiej, której głównym celem jest zwiększenie konkurencyjności europejskiej gospodarki poprzez rozwój gospodarki opartej na wiedzy oraz stworzenie warunków do wzrostu przedsiębiorczości (Kafel 2005). Osiągnięcie tego celu jest możliwe dzięki podjęciu działań edukacyjnych przedstawionych w programie prac Edukacja i szkolenia 2010 przyjętym przez ministrów edukacji UE i Komisję Europejską w 2002 r. Wyróżniono w nim następujące cele strategiczne:

1. „poprawa jakości i efektywności systemów edukacji w UE wobec nowych zasad społeczeństwa opartego na wiedzy oraz zmieniających się metod i treści nauczania i uczenia się" (Strategia MENiS, s. 5),

2. działanie na rzecz zwiększenia szans zdobycia i utrzymania zatrudnienia oraz rozwoju zawodowego,

3. lepsze dostosowanie edukacji do potrzeb pracy zawodowej i wymagań społeczeństwa oraz sprostania wymaganiom wynikającym z globalizacji.

Mając na uwadze założenia strategii lizbońskiej, już w Narodowym planie rozwoju na lata 2004-2006 założono rozwijanie konkurencyjnej gospodarki opartej na wiedzy i przedsiębiorczości. Podobnie kierunki, przedsięwzięcia i działania Priorytetu Wiedza i Kompetencje ${ }^{1}$ zawartego w Narodowym planie rozwoju na lata 2007-2013 obejmują: zwiększenie dostępu do edukacji, wyższą jakość kształcenia oraz wspieranie otwartości systemu edukacji realizowane m.in. poprzez kształtowanie postaw przedsiębiorczych, innowacyjnych i proekologicznych.

Strategia rozwoju edukacji na lata 2007-2013 zakłada, że edukacja w Polsce jako integralny system kształcenia (umożliwianie zdobycia wiedzy i umiejętności) oraz wychowania (kształtowanie i promowanie postaw) będzie: ułatwiać każdemu realizację aspiracji, rozwój i wykorzystanie możliwości, przygotowywać do aktywnego i odpowiedzialnego uczestniczenia w życiu społecznym, kulturalnym i gospodarczym (w wymiarze lokalnym, narodowym i globalnym), skutecznie przeciwdziałać wykluczeniu i marginalizacji osób oraz grup społecznych, reagować na zmiany związane z rozwojem nauki, nowoczesnych technologii i globalizacją,

\footnotetext{
${ }^{1}$ Priorytet Wiedza i Kompetencje rozumiany jest jako poprawa jakości kształcenia i jego upowszechnienie na poziomie średnim i wyższym.
} 
szybko i elastycznie dostosowywać się do zmian zachodzących na rynku pracy. Jak przyjmuje J. Ratajczak: „nie kształcimy bowiem tylko na potrzeby własnej gospodarki, choć jest to celem priorytetowym, ale także na potrzeby zintegrowanej Europy, która dla prawidłowego rozwoju potrzebuje wysoko kwalifikowanych kadr, ludzi zdolnych do innowacji, przedsiębiorczych i zdolnych do kształcenia ustawicznego" (Ratajczak 2005, s. 296).

W świetle powyższych rozważań rodzi się pytanie o to, czy system edukacji szkolnej, w tym kształcenie geograficzne, odpowiada na współczesne wyzwania cywilizacyjne i przygotowuje młodego człowieka do adaptacji w nowych warunkach rozwoju społeczno-gospodarczego, tak aby potrafił on w sposób racjonalny wpływać na podlegające dziś przemianom struktury. Należy przyjąć, że kluczową sprawą w przygotowaniu do życia we współczesnej cywilizacji informacyjnej jest kształtowanie postaw przedsiębiorczych. Za sprawą przyspieszenia rozwoju nauki wynikającego z postępu technologicznego nie sposób bowiem założyć, iż tylko w toku edukacji szkolnej uda się przygotować uczniów do odnalezienia swojego miejsca w świecie, czyli m.in. do wejścia na rynek pracy. Bardzo często wiedza i umiejętności zdobyte w szkole już w momencie jej opuszczenia są niewystarczające do wykazania aktywności zawodowej i wymagają ciągłego aktualizowania. Jest to konieczne nie tylko w wypadku technologii informacyjnej, ale także w wypadku innych przedmiotów szkolnych, w tym geografii. Dzięki kształtowaniu postaw przedsiębiorczych w toku edukacji młody człowiek będzie coraz bardziej rozumiał potrzebę ustawicznego kształcenia poprzez aktualizowanie wiedzy i zdobywanie nowych umiejętności, co pozwoli mu uniknąć marginalizacji w społeczeństwie fazy informacyjnej. Należy tu jednak podkreślić, że nie chodzi o wąskie ujęcie przedsiębiorczości rozumianej często jako zdolność do założenia i poprowadzenia własnej firmy. Chodzi o szersze rozumienie postawy przedsiębiorczej jako: a) zespołu cech osobowych człowieka, takich jak: aktywność, wytrwałość, zapał do pracy, inicjatywa, kreatywność, asertywność, zdolność do koncentracji, pewność siebie i wiara we własne siły, samodyscyplina, uczciwość, skłonność do wyważonego ryzyka oraz brania odpowiedzialności za siebie i innych, postępowanie zgodne z zasadami etycznymi, b) zespołu posiadanych umiejętności, np. wyszukiwania i wykorzystywania szans, które stwarza rynek, stawiania i realizowania wyznaczonych sobie celów poprzez wytyczanie własnej ścieżki kariery zawodowej, zdobywania, selekcji i przetwarzania informacji, interpretowania procesów gospodarczych, rozumienia związków przyczynowo-skutkowych, z zakresu autoprezentacji, komunikacji interpersonalnej itp. Cechy te pozwalają dobrze prowadzić przedsiębiorstwo, tj. być dobrym przedsiębiorcą, oraz aktywnie uczestniczyć w życiu społeczno-gospodarczym (w tym życiu rodzinnym), co umożliwia osiągnięcie satysfakcji, niezależnie od charakteru wykonywanej pracy i zajmowanego stanowiska. Człowiek przedsiębiorczy nie boi się trudności, podejmowania nowych, nieznanych zadań, nie załamuje się niepowodzeniami, jest chętny do zdobywania wiedzy i nowych umiejętności, potrafi cieszyć się z sukcesów, jest otwarty na otoczenie, empatyczny, gotowy do współpracy z innymi ludźmi i postępuje zgodnie z wartościami etycznymi (Borowiec 2005; Rachwał 2004, 2005).

Taki punkt widzenia postawy przedsiębiorczej jest powszechnie przyjmowany przez wielu autorów. Warto tu przytoczyć słowa D. Golemana: „Skoro zmienia się gospodarka, zmieniają się również cechy potrzebne do przetrwania w niej, nie mówiąc już o odnoszeniu sukcesów. [...] Nacisk ze strony konkurencji każe docenić ludzi, którzy potrafią się sami motywować do działania, wykazują inicjatywę, odczuwają wewnętrzną potrzebę prześcignięcia samych siebie i mają tyle optymizmu, że nie zniechęcają się niepowodzeniami i porażkami, lecz uporczywie kroczą naprzód" (Goleman 1999, s. 434). Człowiek przyjmujący postawę przedsiębiorczą jest więc według D. Golemana $(1999,1997)$ bezcennym skarbem dla każdej firmy 
i instytucji. Intensywne przemiany gospodarcze i konieczność nieustannego podnoszenia konkurencyjności przedsiębiorstw oraz instytucji wymagają zatem kształtowania u uczniów - późniejszych pracowników - w ten sposób rozumianej postawy przedsiębiorczości.

Postawa ta kształtowana jest nie tylko przez nauczycieli w szkole, ale także w rodzinie, już od najmłodszych lat, w toku całego procesu kształcenia młodzieży. W wypadku edukacji szkolnej, według nowej koncepcji systemu oświaty, pewne elementy tej postawy powinny pojawić się już w szkole podstawowej, ale zasadniczy nacisk kładzie się na etap szkoły gimnazjalnej i ponadgimnazjalnej. W tym celu podjęto decyzję o wprowadzeniu do edukacji szkolnej modułu wychowanie do aktywnego udziału w życiu gospodarczym w ramach WOS w gimnazjum (obecnie, tj. od 2009 r., zrezygnowano z tej nazwy, ale treści w ramach WOS zostały pozostawione) oraz osobnego przedmiotu podstawy przedsiębiorczości w szkołach ponadgimnazjalnych. W założeniach nowego systemu edukacji właśnie w tych przedmiotach ma się koncentrować edukacja w zakresie przedsiębiorczości. Jednakże wydaje się, że nie jest możliwe zrealizowanie celu głównego zajęć w ciągu zaledwie dwóch czy trzech godzin w cyklu kształcenia (uwzględniając łącznie etap gimnazjum i szkoły ponadgimnazjalnej). Wielką rolę w tym względzie mają więc do odegrania wychowawcy i nauczyciele podejmujący studia podyplomowe z zakresu przedsiębiorczości, w celu zdobycia kwalifikacji do nauczania podstaw przedsiębiorczości (Makieła 2004a, b; Rachwał 2004). Jednak nie tylko lekcje podstaw przedsiębiorczości, ale także lekcje geografii, zajęcia fakultatywne i różnego typu zajęcia pozalekcyjne organizowane przez nauczycieli geografii stwarzają możliwości kształtowania postaw przedsiębiorczych.

Po przeanalizowaniu aktualnie obowiązującej podstawy programowej geografii widać, że z postawą przedsiębiorczości w gimnazjum wiąże się IV cel kształcenia, określony jako „Kształtowanie postaw" (Rozporzadzenie 2009). Obrazuje to tabela 1, w której podkreślono ważniejsze treści związane z przedsiębiorczością.

Tab. 1. Cele kształcenia z zakresu geografii a kształtowanie postaw przedsiębiorczych (gimnazjum)

\begin{tabular}{|l|l|}
\hline \multicolumn{1}{|c|}{$\begin{array}{c}\text { Cele kształcenia - wymagania ogólne - } \\
\text { wg podstawy programowej }\end{array}$} & \multicolumn{1}{|c|}{$\begin{array}{c}\text { Wybrane cechy i umiejętności } \\
\text { osoby przedsiębiorczej* }\end{array}$} \\
\hline $\begin{array}{l}\text { „Uczeń rozwija w sobie: ciekawość świata poprzez } \\
\text { zainteresowanie własnym regionem, Polską, Europą } \\
\text { i światem [...]” }\end{array}$ & $\begin{array}{l}\text { otwartość na otoczenie, ciekawość świata, } \\
\text { umiejętność wyszukiwania i wykorzystywania } \\
\text { szans, które stwarza rynek (regionalny, krajowy, } \\
\text { europejski, światowy) }\end{array}$ \\
\hline $\begin{array}{l}\text { „Uczeń rozwija w sobie: [...], świadomość wartości } \\
\text { i poczucie odpowiedzialności za środowisko } \\
\text { przyrodnicze i kulturowe własnego regionu i Polski; } \\
\text { patriotyzm i poczucie tożsamości (lokalnej, } \\
\text { regionalnej, narodowej) przy jednoczesnym } \\
\text { poszanowaniu innych narodów i społeczności - } \\
\text { ich systemów wartości i sposobów życia.” }\end{array}$ & $\begin{array}{l}\text { postępowie zgodne z wartościami etycznymi } \\
\text { (w tym szacunek dla innych), odpowiedzialność } \\
\text { za siebie i innych, umiejętności z zakresu } \\
\text { komunikacji interpersonalnej (rozwiązywanie } \\
\text { konfliktów, prowadzenie negocjacji) }\end{array}$ \\
\hline
\end{tabular}

*możliwe do kształtowania w toku realizacji danego celu kształcenia

Źródło: opracowanie własne na podstawie Rozporządzenie 2009.

Wiedza i umiejętności związane z przedsiębiorczością mogą być kształtowane na lekcjach geografii w gimnazjum w ramach zajęć realizujących treści nauczania z zakresu geografii gospodarczej Polski i Europy. Podstawa programowa (Rozporzadzenie 2009) zakłada w tym zakresie realizację następujących treści nauczania - wymagań szczegółowych: 


\section{Wybrane zagadnienia geografii gospodarczej Polski. Uczeń:}

1) wyróżnia główne cechy struktury użytkowania ziemi, wielkości i własności gospodarstw rolnych, zasiewów i hodowli w Polsce na podstawie analizy map, wykresów, danych liczbowych [podkreślenia - M. B., T. R.];

2) podaje przyczyny zróżnicowania w rozmieszczeniu wybranych upraw (pszenicy, ziemniaków, buraków cukrowych) oraz chowu bydła i trzody chlewnej w Polsce;

3) przedstawia, na podstawie różnych źródeł informacji, strukturę wykorzystania źródeł energii w Polsce i ocenia jej wpływ na stan środowiska przyrodniczego;

4) wyjaśnia przyczyny zmian zachodzacych w przemyśle w Polsce i we własnym regionie oraz wskazuje najlepiej rozwijajace się obecnie w Polsce gałęzie produkcji przemysłowej;

5) rozróżnia rodzaje usług; wyjaśnia szybki rozwój wybranych usług w Polsce i we własnym regionie;

6) wykazuje na przykładach walory turystyczne Polski oraz opisuje obiekty znajdujące się na Liście światowego dziedzictwa kulturowego i przyrodniczego UNESCO;

7) opisuje na podstawie map i wyjaśnia zróżnicowanie gęstości i jakości sieci transportowej w Polsce i wykazuje jej wpływ na rozwój innych dziedzin działalności gospodarczej;

8) wykazuje konieczność ochrony środowiska przyrodniczego i kulturowego w Polsce; wymienia formy jego ochrony, proponuje konkretne działania na rzecz jego ochrony we własnym regionie.

Europa. Relacje przyroda - człowiek - gospodarka. Uczeń:

1) wykazuje się znajomością podziału politycznego Europy;

2) określa położenie Europy i główne cechy środowiska przyrodniczego na podstawie mapy ogólnogeograficznej i map tematycznych;

3) opisuje, na podstawie map tematycznych, zróżnicowanie regionalne, kulturowe, narodowościowe i etniczne współczesnej Europy oraz najważniejsze przyczyny i konsekwencje tego zróżnicowania;

4) wykazuje, na podstawie map tematycznych, związki między głównymi cechami środowiska przyrodniczego Europy Północnej a głównymi kierunkami rozwoju gospodarczego;

5) wykazuje, na przykładzie rolnictwa Francji lub innego kraju europejskiego, związek pomiędzy warunkami przyrodniczymi a kierunkiem i efektywnością produkcji rolnej; identyfikuje cechy rolnictwa towarowego;

6) przedstawia, na podstawie wskazanych źródeł informacji geograficznej, główne kierunki i przyczyny zmian w strukturze przemysłu wybranego regionu (lub okregu) przemysłowego w Europie Zachodniej;

7) przedstawia główne cechy położenia, wielkości, układu przestrzennego oraz znaczenie Paryża lub Londynu jako światowej metropolii;

8) wykazuje wpływ gór na cechy środowiska przyrodniczego oraz gospodarkę krajów alpejskich;

9) wykazuje związki między rozwojem turystyki w Europie Południowej a warunkami przyrodniczymi oraz dziedzictwem kultury śródziemnomorskiej;

10) prezentuje opracowana na podstawie map, przewodników, Internetu trase wycieczki po Europie lub jej części.

Wybrane regiony świata. Relacje: czlowiek - przyroda - gospodarka. Uczeń:

1) wykazuje, na podstawie map tematycznych, że kontynent Azji jest obszarem wielkich geograficznych kontrastów;

2) przedstawia, na podstawie map tematycznych, warunki przyrodnicze obszarów, na których kształtowały się najstarsze azjatyckie cywilizacje;

3) analizuje wykresy i dane liczbowe dotyczące rozwoju ludnościowego i urbanizacji w Chinach; wyjaśnia, na podstawie map tematycznych, zróżnicowanie rozmieszczenia ludności 
na obszarze Chin; podaje kierunki rozwoju gospodarczego Chin oraz wskazuje zmiany znaczenia Chin w gospodarce światowej;

4) wykazuje znaczenie czynników społeczno-kulturowych w tworzeniu nowoczesnej gospodarki Japonii na tle niekorzystnych cech środowiska przyrodniczego;

5) wykazuje związek pomiędzy rytmem upraw i „kulturą ryżu” a cechami klimatu monsunowego w Azji Południowo-Wschodniej;

6) opisuje kontrasty społeczne i gospodarcze w Indiach; wyjaśnia przyczyny gwałtownego rozwoju nowoczesnych technologii;

7) charakteryzuje region Bliskiego Wschodu pod kątem cech kulturowych, zasobów ropy naftowej, kierunków i poziomu rozwoju gospodarczego; wskazuje miejsca konfliktów zbrojnych;

8) charakteryzuje na podstawie map tematycznych i wyjaśnia występowanie stref klimatyczno-roślinno-glebowych w Afryce;

9) wykazuje, na przykładzie strefy Sahelu, zwiazek pomiędzy formami gospodarowania człowieka a zasobami wodnymi; uzasadnia potrzebę racjonalnego gospodarowania w środowisku charakteryzującym się poważnymi niedoborami słodkiej wody;

10) określa związki pomiędzy problemami wyżywienia, występowaniem chorób (m.in. AIDS) a poziomem życia w krajach Afryki na południe od Sahary;

11) wyróżnia główne cechy i przyczyny zróżnicowania kulturowego i etnicznego Ameryki Północnej i Południowej;

12) identyfikuje konflikt interesów pomiędzy ekologicznymi skutkami wylesiania Amazonii a jej gospodarczym wykorzystaniem; określa cechy rozwoju i problemy wielkich miast w Brazylii;

13) wykazuje zwiazki między gospodarka a warunkami środowiska przyrodniczego w najważniejszych regionach gospodarczych Stanów Zjednoczonych; określa rolę Stanów Zjednoczonych w gospodarce światowej;

14) przedstawia, na podstawie map tematycznych, główne cechy gospodarki Australii na tle warunków środowiska przyrodniczego;

15) przedstawia cechy położenia i środowiska geograficznego Antarktyki i Arktyki; podaje główne cechy i przyczyny zmian w środowisku przyrodniczym obszarów okołobiegunowych.

Widać również związki między kształtowaniem postawy przedsiębiorczej a celami edukacji geograficznej na poziomie szkoły ponadgimnazjalnej, gdzie dwa cele edukacyjne dla szkoły ponadgimnazjalnej kończącej się maturą (poziom podstawowy) można uznać za związane z przedsiębiorczością (tab. 2).

Tab. 2. Cele kształcenia z zakresu geografii a kształtowanie postaw przedsiębiorczych (szkoła ponadgimnazjalna kończąca się maturą - poziom podstawowy)

\begin{tabular}{|l|l|}
\hline \multicolumn{1}{|c|}{$\begin{array}{c}\text { Cele kształcenia - wymagania ogólne } \\
\text { wg podstawy programowej }\end{array}$} & \multicolumn{1}{c|}{$\begin{array}{c}\text { Wybrane cechy i umiejętności osoby } \\
\text { przedsiębiorczej* }\end{array}$} \\
\hline $\begin{array}{l}\text { Wykorzystanie różnych źródeł informacji do } \\
\text { analizy i prezentowania współczesnych } \\
\text { problemów przyrodniczych, gospodarczych, } \\
\text { społecznych, kulturowych i politycznych. }\end{array}$ & $\begin{array}{l}\text { otwartość na otoczenie, ciekawość świata, } \\
\text { umiejętność interpretowania (analizowania) } \\
\text { procesów gospodarczych oraz rozumienia } \\
\text { związków przyczynowo-skutkowych }\end{array}$ \\
\hline $\begin{array}{l}\text { Formułowanie i weryfikowanie hipotez } \\
\text { dotyczących problemów współczesnego świata. }\end{array}$ & $\begin{array}{l}\text { umiejętność interpretowania procesów gospodar- } \\
\text { czych oraz formułowania i weryfikacji hipotez }\end{array}$ \\
\hline
\end{tabular}

*możliwe do kształtowania w toku realizacji danego celu kształcenia

Źródło: opracowanie własne na podstawie Rozporządzenie 2009. 
Treści z zakresu przedsiębiorczości mogą być realizowane w ramach realizacji lekcji dotyczących zróżnicowania gospodarki światowej. W świetle zapisów podstawy programowej jest to moduł 2:

\section{Zróżnicowanie gospodarcze świata. Uczeń:}

1) klasyfikuje państwa na podstawie analizy wskaźników rozwoju społecznego i gospodarczego; wyróżnia regiony bogate i biedne (bogatą Północ i biedne Południe) i podaje przyczyny dysproporcji w poziomie rozwoju społeczno-gospodarczego regionów świata;

2) ocenia i projektuje różne formy pomocy państwa i organizacji pozarządowych państwom i regionom dotkniętym kryzysem (klęskami ekologicznymi, wojnami, głodem);

3) opisuje główne obszary upraw i chowu zwierząt na świecie, wyjaśnia ich zróżnicowanie przestrzenne;

4) wyjaśnia, z czego wynikają różnice w wielkości i strukturze spożycia żywności na świecie (uwarunkowania przyrodnicze, kulturowe, społeczne i polityczne, mechanizmy wpływające na nierównomierny rozdział żywności w skali globalnej);

5) opisuje zmiany w funkcji obszarów wiejskich na wybranych przykładach (np. w Unii Europejskiej, w regionach turystycznych w państwach rozwijających się); potrafi wyjaśnić szanse i zagrożenia dla środowiska przyrodniczego i mieszkańców poszczególnych regionów, wynikające z procesów przemian zachodzących na terenach wiejskich;

6) charakteryzuje kierunki zmian w powierzchni lasów na świecie (w wyniku procesów wylesiania i zalesiania) i podaje przykłady gospodarowania zasobami leśnymi (pozytywne i negatywne);

7) charakteryzuje cechy gospodarki morskiej i podaje przykłady wykorzystania oceanu światowego oraz zagrożeń wynikających ze zbyt intensywnej eksploatacji zasobów morskich;

8) charakteryzuje i ocenia zróżnicowanie i zmiany struktury wykorzystania surowców energetycznych na świecie; dokonuje oceny zjawiska uzależnienia produkcji energii na świecie od źródeł zaopatrzenia surowców nieodnawialnych, potrafi wyjaśnić twierdzenie ,ropa rządzi światem";

9) wyjaśnia, na czym polegaja zmiany zachodzace na rynku pracy w skali globalnej i regionalnej, wynikajace z rozwoju nowoczesnych technologii informacyjno-komunikacyjnych;

10) przedstawia cechy przemysłu wysokiej technologii i podaje przykłady jego lokalizacji na świecie; poznaje nowe funkcje ośrodków przemysłowych i nowe formy przestrzenne technopolie, klastry i dystrykty przemysłowe;

11) charakteryzuje wybrane obszary intensywnie zagospodarowywane turystycznie na świecie; wyjaśnia, dlaczego zmieniają się kierunki wyjazdów turystycznych Polaków; identyfikuje skutki rozwoju turystyki dla środowiska przyrodniczego;

12) ocenia rolę nowoczesnych usług komunikacyjnych w funkcjonowaniu gospodarki i w życiu codziennym;

13) wyjaśnia zmiany zachodzace w kierunkach i natężeniu ruchu osób i towarów; wskazuje przykłady lokalizacji nowoczesnych terminali i ich rolę w rozwoju regionów;

14) podaje przykłady procesów globalizacji i ich wpływu na rozwój regionalny i lokalny;

15) wyjaśnia współczesne zmiany na mapie politycznej świata;

16) wyjaśnia na wybranych przykładach (w skali lokalnej, regionalnej i globalnej) przyczyny procesów integracyjnych i ich skutki gospodarcze, społeczne i polityczne.

Podobnie w podstawie programowej dla szkoły ponadgimnazjalnej na poziomie rozszerzonym wskazać można cele edukacyjne odnoszące się do postawy przedsiębiorczej (tab. 3). 
Tab. 3. Cele kształcenia z zakresu geografii a kształtowanie postaw przedsiębiorczych (szkoła ponadgimnazjalna kończąca się maturą - poziom rozszerzony)

\begin{tabular}{|c|c|}
\hline $\begin{array}{l}\text { Cele kształcenia - wymagania ogólne } \\
\text { wg podstawy programowej }\end{array}$ & $\begin{array}{l}\text { Wybrane cechy i umiejętności } \\
\text { osoby przedsiębiorczej* }\end{array}$ \\
\hline $\begin{array}{l}\text { I. Dostrzeganie prawidłowości dotyczących środowiska przyrod- } \\
\text { niczego, życia i gospodarki człowieka oraz wzajemnych powią- } \\
\text { zań i zależności w systemie człowiek - przyroda-gospodarka. } \\
\text { Uczeń wskazuje i analizuje prawidłowości i zależności wynikają- } \\
\text { ce z funkcjonowania sfer ziemskich oraz działalności człowieka } \\
\text { w różnorodnych warunkach środowiska, wskazujac znaczenie } \\
\text { rosnącej roli człowieka i jego działań w środowisku geograficz- } \\
\text { nym w różnych skalach (lokalnej, regionalnej i globalnej). }\end{array}$ & $\begin{array}{l}\text { umiejętność interpretowania } \\
\text { procesów gospodarczych } \\
\text { oraz rozumienia związków } \\
\text { przyczynowo-skutkowych }\end{array}$ \\
\hline $\begin{array}{l}\text { III. Proponowanie rozwiązań problemów występujących } \\
\text { w środowisku geograficznym, zgodnie z koncepcją zrównoważo- } \\
\text { nego rozwoju i zasadami współpracy, w tym międzynarodowej. } \\
\text { Uczeń wskazuje propozycje rozwiązań lokalnych, regionalnych } \\
\text { i globalnych problemów środowiskowych, demograficznych } \\
\text { i gospodarczych zgodnych z koncepcją zrównoważonego } \\
\text { rozwoju oraz opartych na równoprawnych zasadach współpracy } \\
\text { między regionami i państwami. }\end{array}$ & $\begin{array}{l}\text { gotowość do zdobywania wiedzy } \\
\text { i nowych umiejętności oraz } \\
\text { podejmowania nowych, niezna- } \\
\text { nych zadań, aktywność, kreatyw- } \\
\text { ność, inicjatywa, otwartość na } \\
\text { otoczenie, umiejętność interpreto- } \\
\text { wania procesów gospodarczych } \\
\text { oraz rozumienia związków } \\
\text { przyczynowo-skutkowych }\end{array}$ \\
\hline $\begin{array}{l}\text { IV. Pozyskiwanie, przetwarzanie oraz prezentowanie informacji } \\
\text { na podstawie różnych źródeł informacji geograficznej, w tym } \\
\text { również technologii informacyjno-komunikacyjnych oraz } \\
\text { Geograficznych Systemów Informacyjnych (GIS). } \\
\text { Uczeń zdobywa informacje oraz rozwija i doskonali umiejętności } \\
\text { geograficzne, wykorzystując wszystkie dostępne (w tym } \\
\text { najnowsze) źródła informacji, pomiary i obserwacje bezpośred- } \\
\text { nie; potrafi selekcjonować i przetwarzać informacje do prezenta- } \\
\text { cji wybranych zagadnień. }\end{array}$ & $\begin{array}{l}\text { umiejętność zdobywania, selekcji } \\
\text { i przetwarzania informacji oraz } \\
\text { ich prezentacji }\end{array}$ \\
\hline
\end{tabular}

*możliwe do kształtowania w toku realizacji danego celu kształcenia

Źródło: opracowanie własne na podstawie Rozporządzenie 2009.

Z wymienionymi celami związane są treści nauczania dotyczące źródeł informacji geograficznej oraz działalności gospodarczej na świecie i w Polsce, tj.:

Źródła informacji geograficznej. Uczeń:

1) klasyfikuje mapy ze względu na różne kryteria;

2) oblicza odległości w terenie oraz powierzchnię na podstawie map wykonanych w różnych skalach;

3) odczytuje i opisuje cechy środowiska przyrodniczego (np. ukształtowanie i rzeźbę terenu, budowę geologiczną) i społeczno-gospodarczego (np. rozmieszczenie zasobów naturalnych, ludności, szlaki transportowe) na podstawie map: topograficznej, hipsometrycznej i tematycznej;

4) interpretuje zjawiska geograficzne przedstawiane na wykresach, w tabelach, na schematach i modelach;

5) formułuje zależności przyczynowo-skutkowe, funkcjonalne i czasowe między wybranymi elementami środowiska przyrodniczego i społeczno-gospodarczego oraz dokonuje ich weryfikacji, wykorzystujac mapy tematyczne; 
6) przeprowadza badania wybranych elementów środowiska geograficznego w regionie zamieszkania według przygotowanego planu;

7) stosuje wybrane metody kartograficzne do prezentacji cech ilościowych i jakościowych środowiska geograficznego;

8) korzysta z technologii informacyjno-komunikacyjnych w celu pozyskiwania, przechowywania, przetwarzania i prezentacji informacji geograficznych.

Działalność gospodarcza na świecie. Uczeń:

1) wyjaśnia wpływ czynników przyrodniczych i społeczno-ekonomicznych na rozwój rolnictwa;

2) wykazuje zależności między rodzajami produkcji rolnej a warunkami naturalnymi i rozmieszczeniem ludności oraz charakteryzuje różne typy rolnictwa na świecie;

3) wskazuje problemy związane z upowszechnianiem się roślin uprawnych zmodyfikowanych genetycznie i wskazuje rejony ich upraw;

4) porównuje i uzasadnia strukture spożycia żywności w państwach wysoko i słabo rozwiniętych;

5) uzasadnia konieczność racjonalnego gospodarowania zasobami leśnymi na świecie;

6) wskazuje możliwości rozwoju wykorzystania zasobów oceanów i mórz;

7) charakteryzuje zmiany w strukturze zużycia energii postepujace wraz z rozwojem gospodarczym państw świata i ocenia skutki wynikajace z rosnącego zużycia energii oraz konieczność pozyskiwania nowych źródeł energii;

8) wskazuje wpływ czynników lokalizacji przemysłu na rozmieszczenie i rozwój wybranych branz;

9) uzasadnia różnice ilościowe i jakościowe produkcji przemysłowej państw na różnym poziomie rozwoju gospodarczego i ocenia wpływ przemysłu zawansowanych technologii na rozwój gospodarczy i jakość życia;

10) charakteryzuje znaczenie usług materialnych i niematerialnych;

11) planuje i prowadzi badania zróżnicowania usług w miejscu zamieszkania;

12) przedstawia, na podstawie danych statystycznych, poziom zaspokojenia potrzeb na usługi podstawowe i wyspecjalizowane w państwach o różnym poziomie rozwoju gospodarczego;

13) analizuje kierunki geograficzne i strukture towarowa eksportu i importu w wybranych państwach;

14) wskazuje i uzasadnia pozytywne i negatywne skutki globalizacji i integracji politycznej;

15) wyjaśnia przyczyny i przebieg konfliktów zbrojnych w wybranych regionach współczesnego świata.

Geografia Polski - działalność gospodarcza. Uczeń:

1) ocenia poziom wykorzystania warunków naturalnych na podstawie wielkości i rodzajów produkcji rolniczej w porównaniu z innymi państwami Unii Europejskiej;

2) wskazuje zmiany strukturalne zachodzace w polskim rolnictwie;

3) wskazuje obszary wystepowania podstawowych zasobów naturalnych i analizuje zmiany wielkości ich eksploatacji;

4) porównuje wielkość i strukture produkcji energii elektrycznej w Polsce i innych państwach świata;

5) wskazuje dziedziny produkcji przemysłowej dynamicznie się rozwijajace;

6) przedstawia zmiany w gospodarce Polski spowodowane jej restrukturyzacja i modernizacja po $1990 \mathrm{r}$.;

7) wskazuje przykłady i znaczenie inwestycji zagranicznych w Polsce dla rozwoju społeczno-gospodarczego kraju;

8) przedstawia zróżnicowanie sektora usług w Polsce i innych państwach Unii Europejskiej; 
9) podaje przykłady przekształceń własnościowych w polskiej gospodarce majace wpływ na zmiany struktury produkcji i stopień zaspokojenia potrzeb materialnych i usług;

10) wskazuje głównych partnerów handlowych oraz kierunki geograficzne i strukture towarowa wymiany międzynarodowej Polski.

W zapisach podstawy programowej wyraźnie widać, że na lekcjach geografii realizowane są treści, które pozwalają zrozumieć wpływ różnorodnych czynników, w tym także przyrodniczych, na funkcjonowanie gospodarki w różnych skalach przestrzennych (światowej, krajowej, regionalnej i lokalnej), co ma duże znaczenie z punktu widzenia kompetencji przydatnych w podejmowaniu działalności gospodarczej. Rozumienie przez właściciela (menedżera) procesów i relacji pomiędzy elementami przestrzeni geograficznej (w tym przestrzeni przyrodniczej, społeczno-gospodarczej i kulturowej) jest warunkiem dobrego zarządzania firmą. To przedsiębiorca, na podstawie odpowiednio przygotowanych prac diagnostycznych, których dostarczają studia geograficzne, musi podejmować określone decyzje o kierunkach rozwoju firmy. Dzięki lekcjom geografii uczeń (przyszły przedsiębiorca lub menedżer firmy) zostaje wdrożony w myślenie o rozwoju gospodarczym, oparte na - w swej istocie aprzestrzennych - regułach ekonomicznych, odmiennie realizujących się w konkretnych geograficznych uwarunkowaniach danego układu przestrzennego.

Należy zwrócić uwagę, że w nowych uwarunkowaniach rozwoju społeczno-gospodarczego związanych z budową gospodarki opartej na wiedzy, procesami globalizacyjnymi i integracyjnymi, a w warunkach polskich również transformacyjnymi, zmienia się przedmiot badań geograficznych, a także cele i treści kształcenia geograficznego, w których coraz większą rolę przypisuje się przedsiębiorcy. Współczesna definicja geografii zmierza w kierunku traktowania jej jako „nauki o zarządzaniu przestrzenią geograficzną”, w której przedsiębiorczość będzie odgrywać coraz poważniejszą rolę. Należy bowiem przyjąć, że procesy przemian społeczno-gospodarczych i kulturowych, a także zmiany warunków przyrodniczych, wynikają z podejmowania określonych decyzji, u podstaw których leży przedsiębiorczość określonych osób (w tym przedsiębiorców) czy przedstawicieli władz samorządowych i centralnych. Dlatego współczesna geografia obejmuje coraz szerzej swoim przedmiotem badań działalność przedsiębiorczą, która w warunkach gospodarki rynkowej jest podstawą przemian i podnoszenia jakości życia społeczeństwa w różnej skali układów przestrzennych. Przedsiębiorczość jest podstawowym czynnikiem podnoszenia ich pozycji konkurencyjnej. Dlatego coraz więcej treści z tego zakresu jest włączanych w cele i treści kształcenia geografii na różnych poziomach geograficznych, a problematyka przedsiębiorczości wykazuje coraz silniejsze związki z geografią (Rachwał, Zioło 2010).

Istotną rolę w kształtowaniu postaw przedsiębiorczych powinny odgrywać organizowane przez nauczyciela geografii wycieczki pozaszkolne. Szczególnie pomocne może być tu przesuwanie uprawnień i zadań z tym związanych na uczniów (m.in. projektowanie trasy wycieczki, zamawianie noclegów, koordynacja spraw związanych z transportem, wyżywieniem itd.). W pewnym stopniu można w tę pracę zaangażować już uczniów gimnazjum, ale dużo większe możliwości ma nauczyciel w szkole ponadgimnazjalnej. Wycieczki, poza szerokimi możliwościami kształtowania postaw przedsiębiorczych, sprzyjają kształtowaniu umiejętności pracy zespołowej uczniów. Jak podkreśla bowiem Z. Pisz: „,edukacja szkolna ma do spełnienia zadania związane z kształtowaniem wszystkich cech jednostek, które ułatwiają funkcjonowanie w grupie, współpracowanie w zespołach, a także umożliwiają zrozumienie i akceptację odmienności, wynikających między innymi z zajmowanej pozycji i spełnianych ról społecznych oraz odrębności kulturowych” (Pisz 2003, s. 173). 
Zmiany w sferze edukacyjnej powinny zmierzać zatem do otwartego i elastycznego systemu kształcenia, który wspiera aktywność poznawczą oraz szeroko rozumianą przedsiębiorczość, także na innych przedmiotach, a nie tylko na lekcjach podstaw przedsiębiorczości. Szczególną rolę w tym zakresie odgrywają lub powinni odgrywać nauczyciele geografii.

\section{Literatura}

1. Borowiec M., 2003, Ksztattowanie się krakowskiego ośrodka akademickiego w latach 1960-2001 [w:] Geograficzne aspekty globalizacji i integracji europejskiej, M. Śmigielska, J. Słodczyk (red.), Wydawnictwo Polskiego Towarzystwa Geograficznego, Uniwersytet Opolski, Opole.

2. Borowiec M., 2005, Rola praktyk z przedsiębiorczości w ksztatceniu studentów geografii na specjalności „przedsiębiorczość z gospodarka przestrzenna” [w:] Przedsiębiorczość a współczesne wyzwania cywilizacyjne, Z. Zioło, T. Rachwał (red.), „Przedsiębiorczość - Edukacja”, nr 1, Wydawnictwo MiWa, Zakład Przedsiębiorczości i Gospodarki Przestrzennej Instytutu Geografii Akademii Pedagogicznej w Krakowie, Kraków.

3. Borowiec M., 2009, Rola edukacji w ksztaltowaniu społeczeństwa informacyjnego [w:] Rola przedsiębiorczości w kształtowaniu społeczeństwa informacyjnego, Z. Zioło, T. Rachwał (red.), „Przedsiębiorczość - Edukacja”, nr 5, Nowa Era, Zakład Przedsiębiorczości i Gospodarki Przestrzennej Instytutu Geografii Uniwersytetu Pedagogicznego w Krakowie, Warszawa-Kraków.

4. Borowiec M., 2010, Funkcjonowanie krakowskiego i rzeszowskiego ośrodka akademickiego wświetle koncepcji układów bipolarnych, „Prace Monograficzne” nr 539, Wydawnictwo Uniwersytetu Pedagogicznego w Krakowie.

5. Chojnicki Z., Czyż T., 2008, Gospodarka oparta na wiedzy w regionach metropolitalnych i aglomeracjach miejskich $w$ Polsce [w:] Rola polskich aglomeracji wobec wyzwań strategii lizbońskiej, T. Marszał (red.), Studia KPZK PAN, Tom CXX, Warszawa.

6. Grodzicki J., 2000, Edukacja czynnikiem rozwoju gospodarczego, Wydawnictwo Adam Marszałek, Toruń.

7. Harańczyk A., 2008, Potencjał rozwojowy szkół wyższych Małopolski [w:] Rola przedsiębiorczości w procesie ksztaltowania gospodarki opartej na wiedzy, Z. Zioło, T. Rachwał (red.), „Przedsiębiorczość - Edukacja”, nr 4, Nowa Era, Zakład Przedsiębiorczości i Gospodarki Przestrzennej Instytutu Geografii Uniwersytetu Pedagogicznego w Krakowie, Warszawa-Kraków

8. Janc K., 2003, Rola nauki i techniki we współczesnym świecie [w:] Geograficzne aspekty globalizacji i integracji europejskiej, M. Śmigielska, J. Słodczyk (red.), PTG Uniwersytet Opolski, Opole.

9. Jeruszka U., 2001, Szkoła zawodowa w perspektywie integracji europejskiej [w:] Edukacja w perspektywie integracji europejskiej, M. Ochmański, T. Sokołowska-Dzioba, A. Pielecki (red.), Wydawnictwo WSP Towarzystwa Wiedzy Powszechnej, Warszawa 2001.

10. Juszkiewicz N., 1997, Nauka i technika jako czynniki rozwoju Poznania, UAM, Poznań.

11. Kabaj M., 1997, W kierunku gospodarki opartej na wiedzy, „Polityka Społeczna”, nr 4.

12. Kafel T., 2005, Wyższe uczelnie ekonomiczne w procesie podnoszenia konkurencyjności przedsiębiorstw: nowe warunki, nowe możliwości [w:] Strategia lizbońska a konkurencyjność gospodarki, J. Bieliński (red.), Wydawnictwa Fachowe CeDeWu.Pl, Warszawa.

13. Kołodziejski J., 1998, Strategiczna koncepcja przeksztatceń polskiej przestrzeni a wyzwania cywilizacyjne XXI w. [w:] Współczesne problemy rozwoju regionalnego, T. Marszał i M. Opałło (red.), Biuletyn KPZK PAN, Warszawa, z. 180.

14. Kuźnicki L., 2004, Polska w obliczu wyzwań przyszłości. W świetle studiów Komitetu Prognoz „Polska 2000 Plus” Polskiej Akademii Nauk, Komitet Prognoz „Polska 2000 Plus” przy Prezydium Polskiej Akademii Nauk, ELIPSA, Warszawa. 
15. Pisz Z., 2003, Problemy spoleczne edukacji na Ślasku Opolskim [w:] W odpowiedzi na zjawiska $i$ wyzwania społeczne, K. Frysztacki, K. Heffner (red.), Opole.

16. Rachwał T., 2004, Podstawy przedsiębiorczości - słownik dla liceum ogólnokształcacego, liceum profilowanego i technikum. Nowa Era, Warszawa.

17. Rachwał T., 2005, Ksztaltowanie postaw uczniów na lekcjach podstaw przedsiębiorczości [w:] Przedsiębiorczość a współczesne wyzwania cywilizacyjne, Z. Zioło, T. Rachwał (red.), „Przedsiębiorczość - Edukacja", nr 1, Wydawnictwo MiWa, Zakład Przedsiębiorczości i Gospodarki Przestrzennej Instytutu Geografii Akademii Pedagogicznej w Krakowie, Kraków.

18. Rachwał T., Zioło Z., 2010, III. Rozwój naukowo-dydaktyczny i problematyka badań w zakresie dyscyplin towarzyszacych - 3. Przedsiębiorczość [w:] Rozwój naukowo-dydaktyczny i kierunki badawcze Instytutu Geografii Uniwersytetu Pedagogicznego im. Komisji Edukacji Narodowej w Krakowie, Z. Długosz, Z. Zioło (red.), Wydawnictwo Naukowe UP, Kraków.

19. Rozporzadzenie Ministra Edukacji Narodowej z dnia 23 grudnia 2008 r. w sprawie podstawy programowej wychowania przedszkolnego oraz kształcenia ogólnego w poszczególnych typach szkót, 2009 (Dz.U. z dn. 15 stycznia 2009 r., nr 4, poz. 17).

20. Strategia rozwoju edukacji na lata 2007-2013, sierpień 2005, Ministerstwo Edukacji Narodowej i Sportu, Warszawa.

21. Wieloński A., 2003, Przemyst Nowej Gospodarki [w:] Przemyst w procesie globalizacji, Z. Zioło, Z. Makieła (red.), „Prace Komisji Geografii Przemysłu PTG”, nr 6, Warszawa-Kraków.

22. Narodowy plan rozwoju 2007-2013 (wstepny projekt), 2005, www.npr.gov.pl.

23. Zajączkowska-Jakimiak S., 2002, Wiedza i technologia w erze globalizacji [w:] Globalizacja, mechanizmy $i$ wyzwania, B. Liberska (red.), PWE, Warszawa.

24. Zioło I., 1999, Wybrane atrybuty wartości edukacyjnej wyższej szkoły niepaństwowej [w:] Problemy przemian układów regionalnych, Z. Zioło (red.), cz. II, „Zeszyty Naukowe Wyższej Szkoły Informatyki i Zarządzania w Rzeszowie", nr 3, Rzeszów.

25. Zioło Z., 2009, Rola przedsiębiorczości w kształtowaniu społeczeństwa informacyjnego [w:] Rola przedsiębiorczości w kształtowaniu społeczeństwa informacyjnego, Z. Zioło, T. Rachwał (red.), „Przedsiębiorczość-Edukacja”, nr 5, Zakład Przedsiębiorczości i Gospodarki Przestrzennej Instytutu Geografii Uniwersytetu Pedagogicznego w Krakowie, Nowa Era, Warszawa-Kraków.

26. Zioło Z., 2010, Rola zasobów intelektualnych, kapitału ludzkiego i społecznego w procesach rozwoju obszarów wiejskich [w:] Kapitat ludzki i społeczny w procesie rozwoju obszarów wiejskich, W. Kamińska, K. Heffner (red.), Studia KPZK PAN T. CXXVI, Warszawa.

\section{Developing Entrepreneurial Attitudes on Geography Lessons as an Educational Challenge in the Globalization Process}

The paper aims to highlight the role of entrepreneurial attitudes in school education. This is due to the large role of entrepreneurship in the socio-economic development of different spatial systems (local, regional, national) in a globalized world economy. Developing entrepreneurial attitudes should take place not only during the lessons of Entrepreneurship, but during the whole period of school education and on other subjects. Teachers of Geography play a special role in this field. It is the consequence of large convergence of aims and teaching contents of geographic education with the objectives of entrepreneurship education. 


\section{Wiktor Osuch}

Uniwersytet Pedagogiczny

im. Komisji Edukacji Narodowej

w Krakowie

\section{Kompetencje w zakresie komunikacji interpersonalnej w dobie postępujących procesów globalizacji}

W procesie postępującej globalizacji wzajemne kontakty międzyludzkie oraz komunikacja interpersonalna odgrywają niezwykle istotną rolę, zaś czynnikiem decydującym o rozwoju jest kapitał ludzki oraz umiejętność zarządzania wiedzą i informacją. Wiedza staje się kluczem do sukcesu zarówno dla jednostki, jak i społeczeństwa. Gospodarka oparta na wiedzy potrzebuje obecnie nowego rodzaju pracowników - specjalistów wiedzy, potrafiących wykorzystać zasoby informacji do generowania skutecznych rozwiązań, potrafiących sprawnie korzystać z możliwości stwarzanych przez technologię komunikacyjną i informacyjną (Osiński 2009).

Globalizacja prowadzi do licznych zmian w sferze gospodarczej i kulturowej. Równocześnie gwałtowne zmiany w zakresie międzyludzkiej komunikacji spowodowały nieograniczone możliwości gromadzenia, przetwarzania, przechowywania i przesyłania informacji między różnymi regionami kraju i świata. Procesy te prowadzą do przebudowy modelu społeczeństwa (zwłaszcza krajów rozwiniętych gospodarczo), które stopniowo staje się społeczeństwem informacyjnym i usługowym. Świadczy o tym nie tylko wzrastająca liczba komputerów, telefonów komórkowych, rozbudowującą się sieć internetowa, ale przede wszystkim zmieniająca się struktura zatrudnienia. Wobec powyższych zmian szkoła nie może pozostać instytucją w dotychczasowym wymiarze, zmianie muszą ulec cele oraz metody pracy tak, by odpowiadały one wyzwaniom współczesności, w której wzrasta i rozwija się uczeń (Osuch, Tracz 2010).

Pojęcie komunikacja jest wieloznaczne, bywa więc różnie rozumiane i definiowane. Komunikacja w znaczeniu porozumiewania się to proces, w trakcie którego ludzie w różny sposób (słowny lub bezsłowny, np. gestami) przekazują sobie informacje (komunikaty) (Makieła, Rachwał 2007). Współcześnie sposób nawiązywania kontaktów, prowadzenia dyskusji, negocjacji, a także treści przesyłanych komunikatów i sposobów ich odbierania decydują o sukcesach lub porażkach nie tylko zawodowych, ale i osobistych.

Pojęcie komunikacji interpersonalnej szeroko definiuje w Słowniku podstaw przedsiębiorczości T. Rachwał (2004). Dokonuje on podziału na komunikację werbalną i niewerbalną, a także podaje szereg cech, metod i warunków, które powinny być spełnione, aby komunikacja była skuteczna. Komunikacja werbalna ,powinna być wiarygodna, czyli nietendencyjna, oparta na kompetencyjnych wypowiedziach oraz atrakcyjna dla słuchaczy" (Rachwał 2004, s. 88).

\section{Kompetencje - definicje i ich klasyfikacje}

$\mathrm{Na}$ temat definiowania kompetencji, w tym kompetencji nauczycieli, istnieje bogata literatura. W niniejszej publikacji ograniczono się do prezentacji tylko wybranych. 
Znany autorytet w polskiej pedeutologii - H. Kwiatkowska - termin kompetencje (łac. competentia) rozumie jako, ,zdolność i gotowość podmiotu do wykonania zadań na określonym poziomie; powstaje w wyniku zintegrowania wiedzy, dużej liczby drobnych umiejętności oraz sprawności w dokonywaniu wartościowań” (Kwiatkowska 2008, s. 35). Z kolei J. Szempruch rozumie kompetencje jako „zdolność i gotowość do wykonywania zadań na oczekiwanym poziomie, zgodnym ze standardami, a do kompetencji zawodowych nauczyciela zaliczyć można kompetencje: interpretacyjno-komunikacyjne, kreatywności, współdziałania, pragmatyczne, informacyjno-medialne" (Szempruch 2006, s. 231-232).

Podział profesjonalnych kompetencji nauczycieli Ch. Kyriacou (1991) na: kompetencje specjalistyczne (przedmiotowe), psychodydaktyczne, komunikacyjne, organizacyjne i kierownicze, diagnostyczne i interwencyjne, kompetencje w zakresie refleksji nad własną działalnością, stał się inspiracją dla kolejnych autorów. A. Erhard (2001) pisał o kompetencjach studentów geografii - kandydatów na nauczycieli w związku ze zmianami planu i programu kształcenia w Uniwersytecie w Insbruku. Kompetencje podzielone zostały przez niego na grupy, np. w zakresie komunikacji, specjalistyczne (fachliche) w zakresie kształcenia nauczycielskiego, w zakresie geografii i nauk o gospodarce, dydaktyki geografii.

O klasyfikacji kompetencji i sylwetce absolwenta studiów geograficznych Uniwersytetu w Wiedniu pisał Ch. Vielhaber (2006). Co ciekawe, autor mało uwagi poświęcił kompetencjom przedmiotowym z geografii, eksponując kompetencje w zakresie kooperacji i współpracy, motywacji do działania, planowania, refleksji nad własnym działaniem, wprowadzanie innowacji. Taki podział kompetencji powoduje zwrócenie większej uwagi na kompetencje miękkie, które współcześnie zaczynają być częściej analizowane i opisywane (Osiński 2010). O kształceniu studentów geografii - kandydatów na nauczycieli w Holandii - pisał z kolei H. De Jong (2008). Oprócz analizy programów kształcenia geografów i praktyk w szkole, dał on opis sylwetki absolwenta oraz jego kompetencji. Kompetencje podzielił na: komunikacyjne, pedagogiczne, specjalistyczne i dydaktyczne, organizacyjne, w zakresie współpracy z nauczycielami, rodzicami, w zakresie refleksji i profesjonalnego rozwoju. Co ciekawe, autor nie eksponował oddzielnie kompetencji przedmiotowych z geografii, łączył je natomiast z kompetencjami dydaktycznymi.

W zakresie podziałów i klasyfikacji kompetencji zawodowych nauczycieli istnieje dość bogata literatura, ale brak jest pogłębionych refleksji, popartych przeprowadzonymi badaniami.

S. Dylak wyróżnił trzy grupy kompetencji nauczycielskich:

- bazowe, które służą komunikowaniu się podmiotów interakcji społecznej,

- konieczne, które utożsamiać można z kompetencjami zawodowymi (merytorycznymi),

- użyteczne, nie są one konieczne, ale są wielce pomocne w wykonywaniu zawodu (Dylak 1995). $\mathrm{Z}$ punktu widzenia psychologii pracy ważne są następujące kompetencje wraz z cechami kryterialnymi wzorca:

- kompetencje interpersonalne i przywództwo, zespołowość, przebojowość, negocjacyjność,

- kompetencje intelektualne: organizacyjność, zorientowanie na źródło, motywacja, odporność na stres,

- kompetencje komunikacyjne i jasność komunikowania się w formie pisemnej i ustnej (Bańka 2000).

Według J. Kunikowskiego, głównym celem doskonalenia zawodowego nauczycieli jest rozwijanie ich wiedzy i kompetencji. Autor wylicza następujące kompetencje:

- wychowawcze i społeczne, które dotyczą umiejętności rozpoznawania potrzeb ucznia, współpracy w relacjach międzyludzkich, zwłaszcza z rodzicami, a także rozpoznawania i kształtowania pozytywnych i społecznie oczekiwanych wartości, 
- prakseologiczne, które obejmują planowanie procesu kształcenia, skutecznego działania oraz osiągania zamierzonych celów dydaktycznych i wychowawczych,

- kreatywne, które wynikają z zamiłowania i motywacji do zawodu, a także obejmują innowacyjność działań oraz umiejętność samodoskonalenia,

- komunikacyjne, które dotyczą możliwości wykorzystania wiedzy i umiejętności w sytuacjach edukacyjnych (Kunikowski 2009).

\section{Kompetencje komunikacyjne - przyklady}

Według F. Żurakowskiego (2002), do umiejętności komunikacyjnych zaliczamy: aktywne słuchanie, zachowanie odpowiednich proporcji pomiędzy mówieniem a słuchaniem, mowę ciała, głos, słowa, empatię, asertywność, wywieranie wpływu, występowanie publiczne i wypowiadanie się $\mathrm{w}$ piśmie.

O komunikacji interpersonalnej w nauczaniu podstaw przedsiębiorczości pisała B. Makieła (2006). Autorka wskazała też przykłady ćwiczeń dla uczniów, które można zastosować na lekcji. Celem ćwiczeń jest ukazanie prawidłowego procesu komunikowania się, eliminacja ewentualnych barier, zamiana słabych stron osobowości w atuty, a także umiejętność osiągnięcia kompromisu w negocjacjach. Do podstawowych umiejętności komunikacyjnych B. Makieła (2006) zalicza: aktywne słuchanie, zachowanie odpowiednich proporcji między mówieniem a słuchaniem, połączenie elementów komunikacji werbalnej i niewerbalnej, umiejętność asertywnego zachowania się w różnych sytuacjach, zachowania empatycznego, właściwego posługiwania się mową ciała, głosem, wyrażanymi słowami. Umiejętności komunikacyjnych nie sposób wykształcić w krótkim czasie, dlatego ważne jest permanentne doskonalenie nabywanych w toku edukacji czy treningów kompetencji.

Według B. Ciupińskiej (2005), punktem wyjścia do kształtowania umiejętności interpersonalnych jest poznanie własnej osobowości. Dzięki temu można uświadomić sobie swoje mocne strony, by w dalszych działaniach rozwijać swój potencjał oraz doskonalić te słabsze strony. Ponadto badaczka podkreśla duże znaczenie komunikatów niewerbalnych w procesie komunikowania się ludzi, bowiem:

- wyrażają uczucia i nastroje - poprzez mimikę, rodzaj spojrzeń, gestykulację,

- ilustrują komunikaty werbalne - poprzez wizualną interpretację wypowiedzi, np. kiwnięcie głową przy akceptacji,

- regulują przebieg rozmowy i relacje między rozmówcami - poprzez ruchy rąk, mimikę twarzy, westchnienia,

- służą przekazywaniu znaczeń - poprzez stosowanie emblematów, np. przesyłanie pocałunku to emblemat sympatii, puszczanie oka - wspólnoty,

- pozwalają dostosowywać się do aktualnej sytuacji, np. wygładzanie ubrania w celu uzyskania przychylności innych, poprawianie się na krześle przed zabraniem głosu w celu zajęcia bardziej komfortowej pozycji (Ciupińska 2005).

Niewątpliwie ważnym uzupełnieniem pożądanych umiejętności interpersonalnych są prezentowane wartości moralne. Te wartości w kontaktach personalnych są dość łatwo rozpoznawalne, a często wiążą się z konkretnym typem zachowania wobec współpracowników czy przyjaciół. Typ zachowania agresywny lub manipulacyjny na dłuższy czas nie znajdzie zrozumienia w relacjach interpersonalnych, bowiem prezentowane wartości moralne takiej grupy ludzi są odległe od uczciwości i prawości. Jedynie postawa asertywna, wyrażona pewnością siebie wobec własnych przekonań, zapewni czytelność w relacjach z innymi ludźmi, a także pozytywną ocenę najbliższego otoczenia. $\mathrm{O}$ wartościach moralnych wśród menedżerów pisali M.M. Rachwał i T. Rachwał (2006). Autorzy podkreślają istotną rolę uczciwości, lojalności, 
życzliwości, troskliwości i otwartości w osiąganiu sukcesu przez przedstawicieli biznesu. Prawdomówność, skromność, pokora, pracowitość, wiara w innych i uczciwa współpraca to cechy współcześnie nieczęste wśród przedsiębiorców, a w relacjach interpersonalnych niezwykle pożądane. Pracownicy, wobec których stosuje się przymus jako podstawową formę motywacji, reagują niezadowoleniem albo nawet agresją i nie będą skłonni do należytego zaangażowania się w zadania firmy. Menedżer prawdziwego sukcesu zamiast autokratycznych rozkazów, wysyła pozytywną energię, wzmacniając motywację swoich pracowników i wiarę w sukces (M.M. Rachwał, T. Rachwał 2006).

Według rozporządzenia MENiS z dnia 7 września 2004 r. (poz. 2110) w sprawie standardów kształcenia, przygotowanie do zawodu nauczyciela powinno prowadzić do nabycia kompetencji w następujących zakresach:

- dydaktycznym,

- wychowawczym i społecznym - związanym z umiejętnością rozpoznawania potrzeb ucznia oraz zdolnością do współpracy w różnorodnych relacjach międzyludzkich,

- kreatywnym - wyrażającym się zdolnością do samokształcenia, innowacyjnością i niestandardowością działań w powiązaniu ze zdolnościami,

- prakseologicznym - wyrażającym się skutecznością w planowaniu, realizacji, organizowaniu, kontroli i ocenie procesów edukacyjnych,

- komunikacyjnym - wyrażającym się skutecznością zachowań werbalnych i pozawerbalnych w sytuacjach edukacyjnych,

- informacyjno-medialnym - wyrażającym się umiejętnością korzystania z technologii informacyjnych i komunikacyjnych oraz ich stosowania w nauczaniu,

- językowym - wyrażającym się znajomością co najmniej jednego języka obcego w stopniu zaawansowanym.

\section{Wyniki badań ankietowych wybranych kompetencji}

Autor niniejszej publikacji, planując przeprowadzenie badań ankietowych i konstruując zestawy szczegółowych kompetencji, spośród formalnych oczekiwań kompetencji, zapisanych w sposób bardzo ogólny w cytowanym rozporządzeniu MENiS, wybrał jedynie te, które wydały się ważne w profesjonalnym wykształceniu przyszłego nauczyciela geografii i nauczyciela podstaw przedsiębiorczości. Mało precyzyjny zapis ministerialny skłonił autora do znacznego poszerzenia pola badawczego i opracowania szczegółowych kompetencji oraz przyjęcia innego ich podziału. Autor zaproponował podział kompetencji na merytoryczne (przedmiotowe z geografii i podstaw przedsiębiorczości), psycho-dydaktyczne - podzielone na dydaktyczne w zakresie dydaktyki przedmiotu oraz pedagogiki opiekuńczo-wychowawczej, kompetencje w zakresie prawa oświatowego.

Badania kompetencji przeprowadzono wśród nauczycieli geografii i podstaw przedsiębiorczości w Krakowie oraz studentów geografii różnych typów studiów, w tym specjalności nauczycielskiej (także studentów specjalności przedsiębiorczość i gospodarka przestrzenna) Instytutu Geografii Uniwersytetu Pedagogicznego w Krakowie. Prezentowane wyniki badań są przedmiotem szerszego opracowania monograficznego autora niniejszego artykułu (Osuch 2010).

Poniżej przedstawiono wybrane wyniki nabytych kompetencji nauczycieli i studentów geografii w zakresie:

- rozróżniania postawy asertywnej od niegrzecznego zachowania (uzyskano prawie 54\% ocen bardzo dobrych wśród nauczycieli gimnazjum oraz liceum, ok. 33\% u studentów studiów 
podyplomowych i 23\% u studentów stacjonarnych). Wśród studentów pięcioletnich studiów stacjonarnych (magisterskich) obserwuje się znaczny udział niewykształcenia tej kompetencji (ok. 12\% studentów nie jest kompetentne w zakresie rozróżniania postawy asertywnej od niegrzecznego zachowania, a ok. 8\% studentów studiów stacjonarnych i 10\% studentów studiów licencjackich wykształciło tę umiejętność słabo). Należy zaznaczyć, że studenci obu ankietowanych roczników nie mieli w programie studiów przedmiotu komunikacja interpersonalna. Nie powinno być to jednak żadnym usprawiedliwieniem tak słabo wykształconych kompetencji, zwłaszcza, że pojęcie asertywności czy postawy asertywnej znane jest w Polsce i powszechnie używane od kilkunastu lat. Dodatkowo dziwi fakt, że studenci ci byli ankietowani po odbyciu praktyk zawodowych w szkołach. Spośród studentów studiów podyplomowych kilkuprocentowa grupa nie nabyła bądź w słabym stopniu nabyła tę umiejętność. Dotyczy to prawdopodobnie nauczycieli o bardzo krótkim stażu (ryc. 1);

Ryc. 1. Ocena kompetencji nauczycieli i studentów geografii w zakresie rozróżniania postawy asertywnej od niegrzecznego zachowania

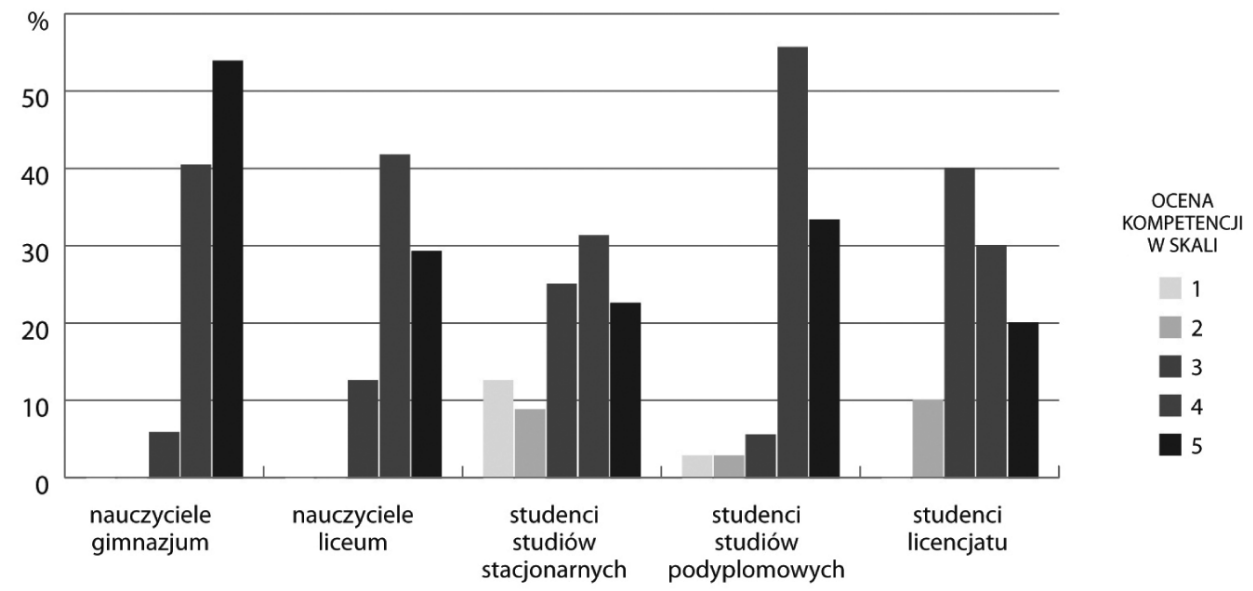

Źródło: W. Osuch 2010 (s. 136, ryc. 47).

- informowania uczniów i rodziców o wymaganiach i osiągnięciach uczniów (aż 32\% studentów studiów stacjonarnych w ogóle nie wykształciło tej kompetencji, a tylko prawie $13 \%$ na ocenę bardzo dobrą). Wśród nauczycieli gimnazjum oraz liceum, jak również studentów studiów podyplomowych - czynnych nauczycieli - wyniki nabycia kompetencji były znacznie wyższe. Tak duże różnice w wykształceniu tej kompetencji można tłumaczyć brakiem doświadczenia studentów w kontaktach personalnych z rodzicami i uczniami. Studenci w trakcie trwającej kilka tygodni praktyki zawodowej w szkołach mają kontakt z uczniami ograniczony do przeprowadzenia kilkunastu lekcji i nie mają praktycznie żadnego kontaktu z rodzicami. Uczestnictwo w zebraniach z rodzicami jest dla studentów pożądane, jednak $\mathrm{w}$ praktyce nawet jeśli do tego dochodzi, to studenci uczestniczą w nich jedynie biernie. Szkoda, że w programach studiów specjalności nauczycielskiej z przedmiotów psychologiczno-pedagogicznych nie przewiduje się zajęć czy szkolenia z zakresu kontaktów, wzajemnych relacji i współpracy z rodzicami (ryc. 2); 
Ryc. 2. Ocena kompetencji nauczycieli i studentów geografii w zakresie informowania uczniów i rodziców o wymaganiach i osiągnięciach edukacyjnych

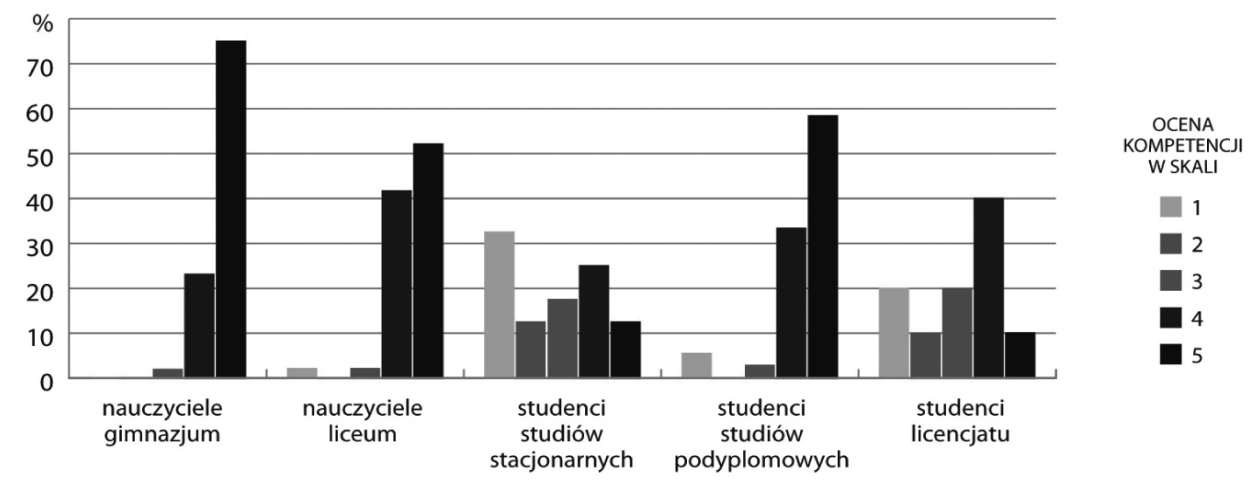

Źródło: W. Osuch 2010 (s. 132, ryc. 44).

- zaplanowania organizacji zajęć pozalekcyjnych i pozaszkolnych oraz spotkań z rodzicami (73\% ocen bardzo dobry wśród nauczycieli gimnazjum, 54\% wśród nauczycieli liceum, 45\% wśród studentów studiów podyplomowych - czynnych nauczycieli oraz tylko $10 \%$ wśród studentów studiów stacjonarnych, ale także ok. 20\% nie nabyło tej kompetencji). W kolejnym przypadku występuje znaczna różnica w nabyciu kompetencji pomiędzy czynnymi nauczycielami a studentami. Okazuje się, że organizacja dodatkowych zajęć pozalekcyjnych, pozaszkolnych i spotkań z rodzicami stanowi poważny problem dla 40\% studentów studiów stacjonarnych (20\% nie nabyło tej kompetencji, a kolejne 20\% w stopniu niewielkim - ocena 2 pkt.), Co ciekawe, wśród studentów studiów podyplomowych, a także licencjatu studiów niestacjonarnych oceny były znacznie wyższe. Studenci studiów stacjonarnych kompetencje dydaktyczne oraz komunikacyjne nabywają nieco później od czynnych nauczycieli, a nawet studentów studiów niestacjonarnych z racji młodszego wieku i prawie żadnego doświadczenia w pracy w szkole z młodzieżą, kontaktach z innymi nauczycielami, rodzicami czy dyrekcją szkoły (ryc. 3).

Ryc. 3. Ocena kompetencji nauczycieli i studentów geografii w zakresie zaplanowania organizacji zajęć pozalekcyjnych i pozaszkolnych oraz spotkań z rodzicami

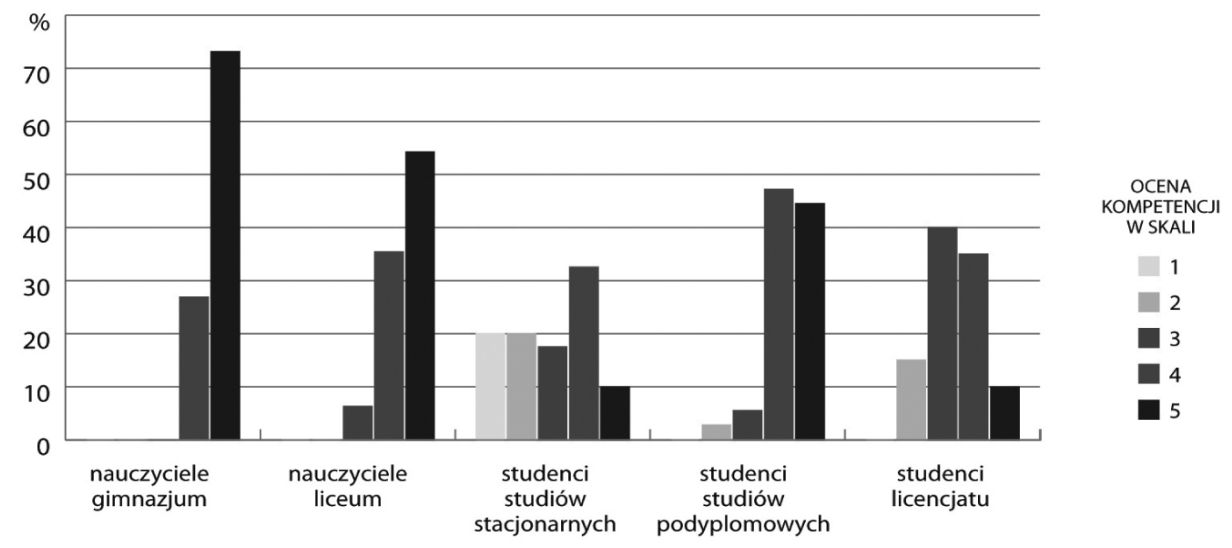

Źródło: W. Osuch 2010 (s. 137, ryc. 48). 
Dużą barierą w komunikacji werbalnej jest brak kompetencji w zakresie korzystania z literatury obcojęzycznej u nauczycieli. W czasie prowadzonych badań przez autora niniejszej publikacji (Osuch 2010), aż 75\% nauczycieli wskazało na możliwość nabycia tej kompetencji na zajęciach teoretycznych w uczelni. Niestety, w zdecydowanej większości nie wykorzystali oni tej możliwości, co można wnioskować po uzyskanych wynikach w zakresie nabycia tej kompetencji (ryc. 3).

Bardzo poważnym problemem wydaje się korzystanie, a właściwie niekorzystanie z literatury obcojęzycznej w nauczaniu geografii czy podstaw przedsiębiorczości. Badania prowadzone wcześniej przez autora niniejszej publikacji (Osuch 2002) pokazują, że niewiele się w tym zakresie zmieniło (do chwili obecnej). Tylko około 8\% nauczycieli przyznaje, że nabyło tę kompetencję w sposób bardzo dobry. W gimnazjum aż 43\% nie wykształciło tej kompetencji wcale (1 pkt) - nie zna żadnego języka obcego, a dalsze 8\% przyznaje, że zna słabo (2 pkt.). Podobne wyniki uzyskano wśród nauczycieli liceum (ryc. 4). Niewysoki jest poziom nabycia kompetencji wśród studentów studiów stacjonarnych (aż 35\% nie nabyło tej kompetencji 1 pkt, $15 \%$ wykształciło na 2 pkt., prawie $28 \%$ na 3 pkt. i tylko niespełna $8 \%$ na ocenę bardzo dobrą), a najniższe wyniki uzyskali studenci studiów podyplomowych (prawie 58\% czynnych nauczycieli nie korzysta w nauczaniu z literatury obcojęzycznej).

Ryc. 4. Ocena kompetencji nauczycieli i studentów geografii w zakresie korzystania z literatury obcojęzycznej

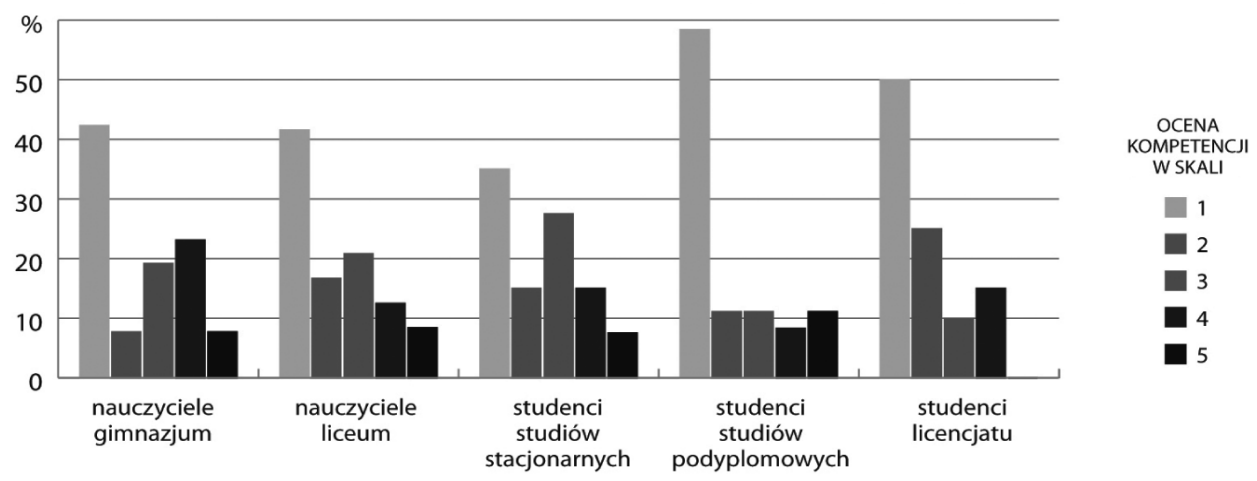

Źródło: W. Osuch 2010 (s. 129, ryc. 40).

Jest to bardzo poważny problem nie tylko w edukacji geograficznej i podstaw przedsiębiorczości, który jednak wymaga szerszej, wielopłaszczyznowej analizy. Brak motywacji studentów do uczenia się języków obcych w macierzystych uczelniach wyższych wynikał często z dużego obciążenia kierunkowymi przedmiotami. Z drugiej strony nierówny poziom prowadzonych zajęć w grupach nie motywował nawet ambitnych studentów. To tylko wybrane aspekty tego zagadnienia. Znane są przykłady bardzo dobrych nauczycieli geografii i podstaw przedsiębiorczości, którzy nie potrafią posługiwać się językiem obcym, a mimo to odnoszą spore sukcesy zawodowe, pracują z laureatami i finalistami konkursów czy olimpiad. Z drugiej jednak strony we współczesnym świecie, rozszerzającej się Unii Europejskiej, prawie codziennych kontaktach z obcokrajowcami, nauczanie - uczenie się bez kontaktów ze źródłami zagranicznymi wydaje vjęzyków obcych, w tym języków zachodnich, z czasów gospodarki centralnie sterowanej, do dzisiaj przynosi negatywne skutki. Zamknięcie nie tylko na wzajemne kontakty ze społeczeństwem krajów wysoko rozwiniętych, ich kulturę, tradycję, ale też stan wiedzy i osiągnięcia technologiczne i cywilizacyjne na długie lata skutecznie ograniczyło, a w pewnych dziedzinach 
nawet zahamowało dostęp do nowoczesnej literatury i publikacji naukowych. Obecne niekorzystanie z obcojęzycznych źródeł wiedzy nie wynika ze złej woli nauczycieli czy studentów, ale ze słabej znajomości języków obcych, braku czasu, trudnego dostępu do światowej literatury (Osuch 2010).

Istotną rolę w procesie komunikacji interpersonalnej i kształceniu odgrywa umiejętność prowadzenia dialogu edukacyjnego z uczniem (w tym umiejętność słuchania). W tym zakresie $50 \%$ u nauczycieli gimnazjum, 54\% u nauczycieli liceum, prawie 53\% u studentów studiów podyplomowych i 35\% u studentów stacjonarnych uzyskało oceny bardzo dobre. To przykład, w którym nie zanotowano w badaniach ankietowych przypadku niewykształcenia umiejętności.

Interesującym przykładem jest kompetencja merytoryczna logicznego argumentowania przemawiającego za lub przeciw procesom globalizacji na lekcjach geografii problematyki systemu społeczno-gospodarczego współczesnego świata. Nauczyciele gimnazjum ocenili swoje kompetencje (ryc. 5), przy prawie 20\% ocen dostatecznych (3 pkt.), 35\% ocen dobrych i tylko $42 \%$ ocen bardzo dobrych (prawie 4\% to oceny poniżej 3 pkt.). Dla porównania, wśród nauczycieli liceum uzyskano wyniki przy prawie 9\% ocen dostatecznych, 37\% ocen dobrych i 54\% ocen bardzo dobrych. Należy zwrócić uwagę, że procesy globalizacji dopiero w ostatnich latach są przedmiotem badań i analiz geografów społeczno-ekonomicznych na tak szeroką skalę, jak również występują w programach i podręcznikach geografii do liceum i gimnazjum. Wśród studentów analizowanych typów studiów studenci stacjonarni uzyskali najwyższe wyniki. Studenci studiów podyplomowych uzyskali niższe wyniki w zakresie nabycia szeregu kompetencji oceniania systemu społeczno-gospodarczego współczesnego świata. Ograniczony do minimum program studiów podyplomowych z geografii nie sprzyja kształtowaniu tych kompetencji merytorycznych, a nie wszyscy czynni nauczyciele wyrażają duże zainteresowanie znajomością problemów współczesnego świata. Nie zawsze też wybór kierunku studiów podyplomowych jest związany z zainteresowaniami nauczyciela, często ma on ścisły związek z aktualną sytuacją kadrową w szkole i koniecznością szybkiego dokształcenia się z przedmiotu, którego doraźnie, w danym czasie trzeba nauczać. Problematyka kształcenia kompetencji, zwłaszcza merytorycznych na studiach podyplomowych, wymaga dokładnego przeanalizowania i przedyskutowania.

Ryc. 5. Ocena kompetencji nauczycieli i studentów geografii w zakresie logicznego argumentowania za lub przeciw procesom globalizacji

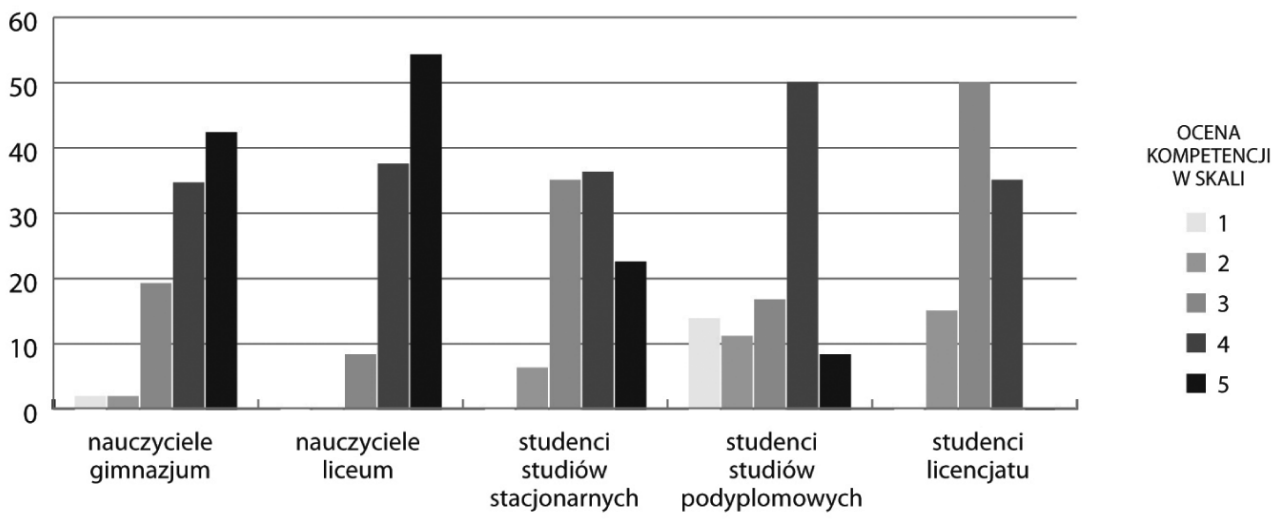

Źródło: W. Osuch 2010 (s. 129, ryc. 40). 


\section{Kompetencje dyrektora - menedżera szkoły}

L. Gawrecki (2003) w książce nt. kompetencji menedżera oświaty prezentuje predyspozycje kandydatów na dyrektorów szkół, proces współpracy i kierowania zespołem. Jest to swoisty poradnik dla dyrektorów szkól, innych placówek edukacyjnych, a także pracowników nadzoru w szkolnictwie. Na szczególną uwagę zasługuje podkreślenie umiejętności socjotechnicznych kandydata na dyrektora $\mathrm{w}$ aspekcie szerokich relacji z rodzicami, uczniami, nauczycielami i władzami lokalnymi. Konieczność nabycia kompetencji komunikacyjnych w zawodzie nauczyciela, a także pełnieniu funkcji dyrektora szkoły oraz innych placówek oświatowo-wychowawczych nie powinna budzić żadnych zastrzeżeń. Współcześnie autoprezentacja kandydatów na stanowiska dyrektora szkoły, umiejętność zaprezentowania własnej wizji kierowania szkołą i współpracy z różnymi grupami społecznymi to tylko niektóre z kompetencji niezbędne dla przyszłych dyrektorów.

W Instytucie Geografii krakowskiego Uniwersytetu Pedagogicznego od kilku lat, po zmianie programów i planów studiów, funkcjonuje przedmiot zarządzanie edukacją. Jest on wykładany na specjalizacji przedsiębiorczość i gospodarka przestrzenna w wymiarze 30 godzin i stanowi pożyteczne uzupełnienie bloku przedmiotów zarówno tej specjalizacji, jak i samej specjalności nauczycielskiej. Młodzi nauczyciele często nie orientują się w przysługujących im prawach i obowiązkach. Uczą się niełatwych na początku relacji z dyrekcją szkoły, pracownikami nadzoru pedagogicznego, przedstawicielami samorządu lokalnego, innymi nauczycielami, a także, przede wszystkim, z rodzicami swoich uczniów. Nabycie kompetencji komunikacyjnych wymaga jednak czasu i doświadczenia. Aktywni i ambitni młodzi nauczyciele po kilku latach pracy zawodowej w szkole w zasadzie są gotowi to startu w konkursie na dyrektora szkoły. Znane są obecnie coraz częstsze przypadki kierowania szkołą przez względnie młodych wiekiem i stażem nauczycieli, którzy odważyli się zaryzykować i podjąć to niełatwe wyzwanie z korzyścią dla szkoły, uczniów, nauczycieli i własnej drogi awansu zawodowego. Dodatkowym atutem dyrektora-menedżera szkoły powinna być znajomość prawa oświatowego, w tym szczególnie kompetencje w zakresie ustaw i rozporządzeń dotyczących kierowania placówką oświatową, przeprowadzaniem awansów zawodowych nauczycieli, znajomość Karty Nauczyciela. Korzystne jest, aby przed podjęciem pracy nauczyciela, kandydat poznał prawa i obowiązki dyrektora szkoły, jego zakres kompetencji i organizację pracy szkoły. Na praktyce zawodowej w szkole nie zawsze są ku temu sprzyjające warunki i możliwości.

Programy i plany studiów nauczycielskich na kierunku geografia dotychczas nie uwzględniały kompetencji z zakresu znajomości przepisów prawa oświatowego i nie były one przedmiotem tak szczegółowych analiz i ocen na zajęciach z dydaktyki geografii, podstaw przedsiębiorczości lub innych przedmiotów bloku nauczycielskiego, jak staje się to obecnie. Działo się tak, mimo że kompetencje te były niezwykle przydatne, a nawet konieczne w zdobywaniu kolejnych stopni awansu zawodowego przez nauczycieli, w tym nauczycieli geografii i podstaw przedsiębiorczości. Dlatego też autor niniejszego artykułu ma świadomość, że zdecydowana większość kompetencji w stu procentach została osiągnięta przez nauczycieli w czasie pracy zawodowej w szkole w procesie samokształcenia i doskonalenia zawodowego. Tylko nieliczne kompetencje i w niewielkim stopniu mogli nauczyciele kształtować w czasie zajęć teoretycznych prowadzonych w uczelni. W kontynuowanych przez autora niniejszego artykułu badaniach ankietowych obejmujących nauczycieli i studentów geografii wśród kompetencji dotyczących znajomości najlepsze wyniki w zakresie nabycia kompetencji z tej grupy dotyczą:

- analizowania zadań szkoły oraz treści nauczania i osiągnięć wynikających z podstawy programowej $(77 \%$ ocen bardzo dobrych wśród nauczycieli gimnazjum i $50 \%$ u nauczycieli 
liceum, 30\% u studentów studiów podyplomowych i tylko 12,5\% u studentów studiów stacjonarnych). Wśród studentów studiów stacjonarnych zauważa się ok. 8\% populacji, która nie nabyła tej kompetencji, jak również kilkunastoprocentowy udział osób o słabo wykształconej kompetencji (2 pkt.). Studenci studiów podyplomowych jako czynni nauczyciele znacznie lepiej wykształcili kompetencje niż studenci studiów stacjonarnych i niestacjonarnych, co wynika z większego doświadczenia w wykonywaniu obowiązków nauczyciela. Wśród nauczycieli geografii znaczna różnica w uzyskanych wynikach nabycia kompetencji wiąże się z większą aktywnością nauczycieli gimnazjum w zakresie dokształcania i doskonalenia na różnych kursach, a nawet studiach podyplomowych niż wśród nauczycieli liceum, stąd dość duże różnice w ocenach 5 pkt. (ryc. 6);

Ryc. 6. Ocena kompetencji nauczycieli i studentów geografii w zakresie analizowania zadań szkoły oraz treści nauczania i osiągnięć wynikających z podstawy programowej

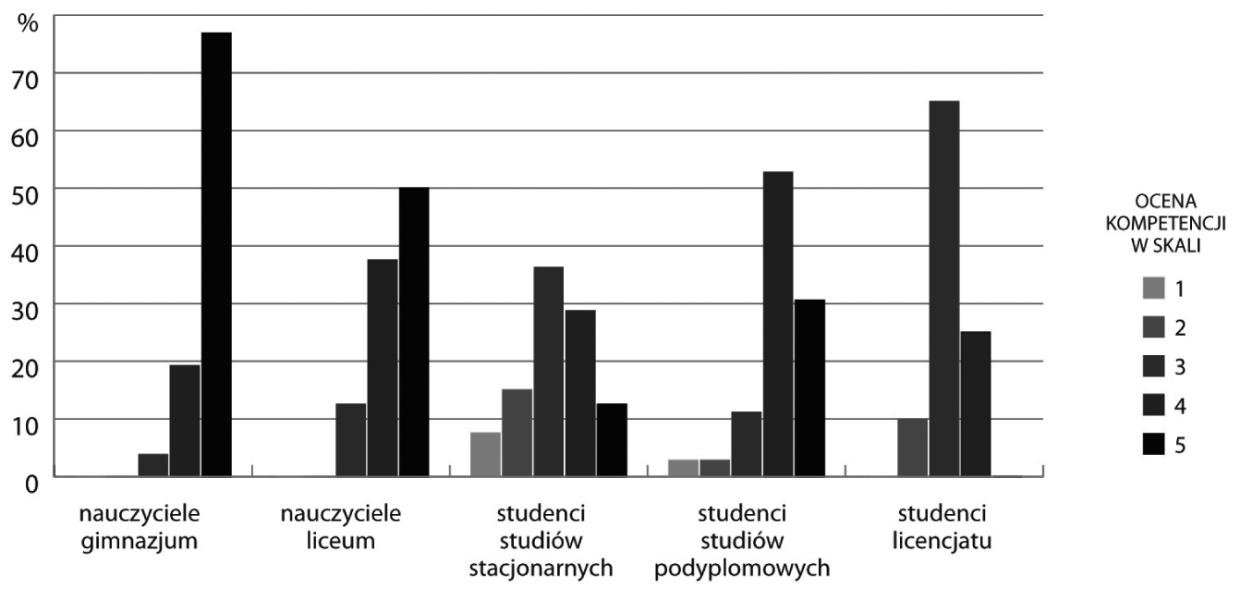

Źródło: W. Osuch 2010 (s. 141, ryc. 50).

- znajomości aktów prawnych dotyczących awansu zawodowego nauczycieli (75\% ocen bardzo dobrych wśród nauczycieli gimnazjum i 58\% u nauczycieli liceum, odpowiednio po prawie $28 \%$ wśród studentów studiów podyplomowych i $22,5 \%$ u studentów studiów stacjonarnych). Znajomość aktów prawnych dotyczących awansu zawodowego wśród studentów geografii i podstaw przedsiębiorczości jest czystą teorią, choć także wśród studentów jest grupa, która nabyła tę umiejętność na ocenę dobrą, a nawet bardzo dobrą. Najwyższe wyniki w nabyciu tej kompetencji uzyskali nauczyciele geografii w gimnazjum jako grupa częściej dokształcająca się na kursach i prawdopodobnie także szybciej osiągająca kolejne stopnie awansu zawodowego. Autor niniejszego artykułu nie dysponuje jednak szczegółowymi wynikami na temat awansu zawodowego nauczycieli geografii w gimnazjum czy liceum. Wśród studentów studiów podyplomowych istotna była grupa kilku nauczycieli młodych, o krótkim stażu pracy w szkole i niewielkim doświadczeniu, stąd wyniki uzyskanych kompetencji w tym zakresie są niższe w stosunku do nauczycieli geografii (ryc. 7).

Zaprezentowane wyniki badań dotyczące uzyskania kompetencji w zakresie znajomości prawa oświatowego w zdecydowanej większości osadzone były dotychczas w procesie do- 
kształcania i doskonalenia nauczycieli i były poruszane w związku z podjęciem procedur awansu zawodowego zainteresowanych nauczycieli, w tym nauczycieli geografii. W najbliższych latach należy się spodziewać znacznie lepiej zdobytych w tym zakresie kompetencji przez studentów geografii - kandydatów na nauczycieli, co związane jest zarówno z wprowadzeniem obligatoryjnego przedmiotu nauczania na specjalności nauczycielskiej do programu studiów licencjackich (prawne i etyczne aspekty zawodu nauczycielskiego), jak i z dowolnością w wyborze specjalności nauczycielskiej. Pierwsze sondaże wśród „nowych roczników” budzą pewien optymizm w zakresie nabycia kompetencji poprzez duże zaangażowanie studentów w podjęcie praktyk zawodowych w szkole, hospitowaniu i prowadzeniu lekcji, zainteresowaniu szeroko rozumianym życiem szkoły (Osuch 2010). Z sondaży wnioskuje się wyższe o kilkanaście punków procentowych wyniki nabycia kompetencji w zakresie prawa oświatowego na oceny bardzo dobre i dobre.

Ryc. 7. Ocena kompetencji nauczycieli i studentów geografii w zakresie znajomości aktów prawnych dotyczących awansu zawodowego nauczycieli geografii

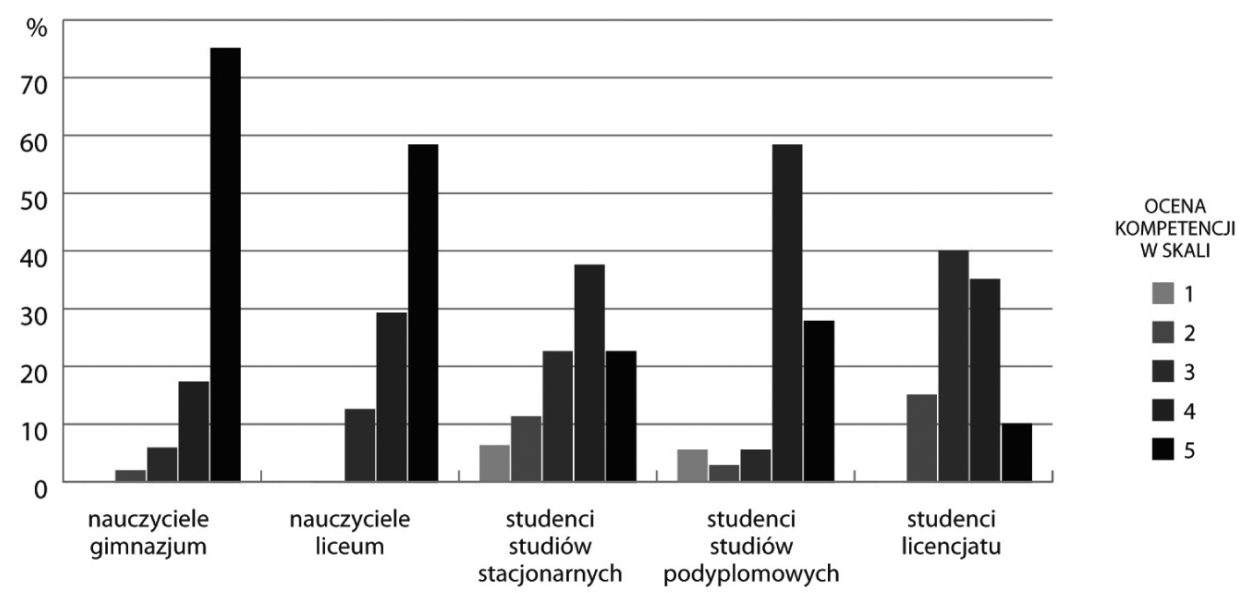

Źródło: W. Osuch 2010 (s. 143, ryc. 53).

\section{Kompetencje a rynek pracy}

W ostatnich latach, szczególnie w krajach Europy Zachodniej, podejmowane są badania dotyczące losów zawodowych absolwentów studiów wyższych, w tym studiów geograficznych. Dotyczą one relacji pomiędzy zapotrzebowaniem pracodawców na konkretne kompetencje absolwentów wyższych uczelni, jakością kształcenia studentów a sytuacją na rynku pracy. Przykładowo podejmowane były badania zapotrzebowania na określone kompetencje, będące efektem geograficznej edukacji akademickiej wśród pracowników na skalę europejską (Donert, Charzyński, Podgórski 2007). Badania pokazują też różne kierunki podejścia do studiów i pracy zawodowej, np. studia dla pasji (to sytuacja idealna), a wyposażenie w liczne kompetencje merytoryczne i formalne stanowi wystarczający wkład uczelni w przygotowanie absolwenta do rynku pracy. Zatrudnienie traktowane jest nie jako cel studiowania, bowiem tym zajmują się szkoły zawodowe, ale jako jeden z jego efektów i jest zadaniem, które leży w gestii absolwenta wyposażonego w zestaw kompetencji (Heron, Le Hathaway 2000; Owen 2001). 
D. Piróg dokonała przeglądu badań szkolnictwo a rynek pracy, badań losów zawodowych absolwentów, poziomu jakości kształcenia akademickiego pod kątem rynku pracy i badań oczekiwań pracodawców wobec absolwentów - kandydatów do pracy. Jak się okazuje, powstał swoisty ranking kompetencji wymaganych na rynku pracy. Od absolwentów wyższych uczelni oczekuje się: ,profesjonalizmu we własnej dziedzinie, myślenia analitycznego, umiejętności kierowania grupą, znajomości dziedzin pokrewnych, zdolności szybkiego uczenia się, umiejętności efektywnego negocjowania, umiejętności obsługi komputera, innowacyjności, otwartości” (Piróg 2010, s. 75). W Polsce badania takie na szerszą skalę nie były prowadzone, choć należy się spodziewać, że wkrótce, także wśród geografów o różnych specjalnościach, zostaną przeprowadzone.

W świecie zmieniających się technologii, techniki i metod organizacji tylko bardzo szerokie, ogólne wykształcenie, wsparte rozwojem kompetencji miękkich może przygotować absolwenta uczelni do aktywnego poruszania się po rynku pracy (Osiński 2009).

Kompetencje miękkie przydatne są na każdym stanowisku pracy i mogą być czynnikiem, który zadecyduje o sukcesie w rozwoju zawodowym. W ogłoszeniach o pracę kompetencje miękkie są często wymieniane i przedstawiane pod postacią cech osobowości: kreatywność, odpowiedzialność, samodzielność, rozpoznawanie swoich mocnych i słabych stron, wysoka motywacja, odporność na stres, innowacyjność (Osiński 2010). Z. Osiński uważa, że kompetencje miękkie można nabyć przez specjalny trening, naturalny - poprzez codzienne doświadczenia interpersonalne - w pracy zawodowej, wśród grupy studentów w uczelni lub trening stacjonarny - specjalne szkolenie w ramach kursu w grupie, prowadzone przez trenera. Naturalny trening polega nie tylko na uczeniu się przez doświadczenie czy obecność w określonych sytuacjach, wymaga także zrozumienia pewnych zasad i przygotowania, które pozwoli wykorzystać dane doświadczenia do kształtowania konkretnych kompetencji (Smółka 2006).

Z. Osiński (2010) do głównych przyczyn słabego poziomu kompetencji miękkich zalicza niedouczenie, czyli brak wiedzy na ten temat i w konsekwencji błędną praktykę postępowania codziennego. Brak wystarczających i właściwych doświadczeń życiowych, nieumiejętność ich odczytywania, silne reakcje nawykowe, trudne do przezwyciężenia wskazuje Smółka (2006). Próby takich szkoleń i treningów w zakresie nabywania kompetencji miękkich są podejmowane w krajach wysoko rozwiniętych, np. w Norwegii oraz Finlandii. Ciekawy przykład rozwiązań wspierających kształtowanie kompetencji, zarówno ogólnych, jak i miękkich, podaje Z. Osiński (2010) w kursie LATINA (Learning and teaching in a digital Word), oferowanym w Oslo University College. Kurs przeznaczony jest dla nauczycieli, studentów, a nawet pracowników bibliotek (z różnych krajów), którzy chcą rozwijać swoje kompetencje dzięki wykorzystaniu Internetu oraz technologii informacyjnych i komunikacyjnych.

Zajęcia na kursie LATINA sprzyjają nabywaniu następujących kompetencji miękkich:

- „kreatywności - poprzez napisanie eseju, prowadzenie bloga, rozwiązywanie doraźnych a swoich odczuć na blogu;

- rozpoznawania swoich mocnych i słabych stron - poprzez przemyślenia na temat własnego funkcjonowania na kursie opisywane na blogu;

- odpowiedzialności - poprzez podział pracy wśród członków grupy i współodpowiedzialność za efekty oraz terminowość rozliczenia się z zadań;

- empatii - poprzez poznawanie odczuć innych członków grupy;

- tolerancji - poprzez współpracę z przedstawicielami różnych ras, religii, narodowości i kręgów kulturowych;

- umiejętności przekonywania - dotyczące uzgadniania kształtu wykonywanego zadania, podziału pracy" (Osiński 2010, s. 62).

Elementy kursu nadają się do kształtowania miękkich kompetencji związanych z pracą w grupie, dyskusją, poszukiwaniem rozwiązań problemów, a także do zastosowania w klasycznej 
strukturze studiów wyższych. To jeden z wielu przykładów wykorzystania mediów oraz technologii informacyjnej i komunikacyjnej w celach dydaktycznych w dzisiejszym, globalnym świecie.

W kolejnych latach należy spodziewać się zarówno dalszych badań dotyczących kompetencji absolwentów wyższych uczelni, w tym kandydatów na nauczycieli, w aspekcie ciągle zmieniającego się rynku pracy, jak i zapotrzebowania na konkretne zawody czy nawet szczegółowiej - wybrane kompetencje. Ponadto należy spodziewać się dalszego rozwoju technologii informacyjnych i komunikacyjnych wykorzystywanych do kształcenia oraz rozwijania kompetencji. W okresie stale postępujących procesów globalizacyjnych problematyka nabywania kompetencji komunikacyjnych i interpersonalnych będzie stanowić o przyszłym sukcesie i to nie tylko zawodowym absolwentów wyższych uczelni.

\section{Literatura}

1. Bańka A., 2000, Działalność zawodowa i publiczna [w:] Psychologia. Podręcznik akademicki, J. Strelau (red.), t. 3, GWP, Gdańsk.

2. Ciupińska B., 2005, Doskonalenie relacji międzyludzkich wyzwaniem społeczeństwa XXI wieku [w:] Przedsiębiorczość a współczesne wyzwania cywilizacyjne, Z. Zioło, T. Rachwał (red.), „Przedsiębiorczość - Edukacja”, nr 1, Wydawnictwo MiWa, Zakład Przedsiębiorczości i Gospodarki Przestrzennej Instytutu Geografii Akademii Pedagogicznej w Krakowie, Kraków, s. 153-157.

3. De Jong H., 2008, Aspekte der Ausbildung von Geographielehrer/inne/n In den Niederlanden, „GW Unterricht”, Nr 109/2008, Wien, s. 27-32.

4. Donert K., Charzyński P., Podgórski Z. (red.), 2007, Teaching geography in and about Europe, Toruń: Herodot Network.

5. Dylak S., 1995, Wizualizacja w kształceniu nauczycieli, Wydawnictwo UAM Poznań,

6. Erhard A., 2001, Der neue Studienplan für das Unterrichtsfach Geographie und Wirtschaftskunde (Lehramt) an der Naturwissenschaftlichen Fakultät der Universität Innsbruck, „GW Unterricht”, $\mathrm{Nr} 82 / 2001$, Wien, s. 54-62,

7. Gawrecki L., 2003, Kompetencje menedżera oświaty, Wydawnictwo eMPi2 Poznań.

8. Heron R., Le Hathaway J.T., 2000, An international perspective on developing skills through geography programmes for employability and life: narratives from New Zeland and the United States, „Journal of Geography in Higher Education”, 24, nr 2, s. 271-276.

9. Kunikowski J., 2009, Zawód wspótczesnego nauczyciela [w:] Wiedza, umiejętności, postawy a jakość ksztatcenia w szkole wyższej, B. Sitarska, K. Jankowski, R. Droba (red.), Wydawnictwo Akademii Podlaskiej, Siedlce, s. 171-177.

10. Kyriacou Ch., 1991, Essentials Teaching Skills, Oxford: Blackwell.

11. Kwiatkowska H., 2008, Pedeutologia, Wydawnictwa Akademickie i Profesjonalne, Warszawa.

12. Makieła B., 2006, Komunikacja interpersonalna w nauczaniu podstaw przedsiębiorczości-propozycje ćwiczeń [w:] Rola przedsiębiorczości w podnoszeniu konkurencyjności spoleczeństwa i gospodarki, Z. Zioło, T. Rachwał (red.), „Przedsiębiorczość - Edukacja”, nr 2, Nowa Era, Zakład Przedsiębiorczości i Gospodarki Przestrzennej Instytutu Geografii Akademii Pedagogicznej w Krakowie, Warszawa-Kraków 2006, s. 287-289.

13. Makieła Z., Rachwał T., 2007, Podstawy przedsiębiorczości. Podręcznik dla liceum ogólnokształcacego, liceum profilowanego i technikum, wydanie szóste, Nowa Era, Warszawa.

14. Osiński Z., 2009, Programy humanistycznych studiów wyższych a wymogi społeczeństwa wiedzy [w:] Wiedza, umiejętności, postawy a jakość kształcenia w szkole wyższej, B. Sitarska, K. Jankowski, R. Droba (red.), Wydawnictwo Akademii Podlaskiej, Siedlce, s. 29-38.

15. Osiński Z., 2010, Kompetencje miękkie absolwenta humanistycznych studiów wyższych a metody prowadzenia zajęć [w:] Studia wyższe z perspektywy rynku pracy, B. Sitarska, K. Jankowski, R. Droba (red.), Wydawnictwo Akademii Podlaskiej, Siedlce, s. 57-66. 
16. Osuch W., 2002, Kształcenie nauczycieli geografii o różnych specjalnościach w świetle reformy systemu edukacji a kompetencje nauczyciela geografii [w:] Czynniki i bariery regionalnej wspótpracy transgranicznej - bilans dokonań, Kitowski J. (red.), Rzeszów 2002, s. 567-580.

17. Osuch W., Tracz M., 2010, Kompetencje zawodowe nauczycieli geografii a wspótczesne wymagania oświatowego rynku pracy [w:] Studia wyższe z perspektywy rynku pracy, B. Sitarska, K. Jankowskiego, R. Droba (red.), Wydawnictwo Akademii Podlaskiej, Siedlce, s. 81-94.

18. Osuch W., 2010, Kompetencje nauczycieli geografii oraz studentów geografii - kandydatów na nauczycieli, „Prace Monograficzne”, nr 570, Wydawnictwo Uniwersytetu Pedagogicznego w Krakowie, Kraków.

19. Owen E., 2001, What skills do employers need?, „Journal of Geography in Higher Education”, 25, nr 1, s. 121-126.

20. Piróg D., 2010, Studia wyższe a rynek pracy w Polsce - zarys stanu badań [w:] Studia wyższe z perspektywy rynku pracy, B. Sitarska, K. Jankowski, R. Droba (red.), Wydawnictwo Akademii Podlaskiej, Siedlce, s. 67-80.

21. Rachwał T., 2004, Podstawy przedsiębiorczości. Stownik dla liceum ogólnokształcacego, liceum profilowanego i technikum, wydawnictwo Nowa Era, Warszawa, s. 264.

22. Rachwał M.M., Rachwał T., 2006, Wartości moralne podstawa prawdziwego sukcesu menedżera [w:] Rola przedsiębiorczości w podnoszeniu konkurencyjności społeczeństwa i gospodarki, Z. Zioło, T. Rachwał (red.), „Przedsiębiorczość - Edukacja”, nr 2, Nowa Era, Zakład Przedsiębiorczości i Gospodarki Przestrzennej Instytutu Geografii Akademii Pedagogicznej w Krakowie, Warszawa-Kraków, s. $193-198$.

23. Rozporzadzenie Ministra Edukacji Narodowej i Sportu z dnia 7 września 2004 r. w sprawie standardów kształcenia nauczycieli (Dz.U. 2004, nr 207, poz. 2110).

24. Smółka P., 2006, Jak skutecznie szkolić umiejętności interpersonalne? [w:] Komunikowanie się. Problemy i perspektywy, B. Kaczmarek, A. Kucharski, M. Stencel (red.), Wyd. UMCS Lublin.

25. Szempruch J., 2006, Kompetencje i zadania nauczyciela w procesie przeksztatcania szkoły [w:] Szkota w nauce i praktyce edukacyjnej. Tom I, B. Muchacka (red.), Wyd. „Impuls” Kraków, s. 223-238.

26. Vielhaber Ch., 2006, Wie viel Nachhaltigkeit verträgt das Schulfach Geographie und Wirtschaftskunde?, „Unterricht“, Nr 103/2006, Wien, s. 17-24.

27. Żurakowski F., 2002, Podstawy przedsiębiorczości. Podręcznik dla liceum ogólnoksztatcacego, liceum profilowanego i technikum. Zakres podstawowy, MAC Edukacja S.A., Kielce.

\section{Competences in Interpersonal Communication in the Era of Globalization Processes}

The subject of the research presented in this article is evaluation of competence of Geography and Entrepreneurship teachers and students who are teachers-to-be. In the teacher training process the crucial role is played by competences, developed mainly in the course of studies and during school practice. The author of this article has for over ten years conducted research on the students' development of subject competence and didactic competence including the research on Geography teacher-trainees. Personal and interpersonal competencies of graduates of higher education significantly affect their chances on the ever-changing labour market.

The presented research results should become an impulse for further analyses and reflection concerning the development of competence in teacher-trainees. Research in this area should successfully contribute to optimization of the teacher-training process, including Geography and Entrepreneurship teachers (not only in Poland), and to the development of an effective and efficient model of education and competence acquisition by graduates. 


\author{
Zbigniew Długosz, Szymon Biały \\ Uniwersytet Pedagogiczny \\ im. Komisji Edukacji Narodowej \\ w Krakowie
}

\title{
Studia w zakresie turystyki na tle szkolnictwa wyższego w kraju
}

Od pewnego czasu coraz głośniej wyrażana jest opinia, że w związku z rysującym się spadkiem liczebności roczników niżowych przełomu lat 80. i 90. ubiegłego stulecia, spadać będzie liczba chętnych na studia, co zresztą w skali globalnej uwidacznia się od 2005 r. i co już odczuło wiele uczelni. Zmniejszająca się liczba kandydatów na poszczególne kierunki studiów w wielu uczelniach wynika jednak nie tylko z faktu spadku liczebności poszczególnych roczników, ale przede wszystkim z tego, że w ostatnich dwóch dekadach przełomu wieków zwielokrotniła się liczba tego typu placówek niepublicznych (tab. 1), otwierając szerokie, ale odpłatne, możliwości studiowania. Sprawcą tego stanu rzeczy jest zwiększający się popyt na odpowiednie wykształcenie, które w powszechnym mniemaniu ma nobilitować głównie młodych ludzi w hierarchii społecznej. Dziś często nie chodzi już tylko o zaspokojenie własnych zainteresowań, ale - ze względów ambicjonalnych - o fakt ukończenia studiów.

Stąd na publicznych uczelniach ograniczony limit miejsc (zgodnie z wytycznymi komisji akredytacyjnej liczba studentów mierzona jest potencjałem kadry dydaktycznej) zmusił wielu chętnych do studiowania odpłatnego i szukania szansy na uczelniach niepaństwowych, szczególnie na zmieniających się w czasie tzw. modnych kierunkach, gdzie część kadry z placówek państwowych znajduje dodatkowe zatrudnienie.

W roku akademickim 2009/2010 we wszystkich uczelniach w kraju studiowało ponad 1,9 mln studentów. Uczelni prowadzących studia na różnych poziomach kształcenia (nie licząc kolegiów nauczycielskich i języków obcych, niemających statusu uczelni wyższych i nieposiadających uprawnień do nadawania tytułów zawodowych oraz będących w likwidacji) było wówczas 456, z czego 131 państwowych, a 325 niepublicznych. Dodatkowo funkcjonowało 218 punktów filialnych (oddziały, wydziały, instytuty, ośrodki lub inne tego typu placówki zamiejscowe, nie licząc poza granicą w Wilnie - Filii Uniwersytetu w Białymstoku oraz we Lwowie - Wydziału Zamiejscowego Wyższej Szkoły Informatyki i Zarządzania w Rzeszowie), w tym 125 państwowych i 93 prywatnych.

Na podstawie Ustawy z dnia 27 lipca 2005 r. Prawo o szkolnictwie wyższym, spośród 131 uczelni państwowych 41 posiadało status uniwersytetu, z tego 18 były to uczelnie humanistyczne (w tym kościelne: Katolicki Uniwersytet Lubelski, Uniwersytet Kardynała S. Wyszyńskiego), 23 funkcjonowały jako tzw. uniwersytety przymiotnikowe (cztery ekonomiczne, siedem rolniczych, jeden muzyczny, jeden sztuk pięknych, dwa pedagogiczne, osiem medycznych), 35 posiadało status akademii (trzy humanistyczne, jedna ekonomiczna, trzy techniczne, dwie medyczne, trzy wojskowe, jedna teatralna, siedem muzycznych, siedem sztuk pięknych, sześć wychowania fizycznego, dwie morskie), pozostałe zaś to politechniki, uczelnie resortowe (Obrony Narodowej, Spraw Wewnętrznych, Administracji Publicznej) i państwowe wyższe szkoły zawodowe. 
Tab. 1. Liczba uczelni i liczba studentów w Polsce

\begin{tabular}{|c|c|c|c|c|c|c|}
\hline \multirow{2}{*}{ Rok* } & \multicolumn{3}{|c|}{ Uczelnie } & \multicolumn{3}{c|}{ Studenci (w tys.) } \\
\cline { 2 - 7 } & razem & publiczne** $^{*}$ & niepubliczne*** & razem & publiczne** $^{*}$ & niepubliczne*** $^{* * \mid}$ \\
\hline 1990 & 112 & - & - & 404 & - & - \\
\hline 1991 & 117 & - & - & 428 & - & - \\
\hline 1992 & 124 & 106 & 18 & 512 & 496 & 16 \\
\hline 1993 & 140 & 104 & 36 & 613 & 584 & 29 \\
\hline 1994 & 160 & 104 & 56 & 678 & 628 & 50 \\
\hline 1996 & 179 & 99 & 80 & 894 & 795 & 89 \\
\hline 1997 & 213 & 99 & 114 & 1071 & 928 & 143 \\
\hline 1998 & 242 & 96 & 146 & 1318 & 1091 & 227 \\
\hline 1999 & 266 & 108 & 158 & 1323 & 1002 & 321 \\
\hline 2000 & 288 & 114 & 174 & 1432 & 1013 & 419 \\
\hline 2001 & 310 & 115 & 195 & 1585 & 1113 & 472 \\
\hline 2002 & 344 & 123 & 221 & 1718 & 1209 & 509 \\
\hline 2003 & 377 & 125 & 252 & 1800 & 1271 & 529 \\
\hline 2004 & 400 & 126 & 274 & 1858 & 1313 & 546 \\
\hline 2005 & 427 & 126 & 301 & 1926 & 1344 & 552 \\
\hline 2006 & 445 & 130 & 315 & 1954 & 1333 & 591 \\
\hline 2007 & 449 & 130 & 319 & 1941 & 1301 & 640 \\
\hline 2008 & 455 & 131 & 324 & 1937 & 1277 & 632 \\
\hline 2009 & 456 & 131 & 325 & 1928 & 1268 & 632 \\
\hline
\end{tabular}

*rok podjęcia studiów, **łącznie ze szkołami resortu obrony narodowej, spraw wewnętrznych i administracji, ***wraz z uczelniami wyznaniowymi

Źródło: roczniki statystyczne GUS.

Uczelnie wyższe i ich filie ulokowane są w 190 miejscowościach, przy czym publiczne w 109 ośrodkach, natomiast niepubliczne - w 146. Po wnikliwej analizie okazało się, że tylko w 38 miejscowościach, gdzie funkcjonują uczelnie państwowe bądź ich filie, nie było uczelni prywatnych, natomiast w 74 miejscowościach, gdzie ulokowały się wyższe szkoły niepubliczne, nie było uczelni państwowych. W przestrzennym rozkładzie uczelni (tab. 2) można zaobserwować dużą dysproporcję zarówno ich liczby, jak i ośrodków w poszczególnych regionach kraju. Najwięcej państwowych uczelni i ich filii zlokalizowanych jest w województwie mazowieckim, o ponad połowę mniej w śląskim, dolnośląskim, wielkopolskim i małopolskim, natomiast najmniej w opolskim i lubuskim. 
Tab. 2. Rozmieszczenie uczelni w Polsce

\begin{tabular}{|c|c|c|c|c|c|c|c|c|c|}
\hline \multirow[b]{2}{*}{ Województwo } & \multicolumn{3}{|c|}{ Ogółem } & \multicolumn{3}{|c|}{ Uczelnie publiczne } & \multicolumn{3}{|c|}{ Uczelnie niepubliczne } \\
\hline & 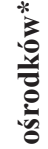 & 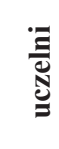 & 青 & 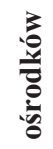 & 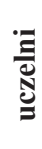 & : & 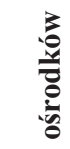 & 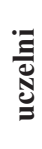 & 青 \\
\hline dolnośląskie & 14 & 41 & 20 & 9 & 13 & 12 & 9 & 28 & 8 \\
\hline $\begin{array}{l}\text { kujawsko- } \\
\text {-pomorskie }\end{array}$ & 7 & 20 & 23 & 5 & 5 & 7 & 7 & 15 & 6 \\
\hline lubelskie & 13 & 21 & 12 & 7 & 8 & 7 & 8 & 13 & 5 \\
\hline lubuskie & 6 & 8 & 8 & 5 & 3 & 8 & 4 & 5 & - \\
\hline łódzkie & 9 & 29 & 10 & 6 & 7 & 6 & 7 & 22 & 4 \\
\hline małopolskie & 11 & 35 & 14 & 8 & 14 & 10 & 9 & 21 & 4 \\
\hline mazowieckie & 25 & 108 & 23 & 7 & 19 & 10 & 23 & 89 & 13 \\
\hline opolskie & 3 & 6 & 2 & 2 & 4 & - & 2 & 2 & 2 \\
\hline podkarpackie & 18 & 17 & 14 & 10 & 7 & 6 & 12 & 10 & 8 \\
\hline podlaskie & 7 & 18 & 7 & 4 & 5 & 5 & 5 & 13 & 2 \\
\hline pomorskie & 9 & 29 & 11 & 5 & 9 & 4 & 10 & 20 & 7 \\
\hline śląskie & 22 & 44 & 31 & 17 & 11 & 23 & 15 & 33 & 8 \\
\hline świętokrzyskie & 8 & 15 & 6 & 3 & 3 & 2 & 7 & 12 & 4 \\
\hline $\begin{array}{l}\text { warmińsko- } \\
\text {-mazurskie }\end{array}$ & 10 & 10 & 7 & 3 & 3 & 2 & 8 & 7 & 5 \\
\hline wielkopolskie & 19 & 37 & 28 & 14 & 13 & 20 & 13 & 24 & 8 \\
\hline zachodnio-pomorskie & 9 & 20 & 12 & 4 & 7 & 3 & 7 & 13 & 9 \\
\hline
\end{tabular}

*ośrodki, w których ulokowane były uczelnie publiczne bądź niepubliczne i ich filie, liczono raz

Źródło: opracowanie własne na podstawie www.uczelnie.pl, www.nauka.gov.pl (dane na dzień 01.07.2010).

Od pewnego czasu jednym z popularnych i można rzec - modnych - kierunków studiów w Polsce jest turystyka, która zgodnie z rozporządzeniem MNiSW z dnia 13.06.2006 r. w myśl wyznaczonych standardów formalnie określana jest jako turystyka i rekreacja. Wśród najpopularniejszych kierunków turystyka w roku akademickim 2009/10 plasowała się na szóstym miejscu po: zarządzaniu, informatyce, finansach, pedagogice i administracji, a przed marketingiem. O popularności tej dyscypliny świadczy ogólnopolski ranking liczby kandydatów na jedno miejsce w poszczególnych uczelniach w ostatnich latach (tab. 3). Nie jest to może najlepszy wskaźnik, gdyż wynika on w dużej mierze nie tylko z pozycji uczelni na krajowym rynku edukacyjnym, ale przede wszystkim z liczby oferowanych przez uczelnię miejsc. Niemniej 
jednak, jak się wydaje, jest to jedyny i porównywalny dla wszystkich jednostek wskaźnik oddający popularność danego kierunku w Polsce. Ponadto należy pamiętać, że od pewnego czasu w niektórych uczelniach kandydaci mogą rejestrować się po opłaceniu wpisowego na dowolną liczbę kierunków bądź specjalności, co również zaburza stan faktyczny liczby chętnych na dany kierunek.

Tab. 3. Turystyka w rankingu popularności w polskich uczelniach

\begin{tabular}{|c|c|c|c|c|}
\hline $\begin{array}{c}\text { Rok } \\
\text { akademicki }\end{array}$ & Uczelnia - ośrodek & $\begin{array}{c}\text { Kandydat/ } \\
1 \text { miejsce }\end{array}$ & $\begin{array}{l}\text { Miejsce } \\
\text { w kraju }\end{array}$ & Kierunek/specjalizacja \\
\hline \multirow{3}{*}{$2003 / 4$} & SGGW - Warszawa & 28,9 & 1 & turystyka i rekreacja \\
\hline & AWF - Wrocław & 8,7 & 20 & turystyka i rekreacja \\
\hline & Politechnika Białostocka & 7,1 & 37 & turystyka i rekreacja \\
\hline \multirow{3}{*}{$2004 / 5$} & UJ - Kraków & 31,1 & 3 & $\begin{array}{c}\text { zarządzanie } \\
\text { i marketing/zarz. w tur. }\end{array}$ \\
\hline & SGGW - Warszawa & 20,8 & 5 & turystyka i rekreacja \\
\hline & UAM - Poznań & 18,7 & 9 & turystyka i rekreacja \\
\hline \multirow[b]{2}{*}{$2005 / 6$} & SGGW - Warszawa & 23,3 & 3 & turystyka i rekreacja \\
\hline & UJ - Kraków & 5,7 & 46 & $\begin{array}{c}\text { zarządzanie } \\
\text { i marketing/zarz. w tur. }\end{array}$ \\
\hline \multirow{3}{*}{$2006 / 7$} & SGGW - Warszawa & 23,3 & 4 & turystyka i rekreacja \\
\hline & UAM - Poznań & 16,0 & 11 & turystyka i rekreacja \\
\hline & Politechnika Białostocka & 5,9 & 107 & turystyka i rekreacja \\
\hline \multirow{4}{*}{$2007 / 8$} & SGGW - Warszawa & 16,2 & 8 & turystyka i rekreacja \\
\hline & UEK - Kraków & 12,9 & 17 & turystyka i rekreacja \\
\hline & UAM - Poznań & 11,8 & 30 & turystyka i rekreacja \\
\hline & UMK - Toruń & 11,4 & 32 & turystyka i rekreacja \\
\hline \multirow{3}{*}{$2008 / 9$} & SGGW - Warszawa & 14,0 & 4 & turystyka i rekreacja \\
\hline & UAM - Poznań & 9,6 & 15 & turystyka i rekreacja \\
\hline & UEK - Kraków & 9,1 & 25 & turystyka i rekreacja \\
\hline \multirow{4}{*}{$2009 / 10$} & SGGW - Warszawa & 14,1 & 9 & turystyka i rekreacja \\
\hline & UP - Kraków & 10,2 & & turystyka i rekreacja \\
\hline & UAM - Poznań & 8,6 & 52 & turystyka i rekreacja \\
\hline & UEK - Kraków & 7,1 & 81 & turystyka i rekreacja \\
\hline
\end{tabular}

Źródło: opracowanie własne na podstawie www.uczelnie.pl (dane na dzień 01.07.2010), źródła własne. 
Tab. 4. Turystyka na krajowym rynku edukacyjnych wśród wyższych szkół wg województw (stan na 01.06.2010 r.)

\begin{tabular}{|c|c|}
\hline Ośrodek & Uczelnia \\
\hline & dolnoślaskie \\
\hline \multirow{2}{*}{ Legnica } & Państwowa Wyższa Szkoła Zawodowa im. Witelona \\
\hline & Wyższa Szkoła Zarządzania/Polish Open University \\
\hline Świdnica & Wyższa Szkoła Technologii Teleinformatycznych \\
\hline Wałbrzych & Państwowa Wyższa Szkoła Zawodowa im. A. Silesiusa \\
\hline \multirow{9}{*}{ Wrocław } & Akademia Wychowania Fizycznego \\
\hline & Dolnośląska Szkoła Wyższa Edukacji Towarzystwa Wiedzy Powszechnej \\
\hline & Szkoła Wyższa Rzemiost Artystycznych i Zarządzania \\
\hline & Uniwersytet Ekonomiczny \\
\hline & Wrocławska Wyższa Szkoła Informatyki Stosowanej „HORYZONT” \\
\hline & Wyższa Szkoła Bankowa \\
\hline & Wyższa Szkoła Edukacja w Sporcie \\
\hline & Wyższa Szkoła Handlowa \\
\hline & Wyższa Szkoła Zarządzania „Edukacja” \\
\hline \multicolumn{2}{|r|}{ kujawsko-pomorskie } \\
\hline Brodnica & $\begin{array}{l}\text { Wydziat Zamiejscowy Społecznej Wyższej Szkoły } \\
\text { Przedsiębiorczości i Zarządzania w Lodzi }\end{array}$ \\
\hline \multirow{5}{*}{ Bydgoszcz } & Kujawsko-Pomorska Szkoła Wyższa \\
\hline & Uniwersytet Kazimierza Wielkiego \\
\hline & Wyższa Szkoła Gospodarki \\
\hline & Zamiejscowy Ośrodek Dydaktyczny Uniwersytetu Ekonomicznego w Poznaniu \\
\hline & Zamiejscowy Wydział Wyższej Szkoły Bankowej w Toruniu \\
\hline \multirow{4}{*}{ Toruń } & Toruńska Wyższa Szkoła Przedsiębiorczości \\
\hline & Uniwersytet Mikołaja Kopernika \\
\hline & Wyższa Szkoła Bankowa \\
\hline & Wyższa Szkoła Kultury Społecznej i Medialnej \\
\hline \multirow[t]{2}{*}{ Włocławek } & Państwowa Wyższa Szkoła Zawodowa \\
\hline & Wyższa Szkoła Humanistyczno-Ekonomiczna \\
\hline \multicolumn{2}{|r|}{ lubelskie } \\
\hline \multirow[t]{2}{*}{ Biała Podlaska } & Państwowa Wyższa Szkoła Zawodowa im. Papieża Jana Pawła II \\
\hline & Zamiejscowy Wydział Wychowania Fizycznego AWF w Warszawie \\
\hline Chełm & Państwowa Wyższa Szkoła Zawodowa \\
\hline Kazimierz Dln. & Kolegium Sztuk Pięknych UMCS \\
\hline
\end{tabular}




\begin{tabular}{|c|c|}
\hline \multirow{4}{*}{ Lublin } & UMCS \\
\hline & Uniwersytet Przyrodniczy \\
\hline & Wyższa Szkoła Ekonomii i Innowacji \\
\hline & Wyższa Szkoła Społeczno-Przyrodnicza \\
\hline Ryki & Lubelska Szkoła Wyższa \\
\hline \multirow[t]{2}{*}{ Zamość } & Państwowa Wyższa Szkoła Zawodowa im. S. Szymonowica \\
\hline & Wydział Nauk Rolniczych Uniwersytetu Przyrodniczego w Lublinie \\
\hline \multicolumn{2}{|r|}{ lubuskie } \\
\hline \multirow[t]{2}{*}{ Gorzów Wlkp. } & Państwowa Wyższa Szkoła Zawodowa \\
\hline & Zamiejscowy Wydział Kultury Fizycznej AWF w Poznaniu \\
\hline Sulechów & Państwowa Wyższa Szkoła Zawodowa \\
\hline Zielona Góra & Zamiejscowy Ośrodek Dydaktyczny Uniwersytetu Ekonomicznego w Poznaniu \\
\hline \multicolumn{2}{|r|}{ lódzkie } \\
\hline \multirow{6}{*}{ Łódź } & Akademia Humanistyczno-Ekonomiczna \\
\hline & Uniwersytet Łódzki \\
\hline & Wyższa Szkoła Edukacji Zdrowotnej i Nauk Społecznych \\
\hline & Wyższa Szkoła Pedagogiczna \\
\hline & Wyższa Szkoła Studiów Międzynarodowych \\
\hline & Wyższa Szkoła Turystyki i Hotelarstwa \\
\hline \multirow{2}{*}{$\begin{array}{l}\text { Piotrków } \\
\text { Trybunalski }\end{array}$} & $\begin{array}{c}\text { Punkt Informacyjno-Rekrutacyjny Wyższej Szkoty } \\
\text { Humanistyczno-Ekonomicznej w Lodzi }\end{array}$ \\
\hline & Wyższa Szkoła Handlowa im. króla S. Batorego \\
\hline \multicolumn{2}{|r|}{ małopolskie } \\
\hline Chrzanów & Wyższa Szkoła Przedsiębiorczości i Marketingu \\
\hline \multirow{10}{*}{ Kraków } & Akademia Górniczo-Hutnicza im. Stanisława Staszica \\
\hline & Akademia Wychowania Fizycznego im. B. Czecha \\
\hline & Krakowska Akademia im. F. Modrzewskiego \\
\hline & Małopolska Wyższa Szkoła Zawodowa im. Józefa Dietla \\
\hline & Uniwersytet Ekonomiczny \\
\hline & Uniwersytet Jagielloński \\
\hline & Uniwersytet Pedagogiczny im. KEN \\
\hline & Wyższa Szkoła Ekonomii i Informatyki \\
\hline & Wyższa Szkoła Ubezpieczeń \\
\hline & Wyższa Szkoła Zarządzania/The Polish Open University \\
\hline \multirow{2}{*}{ Nowy Sącz } & Państwowa Wyższa Szkoła Zawodowa \\
\hline & Wyższa Szkoła Przedsiębiorczości \\
\hline
\end{tabular}




\begin{tabular}{|c|c|}
\hline Nowy Targ & Podhalańska Państwowa Wyższa Szkoła Zawodowa \\
\hline Sucha Beskidzka & Wyższa Szkoła Turystyki i Ekologii \\
\hline \multirow{2}{*}{ Tarnów } & Małopolska Wyższa Szkoła Ekonomiczna \\
\hline & Wydziat Zamiejscowy W.S. Biznesu/National Louis University \\
\hline \multicolumn{2}{|r|}{ mazowieckie } \\
\hline Ciechanów & Wydziat Akademii Humanistycznej im. A. Gieysztora w Puttusku \\
\hline Gostynin & Wydziat Zamiejscowy W.S. Turystyki i Hotelarstwa w Łodzi \\
\hline Legionowo & Wyższa Szkoła Ekonomiczno-Techniczna im. W. Sikorskiego \\
\hline Płock & Państwowa Wyższa Szkoła Zawodowa \\
\hline Pruszków & Wyższa Szkoła Kultury Fizycznej i Turystyki im. H. Konopackiej \\
\hline Pułtusk & Akademia Humanistyczna im. A. Gieysztora \\
\hline \multirow{5}{*}{ Radom } & Prywatna Wyższa Szkoła Ochrony Środowiska \\
\hline & Społeczna Wyższa Szkoła Przedsiębiorczości i Zarządzania \\
\hline & Wyższa Szkoła Biznesu im. bp. J. Chrapka \\
\hline & Wyższa Szkoła Handlowa \\
\hline & Wyższa Szkoła Nauk Społecznych i Technicznych \\
\hline Siedlce & Akademia Podlaska \\
\hline Sochaczew & Wyższa Szkoła Zarządzania i Marketingu \\
\hline \multirow{18}{*}{ Warszawa } & Akademia Wychowania Fizycznego im. J. Piłsudskiego \\
\hline & ALMAMER Wyższa Szkoła Ekonomiczna \\
\hline & OLYMPUS Szkoła Wyższa im. R. Kudlińskiego \\
\hline & Szkoła Główna Gospodarstwa Wiejskiego \\
\hline & Szkoła Główna Handlowa \\
\hline & Szkoła Wyższa Przymierza Rodzin \\
\hline & Uczelnia Warszawska im. M. Skłodowskiej-Curie \\
\hline & Wszechnica Polska - Szkoła Wyższa Towarzystwa Wiedzy Powszechnej \\
\hline & Wyższa Szkoła - Edukacja w Sporcie \\
\hline & Wyższa Szkoła Ekologii i Zarządzania \\
\hline & Wyższa Szkoła Ekonomiczno-Informatyczna \\
\hline & Wyższa Szkoła Finansów i Zarządzania \\
\hline & Wyższa Szkoła Handlu i Finansów Międzynarodowych im. F. Skarbka \\
\hline & Wyższa Szkoła Hotelarstwa, Gastronomii i Turystyki \\
\hline & Wyższa Szkoła Organizacji Turystyki i Hotelarstwa \\
\hline & Wyższa Szkoła Turystyki i Języków Obcych \\
\hline & Wyższa Szkoła Turystyki i Rekreacji im. M. Orłowicza \\
\hline & Wyższa Szkoła Zarzadzania i Prawa im. H. Chodkowskiej \\
\hline
\end{tabular}




\begin{tabular}{|c|c|}
\hline & opolskie \\
\hline \multirow[t]{2}{*}{ Opole } & Politechnika Opolska \\
\hline & Wydział Ekonomiczny Wyższej Szkoły Bankowej we Wrocławiu \\
\hline \multicolumn{2}{|r|}{ podkarpackie } \\
\hline Jarosław & Państwowa Wyższa Szkoła Zawodowa im. ks. B. Markiewicza* \\
\hline Jasło & Podkarpacka Szkoła Wyższa im Bt. Ks. W. Findysza \\
\hline Krosno & Państwowa Wyższa Szkoła Zawodowa \\
\hline Przemyśl & Państwowa Wyższa Szkoła Wschodnioeuropejska \\
\hline \multirow{3}{*}{ Rzeszów } & Uniwersytet Rzeszowski \\
\hline & Wyższa Szkoła Informatyki i Zarządzania \\
\hline & Wyższa Szkoła Inżynieryjno-Ekonomiczna \\
\hline Sanok & Państwowa Wyższa Szkoła Zawodowa im. J. Grodka \\
\hline Stalowa Wola & Wyższa Szkoła Ekonomiczna \\
\hline Tarnobrzeg & Państwowa Wyższa Szkoła Zawodowa im. S. Tarnowskiego \\
\hline \multicolumn{2}{|r|}{ podlaskie } \\
\hline \multirow{5}{*}{ Białystok } & Politechnika Białostocka \\
\hline & Wyższa Szkoła Ekonomiczna \\
\hline & Wyższa Szkoła Finansów i Zarządzania \\
\hline & Wyższa Szkoła Menedżerska \\
\hline & Wyższa Szkoła Wychowania Fizycznego i Turystyki \\
\hline Łomża & Wyższa Szkoła Agrobiznesu \\
\hline Siemiatycze & Nadbużańska Szkoła Wyższa \\
\hline \multirow{2}{*}{ Suwałki } & Państwowa Wyższa Szkoła Zawodowa \\
\hline & Wyższa Szkoła Suwalsko-Mazurska im. Jana Pawła II \\
\hline \multicolumn{2}{|r|}{ pomorskie } \\
\hline Człuchów & Wydziat Zamiejscowy WSP Towarzystwa Wiedzy Powszechnej w Warszawie \\
\hline \multirow{6}{*}{ Gdańsk } & Akademia Wychowania Fizycznego i Sportu im. J. Śniadeckiego \\
\hline & Gdańska Wyższa Szkoła Humanistyczna \\
\hline & Uniwersytet Gdański \\
\hline & Wyższa Szkoła Bankowa \\
\hline & Wyższa Szkoła Turystyki i Hotelarstwa \\
\hline & Wyższa Szkoła Zarządzania \\
\hline \multirow{3}{*}{ Gdynia } & Pomorska Wyższa Szkoła Humanistyczna \\
\hline & Wydział Ekonomii i Zarządzania Wyższej Szkoły Bankowej w Gdańsku \\
\hline & Wyższa Szkoła Komunikacji Społecznej \\
\hline
\end{tabular}




\begin{tabular}{|c|c|}
\hline \multirow{2}{*}{ Słupsk } & Akademia Pomorska \\
\hline & Wyższa Hanzeatycka Szkoła Zarządzania \\
\hline Sopot & Europejska Szkoła Hotelarstwa, Turystyki i Przedsiębiorczości \\
\hline \multicolumn{2}{|r|}{ śląskie } \\
\hline \multirow{2}{*}{ Bielsko-Biała } & Wyższa Szkoła Bankowości i Finansów \\
\hline & Wyższa Szkoła Ekonomiczno-Humanistyczna \\
\hline \multirow{2}{*}{ Chorzów } & Górnośląska Wyższa Szkoła Przedsiębiorczości im. K. Goduli \\
\hline & Wydział Zamiejscowy Wyższej Szkoty Bankowej w Poznaniu \\
\hline Częstochowa & Wyższa Szkoła Hotelarstwa i Turystyki \\
\hline Dąbrowa Górnicza & Wyższa Szkoła Biznesu \\
\hline Gliwice & Gliwicka Wyższa Szkoła Przedsiębiorczości \\
\hline \multirow{5}{*}{ Katowice } & Akademia Ekonomiczna im. K. Adamieckiego \\
\hline & Akademia Wychowania Fizycznego im. J. Kukuczki \\
\hline & Górnośląska Wyższa Szkoła Handlowa im. W. Korfantego \\
\hline & Uniwersytet Śląski \\
\hline & Wyższa Szkoła Zarządzania Marketingowego i Języków Obcych \\
\hline Sosnowiec & Wyższa Szkoła Humanitas \\
\hline Ustroń & $\begin{array}{c}\text { Wyższa Szkoła Inżynierii Dentystycznej i Nauk Humanistycznych } \\
\text { im. prof. Meissnera }\end{array}$ \\
\hline Zawiercie & Wyższa Szkoła Administracji i Zarządzania \\
\hline Żywiec & Beskidzka Wyższa Szkoła Umiejętności \\
\hline \multicolumn{2}{|r|}{ świętokrzyskie } \\
\hline \multirow{4}{*}{ Kielce } & Uniwersytet Humanistyczno-Przyrodniczy im. J. Kochanowskiego \\
\hline & Wszechnica Świętokrzyska \\
\hline & Wyższa Szkoła Ekonomii i Prawa im. prof. E. Lipińskiego \\
\hline & Wyższa Szkoła Umiejętności \\
\hline \multicolumn{2}{|r|}{ warmińsko-mazurskie } \\
\hline Elbląg & Państwowa Wyższa Szkoła Zawodowa \\
\hline Ełk & Wydział Wyższej Szkoła Finansów i Zarządzania w Białymstoku \\
\hline Olsztyn & Uniwersytet Warmińsko-Mazurski \\
\hline \multicolumn{2}{|r|}{ wielkopolskie } \\
\hline Gniezno & Gnieźnieńska Wyższa Szkoła Humanistyczno-Menedżerska „,Milenium” \\
\hline Kalisz & Państwowa Wyższa Szkoła Zawodowa im. Prezydenta S. Wojciechowskiego \\
\hline Konin & Państwowa Wyższa Szkoła Zawodowa \\
\hline Leszno & Państwowa Wyższa Szkoła Zawodowa im. J.A. Komeńskiego \\
\hline
\end{tabular}




\begin{tabular}{|c|c|}
\hline \multirow{3}{*}{ Piła } & Państwowa Wyższa Szkoła Zawodowa im. S. Staszica \\
\hline & Wyższa Szkoła Biznesu \\
\hline & Zamiejscowy Ośrodek Dydaktyczny Uniwersytetu Ekonomicznego w Poznaniu \\
\hline \multirow{12}{*}{ Poznań } & Akademia Wychowania Fizycznego im. E. Piaseckiego \\
\hline & Uniwersytet Ekonomiczny \\
\hline & Uniwersytet im. Adama Mickiewicza \\
\hline & Uniwersytet Przyrodniczy \\
\hline & Wielkopolska Wyższa Szkoła Turystyki i Zarządzania \\
\hline & Wydziat Zamiejscowy Szkoły Wyższej Psychologii Społecznej w Warszawie \\
\hline & Wyższa Szkoła Bezpieczeństwa \\
\hline & Wyższa Szkoła Edukacji Integracyjnej i Interkulturowej \\
\hline & Wyższa Szkoła Handlu i Usług \\
\hline & Wyższa Szkoła Hotelarstwa i Gastronomii \\
\hline & Wyższa Szkoła Nauk Humanistycznych i Dziennikarstwa \\
\hline & Wyższa Szkoła Zawodowa „Kadry dla Europy” \\
\hline \multicolumn{2}{|r|}{ zachodniopomorskie } \\
\hline Koszalin & Wydział Zamiejscowy Społecznej W. S. Przedsiębiorczości i Zarządzania w Łodzi \\
\hline \multirow{8}{*}{ Szczecin } & Szczecińska Szkoła Wyższa Collegium Balticum \\
\hline & Uniwersytet Szczeciński \\
\hline & Wydziat Zamiejscowy Wyższej Szkoły Edukacji i Terapii w Poznaniu \\
\hline & Wyższa Szkoła Bankowa \\
\hline & Wyższa Szkoła Ekonomiczno-Turystyczna \\
\hline & Wyższa Szkoła Humanistyczna Towarzystwa Wiedzy Powszechnej \\
\hline & Wyższa Szkoła Integracji Europejskiej \\
\hline & Wyższa Szkoła Zawodowa „OECONOMICUS” PTE \\
\hline
\end{tabular}

kursywą wpisano nazwy uczelni niepublicznych

* W grudniu 2010 r. uczelnia zmieniła nazwę na Państwowa Wyższa Szkoła Techniczno-Ekonomiczna im. Ks. Bronisława Markiewicza

Źródło: opracowanie własne na podstawie: http://www.uczelnie.pl (dane na dzień 01.07.2010).

W zakresie turystyki kształci się studentów w Polsce w 75 ośrodkach na 183 uczelniach, w tym 63 państwowych (tab. 4). Edukacja na kierunku „turystyka i rekreacja” odbywa się w 83 uczelniach zarówno państwowych, jak i niepublicznych (ryc. 1). Turystyka prowadzona jest także w ramach wydziałów o tej nazwie, bądź w podstawowych jednostkach o innym profilu. Do wydziałów, przy których najczęściej afiliowana jest turystyka, należą dziedziny związane z ekonomią, wychowaniem fizycznym, naukami o Ziemi (gdzie lokowana jest geografia), stosunkami międzynarodowymi, administracją i zarządzaniem czy marketingiem. Turystyka funkcjonuje także w ramach różnych kierunków studiów (tab. 5). 
Tab. 5. Zestawienie kierunków ze specjalizacjami z turystyki

\begin{tabular}{|c|c|}
\hline archeologia & ochrona środowiska \\
\hline bezpieczeństwo narodowe & pedagogika \\
\hline administracja & politologia \\
\hline etnologia & przedsiębiorczość i zarządzanie* \\
\hline ekonomia & rocjologia \\
\hline ekonomia i zarządzanie* & stosunki międzynarodowe \\
\hline geografia & towaroznawstwo \\
\hline gospodarka przestrzenna & zarządzanie \\
\hline gospodarka turystyczna* & zarządzanie i marketing* \\
\hline finanse i rachunkowość & zarządzanie i inżynieria produkcji* \\
\hline filologia & \\
\hline kulturoznawstwo & \\
\hline
\end{tabular}

* w oficjalnym wykazie MNiSW (z 2006 r.) tak ujęte nazwy kierunków nie występują

Źródło: opracowanie własne na podstawie www.uczelnie.pl, www.nauka.pl (dane na dzień 01.07.2010).

Ryc. 1. Rozmieszczenie uczelni prowadzących studia na kierunku turystyka i rekreacja, w tym ośrodki zamiejscowe, bez uczelni w likwidacji (stan na 01.06.2010)

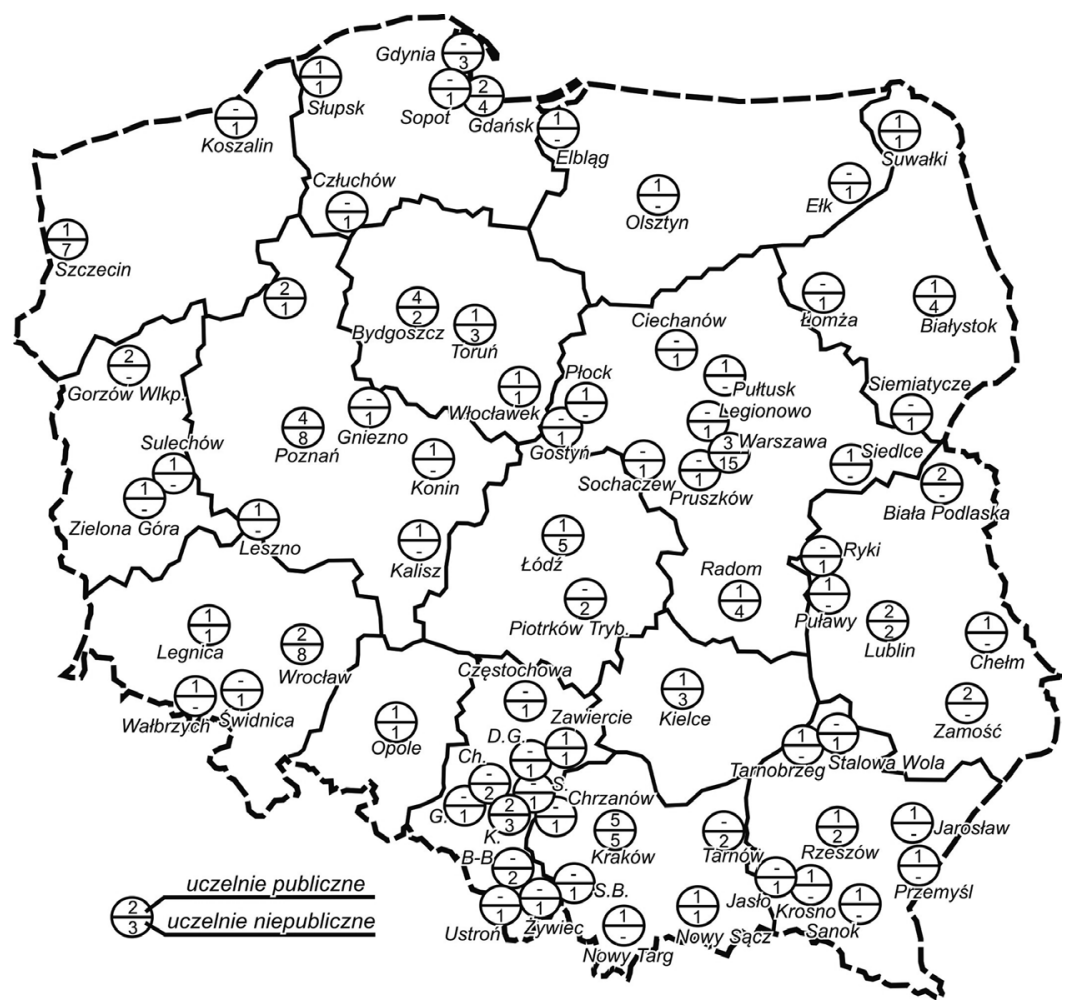

Źródło: opracowanie własne na podstawie www.uczelnie.pl, www.nauka.pl. 
Prawdziwą rewią bądź jak kto woli: koncertem życzeń z zakresu turystyki, są specjalizacje (123 - stan w roku akademickim 2009/10) prowadzone w ramach wydziałów lub kierunków. $\mathrm{Z}$ jednej strony są to pojedyncze albo rzadko spotykane u nas w kraju, bardzo ukierunkowane specjalizacje, takie jak animacja turystyki lotniczej, archeologia turystyczna, dietetyka w turystyce i rekreacji, język rosyjski (angielski) w turystyce, pedagogika sportu, rekreacji i turystyki, socjologia turystyki, wellness (medycyna alternatywna) i spa (leczenie wodą). Z drugiej strony, bardzo często oferowane są specjalności w różnorodnym, choć zbliżonym, ujęciu pojęciowym, jak m.in. agroturystyka, ekonomika turystyki, gospodarka turystyczna, organizacja bądź obsługa ruchu turystycznego, turystyka międzynarodowa, zarządzanie w turystyce czy krótko - turystyka.

Ryc. 2. Turystyka jako specjalność w uczelniach publicznych i ich filiach (stan na 30.06.2010)

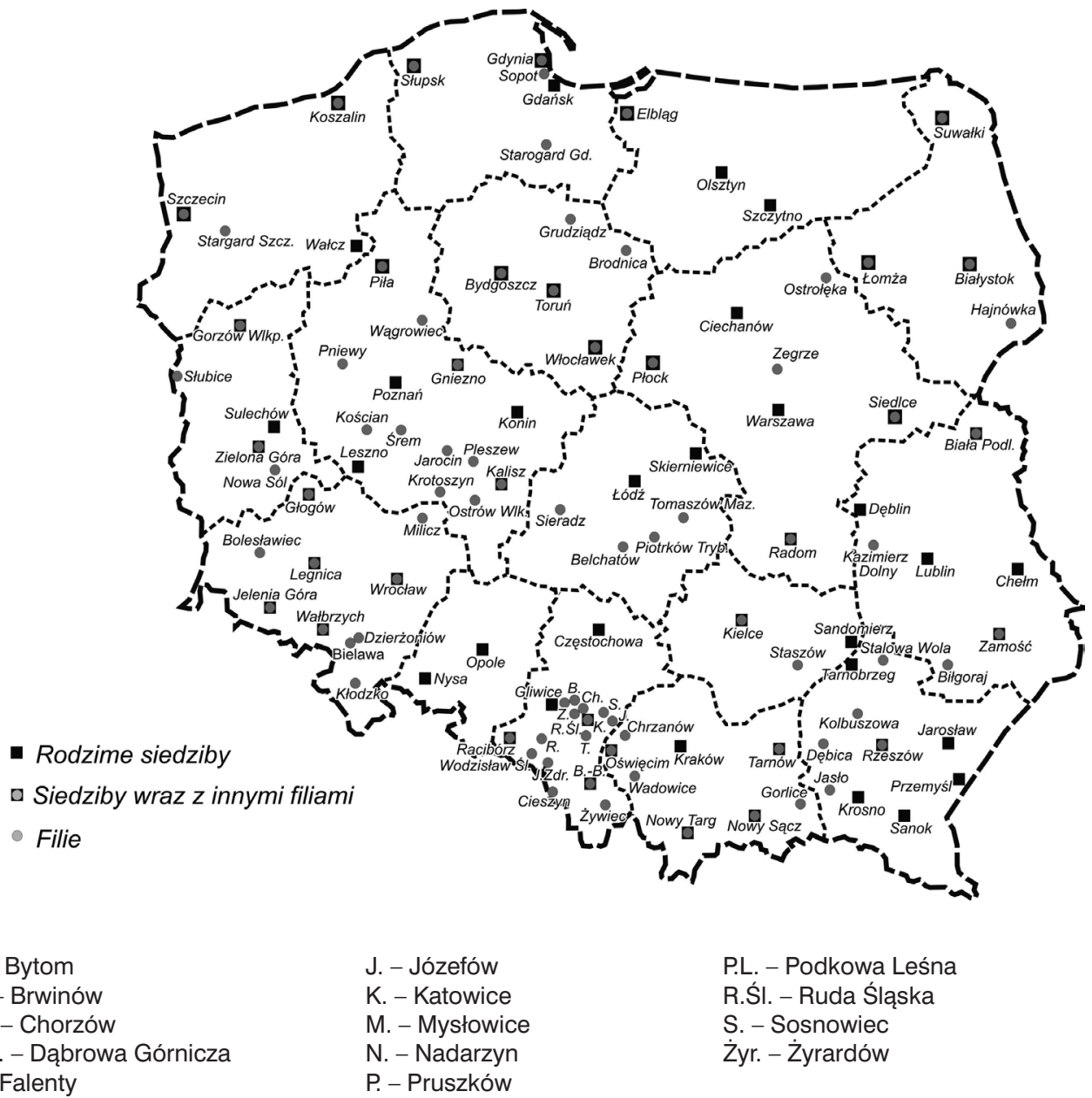

Źródło: opracowanie własne na podstawie www.uczelnie.pl, www.nauka.pl. 
Ryc. 3. Turystyka jako specjalność w uczelniach niepublicznych i ich filiach (stan na 30.06.2010 r.)

Rodzime siedziby

a Siedziby wraz z innymi filiami

- Filie

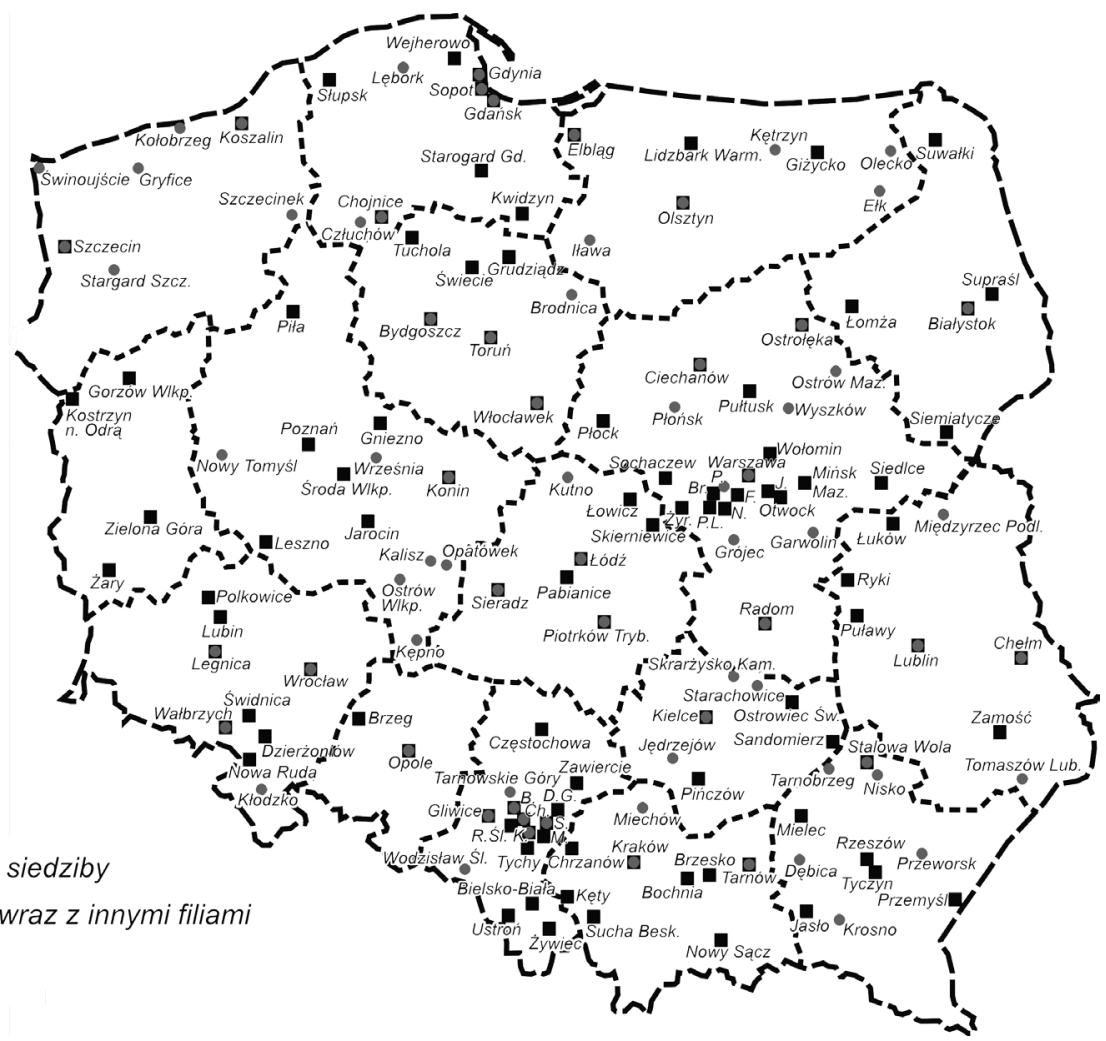

B. - Bytom

Br. - Brwinów

Ch. - Chorzów

D.G. - Dąbrowa Górnicza

F. - Falenty
J. - Józefów

K. - Katowice

M. - Mysłowice

N. - Nadarzyn

P. - Pruszków
P.L. - Podkowa Leśna

R.Śl. - Ruda Śląska

S. - Sosnowiec

Żyr. - Żyrardów

Źródło: opracowanie własne na podstawie www.uczelnie.pl, www.nauka.pl.

Analizując przestrzenne rozmieszczenie uczelni prowadzących studia w zakresie turystyki, tak w grupie uczelni państwowych (ryc. 2), jak i niepublicznych (ryc. 3), można stwierdzić, że największe możliwości studiowania turystyki lub dziedzin z nią związanych (rekreacji, hotelarstwa) reprezentowały uczelnie województw z dużymi ośrodkami, tj. mazowieckie (31 uczelni), wielkopolskie (19), małopolskie (17), śląskie (16). Zdecydowanie mniejsze możliwości studiowania turystyki oferowały uczelnie województw: opolskiego (dwie), warmińsko-mazurskiego (trzy) i lubuskiego (cztery). Ta popularność turystyki bierze się z kilku faktów, m.in. z:

- przejścia turystyki jako indywidualnej formy rekreacji w formę rekreacji masowej,

- rozwoju szeroko rozumianego sektora usług w tzw. obecnie przemysł turystyczny,

- nowych wyzwań w zakresie zrównoważonego rozwoju regionów turystycznych,

- pragmatycznych określeń wynikających z przystąpienia Polski do Unii Europejskiej i włączenia uznawania kwalifikacji związanych z zawodem (przewodnik turystyczny) lub działalnością (pilot wycieczek) w zakresie turystyki, 
- lansowanej do 2015 r. strategii w zakresie współpracy i promocji turystycznej Polski oraz kształtowania jej wizerunku jako kraju atrakcyjnego turystycznie.

Jednak rodzi się pytanie, czy i w jakim stopniu celowa jest dziś tak duża ,produkcja” absolwentów turystyki. Czy celowym jest tworzenie nowych kierunków i specjalizacji? Na ile jest to celowe i racjonalne, zweryfikuje najbliższa przyszłość, m.in. poprzez poziom praktycznego przygotowania absolwentów do zawodu i znalezienia się ich na konkurencyjnym rynku w zakresie nie tylko wyuczonych specjalizacji.

\section{Studies in the Field of Tourism and Higher Education System in Poland}

In recent years, many universities have experienced decline in recruitment. This is due to decrease of birth rate of the late 80's and 90's and the increasing number of private higher education institutions, which allow payable studying. In the academic year 2009/10 1.9 million students in Poland were studying at 456 universities, including 131 public and 325 private ones. 41 state higher education institutions used name of university, of which 18 were humanities universities, and 23 so-called adjectival. 36 universities had the status of the academy. The others were polytechnics departmental universities and state schools of higher professional education.

Among the most popular fields of study Tourism and recreation took 6th place among the 125 in total, as indicated by the number of candidates for 1 place. Students are trained in the field of tourism in 75 municipalities in Poland at 183 universities, including 63 state ones. Tourism also occurs as 123 specializations in the various fields of study. It is found in the fields with similar educational profile, but also as rare and highly focused specializations. The most of universities educating in the field of Tourism and Recreation or related fields are in mazowieckie (31 universities), wielkopolskie (19), małopolskie (17) and śląskie (16) voivodeships. The smallest numbers of colleges offer such voivodeships as: opolskie (2), warmińsko-mazurskie (3) and lubuskie (4).

The popularity of this field is caused by the spread of mass tourism and rapid development of regions and sector of tourism services. An Important reason is also raising the professional qualifications and strategy for the promotion of Poland as a country attractive for tourists. However, the question arises, how useful it is to educate so many specialists in the field of tourism and whether the level of their education would allow them to find their place on a competitive labour market? 


\author{
Roman Malarz \\ Uniwersytet Pedagogiczny \\ im. Komisji Edukacji Narodowej \\ w Krakowie
}

\title{
Terytorialne pochodzenie kandydatów na studia z turystyki i rekreacji w Uniwersytecie Pedagogicznym w Krakowie
}

W roku 2011 Uniwersytet Pedagogiczny im. Komisji Edukacji Narodowej w Krakowie obchodzić będzie 65 rocznicę swej działalności. Początkowo pod szyldem Wyższej Szkoły Pedagogicznej, a później Akademii Pedagogicznej w uczelni kształcili się przyszli nauczyciele, a także studenci kierunków nienauczycielskich. W rozpoczynającym się jubileuszowym roku akademickim w UP w Krakowie funkcjonowało 25 kierunków studiów stacjonarnych i prawie tyle samo niestacjonarnych. Uczelnia kształci na wszystkich trzech poziomach studiów: licencjackim (studia pierwszego stopnia), magisterskim (drugiego stopnia) i doktoranckim (trzeciego stopnia). Uniwersytet Pedagogiczny dzięki wysokim pozycjom w rankingach szkół wyższych w Polsce i dobrej bazie lokalowej cieszy się dużą popularnością wśród kandydatów na studia. Od kilku lat na pierwszy rok studiów w UP przyjmuje się ponad 2500 studentów na studia stacjonarne I stopnia (ryc. 1). W roku 2010 na studia stacjonarne pierwszego stopnia przyjęto 2885 studentów. Do tego doliczyć należy ponad 200 studentów, którzy podjęli studia II stopnia oraz 784 studentów, którzy podjęli studia w systemie niestacjonarnym (711 na studiach I stopnia i 73 na studiach II stopnia). Łącznie ze studentami studiów doktoranckich studia w UP rozpoczęło w 2010 r. prawie 3900 osób.

Ryc. 1. Liczba studentów przyjętych na studia stacjonarne I stopnia w Uniwersytecie Pedagogicznym w Krakowie w wybranych latach.

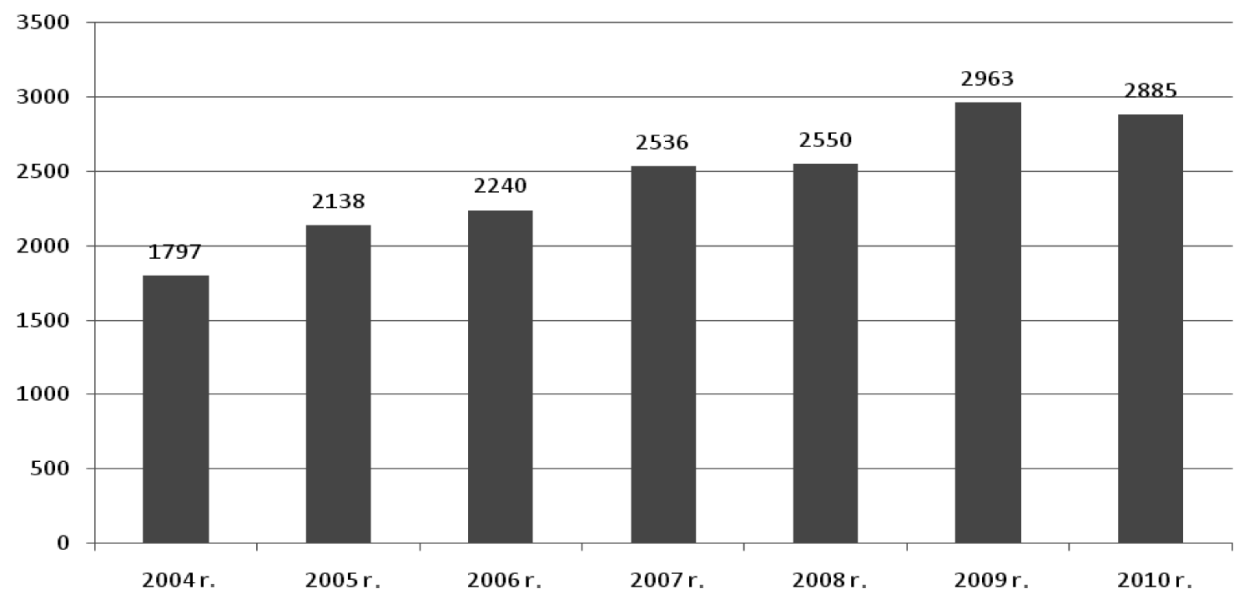

Źródło: materiały niepublikowane Uczelnianej Komisji Rekrutacyjnej UP w Krakowie. 
Ryc. 2. Liczba osób przyjętych na pierwszy rok studiów stacjonarnych (s) i niestacjonarnych (n) w Uniwersytecie Pedagogicznym w Krakowie w 2010 r.

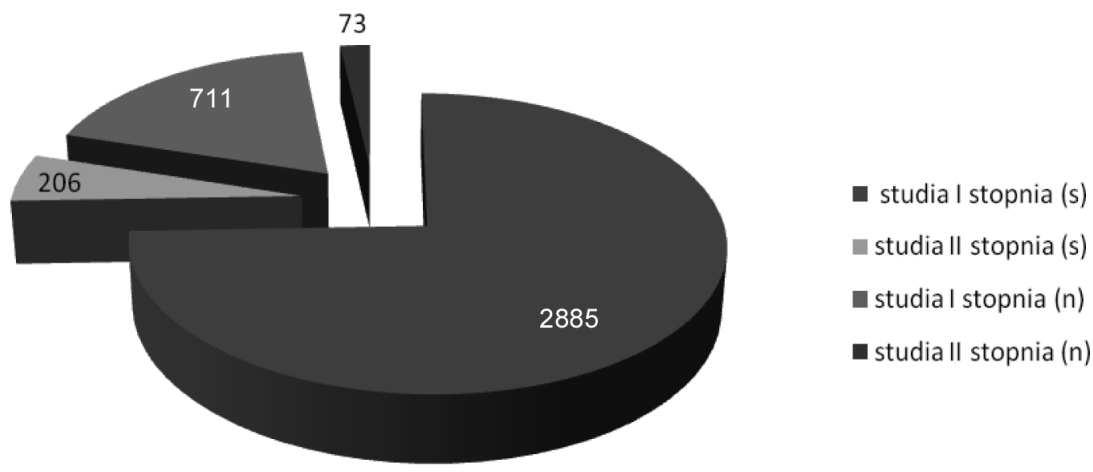

Źródło: materiały niepublikowane Uczelnianej Komisji Rekrutacyjnej UP w Krakowie.

\section{Popularność kierunków studiów}

Spośród 24 kierunków oferowanych kandydatom nie wszystkie cieszyły się jednakową popularnością. W roku 2010 największa liczba kandydatów zgłosiła się na pedagogikę przedszkolną i wczesnoszkolną, turystykę i rekreację oraz na filologię polską (tab. 1). Niewielka liczba chętnych, znacznie poniżej limitu, chciała studiować fizykę oraz filologię rosyjską z językiem rusińsko-łemkowskim. Uwzględniając liczbę miejsc na poszczególnych kierunkach, liczba kandydatów przypadających na jedno miejsce wahała się od 17,76 na filologii angielskiej do 0,18 na fizyce.

Tab. 1. Najpopularniejsze kierunki studiów I stopnia w UP w Krakowie w roku 2010

\begin{tabular}{|c|l|c|c|c|}
\hline Lp. & \multicolumn{1}{|c|}{ Kierunek studiów - specjalność } & $\begin{array}{c}\text { Liczba } \\
\text { kandydatów }\end{array}$ & Limit miejsc & $\begin{array}{c}\text { Średnio } \\
\text { na jedno } \\
\text { miejsce }\end{array}$ \\
\hline 1 & $\begin{array}{l}\text { Pedagogika; specjalność - przedszkolna } \\
\text { i wczesnoszkolna }\end{array}$ & 855 & 50 & 17,10 \\
\hline 2 & Turystyka i rekreacja & 789 & 100 & 7,88 \\
\hline 3 & Filologia polska & 739 & 240 & 3,08 \\
\hline 4 & Administracja & 706 & 60 & 11,76 \\
\hline 5 & Stosunki międzynarodowe & 618 & 60 & 10,30 \\
\hline 6 & Bezpieczeństwo narodowe & 558 & 60 & 9,30 \\
\hline 7 & Filologia angielska - nauczycielska & 533 & 45 & 11,84 \\
\hline 8 & Filologia angielska - nienauczycielska & 444 & 25 & 17,76 \\
\hline 9 & Socjologia & 411 & 90 & 4,57 \\
\hline 10 & $\begin{array}{l}\text { Pedagogika; } \\
\text { specjalność - społeczno-opiekuńcza }\end{array}$ & 384 & 100 & 3,84 \\
\hline
\end{tabular}

Źródło: materiały niepublikowane Uczelnianej Komisji Rekrutacyjnej UP w Krakowie. 


\section{Studia z turystyki i rekreacji}

Opracowania bogatych materiałów statystycznych znajdujących się w dyspozycji komisji rekrutacyjnych mają wieloletnią historię i bogatą literaturę (Długosz 1987, 1977; Jakóbczyk-Gryszkiewicz, Włodarczyk 1995; Jażdzewska, Wolaniuk 1996). Także Wydziałowa Komisja Rekrutacyjna pracująca w UP w Krakowie włączyła się w ten nurt badań (Malarz i inni 2009). Rok 2010 był drugim z kolei rokiem, w którym prowadzono rekrutację na studia z turystyki i rekreacji. W porównaniu $\mathrm{z}$ rokiem poprzednim liczba kandydatów na studia stacjonarne pierwszego stopnia spadła z 1022 (2009 r.) do 789 (2010 r.). Spadek ten był dość znaczny, gdyż wynosił $26 \%$. Tłumaczyć go mogą co najmniej trzy przyczyny. Po pierwsze, spadek urodzeń w latach 1984-2004 powoduje, że coraz mniej liczne roczniki docierają do matury. W roku 2010 maturę zdawali kandydaci urodzeni w większości w roku 1992. W roku tym urodziło się w Polsce o 6\% mniej dzieci niż w poprzednim, 1991 r. (Szymańczak 1998, Szkolnictwo 2009). W liczbach bezwzględnych wielkości te kształtowały się następująco: 547,7 tys. w roku 1991 i 515, 2 tys. w roku 1992. Ten spadek to pierwsza przyczyna mniejszej liczby kandydatów.

Drugą niezwykle ważną przyczyną była informacja o wysokich wymaganiach stawianych kandydatom przez Wydziałową Komisję Rekrutacyjną. W roku 2009 przyjmowano na studia stacjonarne z turystyki i rekreacji kandydatów, których średnia z przedmiotów zapisanych na świadectwie maturalnym przekraczała $90 \%$. Wiadomość ta nie stanowiła tajemnicy i zapewne dotarła do kandydatów, którzy w roku następnym chcieli podjąć starania o przyjęcie na studia. Wielu z nich, mając nie najlepsze świadectwa maturalne, zniechęciła do starań o przyjęcie na turystykę i rekreację. Potwierdzeniem tej tezy może być znaczny spadek kandydatów z Krakowa.

Trzecią, zdaniem autora najmniej ważną, przyczyną był nieznaczny spadek skolaryzacji rocznika 1992 w stosunku do rocznika 1991. Jednak jego wielkość raczej nie zdecydowała o spadku liczby kandydatów na studia w 2010 r. Z dużym zainteresowaniem śledzić należy liczbę kandydatów na ten kierunek studiów w następnych latach.

\section{Terytorialne pochodzenie kandydatów}

Podobnie jak w roku 2009, tak i w roku 2010 dominującą grupę stanowili kandydaci z Małopolski (bez Krakowa). Ich udział procentowy w ogólnej liczbie kandydatów wzrósł z 36,3\% w roku 2009 do 43,5\% w roku 2010 (tab. 2). Zmalał nieco udział kandydatów podających Kraków jako miejsce zamieszkania. Nadal jednak Małopolska, łącznie z Krakowem, jest województwem, z którego rekrutuje się ponad 65\% kandydatów (tab. 2).

$\mathrm{Z}$ województw ościennych najwięcej kandydatów pochodziło $\mathrm{z}$ województwa śląskiego. Odsetek kandydatów z tego województwa wzrósł z 10,2\% (2009 r.) do 12,7\% (2010 r.). Województwo śląskie uplasowało się na drugim miejscu po województwie małopolskim. W roku poprzednim miejsce to zajmowało województwo podkarpackie. Spadek województwa podkarpackiego na miejsce trzecie spowodowany jest zapewne uruchomieniem tego kierunku na państwowych i prywatnych uczelniach Rzeszowa i innych miast tego regionu. W roku akademickim 2009/2010 w województwie podkarpackim funkcjonowało siedem państw i trzy prywatne uczelnie, na których kształcili się studenci na kierunku turystyka i rekreacja (Długosz, Biały 2011). Miejsce czwarte, podobnie jak w roku poprzednim, zajmuje województwo świętokrzyskie. Jego udział wzrósł z 5,2\% w roku 2009 do 7,6\% w roku 2010. W województwie tym istnieje tylko jedna państwowa i trzy prywatne uczelnie, na których prowadzi się kształcenie na kierunku turystyka i rekreacja. Odnotowano natomiast spadek kandydatów pochodzących z województwa lubelskiego: z 3,7\% do $1,9 \%$. Województwo to nadal jednak zajmuje piąte miejsce wśród województw, z których pochodzi najwięcej kandydatów na studia $\mathrm{z}$ turystyki i rekreacji. Pozostałe województwa mają nieznaczny udział w dostarczaniu kandydatów 
na omawiany kierunek studiów. Zdziwienie wywołuje natomiast fakt, że podobnie jak w poprzednim roku, tak i w roku 2010 z województwa kujawsko-pomorskiego nie pojawił się ani jeden kandydat.

Tab. 2. Terytorialne pochodzenie kandydatów na studia z turystyki i rekreacji (licencjackie, stacjonarne) w latach 2009 i 2010.

\begin{tabular}{|c|c|c|c|c|}
\hline \multirow{2}{*}{ Województwo } & \multicolumn{2}{|c|}{ Rok 2010 } & \multicolumn{2}{c|}{ Rok 2009 } \\
\cline { 2 - 5 } & $\begin{array}{c}\text { liczba } \\
\text { kandydatów }\end{array}$ & $\begin{array}{c}\text { udzial } \\
\text { procentowy }\end{array}$ & $\begin{array}{c}\text { liczba } \\
\text { kandydatów }\end{array}$ & $\begin{array}{c}\text { udzial } \\
\text { procentowy }\end{array}$ \\
\hline małopolskie (bez Krakowa) & 337 & $\mathbf{4 3 , 5}$ & 365 & 36,3 \\
\hline Kraków & 174 & 22,3 & 301 & 30,0 \\
\hline śląskie & 99 & $\mathbf{1 2 , 7}$ & 103 & 10,2 \\
\hline podkarpackie & 76 & 9,8 & 117 & 11,6 \\
\hline świętokrzyskie & 59 & $\mathbf{7 , 6}$ & 52 & 5,2 \\
\hline lubelskie & 15 & 1,9 & 31 & 3,1 \\
\hline łódzkie & 7 & 0,9 & 12 & 1,2 \\
\hline mazowieckie & 4 & 0,5 & 9 & 0,9 \\
\hline wielkopolskie & 3 & 0,4 & 4 & 0,4 \\
\hline dolnośląskie & 3 & $\mathbf{0 , 4}$ & 2 & 0,2 \\
\hline opolskie & 3 & $\mathbf{0 , 4}$ & 1 & 0,1 \\
\hline warmińsko-mazurskie & 2 & $\mathbf{0 , 3}$ & 2 & 0,2 \\
\hline zachodniopomorskie & 2 & $\mathbf{0 , 3}$ & 2 & 0,2 \\
\hline podlaskie & 2 & $\mathbf{0 , 3}$ & 2 & 0,2 \\
\hline pomorskie & $\mathbf{0 , 1}$ & 0 & 2 & 0,2 \\
\hline kujawsko-pomorskie & 2 & 0 & 0 \\
\hline
\end{tabular}

Pogrubioną czcionką zaznaczono udziały procentowe z 2010 roku, których wielkość wzrosła w stosunku do roku poprzedniego.

Źródło: Opracowanie własne na podstawie materiałów Wydziałowej Komisji Rekrutacyjnej z lat 2009 i 2010.

\section{Kandydaci z Małopolski}

Województwo małopolskie łącznie z Krakowem to obszar, skąd pochodzi ponad $65 \%$ kandydatów na studia z turystyki i rekreacji. Wydało się godnym uwagi prześledzenie, z których regionów województwa pochodzi najwięcej kandydatów. Aby to wykazać, skonstruowano wskaźnik, w którym podano, ilu mieszkańców danej jednostki terytorialnej przypada na jednego kandydata na omawiany kierunek Uniwersytetu Pedagogicznego w Krakowie. Wyliczenia te zawarto w czwartej i ósmej kolumnie tabeli 3. Generalnym wnioskiem płynącym z tej tabeli jest dość wyraźna zależność pomiędzy odległością Uniwersytetu Pedagogicznego od miejsca 
zamieszkania a liczbą kandydatów. Stąd najlepsze wskaźniki mają: Kraków oraz powiaty krakowski i wielicki (tab. 4). Jeden kandydat przypada tam na poniżej 5 tys. mieszkańców. Grupę drugą (od 5 do 10 tys. na jednego kandydata) stanowią powiaty nieco dalej oddalone od Krakowa. Grupę trzecią (ponad 10 tys. mieszkańców na jednego kandydata) tworzą powiaty nadgraniczne Małopolski (nowotarski, dąbrowski, miechowski, oświęcimski, chrzanowski). Wyjątkiem od tej reguły jest powiat tarnowski zajmujący ostatnie miejsce w tej klasyfikacji, niezbyt oddalony od UP i nieźle skomunikowany (łatwy dojazd) z Krakowem.

Tab. 3. Liczba kandydatów na studia z turystyki i rekreacji z Małopolski w rozbiciu na powiaty i miasta na prawach powiatów.

\begin{tabular}{|c|c|c|c|c|c|c|c|}
\hline Powiat & $\begin{array}{c}\text { Liczba } \\
\text { ludności }\end{array}$ & $\begin{array}{c}\text { Liczba } \\
\text { kand. }\end{array}$ & Wskaźnik & Powiat & $\begin{array}{c}\text { Liczba } \\
\text { ludności }\end{array}$ & $\begin{array}{c}\text { Liczba } \\
\text { kand. }\end{array}$ & Wskaźnik \\
\hline krakowski & 251836 & 69 & 3650 & myślenicki & 116484 & 14 & 8321 \\
\hline wielicki & 108767 & 26 & 4183 & N. Sącz & 84556 & 10 & 8455 \\
\hline m. Kraków & 755000 & 174 & 4339 & Tarnów & 115158 & 13 & 8858 \\
\hline tatrzański & 65362 & 13 & 5028 & nowotarski & 180987 & 18 & 10055 \\
\hline bocheński & 100160 & 19 & 5272 & proszowicki & 43561 & 4 & 10890 \\
\hline olkuski & 114426 & 17 & 6731 & dąbrowski & 58562 & 5 & 11712 \\
\hline suski & 81885 & 12 & 6824 & nowosądecki & 202044 & 16 & 12628 \\
\hline brzeski & 90967 & 13 & 6997 & miechowski & 50577 & 4 & 12644 \\
\hline wadowicki & 155923 & 22 & 7087 & oświęcimski & 153352 & 9 & 17039 \\
\hline limanowski & 121153 & 17 & 7127 & chrzanowski & 127660 & 7 & 18237 \\
\hline gorlicki & 107017 & 13 & 8232 & tarnowski & 195037 & 7 & 27862 \\
\hline
\end{tabular}

Źródło: Opracowanie własne na podstawie danych z Wydziałowej Komisji Rekrutacyjnej UP w Krakowie oraz Rocznika statystycznego Małopolski 2009.

Pozytywnym zaskoczeniem jest natomiast wysoka pozycja powiatu tatrzańskiego. Pochodzi stąd 13 kandydatów, co przy niewielkiej liczbie mieszkańców lokuje ten region na wysokiej, czwartej pozycji (tab. 4).

\section{Wieś i miasto}

Województwa Polski południowo-wschodniej, skąd pochodzi ponad 80\% kandydatów na turystykę i rekreację, charakteryzują się najmniejszym stopniem urbanizacji. W Małopolsce, na Podkarpaciu i w Świętokrzyskim większość mieszkańców mieszka na wsi. Rzutować to powinno na proporcje w udziale kandydatów ze wsi i z miast. Tymczasem z każdego z analizowanych województw młodzież wiejska nie stanowi większości (tab. 3). Przewaga kandydatów z miast jest w niektórych przypadkach ogromna (łódzkie, lubelskie, śląskie). Młodzież wiejska znacznie rzadziej niż młodzież miejska podejmuje próby dostania się na studia. Przyczyn tego faktu szukać należy w znacznie niższym wskaźniku skolaryzacji ponadgimnazjalnej młodzieży wiejskiej. Na ten dyskryminujący społeczeństwo wiejskie proces zwracało uwagę wielu autorów (Szulc 2000). 
Tab. 4. Udział kandydatów z miasta i wsi z województw, z których pochodziło najwięcej kandydatów na studia z turystyki i rekreacji w UP w Krakowie w roku 2010

\begin{tabular}{|c|c|c|c|c|}
\hline Województwo & Miasto & Udzial (\%) & Wieś & Udział (\%) \\
\hline małopolskie (z Krakowem) & 285 & 57,2 & 213 & 42,8 \\
\hline śląskie & 68 & 68,7 & 31 & 31,3 \\
\hline podkarpackie & 37 & 56,0 & 29 & 44,0 \\
\hline świętokrzyskie & 37 & 62,7 & 22 & 37,3 \\
\hline lubelskie & 10 & 71,4 & 4 & 28,6 \\
\hline fódzkie & 6 & 85,7 & 1 & 14,3 \\
\hline
\end{tabular}

Źródło: Opracowanie własne na podstawie materiałów danych z Wydziałowej Komisji Rekrutacyjnej UP w Krakowie.

Spośród osób przyjętych na I rok turystyki i rekreacji z miast pochodziło 69,3\%. To znacznie więcej niż wynosił udział młodzieży miejskiej wśród kandydatów z Małopolski i wszystkich województw ościennych. Oznacza to, że z miast pochodzili także lepsi kandydaci, legitymujący się większą przeciętną na świadectwie maturalnym. W tabeli 5 zestawiono liczbę kandydatów pochodzących z miast, z których co najmniej pięciu kandydatów ubiegało się o przyjęcie na studia z turystyki i rekreacji w Uniwersytecie Pedagogicznym. Takich miast było 24 . Oczywiście dominującą pozycję zajmuje w tym zestawieniu Kraków, z którego pochodziło 174 kandydatów. Dwa następne miejsca zajmują miasta znajdujące się dziś w województwie śląskim: Bielsko-Biała i Częstochowa. W latach 70. XX w. były to miasta wojewódzkie, niezależne od Katowic, stolicy Śląska. Zdaniem autora, fakt wysokiego udziału kandydatów z Bielska-Białej i Częstochowy świadczyć może o większym szacunku dla środowiska akademickiego Krakowa niż Katowic. Ze stolicy Śląska kandydatów było dwóch i w tym zestawieniu ich nie ujęto.

Katowice to jedyna stolica województw ościennych, która nie znalazła się w zestawieniu (tab. 5). Z Kielc i Rzeszowa było po pięciu kandydatów, niewiele w porównaniu z bardziej odległymi: Zamościem (dziewięciu kandydatów) i Sandomierzem (dziewięciu kandydatów).

Zdziwienie budzić może brak w powyższym zestawieniu takich dużych miast Małopolski, jak Nowy Targ czy Oświęcim. W ubiegłym roku kandydatów z Oświęcimia było ośmiu, zaś z Nowego Targu był tylko jeden kandydat. Z listy miast, z których w roku 2009 było więcej niż pięciu kandydatów (Malarz 2009), na obecnej liście nie znalazły się jeszcze: Tarnobrzeg, Sanok, Rabka, Andrychów, Cieszyn, Jędrzejów, Myślenice i Radom. Pojawiły się natomiast miasta, które w roku poprzednim „dostarczyły” mniej niż pięciu kandydatów. Zdecydowaną progresję odnotowały: Wieliczka, Zakopane, Jordanów, Wadowice, Skarżysko-Kamienna i Czechowice-Dziedzice.

Interesujące wydawało się poddanie analizie maturalnych osiągnięć kandydatów. Zapisane są one w postaci procentowej przy każdym zdawanym na maturze przedmiocie. Średnia tych procentowych ocen była lub nie przepustką na studia. Najlepsze świadectwa mieli kandydaci z Tarnowa, Kielc, Olkusza i Zakopanego (ryc. 3, tab. 5). Najsłabszymi wynikami maturalnymi legitymowali się kandydaci z Wieliczki, Buska-Zdroju i Jordanowa. Maturzyści z Krakowa nie błyszczeli na tle innych miast. Średnia 72,1\% lokuje kandydatów ze stolicy Małopolski na 15 miejscu spośród 24 rozpatrywanych miast. 
Tab. 5. Miasta, skąd pochodziło najwięcej kandydatów wraz ze średnią ocen (w \%) z przedmiotów na świadectwie maturalnym

\begin{tabular}{|c|c|c|c|}
\hline Lp. & Miasto & $\begin{array}{c}\text { Liczba } \\
\text { kandydatów }\end{array}$ & $\begin{array}{l}\text { Średnia z przedmiotów } \\
\text { zapisanych na świadectwie }\end{array}$ \\
\hline 1 & Kraków & 174 & 72,1 \\
\hline 2 & Bielsko-Biała & 16 & 76,8 \\
\hline 3 & Częstochowa & 13 & 70,7 \\
\hline 4 & Tarnów & 12 & 83,9 \\
\hline 5 & Nowy Sącz & 10 & 71,4 \\
\hline 6 & Wieliczka & 10 & 67,6 \\
\hline 7 & Zamość & 9 & 75,9 \\
\hline 8 & Sandomierz & 9 & 74,3 \\
\hline 9 & Olkusz & 8 & 79,6 \\
\hline 10 & Mielec & 8 & 79,0 \\
\hline 11 & Skawina & 8 & 74,4 \\
\hline 12 & Bochnia & 8 & 69,0 \\
\hline 13 & Zakopane & 7 & 79,4 \\
\hline 14 & Skarżysko-Kamienna & 7 & 79,0 \\
\hline 15 & Jaworzno & 7 & 69,1 \\
\hline 16 & Czechowice-Dziedzice & 6 & 73,4 \\
\hline 17 & Gorlice & 6 & 67,9 \\
\hline 18 & Kielce & 5 & 83,2 \\
\hline 19 & Wadowice & 5 & 78,3 \\
\hline 20 & Dębica & 5 & 75,4 \\
\hline 21 & Przemyśl & 5 & 74,2 \\
\hline 22 & Rzeszów & 5 & 70,4 \\
\hline 23 & Busko-Zdrój & 5 & 66,2 \\
\hline 24 & Jordanów & 5 & 63,1 \\
\hline
\end{tabular}

Źródło: Opracowanie własne na podstawie materiałów danych z Wydziałowej Komisji Rekrutacyjnej UP w Krakowie. 
Ryc. 3. Średnie wyniki z matury kandydatów z wybranych miast

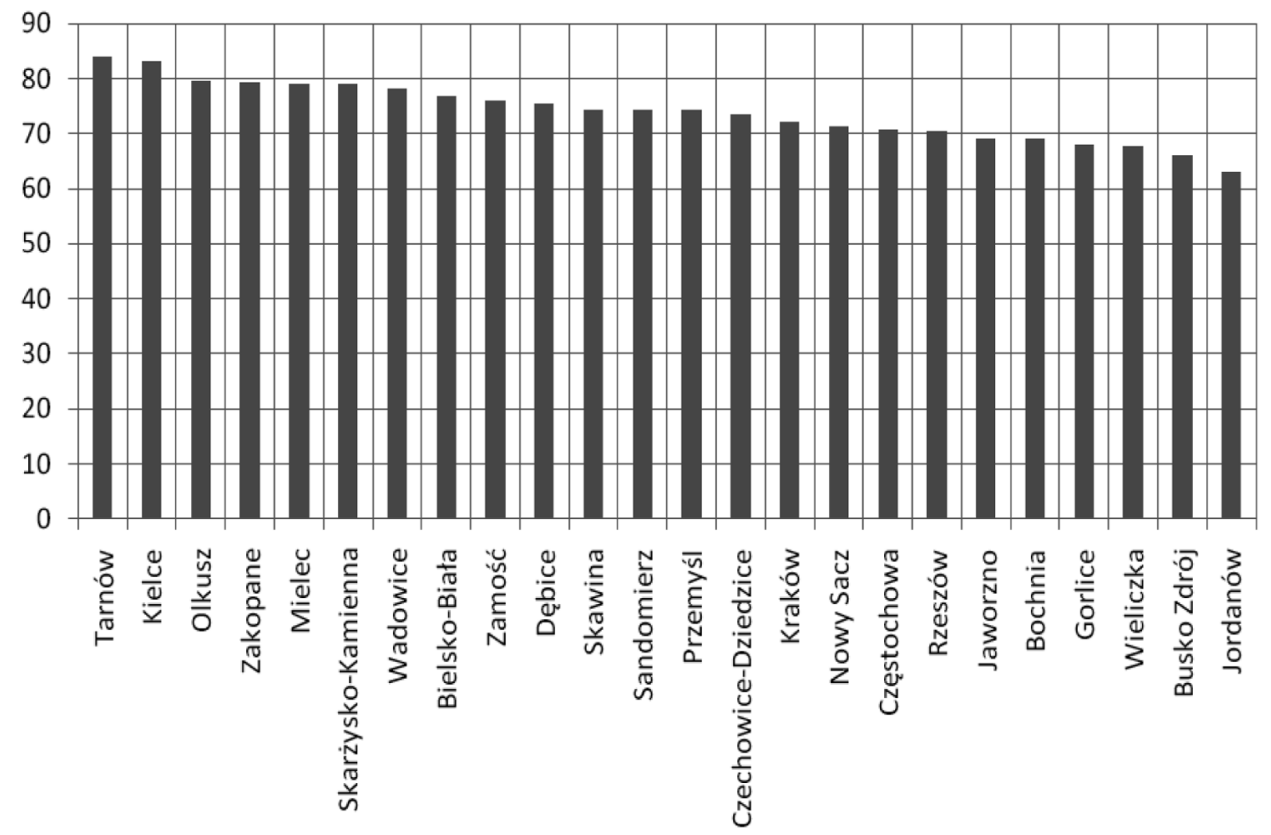

Źródło: Opracowanie własne na podstawie materiałów danych z Wydziałowej Komisji Rekrutacyjnej UP w Krakowie.

Zaprezentowane opracowanie jest kolejną analizą terytorialnego i społecznego pochodzenia kandydatów na studia z turystyki i rekreacji w Uniwersytecie Pedagogicznym w Krakowie. Autor starł się dociec, co było przyczyną spadku liczby kandydatów w stosunku do roku poprzedniego. Dwuletni okres badań zmian w terytorialnym pochodzeniu kandydatów jest zbyt krótki, aby doszukiwać się trwałych trendów i wyraźnych tendencji. Dopiero dalsze badania prowadzone w następnych latach pozwolą na wyciągnięcie prawidłowych wniosków z obfitego materiału statystycznego znajdującego się w dyspozycji Wydziałowej Komisji Rekrutacyjnej. Także badania ankietowe studentów przyjętych na pierwszy rok studiów z turystyki i rekreacji pozwolą poszerzyć wiadomości na tematy społeczne i socjologiczne (wielkość rodziny, status społeczny, wykształcenie i zatrudnienie rodziców, motywacje w wyborze kierunku studiów, oczekiwania i plany studentów). Wyniki takich badań przeprowadzonych na studentach I roku studiów stacjonarnych i niestacjonarnych zaprezentował autor w poprzednim opracowaniu (Malarz 2009).

\section{Literatura}

1. Długosz Z., 1977, Rekrutacja i wyniki egzaminów wstępnych na kierunek ,geografia” Uniwersytetu Jagiellońskiego $w$ niektórych aspektach społeczno-przestrzennych, „Zeszyty Naukowe UJ. Prace Geograficzne", z. 44, 41-54.

2. Długosz Z., 1987, Rekrutacja i wyniki egzaminów wstępnych na kierunek geograficzny w Uniwersytecie Jagiellońskim w latach 1968-1985, „Zeszyty Naukowe UJ. Prace Geograficzne”, z. 70, 167-181. 
3. Długosz Z., Biały S., 2011, Studia w zakresie turystyki na tle szkolnictwa wyższego w kraju, Konferencja „Przedsiębiorczość w warunkach globalizacji” UP Kraków, październik 2010 (w druku).

4. Jakóbczyk-Gryszkiewicz J., Włodarczyk B., 1995, Charakterystyka kandydatów na studia z geografii turyzmu $i$ hotelarstwa $w$ Uniwersytecie Lódzkim w roku akademickim 1994/95, „Turyzm”, t. 5, z. $1,84-88$.

5. Jażdżewska I., Wolaniuk A., 1996, Charakterystyka kandydatów na specjalność geografia turyzmu i hotelarstwa Uniwersytetu Łódzkiego w roku 1995, „Turyzm”, t. 6, z. 2, 121-126.

6. Malarz R., Rettinger R., Warcholik W., 2009, Preferencje młodzieży wiejskiej w wyborze kierunku studiów (na przyktadzie Uniwersytetu Pedagogicznego w Krakowie), Wydawnictwo WSEiP, Kielce (w druku).

7. Malarz R., 2009, Charakterystyka kandydatów na studia z turystyki i rekreacji $w$ Uniwersytecie Pedagogicznym w Krakowie (oddane do druku).

8. Prestiż, profesjonalizm, nowoczesność, 2009, folder reklamowy Uniwersytetu Pedagogicznego w Krakowie, Wyd. Naukowe. UP w Krakowie.

9. Rocznik statystyczny województwa małopolskiego 2009, Urząd Statystyczny w Krakowie, Kraków.

10. Szkolnictwo wyższe w Krakowie - perspektywy rozwoju w kontekście zmian demograficznych. Prognoza na lata 2009-2014, K. Jakubik (red.), Urząd Statystyczny w Krakowie, Kraków, listopad 2009.

11. Szulc T., 2000, Wyjść z wiejskiego kręgu niemocy, „Głos Uczelni”, nr 84, Wyd. Uniwersytetu Przyrodniczego we Wrocławiu, s. 16-24.

12. Szymańczak J., 1998, Zmiany demograficzne, „Studia Demograficzne”, nr 4/134, s. 8-14.

\section{Region-wise Distribution of Candidates for the Faculty of Tourism and Recreation at the Pedagogical University of Cracow}

2010 was the second year of recruitment for Tourism and Recreation studies at the Pedagogical University in Krakow. In 2009 as many as 1022 candidates applied for the full-time first stage studies at this faculty. In 2010 the number decreased by $26 \%$ (789 candidates). Despite this decrease the faculty was still one of the most popular at the Pedagogical University, and in the ranking of the number of candidates took the second place. Candidates for Tourism and Recreation faculty in $65 \%$ originated from the Malopolskie voivodeship, including $22.3 \%$ of candidates from Krakow. As compared to the previous year, the share of candidates from the capital of Malopolskie voivodeship decreased by a few per cent. A significant number of candidates originated from the surrounding voivodeships: the Silesian, Subcarpathian and Świętokrzyskie voivodeships. From amongst other voivodeships a significant number of candidates originated from the Lubelskie voivodeship. In the recruitment so far there were no candidates from Kuyavia and Pomerania voivodeship.

Most candidates from the Malopolskie voivodeship came from the nearest - Wielicki and Krakovian - poviats, whereas the fewest from the frontier regions (Nowotarski, Miechowski, Oswiecimski and Chrzanowski poviats). Most candidates were town inhabitants - over 69\% of the total candidates. There were as many as 24 towns with 5 candidates and more. The secondary school final examinations [Matura] results were also assessed. The best results were achieved by candidates from Tarnow, Kielce, Olkusz and Zakopane. The poorest results were achieved by candidates from Wieliczka, Busko Zdroj and Jordanow. A two-year cycle of research devoted to the candidates for tourism and recreation faculty reveals a considerable shift in the region-wise distribution of candidates for the faculty, however the period is too short to distinguish clear directions and trends in the shift. 


\author{
Alina Haczek \\ Uniwersytet Pedagogiczny \\ im. Komisji Edukacji Narodowej \\ w Krakowie
}

\title{
Funkcjonowanie bielskiego ośrodka akademickiego w warunkach globalizacji
}

Globalizację można najprościej zdefiniować jako wzrost zasięgu, wielości, różnorodności, szybkości i intensywności wzajemnych wpływów, zależności i oddziaływań między państwami oraz społecznościami. Jest ona procesem złożonym, wielowymiarowym, dotyczącym wszystkich dziedzin życia i w określony sposób wpływającym na kondycję ekonomiczną poszczególnych regionów, państw oraz społeczeństw. Głównym narzędziem, a zarazem nośnikiem współczesnej globalizacji jest postęp naukowo-techniczny, zwłaszcza w zakresie środków transportu i komunikacji. Jest on przyczyną niespotykanego w historii wzrostu efektywności gospodarowania (Polak 2009). Nowe technologie są coraz bardziej skomplikowane, wymagają coraz bardziej szczegółowej i wyspecjalizowanej wiedzy oraz umiejętności skumulowanych w kapitale ludzkim. Dlatego też, jak podkreśla wielu autorów (m.in. Denek 2001, Gnitecki 2002, Radło 2003, Janc 2004, Zioło 2008, Borowiec 2010) w warunkach postępującej globalizacji i rozwoju gospodarki opartej na wiedzy, niezwykle ważne jest podnoszenie jakości zasobów ludzkich. Inwestowanie w kapitał ludzki wpływa bowiem na zdolność jego szybkiej adaptacji do nowej rzeczywistości oraz stanowi podstawowy warunek trwałego wzrostu gospodarczego i postępu technicznego. Jednym z podstawowych czynników wpływających na podnoszenie jakości kapitału ludzkiego i kształtowanie społeczeństwa informacyjnego jest edukacja, zwłaszcza edukacja na poziomie wyższym. Dlatego też bardzo ważnym wyzwaniem, które powinno podjąć ,,społeczeństwo globalne”, jest upowszechnienie szkolnictwa wyższego wraz z jego przystosowaniem do zmian cywilizacyjnych. Jednocześnie można stwierdzić, że w dobie nowoczesnych technologii, wynalazków, funkcjonowanie bez edukacji jest wręcz niemożliwe i odwrotnie. To ewolucja ekonomiczna napędza system edukacji, wymuszając na nim dokonywanie zmian i dostosowanie się do potrzeb rynku. Z drugiej strony natomiast to właśnie edukacja na wysokim poziomie pozwala na istnienie i rozwijanie się (Słobodzian 2001).

Szczególnego znaczenia w zakresie kształtowania jakości kapitału ludzkiego nabierają więc szkoły wyższe i ośrodki akademickie, których potencjał traktowany jest jako jeden z kluczowych czynników budowania nowoczesnej gospodarki. Zasoby ludzkie - wykształcone społeczeństwo o wysokich kwalifikacjach zawodowych, przedsiębiorcze i mobilne zawodowo - są fundamentem konkurencyjności i atrakcyjności regionu w globalnej gospodarce (Nowakowska, Boryczka 2008).

W nawiązaniu do powyższych przesłanek w artykule podjęto problematykę funkcjonowania bielskiego ośrodka akademickiego w warunkach globalizacji. Celem pracy jest przedstawienie zmian potencjału edukacyjnego ośrodka w latach 1969-2009, a także zmian kierunków 
kształcenia oraz ich dopasowanie do warunków nasilających się procesów globalizacji i nowoczesnej gospodarki. Ponadto zmierzać się będzie do ukazania zasięgu przestrzennego oddziaływania bielskiego ośrodka akademickiego określonego na podstawie miejsc stałego zamieszkania jego studentów w roku akademickim 2008/2009¹.

Bielski ośrodek akademicki funkcjonuje już przeszło 40 lat. Jego geneza związana jest bezpośrednio $\mathrm{z}$ dynamicznie rozwijającym się $\mathrm{w}$ latach powojennych bielskim przemysłem włókienniczym i elektromaszynowym. Ogromne zapotrzebowanie na wykształconych w tych dziedzinach specjalistów zrodziło potrzebę założenia w mieście pierwszych szkół wyższych. W 1966 r. utworzono w Bielsku-Białej zamiejscowy ośrodek ówczesnej Wyższej Szkoły Ekonomicznej w Katowicach (dzisiejszej Akademii Ekonomicznej im. K. Adamieckiego), a trzy lata później powstała bielska filia Politechniki Łódzkiej. Kolejne uczelnie, w większości niepubliczne, powstały w bielskim ośrodku akademickim w latach transformacji polityczno-gospodarczej. W wyniku długoletniego rozwoju szkolnictwa wyższego Bielsko-Biała stała się w pełni ukształtowanym i prężnie działającym ośrodkiem akademickim. Jedyną publiczną, samodzielnie działającą tutaj uczelnią, jest Akademia Techniczno-Humanistyczna, utworzona w 2001 r. z przekształcenia bielskiej filii Politechniki Łódzkiej. Oprócz niej działa tu także wspomniana wcześniej filia państwowej Akademii Ekonomicznej w Katowicach (Bielski Ośrodek Naukowo-Dydaktyczny Akademii Ekonomicznej w Katowicach), a także jedna szkoła posiadająca status kościelnej szkoły wyższej (Instytut Teologiczny w Bielsku-Białej). W bielskim ośrodku akademickim funkcjonuje również pięć niepublicznych szkół wyższych. Są to: Bielska Wyższa Szkoła im. J. Tyszkiewicza, Wyższa Szkoła Administracji, Wyższa Szkoła Bankowości i Finansów, Wyższa Szkoła Ekonomiczno-Humanistyczna oraz Wyższa Szkoła Informatyki i Zarządzania. Ponadto w Bielsku-Białej funkcjonuje Kolegium Nauczycielskie, które pod opieką naukowo-dydaktyczną kilku uczelni patronackich kształci przyszłych nauczycieli. Jest to jedna z największych placówek tego typu w Polsce, liczbą studentów dorównująca innym bielskim szkołom wyższym.

W konsekwencji kształtowania się bielskiego ośrodka akademickiego można zauważyć znaczące przemiany w liczbie studentów. W latach 1969-2009 ich liczba wzrosła z 225 do 15,8 tys., tj. prawie siedemdziesięciokrotnie (ryc. 1, tab. 1). Na podstawie analizy dynamiki liczby studentów bielskiego ośrodka akademickiego można wyróżnić cztery okresy. Okres pierwszy to lata akademickie 1969/1970-1977/1978, kiedy to liczba studentów wzrosła z 225 do 1,4 tys., czyli do 622,2\%. Był to czas gospodarki centralnie sterowanej, charakteryzujący się powszechną industrializacją, która w ogromnym stopniu zwiększyła zapotrzebowanie na wykształcone kadry dla prężnie rozwijającego się przemysłu, w przypadku Bielska-Białej dla przemysłu włókienniczego i elektromaszynowego. W drugim okresie, obejmującym lata akademickie 1977/1978-1986/1987, nastąpił spadek liczby studentów z 1,4 tys. do 509, tj. do 36,4\%. Sytuacja taka wywołana była wieloma różnorodnymi czynnikami społeczno-ekonomicznymi. Przede wszystkim ogólny kryzys gospodarczy spowodował znaczny spadek produkcji, a tym samym przyczynił się do zmniejszenia zapotrzebowania na kadry specjalistów. Ponadto pogarszające się warunki materialne ludności w zasadniczym stopniu wpłynęły na obniżenie presji społecznej w dążeniu do uzyskania wyższego wykształcenia. Na te czynniki dodatkowo nałożył się niż demograficzny grupy wiekowej typowej dla kandydatów na studia wyższe, skutkując znacznym obniżeniem liczby studentów nie tylko w bielskim ośrodku akademickim, ale także w całej Polsce (Kluczyński 1991).

\footnotetext{
${ }^{1}$ Prezentowane wyniki badań pochodzą z pracy magisterskiej autorki artykułu pt. Rozwój i przestrzenne oddziaływanie bielskiego ośrodka akademickiego napisanej pod kierunkiem prof. dr hab. inż. E. Kaczmarskiej oraz dr M. Borowiec w roku akademickim 2009/2010.
} 
Ryc. 1. Zmiany liczby studentów w bielskim ośrodku akademickim w latach 1969-2009

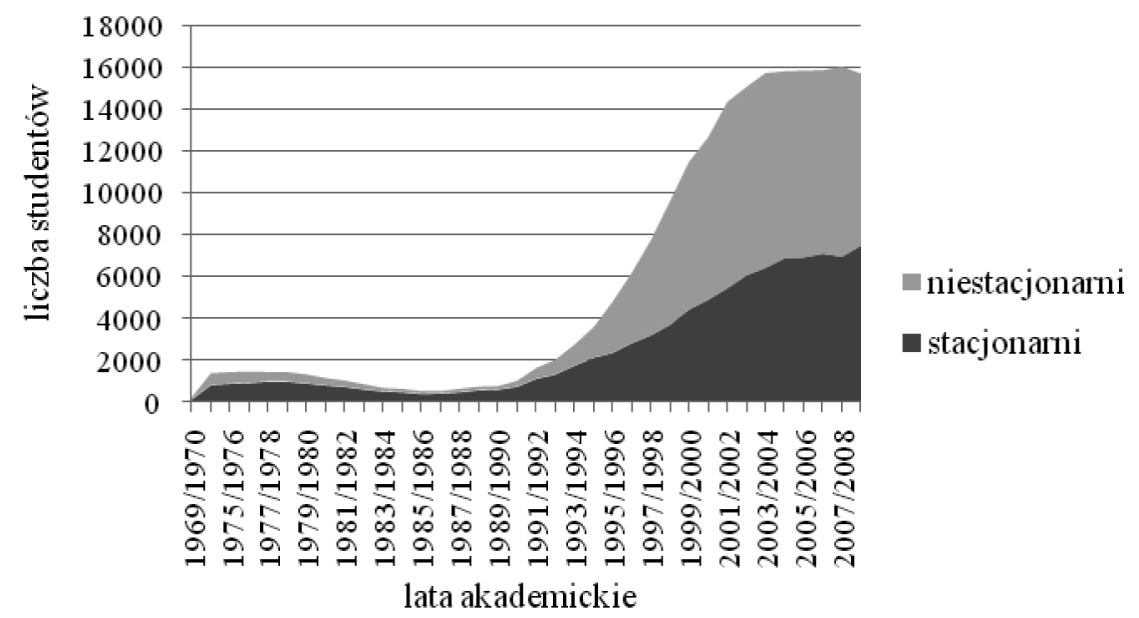

Źródło: opracowanie własne na podstawie tabeli 1.

Trzeci okres charakteryzował się dynamicznym wzrostem liczby studentów z 509 w roku akademickim 1986/1987 do 16,1 tys. w 2007/2008, czyli aż do 3163,1\%. Na taką sytuację wpłynęły głównie licznie powstające po 1990 r. szkoły wyższe. Uczelnie te, w większości przypadków niepubliczne, zwiększyły dostęp do edukacji na poziomie wyższym. Ponadto, pod wpływem przemian społeczno-gospodarczych w naszym kraju, diametralnie zmieniło się nastawienie do studiów wyższych. Dla wielu młodych ludzi stały się one szansą podniesienia kwalifikacji, a tym samym gwarantem znalezienia lepszej pracy w przyszłości. Natomiast w ostatnim badanym roku akademickim: 2008/2009, w porównaniu z rokiem poprzednim zaznaczył się spadek liczby studentów o 325 osób, tj. do 98,0\%. Jest to pierwsza oznaka wchodzenia w wiek typowy dla kandydatów na studia roczników z niżu demograficznego. Dlatego też można przypuszczać, iż w ciągu następnych kilku lat liczba studentów bielskiego ośrodka akademickiego będzie charakteryzowała się tendencją spadkową.

Na zróżnicowanie dynamiki liczby studentów w latach 1969-2009 zmienny wpływ mieli zarówno studenci studiów stacjonarnych, jak i studiów niestacjonarnych (ryc. 1, tab. 1). W pierwszym wyróżnionym okresie liczba studentów stacjonarnych zwiększyła się ze 127 w roku akademickim 1969/1970 do 978 w roku akademickim 1977/1978, czyli do 770,1\%. Równocześnie liczba studentów niestacjonarnych wzrosła z 98 w roku akademickim 1969/1970 do 547 w roku akademickim 1974/75, czyli do 558,1\%, a w ciągu następnych trzech lat zanotowano ich nieznaczny spadek do 448 w roku akademickim 1977/1978, tj. do 457,1\%. Jednocześnie można zauważyć, że w badanym okresie czasu wyższą dynamiką wzrostu liczby studentów charakteryzowali się studenci studiów stacjonarnych, co odzwierciedla zwiększenie się ich udziału w ogólnej liczbie studentów z 56,4\% w roku akademickim 1969/1970 do 68,6\% w roku akademickim 1977/1978. W drugim okresie czasu nastąpił znaczny spadek liczby studentów zarówno studiów stacjonarnych, jak i studiów niestacjonarnych. W pierwszej z tych grup zaznaczył się spadek z 978 studentów w roku akademickim 1977/1978 do 412 w roku 1986/1987, czyli do 42,1\%. Natomiast w przypadku studentów niestacjonarnych zanotowano spadek z 448 w 1977/1978 do 97 studiujących w 1986/1987, czyli do 21,6\%. W analizowanym okresie czasu zwiększył się udział studentów stacjonarnych w ogólnej liczbie studentów 
bielskiego ośrodka akademickiego z 68,6\% w 1977/1978 do 80,0\% w roku akademickim 1986/1987. W trzecim okresie liczba studentów stacjonarnych wzrosła z $412 \mathrm{w}$ roku akademickim 1986/1987 do 6,9 tys. w 2007/2008, czyli do $1674,8 \%$, natomiast w wypadku studentów studiów niestacjonarnych w tych samych latach akademickich zanotowano wzrost z 97 do 9,1 tys., tj. do $9381,4 \%$. Warto zauważyć, że w badanym okresie, przeciwnie do okresów wcześniejszych, dynamika wzrostu liczby studentów niestacjonarnych była wyższa niż studentów stacjonarnych. Wyrazem tego procesu jest zwiększenie się udziału liczby studentów niestacjonarnych w ogólnej liczbie studentów bielskich uczelni z 19,1\% w roku akademickim 1986/1987 do 56,8\% w roku 2007/2008. Taka diametralna zmiana wynika ze zmieniających się warunków na rynku pracy. Obecnie samo wyższe wykształcenie nie gwarantuje znalezienia dobrze płatnej i atrakcyjnej pracy. Coraz bardziej liczą się za to zdobyte umiejętności i doświadczenie zawodowe. Dlatego też wiele młodych ludzi podejmuje studia niestacjonarne i równocześnie odbywa staż zawodowy, bardzo pożądany, a niekiedy wręcz wymagany przez przyszłych pracodowaców. Doświadczenie zawodowe zdobyte podczas studiów czyni ich w przyszłości bardziej konkurencyjnymi na rynku pracy w stosunku do osób kończących studia trybem stacjonornym i nieposiadających odpowiedniego przygotowania praktycznego. Ostatni badany rok akademicki (2008/2009) charakteryzował się niewielkim wzrostem liczby studentów stacjonarnych z 6,9 tys. w roku poprzednim do 7,5 tys., tj. do 108,7\%. Odwrotna sytuacja dotyczyła natomiast studentów niestacjonarnych, gdyż ich liczba spadła z 9,1 tys. w roku akademickim 2007/2008 do 8,3 tys. w roku $2008 / 2009$, czyli do $91,2 \%$. Ponadto w porównaniu z rokiem poprzednim nieznacznie zmniejszył się ich udział w ogólnej liczbie studentów z 56,8\% do 52,5\%.

Tab. 1. Zmiany liczby studentów w bielskim ośrodku akademickim w latach 1969-2009

\begin{tabular}{|c|c|c|c|c|c|c|c|c|}
\hline \multirow[b]{2}{*}{$\begin{array}{c}\text { Lata } \\
\text { akademickie }\end{array}$} & \multicolumn{3}{|c|}{ Liczba studentów } & \multicolumn{2}{|c|}{ Udzial studentów } & \multicolumn{3}{|c|}{ Dynamika liczby studentów } \\
\hline & $\frac{\Xi}{0}$ & 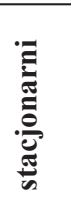 & 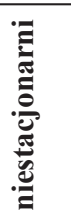 & 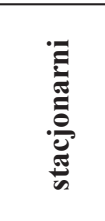 & 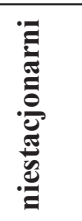 & $\frac{\Xi}{0}$ & 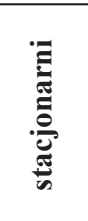 & 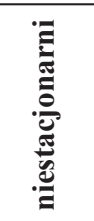 \\
\hline $1969 / 1970$ & 225 & 127 & 98 & 56,4 & 43,6 & 100,0 & 100,0 & 100,0 \\
\hline $1974 / 1975$ & 1372 & 825 & 547 & 60,1 & 39,9 & 609,8 & 649,6 & 558,2 \\
\hline $1975 / 1976$ & 1422 & 879 & 543 & 61,8 & 38,2 & 632,0 & 692,1 & 554,1 \\
\hline $1976 / 1977$ & 1450 & 915 & 535 & 63,1 & 36,9 & 644,4 & 720,5 & 545,9 \\
\hline $1977 / 1978$ & 1426 & 978 & 448 & 68,6 & 31,4 & 633,8 & 770,1 & 457,1 \\
\hline $1978 / 1979$ & 1424 & 973 & 451 & 68,3 & 31,7 & 632,9 & 766,1 & 460,2 \\
\hline $1979 / 1980$ & 1314 & 887 & 427 & 67,5 & 32,5 & 584,0 & 698,4 & 435,7 \\
\hline $1980 / 1981$ & 1136 & 796 & 340 & 70,1 & 29,9 & 504,9 & 626,8 & 346,9 \\
\hline $1981 / 1982$ & 1014 & 723 & 291 & 71,3 & 28,7 & 450,7 & 569,3 & 296,9 \\
\hline $1982 / 1983$ & 841 & 603 & 238 & 71,7 & 28,3 & 373,8 & 474,8 & 242,9 \\
\hline $1983 / 1984$ & 667 & 510 & 157 & 76,5 & 23,5 & 296,4 & 401,6 & 160,2 \\
\hline $1984 / 1985$ & 615 & 470 & 145 & 76,4 & 23,6 & 273,3 & 370,1 & 148,0 \\
\hline
\end{tabular}




\begin{tabular}{|c|c|c|c|c|c|c|c|c|}
\hline \multirow[b]{2}{*}{$\begin{array}{c}\text { Lata } \\
\text { akademickie }\end{array}$} & \multicolumn{3}{|c|}{ Liczba studentów } & \multicolumn{2}{|c|}{ Udział studentów } & \multicolumn{3}{|c|}{ Dynamika liczby studentów } \\
\hline & $\frac{\Xi}{0}$ & 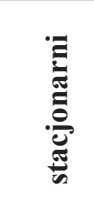 & 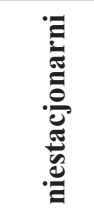 & 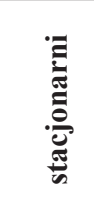 & 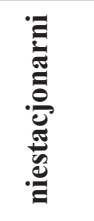 & $\frac{\Xi}{0}$ & 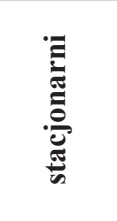 & 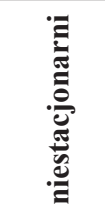 \\
\hline $1985 / 1986$ & 517 & 387 & 130 & 74,9 & 25,1 & 229,8 & 304,7 & 132,7 \\
\hline $1986 / 1987$ & 509 & 412 & 97 & 80,9 & 19,1 & 226,2 & 324,4 & 99,0 \\
\hline $1987 / 1988$ & 621 & 472 & 149 & 76,0 & 24,0 & 276,0 & 371,7 & 152,0 \\
\hline $1988 / 1989$ & 725 & 570 & 155 & 78,6 & 21,4 & 322,2 & 448,8 & 158,2 \\
\hline $1989 / 1990$ & 753 & 595 & 158 & 79,0 & 21,0 & 334,7 & 468,5 & 161,2 \\
\hline 1990/1991 & 1006 & 734 & 272 & 73,0 & 27,0 & 447,1 & 578,0 & 277,6 \\
\hline 1991/1992 & 1615 & 1113 & 502 & 68,9 & 31,1 & 717,8 & 876,4 & 512,2 \\
\hline $1992 / 1993$ & 2006 & 1321 & 685 & 65,9 & 34,1 & 891,6 & 1040,2 & 699,0 \\
\hline 1993/1994 & 2737 & 1740 & 997 & 63,6 & 36,4 & 1216,4 & 1370,1 & 1017,3 \\
\hline $1994 / 1995$ & 3576 & 2121 & 1455 & 59,3 & 40,7 & 1589,3 & 1670,1 & 1484,7 \\
\hline 1995/1996 & 4789 & 2351 & 2438 & 49,1 & 50,9 & 2128,4 & 1851,2 & 2487,8 \\
\hline $1996 / 1997$ & 6184 & 2814 & 3370 & 45,5 & 54,5 & 2748,4 & 2215,7 & 3438,8 \\
\hline $1997 / 1998$ & 7752 & 3191 & 4561 & 41,2 & 58,8 & 3445,3 & 2512,6 & 4654,1 \\
\hline 1998/1999 & 9634 & 3697 & 5937 & 38,4 & 61,6 & 4281,8 & 2911,0 & 6058,2 \\
\hline $1999 / 2000$ & 11512 & 4425 & 7087 & 38,4 & 61,6 & 5116,4 & 3484,3 & 7231,6 \\
\hline $2000 / 2001$ & 12696 & 4893 & 7803 & 38,5 & 61,5 & 5642,7 & 3852,8 & 7962,2 \\
\hline $2001 / 2002$ & 14392 & 5444 & 8948 & 37,8 & 62,2 & 6396,4 & 4286,6 & 9130,6 \\
\hline $2002 / 2003$ & 15112 & 6064 & 9048 & 40,1 & 59,9 & 6716,4 & 4774,8 & 9232,7 \\
\hline $2003 / 2004$ & 15775 & 6414 & 9361 & 40,7 & 59,3 & 7011,1 & 5050,4 & 9552,0 \\
\hline $2004 / 2005$ & 15861 & 6877 & 8984 & 43,4 & 56,6 & 7049,3 & 5415,0 & 9167,3 \\
\hline $2005 / 2006$ & 15893 & 6914 & 8979 & 43,5 & 56,5 & 7063,6 & 5444,1 & 9162,2 \\
\hline $2006 / 2007$ & 15912 & 7090 & 8822 & 44,6 & 55,4 & 7072,0 & 5582,7 & 9002,0 \\
\hline $2007 / 2008$ & 16080 & 6951 & 9129 & 43,2 & 56,8 & 7146,7 & 5473,2 & 9315,3 \\
\hline $2008 / 2009$ & 15755 & 7483 & 8272 & 47,5 & 52,5 & 7002,2 & 5892,1 & 8440,8 \\
\hline
\end{tabular}

Źródło: opracowanie własne na podstawie danych uzyskanych w dziekanatach bielskich uczelni.

Jednym z podstawowych wyzwań, które globalizacja stawia przed szkolnictwem wyższym, jest dopasowanie kierunków kształcenia do wymogów nowoczesnej gospodarki i coraz bardziej wymagającego rynku pracy. W związku z dynamicznym postępem naukowo-technicznym 
szczególnie ważny jest rozwój nauk ścisłych, głównie technicznych i inżynieryjnych. Niezwykle istotny jest także rozwój filologii, zwłaszcza filologii angielskiej, gdyż pod wpływem zachodzących procesów globalizacji język ten stał się językiem globalnym. Umożliwia on komunikowanie się ludźmi, dominuje również w różnego rodzaju publikacjach naukowych, stając się fundamentem funkcjonowania w ,globalnej wiosce”. Na potrzeby niniejszej pracy spośród różnorodnych kierunków oferowanych przez bielskie szkoły wyższe wybrano tylko tzw. kierunki nośne współczesnej globalizacji, które są podstawą rozwoju technologicznego i wdrażania innowacji. Są to: automatyka i robotyka, informatyka, inżynieria środowiska, mechanika i budowa maszyn, zarządzanie i inżynieria produkcji oraz wspomniana już wcześniej filologia angielska².

Ryc. 2. Zmiany liczby studentów na wybranych kierunkach kształcenia bielskiego ośrodka akademickiego w latach 1969-2009

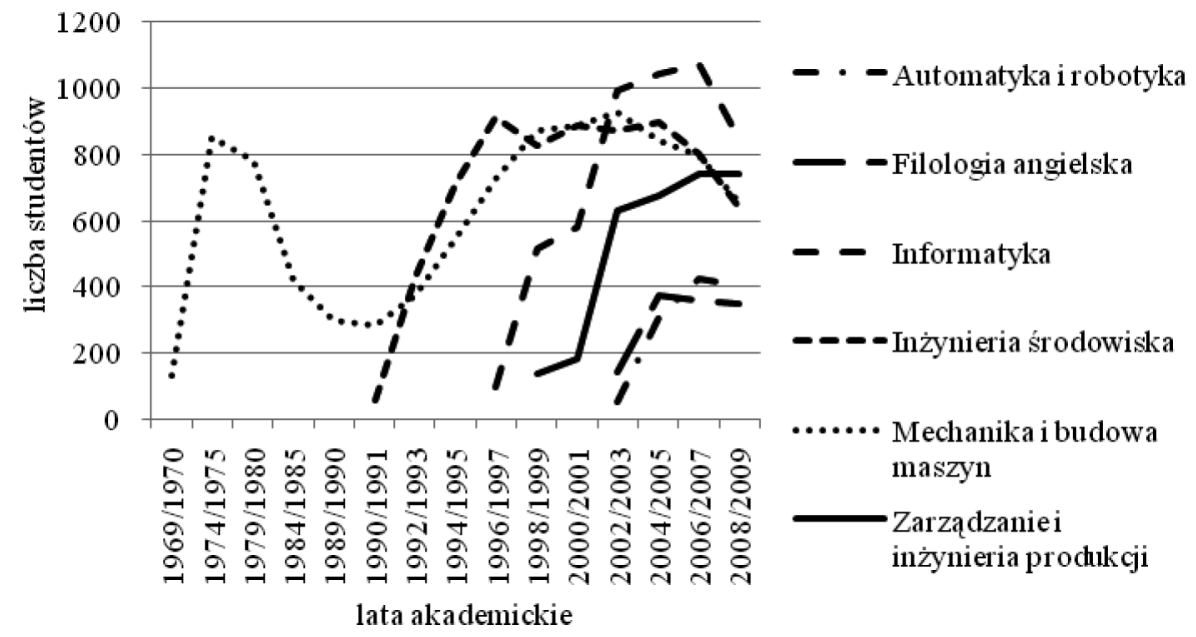

Źródło: opracowanie własne na podstawie tabeli 2.

Wszystkie te kierunki charakteryzowały się bardzo dużą dynamiką wzrostu liczby studentów, zwłaszcza w latach transformacji gospodarki narodowej (ryc. 2, tab. 2). Najwyższa dynamika liczby studentów cechowała inżynierię środowiska. Liczba studentów tego kierunku wzrosła z 55 w roku akademickim 1990/1991 do 912 w roku 1996/1997, czyli do 1658,2\%, a następnie zaznaczył się spadek do 639 w roku 2008/2009, czyli do 70,1\%. Na drugim miejscu znalazła się informatyka. Liczba studentów tego kierunku wzrosła z 95 w roku akademickim 1996/1997 do 1073 w roku 2006/2007, czyli do 1129,5\%. Natomiast w ostatnich latach zaznaczył się spadek liczby studentów informatyki z 1073 w roku 2006/2007 do 848 w roku 2008/2009, czyli do $79 \%$. W ramach obu wymienionych kierunków funkcjonują nowoczesne specjalizacje, tj. technologie materiałowe w inżynierii środowiska oraz telekomunikacja i sieci komputerowe $\mathrm{w}$ informatyce.

$\overline{2}$ Ze względu na trudności z uzyskaniem danych poniższa analiza obejmuje kierunki kształcenia oferowane tylko przez pięć bielskich szkół wyższych (Akademię Techniczno-Humanistyczną, Akademię Ekonomiczną, Instytut Teologiczny, Bielską Wyższą Szkołę im. J. Tyszkiewicza oraz Kolegium Nauczycielskie). 
Tab. 2. Zmiany liczby studentów na wybranych kierunkach bielskiego ośrodka akademickiego w latach 1969-2009

\begin{tabular}{|c|c|c|c|c|c|c|}
\hline $\begin{array}{c}\text { Lata } \\
\text { akademickie }\end{array}$ & $\begin{array}{c}\text { Automatyka } \\
\text { i robotyka }\end{array}$ & $\begin{array}{l}\text { Filologia } \\
\text { angielska }\end{array}$ & Informatyka & $\begin{array}{c}\text { Inżynieria } \\
\text { środowiska }\end{array}$ & $\begin{array}{c}\text { Mechanika } \\
\text { i budowa } \\
\text { maszyn }\end{array}$ & $\begin{array}{c}\text { Zarządzanie } \\
\text { i inżynieria } \\
\text { produkcji }\end{array}$ \\
\hline $1969 / 1970$ & - & - & - & - & 134 & - \\
\hline $1974 / 1975$ & - & - & - & - & 852 & - \\
\hline $1979 / 1980$ & - & - & - & - & 780 & - \\
\hline $1984 / 1985$ & - & - & - & - & 419 & - \\
\hline $1989 / 1990$ & - & - & - & - & 300 & - \\
\hline 1990/1991 & - & - & - & 55 & 283 & - \\
\hline $1992 / 1993$ & - & - & - & 429 & 374 & - \\
\hline $1994 / 1995$ & - & - & - & 712 & 545 & - \\
\hline $1996 / 1997$ & - & - & 95 & 912 & 728 & - \\
\hline 1998/1999 & - & - & 512 & 826 & 870 & 138 \\
\hline $2000 / 2001$ & - & - & 580 & 887 & 886 & 183 \\
\hline $2002 / 2003$ & 50 & 141 & 990 & 874 & 927 & 628 \\
\hline $2004 / 2005$ & 308 & 376 & 1043 & 897 & 841 & 673 \\
\hline $2006 / 2007$ & 422 & 361 & 1073 & 799 & 796 & 742 \\
\hline $2008 / 2009$ & 403 & 346 & 848 & 639 & 655 & 739 \\
\hline
\end{tabular}

Źródło: opracowanie własne na podstawie danych uzyskanych w dziekanatach bielskich uczelni.

Najstarszym spośród omawianych kierunków jest mechanika i budowa maszyn. W pierwszym roku akademickim (1960/1970) studiowały ją 134 osoby i ich liczba systematycznie rosła aż do 852 w roku 1974/1975, czyli do 635,8\%. Następnie zaznaczył się spadek liczby studentów tego kierunku z 852 w roku 1974/1975 do 283 w roku 1990/1991, czyli do 33,2\%, związany z ogólnym kryzysem gospodarczym w całym kraju. Następne lata przyniosły wzrost liczby studentów z 283 w roku 1990/1991 do 927 w roku akademickim 2002/2003, czyli do $327,6 \%$. Od tego roku liczba studentów mechaniki i budowy maszyn charakteryzowała się tendencją malejącą. W latach 2002/2003-2008/2009 ich liczba spadła z 927 do 655, tj. do $70,7 \%$. Absolwenci tego kierunku dysponują szeroką wiedzą z zakresu budowy, konstrukcji i eksploatacji maszyn dla różnych sektorów produkcji przemysłowej, a także, dzięki prowadzonej specjalizacji, umiejętnościami wykorzystania nowoczesnych narzędzi komputerowych w projektach inżynierskich.

Kolejnym wyróżnionym kierunkiem jest automatyka i robotyka. Liczba studentów tego kierunku w latach akademickich 2002/2003-2006/2007 wzrosła z 50 do 422, czyli do 844\%. Następnie ich liczba spadła z 422 w roku 2006/2007 do 403 w roku 2008/2009, czyli do 95,5\%. Automatyka i robotyka jest nowoczesnym i przyszłościowym kierunkiem studiów, w ramach którego studenci uczą się sterowania procesami technologicznymi za pomocą urządzeń różnego rodzaju, a dzięki swojej wiedzy mają możliwość uzyskania atrakcyjnej pracy. 
Natomiast liczba studentów kolejnego kierunku - filologii angielskiej - wzrosła ze $141 \mathrm{w}$ roku akademickim 2002/2003 do 376 w roku akademickim 2004/2005, czyli do 266,7\%, a następnie spadła do 346 w roku akademickim 2008/2009, czyli do 92,0\%. Ostatnim wyróżnionym kierunkiem studiów jest zarządzanie i inżynieria produkcji. Liczba studentów tego kierunku zwiększyła się ze 138 w roku akademickim 1998/1999 do 742 w roku 2006/2007, czyli do 537,7\%, a następnie zaznaczył się ich niewielki spadek do 739 w roku 2008/2009, czyli do 99,6\%. Absolwenci tego kierunku studiów posiadają bogate umiejętności menedżerskie pozwalające im na kierowanie personelem oraz projektowanie, organizowanie i zarządzanie procesem produkcyjnym. Ponadto w ramach studiów studenci mogą wybrać nowoczesną specjalizację, jaką są informatyczne systemy zarządzania.

Analizując dynamikę liczby studentów na wyszczególnionych kierunkach studiów, należy zauważyć, że na wszystkich z nich w ciągu kilku ostatnich lat nastąpił spadek liczby studentów. Z jednej strony sytuacja taka może wynikać z omawianego już wcześniej niżu demograficznego i mniejszej podaży kandydatów na studia, a z drugiej strony związana jest z powstawaniem nowych kierunków studiów, w większości humanistycznych, a zarazem modą na takie kierunki studiów. Przykładem mogą być architektura krajobrazu, filologia słowiańska, filologia hiszpańska, pielęgniarstwo, charakteryzujące się w ostatnich latach dużą dynamiką wzrostu liczby studentów oraz coraz większym zainteresowaniem przyszłych kandydatów na studia (ryc. 3.). Liczba studentów architektury krajobrazu wzrosła w latach 2006/2007-2008/2009 z 21 do 162, czyli do 771,4\%. Podobnie liczba studentów pielęgniarstwa w tych samych latach wzrosła z 284 do 324, czyli do 114,1\%. Natomiast liczba studentów filologii słowiańskiej zwiększyła się z 148 w roku 2002/2003 do 415 w roku 2008/2009, czyli do 280,4\%, a liczba studentów filologii hiszpańskiej wzrosła w latach 2004/2005-2008/2009 z 47 do 193, czyli do 410,6\%.

Ryc. 3. Zmiany liczby studentów na wybranych kierunkach studiów bielskiego ośrodka akademickiego w latach 1969-2009

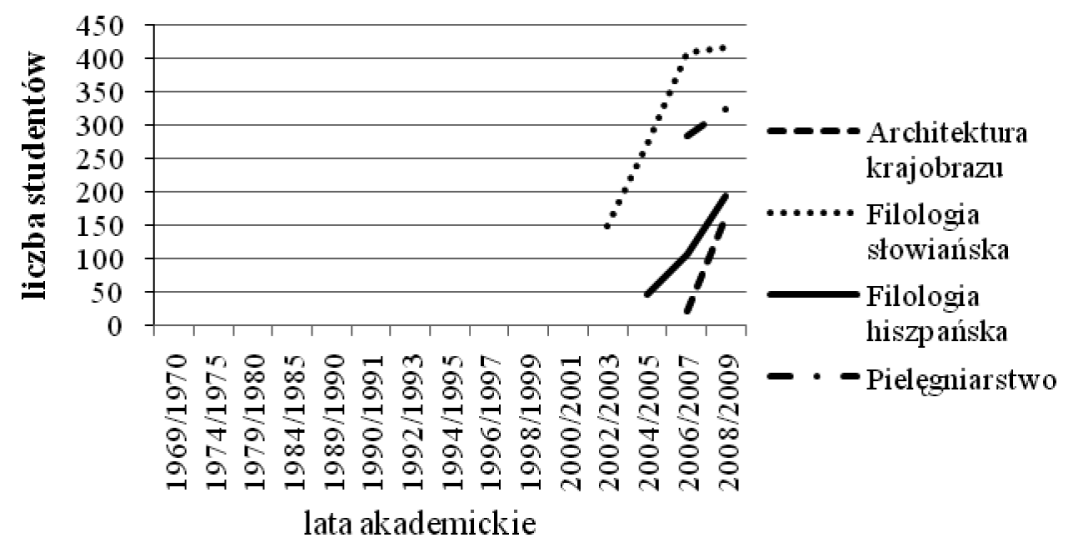

Źródło: opracowanie własne na podstawie danych uzyskanych w dziekanatach bielskich uczelni.

Spośród wybranych sześciu kierunków studiów w roku akademickim 2008/2009 największą liczbę studentów skupiała informatyka (7,9\%) oraz zarządzanie i inżynieria produkcji (6,9\%). Następne kierunki pod względem liczby studentów to mechanika i budowa maszyn $(6,1 \%)$, inżynieria środowiska (6,0\%), automatyka i robotyka (3,8\%). Najmniejsza grupa studentów kształciła się na filologii angielskiej (3,2\%). 
Pomimo faktu, iż dynamika wzrostu liczby studentów na tych kierunkach była bardzo wysoka w ciągu ostatnich 20 lat, to łącznie kierunki te w roku akademickim 2008/2009 skupiały tylko 33,8\% studentów. Dlatego przed bielskimi uczelniami wyższymi stoi trudne zadanie zachęcenia przyszłych kandydatów na studia do podjęcia nauki na tych ważnych z punktu widzenia rozwoju gospodarczego i postępujących procesów globalizacji kierunkach. Takie działanie podejmuje na przykład Akademia Techniczno-Humanistyczna, która wprowadziła w zeszłym i obecnym roku akademickim (2009/2010 i 2010/2011) nowe kierunki studiów, takie jak budownictwo czy transport. Ponadto uczelnia w ramach Poddziałania 4.1.2 Zwiększenie liczby absolwentów kierunków o kluczowym znaczeniu dla gospodarki opartej na wiedzy Programu Operacyjnego Kapitał Ludzki realizuje projekt „Inżynier na miarę XXI wieku”. Objęto nim mechanikę i budowę maszyn, automatykę i robotykę, informatykę oraz inżynierię środowiska jako kierunki kluczowe dla rozwoju gospodarki opartej na wiedzy. Celem tego projektu jest powiązanie bielskiego szkolnictwa wyższego z lokalną gospodarką i zapotrzebowaniem lokalnego rynku pracy ${ }^{3}$.

Ryc. 4. Struktura kierunków kształcenia bielskiego ośrodka akademickiego w roku akademickim $2008 / 2009$

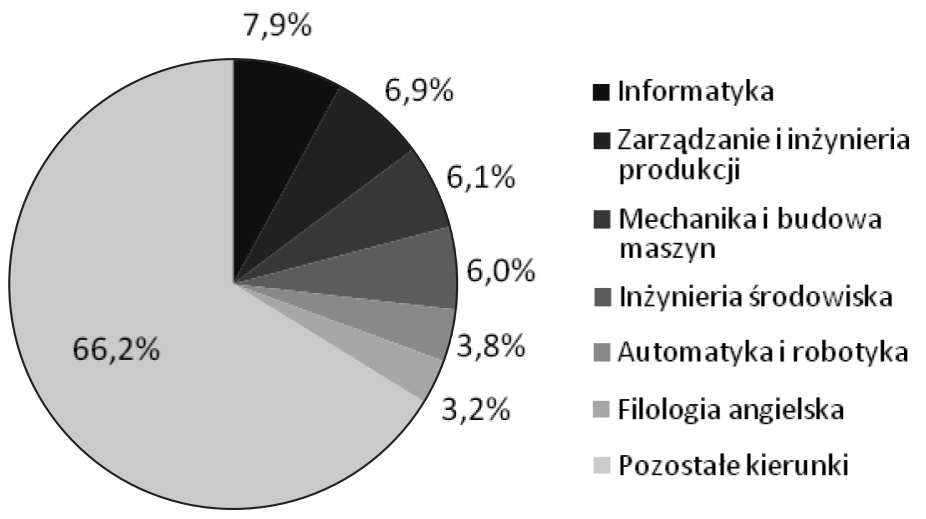

Źródło: opracowanie własne na podstawie danych uzyskanych w dziekanatach bielskich uczelni.

Omawiając funkcjonowanie danego ośrodka akademickiego, należy również zwrócić uwagę na jest jego przestrzenne oddziaływanie. Świadczy ono bowiem o zasięgu kształtowania zasobów intelektualnych tego ośrodka zarówno w przestrzeni lokalnej, jak i regionalnej. Niniejsze zestawienie przygotowano na podstawie danych dotyczących miejsca stałego zamieszkania studentów, uzyskanych w dziekanatach poszczególnych bielskich szkół wyższych ${ }^{4}$. Studenci bielskiego ośrodka akademickiego w roku 2008/2009 rekrutowali się prawie ze

\footnotetext{
${ }^{3}$ Informację o projekcie oraz szczegóły dotyczące realizowanych kierunków studiów zaczerpnięto ze strony internetowej Akademii Techniczno-Humanistycznej http://info.ath.bielsko.pl/

${ }^{4}$ Niniejsza analiza została przeprowadzona na podstawie danych jednostkowych uzyskanych w dziekanatach bielskich szkół wyższych i obejmuje studentów pierwszego roku Akademii Techniczno-Humanistycznej, studentów pierwszego roku Kolegium Nauczycielskiego oraz studentów Bielskiej Wyższej Szkoły im. J. Tyszkiewicza, Instytutu Teologicznego oraz Akademii Ekonomicznej. Łącznie badana grupa osób obejmuje 25,6\% bielskich studentów w roku akademickim 2008/2009.
} 
wszystkich województw za wyjątkiem województwa zachodniopomorskiego. Dominujące znaczenie w tym względzie miało województwo śląskie, z którego pochodziło 3454 studentów - stanowili oni $85,6 \%$ ogólnej liczby badanych studentów. Kolejną pozycję zajmowało województwo małopolskie, z którego rekrutowało się 528 studentów, czyli 13,1\% ich ogólnej liczby. Łącznie z tych dwóch województw pochodziło 3982 studentów, którzy stanowili aż 98,7\% ogółu badanych osób. Pozostałe województwa miały marginalne znaczenie w zakresie pochodzenia studentów bielskich uczelni. Z każdego z nich rekrutowało się od jednego do dziewięciu studentów, co stanowi od 0,02\% do 0,22\% ich ogólnej liczby. Łącznie z tych 13 województw pochodziło 55 studentów, czyli 1,3\% ich ogólnej liczby.

Tab. 3. Koncentracja osadnicza studentów bielskich szkół wyższych w roku akademickim 2008/2009

\begin{tabular}{|c|c|c|c|c|}
\hline $\begin{array}{c}\text { Przedziały liczby } \\
\text { studentów }\end{array}$ & $\begin{array}{c}\text { Liczba } \\
\text { jednostek } \\
\text { (gmin) }\end{array}$ & $\begin{array}{c}\text { Liczba } \\
\text { studentów }\end{array}$ & $\begin{array}{c}\text { Struktura } \\
\text { jednostek (gmin) }\end{array}$ & $\begin{array}{c}\text { Struktura } \\
\text { studentów }\end{array}$ \\
\hline 1 & 94 & 94 & 44,76 & 2,33 \\
\hline 2 & 21 & 42 & 10,00 & 1,04 \\
\hline $3-5$ & 26 & 103 & 12,38 & 2,55 \\
\hline $6-10$ & 16 & 123 & 7,62 & 3,05 \\
\hline $11-30$ & 20 & 409 & 9,52 & 10,13 \\
\hline $31-50$ & 14 & 539 & 6,67 & 13,35 \\
\hline $51-70$ & 5 & 299 & 2,38 & 7,41 \\
\hline $71-100$ & 7 & 624 & 3,33 & 15,46 \\
\hline $101-200$ & 6 & 801 & 2,86 & 19,84 \\
\hline $201-1100$ & 1 & 1003 & 0,48 & 24,85 \\
\hline Ogółem & 210 & 4037 & 100,00 & 100,00 \\
\hline
\end{tabular}

Źródło: opracowanie własne na podstawie danych jednostkowych uzyskanych w dziekanatach bielskich uczelni.

Natomiast na podstawie analizy gmin, z których rekrutowali się bielscy studenci, można stwierdzić, że w roku akademickim 2008/2009 rekrutowali się oni z 210 różnych gmin (tab. 3). Dominujące znaczenie w tym względzie miała gmina Bielsko-Biała. Pochodziło z niej 1003 studentów, którzy stanowili 24,8\% ich ogólnej liczby, podczas gdy sama Bielsko-Biała stanowiła tylko 0,48\% ogólnej liczby gmin. Kolejną pozycję zajmowały Czechowice-Dziedzice, Żywiec, Jasienica Pszczyna, Cieszyn i Kęty, z których rekrutowało się od 101 do 200 studentów, a łącznie pochodziło z nich 19,8\% ich ogólnej liczby, podczas gdy stanowiły one 2,9\% badanych gmin. Następne były Andrychów, Wilamowice, Radziechowy-Wieprz, Kozy, Skoczów, Węgierska Górka i Porąbka, z których łącznie pochodziło 15,6\% wszystkich badanych studentów, a stanowiły one tylko 3,33\% wszystkich gmin. Wszystkie wymienione wyżej gminy odgrywały kluczową rolę w zakresie rekrutacji studentów, ponieważ łącznie pochodziło z nich aż $60,1 \%$ wszystkich studentów.

Wyrazem relacji między udziałem studentów i jednostek osadniczych, z których się oni rekrutują, jest wysoka wartość wskaźnika koncentracji osadniczej studentów, która w roku 
akademickim 2008/2009 wyniosła 0,658. Wskazuje ona na duże skupienie studentów bielskiego ośrodka akademickiego ${ }^{5}$. Największa liczba studentów pochodzi z ośrodka, w którym jest zlokalizowana, czyli z Bielska-Białej.

Oddziaływanie bielskiego ośrodka akademickiego obejmuje głównie południową i centralną część województwa śląskiego oraz południowo-zachodnią część województwa małopolskiego (ryc. 5). Można więc stwierdzić, iż w zakresie kształtowania zasobów intelektualnych społeczeństwa bielski ośrodek akademicki spełnia funkcje ponadlokalne. Zasięg przestrzennego oddziaływania bielskich uczelni wyższych jest wyraźnie ograniczony poprzez funkcjonowanie katowickiego i krakowskiego ośrodka akademickiego, które charakteryzują się o wiele wyższym potencjałem edukacyjnym oraz liczbą szkół wyższych.

Ryc. 5. Terytorialne pochodzenie studentów bielskich szkół wyższych w roku akademickim 2008/2009

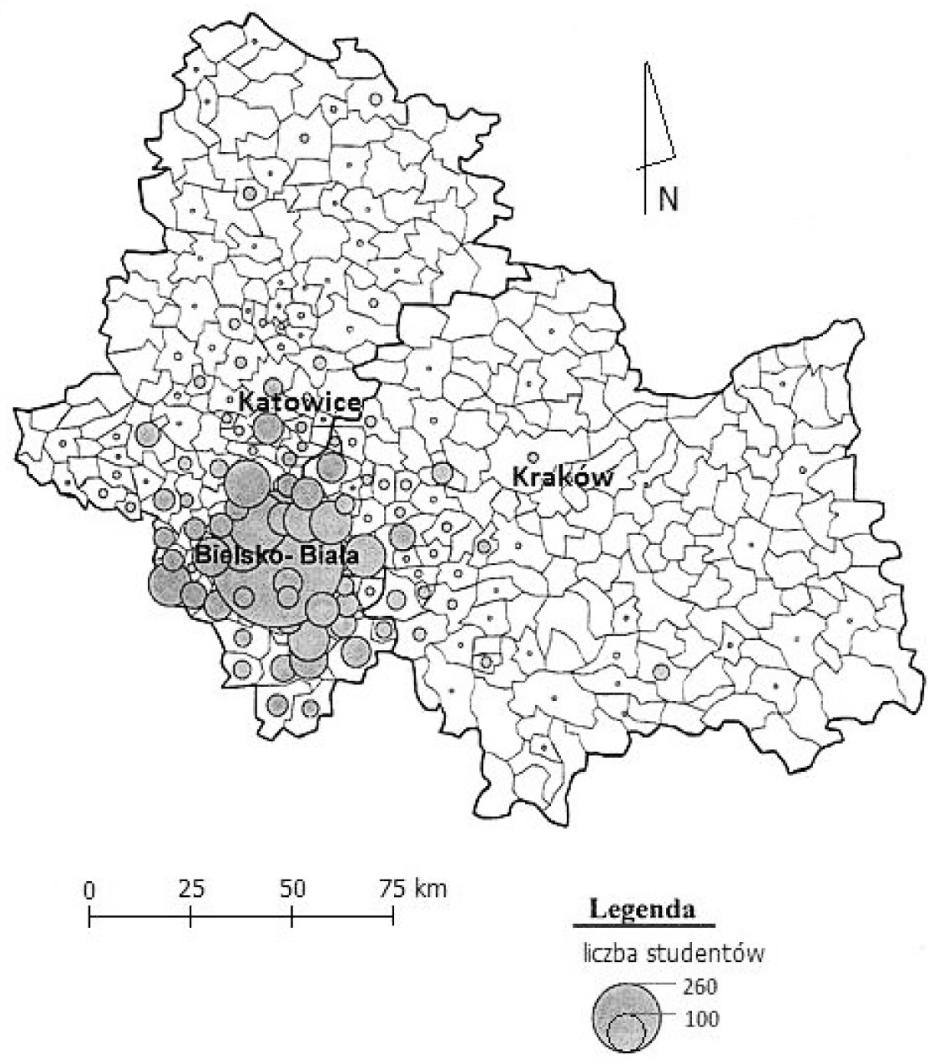

Źródło: opracowanie własne na podstawie danych jednostkowych uzyskanych w dziekanatach bielskich uczelni.

\footnotetext{
${ }^{5}$ Wskaźnik koncentracji obliczono z szeregu rozdzielczego poprzez porównanie udziału liczebności gmin udziału pochodzących z nich studentów według wzoru:$$
\mathrm{K}_{\mathrm{o}}=\frac{\sum_{\mathrm{i}=1}^{\mathrm{n}}\left|\mathrm{o}_{\mathrm{i}}-\mathrm{s}_{\mathrm{i}}\right|}{200}
$$

gdzie: o - udział gmin i - tego wyznaczonego przedziału klasowego; s - udział studentów i - tego wyznaczonego przedziału klasowego jednostek przestrzennych (gmin).
} 
Nowe warunki ekonomiczne i kulturowe, które niesie za sobą globalizacja, wymagają przystosowania do nich gospodarki narodowej, a przede wszystkim społeczeństwa. Ważną rolę w tym procesie odgrywają ośrodki akademickie, kształtujące w warunkach lokalnych zasoby ludzkie. Nasilające się procesy globalizacji stawiają przed nimi nowe wyzwania związane z dopasowaniem struktury kształcenia do warunków rozszerzającego się rynku pracy i rozwoju gospodarki opartej na wiedzy. Szansą dla tych ośrodków może być współpraca z zagranicznymi ośrodkami naukowymi i akademickimi, wymiana studentów oraz nauczycieli akademickich, pozyskanie studentów zagranicznych oraz wprowadzenie języka angielskiego jako wykładowego. Można więc stwierdzić, że globalizacja stwarza dla rozwoju szkolnictwa wyższego wiele nowych możliwości. Mobilizuje władze poszczególnych szkół wyższych do poszukiwania nowych dróg pozyskania studentów, wprowadzania zmian i przekształceń kierunków studiów, prowadzenie studiów podyplomowych i kursów umożliwiających szybkie przekwalifikowanie.

\section{Literatura}

1. Borowiec M., 2010, Funkcjonowanie uczelni krakowskiego i rzeszowskiego ośrodka akademickiego w świetle koncepcji uktadów bipolarnych, Wyd. Naukowe Uniwersytetu Pedagogicznego, Kraków.

2. Denek K., 2001, Tryptyk wątków koniecznych [w:] Edukacyjne konteksty procesów globalizacji, W. Kojs (red.), Uniwersytet Śląski Filia w Cieszynie, Cieszyn.

3. Gnitecki J., 2002, Szkoła i edukacja wobec wyzwań globalnych współczesnego świata [w:] WartośćEdukacja - Globalizacja. Wybrane zagadnienia, W. Kojs (red.), UŚ Filia w Cieszynie, Cieszyn.

4. Haczek A., 2010, Rozwój i przestrzenne oddziaływanie bielskiego ośrodka akademickiego (niepublikowane).

5. Janc K., 2004, Znaczenie kapitału ludzkiego w procesach globalizacji [w:] Człowiek, region, państwo w procesach globalizacji, regionalizacji i integracji, G. Rdzanek, E. Stadtmuller (red.), Uniwersytet Wrocławski, s. 71-82.

6. Kluczyński J., 1991, Prognozy i uwarunkowania rozwoju szkolnictwa wyższego w Polsce, Instytut Polityki Naukowej i Szkolnictwa Wyższego, Wyd. Naukowe PWN, Warszawa-Lódź.

7. Musiał G., 2001, Dylematy uczelni wyższych w dobie globalizacji [w:] Edukacyjne konteksty procesów globalizacji, W. Kojs (red.), Uniwersytet Śląski Filia w Cieszynie, Cieszyn.

8. Nowakowska A., Boryczka E., 2008, Wyższe uczelnie jako czynnik kształtujący strukturę przestrzennq wspótczesnych miast [w:] Rola wyższych uczelni w rozwoju społeczno-gospodarczym i przestrzennym miast, T. Markowski, D. Drzazga (red.), Studia KPZK PAN, z. 121, Warszawa.

9. Polak E., 2009, Globalizacja a zróżnicowanie społeczno-ekonomiczne, Wyd. Difin, Warszawa, s. 7-35.

10. Radło M.J., 2003, Wyzwanie konkurencyjności. Strategia lizbońska w poszerzonej UE, Instytut Spraw Zagranicznych, Warszawa, s. 42-62.

11. Słobodzian B., 2001, W kierunku globalizacji opartej na wiedzy. Edukacyjne konteksty procesów globalizacji, W. Kojs (red.), Uniwersytet Śląski Filia w Cieszynie, Cieszyn.

12. Zioło Z., 2008, Ekonomiczne i społeczne uwarunkowania rozwoju gospodarki opartej na wiedzy [w:] Rola przedsiębiorczości w gospodarce opartej na wiedzy, Z. Zioło, T. Rachwał (red.), „Przędsiębiorczość - Edukacja”, nr 4, Nowa Era, Zakład Przedsiębiorczości i Gospodarki Przestrzennej Instytutu Geografii Uniwersytetu Pedagogicznego w Krakowie, Warszawa-Kraków. 


\section{The Functioning of Bielsko-Biala academic Center in the Conditions of Globalization}

In the process of globalization, which is directly connected with scientific and technological progress, human capital receives special significance. Education, especially higher education, has the most important meaning as a factor leading to the improvement of the intellectual potential of societies. Educated, entrepreneurial society, which can easier be found in the new reality, is the foundation of the functioning of the global economy and raising the competitiveness of individual regions and countries.

The article discusses the functioning of the Bielsko-Biala academic center in the conditions of the globalization. It presents changes in the educational potential of the center in the years 1969-2009. Particular attention was paid to changes in the educational structure of the BielskoBiala academic center and its adaptation to the conditions of modern economy. In addition, the range of influence of the Bielsko-Biala academic center was defined based on the permanent residence of the students in the academic year 2008/2009.

The results of this study assess the impact of globalization on the functioning of the academic centers, as well as the role of the Bielsko-Biala academic center in the development of human capital in local conditions. 


\section{Krystian Sowislok}

II Liceum Ogólnokształcące

w Zabrzu

\section{Proces globalizacji. Ocena pozytywnych i negatywnych skutków globalizacji przez młodych Polaków}

Czym jest globalizacja? Co to pojęcie oznacza dla młodych ludzi? Czy słownikowe wyjaśnienia tego pojęcia są dla nich zrozumiałe, a informacje podręcznikowe na ten temat - wystarczające i precyzyjne? Czy wiedzą, jakie są pozytywne oraz czy dostrzegają także negatywne skutki globalizacji w Polsce i na świecie? Jak mogą wspierać, a może przeciwdziałać temu procesowi? Takie i podobne pytania związane z globalizacją zadałem uczniom klas drugich i trzecich liceum ogólnokształcącego. Zawsze podkreślam, że jako nauczyciela przedmiotu podstawy przedsiębiorczości najbardziej interesują mnie opinie i postawy młodzieży. Biorąc jednak pod uwagę młody wiek ankietowanych, uznałem, że formułowanie pytań bezpośrednio związanych z tytułem tegorocznej konferencji i zjazdu nauczycieli, czyli przedsiębiorczością w warunkach globalizacji, byłoby przedwczesne.

Procesy globalizacji są jednym z tematów (ostatnim) w podręczniku Podstawy przedsiębiorczości dla uczniów szkót ponadgimnazjalnych wydawnictwa Nowa Era. Ze względu na ogromne znaczenie tych procesów i ich wpływ na nasze codzienne życie i rozwój Polski, ten temat, wraz z całym rozdziałem Wspótpraca międzynarodowa omawiam jednak wcześniej. Staram się przekazywane wiadomości rozszerzyć, również z udziałem uczniów, o dostępne w Internecie i literaturze materiały.

Aby przybliżyć skutki globalizacji, trzeba oczywiście rozpocząć od przedstawienia powszechnie przyjętych definicji tego pojecia. Oprócz encyklopedycznych, nie zawsze łatwych do zrozumienia dla młodzieży, przedstawiam im wyjaśnienie sformułowane przez humanistę Richarda Schechnera (badacz, teoretyk, reżyser i krytyk teatralny, profesor performatyki na Uniwersytecie w Nowym Yorku) w książce Performatyka: Wstęp. Można tam przeczytać, że „Zadaniem naczelnym globalizacji jest integracja wszystkich systemów - informacyjnych, gospodarczych, wojskowych, ideologicznych, społecznych, politycznych i kulturalnych - wedle zasady high performance (wysokiej klasy; dużej wydajności.), czyli w tym przypadku: wysokiej wydajności. Jeżeli się to powiedzie, powstanie światowa sieć maksymalnej produktywności" (2007). Okazuje się, że to wyjaśnienie jest bardzo dobrze odbierane i, co najważniejsze, w pełni zrozumiałe dla młodzieży. Opierając się na przytoczonych wyżej słowach Schechnera, sformułowałem pierwsze pytanie w ankiecie przygotowanej dla uczniów szkoły, w której pracuję. Dotyczyło ono obszarów, na które ich zdaniem globalizacja ma największy wpływ. Mieli je ponumerować od 1 do 6, według posiadanej wiedzy i indywidualnych poglądów.

Zdaniem większości uczniów, procesy globalizacji najbardziej są odczuwane w sferze gospodarczej. Na pierwszym miejscu umieściło ją $62 \%$ ankietowanych, systemy informacyjne $-20 \%$, społeczne $-10 \%$ (ryc. 1). Nieco inna kolejność jest w wypadku podsumowania wyników 
zaznaczonych odpowiedzi na trzech kolejnych miejscach (1-3). Systemy gospodarcze i w tym wypadku były wybierane najczęściej - przez $88 \%$ badanych, następnie: społeczne - $71 \%$ i informacyjne $-50 \%$ (ryc. 2 ).

Wybory młodzieży nie są zaskoczeniem. Kiedy młodzi ludzie słyszą informacje o globalizacji, w większości są one związane z gospodarką. Żyją w czasach ciągłych zmian, w tym również społecznych, stąd i ten obszar był przez nich często wybierany. Wydaje się, że trochę inaczej jest z systemami informacyjnymi. Starsze pokolenia odczuwają w tej dziedzinie olbrzymi krok naprzód, dla młodzieży jest to coś zupełnie normalnego, co towarzyszy im w codziennym życiu. Nie dziwi rzadszy wybór systemów politycznych i wojskowych, gdyż tymi obszarami młodzi ludzie niewiele się na razie interesują.

Ryc. 1. Najczęściej zaznaczane na pierwszym miejscu przez uczniów II LO w Zabrzu obszary wpływu procesu globalizacji

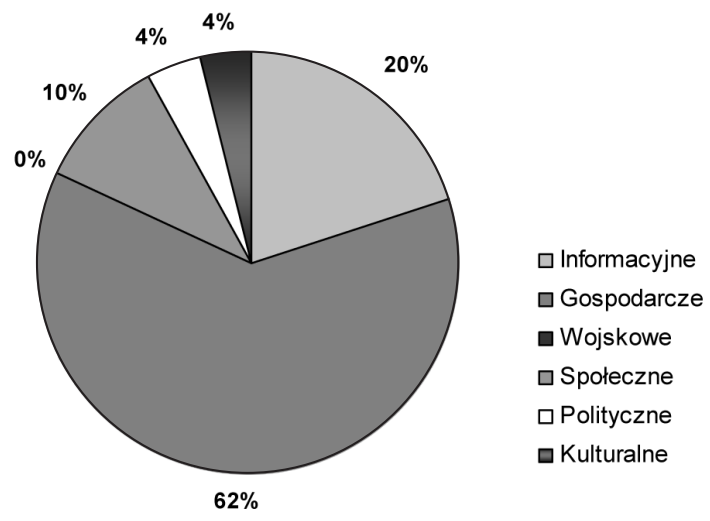

Źródło: opracowanie własne.

Ryc. 2. Najczęściej zaznaczane na miejscach 1-3 przez uczniów II LO w Zabrzu obszary wpływu procesu globalizacji

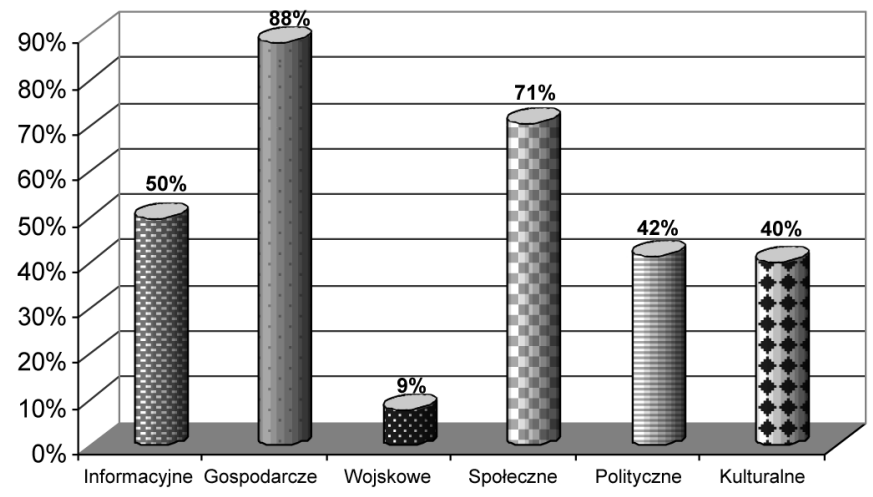

Źródło: opracowanie własne.

Globalizacja powoduje nieustanne zmiany. Ogromną rolę w zachodzących procesach odgrywają korporacje transnarodowe, które stale poszerzają zakres swojej działalności. „Ich znaczenie będzie wzrastać dzięki rosnącej finansowej sile, coraz większym możliwościom 
wpływu na narodowe państwa i na globalną gospodarkę. Z tego też powodu należy nieustannie obserwować ich dalszy rozwój, ponieważ może się ziścić scenariusz wielu ekonomistów, którzy oczekują na znaczny spadek roli państwa na rzecz korporacji transnarodowych oraz innych pozapaństwowych podmiotów procesu globalizacji” (Kolka 2007). Mówiąc o roli korporacji transnarodowych, istotne wydaje się określenie, czym zajmują się największe z nich. Na pytanie o to, z jakimi rodzajami działalności kojarzą się największe korporacje transnarodowe, uczniowie odpowiadali w drugim punkcie ankiety. Najczęściej wskazywany był przemysł surowcowy związany przede wszystkim z wydobyciem i przetwarzaniem ropy naftowej. Tak zaznaczyło 59\% badanych. Kolejne miejsca to elektronika - 19\% i motoryzacja - 12\% (ryc. 3). Rozpatrując wskazania uczniów pod względem miejsc 1-3, ze względu na dużą liczbę wskazań na drugim i trzecim miejscu branży motoryzacyjnej kolejność się zmieniła: na pierwszym miejscu znalazł się przemysł surowcowy (76\%), na drugim - motoryzacja (67\%), a na trzecim - elektronika (62\%; ryc. 4).

Ryc. 3. Największe aktywa wśród światowych korporacji transnarodowych posiadają według uczniów II LO w Zabrzu przedsiębiorstwa branży (najczęściej zaznaczane na pierwszym miejscu)

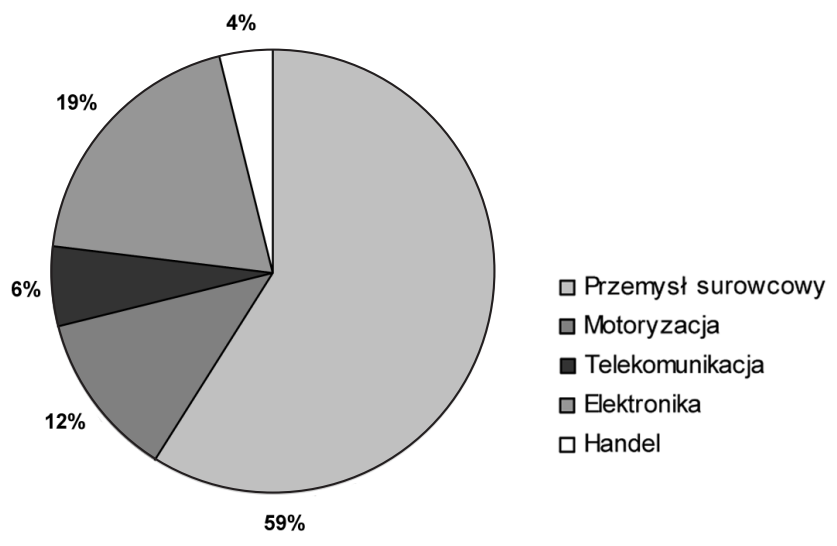

Źródło: opracowanie własne.

Ryc. 4. Największe aktywa wśród światowych korporacji transnarodowych posiadają według uczniów II LO w Zabrzu przedsiębiorstwa branży (najczęściej zaznaczane na miejscach 1-3)

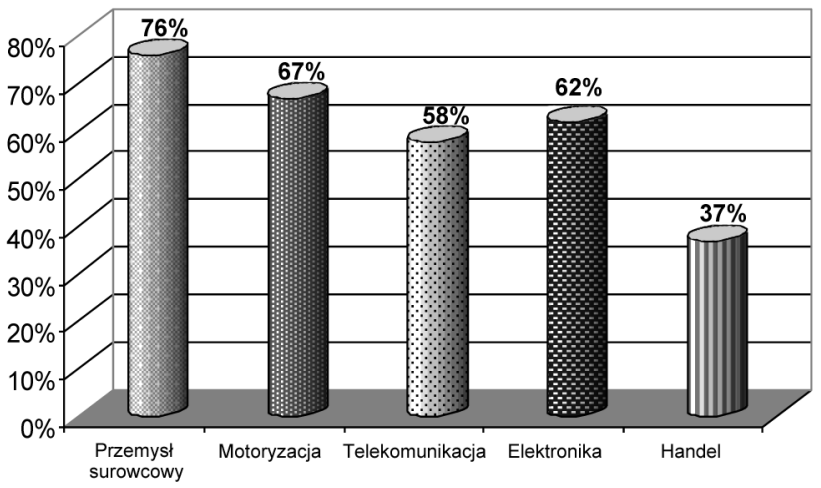

Źródło: opracowanie własne. 
Podsumowując te odpowiedzi, można stwierdzić, że poglądy młodzieży w dużym stopniu są zbieżne z publikowanymi rankingami największych korporacji transnarodowych.

Globalizacja, jak podkreślają wszyscy, jest procesem nieodwracalnym. Ma zwolenników i przeciwników. Ważne jest, żeby zdawać sobie sprawę z szans i zagrożeń, które stwarza. Najważniejsze pozytywne i negatywne skutki globalizacji uczniowie mogli wybrać w kolejnych pytaniach ankiety. Skutki te rozpatrywali w kontekście wpływu na gospodarkę Polski i codzienne życie młodego Polaka. Każdy ankietowany mógł zaznaczyć pięć z dwunastu pozytywnych i jedenastu negatywnych skutków globalizacji.

Zaznaczając najważniejsze pozytywne skutki globalizacji dla gospodarki Polski, uczniowie najczęściej wskazywali na postęp naukowo-techniczny (w tym np.: Internet, telefony komórkowe). Takiego wyboru dokonało aż 90\% z nich. Na kolejnych miejscach znalazły się: nowoczesność i udoskonalanie nowych produktów - 71\%, integracja gospodarcza - 60\%, zacieranie barier międzynarodowej wymiany handlowej oraz łatwość dostępu do informacji - po 59\% (ryc. 5). Analizując te wyniki, można stwierdzić, że uczniowie dokonali dość trafnych wyborów. Możemy się ewentualnie zastanawiać nad ustaloną przez nich kolejnością, na przykład, czy postęp naukowo-techniczny jest ważniejszy dla naszej gospodarki od integracji gospodarczej związanej z członkowstwem w Unii Europejskiej.

Ryc. 5. Pozytywne skutki globalizacji najważniejsze dla gospodarki kraju - według uczniów II LO w Zabrzu (zaznacz maksymalnie pięć najważniejszych według Ciebie odpowiedzi)

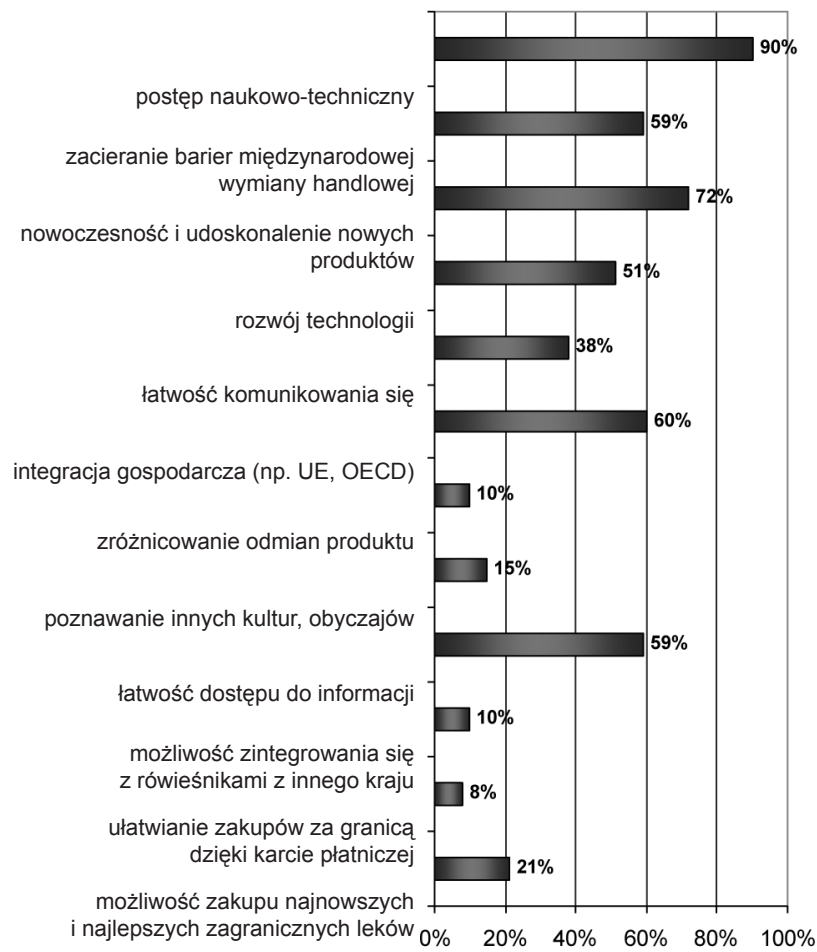

Źródło: opracowanie własne. 
Dla młodych Polaków, zdaniem uczniów II LO w Zabrzu, najważniejsze z pozytywnych skutków globalizacji są: postęp naukowo-techniczny - 83\%, łatwość komunikowania się - 74\%, rozwój technologii (np. sprzęt komputerowy) - 55\%, łatwość dostępu do informacji - 53\% i poznawanie innych kultur, obyczajów - 47\% (ryc. 6). W porównaniu z wynikami z poprzedniego pytania zmieniły się trzy odpowiedzi. Na pierwszym miejscu ponownie uczniowie wybrali postęp naukowo-techniczny. Należy jednak podkreślić dużą liczbę wskazań na łatwość komunikowania się oraz fakt, że dla uczniów istotne jest także poznawanie innych kultur i obyczajów wynikające z chęci poznawania ludzi i świata.

Ryc. 6. Pozytywne skutki globalizacji najważniejsze dla młodych Polaków - według uczniów II LO w Zabrzu

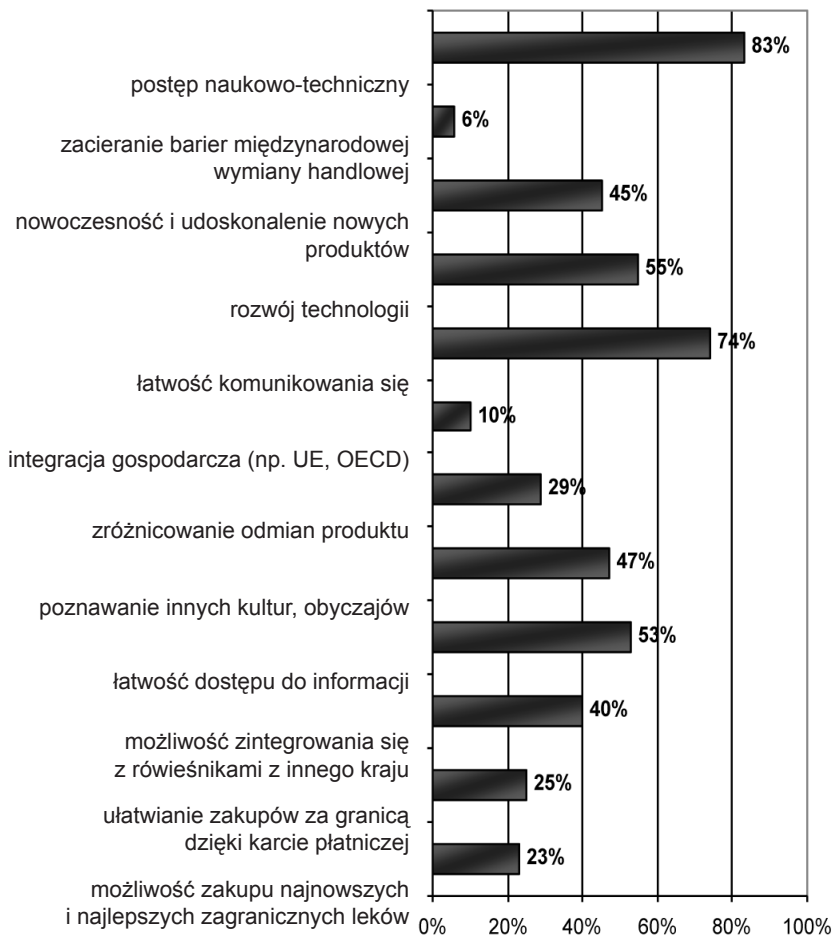

Źródło: opracowanie własne.

Dwa następne pytania, podobnie sformułowane jak poprzednie, dotyczyły negatywnych skutków globalizacji. Według uczniów największy wpływ na gospodarkę Polski mają: większa wrażliwość gospodarek narodowych na załamania na rynkach światowych - 59\%, wzrost zużycia energii i zanieczyszczenia środowiska poprzez przeniesienie produkcji do regionów o niższych standardach ekologicznych - 56\%, powstanie i rozrastanie się globalnych dysproporcji - 55\%, upadek drobnych przedsiębiorstw, które są mało konkurencyjne - 52\% (ryc. 7). Przyglądając się tym wynikom i porównując najwyższe wartości z dotyczącymi pozytywnych skutków globalizacji, widzimy, że młodzież miała większe problemy z jednoznacznym wskazaniem najważniejszych negatywnych skutków. Różnice pomiędzy przedstawionymi wyżej skutkami a pozostałymi są mniejsze niż w poprzednich pytaniach. 
Ryc. 7. Negatywne skutki globalizacji najważniejsze dla gospodarki kraju - według uczniów II LO w Zabrzu Źródło: opracowanie własne.

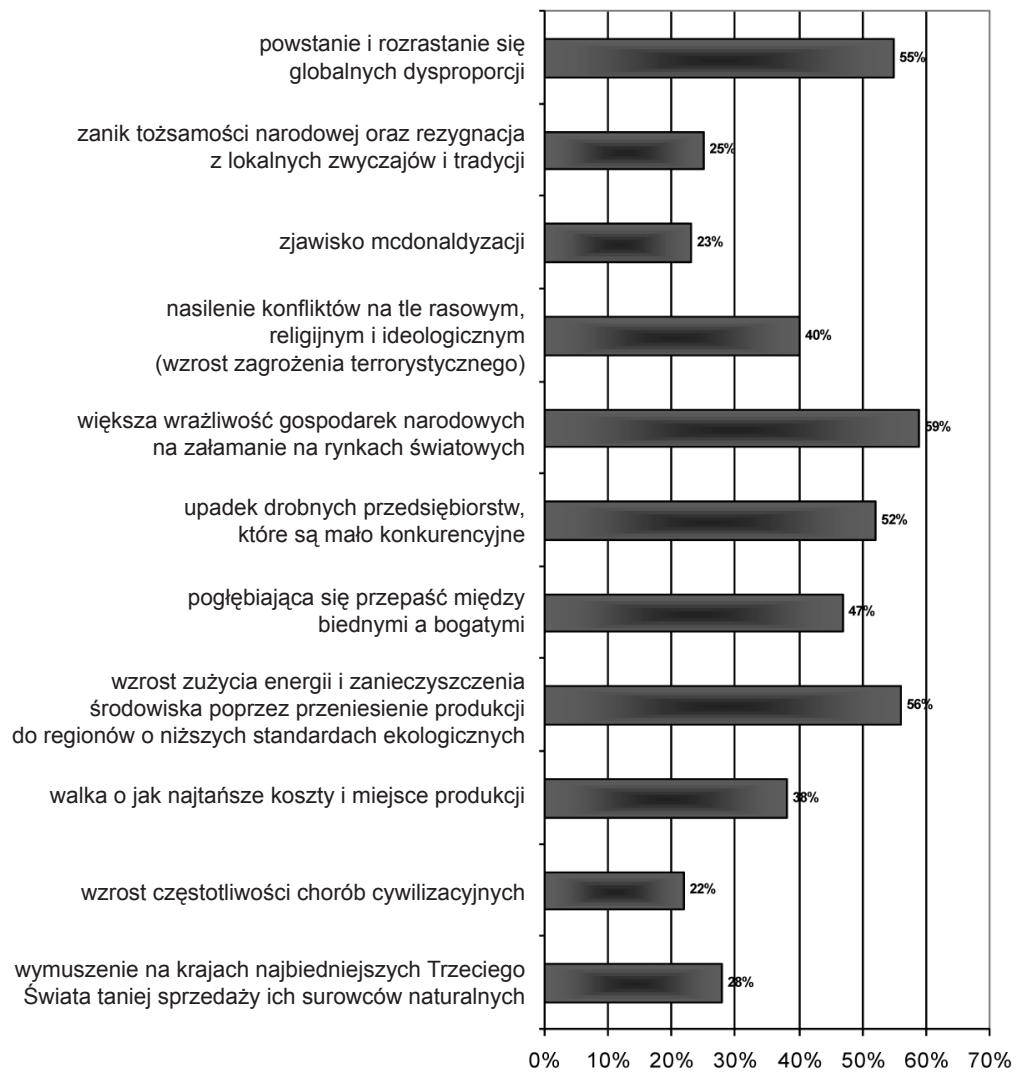

Odpowiedzi na pytanie o wpływ negatywnych skutków globalizacji na życie młodego Polaka, jeżeli chodzi o wartości procentowe, wyglądają podobnie. Uczniowie jednak wybierali najczęściej inne odpowiedzi niż w poprzednim pytaniu. Najczęściej zaznaczane odpowiedzi to: pogłębiająca się przepaść między biednymi a bogatymi - 58\%, wzrost częstotliwości występowania chorób cywilizacyjnych - 55\%, zanik tożsamości narodowej oraz rezygnacja z lokalnych zwyczajów i tradycji na rzecz powstającej kultury masowej - 53\% oraz wzrost zużycia energii i zanieczyszczenia środowiska poprzez przeniesienie produkcji do regionów o niższych standardach ekologicznych - 51\%; jest to jedyny negatywny skutek, który się powtórzył w odpowiedziach na dwa ostatnie pytania (ryc. 8).

Na podstawie przedstawionych wyników widzimy, że młodzież rozróżnia wagę i wpływ skutków globalizacji na sferę gospodarczą kraju od jej szans i zagrożeń dla społeczeństw i pojedynczego człowieka. Zdaje sobie też sprawę, że Polska nie jest wydzieloną wyspą na mapie świata i wszystkie dobrodziejstwa globalizacji jej dotyczą.

„Polska poprzez rosnące inwestycje zagraniczne oraz wymianę handlową włączana jest w procesy globalizacyjne. Dzieje się tak głównie dzięki postępowi technologicznemu, który ułatwia oraz powoduje obniżkę kosztów komunikacji, transportu, co w efekcie prowadzi do wzrostu 
międzynarodowego handlu oraz inwestycji zagranicznych. Za lokomotywy globalizacji uznaje się przede wszystkim nowoczesną komunikację rozumianą jako szybki i wydajny przepływ informacji. Za nimi idzie rozwinięta infrastruktura telekomunikacyjna, wymiana handlowa, wzrost gospodarczy, czy też wymiana turystyczna” (Stępkowicz 2007).

Ryc. 8. Negatywne skutki globalizacji najważniejsze dla młodych Polaków - według uczniów II LO w Zabrzu

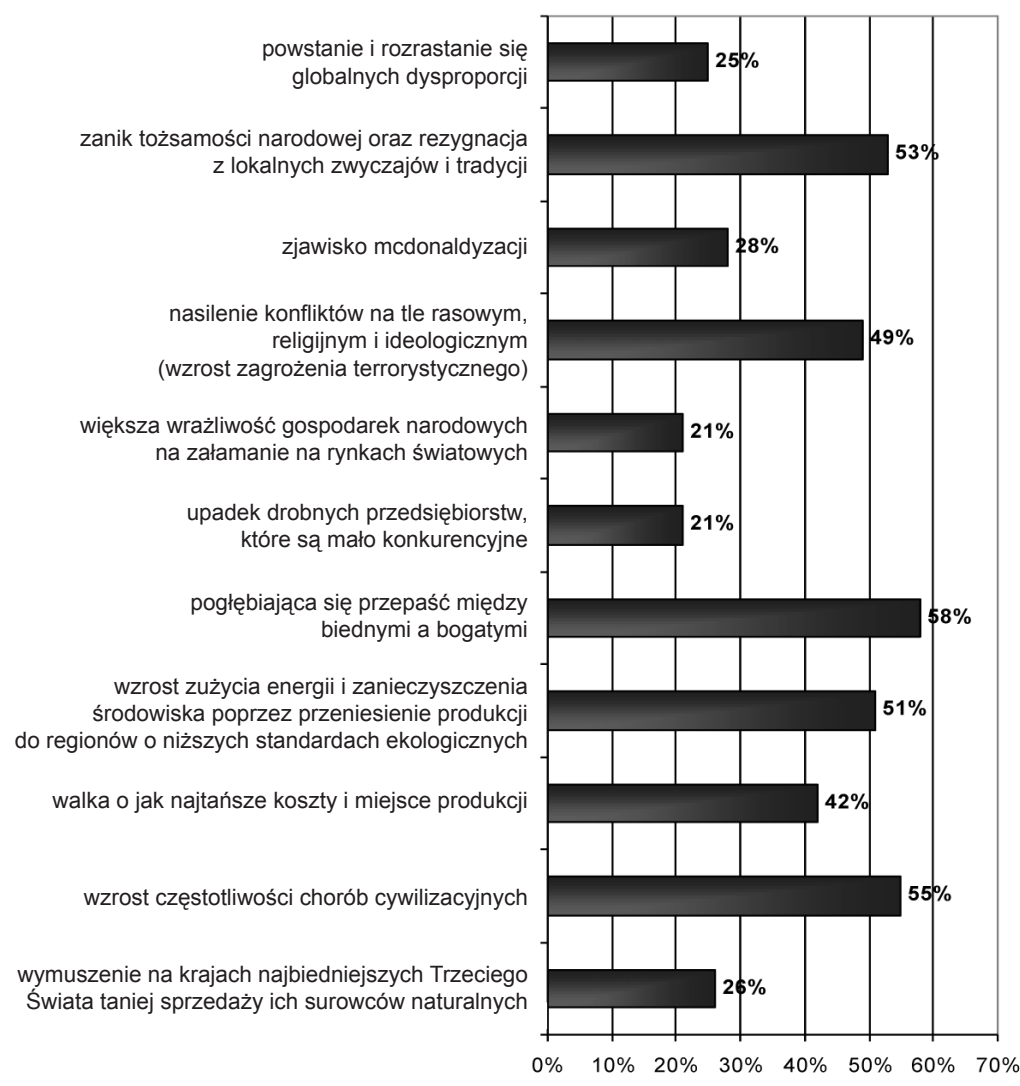

Źródło: opracowanie własne.

Uświadamianie młodzieży, że proces globalizacji wpływa na nasze otoczenie i życie jest jednym z celów prowadzonych przeze mnie zajęć poświęconych tematyce globalizacji. Chcę aby wiedzieli, że nie warto się teraz zastanawiać czy jest się „,za” czy „przeciw” czemuś co jest powszechnie uważane za nieodwracalne. Może młodzi ludzie mogą pokierować tym procesem w taki sposób, aby wykorzystać globalizację do budowania równych szans na całym świecie, utrwalania wolności i pokoju i aby w przyszłości spełniła się tylko pierwsza część słów cytowanego już wcześniej Richarda Schechnera „Zwolennicy globalizacji twierdzą, że przeważająca część ludzkości może osiągnąć wysoki poziom życia tylko poprzez systematyczną integrację, jakkolwiek bolesny byłby na krótką metę sam proces. Przeciwnicy globalizacji twierdzą, że usystematyzowanie oznacza, iż władza (i korzyści) pozostaną w rękach niewielu, powodując olbrzymie nierówności” (2007). 


\section{Literatura}

1. Kolka M.A., 2007, Korporacje transnarodowe-ich znaczenie w erze globalizacji, Wydawnictwo Instytutu Prognoz i Analiz, www.GlobalEconomy.pl.

2. Stępkowicz W., 2007, Globalizacja gospodarki - wybrane cechy procesu, Ministerstwo Gospodarki, Departament Analiz i Prognoz, Warszawa.

3. Schechner R., 2007, Performatyka: Wstęp, Kubikowski T. (przekł.), Instytut im. Jerzego Grotowskiego, Wrocław.

\section{The Process of Globalization. Evaluation of Positive and Negative Results of Globalization by the Polish Youth}

What is globalization? What does this term mean to young people? Is the dictionary definition of th is term meaningful to them; is schoolbook information on this issue thorough and precise? What are positive results of globalization and does the youth notice any negative results of globalization in Poland and worldwide? How can they support or counteract this process? Second and third grade secondary school students were asked these and similar questions connected with globalization. As a teacher of Entrepreneurship I have always emphasized my interest in opinions and attitudes of young people. Taking into consideration the young age of the surveyed, I decided that posing questions directly connected to this year conference and teachers' meetings title, that is entrepreneurship in the context of globalization, would be premature.

I would like to present the results of the survey conducted among the students of the school I work in and their opinions on the process as well as results of globalization in this year conference sessions. 


\author{
Zbigniew Janusz Ożdżyński \\ Zespół Szkół w Gąbinie
}

\title{
Szkolenie kierowców w warunkach globalizacji
}

Globalizacja polega na rozprzestrzenianiu się podobnych zjawisk i procesów ekonomicznych, politycznych, społecznych i kulturowych, niezależnie od stopnia cywilizacyjnego zaawansowania czy położenia geograficznego. Za jej początki powszechnie przyjmuje się lata 90. XIX w., a jej pionierami są takie firmy, jak: Ford, Singer, Gillette, National Cash Register. Na procesy globalizacyjne wpływ miały i mają organizacje międzynarodowe, m.in.: Bank Światowy, Międzynarodowy Fundusz Walutowy czy Organizacja Współpracy Gospodarczej i Rozwoju (OECD). Globalizacja jest procesem, w którym można wyróżnić następujące nurty główne:

- gospodarczy, charakteryzujący się utworzeniem światowej gospodarki umożliwiającej swobodny przepływ dóbr, usług i czynników wytwórczych,

- ekonomiczny polegający na konsolidacji firm powodującej powstawanie korporacji krajowych i międzynarodowych,

- techniczny, charakteryzujący się rozwojem transportu, komunikacji, telekomunikacji, szybkim przepływem informacji w mediach oraz szerokim wykorzystaniem Internetu,

- społeczno-kulturowy ujednolicający różnice kulturowe, prowadząc do lepszego zrozumienia innych narodowości. Także dziedziny takie jak film, teatr, muzyka stają się do siebie podobne, bez względu na to, w której części świata się znajdujemy,

- polityczno-ustrojowy, polegający na rozwoju nowych form rządów, a także mogący doprowadzić do rozszerzenia demokracji na wiele państw. Ujednoliceniu uległ również system walutowy, co ułatwiło m.in. wyjazdy zagraniczne. Dzięki globalizacji łatwiejsze są migracje do innych państw.

Szeroko rozumiany proces globalizacji i powiązane z nim zjawiska gospodarcze, społeczne i polityczne obejmujące swym zasięgiem wiele państw mają duży wpływ na bezpieczeństwo ruchu drogowego. Proces ten warunkują: rozwój technicznych środków komunikacji, liberalizacja handlu międzynarodowego i redukcja barier przepływu towarów oraz kapitału, czemu sprzyjają m.in. korzystne warunki polityczne i działalność organizacji światowych, np. MFW, WTO etc. (ryc. 1). Globalizacja jest procesem intensywnym i niemożliwym do zahamowania. Ma wiele ujęć i definicji, a rozwija się dzięki silnym dążeniom społeczeństw do poprawy warunków życia, przede wszystkim dzięki rozwojowi nowoczesnych technik i technologii. Dominujące ujęcia definicji globalizacji dotyczą uniwersalizmu, internacjonalizacji i liberalizacji (Micał 2008). Uniwersalizm w branży edukacji kierowców przejawia się ujednoliceniem przepisów ruchu drogowego, metod szkolenia, wzorów praw jazdy i innych dokumentów. Internacjonalizacja odnosi się do wzrostu międzynarodowego ruchu drogowego i zależności podmiotów uczestniczących w ruchu drogowym. Na drogach całego świata dominują te same problemy: zatłoczone ulice, wypadki wymagające podobnych przeciwdziałań i rozwiązań 
z zakresu bezpieczeństwa ruchu drogowego. Celem liberalizacji jest budowanie światowego ruchu drogowego bez granic, ponieważ globalizacja wiąże się z procesem międzynarodowej integracji przepisów ruchu drogowego i edukacji kierowców.

Ryc. 1. Uwarunkowania i czynniki sprzyjające procesowi globalizacji w branży motoryzacyjnej

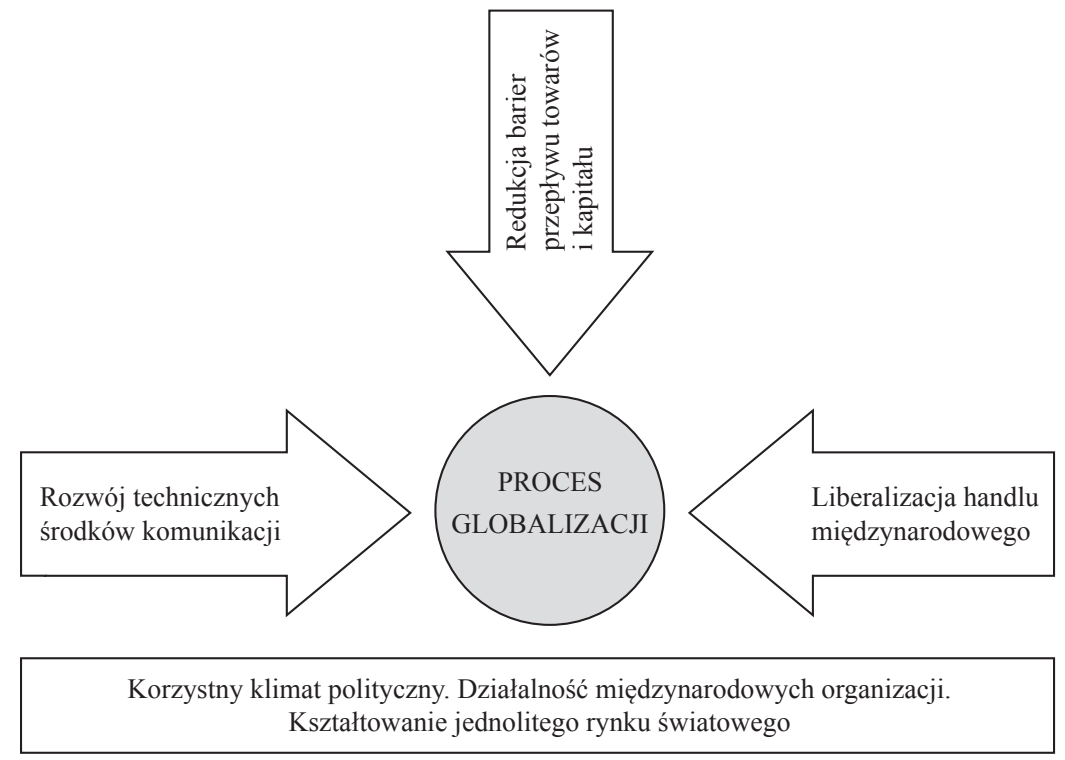

Źródło: Włodarczyk M., Janczewski J., Warsztaty samochodowe w warunkach globalizacji, referat wygłoszony na VII Ogólnopolskiej Metodycznej Konferencji Naukowej pt.: „Przedsiębiorczość w warunkach globalizacji”, w Zakładzie Przedsiębiorczości i Gospodarki Przestrzennej Instytutu Geografii Uniwersytetu Pedagogicznego im. Komisji Edukacji Narodowej w Krakowie w dniach 4-5 października $2010 \mathrm{r}$.

Płynność i bezpieczeństwo ruchu środków transportu drogowego to warunek szybkiego przepływu towarów i usług. Był on powodem opracowania nowej generacji przepisów regulujących międzynarodowy ruch środków transportu, w tym transportu drogowego. Można zatem stwierdzić, że opracowanie nowego modelu prawnego regulującego międzynarodowy ruch drogowy jest jednym z elementów procesu globalizacji. Proces ten warunkuje zmiany w obszarze edukacji kierowców w poszczególnych krajach. Międzynarodowy proces zmian przepisów ruchu drogowego rozpoczął się w 1968 r. w Wiedniu. W tym roku 58 państw sygnatariuszy podpisało Konwencję o ruchu drogowym. Wśród państw sygnatariuszy nie było Polski. Dopiero w roku 1984 Konwencja o ruchu drogowym została ratyfikowana przez Radę Państwa PRL z zastrzeżeniem art. 52 dotyczącego możliwości rozstrzygania sporów przed Trybunałem Sprawiedliwości. Zmiany polskiego modelu prawnego regulującego ruch drogowy zapoczątkowano w 1961 r. Jednak to rok 1983 należy przyjąć za datę rozpoczęcia procesu zmian dostosowujących polskie przepisy ruchu drogowego do wymagań ruchu międzynarodowego.

\section{Proces zmian przepisów o ruchu drogowym}

W procesie zmian polskich przepisów ruchu drogowego można wyróżnić cztery główne etapy: etap I - okres od 1945 r. do 1961 r., etap II - okres od 1961 r. do 1983 r., etap III - okres od 1984 r. do 1997 r. oraz trwający od 1998 r. etap IV (ryc. 2). 
Ryc. 2. Proces zmian polskich przepisów ruchu drogowego

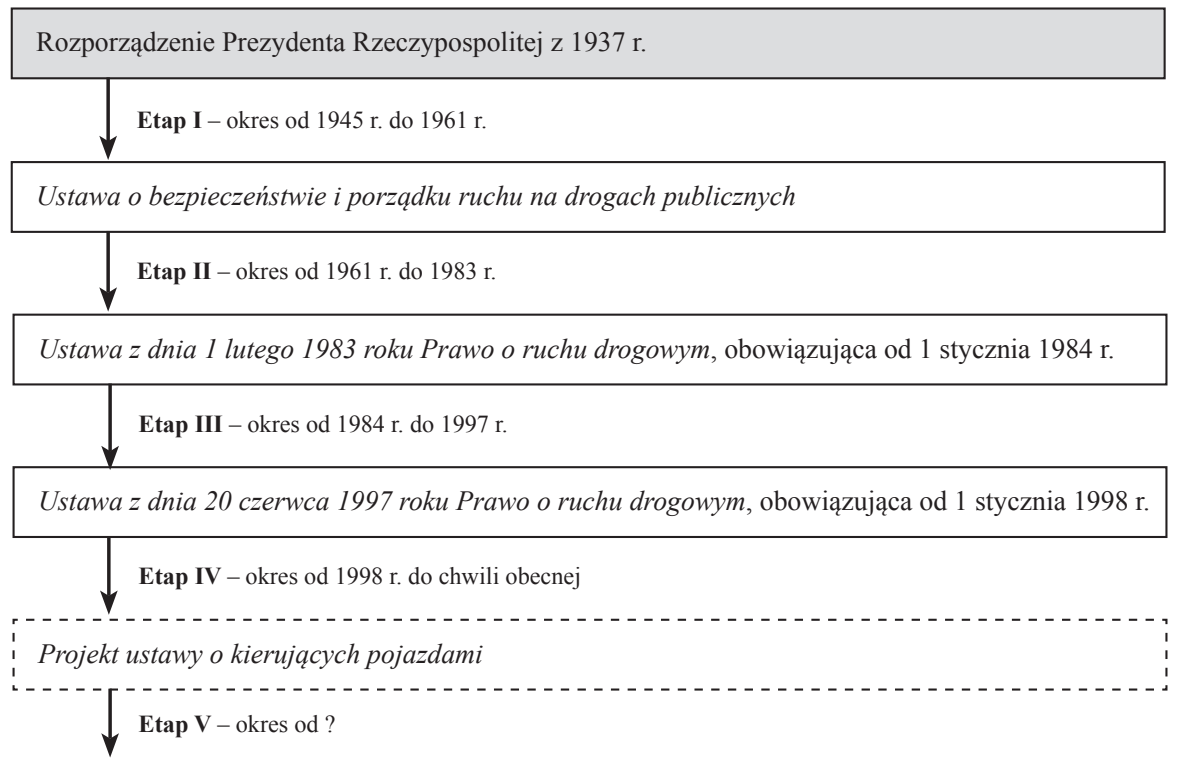

Źródło: opracowanie własne.

W fazie projektu jest Ustawa o kierujacych pojazdami. Wprowadzenie jej w życie zapoczątkuje $\mathrm{V}$ etap zmian polskich przepisów ruchu drogowego, dostosowując je do wymagań międzynarodowych.

Po zakończeniu II wojny światowej obowiązywało rozporządzenie prezydenta Rzeczpospospolitej z 1937 r., które wystarczająco regulowało ruch drogowy. Jednak rozwój motoryzacji przyczynił się do wzrostu natężenia ruchu pojazdów na drogach, przez co konieczne stało się dostosowanie przepisów ruchu drogowego. Proces ten rozpoczął się już w $1961 \mathrm{r}$. W listopadzie 1961 r. sejm wydał ustawę O bezpieczeństwie i porzadku ruchu na drogach publicznych, która weszła w życie 02.12.1961 r. i obowiązywała do końca 1983 r. Jednak rzeczywisty proces dostosowania przepisów do wymagań ruchu międzynarodowego rozpoczął się w 1983 r. z chwilą ogłoszenia ustawy Prawo o ruchu drogowym z mocą obowiązującą od 1 stycznia 1984 r. Przepisy tej ustawy w dużej części opierały się na przepisach wiedeńskiej Konwencji o ruchu drogowym. Kontynuacją procesu zmian dostosowujących polskie przepisy o ruchu drogowym do wymagań ruchu międzynarodowego jest obowiązująca od 1998 r. ustawa Prawo o ruchu drogowym i akty wykonawcze wydane na jej podstawie (Ożdżyński 2009). Projektowana Ustawa o kierujących pojazdami utrzyma rozwiązania, które się sprawdziły i wprowadzi wiele nowelizacji przepisów bezpośrednio dotyczących kierowców. Projekt ustawy wdraża postanowienia dyrektyw Wspólnoty Europejskiej, Parlamentu Europejskiego i Rady (EWG) ${ }^{1}$.

\footnotetext{
${ }^{1}$ Projekt ustawy dokonuje w zakresie swojej regulacji wdrożenia Dyrektywy $\mathrm{nr}$ 2006/126/WE Parlamentu Europejskiego i Rady z dnia 20 grudnia 2006 r. w sprawie praw jazdy (przeksztatcenie) (Dz.Urz. UE L 403 z 30.12.2006, s. 18) oraz częściowo Dyrektywy 2003/59/WE Parlamentu Europejskiego i Rady z dnia 15 lipca 2003 r. w sprawie wstepnej kwalifikacji i okresowego szkolenia kierowców niektórych pojazdów drogowych do przewozu rzeczy lub osób, zmieniającej rozporzadzenie Rady (EWG) nr 3820/85 oraz dyrektywę Rady 91/439/EWG i uchylajacej dyrektywę Rady 76/914/EWG (Dz.Urz. UE L 226 z 10.09.2003, s. 4, z późn. zm.; Dz.Urz. UE polskie wydanie specjalne, rozdz. 7, t. 7, s. 441, z późn. zm.).
} 


\section{Proces zmian w edukacji kierowców kategorii B}

Proces globalizacji spowodował konieczność ujednolicenia przepisów w różnych dziedzinach gospodarki, kultury i edukacji, w tym w systemie edukacji kierowców. W etapie obowiązywania przepisów z 1937 i 1961 r. szkolenie podstawowe obejmowało budowę i naprawę pojazdu, a także szkolenie teoretyczne w zakresie przepisów i szkolenie praktyczne w zakresie techniki jazdy. Szkolenie w zakresie pozwoleń na prowadzenie pojazdów o dopuszczalnej masie całkowitej powyżej 3,5 tony nie było uzależnione od posiadania pozwolenia na prowadzenie pojazdów o dopuszczalnej masie całkowitej poniżej 3,5 tony. Proces szkolenia trwający trzy miesiące kończył się egzaminem zdawanym przed kilkuosobową komisją. Egzamin składał się z dwóch części:

- teoretycznej, w której należało wykazać się umiejętnością naprawy uszkodzonego pojazdu oraz znajomością przepisów ruchu drogowego,

- praktycznej, obejmującej umiejętności prowadzenia pojazdu oraz zastosowania przepisów w rzeczywistym ruchu drogowym.

W etapie drugim szkolenie podstawowe składało się z części teoretycznej oraz praktycznej. Szkolenie w zakresie praw jazdy w kategoriach pozwalających na prowadzenie pojazdów o dopuszczalnej masie całkowitej powyżej 3,5 tony nie było uzależnione od posiadania prawa jazdy kategorii III. Posiadanie prawa jazdy kategorii II lub I nie upoważniało do prowadzenia pojazdów objętych innymi kategoriami. Istotną zmianą było wprowadzenie do części teoretycznej egzaminu standartowego testu wielokrotnego wyboru, w którym tylko jedna odpowiedź była prawidłowa. Testy wprowadzono pod koniec lat 70. XX w. W późniejszym okresie wprowadzono specyficzne testy wielokrotnego wyboru, w których prawidłowe są jedna, dwie lub trzy odpowiedzi. W części praktycznej należało zdać jednoczęściowy egzamin ze znajomości techniki jazdy w obecności egzaminatora oraz instruktora w pojeździe, w którym odbywała się nauka. Egzamin był przeprowadzany w tym ośrodku, gdzie odbywało się szkolenie.

Duże zmiany przyniósł etap III wprowadzony ustawą Prawo o ruchu drogowym z 1983 r. Przepisy ustawy wprowadzały m.in. następujące zmiany:

- powołanie do życia ośrodków egzaminowania,

- powołanie do życia instytucji egzaminatora,

- podział części praktycznej egzaminu na dwa etapy: w etapie pierwszym należało wykazać się umiejętnością wykonania 11 manewrów na placu; w etapie drugim następował egzamin w ruchu miejskim,

- zmniejszenie liczby godzin szkolenia teoretycznego do 10.

Przedstawione zmiany przepisów wymusiły zmiany form szkolenia, przenosząc jego ciężar z ruchu miejskiego na plac manewrowy i skracając jednocześnie czas poświęcony na szkolenie w ruchu miejskim. Skutkowało to obniżeniem poziomu nauczania, ponieważ przy tej samej liczbie obowiązkowych godzin szkolenia praktycznego znaczną ich część należało poświęcić na naukę parkowania prowadzoną na wyłączonym z ruchu placu manewrowym.

W etapie IV wprowadzonym ustawą Prawo o ruchu drogowym z dnia 20 czerwca 1997 r. dokonano szeregu zmian w procesie edukacji. Do najważniejszych należy zaliczyć: zwiększenie liczby godzin obowiązkowego szkolenia teoretycznego z 10 do 30 oraz praktycznego z 20 do 30, wprowadzenie do części praktycznej egzaminu elementów obsługi pojazdu, a także przydział instruktora prowadzącego i przeniesienie części zadań z placu manewrowego do ruchu miejskiego (więcej w Ożdżyński 2009). Te zmiany spowodowały częściowy powrót szkolenia do ruchu miejskiego.

Do najnowszych zmian związanych z edukacją kierowców należą zmiany wprowadzone przepisami Ustawy z dnia 22 lipca 2010 r. o zmianie ustawy - Prawo o ruchu drogowym oraz niektórych innych ustaw. Obowiązujący proces edukacji polskich kierowców przedstawiono na rycinie 3. 
Ryc. 3. Proces edukacji kierowców w poszczególnych etapach zmian polskich przepisów ruchu drogowego

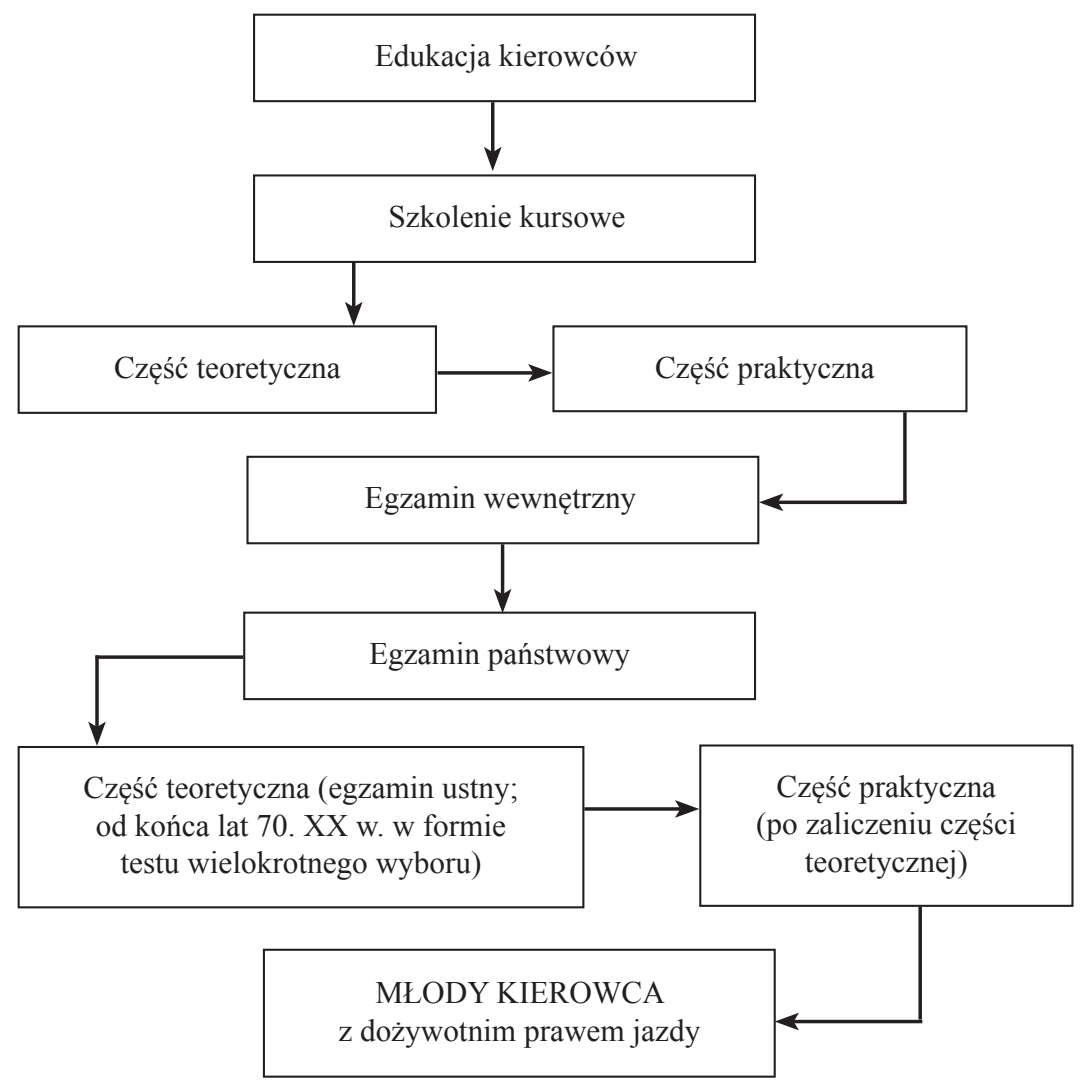

Źródło: opracowanie własne.

Przepisy wspomnianej ustawy m.in.:

- definiują pojęcie drogi publicznej, drogi wewnętrznej oraz strefy ruchu,

- rozszerzają stosowanie przepisów ruchu drogowego na drogi wewnętrzne położone w oznakowanych strefach ruchu.

Ustanowienie stref ruchu spowodowało konieczność ustalenia znaków oznaczających ich początek i koniec. Znaki te wprowadzone będą rozporządzeniem zmieniającym rozporządzenie w sprawie znaków i sygnałów drogowych (projekt rozporządzenia). Ich wzory przedstawiono na rycinie 4.

Ryc. 4. Projekt nowych znaków informacyjnych: a) znak „strefa ruchu”, b) znak „koniec strefy ruchu”

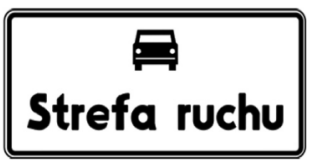

D-52

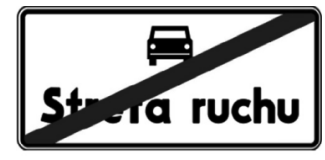

D-53

Źródło: Biuletyn Informacji Publicznej Ministerstwa Infrastruktury, Projekt rozporządzenia Ministrów Infrastruktury oraz Spraw Wewnętrznych i Administracji zmieniającego rozporządzenie w sprawie znaków i sygnałów drogowych, http://bip.mi.gov.pl/pl/bip/projekty_aktow_prawnych/projekty_rozporzadzen/ rozp_transport_drogowy/zna/px_17092010wa.pdf wrzesień 2010 
Etap V wprowadzony będzie Ustawa o kierujacych pojazdami, która od kilku lat jest w fazie szerokich konsultacji społecznych. Zgodnie z uzasadnieniem do projektu ustawy jej ,głównym celem jest:

- poprawa bezpieczeństwa ruchu drogowego przez podniesienie kwalifikacji kierujących pojazdami,

- minimalizacja negatywnych zjawisk związanych z procesem uzyskiwania uprawnień do kierowania pojazdami, takich jak oszustwa, nierzetelne wykonywanie usług w zakresie szkolenia kierowców i korupcja" (Projekt ustawy o kierujacych pojazdami-uzasadnienie, wrzesień 2010).

Szczegółowe przepisy zaproponowane w Projekcie ustawy o kierujących pojazdami utrzymują wszystkie wprowadzone do tej pory rozwiązania, które okazały się efektywne. Jednocześnie w projekcie zaproponowano nowe rozwiązania oparte na doświadczeniach europejskich krajów o wysokim stopniu rozwoju motoryzacji. Zmieni się także system uzyskiwania prawa jazdy kategorii B (ryc. 5). W projekcie zaproponowano również kilka istotnych zmian dotyczących osoby, która pierwszy raz uzyskała prawo jazdy kategorii B. Najważniejsze zmiany w systemie szkolenia to:

- wprowadzenie okresu próbnego trwającego dwa lata,

- wprowadzenie zakazu podejmowania pracy zarobkowej w charakterze kierowcy w zakresie przewozu osób w pierwszym roku okresu próbnego,

- wprowadzenie zakazu podejmowania osobiście działalności gospodarczej polegającej na kierowaniu pojazdem w zakresie przewozu osób w pierwszym roku okresu próbnego,

- wprowadzenie obowiązkowych kursów reedukacyjnych dla kierowcy, który w okresie próbnym popełnił dwa wykroczenia przeciwko bezpieczeństwu w komunikacji stwierdzone prawomocnymi wyrokami sądów lub przypisanymi punktami.

Ryc. 5. Model szkolenia reedukacji kierowców według Projektu ustawy o kierujących pojazdami

SZKOLENIE

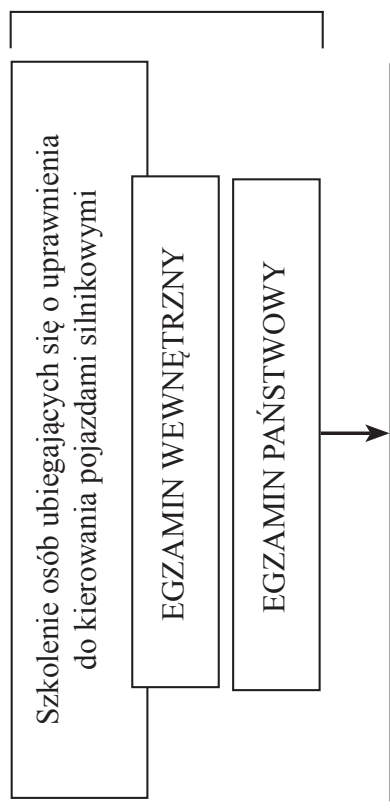

REEDUKACJA

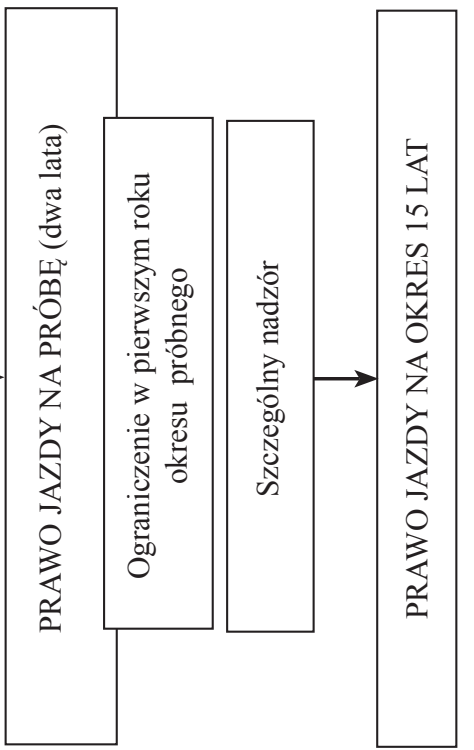

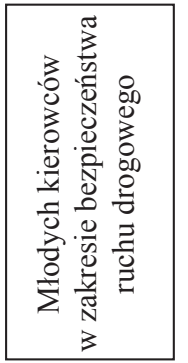
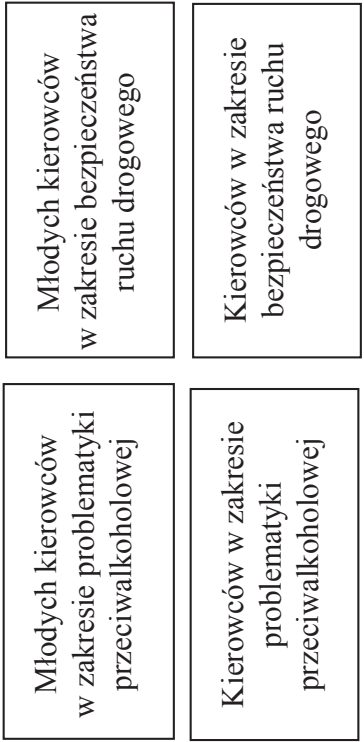

Źródło: opracowanie własne na podstawie Projektu ustawy o kierujących pojazdami. 
Proponowane zmiany koncentrują się na podniesieniu kwalifikacji kierowców. Ma to uzasadnienie w następujących faktach (uzasadnienie projektu ustawy):

- w grupie osób w wieku 18-24 lata posiadających prawo jazdy krócej niż dwa lata zanotowano tendencję wzrostową (o 10\%) ich udziału jako sprawców wypadków,

- w wypadkach z udziałem młodych kierowców 83\% zabitych są to również ludzie w wieku 18-24 lata,

- liczba ciężkich wypadków drogowych w Polsce jest trzykrotnie wyższa niż w krajach UE, a w wypadkach drogowych w Polsce w porównaniu z liczbą ludności ginie trzykrotnie więcej osób niż w krajach UE,

- w 73\% ośrodków szkolenia kierowców kontrolowanych przez Najwyższą Izbę Kontroli stwierdzono nieprawidłowości,

- egzamin teoretyczny zdaje za pierwszym razem 70,2\% kandydatów na kierowców, a egzamin praktyczny $32,7 \%$ kandydatów,

- 31\% zdających osób ocenia negatywnie sposób przeprowadzania egzaminów państwowych. Przyczyn tej niekorzystnej sytuacji jest wiele. Do najważniejszych należy zaliczyć niewłaściwy przebieg procesu nauczania kandydatów na kierowców (tab. 1).

Tab. 1. Niewłaściwy przebieg procesu nauczania kandydatów na kierowców jako czynnik wpływający niekorzystnie na stan bezpieczeństwa ruchu drogowego

\begin{tabular}{|l|l|l|}
\hline \multicolumn{1}{|c|}{ Cecha procesu nauczania } & \multicolumn{1}{|c|}{ Skutek } & \multicolumn{1}{c|}{ Ocena } \\
\hline $\begin{array}{l}\text { Niska jakość usług świadczonych } \\
\text { przez ośrodki szkolenia kierowców }\end{array}$ & $\begin{array}{l}\text { brak realizacji } \\
\text { programu }\end{array}$ & $\begin{array}{l}\text { kandydat jest nieprzygotowany } \\
\text { do uczestnictwa w ruchu drogowym }\end{array}$ \\
\hline $\begin{array}{l}\text { Ewidentne oszustwa polegające na } \\
\text { obietnicach typu ,u nas zdobędziesz } \\
\text { prawo jazdy w trzy dni” }\end{array}$ & $\begin{array}{l}\text { brak realizacji } \\
\text { programu }\end{array}$ & $\begin{array}{l}\text { kandydat jest nieprzygotowany } \\
\text { do uczestnictwa w ruchu drogowym }\end{array}$ \\
\hline $\begin{array}{l}\text { Nieuczciwa konkurencja w stosunku } \\
\text { do rzetelnych ośrodków szkolenia } \\
\text { kierowców }\end{array}$ & $\begin{array}{l}\text { brak pełnej } \\
\text { realizacji programu }\end{array}$ & $\begin{array}{l}\text { kandydat jest nieprzygotowany } \\
\text { do uczestnictwa w ruchu drogowym }\end{array}$ \\
\hline $\begin{array}{l}\text { Prowadzenie nauki wyłącznie pod } \\
\text { kątem egzaminu }\end{array}$ & $\begin{array}{l}\text { realizacja programu } \\
\text { pod kątem wykony- } \\
\text { wania manewrów }\end{array}$ & $\begin{array}{l}\text { Kandydat jest słabo przygotowany } \\
\text { do jazdy w ruchu miejskim }\end{array}$ \\
\hline $\begin{array}{l}\text { Brak właściwego nadzoru nad pracą } \\
\text { ośrodków szkolenia kierowców }\end{array}$ & błędy w szkoleniu & $\begin{array}{l}\text { kandydat jest słabo przygotowany } \\
\text { do jazdy w ruchu miejskim }\end{array}$ \\
\hline Afery łapówkarskie & handel egzaminami & $\begin{array}{l}\text { dopuszczenie do ruchu nieprzygoto- } \\
\text { wanych lub słabo przygotowanych } \\
\text { kandydatów }\end{array}$ \\
\hline
\end{tabular}

Źródło: opracowanie własne na podstawie Projekt ustawy o kierujących pojazdami - uzasadnienie, http://bip.mi.gov.pl/pl/bip/projekty_aktow_prawnych/projekty_ustaw/ustawy_transport_drogowy/ proj_ust_kieruj_pojazd wrzesień 2010

Ostatnie dziesięciolecie przyniosło również pozytywne doświadczenia i rozwiązania, do których należy zaliczyć:

- wprowadzenie jednolitych kryteriów oceny oraz ujednolicenie przebiegu egzaminów państwowych dla kandydatów na kierowców w całej Polsce, co umożliwiło m.in. powstanie wojewódzkich ośrodków ruchu drogowego, 
- wprowadzenie efektywnego systemu wydawania praw jazdy ograniczającego skutecznie zjawisko tzw. przestępstw przeciwko dokumentom,

- uregulowanie zasad wykonywania działalności gospodarczej w zakresie szkolenia kierowców,

- wprowadzenie systemu punktowej oceny kierowców mającego duże znaczenie dla profilaktyki w zakresie bezpieczeństwa ruchu drogowego.

W zakresie poprawy jakości procesu szkolenia w Projekcie ustawy o kierujących pojazdami zaproponowano następujące działania:

- podniesienie kwalifikacji wymaganych od instruktorów,

- zmiana wymagań w stosunku do ośrodków szkolenia kierowców,

- opracowanie standardów edukacyjnych przez wprowadzenie szczegółowych programów szkolenia określanych w drodze rozporządzenia przez ministra właściwego do spraw transportu,

- nałożenie na ośrodki szkolenia kierowców obowiązku przekazywania staroście dokładnych informacji o czasie, miejscu i osobach uczestniczących w kursie,

- sprecyzowanie uprawnień i obowiązków starosty w zakresie sprawowania nadzoru nad ośrodkami szkolenia kierowców,

- wprowadzenie nadzoru wojewody nad wykonywaniem zadań związanych ze szkoleniem kierowców przez samorząd szczebla powiatowego.

\section{Rola instruktora w procesie szkolenia kandydatów na kierowców}

W procesie szkolenia kandydatów na kierowców najważniejszą rolę odgrywa instruktor. Zakres proponowanych w Projekcie ustawy o kierujacych pojazdami zmian w stosunku do instruktorów przedstawiono w tabeli 2.

Tab. 2. Wymagania w stosunku do instruktorów zaproponowane w Projekcie ustawy o kierujących pojazdami

\begin{tabular}{|c|c|c|}
\hline \multicolumn{3}{|c|}{ Wymagania w stosunku do instruktorów } \\
\hline \multirow{2}{*}{ wyksztalcenie } & obecnie & po wejściu w życie ustawy \\
\hline & średnie & średnie \\
\hline $\begin{array}{l}\text { Posiadanie } \\
\text { uprawnień do } \\
\text { kierowania }\end{array}$ & $\begin{array}{l}\text { posiadanie prawa jazdy odpowiedniej } \\
\text { kategorii przez okres min. trzech lat }\end{array}$ & $\begin{array}{l}\text { posiadanie prawa jazdy kategorii B przez } \\
\text { okres min. trzech lat oraz prawa jazdy } \\
\text { odpowiedniej kategorii przez okres min. } \\
\text { roku }\end{array}$ \\
\hline Stan zdrowia & $\begin{array}{l}\text { brak przeciwwskazań zdrowotnych do } \\
\text { kierowania pojazdem }\end{array}$ & $\begin{array}{l}\text { brak przeciwwskazań zdrowotnych } \\
\text { do pracy na stanowisku instruktora }\end{array}$ \\
\hline $\begin{array}{l}\text { Sprawność } \\
\text { psychiczna }\end{array}$ & $\begin{array}{l}\text { brak przeciwwskazań psychologicz- } \\
\text { nych do kierowania pojazdem }\end{array}$ & $\begin{array}{l}\text { brak przeciwwskazań psychologicznych } \\
\text { do pracy na stanowisku instruktora }\end{array}$ \\
\hline Przeszkolenie & kurs kwalifikacyjny & $\begin{array}{l}\text { kurs prowadzony przez posiadający } \\
\text { poświadczenie Ośrodek Szkolenia } \\
\text { Kierowców }\end{array}$ \\
\hline $\begin{array}{l}\text { Potwierdzenie } \\
\text { posiadania } \\
\text { kompetencji }\end{array}$ & $\begin{array}{l}\text { egzamin kończący kurs i egzamin } \\
\text { przed komisją powołaną przez } \\
\text { wojewodę }\end{array}$ & $\begin{array}{l}\text { egzamin kończący kurs i egzamin przed } \\
\text { komisją powołaną przez wojewodę }\end{array}$ \\
\hline
\end{tabular}




\begin{tabular}{|l|l|l|}
\hline $\begin{array}{l}\text { Doskonalenie } \\
\text { zawodowe }\end{array}$ & $\begin{array}{l}\text { brak obowiązku doskonalenia } \\
\text { zawodowego }\end{array}$ & $\begin{array}{l}\text { coroczne uczestnictwo w warsztatach } \\
\text { doskonalenia zawodowego }\end{array}$ \\
\hline Niekaralność & $\begin{array}{l}\text { za przestępstwo przeciwko bezpieczeń- } \\
\text { stwu ruchu drogowego }\end{array}$ & $\begin{array}{l}\text { za przestępstwo przeciwko bezpieczeństwu } \\
\text { w komunikacji, za przestępstwo w celu } \\
\text { osiągnięcia korzyści majątkowej i osobistej, } \\
\text { za przestępstwo przeciwko wiarygodności } \\
\text { dokumentów, za przestępstwo przeciwko } \\
\text { zdrowiu i życiu, za przestępstwo przeciwko } \\
\text { wolności seksualnej i obyczajności oraz za } \\
\text { prowadzenie pojazdu po użyciu alkoholu }\end{array}$ \\
\hline $\begin{array}{l}\text { Wymogi } \\
\text { formalne }\end{array}$ & wpis do ewidencji instruktorów & wpis do ewidencji instruktorów \\
\hline
\end{tabular}

Źródło: Projekt ustawy o kierujących pojazdami - uzasadnienie, http://bip.mi.gov.pl/pl/bip/projekty_aktow _prawnych/projekty_ustaw/ustawy_transport_drogowy/proj_ust_kieruj_pojazd wrzesień 2010

Analiza danych zawartych w tabeli wskazuje na istotne zmiany wymagań w stosunku do instruktorów. Dotyczą one:

- wymaganych badań lekarskich i psychologicznych, które mają być przeprowadzane pod kątem przeciwwskazań do wykonywania pracy na stanowisku instruktora, a nie jak dotychczas wyłącznie pod kątem przeciwwskazań do kierowania pojazdem,

- szkolenia kandydatów na instruktorów, gdzie proponuje się ich prowadzenie przez posiadające poświadczenie ośrodki szkolenia kierowców,

- doskonalenia zawodowego przez coroczne uczestnictwo w warsztatach doskonalenia zawodowego,

- rozszerzenia katalogu przestępstw eliminujących osobę z ewidencji instruktorów.

Ważną misją społeczną instruktora nauki jazdy jest przygotowanie przyszłego kierowcy do uczestnictwa w ruchu drogowym. Zadaniem instruktora jest wyposażenie go w odpowiedni zasób wiedzy i umiejętności konieczne do prowadzenia pojazdu w ruchu drogowym oraz ukształtowanie tych cech osobowości, które są niezbędne do bycia dobrym i odpowiedzialnym jego uczestnikiem. Dlatego sam instruktor musi mieć stosowne kwalifikacje psychologiczno-pedagogiczne, dzięki którym proces nauczania będzie przebiegał prawidłowo i efektywnie. Ponadto ważną umiejętnością w procesie nauczania jest asertywność rozumiana jako szacunek dla samego siebie, dzięki któremu możemy komunikować innym, jakie są nasze potrzeby i oczekiwania przy jednoczesnym uszanowaniu ich praw do wyrażania własnych potrzeb. Asertywność można rozumieć jako zachowanie, pewność siebie i dobrą samoocenę, porozumiewanie się, umiejętność samorealizacji. Instruktor czy wykładowca, od początku sprawiający wrażenie osoby komfortowo czującej się w swojej roli, dobrze zorganizowanej, nawiązujący kontakt wzrokowy, przyjaźnie uśmiechający się i serdecznie witający się z innymi, ma największe szanse na zdobycie zaufania kursantów. Rolą instruktora w trakcie szkolenia jest również wskazanie uczniowi jego mocnych i słabych stron, co pomoże mu w ocenie swoich predyspozycji w kierowaniu pojazdem. Od tego, jak uczeń będzie postrzegał siebie, swoją wiedzę, umiejętności oraz kondycję psychiczną, będą zależały podejmowane przez niego działania w ruchu drogowym. Instruktor powinien umieć ocenić stan i tempo przyswajania nowych treści przez ucznia oraz jego sprawność psychomotoryczną, a także ćwiczyć to, co sprawia szczególne trudności. Z zadań stawianych instruktorowi wynikają dwie funkcje: nauczyciela i wychowawcy (ryc. 6). 
Ryc. 6. Funkcje pełnione przez instruktora nauki jazdy

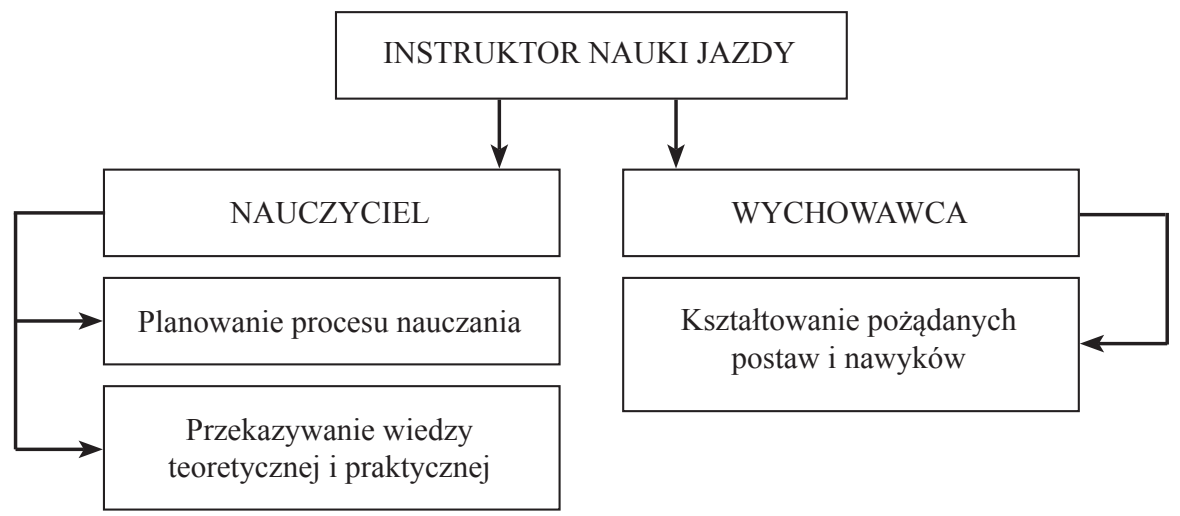

Źródło: Magierka M., Poradnik metodyczny dla instruktorów nauki jazdy - integralna część pakietu szkoleniowego Teka L-instruktor.pl, http://word.osk.net.pl/index.php/materiay-promocyjne, wrzesień 2010.

Instruktor jako nauczyciel jest odpowiedzialny za zaplanowanie procesu kształcenia, kierowanie nim oraz przekazywanie wiedzy teoretycznej i praktycznej. Jako wychowawca odpowiada za wychowanie uczniów poprzez kształtowanie pożądanych postaw i nawyków oraz formowanie systemu wartości, który motywuje do bezpiecznych zachowań na drodze i uwzględnia zasadę partnerstwa wobec innych uczestników ruchu drogowego. Projekt ustawy o kierujacych pojazdami wprowadza również obligatoryjne, cykliczne szkolenia kadry instruktorskiej, by utrzymywać i podnosić na wyższy poziom stan kompetencji i kwalifikacji w zakresie umiejętności szkolenia kandydatów na kierowców. Regularny udział w szkoleniach oraz praca samokształceniowa instruktorów umożliwi poprawę jakości procesu szkolenia kandydatów na kierowców, a tym samym poprawę bezpieczeństwa ruchu drogowego. Zaproponowane w Projekcie rozwiązania są również ogromną szansą przywrócenia instruktorom adekwatnego statusu. Pierwsze szkolenia kadry instruktorskiej rozpoczęły się w czerwcu 2010 r., przed wejściem w życie Projektu, w ramach unijnego projektu ,Wzrost kompetencji kadr ośrodków szkolenia kierowców".

Wchodzące w życie w najbliższym czasie przepisy Projektu ustawy o kierujacych pojazda$m i$ (według Mikołaja Karpińskiego, rzecznika Ministerstwa Infrastruktury, najrealniejszy termin to połowa 2011 r.) powinny przynieść znaczne zmiany w procesie szkolenia kierowców. Rosnąca świadomość społeczna w zakresie bezpieczeństwa ruchu drogowego, konieczność poruszania się w międzynarodowym ruchu drogowym po krajach Unii Europejskiej doprowadzi do zmian organizacyjnych ośrodków szkolenia kierowców oraz unowocześnienia metod szkolenia kandydatów na kierowców w skali globalnej. Można oczekiwać, iż wejście w życie wspomnianego projektu ustawy wprowadzi Polskę do czołówki krajów o wysokich standardach bezpieczeństwa ruchu drogowego. Rynek edukacji kierowców w Polsce dysponuje dużymi rezerwami intelektualnymi i techniczno-organizacyjnymi, których nie wykorzystuje w pełni. Wprowadzenie przepisów Projektu powinno zmienić obecny rynkowy charakter usług edukacji kierowców na rywalizację w zakresie ich jakości. Siłą napędową tej zmiany jest potrzeba zapewnienia poczucia bezpieczeństwa uczestników ruchu drogowego. 


\section{Literatura}

1. Bąk J., 2003, Wypadki drogowe a ksztatcenie młodych kierowców, Instytut Transportu Samochodowego, Warszawa.

2. Bem Z., Olszańska A., 2008, Uczę jeździć samochodem. Wskazówki metodyczne dla instruktorów nauki jazdy, Grupa IMAGE, Warszawa.

3. Brown P., Globalizacja - szansa czy zagrożenie?, http://pl.shvoong.com/social-sciences/1683578globalizacja-szansa-czy-zagro\%C5\%BCenie/ sierpień 2010.

4. Globalizacja przedsiębiorstw i gospodarki - skutki i znaczenie globalizacji, http://globalizacja.genialne.info/ lipiec 2010.

5. Górny M., Lewandowska B., 2010, Metodyka nauczania dla kandydatów na instruktorów nauki jazdy, Grupa IMAGE, Warszawa.

6. Leśnikowska-Matusiak I. (red.), 2009, Bezpieczeństwo ruchu drogowego. Teoria i praktyka szkoleń, Instytut Transportu Samochodowego, Warszawa.

7. Magierka M., Poradnik metodyczny dla instruktorów nauki jazdy - integralna część pakietu szkoleniowego Teka L-instruktor.pl, http://word.osk.net.pl/index.php/materiay-promocyjne, wrzesień 2010,

8. Micał M., Proces globalizacji we współczesnym świecie, „Zeszyty Naukowe Zakładu Europeistyki Wyższej Szkoły Informatyki i Zarządzania w Rzeszowie”, 3/2008 (8).

9. Ożdżyński Z., Zmiany procesu edukacji kierowców w warunkach integracji europejskiej, referat wygłoszony na VI Ogólnopolskiej Metodycznej Konferencji Naukowej pt. „Przedsiębiorczość w warunkach integracji europejskiej", która odbyła się w Zakładzie Przedsiębiorczości i Gospodarki Przestrzennej Instytut Geografii Uniwersytetu Pedagogicznego im. Komisji Edukacji Narodowej w Krakowie w dniach 5-6 października 2009 r.

10. Projekt rozporządzenia Ministrów Infrastruktury oraz Spraw Wewnętrznych i Administracji zmieniającego rozporządzenie $w$ sprawie znaków i sygnałów drogowych, Biuletyn Informacji Publicznej Ministerstwa Infrastruktury, http://bip.mi.gov.pl/pl/bip/projekty_aktow_prawnych/projekty_rozporzadzen/rozp_transport_drogowy/zna/px_17092010wa.pdf wrzesień 2010.

11. Projekt ustawy o kierujacych pojazdami, Biuletyn Informacji Publicznej Ministerstwa Infrastruktury, http://bip.mi.gov.pl/pl/bip/projekty_aktow_prawnych/projekty_ustaw/ustawy_transport_drogowy/ proj_ust_kieruj_pojazd wrzesień 2010 .

12. Projekt ustawy o kierujacych pojazdami-uzasadnienie, Biuletyn Informacji Publicznej Ministerstwa Infrastruktury, http://bip.mi.gov.pl/pl/bip/projekty_aktow_prawnych/projekty_ustaw/ustawy_transport_drogowy/proj_ust_kieruj_pojazd wrzesień 2010.

13. Włodarczyk M., Janczewski J., Warsztaty samochodowe w warunkach globalizacji, referat wygłoszony na VII Ogólnopolskiej Metodycznej Konferencji Naukowej pt.: „Przedsiębiorczość w warunkach globalizacji”, w Zakładzie Przedsiębiorczości i Gospodarki Przestrzennej Instytutu Geografii Uniwersytetu Pedagogicznego im. Komisji Edukacji Narodowej w Krakowie w dniach 4-5 października $2010 \mathrm{r}$.

14. Wzrost kompetencji kadr ośrodków szkolenia kierowców, projekt wspólfinansowany przez Unię Europejska w ramach Europejskiego Funduszu Społecznego w ramach Programu Operacyjnego Kapitat Ludzki, Działanie 2.1.1, http://word.osk.net.pl/index.php/home wrzesień 2010.

15. Ustawa z dnia 22 lipca 2010 r. o zmianie ustawy Prawo o ruchu drogowym oraz niektórych innych ustaw (Dz.U. Nr 152, poz. 1018), http://www.mi.gov.pl/2-48203f1e24e2f-1793054-p_1.htm wrzesień 2010. 


\section{Drivers Training in Conditions of Globalization}

The process of globalization makes it necessary to harmonize the regulations in various fields of economy, culture and education, including changes in the system of driver education. This paper presents the changes in Polish traffic law in the process of its adaptation to the international requirements and changes in driver training process in terms of improving road safety. It also identifies the areas of training that are undergoing the process of changes in conditions of globalization with emphasis on the role of instructor in the continuing education of drivers and improvement in their knowledge and skills. 


\section{SPIS TREŚCI}

Wprowadzenie

\section{Część 1}

\section{Ksztaltowanie się podmiotów gospodarczych w warunkach globalizacji}

Zbigniew Zioło, Rola przedsiębiorczości w warunkach nasilających się procesów globalizacji

Sławomir Dorocki, Inwestycje zagraniczne we Francji w dobie globalizacji

Aneta Oniszczuk-Jastrząbek, Otoczenie a przedsiębiorczość w warunkach globalizacji .....42

Tomasz Gutowski, Zmiany w przedsiębiorstwie wobec procesu globalizacji

Paweł Czapliński, Zarządzanie wiekiem jako strategia wzrostu konkurencyjności przedsiębiorstw w dobie globalizacji

Andrzej Tokarski, Globalizacja a ryzyko bankructwa przedsiębiorstw

Magdalena Kochmańska, Zarządzanie innowacjami w małych i średnich przedsiębiorstwach w warunkach globalizacji

Danuta Janczewska, Kształtowanie łańcucha wartości innowacji firm MŚP w warunkach globalizacji

Wioletta Kilar, Kształtowanie się Grupy Samsung w warunkach globalizacji

Marta Boguś, Proces kształtowania się korporacji ponadnarodowej Google

Wioletta Nogaj, Globalizacja a lokalizacja działalności gospodarczej

Mirosław Włodarczyk, Jerzy Janczewski, Warsztaty samochodowe w warunkach globalizacji

Tomasz Tadeusz Brzozowski, Globalizacja a wykluczenie społeczne. Etyczna i kulturowa geneza procesu marginalizacji

\section{Część 2}

\section{Rola przedsiębiorczości w aktywizacji gospodarczej}

Małgorzata Zdon-Korzeniowska, Marketing terytorialny jako forma działań przedsiębiorczych samorządów terytorialnych w Polsce

Agnieszka Kłos, Rola przedsiębiorczości władz i mieszkańców gminy Horyniec-Zdrój w aktywizacji gospodarczej regionu

Nina Grad, Przedsiębiorczość miejska - lokalne programy rewitalizacji instrumentami odnowy miast

Patrycja Majcher, Strategiczne kierunki kształtowania Kielc jako potencjalnej metropolii 


\section{Część 3}

\section{Źródla finansowe działalności przedsiębiorstw}

Maciej Tokarski, Międzynarodowe standardy sprawozdawczości finansowej

w procesie harmonizacji i standaryzacji rachunkowości w Polsce .236

Grażyna Voss, Rachunkowość kreatywna - ukryty program edukacyjny

Halina Pawlak, Ocena wykorzystania środków finansowych w ramach programu „Różnicowanie w kierunku działalności nierolniczej”

Paweł Czapliński, Sektor MŚP jako potencjalny odbiorca środków Funduszu Rozwoju Lokalnego Eksportu na przykładzie województwa podkarpackiego.

Agnieszka Buś-Bidas, Fundusze pożyczkowe w finansowaniu przedsiębiorstw sektora MŚP na przykładzie Funduszu Mikro Sp. z o.o. oddział w Tarnobrzegu 285

\section{Część 4}

\section{Ksztaltowanie postaw przedsiębiorczych w edukacji w warunkach globalizacji}

Monika Borowiec, Rola edukacji w procesach globalizacji

Sławomir Dorocki, Wioletta Kilar, Tomasz Rachwał, Założenia i cele Projektu „Krok w przedsiębiorczość” dla nauczycieli szkół ponadgimnazjalnych 308

Monika Borowiec, Tomasz Rachwał, Kształtowanie postaw przedsiębiorczych na lekcjach geografii wyzwaniem edukacyjnym w procesach globalizacji

Wiktor Osuch, Kompetencje w zakresie komunikacji interpersonalnej w dobie postępujących procesów globalizacji

Zbigniew Długosz, Szymon Biały, Studia w zakresie turystyki na tle szkolnictwa wyższego w kraju

Roman Malarz, Terytorialne pochodzenie kandydatów na studia z turystyki i rekreacji w Uniwersytecie Pedagogicznym w Krakowie

Alina Haczek, Funkcjonowanie bielskiego ośrodka akademickiego w warunkach globalizacji

Krystian Sowislok, Proces globalizacji. Ocena pozytywnych i negatywnych skutków globalizacji przez młodych Polaków

Zbigniew Janusz Ożdżyński, Szkolenie kierowców w warunkach globalizacji 


\section{CONTENTS}

Introduction

\section{Part 1}

\section{Formation of Business Entities in the Conditions of Globalization}

Zbigniew Zioło, The Role of Entrepreneurship in the Conditions of Intensifying Globalization Processes

Sławomir Dorocki, Foreign Investments in France in the Period of Globalization

Aneta Oniszczuk-Jastrząbek, Environment and Entrepreneurship under

Global Conditions ....

Tomasz Gutowski, Competitiveness of Enterprises in the Global Economy

Paweł Czapliński, Age Management as a Strategy of Improving the Competitiveness

of Companies in the Era of Globalization

Andrzej Tokarski, The Globalization of Business and the Bankruptcy Risk

Magdalena Kochmańska, Management of the Innovation in Small and Medium

Companies in Globalization Conditions

Danuta Janczewska, Formation of the Value Chain of Innovation of SMEs

in the Conditions of Globalization

Wioletta Kilar, Formation of Samsung Group in the Globalization Era

Marta Boguś, The Formation of the Multinational Corporation Google

Wioletta Nogaj, Location of Companies as a Function of Globalization Processes

Mirosław Włodarczyk, Jerzy Janczewski, Car Workshops in the Conditions

of Globalization

Tomasz Tadeusz Brzozowski, Globalization and the Exclusion from Society. Ethical and Cultural Origin of the Social Marginalization

\section{Part 2}

\section{The Role of Entrepreneurship in Activation of the Economy}

Małgorzata Zdon-Korzeniowska, Territorial Marketing as a Form of Entrepreneurship of Local Governments in Poland

Agnieszka Kłos, Role of Entrepreneurship and the Government and Local Residents Horyniec-Zdrój in the Activation of the Region's Economy

Nina Grad, The Urban Enterprise - Local Revitalisation Programmes as the Cities'

Revival Tools

Patrycja Majcher, Strategic Directions in Molding Kielce as a Potential Metropolis 


\section{Part 3}

\section{Financial Resources for Operation of Enterprises}

Maciej Tokarski, International Financial Reporting Standards in the Process of Harmonization and Standardization of Accountancy in Poland .236

Grażyna Voss, Creative Accounting - Indirect Syllabus

Halina Pawlak, Assessment of the Use of Funds under the Programme

„Różnicowanie w kierunku działalności nierolniczej” [Diversification into non-agricultural activities]

Paweł Czapliński, SME Sector as a Potential Recipient of the Local Export

Development Fund

Agnieszka Buś-Bidas, The Loan Funds as the Source of Financing for Enterprises

of SMEs Sector on the Example of Mikro Limited Company Fund, Tarnobrzeg Branch....285

\section{Part 4}

\section{Formation of Entrepreneurial Attitudes in Education in the Conditions of Globalization}

Monika Borowiec, The Role of Education in the Globalization Process .296

Sławomir Dorocki, Wioletta Kilar, Tomasz Rachwał, The Aims and Objectives of The Project "Step In Entrepreneurship" for Upper Secondary School Teachers .308

Monika Borowiec, Tomasz Rachwał, Developing Entrepreneurial Attitudes on Geography Lessons as an Educational Challenge in the Globalization Process

Wiktor Osuch, Competences in Interpersonal Communication in the Era of Globalization Processes

Zbigniew Długosz, Szymon Biały, Studies in the Field of Tourism and Higher

Education System in Poland

Roman Malarz, Region-wise Distribution of Candidates for the Faculty of Tourism and Recreation at the Pedagogical University of Cracow

Alina Haczek, The Functioning of Bielsko-Biala academic Center in the Conditions of Globalization

Krystian Sowislok, The Process of Globalization. Evaluation of Positive and Negative Results of Globalization by the Polish Youth

Zbigniew Janusz Ożdżyński, Drivers Training in Conditions of Globalization 
